\author{
Universidade de São Paulo \\ Instituto de Física \\ Instituto de Química \\ Instituto de Biociências \\ Faculdade de Educação
}

\title{
Leitura da história em quadrinhos "Trinity" por licenciandos em química: exercício da argumentação e da sensibilidade moral por meio de questões sociocientíficas
}

\section{Guilherme Balestiero da Silva}

Dissertação de mestrado apresentada ao Instituto de Física, ao Instituto de Química, ao Instituto de Biociências e a Faculdade de Educação da Universidade de São Paulo, para a obtenção do título de Mestre em Ensino de Ciências.

Modalidade: Química

Orientadora: Profa. Dra. Salete Linhares Queiroz

São Paulo 



\title{
Leitura da história em quadrinhos "Trinity" por licenciandos em química: exercício da argumentação e da sensibilidade moral por meio de questões sociocientíficas
}

\author{
Versão Corrigida \\ (Versão original encontra-se na unidade que aloja o Programa de Pós-graduação)
}

Dissertação de mestrado apresentada ao Instituto de Física, ao Instituto de Química, ao Instituto de Biociências e a Faculdade de Educação da Universidade de São Paulo, para a obtenção do título de Mestre em Ensino de Ciências.

Modalidade: Química

Orientadora: Profa. Dra. Salete Linhares Queiroz

Orientadora

São Paulo 
Autorizo a reprodução e divulgação total ou parcial deste trabalho, por qualquer meio convencional ou eletrônico, para fins de estudo e pesquisa, desde que citada a fonte.

\section{FICHA CATALOGRÁFICA}

\section{Preparada pelo Serviço de Biblioteca e Informação} do Instituto de Física da Universidade de São Paulo

Silva, Guilherme Balestiero da

Leitura da história em quadrinhos "Trinity” por licenciandos em química: exercício da argumentação e da sensibilidade moral por meio de questões sociocientíficas. São Paulo, 2019.

Dissertação (Mestrado) - Universidade de São Paulo, Faculdade de Educação, Instituto de Física, Instituto de Química e Instituto de Biociências.

Orientador: Profa. Dra. Salete Linhares Queiroz

Área de Concentração: Ensino de Química

Unitermos: 1. Química - Estudo e ensino; 2. Histórias em quadrinhos;

3. Formação de professores; 4. Argumentação; 5. Raciocínio moral; 6. Sensibilidade moral. 


\section{AGRADECIMENTOS}

Início este texto agradecendo àqueles e àquelas que direta ou indiretamente contribuíram para a realização deste trabalho.

Logo, agradeço primeiramente à Deus que certamente me guia e me fortalece em cada etapa e cada escolha.

Agradeço àquela que me introduziu diretamente no universo da pesquisa acadêmica, minha orientadora, professora e doutora, Salete Linhares Queiroz, que nesses dois anos não mediu esforços para me guiar na tortuosa caminhada que é o mestrado acadêmico.

Aos meus pais, Rafael Claudio da Silva e Sandra Regina Balestiero da Silva, que desde o princípio de minha vida contribuíram para que eu tivesse uma oportunidade que ainda é reservada a poucos em nosso país. Que me ensinaram desde pequeno com palavras e atitudes, por meio de acertos e erros, e hoje entendo o quanto se dedicaram à minha formação. E esse agradecimento é extensivo ao meu irmão Rafael Claudio da Silva Filho, que apesar das brigas sempre esteve ao meu lado

À minha companheira, amiga, e agora também esposa, Suzana Aparecida Silva Queiroz Balestiero, também vão meus cumprimentos. Ela não somente me apoiou nessa caminhada como mergulhou em uma semelhante em que pudemos crescer e aprender mutuamente.

Aos colegas do Grupo de Pesquisa em Ensino de Química do Instituto de Química de São Carlos (GPEQSC), que aos poucos me fizeram sair da minha concha e mostraram que o mestrado é mais do que ficar sentado em frete ao computador digitando. Agradeço, portanto à Dani, Patrícia, Mikeas, Moisés, Adriele, Flávia, Thamires e Arieli.

Ao Instituto de Química de São Carlos da Universidade de São Paulo, pela oportunidade de realização deste trabalho, bem como ao Programa de Pós-Graduação Interunidades em Ensino de Ciências pela estrutura fornecida aos alunos de mestrado.

Por fim, o presente trabalho foi realizado com apoio da Coordenação de Aperfeiçoamento de Pessoal de Nível Superior - Brasil (CAPES) - Código de Financiamento 001 



\section{RESUMO}

SILVA, Guilherme Balestiero. Leitura da história em quadrinhos "Trinity" por licenciandos em química: exercício da argumentação e da sensibilidade moral por meio de questões sociocientíficas. 2019. 297f. Dissertação (Mestrado em Ensino de Ciências Modalidade Química) - Faculdade de Educação, Instituto de Física, Instituto de Química, Instituto de Biociências, Universidade de São Paulo, São Paulo, 2019.

Face aos obstáculos presentes em salas de aula de ciências e à busca por ações que vão ao encontro das necessidades educacionais atuais, a inserção de práticas argumentativas ganha espaço na literatura científica. Dentre as estratégias promotoras da argumentação, a abordagem de questões sociocientíficas (QSC) é de particular interesse, uma vez que, consoante suas características, pode não somente contribuir para a formação de cidadãos que entendam a natureza da ciência, suas aplicações e implicações sociais, econômicas e políticas do conhecimento científico, como também auxiliar no desenvolvimento moral dos mesmos. Contudo, para que práticas sugeridas pela literatura possam ser empregadas de maneira eficaz em sala de aula da educação básica, faz-se necessário a formação de professores que, para além de possuir as habilidades fundamentais, como da argumentação, compreendam e valorizem essas diferentes práticas como formas viáveis de promoção da aprendizagem significativa em ciências. Nesse contexto, temos como objetivo promover, exercitar e analisar a argumentação e a sensibilidade moral exibida por licenciandos em química diante de QSC, a partir do estabelecimento de práticas de leitura de histórias em quadrinhos (HQ). Dessa forma, para a promoção da argumentação e exercício da sensibilidade moral dos futuros professores foram extraídos três casos da HQ "Trinity - a história em quadrinhos da primeira bomba atômica", a qual foi previamente submetida a análise para identificação da sua pertinência para pesquisa, bem como do seu potencial pedagógico. Os casos para argumentação foram elaborados com base no material Moral reasoning in scientific research e permite o contato com o raciocínio informal dos licenciandos, mais especificamente com a sua sensibilidade moral. No que diz respeito aos dados coletados, estes foram inicialmente estudados à luz do Padrão de Argumento de Toulmin (TAP) e, posteriormente, analisados com base no Modelo dos Quatro Componentes, que permitiu a investigação da sensibilidade moral dos educandos. Foram identificados neste estudo, em consonância com a literatura, argumentos de pouca complexidade estrutural, que apesar de aprimorados no decorrer das atividades foram pouco influenciados pela leitura da HQ. Em contraponto, a sensibilidade moral exibida pelos licenciandos, embora limitada, foi diretamente afetada pela leitura do texto quadrinizado, o que pode ser atribuído a diferentes recursos da linguagem dos quadrinhos que promovem uma maior sensibilização no leitor. Outrossim, os resultados discutidos neste trabalho reforçam a necessidade de práticas não somente voltadas para o desenvolvimento das habilidades argumentativas de professores em formação, como também para o desenvolvimento moral. Cabe também salientar a validade do Modelo dos Quatro Componentes e do material Moral reasoning in scientific research para estudos envolvendo o raciocínio moral, o que se torna ainda mais relevante face o número incipiente de trabalhos existentes sobre a temática na literatura nacional

Palavras-chave: Histórias em quadrinhos. Formação de professores. Argumentação. Raciocínio moral. Sensibilidade moral. 



\begin{abstract}
SILVA, Guilherme Balestiero. Chemistry Education undergraduates reading the "Trinity" graphic novel: argumentation and moral sensitivity exercises using socio-scientific issues. 2019. 297f. Dissertação (Mestrado em Ensino de Ciências - Modalidade Química) - Faculdade de Educação, Instituto de Física, Instituto de Química, Instituto de Biociências, Universidade de São Paulo, São Paulo, 2019.
\end{abstract}

Faced with obstacles encountered in lessons and the search for actions that meet current educational needs, some attention has been paid to argumentative practices in the literature. Among the strategies encouraging argumentation, the approach to socio-scientific issues (SSI) is of particular interest, as, according to its characteristics, it does not only contribute to peoples' education who understand the nature of science, its applications and social implications, economic and political aspects of scientific knowledge, but also helps their moral development. However, so that the practices suggested by the literature can be effectively used in basic education lessons, teachers need to be trained in fundamental skills such as the ability to argue, understand and value these different practices as viable ways of promoting meaningful learning in science. In this context, we aim to encourage, practice and analyze argumentation and the moral sensitivity shown by Chemistry Education undergraduates considering SSI, based on establishing practices of reading graphic novels. Thus, to promote future teachers' argumentation skills and practice moral sensitivity, three cases from the graphic novel "Trinity - a Graphic History of the First Atomic Bomb", were extracted, which were previously analyzed to identify their importance for research, as well as the pedagogical potential. The cases for argumentation were developed based on the material Moral Reasoning in Scientific Research and enables contact with the undergraduates' informal reasoning, more specifically with their moral sensitivity. Collected data were initially studied considering the Toulmin's Argument Pattern (TAP) and later analyzed based on the Four Component Model, which enabled us to investigate the students' moral sensitivity. In this study, in agreement with the literature, we identified arguments of low structural complexity that, although improved while doing the activities, were little influenced by the reading the graphic novel. In contrast, the moral sensitivity shown by the undergraduates, although limited, was directly affected by reading the graphic text, which can be attributed to different language resources of graphic novels that encourage greater sensitivity in the reader. Moreover, the results discussed in this paper reinforce the need for practices not only aimed at developing trainee teachers' argumentative skills, but also for moral development. The validity of the Four Component Model and the Moral Reasoning in Scientific Research material for studies involving moral reasoning should be emphasized, which is even more relevant given the incipient number of studies on the subject in the literature in Brazil.

Keywords: Graphic novels. Teacher training. Argumentation. Moral reasoning. Moral sensitivity. 



\section{SUMÁRIO}

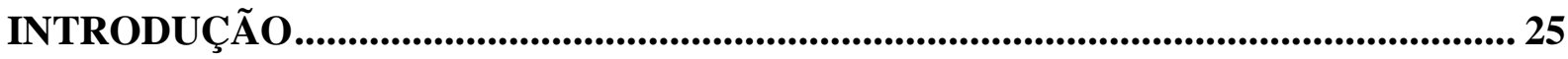

CAPÍTULO 1 - Argumentação e o ensino de ciências ................................................. 33

1.1 Contribuições da inserção de práticas argumentativas no ensino de ciências ................... 34

1.2 A necessária inserção de práticas argumentativas no âmbito da formação de professores de

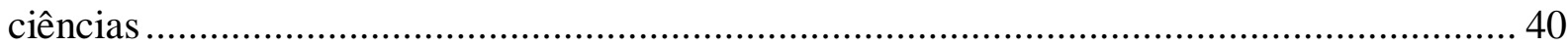

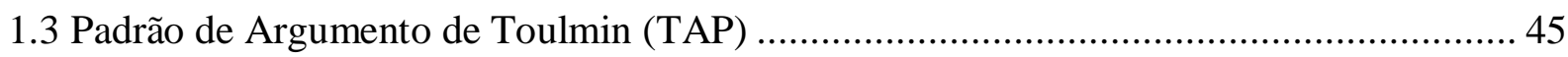

CAPÍTULO 2 - Questões sociocientíficas e o desenvolvimento moral ................................ 53

2.1 A relevância das questões sociocientíficas e a educação científica ................................ 54

2.2 Argumentação sobre questões sociocientíficas.......................................................... 57

2.3 Raciocínio informal e o desenvolvimento moral .......................................................... 59

2.4 Questões sociocientíficas e pesquisas em ensino de ciências.......................................... 64

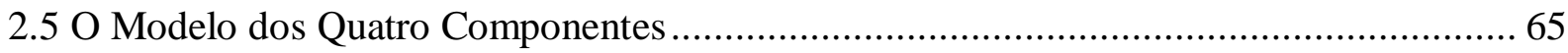

CAPÍTULO 3 - O caminho para a construção dos dados: a HQ "Trinity: a história em quadrinhos da primeira bomba atômica" ................................................................. 75

3.1 Histórias em quadrinhos e suas potencialidades didáticas ........................................... 75

3.2 Um histórico recente das HQ e o espaço formal de ensino no Brasil .............................. 78

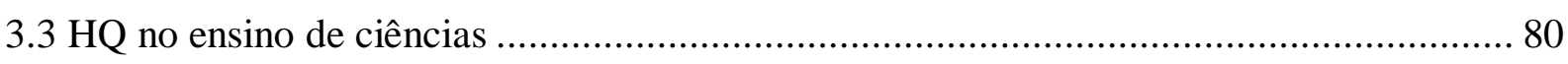

3.4 A seleção da HQ "Trinity: a história em quadrinhos da primeira bomba atômica" ......... 85

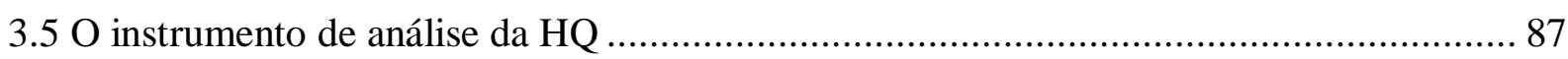

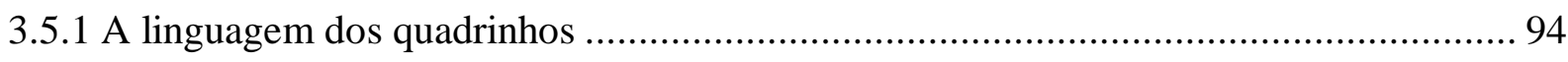

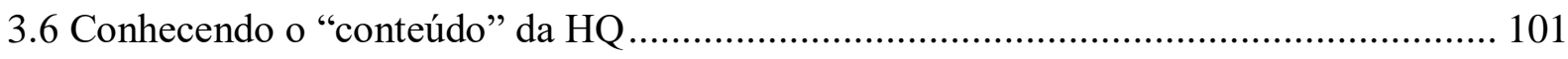

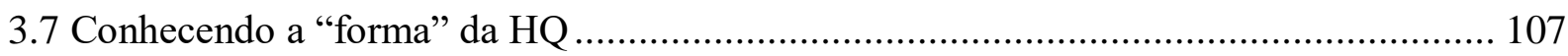

CAPÍTULO 4 - O caminho para a construção dos dados: ações na formação inicial de professores de química........................................................................................................... 133

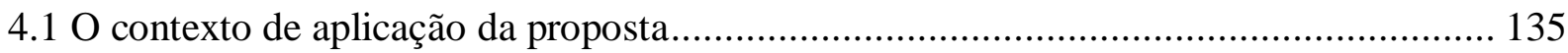

4.2 Atividades realizadas na formação inicial de professores .......................................... 138

CAPÍTULO 5 - As características estruturais dos argumentos empregados por

licenciandos em química diante de questões socialmente controversas .......................... 151

5.1 Análise global dos argumentos empregados pelos licenciandos em respostas aos casos

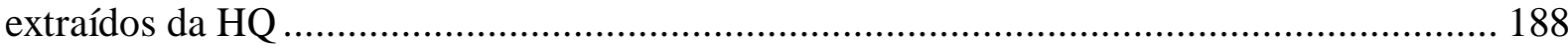

CAPÍTULO 6 - A sensibilidade moral evidenciada por licenciandos em química diante de questões socialmente controversas

6.1 Análise global da sensibilidade moral evidenciada pelos licenciandos em respostas aos casos extraídos da HQ. 
CAPÍTULO 7 - Considerações finais........................................................................ 267

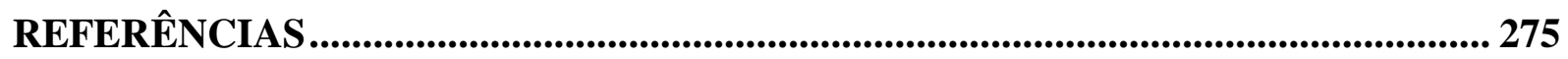

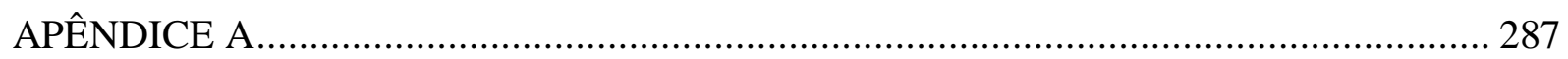

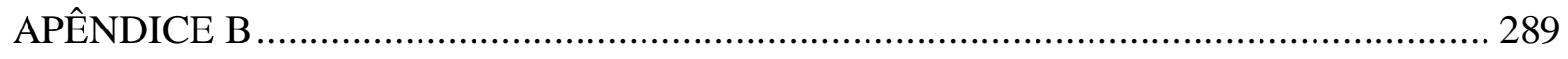

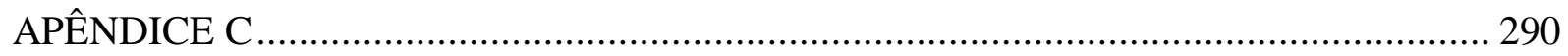

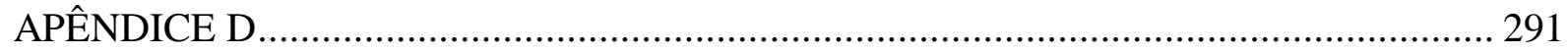

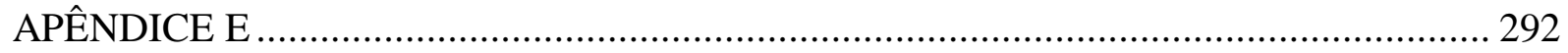

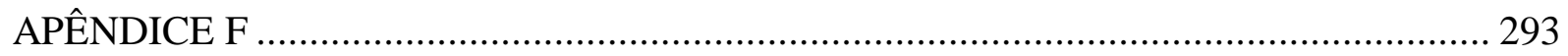

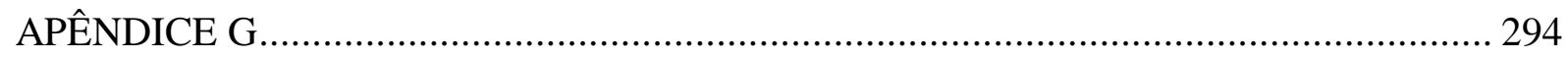

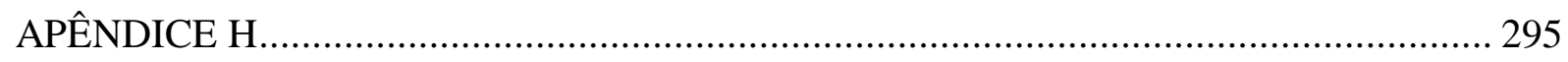

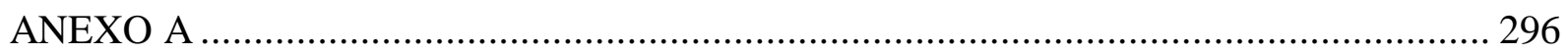




\section{LISTA DE FIGURAS}

Figura 1 - A argumentação enquadrada no processo de construção do conhecimento científico, na perspectiva de Jiménez-Aleixandre.

Figura 2 - Potenciais contribuições da argumentação na perspectiva de Jiménez-Aleixandre e Erduran (2008)

Figura 3 - Esqueleto básico de um padrão para analisar argumentos de acordo com Toulmin (2001) 45

Figura 4 - Padrão de Argumento de Toulmin (2001) 48

Figura 5 - O caso de Harry na perspectiva do Padrão de Argumento de Toulmin (2001). 49

Figura 6 - Componentes da alfabetização científica funcional........................................ 56

Figura 7 - Modelo dos Quatro Componentes (Rest, Bebeau e Volker, 1986)................... 70

Figura 8 - Os ingredientes da água régia apresentadas no quadrinho "Jornada ao Centro da Terra". 84

Figura 9 - Capa do quadrinho "Bolinha" (Tubby) nº10, mostrando uma reação que sai do controle 84

Figura 10 - Relação de trabalhos e focos temáticos identificados por Ferreira e Queiroz (2012) 88

Figura 11 - A abstração de uma imagem e a ampliação do seu significado na linguagem dos

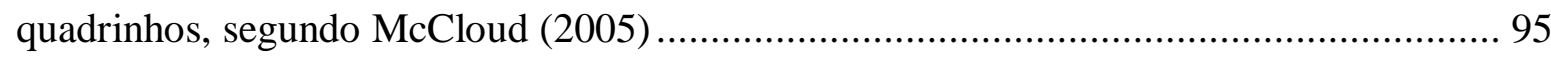

Figura 12 - Os desenhos e o envolvimento do leitor com os quadrinhos........................ 96

Figura 13 - Transição momento-para-momento ..................................................... 98

Figura 14 - Transição ação-para-ação .................................................................... 98

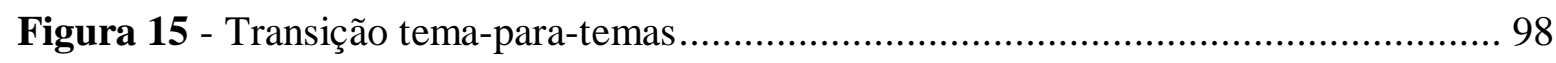

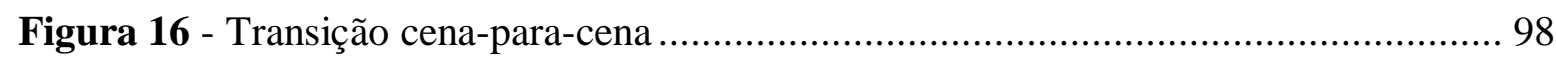

Figura 17 - Transição aspecto-para-aspecto .......................................................... 98

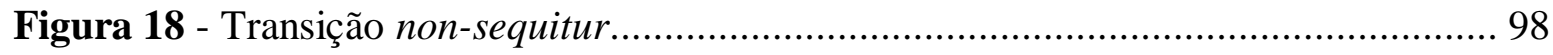

Figura 19 - Oppenheimer e Groves discutem a respeito do comportamento dos cientistas diante a obrigatoriedade de sigilo .114

Figura 20 - Diante da possibilidade de construção de armamentos nucleares, Leo Szilard busca conselhos com Albert Einstein 114

Figura 21 - Ilustração do modelo planetário da estrutura atômica proposto por Rutherford 
Figura 22 - Ilustração das forças elétricas que constituem o átomo esquematizadas por James Chadwick

Figura 23 - Exemplo de fontes empregadas na fala do narrador e dos demais personagens

Figura 24 - Letreiramento especial que evidencia o poder de uma reação nuclear

Figura 25 e 26 - Letreiramentos especiais que evidenciam uma das principais características do Projeto Manhattan: o sigilo 118

Figura 27 - Representação de alarme tocando por meio de letreiramento especial 119

Figura 28 - Representação de som em uma reação de fissão nuclear controlada 120

Figura 29 - Exemplo de transição momento-para-momento 121

Figura 30 - Exemplo de transição ação-para-ação 122

Figura 31 - Exemplo de transição tema-para-tema 123

Figura 32 - Exemplo de transição tema-para-tema com foco na expressão dos personagens

Figura 33 - Exemplo de transição cena-para-cena 125

Figura 34 - Exemplo dos diferentes tipos de transições de cena identificados na HQ..... 126

Figura 35 - Exemplo de plano geral . 127

Figura 36 - Exemplo de plano total 127

Figura 37 - Exemplo de plano aproximado. 128

Figura 38 - Exemplo de plano de detalhe 129

Figura 39 - Exemplo de primeiro plano 129

Figura 40 - Exemplo de ângulo de visão superior 130

Figura 41 - Sequência de passos para aplicação dos casos proposta por Bebeau (1995). 134 Figura 42 - Distribuição gráfica da combinação de elementos do TAP apresentados por Alice em seus argumentos 189

Figura 43 - Distribuição gráfica da combinação de elementos do TAP apresentados por Bianca em seus argumentos 189

Figura 44 - Distribuição gráfica da combinação de elementos do TAP apresentados por Caroline em seus argumentos 190

Figura 45 - Distribuição gráfica da combinação de elementos do TAP apresentados por Débora em seus argumentos 190

Figura 46 - Distribuição gráfica da combinação de elementos do TAP apresentados por Gabriel em seus argumentos 190 
Figura 47 - Distribuição gráfica da frequência de cada combinação de elementos propostos por Toulmin (2001) nas respostas dos licenciandos nos diferentes casos estudados 194 Figura 48 - Trecho extraído da HQ “Trinity” com diferentes recursos gráficos adotados pelo autor no intuito de promover uma maior empatia entre leitor e personagem 257 Figura 49 - Distribuição gráfica dos valores obtidos a respeito da sensibilidade moral conferida à licencianda Alice a partir dos seus diferentes argumentos escritos .258 Figura 50 - Distribuição gráfica dos valores obtidos a respeito da sensibilidade moral conferida à licencianda Bianca a partir dos seus diferentes argumentos escritos .258 Figura 51 - Distribuição gráfica dos valores obtidos a respeito da sensibilidade moral conferida à licencianda Caroline a partir dos seus diferentes argumentos escritos .258 Figura 52 - Distribuição gráfica dos valores obtidos a respeito da sensibilidade moral conferida à licencianda Débora a partir dos seus diferentes argumentos escritos .258 Figura 53 - Distribuição gráfica dos valores obtidos a respeito da sensibilidade moral conferida ao licenciando Gabriel a partir dos seus diferentes argumentos escritos .258 Figura 54 - Representação gráfica das frequências de menções às partes interessadas, às consequências, às obrigações do protagonista e aos pontos de conflito nas respostas dos licenciados para cada um dos casos .263 



\section{LISTA DE QUADROS}

Quadro 1 - Grau de complexidade dos argumentos proposto por Erduran, Simon e Osborne (2004)

Quadro 2 - Rubrica de pontuação e alguns exemplos de respostas para análise da sensibilidade moral utilizada por Fowler, Zeidler e Sadler (2009) 73

Quadro 3 - Esquema proposto por Ferreira e Queiroz (2011) para análise de TDC

Quadro 4 - Esquema proposto para análise da HQ adaptado de Ferreira e Queiroz (2011). 100

Quadro 5 - Atividades realizadas na disciplina Química, Sociedade e Cotidiano 139

Quadro 6 - Dados coletados a partir das atividades realizadas na disciplina Química, Sociedade e Cotidiano

Quadro 7 - Análise estrutural, na perspectiva de Toulmin (2001), do argumento inicial empregado por Alice em resposta ao Caso 1

Quadro 8 - Análise estrutural, na perspectiva de Toulmin (2001), do argumento final empregado por Alice em resposta ao Caso 1

Quadro 9 - Análise estrutural, na perspectiva de Toulmin (2001), do argumento inicial empregado por Bianca em resposta ao Caso 1 155

Quadro 10 - Análise estrutural, na perspectiva de Toulmin (2001), do argumento final empregado por Bianca em resposta ao Caso 1 156

Quadro 11 - Análise estrutural, na perspectiva de Toulmin (2001), do argumento inicial empregado por Caroline em resposta ao Caso 1

Quadro 12 - Análise estrutural, na perspectiva de Toulmin (2001), do argumento final empregado por Caroline em resposta ao Caso 1

Quadro 13 - Análise estrutural, na perspectiva de Toulmin (2001), do argumento inicial empregado por Débora em resposta ao Caso 1

Quadro 14 - Análise estrutural, na perspectiva de Toulmin (2001), do argumento final empregado por Débora em resposta ao Caso 1

Quadro 15 - Análise estrutural, na perspectiva de Toulmin (2001), do argumento inicial empregado por Gabriel em resposta ao Caso 1

Quadro 16 - Análise estrutural, na perspectiva de Toulmin (2001), do argumento final empregado por Gabriel em resposta ao Caso 1

Quadro 17 - Análise estrutural, na perspectiva de Toulmin (2001), do argumento inicial empregado por Alice em resposta ao Caso 2 
Quadro 18 - Análise estrutural, na perspectiva de Toulmin (2001), do argumento final empregado por Alice em resposta ao Caso 2

Quadro 19 - Análise estrutural, na perspectiva de Toulmin (2001), do argumento inicial empregado por Bianca em resposta ao Caso 2

Quadro 20 - Análise estrutural, na perspectiva de Toulmin (2001), do argumento final empregado por Bianca em resposta ao Caso 2

Quadro 21 - Análise estrutural, na perspectiva de Toulmin (2001), do argumento inicial empregado por Caroline em resposta ao Caso 2

Quadro 22 - Análise estrutural, na perspectiva de Toulmin (2001), do argumento final empregado por Caroline em resposta ao Caso 2

Quadro 23 - Análise estrutural, na perspectiva de Toulmin (2001), do argumento inicial empregado por Débora em resposta ao Caso 2

Quadro 24 - Análise estrutural, na perspectiva de Toulmin (2001), do argumento final empregado por Débora em resposta ao Caso 2

Quadro 25 - Análise estrutural, na perspectiva de Toulmin (2001), do argumento inicial empregado por Gabriel em resposta ao Caso 2

Quadro 26 - Análise estrutural, na perspectiva de Toulmin (2001), do argumento final empregado por Gabriel em resposta ao Caso 2

Quadro 27 - Análise estrutural, na perspectiva de Toulmin (2001), do argumento inicial empregado por Alice em resposta ao Caso 3

Quadro 28 - Análise estrutural, na perspectiva de Toulmin (2001), do argumento final empregado por Alice em resposta ao Caso 3

Quadro 29 - Análise estrutural, na perspectiva de Toulmin (2001), do argumento inicial empregado por Bianca em resposta ao Caso 3

Quadro 30 - Análise estrutural, na perspectiva de Toulmin (2001), do argumento final empregado por Bianca em resposta ao Caso 3

Quadro 31 - Análise estrutural, na perspectiva de Toulmin (2001), do argumento inicial empregado por Caroline em resposta ao Caso 3

Quadro 32 - Análise estrutural, na perspectiva de Toulmin (2001), do argumento final empregado por Caroline em resposta ao Caso 3

Quadro 33 - Análise estrutural, na perspectiva de Toulmin (2001), do argumento inicial empregado por Débora em resposta ao Caso 3 .....

Quadro 34 - Análise estrutural, na perspectiva de Toulmin (2001), do argumento final empregado por Gabriel em resposta ao Caso 3 
Quadro 35 - Análise estrutural, na perspectiva de Toulmin (2001), do argumento inicial empregado por Gabriel em resposta ao Caso 3

Quadro 36 - Análise estrutural, na perspectiva de Toulmin (2001), do argumento final empregado por Gabriel em resposta ao Caso 3

Quadro 37 - Grelha de aspectos morais referente ao Caso 1

Quadro 38 - Análise da sensibilidade moral de Alice, de acordo com a resposta inicial fornecida ao Caso 1

Quadro 39 - Análise da sensibilidade moral de Alice, de acordo com a resposta final fornecida ao Caso 1

Quadro 40 - Análise da sensibilidade moral de Bianca, de acordo com a resposta inicial fornecida ao Caso 1 204

Quadro 41 - Análise da sensibilidade moral de Bianca, de acordo com a resposta final fornecida ao Caso 1 206

Quadro 42 - Análise da sensibilidade moral de Caroline, de acordo com a resposta inicial fornecida ao Caso 1 208

Quadro 43 - Análise da sensibilidade moral de Caroline, de acordo com a resposta final fornecida ao Caso 1

Quadro 44 - Análise da sensibilidade moral de Débora, de acordo com a resposta inicial fornecida ao Caso 1

Quadro 45 - Análise da sensibilidade moral de Débora, de acordo com a resposta final fornecida ao Caso 1

Quadro 46 - Análise da sensibilidade moral de Gabriel, de acordo com a resposta inicial fornecida ao Caso 1

Quadro 47 - Análise da sensibilidade moral de Gabriel, de acordo com a resposta final fornecida ao Caso 1 216

Quadro 48 - Grelha de aspectos morais referente ao Caso 2 221

Quadro 49 - Análise da sensibilidade moral de Alice, de acordo com a resposta inicial fornecida ao Caso 2

Quadro 50 - Análise da sensibilidade moral de Alice, de acordo com a resposta final fornecida ao Caso 2

Quadro 51 - Análise da sensibilidade moral de Bianca, de acordo com a resposta inicial fornecida ao Caso 2 
Quadro 52 - Análise da sensibilidade moral de Bianca, de acordo com a resposta final fornecida ao Caso 2

Quadro 53 - Análise da sensibilidade moral de Caroline, de acordo com a resposta inicial fornecida ao Caso 2

Quadro 54 - Análise da sensibilidade moral de Caroline, de acordo com a resposta final fornecida ao Caso 2

Quadro 55 - Análise da sensibilidade moral de Débora, de acordo com a resposta inicial fornecida ao Caso 2

Quadro 56 - Análise da sensibilidade moral de Débora, de acordo com a resposta final fornecida ao Caso 2

Quadro 57 - Análise da sensibilidade moral de Gabriel, de acordo com a resposta inicial fornecida ao Caso 2

Quadro 58 - Análise da sensibilidade moral de Gabriel, de acordo com a resposta final fornecida ao Caso 2

Quadro 59 - Grelha de aspectos morais referente ao Caso 3

Quadro 60 - Análise da sensibilidade moral de Alice, de acordo com a resposta inicial fornecida ao Caso 3

Quadro 61 - Análise da sensibilidade moral de Alice, de acordo com a resposta final fornecida ao Caso 3

Quadro 62 - Análise da sensibilidade moral de Bianca, de acordo com a resposta inicial fornecida ao Caso 3

Quadro 63 - Análise da sensibilidade moral de Bianca, de acordo com a resposta final fornecida ao Caso 3

Quadro 64 - Análise da sensibilidade moral de Caroline, de acordo com a resposta inicial fornecida ao Caso 3

Quadro 65 - Análise da sensibilidade moral de Caroline, de acordo com a resposta final fornecida ao Caso 3

Quadro 66 - Análise da sensibilidade moral de Débora, de acordo com a resposta inicial fornecida ao Caso 3

Quadro 67 - Análise da sensibilidade moral de Débora, de acordo com a resposta final fornecida ao Caso 3

Quadro 68 - Análise da sensibilidade moral de Gabriel de acordo com a resposta inicial fornecida ao Caso 3 
Quadro 69 - Análise da sensibilidade moral de Gabriel, de acordo com a resposta final

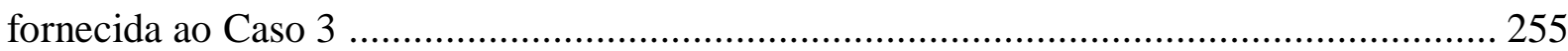





\section{LISTA DE SIGLAS}
A Alice
B Backing
Bi Bianca
C Conclusão
Ca Caroline
CDCC Centro de Divulgação Científica e Cultural
CDJ Conclusão/Dado/Justificativa
CDJB Conclusão/Dado/Justificativa/Backing
CDJR Conclusão/Dado/Justificativa/Refutação
CDJQ Conclusão/Dado/Justificativa/Qualificador Modal
CDJBQ Conclusão/Dado/Justificativa/Backing/Qualificador Modal
CDJBQR Conclusão/Dado/Justificativa/Backing/Qualificador Modal/Refutação
CTS Ciência Tecnologia e Sociedade
D Dado
DC Divulgação Científica
De Débora
DSTs Doenças Sexualmente Transmissíveis
E Érica
ENEM Exame Nacional do Ensino Médio
ENPEC Encontro Nacional de Pesquisa em Educação em Ciências
EUA Estados Unidos da América
F Francisco
G Gabriel
GEPCE Grupo de Estudo e Pesquisa em Ciência e Ensino
GPEQsc Grupo de Pesquisa em Ensino de Química do IQSC
HQ História(s) em Quadrinho(s)
IFSC Instituto de Física de São Carlos
J Justificativa
LDB Lei de Diretrizes e Bases
NdC Natureza da Ciência
P Professora
PCN Parâmetros Curriculares Nacionais
PIBID Programa Institucional de Bolsa de Iniciação à Docência
PNBE Programa Nacional da Biblioteca da Escola
PPR Processo de Peer Review
Q Qualificador Modal
QSC Questões Sociocientíficas
R Refutação
SSI Socio-scientific Issues
TAP Toulmin's Argument Pattern
TDC Texto de Divulgação Científica
U-235 Urânio 235
U-238 Urânio 238
UFSCar Universidade Federal de São Carlos
UNICAMP Universidade de Campinas
USP Universidade de São Paulo 



\section{INTRODUÇÃO}

Diante dos obstáculos presentes em sala de aula, como a desmotivação dos alunos e as dificuldades de aprendizagem de conceitos, o ensino de ciências vem sendo amplamente debatido de forma a torná-lo mais relevante e mais compreensível aos estudantes (ARROIO, 2011). Tais debates não são recentes e conduziram ao surgimento do campo que Cachapuz et. al. (2005) denominam de Didática das Ciências, o qual surge em resposta à necessária renovação desse ensino e que se torna relevante por dois principais fatores: a urgência da alfabetização científica mediante a importância da crescente produção científica e tecnológica para o desenvolvimento das nações; e a associação de fracasso escolar ao ensino de ciências (SCHNETZLER, 2002).

Nessa perspectiva, na busca por ações que vão ao encontro das necessidades educacionais atuais, como a alfabetização científica e a formação para a cidadania, a inserção de práticas argumentativas em sala de aula ganha espaço e é foco de diversos estudos que apresentam a argumentação desde uma perspectiva teórica, até propostas para a sua promoção no espaço formal de ensino (DRIVER, NEWTON e OSBORNE, 2000; JIMÉNEZALEIXANDRE e ERDURAN, 2008; MENDONÇA e JUSTI, 2013, CABRAL, SOUZA e QUEIROZ, 2017). Há também trabalhos interessados em analisar os argumentos de alunos e professores diante de questões controversas, os quais apontam para lacunas no que diz respeito à formação de professores que não somente compreendam a importância da argumentação no ensino das ciências na educação básica, mas que sejam capazes de refletir criticamente sobre diferentes situações e, assim, apresentar argumentos bem fundamentados (AYDENIZ e GÜRÇAY, 2013; ROBERTSHAW e CAMPBELL, 2013; OZDEN et. al., 2013; CETIN, 2014; LOURENÇO, FERREIRA e QUEIROZ, 2016).

Dentre as estratégias promotoras da argumentação encontradas na literatura, estas podem envolver questões de natureza científica ou sociocientífica (SÁ e QUEIROZ, 2011). Centrando-se nas de natureza sociocientíficas, estas são caracterizadas como questões sociais controversas com conceitos ou procedimentos relacionados com a ciência. A discussão a seu respeito, além de contribuir para o desenvolvimento moral dos alunos, se torna interessante para a formação de cidadãos que entendam a natureza da ciência, suas aplicações e as implicações sociais, econômicas e políticas do conhecimento científico (SADLER, 2011; OWENS, SADLER e ZEIDLER, 2017; CONRADO e NUNES-NETO, 2018). Nesse contexto, o trabalho com questões sociocientíficas (QSC) se torna importante na formação de professores como bem 
apontam Pérez e Carvalho (2012, p. 729): “Geralmente, os professores de ciências são especializados em disciplinas específicas e não foram preparados para trabalhar aspectos sociais, políticos e éticos envolvidos em assuntos públicos adjacentes ao progresso científico e tecnológico".

Ao abordarmos as contribuições desse tipo de questão para o desenvolvimento moral dos educandos, nos deparamos com a ideia de raciocínio informal e, consequentemente, de raciocínio moral (SADLER, 2004a). Nessa perspectiva, diferentes autores como Fowler, Zeidler e Sadler (2009) salientam que se o raciocínio moral é utilizado para determinar o curso de ações diante de um problema controverso, uma das principais necessidades seria a habilidade de reconhecer os aspectos morais das situações, isto é, possuir uma sensibilidade moral satisfatória que permita ao indivíduo a análise crítica desse problema e que o auxilie na sua tomada de decisão. Assim sendo, concordamos com estes autores e consideramos o emprego de estudos voltados para o exame da relação entre sensibilidade moral e QSC relevantes para a elaboração de estratégias pedagógicas futuras que de fato favoreçam o desenvolvimento moral dos educandos.

Contudo, além das dificuldades comumente encontradas no ensino das ciências, uma série de estudos, como os desenvolvidos pelo Grupo de Estudos e Pesquisa em Ciência e Ensino (gepCE) da Universidade de Campinas (UNICAMP), salienta o insucesso dos alunos brasileiros em outras áreas, como a leitura, e consequentemente a necessidade de práticas alinhadas a essas dificuldades (ALMEIDA e PAGLIARINI, 2016).

Ao direcionar o olhar para a formação de professores de ciências e sua relação com a leitura, Flôr (2009) destaca que diferentes trabalhos envolvendo essa relação vêm sendo realizados. No entanto, o que se verifica é que os estudantes dos cursos de graduação em ciências naturais não têm o hábito e/ou não são solicitados a escrever sobre suas ideias, pensamentos, impressões e críticas. Este fato, segundo o autor, corrobora para o fortalecimento da visão que muitos professores de ciências têm de que atividades que incluam ler e escrever só têm relação com a disciplina de língua portuguesa.

Dentre os trabalhos citados por Flôr (2009), o estudo de Andrade e Martins (2006) voltado para um grupo de professores de física, química e biologia de uma escola federal de ensino médio, confirma a não existência de espaços e oportunidades, durante a formação inicial, para a reflexão sobre o papel da leitura no ensino e na aprendizagem de ciências. E os autores ainda acrescentam que os professores não se veem como formadores de leitores, mas sim como mediadores entre os estudantes e os textos de forma a direcioná-los à leitura "correta". 
Utilizando os tipos de leitura apontados por Geraldi (2003), a saber: leitura-busca-deinformações (o leitor vai ao texto em busca de respostas a perguntas prévias que faz a si mesmo); leitura-estudo-de-texto (o leitor vai ao texto para extrair dele tudo que possa oferecer); leitura-pretexto (o leitor vai ao texto para usá-lo na produção de outras obras, inclusive textos); e leitura-fruição (sem nenhuma das intenções anteriores, o leitor apenas desfruta da gratuidade da presença do texto), Andrade e Martins (2006) verificaram que os professores investigados possuem uma compreensão de leitura polarizada entre a leitura-busca-de-informações, e a leitura-fruição, sendo a primeira voltada para textos didáticos e científicos e a segunda para textos literários, por exemplo. Dessa forma, o que se observa é que, apesar de compreenderem a importância da leitura na formação dos estudantes e valorizarem a utilização de textos nas aulas, os professores investigados veem seus estudantes como "não leitores" (FLÔR, 2009).

Nessa perspectiva, Ferreira (2012) salienta:

... as diferentes disciplinas escolares devem contribuir para o desenvolvimento de atividades que possibilitem aos alunos o aumento gradativo na capacidade de compreensão dos materiais lidos, também, no gosto pela leitura. Logo, o estabelecimento nos alunos do hábito da leitura - fundamental para que possam participar plenamente do desenvolvimento de qualquer disciplina escolar - não é tarefa exclusiva dos professores da área de linguagem. Para que isso ocorra, é de fundamental importância que os professores percebam o potencial didático de outros textos que estejam mais próximos da leitura espontânea de seus alunos do que os textos dos livros didáticos (FERREIRA, 2012, p. 9).

Portanto, de modo a associar leitura ao ensino de ciências, o uso de textos de divulgação científica (TDC) tem despertado o interesse de diversos pesquisadores (NASCIMENTO, 2005; CUNHA e GIORDAN, 2009), uma vez que se configuram como um artifício no auxílio ao ensino formal e uma alternativa aos materiais comumente empregados em sala de aula, como os livros didáticos. Dentre as vantagens advindas da sua utilização no contexto escolar, Rocha (2012) pontua:

... acesso à informação, a possibilidade de contextualização de conteúdos e a
ampliação da discussão sobre questões atuais dentro da sala de aula. Vale ressaltar
ainda, o desenvolvimento de habilidades de leitura, o domínio de conceitos, de formas
de argumentação e a familiarização de certos termos científicos, tais como clonagem,
radicais livres, camada de ozônio, ultravioleta, efeito estufa entre outros. Desta forma,
o texto de divulgação científica se torna um material interessante, rico e sintonizado
com o cotidiano quando passa a constituir a "ponte" entre os conteúdos curriculares e
o mundo do aluno, fazendo conexão entre o que se aprende na escola e o que está fora
dela (ROCHA, 2012, p.50).

Voltados para um público "não-científico", o discurso da divulgação científica, dispensa, a princípio, a linguagem esotérica exigida pelo discurso científico direcionado a especialistas, e ao mesmo tempo se orienta para três diferentes objetivos: cívico (transmitir a informação científica de modo a ampliar a consciência do cidadão a respeito de questões 
associadas ao desenvolvimento científico e tecnológico); mobilização popular (transmitir informações científicas que permitam a instrumentalização dos atores nas tomadas de decisão); e educacional (transmitir a informação cientifica almejando o esclarecimento dos indivíduos quanto à solução de problemas relacionados aos fenômenos estudados, e o estímulo à curiosidade científica) (ALBAGLI, 1996).

Assim sendo, de acordo com Zamboni (2001), essas características e objetivos dos TDC vão possibilitar a superposição de traços de cientificidade, laicidade e didaticidade, que irão apresentar diferentes intensidades nos textos. A cientificidade diz respeito a traços típicos do discurso científico, os quais revelam aspectos explícitos da práxis cientifica, e implícitos, como características pessoais dos cientistas. Os traços de laicidade envolvem elementos inerentes ao discurso cotidiano e, assim, compreendem as diferentes formas de contextualização. Por fim, os traços de didaticidade compreendem elementos próprios do discurso didático com o emprego de procedimentos como simplificações, explicações, recapitulações etc.

Nesse contexto, desponta como um texto mais próximo da leitura espontânea dos alunos, e com particularidades que lhes tornam interessantes para emprego no espaço formal de ensino, histórias em quadrinhos (HQ) de divulgação científica. Próprias do cotidiano dos alunos, e com um discurso teoricamente mais acessível, foi a partir da Terceira Revolução Industrial e do desenvolvimento tecnológico e científico sem precedentes do século XX, que as HQ se tornaram um meio de comunicação bastante difundido (MENDONÇA, 2008). Isto porque, dado ao avanço de áreas como das tecnologias da informação e comunicação e a nova concorrência em prender a atenção de seu público contra o mais novo advento do século, a televisão, a indústria produtora dos quadrinhos passou por diversas mudanças, alterando algumas características de seu produto com o objetivo de alcançar mais efetivamente os seus leitores (VERGUEIRO, 2007a). Consequentemente, junto com reportagens, notícias e revistas, as HQ passaram então a representar de certa forma a "ciência fora dos muros escolares", um novo gênero de divulgação científica. Diferentes profissionais as consideram um meio de comunicação relevante para áreas distintas do conhecimento, exercendo uma influência considerável na formação de seu público (CORRÊA et. al., 2016).

Dessa forma, considerando a relevância da promoção da argumentação e do exercício da sensibilidade moral, bem como da leitura e da escrita em salas de aula de ciências, TDC, dada a sua abordagem diferenciada, se tornam valiosos para a implementação de práticas dessa natureza em ambientes de ensino. E dentre esses textos, destacamos as HQ, que comum ao cotidiano dos alunos e muitas vezes disponíveis nas escolas por meio do PNBE (Programa 
Nacional Biblioteca da Escola), se configuram como um instrumento que possibilita, de forma lúdica e com uma linguagem teoricamente mais acessível, o tratamento não somente do conhecimento científico vinculado ao ensino de química, como também possibilitam fomentar o hábito da leitura nos estudantes. Dessa forma se torna possível, por exemplo, contribuir para vencer as dificuldades evidenciadas pelos diferentes estudos citados anteriormente.

Mediante o exposto, com o presente estudo buscamos promover, exercitar e analisar a argumentação e a sensibilidade moral exibida por licenciandos em química diante de QSC a partir do estabelecimento de práticas de leitura de quadrinhos. A pertinência dessa investigação parte do pressuposto que as ações de argumentação em sala de aula da educação básica estão diretamente relacionadas com as habilidades argumentativas dos docentes que as empregam. Portanto, contamos como questão geral de investigação: Como se configuram os argumentos de licenciandos em química diante de questões que envolvem dimensões morais extraídas de uma HQ?

Dessa forma, pretendemos a partir desse objetivo fazer uso de uma HQ que, para além de conteúdos próprios do ensino formal de química, apresente temáticas transversais e QSC, de modo que estas possam subsidiar a argumentação de futuros professores a respeito de temas sociais controversos. A HQ selecionada para estudo é a obra denominada "Trinity: a história em quadrinhos da primeira bomba atômica" (FETTER-VORM, 2013), a qual foi submetida incialmente a uma análise do seu conteúdo e da sua forma tendo em vista a tessitura de considerações sobre o seu potencial educativo para o ensino de química, e a investigação sobre o funcionamento da leitura e das atividades decorrentes desta para a construção dos argumentos escritos dos licenciandos. Assim sendo, buscamos responder com a realização deste trabalho outras duas questões de investigação derivadas:

I) Quais são as características estruturais dos argumentos escritos que licenciandos produzem diante de QSC e de que forma estas foram afetadas pela leitura de um texto quadrinizado?

II) Em que extensão as atividades didáticas realizadas a partir da leitura de uma HQ contribuíram para o desenvolvimento da sensibilidade moral dos educandos?

Dessa forma, a fim de respondermos nosso problema de investigação, estruturamos o texto em sete capítulos, os quais são representativos de dois principais momentos. Na primeira parte do texto, dois capítulos iniciais, discorremos a respeito do marco teórico e analítico que enviesa o nosso trabalho, isto é, tecemos um panorama a respeito da argumentação e da 
abordagem de QSC no ensino de ciências buscando estabelecer não somente a relação existente entre essas temáticas e a formação de professores, bem como apresentar ao leitor os referenciais teóricos analíticos que nos permitiram concluir sobre os problemas aqui elencados tendo como base os dados tomados e discutidos no segundo momento do texto. Portanto, na outra parte deste trabalho abordaremos a esfera prática da pesquisa, evidenciando os aspectos que subsidiaram a tomada de dados, isto é, as dimensões metodológicos e de contexto. Além disso, apresentamos uma discussão acerca dos resultados obtidos que nos permitirão sistematizar nossas considerações finais. Dessa forma, o texto se encontra dividido de acordo com os seguintes capítulos:

No Capítulo 1 intitulado “Argumentação e o ensino ciências" ponderamos sobre as diversas contribuições oriundas da inserção de práticas argumentativas no espaço formal de ensino de ciências. Discutimos sobre os resultados obtidos por diferentes autores interessados na temática que apontam para algumas lacunas que corroboram a relevância do nosso trabalho. Assim sendo, destacamos, dentre outros aspectos, a patente necessidade de inserção de práticas argumentativas no âmbito da formação inicial de professores de ciências, o qual representa o contexto de aplicação desta pesquisa. No mais, ao final do capítulo discorremos a respeito do modelo que nos permitirá analisar a complexidade estrutural dos argumentos empregados pelos licenciandos diante de questões socialmente controversas. Dessa forma, expomos considerações a respeito do Padrão de Argumento de Toulmin (TAP) (TOULMIN, 2001), desde suas contribuições até as suas limitações, que em nossa concepção não invalidam o seu emprego como instrumento de análise neste estudo.

Com uma discussão sobre QSC, o Capítulo 2, intitulado "Questões sociocientíficas e o desenvolvimento moral", apresenta considerações a respeito da validade e relevância do emprego de tais questões no ensino de ciências tendo em vista os objetivos da educação científica. Assim sendo, dentre as contribuições possíveis da inserção de problemas de natureza socialmente controversos em sala de aula, destacamos neste capítulo, com base em trabalhos realizados principalmente em âmbito internacional, a importância de práticas e estudos voltados para o desenvolvimento moral dos educandos. Discorremos a respeito de tópicos concernentes a esse desenvolvimento, como o exercício do raciocínio informal e da sensibilidade moral no ambiente de ensino e aprendizagem. Também, de modo semelhante ao que será apresentado no Capítulo 1, ao final deste capítulo tecemos considerações a respeito do Modelo dos Quatro Componentes (REST, BEBEAU e VOLKER, 1986), o qual em conjunto com o material Moral reasoning in scientific research (BEBEAU, 1995) diz respeito ao referencial teórico que nos 
permitirá responder em que extensão as atividades didáticas realizadas a partir da leitura de uma HQ contribuíram para o desenvolvimento da sensibilidade moral dos educandos.

A respeito dos aspectos metodológicos e de contexto que suportaram a realização de nossa investigação, estes se encontram divididos nos Capítulos 3 e 4. No Capítulo 3 "Caminho para construção dos dados - a HQ 'Trinity: a história em quadrinhos da primeira bomba atômica" discorremos sobre os aspectos que conduziram à seleção da referida HQ e dissertamos sobre a forma e o conteúdo do texto, de modo a identificar as suas potencialidades educativas e indicar elementos que possam influenciar a argumentação dos licenciandos. Para tanto, discutimos também a respeito do quadro teórico que permitiu a análise da HQ em questão.

Com relação ao Capítulo 4, "Caminho para a construção dos dados - ações na formação inicial de professores de química”, apresentamos uma caracterização do contexto e dos sujeitos envolvidos na pesquisa, ou seja, abordamos questões referentes à disciplina em que se desenvolveu o estudo e aos licenciandos matriculados participantes das diferentes atividades realizadas em sala de aula. Neste capítulo também apresentamos todas as atividades desenvolvidas no âmbito da formação inicial de professores, destacando os princípios de sua elaboração e evidenciando o conjunto de dados e a forma de coleta.

Diante dos dados obtidos conforme descritos nos Capítulos 3 e 4, no Capítulo 5, “A qualidade estrutural dos argumentos empregados por licenciandos em química diante de questões socialmente controversas", discutimos os resultados que nos permitem responder nossa primeira questão de investigação derivada do objetivo central, isto é, quais são as características estruturais dos argumentos escritos que licenciandos produzem diante de QSC e de que forma estas foram afetadas pela leitura de um texto quadrinizado. Assim sendo, apresentamos neste capítulo uma análise sistemática de todos os argumentos escritos fornecidos pelos futuros professores de química nos diferentes momentos de aplicação da proposta de ensino, tendo em vista os aspectos metodológicos mencionados e o TAP (TOULMIN, 2001), destacado no Capítulo 1.

Analogamente, no Capítulo 6, intitulado "A sensibilidade moral evidenciada por licenciandos em química diante de questões socialmente controversas", dissertamos sobre a segunda questão de investigação elencada neste estudo, ou seja, em que extensão as atividades didáticas realizadas a partir da leitura de uma HQ contribuíram para o desenvolvimento da sensibilidade moral dos educandos. Também apresentamos neste capítulo uma discussão sobre os diferentes argumentos empregados pelos licenciandos em resposta às questões controversas 
utilizadas em sala de aula, contudo sob uma outra ótica de análise, isto é, com base no Modelo dos Quatro Componentes (REST, BEBEAU e VOLKER, 1986).

Por fim, no Capítulo 7, "Considerações finais", apresentamos uma síntese reflexiva acerca dos resultados obtidos com este estudo. Discutimos nesse momento as respostas obtidas às questões elencadas inicialmente como também a respeito do percurso empregado e dos instrumentos que permitiram a coleta e análise dos dados. Por fim, discorremos a respeito da validade e limitações do estudo aqui proposto, salientando as suas contribuições para o ensino de ciências e para investigações futuras. 


\section{Capítulo 1 - Argumentação e o ensino de ciências}

Como mencionado, a busca por ações de ensino e aprendizagem que favoreçam a formação do cidadão apto a atuar na sociedade contemporânea, formação esta preconizada pelos diferentes documentos que regem a educação em diversos países, conduziu pesquisadores da área de ensino de ciências a se interessar pela argumentação e seu exercício em sala de aula (SIMON, ERDURAN e OSBORNE, 2006; JIMÉNEZ-ALEIXANDRE e ERDURAN, 2008; SASSERON e CARVALHO, 2011; MENDONÇA e JUSTI, 2013). Dessa forma, nas últimas duas décadas, tal temática vem sendo amplamente explorada de modo a estabelecer não somente sequências didáticas ou estratégias que favoreçam seu emprego no espaço formal de ensino (REZENDE e CASTELLS, 2010; HEWSON e OGUNNIYI, 2011; OSBORNE et. al., 2013), como também identificar a qualidade e características dos argumentos empregados por alunos e professores mediante referenciais elaborados para este fim (TEIXEIRA et. al., 2010; AYDENIZ e GÜRÇAY, 2013; ROBERTSHAW e CAMPBELL, 2013; OROFINO e TRIVELATO, 2015). Tais referenciais permitem o acesso à qualidade dos argumentos e, assim, é possível inferir sobre medidas que possam ser adotadas nos espaços de ensino. De forma geral, os diferentes estudos sugerem a contribuição do exercício da argumentação não somente para a compreensão de conteúdos científicos, como também para o desenvolvimento de competências investigativas, epistemológicas e de tomada de decisão dos alunos.

No entanto, se faz interessante diferenciar a argumentação de uma simples explicação. Segundo o Novo Dicionário Aurélio da Língua Portuguesa (FERREIRA, 2009), argumentar consiste, dentre outros significados, em apresentar argumentos e sustentar controvérsias. E o argumento diz respeito ao raciocínio, indício ou prova pelo qual se tira uma consequência ou dedução. Em contrapartida, segundo o mesmo dicionário, explicar se limita em tornar inteligível ou claro o que é ambíguo ou obscuro.

Quanto à definição do Dicionário Online da Língua Portuguesa ${ }^{1}$, a explicação restringe-se ao ato de explicar, desenvolver, fazer compreender. Enquanto que o argumento diz respeito ao meio usado para persuadir, para tentar convencer alguém fazendo com que esta pessoa mude de ponto de vista ou de maneira de agir. Para Kunh (1991), portanto, o argumento é uma afirmação acompanhada de uma justificativa, e quando o indivíduo argumenta, não somente faz uso de seus conhecimentos científicos, como também emprega aspectos retóricas almejando convencer o interlocutor.

\footnotetext{
${ }^{1}$ Disponível em: https://www.dicio.com.br/
} 
No que diz respeito às definições para argumentação encontradas na literatura, no campo da lógica formal, Bricker e Bell (2008) a definem como o meio pelo qual é gerado um produto (argumento), e este é concebido para apoiar conclusões que podem ser validadas dedutivamente. Ainda no trabalho desses autores, com suporte nas ideias de van Eemeren e Grootendorst (2004), verifica-se que a argumentação é uma atividade essencialmente verbal, social e racional. Verbal na medida que faz uso da linguagem falada e/ou escrita para ser produzida; social pois consiste em um processo que envolve duas ou mais pessoas; e racional pois almejando defender um ponto de vista de tal forma que este se torne aceitável para um crítico, o indivíduo apresenta um conjunto de proposições que justificam ou refutam a alegação expressa.

No mais, Jiménez-Aleixandre (2010) define o processo de argumentação como:

Argumentar consiste em ser capaz de avaliar as afirmações baseadas em evidências, isto é, reconhecer que conclusões e afirmações científicas devem ser justificadas, em outras palavras, apoiadas por evidências. O argumento é uma ferramenta que temos para avaliar o conhecimento (JIMÉNEZ-ALEIXANDRE, 2010, p. 23, tradução nossa).

\subsection{Contribuições da inserção de práticas argumentativas no ensino de ciências}

No ensino de ciências, Jiménez-Aleixandre e Brocos (2015) apresentam duas caracterizações relevantes da argumentação, sendo essas a avaliação de conhecimentos à luz de evidências disponíveis, e a persuasão da audiência. Com base nos três tipos de práticas epistêmicas da comunidade científica propostas por Kelly (2008) (produção, avaliação e comunicação do conhecimento), a argumentação corresponderia à prática de avaliação, embora os três tipos estejam relacionados entre si. Dessa forma os autores apresentam o esquema expresso na Figura 1 elaborado previamente por Jiménez-Aleixandre (2011). 
Figura 1 - A argumentação enquadrada no processo de construção do conhecimento científico, na perspectiva de Jiménez-Aleixandre.

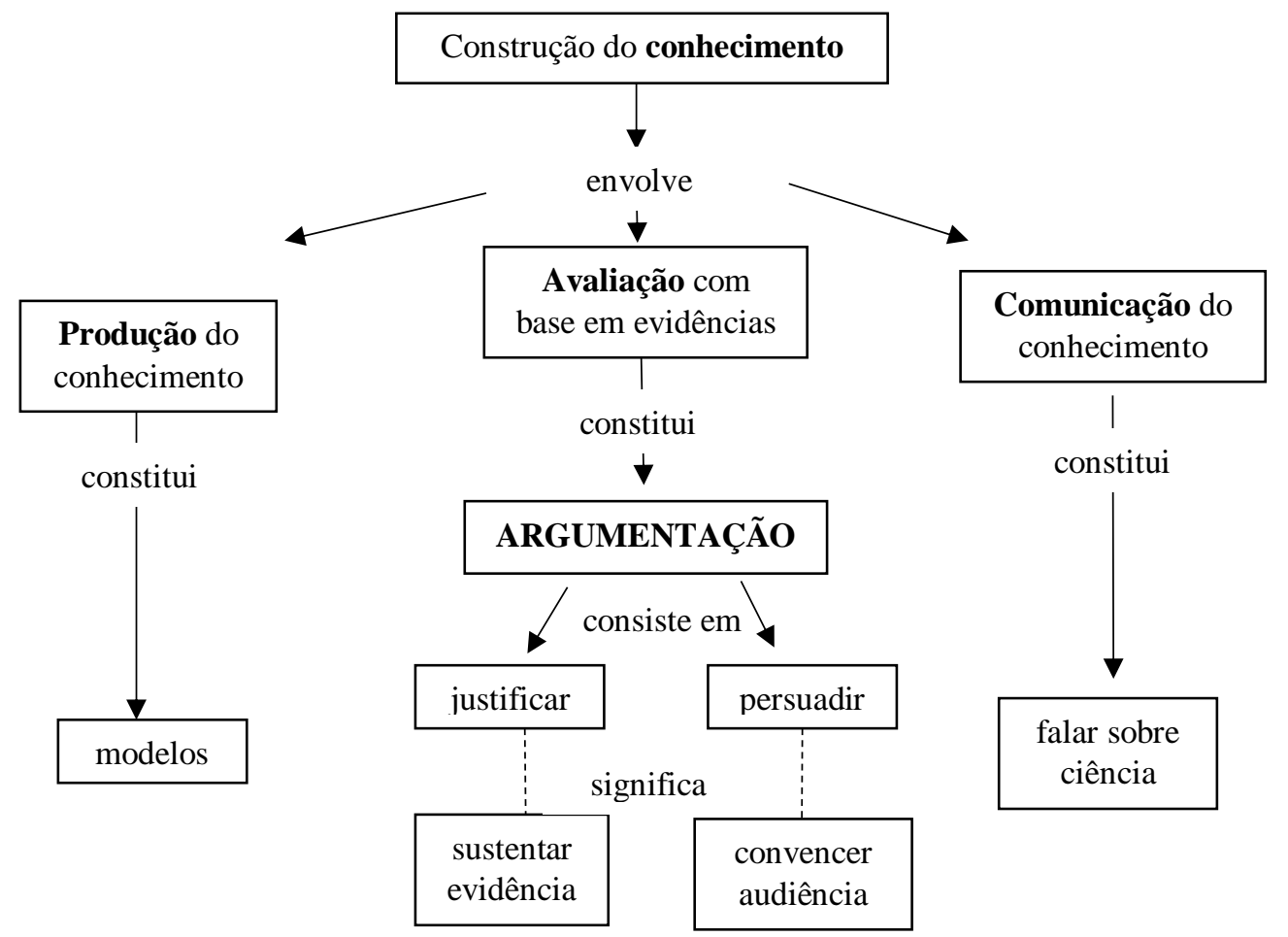

Fonte: Adaptado de Jiménez-Aleixandre; Brocos (2015)

Nessa perspectiva, de acordo com Duschl et. al. (2007), corroborado pelo esquema proposto por Jiménez-Aleixandre (2011), a argumentação é uma prática epistêmica central em ciências. Dessa forma, a sua promoção em salas de aula consiste em uma estratégia relevante para aproximar os educandos do processo natural do desenvolvimento cientifico, isto é, da prática científica e de sua natureza.

Em sua obra "Ciência em Ação: como seguir cientistas e engenheiros sociedade afora" Bruno Latour (2000), por exemplo, destaca o papel das controvérsias para esse desenvolvimento, e a importância que adquire a retórica nesse processo. Para o autor, para sobreviver no meio científico, e almejando que afirmações se tornem fatos e virem "caixaspretas", os cientistas devem negociar, convencer aliados, arregimentar argumentos de autoridade etc. Ou seja, argumentar/discutir é o processo pelo qual o conhecimento científico é desenvolvido e verificado e, assim, de acordo com Dawson e Venville (2010, p. 134), “quando estudantes se envolvem em discussões, eles começam a entender as normas, a linguagem científica, e como o conhecimento é construído na ciência"

Newton, Driver e Osborne (1999) também sugerem outras duas razões para a inserção de práticas argumentativas no ensino de ciências. Para estes autores, além desse ser um processo 
natural pelo qual ocorre o desenvolvimento da ciência, quando os alunos argumentam sobre determinado fenômeno, para explicar conceitos ou tomar decisões, ocorre o aprendizado científico, uma vez que, ao falar ou escrever sobre ciência, o estudante irá construir um entendimento conceitual. Por fim, ao encontro da formação completa do educando, os autores sugerem ainda que as habilidades de argumentação desenvolvidas têm valor além da educação científica propriamente dita. Nas palavras de Dawson e Venville (2010):

"A habilidade dos jovens raciocinarem, pensarem criticamente, entender e
apresentarem argumentos de forma lógica e coerente, oralmente e na escrita, permite-
os a participar plenamente na sociedade, o qual é um resultado desejável da educação
em uma sociedade democrática (DAWSON; VENVILLE, 2010, p. 134).

Corroborando e incrementando a ideia desses autores, ao estabelecerem motivos para inserção da argumentação em salas de aula de ciências, Jiménez-Aleixandre e Erduran (2008) propõem que existem ao menos cinco potenciais contribuições advindas dessa prática no espaço formal de ensino. São elas: evidenciar e caracterizar os processos cognitivos, isto é, por meio da argumentação o indivíduo externaliza suas ideias e concepções, o que contribui para o exercício de processos cognitivos de alta ordem; desenvolver competências investigativas e pensamento crítico por meio de um processo de reflexão sobre si mesmo e o mundo, e na busca por justificativas que sustentem suas opiniões; alcançar o letramento científico ao falar e escrever sobre ciência em movimentos retóricos almejando persuadir o interlocutor; enculturação de práticas da ciência por meio do desenvolvimento de critérios epistêmicos; e desenvolvimento de raciocínio e critérios lógicos. Em síntese, partindo do pressuposto apresentado no esquema da Figura 1 em que a argumentação consiste em justificar e persuadir, suas potenciais contribuições para a educação científica estão evidenciadas no esquema proposto pelos autores, apresentado na Figura 2. 
Figura 2 - Potenciais contribuições da argumentação na perspectiva de Jiménez-Aleixandre e Erduran (2008)

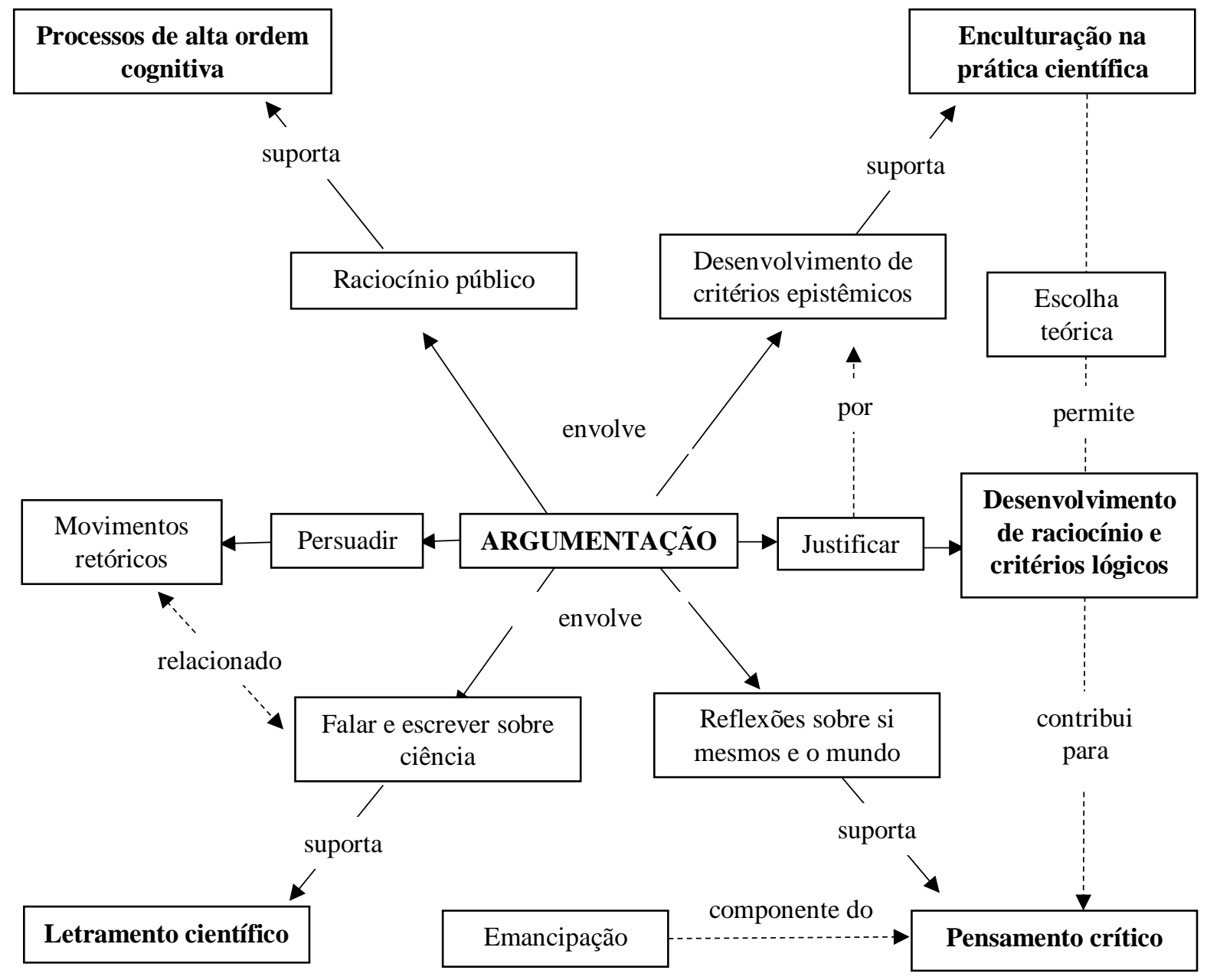

Fonte: Adaptado de Jiménez-Aleixandre e Erduran (2008) (tradução nossa)

Essas considerações, portanto, conduzem, de acordo com Jiménez-Aleixandre (2010), a três tipos de objetivos que podem ser alcançados com a argumentação em sala de aula. $\mathrm{O}$ primeiro, de caráter transversal, se relaciona com a melhoria dos processos de aprendizagem, ou seja, em aprender a aprender. Assim sendo, o exercício da argumentação auxilia no desenvolvimento de uma competência que confere ao educando a capacidade para continuar a aprender por toda a vida de maneira eficaz e autônoma.

O segundo objetivo, também de caráter transversal, consiste na formação para a cidadania, em que o educando se torna capaz de participar das decisões sociais exercendo o pensamento crítico, que, de acordo com o esquema da Figura 2, envolve o raciocínio independente do indivíduo que reflete sobre si mesmo e sobre a realidade, de forma a contribuir para a sua melhora. 
Por fim, o terceiro objetivo diz respeito ao desenvolvimento de competências relacionadas ao trabalho na comunidade científica, isto é, por meio da compreensão de aspectos da natureza da ciência. De forma geral, o contato dos educandos com práticas argumentativas os auxilia a aprender a comunicar, a falar e escrever usando linguagens cientificas (LOURENÇO, 2013).

Dessa forma, a inserção de práticas argumentativas se torna valiosa para a educação científica, o que reforça, portanto, o interesse de diversos pesquisadores pela temática. Nessa perspectiva, diferentes trabalhos de revisão estão voltados para discussões a respeito do conhecimento produzido sobre a argumentação no ensino de ciências (SÁ e QUEIROZ, 2011; SAMPSON e BLANCHARD, 2012; MENDONÇA e JUSTI, 2013).

Com foco em produções que tivessem relação explícita com argumentação e o processo de ensino e aprendizagem em salas de aula de ciências, Mendonça e Justi (2013) apresentam algumas considerações sobre trabalhos publicados em periódicos, anais de congresso e livros, nacionais e internacionais, até o ano de 2012. De forma geral, os autores constataram que a maior parte das pesquisas envolvendo a argumentação e a visão de ciência tem analisado: o uso de dados pelos estudantes em seus argumentos; os tipos de justificativas mais utilizadas pelos estudantes para respaldar suas afirmações; e como os alunos fazem uso da persuasão para convencer os demais sobre suas escolhas teóricas. Também foram verificadas menções em diferentes trabalhos sobre as relações entre visão de ciência e contraargumentação.

A partir dessa revisão, os autores concluem a inexistência de espaços para a argumentação em sala de aula de ciências. Essa inexistência vai ao encontro da visão predominante dos professores como transmissores de conhecimentos, os quais pouco aproveitam essa atividade como favorável à externalização de crenças epistemológicas dos sujeitos, o que conforme evidenciado pelo esquema da Figura 2, suporta processos cognitivos de alta ordem em sala de aula. Ademais, predomina também a visão de ciência como algo estático e absoluto, sendo transmitida como uma retórica de conclusões.

Nessa perspectiva, ainda que a formação de professores não tenha sido alvo desse levantamento, os autores salientam a importância da discussão de aspectos inerentes à argumentação na formação inicial e continuada de professores, de modo a contribuir para o cotidiano das salas de aula de ciência da educação básica.

Com interesse no contexto nacional envolvendo a argumentação no ensino de ciências, Sá e Queiroz (2011) apresentam uma revisão de trabalhos completos apresentados nos Encontros Nacionais de Pesquisa em Educação em Ciências (ENPEC) até sua sétima edição, 
isto é, no período de 1997 a 2009. Os autores também consideraram publicações em revistas nacionais das áreas de Educação e Educação em Ciências.

Foram encontrados 43 trabalhos nesse estudo, sendo 12 em periódicos nacionais e 31 nas diferentes edições do ENPEC. O que se verificou foi uma expansão de trabalhos envolvendo a temática a partir do ano de 2007, quando, nos anais da última edição do ENPEC analisado pelos autores, por exemplo, foram encontrados 16 dos 31 trabalhos, ou seja, 51,6\% de todas as produções se apresentaram apenas em uma das setes edições consideradas na revisão.

Também se observa, além de um predomínio de trabalhos endereçados para o ensino médio, um maior número de trabalhos voltados para o ensino de física, que por ser uma área consolidada a mais tempo, apresenta um grande predomínio de publicações em periódicos "qualizados".

Ademais, foram identificados sete focos temáticos para os trabalhos, os quais são: estratégias promotoras da argumentação; formação de professores; elaboração de modelos; espaço para argumentação; mecanismos de ensino de argumentação; levantamento bibliográfico; análise de material didático.

Com relação às estratégias promotoras da argumentação, oito dos 25 trabalhos se encontram em periódicos, e desses, seis contam com a abordagem de aspectos científicos e apenas dois de aspectos sociocientíficas. Dessa forma, observa-se que embora a inserção de questões de natureza sociocientifica seja bastante recomendada por pesquisadores de diversas áreas de ensino, com produção abundante na literatura internacional, poucos trabalhos analisados em contexto nacional apresentam esse tipo de abordagem.

De acordo com essa variedade de trabalhos existentes no âmbito internacional, a inserção de aspectos de natureza sociocientífica em sala de aula permite a discussão de tópicos relevantes não somente para a aprendizagem do conteúdo científico, como também para o desenvolvimento moral dos educandos e a formação de cidadãos que compreendam a natureza da ciência $(\mathrm{NdC})$, suas aplicações e as implicações sociais, econômicas e políticas do conhecimento científico. Assim sendo, face a essas considerações e às constatações de Sá e Queiroz (2011), a argumentação diante de questões dessa natureza é um campo de investigação interessante e ainda pouco explorado nacionalmente.

A revisão empreendida por esses autores também permitiu a localização de um outro levantamento bibliográfico (WINCH e TERRAZAN, 2007), em que fica evidente a grande preocupação na compreensão da linguagem utilizada por professores de modo a estimular os alunos a expressar e a defender seus pontos de vista. Os autores desse trabalho ressaltam que, 
ao mesmo tempo que professores se mostram interessados em desenvolver as habilidades argumentativas dos educandos, há uma falta de uma melhor preparação desses docentes quanto ao tipo de discurso a ser empregado em sala de aula, e como conduzir as discussões envolvendo esse processo. Essa constatação, portanto, entra em consonância com a conclusão de Mendonça e Justi (2013) a respeito da importância da abordagem de aspectos próprios do processo de argumentação na formação inicial e continuada de professores. E nessa perspectiva discorremos na sequência a respeito da patente necessidade de mais práticas argumentativas em contexto de formação de professores de ciências.

\subsection{A necessária inserção de práticas argumentativas no âmbito da formação de professores de ciências}

De acordo com o que vem sendo exposto, para formar alunos que possam processar e avaliar informações científicas, de modo a coordenar evidências e teorias, a argumentação é uma forma de discurso que precisa ser por eles apropriada. Para isso, portanto, são necessários professores qualificados no sentido de compreender e valorizar esse tipo de atividade como uma forma viável de promoção de aprendizagem significativa em ciências.

No entanto, a partir das revisões bibliográficas empreendidas por Mendonça e Justi (2013) e Sá e Queiroz (2011), emerge da literatura a necessidade de maiores esforços voltados para a formação destes professores. Nessa perspectiva, Sampson e Blanchard (2012), apresentam, a partir de uma revisão bibliográfica, considerações a respeito da relação entre argumentação e a formação de professores em ciências.

De acordo com os autores, há um grande número de pesquisas focadas em como os estudantes participam da argumentação, como estes desenvolvem suas explicações e a natureza dos seus argumentos. No entanto, há relativamente poucos estudos que têm examinado tais questões com um olhar direcionado aos professores, isto é, como os docentes, responsáveis por promoverem esse tipo de atividade em sala de aula, participam do processo argumentativo, desenvolvem explicações, e qual é a natureza dos argumentos por eles empregados. Além disso, na percepção dos autores, há poucos estudos destinados a averiguar a relação entre as concepções dos professores e do que ocorre em sala de aula quando estes tentam promover e apoiar a participação dos seus educandos na argumentação científica.

Nesse sentido, Sampson e Blanchard (2012) partem do pressuposto de que compreender o que os professores e futuros professores sabem sobre a argumentação e suas impressões sobre o seu papel no ensino de ciências é de grande relevância, uma vez que as 
ações a serem adotadas em sala de aula da educação básica dependem do que os docentes sabem a respeito, e de como valorizam e decidem usar tais estratégias. Ou seja, o que professores sabem a respeito de argumentação pode influenciar a natureza das atividades em sala de aula e na forma como os estudantes aprendem.

A partir dessa revisão da literatura, verificou-se que a maioria dos professores de ciências não engaja os estudantes em atividades envolvendo a argumentação científica em sala de aula. Dessa forma, os autores apresentam duas possíveis explicações para isso: o limitado conhecimento pedagógico dos professores e a escassez de recursos instrucionais voltados para a temática.

No entanto, dada à vasta quantidade de trabalhos que sugerem que os professores de ciências tendem a valorizar a explicação de conceitos, e de que estes muitas vezes possuem uma compreensão inadequada da natureza da ciência, ou da natureza da investigação científica, Sampson e Blanchard (2012) ressaltam a existência de outros obstáculos que dificultam a integração da argumentação no processo de ensino e aprendizagem de ciências. Alguns professores, por exemplo, não promovem esse tipo de atividade porque enxergam a ciência como um corpo de conhecimentos acabados a ser aprendido pelos alunos, e ainda a argumentação seria ineficaz para que os estudantes aprendam o conteúdo científico.

Também pode ser um obstáculo para a inserção da argumentação, o fato de professores não saberem como participar nesse processo, e não entenderem como a argumentação científica difere da natureza da argumentação que ocorre em outros contextos ${ }^{2}$. Dessa forma, os autores salientam a necessidade de pesquisadores e formadores de professores de ciências aprenderem mais sobre o que estes sabem sobre argumentação científica, e o que pensam sobre as propostas atuais para integrar a argumentação no processo de ensino e aprendizagem.

Em estudo realizado no contexto da formação de professores, Robertshaw e Campbell (2013) também apontam alguns fatores que podem criar obstáculos à inserção de práticas argumentativas em sala de aula da educação básica, são eles: a necessidade de professores em serviço construírem suas práticas de forma a permitir que os alunos exercitem efetivamente habilidades argumentativas, e a necessidade da realização de ações com o intuito de alinhar os compromissos epistemológicos dos professores com os da ciência. Ainda segundo os autores,

\footnotetext{
${ }^{2}$ De acordo com Sampson e Blanchard (2012), pautados nos estudos de Duschl e Osborne (2002), a argumentação científica é uma importante prática científica utilizada na resolução de problemas e para o desenvolvimento do conhecimento. Assim, se diferindo da argumentação que ocorre naturalmente em outros contextos, os autores a definem como uma prática de construção e validação do conhecimento, na qual os indivíduos buscam estabelecer ou validar uma conclusão, explicação ou outra afirmação com base em razões. Nessa perspectiva a argumentação que ocorre no contexto científico envolve, por exemplo, leis, modelos, teorias ou conceitos.
} 
embora existam estudos que investigam formas de auxiliar docentes de ciência em serviço no alcance das necessidades citadas, são ainda escassos estudos que abordam tais questões na formação inicial de professores.

Nessa perspectiva, Archila (2012) apresenta uma revisão de estudos envolvendo a temática com olhar para esta formação inicial. Esse autor defende que devido aos avanços de estudos sobre a questão, os quais expõem alguns benefícios teóricos e práticos da argumentação em ciências, se faz cada vez mais necessária a inclusão desse tipo de atividade em programas e práticas curriculares de formação de professores de ciências.

Essa necessidade, encontra subsídios na ideia de Stipcich et. al. (2006) que ressaltam a importância de formar professores que reconheçam as características mais relevantes da dinâmica própria da construção do conhecimento científico. Considerando, portanto, conforme Jiménez-Aleixandre (2011), que a argumentação consiste em uma prática epistêmica central da ciência, o conhecimento da sua relevância pelos professores é fundamental. Dessa forma, de acordo com Stipcich et. al. (2006), os professores teriam disponíveis ferramentas para que promovam em seus estudantes a construção de uma imagem de ciência contrária a uma ciência acabada e inquestionável em que o debate não tem espaço.

Em estudo teórico, também voltado para a relação da argumentação e a formação de professores de física, Islas, Sgro e Pesa (2009) concluem que dentre as concepções epistemológicas que os docentes têm destaca-se uma visão acerca da dinâmica interna da ciência que não condiz com o que ocorre no cotidiano científico. Segundo os autores, os professores estão habituados a estudar e ensinar em torno de assuntos consensuais, e acabam deixando de lado o processo de produção do conhecimento científico e minimizando suas características sociais, como as disputas internas e os debates sobre as possíveis interpretações para explicar mais adequadamente um fenômeno.

Dessa forma, na percepção dos autores, um professor que compreenda o valor da argumentação na prática científica poderia ajudar seus alunos a entender significativamente, não somente a informação científica, mas também o contexto no qual este é gerado e desenvolvido.

Voltando para o estudo de Archila (2012), este, como base no trabalho de Zohar (2008), afirma que a incorporação de práticas argumentativas em sala de aula da educação básica exige não somente uma reforma do currículo, mas a mudança na visão de professor predominante, como aquela apresentada por Mendonça e Justi (2013), de transmissor do conhecimento que detém as respostas certas, para uma visão de professores como facilitadores da construção da aprendizagem por meio do emprego de práticas argumentativas. 
De forma geral, em seu estudo, Archila (2012) considera haver aportes relevantes para a compreensão geral do papel da argumentação no ensino de ciências, no entanto, o autor conclui que embora a temática da argumentação na formação inicial de professores de ciências tenha surgido como necessidade após desenvolvimentos teóricos e práticos importantes sobre a argumentação para educação científica, ainda são escassos os trabalhos dessa natureza. Ademais, a inclusão de práticas argumentativas na formação inicial contribuiria para a melhoria da qualidade dessa formação, na medida que os futuros professores conceberiam as formas de argumentação não como uma "técnica" da didática da ciência, mas como algo mais complexo que sugere um estudo rigoroso e profundo acerca dessas formas empregadas pelos professores em formação.

No que tange às habilidades argumentativas e às características dos argumentos empregados por professores e futuros professores, diferentes trabalhos indicam a dificuldade dos docentes em apresentar argumentos bem fundamentados diante das mais variadas temáticas, o que sugere, por sua vez, a necessidade de ações voltadas para o desenvolvimento de tais habilidades.

A título de exemplo, Aydeniz e Gurçay (2013) realizaram um estudo com 171 professores de física em formação inicial, de modo a acessar a qualidade dos argumentos escritos produzidos por estes. Para a promoção da argumentação, e envolvendo questão de natureza sociocientífica, os autores solicitaram que os futuros professores desenvolvessem argumentos escritos a favor ou contra a decisão do governo turco em investir em centrais nucleares. O que se identificou foi uma qualidade dos argumentos inferior ao que os autores esperavam: a maioria dos professores, apesar de fornecer provas para justificar suas reinvindicações, não conseguiu coordenar efetivamente evidências e teorias para desenvolver o argumento.

Herawati e Ardianto (2017) também realizaram um estudo envolvendo a argumentação diante de QSC na formação inicial de professores. A questão abordada teve relação com organismos geneticamente modificados $(\mathrm{OGM})$ e as polêmicas em que estão envolvidos. $\mathrm{O}$ estudo foi levado a cabo com dois grupos de licenciandos, sendo estes 28 futuros professores de ciências e 28 futuros professores de outras áreas.

Ao analisar a qualidade dos argumentos empregados pelos estudantes, os autores verificaram que não houve diferença significativa entre os grupos, no entanto, apesar dos futuros professores apresentarem um argumento contendo conclusão, dados e garantias, estes 
possuíam uma coerência limitada, isto é, os dados ou as justificativas empregadas pelos estudantes não eram válidas, ou eram irrelevantes para a conclusão que apresentavam.

Ainda com relação às dificuldades de professores e futuros professores a respeito da argumentação, agora no que tange à argumentação diante de questões científicas, Lourenço, Ferreira e Queiroz (2016) realizaram um estudo com licenciandos matriculados em disciplina de Práticas de Ensino de Química. Os autores analisaram a regência, em contexto de estágio supervisionado, dos futuros professores após estes terem contato com uma abordagem explícita de aspectos da argumentação na referida disciplina. As regências foram gravadas e analisadas à luz do quadro analítico proposto por Simon, Erduran e Osborne (2006), os quais categorizam ações/declarações pró-argumentação em sala de aula.

A partir dessa investigação, Lourenço, Ferreira e Queiroz (2016) identificaram como ações pró-argumentação nas regências dos licenciandos: falar e ouvir (incentiva a discussão entre os alunos e que estes escutem as opiniões dos colegas); posicionar-se na construção de argumentos (encoraja a apresentação de ideias, incentiva o posicionamento diante dessas ideias etc.); justificar com evidências (solicita justificativas para as conclusões dos alunos, avalia e confere se estas são subsidiadas por evidências etc.); e construir argumentos (elabora estratégias de ensino e aprendizagem, como debates, que incentivem a construção de argumentos na forma escrita e oral pelos alunos).

No entanto, ações de natureza mais complexa não foram identificadas, como, por exemplo: conhecer o significado de argumento (define argumento, apresenta alguns exemplos, faz questionamentos sobre a dinâmica envolvida no processo de argumentação); avaliar argumentos (incentiva a avaliação dos argumentos pelos alunos, incentiva a reflexão sobre o que seria um bom argumento etc.); e refletir sobre o processo de argumentação (estimula a reflexão sobre os processos adotados na construção do argumento pelos alunos). Essa constatação ressalta algumas das lacunas na formação de professores, os quais encontram dificuldades em definir o que é argumento, incentivar a reflexão sobre os seus aspectos, bem como avaliar e incentivar a avaliação de argumentos, isto é, conhecer e analisar a sua estrutura básica e, consequentemente a sua adequação.

Assim sendo, face às contribuições teóricas e práticas sugeridas pela literatura, e à necessidade de professores qualificados para o emprego de ações dessa natureza de forma eficaz em sala de aula da educação básica, se torna imperativo envidar esforços no que diz respeito ao contato com práticas argumentativas na formação inicial de professores. Esse contato se torna relevante para que os futuros docentes não somente compreendam a importância da inserção da argumentação em salas de aula do ensino de ciências, como também venham a ser capazes de 
desenvolver as próprias habilidades argumentativas e de reflexão crítica. Afinal, "um professor que aprende a argumentar, ensina para que se aprenda argumentando" (ARCHILA, 2012, p. 368, tradução nossa). Assim sendo, tais contribuições da argumentação, bem como as lacunas identificadas no que diz respeito à formação docente e ao desenvolvimento de suas habilidades argumentativas, buscamos com este trabalho envidar esforços que contemplem as necessidades evidentes de acordo com a literatura, além de ampliar o estudo sobre a temática, a qual constatamos de suma importância para a formação cidadã do indivíduo.

\subsection{Padrão de Argumento de Toulmin (TAP)}

Até agora está claro que a argumentação no ensino de ciências é uma temática relevante para diversos pesquisadores que apontam uma série de benefícios dela provenientes para a formação dos estudantes, tanto da educação básica quanto do ensino superior. No entanto, quando consideramos estudos como de Lourenço, Ferreira e Queiroz (2016), e de Aydeniz e Gurçay (2013), concluímos que ainda existem diversas lacunas a serem contempladas por pesquisadores interessados pela temática.

Dentre as lacunas, Lourenço, Ferreira e Queiroz (2016) destacam em seu estudo a dificuldade de professores em formação avaliarem argumentos e, consequentemente abordarem esse aspecto do processo argumentativo em sala de aula. Contudo, assumindo que para avaliar argumentos e identificar a sua adequação para determinadas situações o indivíduo deve conhecer os elementos que os compõem, podemos inferir que aí está outra dificuldade para alunos e professores.

Dessa forma, para entendermos melhor sobre os elementos necessários em um bom argumento, recorremos a definições apresentadas para o que seria um argumento/argumentação, em especial as colocações de Jímenez-Aleixandre (2010). Das colocações propostas pelo autor, destacamos que a argumentação consiste em um processo de avaliação com base em evidências, que envolve não somente justificar um ponto de vista, como também persuadir, convencer uma audiência a respeito da posição adotada diante de uma situação. A partir dessa definição podemos inferir que um argumento deve conter ao menos uma justificativa com base em uma ou mais evidências para convencer uma plateia e, assim, ressaltamos novamente a argumentação como uma atividade social.

Nessa perspectiva diversos autores se interessaram nas últimas décadas em desenvolver e empregar modelos que subsidiassem a análise da qualidade dos argumentos. $\mathrm{E}$ desses estudos observa-se um vasto uso do modelo elaborado por Stephen Toulmin (2001), o qual inicialmente direcionado para a área de direito passou a ser empregado por esses 
pesquisadores na área do ensino de ciências. Esse modelo, o TAP, permite o acesso à qualidade estrutural dos argumentos apresentados.

Em sua amplamente conhecida obra "Os usos do argumento" (2001), Toulmin apresenta diversas considerações a respeito da argumentação em contexto jurídico, o que, no entanto, trouxe diversas contribuições à área de ensino de ciências. Nessa obra, o autor sugere que o argumento envolve duas estruturas, uma mais bruta (anatômica), isto é, o argumento como produto em uma ou mais páginas, em que as fases principais estão distribuídas em parágrafos, e uma mais fina (fisiológica) em que a validade dos argumentos tem de ser estabelecida ou refutada. É para essa estrutura mais fina que direcionaremos nosso olhar, ou seja, no que Toulmin (2001) denominou como o layout dos argumentos.

Segundo o autor, um argumento tem inicialmente uma estrutura básica composta por dado (D), justificativa (J) e conclusão (C). No que diz respeito a cada um desses elementos, Toulmin (2001) define como dados, os fundamentos nos quais se baseiam uma alegação (conclusão). Embora associemos dados a números, porcentagens etc., estes podem assumir um caráter qualitativo. Utilizando um dos exemplos apresentados por Toulmin (2001), suponhamos que afirmemos que Harry é um súdito britânico, esta alegação pode ser desafiada, e a menos que a tenhamos feita de modo irrefletido e irresponsável, teremos alguns fatos (dados) que podem apoiar a nossa alegação, no caso o fato de Harry ter nascido em Bermudas.

No entanto, conforme resultados obtidos por Herawati e Ardinato (2017) em estudo envolvendo a argumentação na formação inicial de professores, estudantes dos mais variados níveis de ensino têm dificuldade em relacionar dados com conclusões, o que exige mais práticas em espaços formais de ensino de atividades que promovam esse exercício. E é nessa perspectiva que tomamos contato com a necessidade do emprego de justificativas ou garantias (J) no argumento.

$\mathrm{Na}$ alegação apresentada no caso de Harry, alguém pode pedir que não acrescentemos novas informações, ou dados, mas que indiquemos a relação entre esses dados e a conclusão. As justificativas são, portanto, responsáveis por estabelecer essa ponte, ou seja, o seu papel é mostrar que a conclusão feita a partir dos dados é adequada e legítima. Isto exposto, para o exemplo adotado, partindo do fato que Harry nasceu em Bermudas, podemos concluir que ele é britânico, pois um homem nascido nas Bermudas é súdito britânico. No entanto, pode haver alguma dúvida quanto a distinção entre dados e justificativas, e para isso Toulmin (2001) indica que recorramos aos primeiros de modo explícito (local de nascimento) e ao segundo de modo implícito (o que podemos concluir a partir do local de nascimento). Assim sendo o esqueleto base de um argumento é apresentado na Figura 3. 
Figura 3 - Esqueleto básico de um padrão para analisar argumentos de acordo com Toulmin (2001).

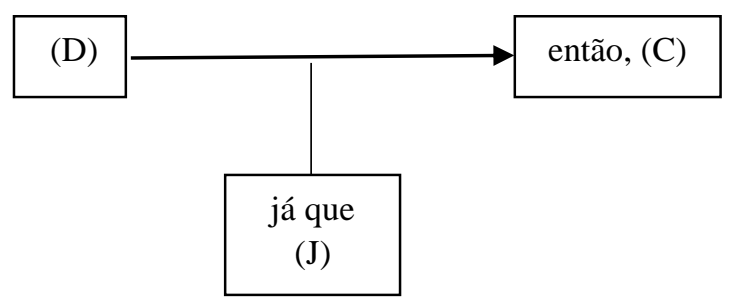

Fonte: Toulmin (2001, p. 143)

Contudo, outros elementos podem ser adicionados ao esqueleto apresentado na Figura 3, de modo a torná-lo mais completo. Por exemplo, de acordo com Toulmin (2001), existem garantias de diversos tipos, as quais podem conferir diferentes graus de força às conclusões que justificam. Algumas permitem aceitar inequivocamente determinada alegação, e para esses casos o emprego de qualificadores modais (Q) como o advérbio "necessariamente" pode ser adequado e reforçar o grau de certeza da conclusão apresentada. Geralmente na forma de advérbios, os qualificadores modais modulam o argumento expressando o grau de força que os dados conferem à alegação em virtude da garantia. Em outro caso, em que a justificativa permite traçar apenas provisoriamente a ponte entre dado e conclusão, isto é, sob certas condições com exceções ou qualificações, qualificadores, como "provavelmente" e "possivelmente", podem ser adequados.

Nesse sentido, outro elemento se apresenta, e diz respeito às condições de exceção ou refutação (R), as quais indicam circunstâncias em que tem de se deixar de lado a autoridade geral da justificativa. Ao regressarmos, portanto, ao esqueleto básico do argumento proposto por Toulmin (2001), ao passo que (Q) indica a força conferida pela garantia podemos escrevêlo imediatamente ao lado da conclusão, e como $(\mathrm{R})$ indica as condições capazes de invalidar a conclusão garantida, o colocamos imediatamente abaixo do qualificador no esquema.

Considerando novamente o exemplo de Harry, o argumento de que ele é britânico uma vez que nasceu em Bermudas, e que todos que nascem em Bermudas são súditos britânicos, não é conclusivo pois não mencionam a possibilidade de ele ter ou não mudado de nacionalidade em algum momento da sua vida em virtude da sua ascendência. Dessa forma, a garantia empregada permite apenas presumir a alegação e, surge nesse caso, o advérbio "presumivelmente" como qualificador modal, cuja refutação é a possibilidade de seus pais serem estrangeiros e ele ter adotado outra cidadania.

Por fim, como último elemento do padrão de argumento proposto por Toulmin (2001), surgem os apoios às justificativas, os quais o autor denomina de backings e que convencionou 
ser indicado por (B) mesmo por alguns pesquisadores nacionais. Na construção de um argumento, alguém pode colocar em dúvida se a garantia empregada é de algum modo aceitável. Dessa forma, o autor sugere que por trás da cada garantia normalmente haverá outros avais que podem ser tomados como apoio a elas. Assim sendo, os backings ou conhecimentos básicos dão sustentação às justificativas por meio de conhecimentos teóricos ou empíricos, modelos, leis ou teorias (JIMÉNEZ-ALEIXANDRE, 2010).

O que diferencia, portanto, os backings das justificativas é que, enquanto as garantias são afirmações hipotéticas, afirmações pontes que relacionam dados e conclusões, os apoios a elas representam afirmações categóricas de fato. Porém, quando consideramos (B) e (D) observamos que ambos dizem respeito a informações de fato e isso pode implicar em alguma confusão quanto à distinção desses dois elementos. No que tange a essa questão, Toulmin (2001) afirma que, embora ambos possam ser afirmados como informações verdadeiras, os papéis que desempenham no argumento são decididamente diferentes e nesse sentido o autor salienta a possibilidade de haver argumento sem apoios, o que não é possível sem a existência de dados:

Para haver argumento é preciso apresentar dados de algum tipo; uma conclusão pura, sem quaisquer dados apresentados em seu apoio, não é um argumento. Mas o apoio das garantas que invocamos não tem de ser explicitado, pelo menos para começar; as garantias podem ser aceitas sem desafio, e seu apoio pode ser deixado subentendido (TOULMIN, 2001, p. 152).

Diante dessas considerações o esquema apresentado na Figura 3 pode ser estendido para o que está representado na Figura 4, o qual consiste, portanto, no TAP.

Figura 4 - Padrão de Argumento de Toulmin (2001).

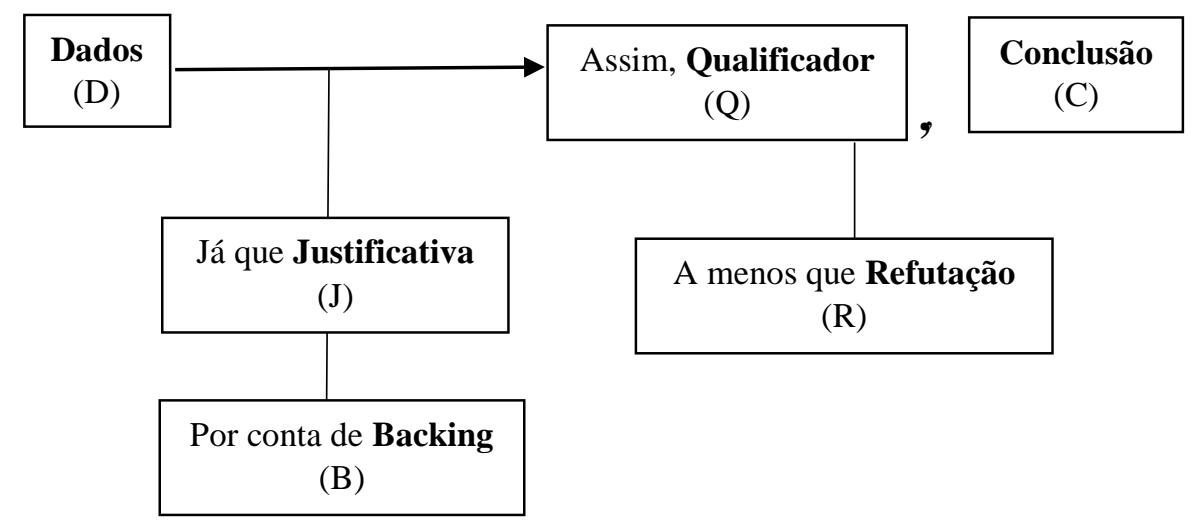

Fonte: Toulmin (2001, p. 143)

Nessa perspectiva, para o exemplo citado de Harry teríamos como esquematizado na Figura 5. 
Figura 5 - O caso de Harry na perspectiva do Padrão de Argumento de Toulmin (2001).

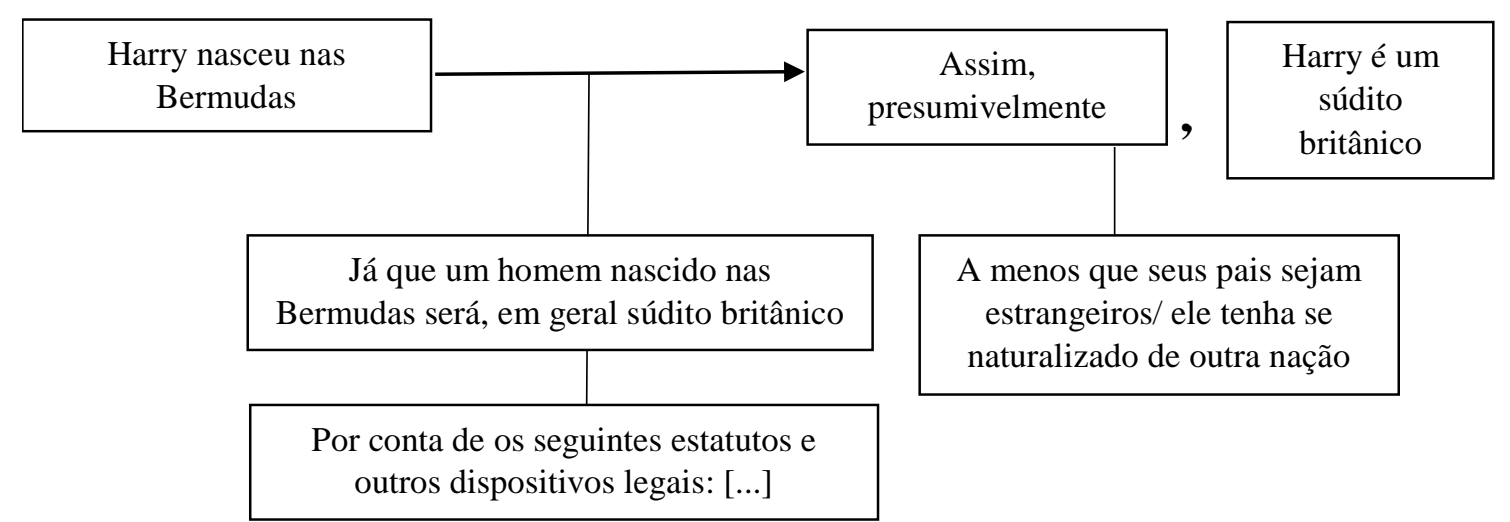

Fonte: Toulmin (2001, p. 143)

Diante dessas considerações de Toulmin (2001), diversos pesquisadores interessados em analisar as características dos argumentos, tanto de alunos como de professores (em atividade ou em formação), fizeram uso do TAP ou adaptações, como é o caso de Vieira e Nascimento (2007). Em seu estudo os autores investigaram um episódio argumentativo na formação inicial de professores diante de uma questão de natureza científica, isto é, o repouso mecânico.

Segundo Vieira e Nascimento (2007), a escolha pela investigação da argumentação sobre esse tema surge do fato que a definição de repouso comumente encontrada na literatura conduz a interpretações equivocadas devido à ausência ou inadequada formalização conceitual dessa noção. Nesse contexto, em aula da disciplina de Práticas de Ensino de Física, os autores analisaram um episódio que contou com a participação de quatro licenciados além do professor formador. Para explicitar e analisar os argumentos do ponto de vista estrutural foi empregado o TAP (TOULMIN, 2001).

Diante dos resultados obtidos, Vieira e Nascimento (2007) concluíram que a análise dos argumentos orais, segundo o TAP, permitiu contemplar alguns elementos discursivos na fala do formador que foram apropriados pelos licenciados, principalmente no que diz respeito às garantias e refutações de definições opostas para o tema abordado, o repouso mecânico. No que diz respeito à promoção da argumentação, os autores consideram que a ambiguidade semântica da noção de repouso foi fundamental para que esta ocorresse em sala de aula, uma vez que as suas diferentes conceituações cumpriram papéis bem definidos em quase todos os argumentos.

No que diz respeito ao uso do TAP para a análise de argumentos elaborados diante de QSC, Sá, Kasseboehmer e Queiroz (2014) apresentam uma atividade em curso de Bacharelado 
em Química, envolvendo estudos de caso. Nesse trabalho os autores solicitaram, a duas turmas distintas, a resolução de casos investigativos de caráter sociocientífico, no entanto, em uma dessas turmas, antes da apresentação oral da solução, houve o emprego de uma série de atividades que versavam sobre os elementos que constituem um "bom" argumento na perspectiva de Toulmin (2001). Dentre as atividades empregadas pelos autores temos: jogo argumentativo que envolvia a argumentação sobre o porquê do merecimento de uma caixa de chocolates pela equipe; identificação de componentes argumentativos em artigos de DC; atividade escrita baseada em leitura de artigo científico.

Nesse sentido, os autores realizaram uma análise comparativa da estrutura dos argumentos identificados nas apresentações orais dos grupos pertencentes às diferentes turmas, uma que teve acesso à exposição sobre o TAP e outra que não. Dessa forma, Sá, Kasseboehmer e Queiroz (2014) concluíram que as orientações oferecidas a uma das turmas sobre como argumentar surtiram efeito positivo na argumentação dos grupos. Assim, em consonância com o que foi encontrado na literatura pelos autores, e reafirmando as observações, aqui já abordadas, de Lourenço, Ferreira e Queiroz (2016), Sá, Kasseboehmer e Queiroz (2014) enfatizam que além do papel desempenhado pelo professor e pelos alunos no contexto de realização de atividades didáticas que se caracterizam como problemas autênticos, o oferecimento de instruções que permitam aos educandos o entendimento sobre a estrutura de um "bom" argumento é relevante para a ocorrência da argumentação.

No entanto, algumas limitações envolvendo o TAP e seu emprego em sala de aula são citadas. Para Vieira e Nascimento (2007), por exemplo, este desconsidera o contexto em que os argumentos são construídos e a falta de precisão de julgamento dos mesmos. Outro aspecto relevante, e que o TAP não envolve, principalmente no ambiente em que o estudo desses autores foi levado a cabo, é a construção coletiva dos argumentos, uma vez que em uma discussão oral as falas dos alunos se complementam, além disso, é esse aspecto coletivo um elemento fundamental das explicações científicas.

Nesse sentido, o TAP por ser amplamente empregado no ensino de ciências, tem atraído um olhar crítico de diversos pesquisadores da área. Nessa perspectiva, Ogunniyi (2007) também apresenta algumas críticas com relação ao TAP. Dentre elas a própria distinção entre dados e justificativas, mesmo Toulmin (2001) afirmando que o primeiro elemento se apresenta sempre na forma explícita e o segundo, servindo como ponte entre dado e conclusão, permanece implícito.

Outra crítica ao Modelo de Toulmin (2001) diz respeito à validade dos dados, isto é, se podemos aceitar ou não um conjunto de dados que formam a base de uma reivindicação sem 
considerar as premissas subjacentes ou construtos teóricos que dão a tais dados significados específicos. Ogunniyi (2007) ainda salienta que essa vem sendo uma situação frequente na ciência, em que um conjunto de resultados ou evidências empíricas favoráveis pode não explicar completamente uma afirmação sobre a(s) causa(s) de um dado fenômeno. E também uma alegação pode ser falsa, mesmo que as provas ou garantias sejam verdadeiras. No mais, o autor afirma que existem diferentes tipos e níveis de argumentos os quais desempenham uma variedade de funções e, portanto, utilizar um único modelo para representar todas as formas de argumentos não parece plausível.

Kelly e Takao (2002) também apresentam considerações a respeito do TAP. De acordo com os autores, estudos anteriores evidenciaram alguns problemas metodológicos do seu emprego salientando que enquanto o TAP faz uma distinção entre dados, justificativas, e backings o esquema é limitado a estruturas relativamente pequenas e alguns dos seus elementos, como enfatizado por Ogunniyi (2007), apresentam ambiguidades. Para estes autores, portanto, esse modelo não leva a julgamentos sobre a adequação ou validade do argumento. Dessa forma para além do ponto de vista estrutural, Kelly e Takao (2002) sugerem que os argumentos produzidos pelos educandos devam ser analisados sob uma ótica epistêmica.

Assim sendo, diversos autores têm apresentado adaptações do Modelo de Toulmin (2001), como aquela proposta por Jiménez-Aleixandre, Castro e Pérez (1998), os quais, considerando todos os elementos do TAP, especificam os diferentes tipos de dados, afirmações ou enunciados que podem compor os argumentos em sala de aula. Os autores sugerem subcategorias com relação ao elemento "dado" do Modelo de Toulmin (2001), o qual pode ser classificado, por exemplo, como dado fornecido, que como sugere o nome é fornecido ao aluno pelo professor, livro e/ou texto ou roteiro de experimentos. $\mathrm{O}$ dado pode ainda ser classificado como obtido, o qual pode ser proveniente de fontes empíricas, isto é, de experimentos realizados pelos próprios alunos em laboratório, ou dado hipotético, advindo de uma atividade ou situação problema.

Outra adaptação do modelo diz respeito à análise dos argumentos proposta por Erduran, Simon e Osborme (2004), os quais afirmam:

Apesar do uso do TAP em estudos anteriores ter fornecido informações valiosas sobre o raciocínio e argumentação dos estudantes, não se produziu muito discernimento sobre como a qualidade do discurso argumentativo pode progredir por meio de intervenções em sala de aula ou até mesmo como TAP pode ser utilizado para monitorar essa mudança [...]. Nós consideramos uma fraqueza significativa que o uso do TAP como indicador da melhora da qualidade da argumentação tem sido pouco estudado na educação científica. Uma das consequências é que nós temos pouco conhecimento sobre como, por exemplo, o TAP pode ser usado como indicador 
quantitativo bem como qualitativo da argumentação ao longo do tempo (ERDURAN, et. al., 2004, p. 920, tradução nossa).

Dessa forma, para análise da qualidade estrutural dos argumentos Erduran, Simon e Osborne (2004) observam a combinação dos componentes do argumento segundo Toulmin (2001). Logo, combinações que possuem um maior número de elementos são típicas de um argumento mais complexo e bem elaborado, conforme sintetizado no Quadro 1.

Quadro 1 - Grau de complexidade dos argumentos proposto por Erduran, Simon e Osborne (2004).

\begin{tabular}{|c|c|c|}
\hline \multirow{7}{*}{ 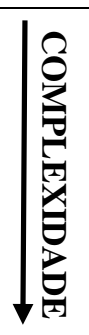 } & Combinação dos elementos & $\begin{array}{c}\text { Código da } \\
\text { combinacão }\end{array}$ \\
\hline & Conclusão/Dado/Justificativa & CDJ \\
\hline & Conclusão/Dado/Justificativa/Backing & CDJB \\
\hline & Conclusão/Dado/Justificativa/Refutação & CDJR \\
\hline & Conclusão/Dado/Justificativa/Qualificador Modal & CDJQ \\
\hline & Conclusão/Dado/Justificativa/Backing/Qualificador Modal & CDJBQ \\
\hline & Conclusão/Dado/Justificativa/Backing/Qualificador Modal/Refutacão & CDJBQR \\
\hline
\end{tabular}

Conforme ilustra o Quadro 1, os autores consideram a presença de refutações um indicador significativo para a qualidade do argumento, uma vez que a refutação e como ela se opõe ao discurso do outro indivíduo obriga ambos a avaliar a validade e a força desse argumento. No mais, não há, para os autores, diferença entre duas alegações que apresentem uma mesma combinação de elementos, por exemplo, seriam nessa perspectiva equivalentes dois argumentos em que se verifique a sequência CDJB, mesmo que em um exista apenas uma justificativa e em outro três.

Contudo, concordamos com Sá, Kasseboehmer e Queiroz (2014) e consideramos essa uma limitação do que é proposto por Erduran, Simon e Osborne (2004). Para os autores, além da simples combinação dos elementos, a frequência de justificativas e backings também é indicativa da qualidade estrutural dos argumentos.

No mais, mesmo diante dessas considerações apontadas, acreditamos que o TAP seja suficiente para atender os objetivos propostos por este estudo, uma vez que estamos interessados em analisar a qualidade estrutural dos argumentos associada aos aspectos inerentes à sensibilidade moral dos licenciandos diante de QSC, cuja fundamentação teórica abordamos no próximo capítulo. 


\section{Capítulo 2 - Questões sociocientíficas e o desenvolvimento moral}

Com base nas considerações feitas por Sá e Queiroz (2011), discutidas no capítulo anterior, a respeito da argumentação no ensino de ciências em contexto nacional, a inserção de QSC é bastante recomendada por pesquisadores de diversas áreas de ensino, com produção abundante na literatura internacional. A discussão desse tipo de questão em sala de aula de ciências tem sido apontada como um instrumento que auxilia professores e estudantes na compreensão de aspectos da $\mathrm{NdC}$ ou da investigação científica (SADLER, CHEMBERS e ZEIDLER, 2004; EASTWOOD et. al., 2012; EASTWOOD, et. al., 2013; KARISAN e ZEIDLER, 2017), no entendimento de conteúdos próprios do espaço formal de ensino (SADLER, ROMINE e TOPÇU, 2016; KLOSTERMAN e SADLER, 2010), no desenvolvimento de habilidades argumentativas e de tomada de decisão (GRESCH, HASSELHORN e BÖGEHOLZ, 2013; ACAR, TURKMEN e ROYCHOUDHURY, 2010; KARISAN, TUZUN e ZEIDLER, 2017; KAPICI e ILHAN, 2016), além do exercício do raciocínio informal e da sensibilidade moral (FOWLER, ZEIDLER e SADLER, 2009; SADLER, 2004a,b; KOLAROV, HADJIALI e DENEV, 2013).

Sadler (2004a) define as QSC ou SSI (sigla oriunda da língua inglesa Socioscientific Issues) como dilemas sociais com conceitos, procedimentos ou tecnologias associadas com a ciência. É o caso, por exemplo, de alterações climáticas, como o aquecimento global, terapias genéticas e polêmicas médicas como a questão da vacinação. Controversas por natureza, elas consistem em problemas mal estruturados que podem ser considerados por uma variedade de perspectivas, cujas conclusões são complexas e influenciadas por uma série de fatores sociais, incluindo políticos, econômicos e éticos (SADLER, 2011). De relevância social, esse tipo de questão é frequentemente divulgada pela mídia criando oportunidades para que todos os cidadãos, independentemente de sua profissão, interajam com a ciência (FRIEDRICHSEN et. al., 2016).

Nessa perspectiva, Ratclife e Grace (2003) apresentam algumas características das QSC, dentre as quais: se fundamentam na ciência; envolvem a formação de opiniões e a realização de escolhas no nível pessoal e social; são frequentemente divulgadas pela mídia; lidam com informações/evidências científicas incompletas ou conflitantes; envolvem problemas locais e globais, e suas estruturas sociais e políticas; envolvem a análise de prós e contras em que os riscos interagem com os valores; envolvem valores e raciocínio ético; são frequentemente pontuais durante a transição da vida. 
Ressaltando a relevância social do problema, sua natureza controversa, e a multiplicidade de pontos de vista que esse tipo de questão envolve, Eastwood et. al. (2012) salientam o seu potencial para promover o interesse dos educandos, que além de incorporar dados e os conteúdos "próprios" do espaço formal de ensino, têm a oportunidade de considerar os aspectos sociais, econômicos, éticos e morais dos problemas.

\subsection{A relevância das questões sociocientíficas e a educação científica}

Isto exposto, a inserção de QSC em salas de aula de ciência vai ao encontro do que, segundo Karisan e Zeidler (2017), consiste na premissa da educação científica das últimas três décadas, a alfabetização científica, que por sua vez é um constructo multidimensional e complexo. Para Sadler (2011), reiterado por Karisan e Zeidler (2017), um indivíduo cientificamente alfabetizado deve ser capaz de negociar e tomar decisões diante de situações do cotidiano que envolvam o conteúdo científico. Ademais, deve ser capaz de compreender os impactos da ciência e tecnologia no dia a dia, além de ler e entender os tópicos essenciais veiculados pela mídia, refletindo criticamente sobre as informações.

Nesse sentido, dada à veiculação de QSC pela mídia, e a necessária capacidade de os indivíduos avaliarem e refletirem sobre as informações apresentadas, diferentes trabalhos, como de Klosterman, Sadler e Brown (2012), têm como foco o uso da mídia no espaço formal de ensino para a sua inserção. Neste trabalho em específico, os autores investigaram em que extensão professores de ciências fazem uso dos veículos de comunicação em massa para explorar problemas sociocientíficos e de sustentabilidade.

Segundo os autores, um dos aspectos importantes da educação científica seria a alfabetização midiática, ou MLE (Media Literacy Education), cujo objetivo é desenvolver a habilidade dos estudantes acessarem, analisarem, avaliarem e criarem mídias. Nessa perspectiva, acessar corresponderia localizar fontes de informação, analisar envolveria examinar a informação na busca por elementos específicos que auxiliariam o seu entendimento sobre a mensagem veiculada. Avaliar diz respeito a determinar o "valor" da informação, isto é, sua relevância, precisão, credibilidade, adequação e usabilidade. Por fim, criar mídias demonstra a habilidade do indivíduo interagir com a sociedade, elaborando mensagens que possam ser compartilhadas com os outros.

A partir desse estudo, Klosterman, Sadler e Brown (2012) identificaram que professores de ciências utilizam alguns veículos de comunicação de massa para explorar QSC e sustentabilidade, no entanto, ainda de forma limitada. Em suma, com os resultados da investigação, os autores ressaltam a necessidade de professores formadores auxiliarem os 
docentes da educação básica a melhor compreender o significado das oportunidades que os estudantes têm de acessar a mídia. Ademais, os autores verificaram que, o quarto aspecto do MLE, a criação de novas mídias, a qual demanda uma maior carga cognitiva, não foi observada, e assim pontuam:

Acessar, analisar e avaliar informações relativas a problemas contemporâneos são essenciais para a tomada de decisão, mas promover oportunidades para os estudantes realmente criarem mídias sobre QSC e sustentabilidade poderia levar a novas formas de alfabetização científica participativa (KLOSTERMAN, SADLER e BROWN, 2012, p. 72, tradução nossa).

No que diz respeito, portanto, a essa associação entre a integração de QSC na educação científica e sua importância para a formação de cidadãos alfabetizados cientificamente, Sadler e Zeidler (2009) destacam três princípios:

(1) A alfabetização científica deve ser o objetivo de todos os estudantes. A educação científica não deve ser reservada para aqueles poucos que estão destinados a ser tornar a próxima geração de cientistas, engenheiros e físicos. Dessa forma, a educação científica não deve focar exclusivamente em formalismos científicos que tenham relevância somente para os profissionais que praticam ciência. (2) A educação científica deve propiciar oportunidades para os aprendizes experimentaram a ciência em contextos análogos aqueles que eles confrontam em suas experiências diárias além dos muros escolares. (3) Quando educadores querem usar problemas reais relacionados à ciência como veículo para engajar estudantes em experiências de aprendizagem significativas eles não devem tentar destilar a ciência de forma a descartar outros elementos dos problemas que podem ser vistos como além dos limites da ciência tradicional. [...] essa abordagem "segura" vai contra o propósito de usar QSC como contextos para a aprendizagem (SADLER e ZAIDLER, 2009, p. 912, tradução nossa).

Com relação a esse terceiro princípio, Bossér e Lindahl (2017) enfatizam algumas das dificuldades encontradas pelos professores ao lidarem com QSC. Segundo os autores, práticas dialógicas estabelecidas a partir de questões socialmente controversas exigem novas demandas para os professores, como propiciar um ambiente que encoraja os educandos a expressarem suas opiniões durante as discussões. Contudo, de acordo com as características desse tipo de questão, podem emergir em sala de aula aspectos relacionados a emoções oriundas da empatia com outros indivíduos. Dessa forma, desenvolver estratégias que os possibilitem no trato de tais emoções se torna importante para os professores. No entanto, o que tem se verificado na literatura é a falta de confiança dos docentes para lidarem com outros aspectos que possam emergir das discussões para além dos conteúdos científicos tradicionais. Por mais que os docentes demonstrem interesse na abordagem de QSC no ensino de ciências, estes optam por uma abordagem mais segura que se contrapõe aos próprios objetivos da atividade.

Dada a complexidade e multidimensionalidade do termo alfabetização científica, diferentes pesquisadores interessados em QSC (ZEIDLER e KEEFER, 2003; ZEIDLER et. al., 
2005) assumem em seus trabalhos uma das visões que Roberts $(2007)^{3}$ apresenta para o tema. Para esses pesquisadores, o ensino de ciências com foco na abordagem contextualizada do conhecimento científico promove uma espécie de alfabetização "sobre ciência" relacionada com situações as quais os educandos estão sujeitos a encontrar em suas vidas como cidadãos. Dessa forma, a inserção de QSC na educação científica conduziria ao que os autores denominam como "alfabetização científica funcional", cujos elementos estão sintetizados no esquema da Figura 6.

Figura 6 - Componentes da alfabetização científica funcional.

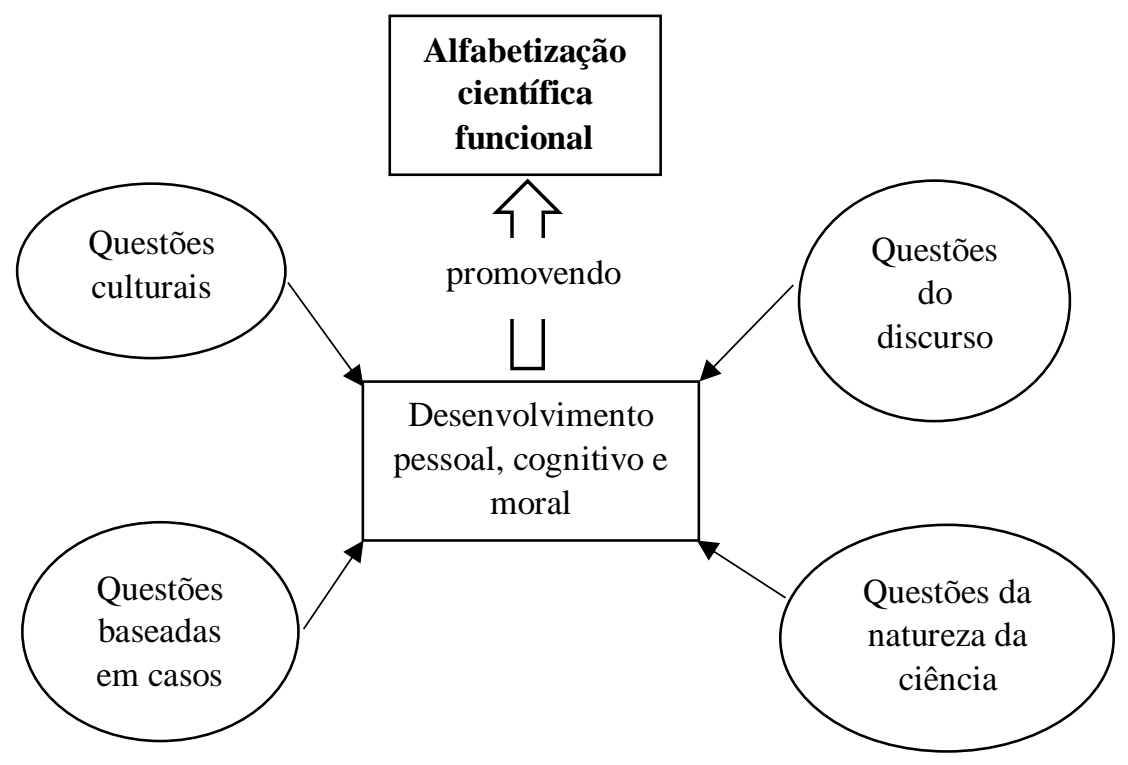

Fonte: Adaptado de Zeidler e Keefer (2003), tradução nossa.

Pelo esquema proposto por Zeidler e Keefer (2003), é possível inferir que cada um dos componentes contribui para o desenvolvimento pessoal, cognitivo e moral dos alunos, o que, por sua vez, promove essa alfabetização científica funcional. Conforme sugerido por Eastwood et. al. (2013), ambientes de aprendizagem baseados em QSC devem encorajar a participação dos estudantes, a colaboração e o respeito mútuo. Além disso, os educandos devem ter oportunidades de se engajarem em processos argumentativos, interagir com ideias científicas, dados reais, e negociar os aspectos sociais do problema. Dessa forma, as questões do discurso se apresentam na construção de argumentos, seus mecanismos, e como respostas e pontos de vista diante de problemas morais são afetados por crenças e convicções prévias.

\footnotetext{
${ }^{3}$ ROBERTS, D. A. Scientific Literacy/ Science Literacy. In: ABELL, S. K., LEDERMAN, N. G. (Eds.) Handbook of Research on Science Education. Mahwah, NJ: Lawrence Erlbaum Associates. 2007, p. 729-780
} 
Com relação às questões de $\mathrm{NdC}$, estas se tornam relevantes pois podem revelar como as visões epistemológicas influenciam a seleção e avaliação das evidências pelos estudantes, e assim afetar a construção de novos argumentos. As questões culturais se relacionam com a necessidade do respeito mútuo e tolerância a opiniões divergentes. E, por fim, questões baseadas em casos se tornam pertinentes, uma vez que permitem aos educadores irem além do currículo CTS (ciência, tecnologia e sociedade) e cultivar hábitos que promovam a sensibilidade ética e moral (ZEIDLER, et. al., 2005).

\subsection{Argumentação sobre questões sociocientíficas}

Considerando os componentes da alfabetização científica funcional, como esquematizados na Figura 6, há pesquisas endereçadas para cada um deles. No que tange, por exemplo, aos aspectos do discurso, mais especificamente da argumentação diante de QSC, Acar, Turkmen e Roychoudhury (2010) apresentam uma revisão da literatura, indicando os principais elementos da argumentação sociocientifica e estabelecendo algumas das dificuldades dos alunos nesse processo.

Uma vez que, mais de uma teoria científica pode explicar um mesmo problema de natureza sociocientífica, essas questões constituem um excelente contexto para examinar a argumentação dos estudantes. De acordo com os autores, a relevância da tomada de decisão, e consequentemente da argumentação, se encontra quando observamos que os problemas contemporâneos estão cada vez mais complexos, os quais requerem acessar e avaliar prós e contras de posições alternativas.

Especificamente com relação à argumentação sobre QSC, essa é afetada por uma série de fatores como avaliação de evidências, concepções de $\mathrm{NdC}$ e raciocínio baseado em valores. Dessa forma, dificuldades ou lacunas dos educandos nessas áreas influenciam diretamente a qualidade dos argumentos por eles empregados, isto é, dificuldade em avaliar evidências, concepções equivocadas de $\mathrm{NdC}$ ou uma baixa sensibilidade moral podem afetar negativamente as respostas dos alunos sobre questões controversas vinculadas à ciência.

Quanto à avaliação de evidências, os autores salientam que, diferente das evidências em questões de natureza científica, aquelas próprias de QSC apresentam um grau de incerteza muito maior, portanto, entender e considerar essa incerteza no processo de argumentação é necessário para a construção de um argumento sofisticado.

No que tange aos aspectos de $\mathrm{NdC}$, as QSC se configuram como um bom contexto para o estudo das visões dos estudantes a esse respeito. E com relação ao raciocínio baseado em valores, Acar, Turkmen e Roychoudhury (2010) ressaltam que QSC estão intimamente 
relacionadas com a sociedade como um todo, e a partir do momento que cada indivíduo possui seus próprios interesses sobre problemas dessa natureza, seu julgamento de valores pode estar em jogo, o que não consiste especificamente em um problema. Contudo, a extensão com que esses indivíduos fazem uso de seus valores, e se estão cientes deles, constitui um obstáculo para a elaboração de argumentos bem fundamentados.

Além desses três aspectos, os autores também verificaram nos diferentes estudos analisados uma outra estratégia que tem afetado a argumentação dos estudantes, a qual é o uso de heurísticas comuns, isto é, estratégias que ignoram parte da informação com o objetivo de tornar a escolha mais fácil e rápida. Dessa forma, conhecer a natureza dessas heurísticas e identificar como elas afetam a qualidade dos argumentos dos educandos se torna particularmente relevante no campo das pesquisas envolvendo a argumentação em QSC. Em síntese, com relação a essas heurísticas os autores salientam:

Pessoas geralmente utilizam heurísticas quando tomam decisão sobre um tópico,
especialmente para aqueles com os quais estão familiarizados. O uso de heurísticas
pode ser uma estratégia eficiente quando a decisão deve ser tomada imediatamente e
o contexto não requer o uso de raciocínio analítico. No entanto, o uso excessivo de
heurísticas pode ser problemático em contextos nos quais o uso desse raciocínio
analítico é essencial (ACAR, TURKMEN e ROYCHOUDHURY, 2010, p. 1201,
tradução nossa).

Como exemplos de heurísticas comuns adotadas pelas pessoas diante de questões controversas, Acar, Turkmen e Roychoudhury (2010) destacam a heurística da representatividade e a heurística da disponibilidade ${ }^{4}$. Na primeira, os indivíduos avaliam a probabilidade de um evento " $B$ " ocorrer pelo nível que um evento " $A$ " se assemelha à " $B$ ", isto é, pelo nível em que A é representativo de B. Esse tipo de heurística representaria, por exemplo, a tendência em utilizarmos estereótipos para realizar julgamentos.

O segundo tipo, a heurística da disponibilidade, diz respeito à tomada de decisão pela facilidade com que exemplos ocorrem em nossas mentes. Considerando, por exemplo, o estudo que questionou a probabilidade de pessoas serem mortas por uma parte do avião em queda ou em um ataque de tubarão, Acar, Turkmen e Roychoudhry (2010) apresentam que, por causa da vivacidade e facilidade de imaginar o ataque de um tubarão, este foi percebido pela maioria dos sujeitos investigados como mais provável, embora estatísticas demonstrem o contrário.

Diante dos trabalhos levantados, os autores concluem que diferentes programas educativos têm se interessado na elaboração de um currículo com ênfase em QSC para o desenvolvimento de habilidades de argumentação e tomada de decisão e os resultados obtidos

\footnotetext{
${ }^{4}$ Tversky, A., \& Kahneman, D. (1974). Judgment under uncertainty: Heuristics and biases. Science, 211, 453458.
} 
até então têm indicado a sua eficiência para o atendimento desses objetivos. Verificou-se também que áreas problemáticas da argumentação em QSC se relacionam com a avaliação de evidências pelos estudantes, suas concepções de $\mathrm{NdC}$ e o raciocínio baseado em valores. Ademais, falhas no raciocínio dos estudantes podem ocorrer devido ao fato destes não se darem conta do uso de heurísticas, as quais podem ser eficientes em situações simples do dia a dia, mas deficiente em contextos em que decisões complexas são necessárias. Uma das possíveis soluções proposta pelos autores é o trabalho com essas heurísticas junto dos estudantes, de modo que estes venham a estar cientes dessa estratégia que utilizam de maneira inconsciente frente a problemas de natureza sociocientífica.

Seguindo a perspectiva da argumentação, Karisan, Tüzun e Zeidler (2017) investigaram a qualidade dos argumentos empregados por vinte futuros professores em discussões em sala de aula envolvendo QSC. Em síntese, os resultados obtidos corroboram a eficiência desse tipo de abordagem para o desenvolvimento de habilidades argumentativas, dado que, durante o estudo, o uso de evidências pelos professores em formação para apoiar ideias conflitantes aumentou ao mesmo tempo que uso incorreto ou ineficiente dessas evidências decaiu.

O particular interesse para o trabalho no âmbito da formação inicial de professores se deve ao fato de que, para os autores, independente da área dos docentes, estes são responsáveis pela formação dos estudantes enquanto cidadãos. E esse objetivo é alcançado quando os educandos têm a oportunidade de explorar a vasta gama de decisões e desenvolver atitudes positivas em relação a aspectos sociais críticos. Contudo, o desenvolvimento dessas atitudes só ocorre se os professores vislumbrarem essas questões como parte central do ensino de ciências. Assim sendo, explorar como os futuros docentes se posicionam diante desses problemas é válido, uma vez que suas experiências pessoais podem afetar diretamente como abordarão esse tipo de questão em sala de aula com seus alunos.

\subsection{Raciocínio informal e o desenvolvimento moral}

Quando consideramos o esquema proposto de Zeidler e Keefer (2003) (Figura 6), o que os autores denominam como questões baseadas em casos, isto é, situações que permitam promover a sensibilidade moral para ouvir vozes dissidentes e analisar como o poder de autoridade está incorporado na atividade científica, consistem em um componente da alfabetização científica funcional que ressalta uma das principais diferenças entre o ensino com ênfase CTS e aquele com a abordagem de QSC (ZEIDLER et. al. 2005). Com início no final da década de 1970, o primeiro surgiu a partir de reflexões de diversos pesquisadores que 
concluíram que a ciência se tornaria mais significativa para os estudantes quando colocadas em contexto, ou seja, como ela afeta a tecnologia e como esta, por sua vez, se direciona à sociedade. No entanto, para Zeidler et. al. (2005), apesar dessa abordagem ter servido para convencer a comunidade educacional que ciência, tecnologia e sociedade não estão isoladas umas das outras, ela não considera abertamente os fundamentos epistemológicos, o desenvolvimento moral e ético, e os aspectos emocionais do aprendizado científico.

Dessa forma, a abordagem de QSC representa uma reconstrução e evolução da CTS, que fornece meios não somente para o contato dos educandos com as implicações do desenvolvimento científico, mas também meios para explorar as filosofias pessoais dos alunos e seus sistemas de crenças. Para Zeidler et. al. (2005), portanto:

\footnotetext{
Enquanto a educação CTS tipicamente salienta o impacto das decisões em ciência e tecnologia na sociedade, ela não impõe uma atenção explícita às questões éticas contidas nas escolhas sobre meios e fins, nem considera o desenvolvimento moral ou o caráter dos estudantes.

$[\ldots]$

Por adicionar o desenvolvimento moral, ético, emocional e epistemológico do estudante, a abordagem QSC fornece um elo que une as várias forças que contribuem para o desenvolvimento do conhecimento científico. A introdução de casos baseados em QSC representa uma estratégia pedagógica direcionada não somente para as ramificações sociológica, como também para as ramificações psicológicas do currículo e do discurso em sala de aula (ZEIDLER et. al., 2005, p. 359 e 371, tradução nossa).
}

Diante dessa característica, que diferencia o ensino baseado em QSC da abordagem CTS, aspectos éticos e morais são particularmente relevantes para a formação e o desenvolvimento de caráter e valores de cidadãos globais (LEE et. al., 2012). E, ainda, com relação às questões políticas e econômicas do contexto brasileiro atual, a abordagem de aspectos morais na educação formal se torna imprescindível aos estudantes.

Quando considerados os objetivos da educação básica, segundo os documentos oficiais que regem a educação no Brasil, como a Lei de Diretrizes e Bases (LDB), a formação ética do indivíduo ganha evidência:

Art. 35 - O ensino médio etapa final da educação básica, com duração mínima de três anos, terá como finalidade: [...] III - o aprimoramento do educando como pessoa humana, incluindo a formação ética e o desenvolvimento da autonomia intelectual e do pensamento crítico (BRASIL, 2017, p. 24).

Configurando-se como uma temática transversal, a abordagem da ética se torna pertinente às diferentes áreas do saber, e envolve o acesso ao conhecimento e à capacidade de, a partir dele, o aluno tomar decisões e agir em serviço e a favor da comunidade. No entanto, para a tomada de decisão e participação socialmente ativa, o indivíduo deve ser capaz de agir moralmente e assim utilizar valores considerados como norteadores das relações sociais e da conduta dos homens. 
Nessa perspectiva é interessante, inicialmente, estabelecer uma distinção entre moral e ética. Dentre a variedade de definições existentes na literatura, compartilhamos a visão de La Taille (2006) que considera a moral referente à dimensão dos deveres, isto é, com ela buscamos responder "como devo agir?” ou “o que devo fazer?”, e a ética uma reflexão filosófica ou científica sobre a moral. Assim, fazendo uso das palavras de Guimarães (2011, p. 7), “o dever de não mentir pertence à dimensão moral, mas a reflexão sobre se algumas vezes a mentira pode ser melhor ou menos danosa que a verdade, pertence à dimensão da ética”. De modo geral, a moral é externa ao indivíduo e varia de acordo com a sociedade e a cultura em que está imerso.

A moral estabelecida a partir dessa relação é descrita por Kant (2005) como uma moral heterônoma, a qual é guiada por motivos extrínsecos à pessoa. Nesse caso, conforme afirma Guimarães (2011), o indivíduo não enxerga o valor das regras em si, mas sim o valor que a sociedade atribui a elas. Esse aspecto ressalta a importância da abordagem de questões que envolvam dimensões éticas e morais nos espaços formais de ensino. Segundo Bebeau (1995), o indivíduo é treinado desde pequeno a seguir regras sem uma reflexão crítica do porquê delas, assim, quando nos deparamos com situações que não possuem regras estabelecidas a priori encontramos dificuldades na tomada de decisão, ainda mais quando esta envolve o bem-estar de outras pessoas.

Diante das características dessa moral heterônoma, baseada somente na afetividade, Guimarães (2011) apresenta um dos seus principais problemas, o relativismo moral para o qual não existem preceitos morais universais. A partir do momento que a moral é de cada sociedade e o indivíduo age de acordo com ela, este pode observar barbáries sendo cometidas em algumas sociedade e culturas, sem emitir qualquer condenação de juízo moral. Segundo Guimarães (2011, p. 8): "ser tolerante em relação às diferentes culturas não significa endossar atos reprováveis do ponto de vista moral".

Em contraposição a esta moral heterônoma, Kant (2005) propõe uma moral autônoma como ideal a ser alcançado, a qual também consiste no objetivo da educação voltada para essa questão. Nesse caso, fundamentada na razão e não na coerção social, as decisões e ações vêm do interior dos sujeitos.

Diante desses aspectos, e as particularidades envolvendo o uso de QSC, ao abordar esse tipo de questão no ensino de ciências entramos em contato com a ideia de raciocínio informal, que intimamente ligado à afetividade, envolve emoções, interesses particulares, hipóteses, suposições e analogias. Esse raciocínio se relaciona com o próprio processo de construção do conhecimento científico, uma vez que, segundo Sadler (2004a), embora os 
resultados da ciência sejam apresentados por meio de um raciocínio formal e lógico, estes se originam por meio do raciocínio informal dos cientistas.

De acordo com Wu e Tsai (2007), dentre as diferenças entre raciocínio formal e raciocínio informal destacam-se os tipos de problemas os quais estes estão relacionados. Enquanto os problemas envolvendo o raciocínio formal são bem definidos com premissas sempre explícitas e claras, os problemas do raciocínio informal são mal estruturados e com conclusões complexas. Nessa perspectiva, Zohar e Nemet (2002) definem o raciocínio informal como:

Raciocínio sobre causas e consequências e sobre vantagens e desvantagens, ou prós e contras, de proposições particulares ou decisões alternativas. Está sujeito a atitudes e opiniões, envolve problemas mal estruturados que não tem solução definida, e frequentemente envolve o raciocínio indutivo (no lugar de dedutivo) (ZOHAR e NEMET, 2002, p. 38, tradução nossa).

Logo, com base em suas definições, as QSC são para Sadler (2004a) ideais para o exercício do raciocínio informal em salas de aula do ensino de ciências, onde se espera que os estudantes negociem e resolvam problemas controversos. Dada a complexidade de problemas dessa natureza e a ausência de soluções claras, Sadler e Zeidler (2005) estabelecem três padrões de raciocínio informal que afetam a tomada de decisão do indivíduo, o racionalista, o emotivo e o intuitivo.

Em seu estudo, Sadler e Zeidler (2005) investigaram como estudantes negociam e resolvem dilemas envolvendo engenharia genética. Para tanto, foram realizadas com cada estudante duas entrevistas semiestruturadas que envolviam seis cenários de terapia genética por meio de problemas extremante abertos. O que se identificou, portanto, foi o uso desses três padrões de raciocínio informal, sendo o racionalista descrito como considerações baseadas nas razões, o emotivo descrito por uma perspectiva de "cuidado" em que a empatia e a preocupação pelo bem-estar dos outros guiaram suas decisões e o curso das ações, e o intuitivo baseado em reações imediatas ao contexto de um cenário particular, o qual não pode ser necessariamente explicitado em termos racionais.

Como exemplo para esses padrões temos:

Padrão de raciocínio informal racionalista: considerando o cenário de terapia genética para a inteligência, isto é: se a ciência fosse capaz de isolar genes que contribuam significativamente para a inteligência do indivíduo, poderiam estes ser utilizados para o aumento da inteligência dos filhos?

- Os outros [cenários de doença de Huntington e miopia] são as doenças. Isso [a inteligência] é algo que você nasce com. Ela é quem você é, é a sua personalidade, ela tem mais fatores que estão nela. Aquelas são as doenças ou deficiências - esta não é 
uma deficiência. Pode ser uma deficiência de alguma forma, se uma pessoa tem um cromossomo extra, que a torne retardada, mas para torná-los mais inteligentes, não. Eu não penso assim (SADLER e ZEIDLER, 2005, p. 122, tradução nossa).

Considerando o cenário da doença de Huntington, isto é: uma vez que essa doença é controlada por um gene, ela pode ser candidata para a terapia genética. Dessa forma, deveria esse gene ser eliminado das células sexuais que serão usadas na geração de um filho que poderia nascer com essa doença?

- Essa é um tipo de questão complicada porque existe um monte de problemas envolvidos. Eu penso que quando você faz isso, quando você usa a terapia genética para consertar esses problemas, é uma forma de seleção natural artificial porque naturalmente você reproduziria esses genes, eu acho. Eu acho que no caso da doença de Huntington, ela vem depois então eles já reproduziram. Mas se você pode se livrar da doença, por que não? O único problema que eu vejo com a engenharia genética é que esta vai ser uma coisa cara. Somente algumas pessoas seriam capazes de pagar? .... Pode haver uma diferença de classes (SADLER e ZEIDLER, 2005, p. 122, tradução nossa).

Padrão de raciocínio informal emotivo: Considerando o mesmo cenário envolvendo a doença de Huntington:

- Eu penso que seria legal se fosse ajudar o bebê ... se a doença vai ser prejudicial para o humano, então porque não a consertar em um estágio inicial se você pode ... se nós temos a habilidade de impedir alguém de sofrer no futuro, então, por que não? Quanto a alguém pensar que isso é contra o curso da natureza, eu só penso que essa não é uma boa desculpa para deixar alguém sofrer (SADLER e ZEIDLER, 2005, p. 123, tradução nossa).

Padrão de raciocínio informal intuitivo: Considerando o cenário de clonagem reprodutiva, isto é: deveriam indivíduos que querem gerar e ter seus próprios filhos serem permitidos a escolher a clonagem como uma opção para a reprodução?

- Eu só não acho que está certo. Eu realmente não sei por quê; é só esse sentimento. Eu não acho que é uma boa ideia

- Eu não sei como resumir, mas isto simplesmente não parece certo. Eu não tenho qualquer razão específica.

- Não! [Clonagem reprodutiva não deve ser permitida]

Pesquisador: Por que não?

Estudante: Você vai basicamente ter como se fosse sua esposa crescendo na sua frente de novo. Isso é simplesmente errado eu penso. É basicamente como ter outro gêmeo vindo depois de você. Eu não penso que isso é correto.... Você nem sabe se essa pessoa é real.

Pesquisador: Quais fatores contribuíram para a sua decisão?

Estudante: Simplesmente isso - isso não é certo. Eu penso que vai contra a minha religião (SADLER e ZEIDLER, 2005, p. 123, tradução nossa).

Nessa perspectiva, diversos outros pesquisadores realizaram estudos voltados para o exercício e análise do raciocínio informal de alunos e professores e a sensibilidade moral destes. 
Assumindo como exemplo de raciocínio informal o raciocínio moral, o qual considera as ramificações morais das decisões tomadas em QSC (GUIMARÃES, 2011), este também é passível de investigação, e consiste em um dos focos do nosso trabalho.

\subsection{Questões sociocientíficas e pesquisas em ensino de ciências}

Do exposto até então, dadas suas características e particularidades, ficam evidentes as contribuições de práticas baseadas em QSC no ensino de ciências para a formação de cidadãos ativos na sociedade contemporânea. No entanto, como afirmam Sá e Queiroz (2011), apesar da grande contribuição teórica e prática sobre a temática em âmbito internacional, ainda é incipiente o trabalho com QSC em contexto nacional. Em estudo mais recente, Sousa e Gehlan (2017) realizaram um levantamento bibliográfico de pesquisas com olhar voltado para esse tipo de questão, estabelecendo assim, algumas de suas características.

Para esse levantamento, os autores analisaram os anais do ENPEC até a sua nona edição, 2013. Foram identificados 47 trabalhos que discutem a abordagem de QSC, sendo o primeiro encontrado apenas na terceira edição do evento (2001). Verifica-se que desde a quinta edição a quantidade de trabalhos endereçados para essa temática é crescente, com um aumento significativo a partir de 2009, isto é, da sétima edição.

Com relação aos focos temáticos dos trabalhos localizados, a análise do envolvimento dos estudantes diante de atividades envolvendo QSC parece ser predominante. No entanto, quando consideradas as edições mais recentes, a relação entre o emprego de QSC no ensino de ciências e a formação de professores ganha destaque. Dentre os trabalhos dessa natureza, estão aqueles voltados para análise do desempenho docente e de suas ações que contribuam para o envolvimento dos alunos nas discussões envolvendo QSC. Esses trabalhos, portanto, vão ao encontro do que Bossér e Lindahl (2017) apresentam como novas demandas oriundas dessa prática para os professores de ciências, como a necessidade de promover um ambiente que encoraja os estudantes a se engajarem nas atividades realizadas em sala de aula, expondo suas ideias e opiniões.

Sousa e Gehlan (2017) também identificaram trabalhos voltados para a elaboração de propostas por professores da educação básica que envolvam elementos sociocientíficos, em vista de suprir possíveis necessidades formativas. Ou seja, voltados para a promoção de estratégias que auxiliem os docentes na formação de cidadãos que gozem da chamada alfabetização científica funcional. Existem também trabalhos endereçados para o desenvolvimento de discussões de natureza sociocientífica na formação inicial e continuada de professores, tendo em vista a influência das experiências dos docentes em sua prática 
pedagógica, o que vai ao encontro das considerações apresentadas por Karisan, Tüzun e Zeidler (2017) que indicam a pertinência de investigações no âmbito da formação de professores, dado que suas experiências pessoais podem afetar diretamente a forma como abordam QSC em sala de aula

Outros aspectos constatados pelos autores foram: (1) a tendência dos pesquisadores brasileiros em relacionar a abordagem de QSC com o enfoque CTS, apesar das diferenças evidenciadas pela literatura internacional, principalmente no que diz respeito ao exercício do raciocínio informal; (2) a incipiência de estudos que articulam QSC com o desenvolvimento de habilidades argumentativas, ou seja, a potencialidade de um ambiente de aprendizagem baseado em QSC para a promoção da argumentação tem sido pouco explorada. Dessas constatações, portanto, Sousa e Gehlan (2017) concluem que a discussão de QSC em âmbito nacional necessita de maiores sistematizações acerca de suas características e suas relações com outros referenciais para além do enfoque CTS, como por exemplo dos padrões de raciocínio informal e modelos de sensibilidade moral.

A partir do que foi apresentado nessa seção, emergem da literatura a vasta gama de possibilidades que QSC, comuns ao educando face a sua veiculação pela mídia, assumem no espaço formal de ensino de ciências, seja para abordagem de conteúdos científicos, ou para a compreensão de aspectos de NdC. No entanto, de particular relevância para o trabalho aqui empreendido, observa-se também as contribuições desse tipo de abordagem não somente para o desenvolvimento de habilidades argumentativas e de tomada de decisão dos indivíduos, como também para o desenvolvimento moral do educando, o qual se configura como um elemento relevante e valioso quando consideramos o cenário brasileiro atual. Ademais, esses elementos e características das QSC propiciam um contexto adequado para que o objetivo principal da educação científica seja alcançado, isto é, para o que Zeidler e Keefer (2003) denominam como alfabetização científica funcional.

\subsection{O Modelo dos Quatro Componentes}

Ao consideramos, portanto, a importância de estudos voltados para o desenvolvimento moral dos educandos, nos deparamos com diferentes modelos e teorias, dentre as quais, o Modelo dos Quatro Componentes, e é sobre esse modelo, o qual subsidiará nossas análises em vista de investigarmos as contribuições das atividades realizadas em sala de aula para o desenvolvimento da sensibilidade moral dos futuros professores, que discorremos na sequência. Para tanto, retomamos alguns tópicos concernentes à inserção de QSC no ensino de ciências. Consoante as características desse tipo de questões apontadas por Ratcliffe e Grace (2003), 
destacamos o fato destas envolverem o raciocínio baseado em valores, isto é, em sala de aula do ensino de ciências, a própria natureza dessas questões desafia os estudantes a utilizarem, em suas conclusões, mais do que a análise de dados científicos, mas a empregarem uma argumentação baseada em valores, emoções e em aspectos éticos e morais. Uma vez que, consideramos a moral heterônoma de Kant (2005) como predominante na sociedade moderna pelos motivos já descritos, tais valores são adquiridos culturalmente no meio social em que estão inseridos.

Nesse sentido, se torna interessante despender esforços para o estudo dessas temáticas e, de acordo com Zeidler e Sadler (2008), o principal objetivo seria a busca por uma compreensão de como os estudantes raciocinam e reagem reflexivamente às diferentes evidências e crenças, bem como o estabelecimento de um ambiente em que os educandos possam negociar, discutir e refletir sobre como fazer julgamentos diante de questões controversas. No que diz respeito ao exercício do raciocínio informal, e da respectiva análise da sensibilidade moral dos licenciandos, partimos do pressuposto que a abordagem de QSC, como promotora da alfabetização cientifica funcional, na perspectiva de Zeidler e Keefer (2003), envolve aspectos culturais relacionados à moralidade, os quais diferenciam as QSC do ensino com ênfase CTS.

Nessa perspectiva, localizamos diversos estudos, em âmbito internacional, interessados em promover o exercício desse raciocínio relacionado à afetividade, suposições etc., e investigar as respostas dos educandos a esse tipo de questão. De forma geral, nessas pesquisas tem se identificado que os alunos comumente fazem uso de um raciocínio emotivo e intuitivo de acordo com os padrões de raciocínio informal estabelecidos por Sadler e Zeidler (2005). Nessa mesma linha de estudos, Wu e Tsai (2007) sugerem que, em seus argumentos, os alunos tendem a orientar o seu raciocínio informal a partir de diferentes aspectos. Dessa forma, os autores apresentam quatro principais modos de orientação desse raciocínio: orientado socialmente, orientado ecologicamente, orientado economicamente e orientado científica e tecnologicamente.

O primeiro se relaciona às considerações baseadas no bem-estar da sociedade, e na empatia pelos outros. O raciocínio orientado ecologicamente envolve considerações ecológicas e ambientais enquanto aquele orientado economicamente se baseia na perspectiva do desenvolvimento econômico. Por fim, o raciocínio informal orientado científica e tecnologicamente é fundamentado em considerações a respeito da ciência e tecnologia. No entanto, face à dificuldade que os educandos apresentam em conectar o que aprendem em sala de aula e as QSC que se encontram no cotidiano, esta última orientação é pouco encontrada nos 
estudos. No processo de argumentação, Wu e Tsai (2007) ainda salientam a importância do uso desses diferentes modos de orientação como precursores para a construção de refutações. E aqui, portanto, ressaltamos o destaque que Erduran, Simon e Osborne (2004) dão para as refutações, considerando a presença destas como um indicador significativo da qualidade dos argumentos.

No que diz respeito especificamente às dimensões morais das QSC, Guimarães e Carvalho (2009) ressaltam que a sua discussão permite que os alunos tematizem o assunto e passem a refletir sobre algo que, aparentemente, parecia trivial e previamente tido como definido, contribuindo assim para o desenvolvimento moral dos mesmos. Assim, interessado em relacionar esse desenvolvimento moral com o desenvolvimento intelectual/cognitivo, Piaget $(1994)^{5}$, realizou uma série de estudos empregando dilemas morais para crianças de diferentes idades. Um dilema típico trabalhado pelo autor consistia no julgamento do que seria mais grave, um menino que acidentalmente quebrou doze xícaras, ou outro, que por desobediência, quebrou uma única. Diante dessa questão, crianças da faixa dos seis anos, com base na quantificação das consequências, julgam que o menino que quebrou doze xícaras cometeu a falta mais grave. No entanto, por volta dos onze anos, a resposta se inverte, e o fator preponderante do julgamento passa a ser o motivo, a intenção.

Em seus estudos, Piaget (1994) chegou à conclusão que há um paralelo entre o desenvolvimento moral e o desenvolvimento cognitivo, e que todo o ser humano passa por estágios de desenvolvimento quanto ao julgamento moral. Inicialmente existe uma fase de anomia, seguida pela fase de heteronomia, até que alcancemos a autonomia. No primeiro, estágio, da anomia, não há qualquer consciência de obrigação com os outros. Nessa fase, as crianças exercitam seus sentidos e movimentos sem que sigam propriamente regras estabelecidas. $\mathrm{O}$ momento de heteronomia ocorre quando há um respeito unilateral às regras, o qual é fortemente influenciado pelo componente afetivo. Por fim, na fase da autonomia, as crianças entendem que as regras, sendo um tipo de contrato social, podem ser julgadas e modificadas (GUIMARÃES, 2011).

Baseado nos estudos de Piaget, Lawrence Kohlberg, foi outro estudioso que apresentou grandes contribuições para educação moral dos indivíduos, e de como este se desenvolve. Assim como Piaget (1994), ressaltou a existência de uma sequência de passos do desenvolvimento moral, os quais nem todos são alcançados pelas pessoas. Kohlberg $(1992)^{6}$,

\footnotetext{
${ }^{5}$ Obra publicada pela primeira vez no ano de 1932.

${ }^{6}$ Obra derivada de estudos anteriores a sua morte, como o volume publicado no ano de 1984.
} 
portanto, postulou seis estágios para esse desenvolvimento. Inicialmente, em um nível PréConvencional, o indivíduo pode apresentar dois estágios, o primeiro, orientado para a punição e obediência, se fundamenta nas consequências físicas do ato. Se a ação é punida (fisicamente), é moralmente errada, mas se não há punição, é moralmente correta. No segundo estágio, ainda no nível pré-convencional e conhecido como hedonismo instrumental relativista, a ação justa é aquela que satisfaz a própria necessidade. Nesse momento também há a possibilidade de relação de troca, em que um indivíduo ajuda o outro, desde que tenha algum tipo de ganho.

O terceiro estágio, a moralidade do bom garoto, de aprovação social e relações interpessoais, se encontra no nível Convencional e consiste na ação para aprovação, isto é, o comportamento certo é o que leva à aprovação dos outros. O quarto estágio, também no nível convencional, se orienta para a lei e a ordem, típica da moral heterônoma, envolve o respeito pela autoridade, por regras fixas e pela manutenção da ordem social. Os últimos dois estágios se encontram no nível Pós-Convencional, e no primeiro (quinto), orientado para o contrato social, há uma reflexão sobre as leis, elas não são mais aceitas apenas por serem leis. Nesse estágio, para além das regras fixas, as situações são analisadas levando-se em consideração valores e opiniões pessoais e, assim, por meio de um contrato social, há a possibilidade de mudança dessas regras. O sexto e último estágio, alcançado por poucas pessoas, compreende os princípios universais da consciência, em que há por parte do indivíduo o reconhecimento de princípios morais universais da consciência individual, e age de acordo com eles.

A título de exemplo, consideremos um dos principais dilemas adotados por Kolhberg, e descrito por Biaggio (2006):

$\mathrm{Na}$ Europa, uma mulher estava à beira da morte devido a uma doença muito grave, um tipo de câncer. Havia apenas um remédio que os médicos achavam que poderia salvá-la. Era uma forma de radium pela qual um farmacêutico estava cobrando dez vezes mais do que o preço de fabricação da droga. O marido da mulher doente, Heinz, foi a todo mundo que ele conhecia para pedir dinheiro emprestado, mas só conseguiu juntar mais ou menos a metade do que o farmacêutico estava cobrando. Ele disse ao farmacêutico que sua mulher estava à morte, e pediu que lhe vendesse mais barato ou que o deixasse pagar depois. Mas o farmacêutico disse: 'Não, eu descobri a droga e vou fazer dinheiro com isso'. Então Heinz ficou desesperado e assaltou a loja para roubar o remédio para a sua mulher. O marido deveria ter feito isso? Por quê? (BIAGGIO, 2006, p. 29)

Para Kolhberg (BIAGGIO, 2006), a ideia a partir desse dilema não está em considerar o julgamento que as pessoas davam a Heinz, mas a forma como justificavam suas ideias. Por exemplo, as decisões poderiam ser justificadas das seguintes formas: "o marido agiu certo em roubar um remédio para salvar sua esposa desde que não tenha sido pego em flagrante" ou "o marido deve roubar para salvar a vida da mulher porque ele precisa dela para cozinhar” ou ainda 
“se ele não roubasse, seus amigos diriam que ele é um cara mau, deixou a mulher morrer". Cada uma dessas afirmações representaria os estágios 1, 2 e 3, respectivamente (BIAGGIO, 2006).

Isto exposto, no que diz respeito à investigação dos aspectos morais em sala de aula e da sensibilidade moral dos estudantes, emerge da literatura o The Four-Component Model, ou Modelo dos Quatro Componentes proposto por Rest, Bebeau e Volker (1986). De acordo com Bebeau, Rest e Narvaez (1999), este modelo foi proposto como forma de sobrepor o obstáculo que impede a realização de pesquisas sólidas envolvendo a educação moral. Esse obstáculo é o que os autores chamam de visão tripartida da moral, a qual fornece subsídios para medidas, por exemplo, envolvendo os estágios do raciocínio moral de Kolhberg (1992) e Piaget (1994). Essa visão tripartida da moral assume como elementos básicos da moralidade o afeto, a cognição e o comportamento, isto é, motivação (consideração pelos outros), habilidade (autorregulação) e identidade (identidade moral) (COHEN e MORSE, 2014).

Para Bebeau, Rest e Narvaez (1999), embora grande número de trabalhos tenha sido escrito a respeito desses três elementos básicos, estes podem ter considerado uma lista equivocada de elementos. Dessa forma, essa visão tripartida pode ser considerada como um obstáculo às pesquisas referentes à educação moral por sugerir que exista um tipo limitado de interação cognitiva-afetiva, o que segundo os autores não se sustenta mediante uma série de estudos que tem mostrado que existem muitos tipos de cognições, muitos tipos de emoções (afetos) e muitos tipos de comportamentos observáveis envolvendo a moralidade. Com relação ao novo modelo proposto, Bebeau, Rest e Narvaez (1999) afirmam:

Assim, não há sentimentos puros completamente desprovidos de cognições, nem
cognições completamente desprovidas de afetos, e todos os comportamentos são
resultados do processo cognitivo-afetivo. Em vez de tentar dividir a moralidade em
cognições, afetos e comportamentos, sugerimos analisar a moralidade mediante os
processos psicológicos funcionais que devem surgir para produzir um comportamento
moral (BEBEAU, REST e NARVAEZ, 1999, p. 22, tradução nossa).

Nessa perspectiva, o Modelo dos Quatro Componentes surge na tentativa de incorporar diferentes teorias para defender uma concepção mais ampla do funcionamento moral, lidar com uma série de problemas conceituais, como as relações entre cognição, afeto e comportamento, inerentes ao modelo tripartido da moral, e fornecer uma estrutura para a implementação e avaliação de intervenções morais (WALKER, 2002). Assim sendo, esse Modelo sugere que a moralidade é construída com base em quatro componentes: a sensibilidade moral, o julgamento moral, o comprometimento moral e o caráter moral/ perseverança moral. A Figura 7 ilustra os componentes e como se relacionam. 
Figura 7 - Modelo dos Quatro Componentes (Rest, Bebeau e Volker, 1986).

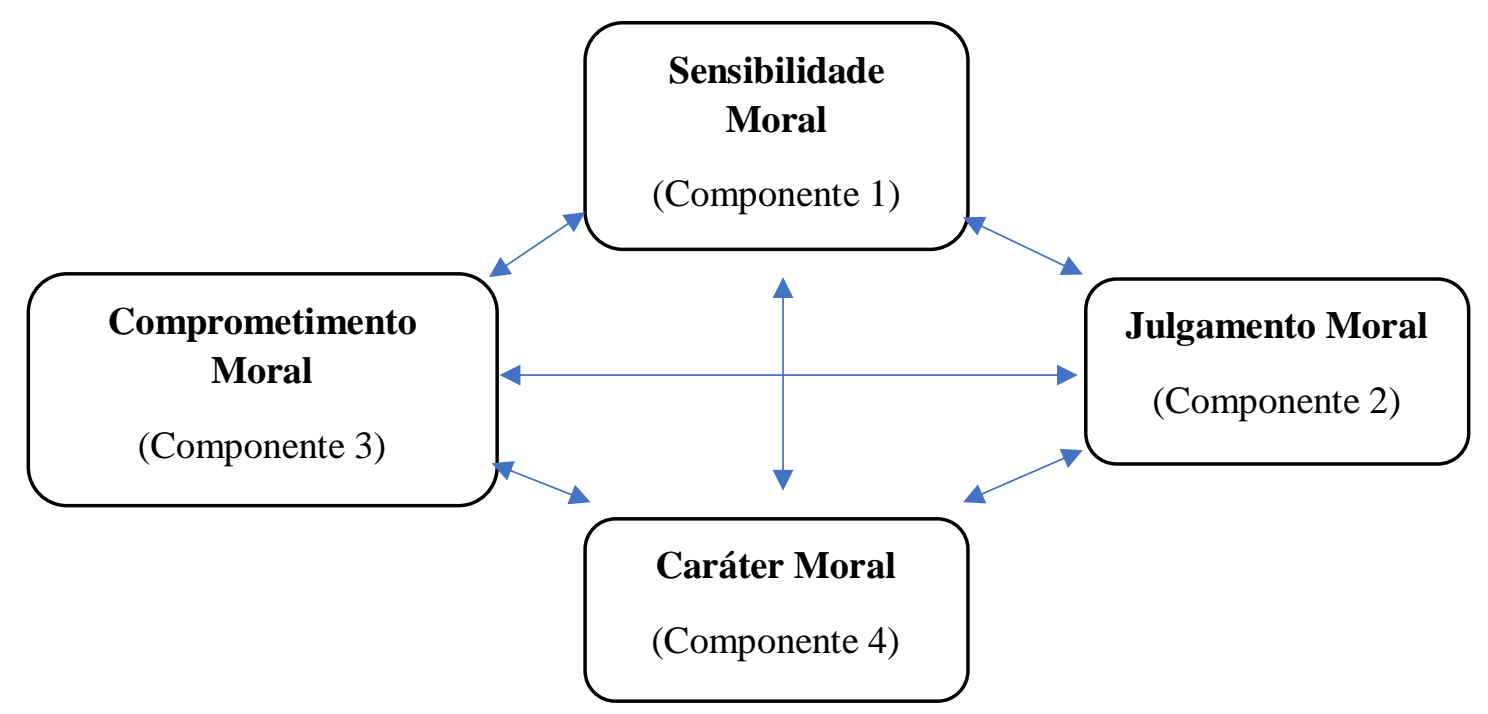

Fonte: Adaptado de Thoma (2006), tradução nossa.

A sensibilidade moral diz respeito à capacidade de interpretação da situação. É a partir dela que o sujeito, em sintonia com as reações dos outros, cria cenários, por meio de pistas limitadas e informações parciais, que o permite tomar conhecimento dos possíveis cursos de ações para situação. É com base nessa sensibilidade moral que o sujeito se torna consciente que um problema moral está envolvido na situação e, assim, deve ser capaz de reconhecer os pontos de conflito, as possíveis ações, antecipar como cada uma dessas ações poderia afetar o bemestar das partes interessadas, e ainda, quem, incluindo a si mesmo, poderia ser afetado por essas ações.

O julgamento moral envolve uma deliberação a respeito das várias considerações relevantes para os diferentes cursos de ações, identificando a moralmente justificável. Isto é, conhecendo as várias ações possíveis, a partir do julgamento moral o indivíduo deve ser capaz de avaliar qual ação é moralmente correta e qual é errada. Com relação aos estudos de Piaget (1994) e Kolhberg, citado pelo trabalho de Biaggio (2006), sabemos que, mesmo em estágios iniciais, as pessoas têm intuições sobre o que é justo e moral, e fazem julgamentos morais a respeito das mais variadas atividades humanas. Dessa forma, por meio da análise desse processo, cabe compreendermos como essas intuições surgem, e o que determina sua aplicação em eventos do cotidiano do indivíduo (BEBEAU, REST e NARVAEZ, 1999).

O terceiro processo, comprometimento moral, ou também conhecido, motivação moral, diz respeito ao ato de, na tomada de decisão, o indivíduo priorizar valores morais acimas 
de outros valores pessoais e se comprometer com o curso de ações se responsabilizando pelos possíveis resultados. A título de exemplo do porquê priorizar tais valores, Bebeau, Rest e Narvaez (1999) afirmam que pessoas consideradas "más" no mundo, como assassinos em série, podem ser explicadas não em termos de deficiências dos dois primeiros componentes, isto é, da sensibilidade ou do julgamento moral, mas em termos dos seus próprios valores, eles não se importam com o justo, ou com aquilo considerado decente, para eles outros valores são mais importantes.

Por fim, o caráter moral ou perseverança moral, se relaciona com a força das convicções, coragem, persistência em superar distrações e obstáculos. Envolve habilidades e estratégias de implementação que suportam a decisão tomada no âmbito do julgamento moral (componente 2). Dessa forma, uma pessoa pode apresentar os três primeiros componentes, mas perder a força sob pressão, não seguir adiante, ser desencorajada e o comportamento moral, terceiro elemento do Modelo que considera moral tripartida irá falhar.

Apesar de se complementarem de certa forma, interagindo e influenciando mutuamente, um processo pode ocorrer independentemente do outro, por exemplo, uma pessoa pode ser capaz de reconhecer as dimensões éticas de uma situação (sensibilidade moral), mas não ter a habilidade de traçar um plano de ações ou apresentar uma resposta bem fundamentada para o julgamento moral. Dessa forma, Rest, Bebeau e Volker (1986) salientam que uma falha moral pode ser devida a uma deficiência em qualquer um desses quatro componentes. E, é nessa possibilidade de entender as razões de uma falha moral que se encontra, para Bebeau, Rest e Narvaez (1999), o valor do Modelo dos Quatro Componentes, o qual permite ao educador desenvolver estratégias mais efetivas e ao pesquisador estabelecer variáveis de investigação.

Para os autores, esse Modelo permite considerar os vários tipos de compreensões morais, por exemplo, o tipo de compreensão necessária para tomar conhecimento das ramificações morais de determinados atos (sensibilidade moral) é diferente do conhecimento necessário para julgar qual curso de ações é moralmente mais justificável (julgamento moral), o que, por sua vez, é diferente daquele envolvido no ato de priorizar valores morais acima de outros valores (comprometimento moral), o que, por fim, também é diferente do conhecimento necessário para manter os objetivos claros em mente e suportar qualquer impedimento de implementação da ação tomada (caráter moral). Enquanto todos os quatro componentes envolvem, de certa forma, um discernimento moral, eles necessitam de processos cognitivos qualitativamente diferentes. Assim, diferentes pesquisadores podem estudar esses processos por meio de diferentes operações e utilizando diferentes teorias para explicar o seu funcionamento. 
Essa característica difere esse Modelo do problema descrito pelos autores no que diz respeito à visão tripartida da moral, a qual falha em distinguir os tipos de conhecimentos necessários para um funcionamento moral efetivo.

O referido modelo pode ser usado para análise de cada um dos componentes e é nessa perspectiva, por exemplo, que Fowler, Zeidler e Sadler (2009) analisam a sensibilidade moral de estudantes de ciências do ensino médio ${ }^{7}$ em contexto de QSC. Em particular, os autores examinaram como a exposição regular a QSC afeta a propensão dos alunos em identificar e considerar os aspectos morais de uma questão controversa. Em outras palavras: Um currículo de ciências dirigido por QSC afeta a sensibilidade moral de estudantes do ensino médio?

Para os autores, a necessidade de maior conhecimento sobre a sensibilidade moral para pesquisas envolvendo o desenvolvimento moral parte do pressuposto que se o raciocínio moral é usado para determinar o curso de uma ação, então uma das primeiras necessidades desse processo consiste na habilidade de reconhecer os aspetos morais da situação. E a opção de Fowler, Zeidler e Sadler (2009) por fazer esse estudo utilizando o quadro proposto por Rest, Bebeau e Volker (1986) se dá devido ao fato deste, mais do que se ater exclusivamente ao raciocínio moral, envolver outros processos os quais consideram relevantes, como a afetividade e questões emotivas.

Para os autores desse estudo, na busca pela compreensão da reação dos indivíduos diante de QSC, se faz importante examinar a relação entre sensibilidade moral e QSC. Assim, enquanto essa relação não for melhor compreendida, os efeitos das emoções na tomada de decisão e estratégias pedagógicas que facilitem o que se denominou alfabetização científica funcional, permanecerão pouco ou não explorados na literatura.

Nessa perspectiva, o estudo foi realizado com quatro turmas de alunos do que no Brasil se denomina ensino médio, com idades entre 16 e 18 anos. Duas turmas eram classificadas de "avançadas" com estudantes considerados academicamente excelentes e duas turmas "regulares". Para o estudo os autores selecionaram uma turma avançada e uma regular para ser do grupo de tratamento submetido ao currículo governado por QSC e as outras duas foram classificadas como do grupo de comparação. Para a investigação da sensibilidade moral, portanto, Fowler, Zeidler e Sadler (2009) empregaram pré e pós testes adaptados do Test for Ethical Sensitivity de Clarkeburn (2002). Esse teste envolvia a leitura, pelos alunos, de um cenário que apresenta dimensões morais e, então, era solicitado que respondessem por escrito a questão elencando até cinco aspectos que acreditavam que deveriam ser considerados na

\footnotetext{
${ }^{7} \mathrm{O}$ estudo, realizado em contexto norte americano, ocorreu com alunos do que lá se denomina High School de idades entre 16 e 18 anos, o que corresponderia ao ensino médio brasileiro.
} 
situação. Um exemplo de cenário empregado no teste descrevia uma situação envolvendo o desenvolvimento de um leite utilizando vacas geneticamente modificadas. As respostas eram então analisadas de acordo com a profundidade das considerações morais apresentadas e recebiam uma pontuação de 0 a 3 baseado no grau da consideração moral, 0 representava nenhuma e 3 uma consideração moral forte. Para a classificação das respostas apresentadas pelos alunos ao teste, os autores desenvolveram a rubrica presente no Quadro 2.

Quadro 2 - Rubrica de pontuação e alguns exemplos de respostas para análise da sensibilidade moral utilizada por Fowler, Zeidler e Sadler (2009).

\begin{tabular}{|c|c|c|c|}
\hline Pontuação & Critério & $\begin{array}{l}\text { Exemplos de respostas ao cenário } \\
\text { de modificação genética }\end{array}$ & $\begin{array}{l}\text { Exemplos de resposta ao } \\
\text { cenário de clonagem }\end{array}$ \\
\hline 0 & $\begin{array}{l}\text { Nenhuma indicação de } \\
\text { considerações éticas/morais }\end{array}$ & $\begin{array}{l}\text { Onde eles poderiam conseguir o } \\
\text { dinheiro para a pesquisa? }\end{array}$ & $\begin{array}{l}\text { Seria o clone exatamente } \\
\text { igual? }\end{array}$ \\
\hline 1 & $\begin{array}{l}\text { Alguns riscos éticos/morais } \\
\text { eram reconhecidos, os quais } \\
\text { podem ser um passo para } \\
\text { considerações de nível } \\
\text { superior, no entanto, não } \\
\text { aparentes na resposta }\end{array}$ & $\begin{array}{l}\text { Quais as possíveis reações isto } \\
\text { pode causar? }\end{array}$ & $\begin{array}{l}\text { Teria o clone os mesmos } \\
\text { problemas de saúde dos } \\
\text { seus pais? }\end{array}$ \\
\hline 2 & $\begin{array}{l}\text { Considerações de riscos } \\
\text { éticos e morais que podem } \\
\text { incluir fortes declarações de } \\
\text { valor }\end{array}$ & $\begin{array}{l}\text { Eu penso que deve ser } \\
\text { extensivamente testado antes de } \\
\text { colocá-lo no mercado. Brincar } \\
\text { com a natureza pode promover } \\
\text { efeitos futuros imprevisíveis }\end{array}$ & $\begin{array}{l}\text { E se o garoto descobrisse } \\
\text { que iria morrer da mesma } \\
\text { forma que o seu clone? É } \\
\text { certo assustá-lo? }\end{array}$ \\
\hline 3 & $\begin{array}{l}\text { Considerações fortes de } \\
\text { consequências éticas/morais } \\
\text { incluindo o papel de quem } \\
\text { toma a decisão e o que } \\
\text { influencia a aceitação do } \\
\text { risco }\end{array}$ & $\begin{array}{l}\text { Eu não penso que é correto porque } \\
\text { primeiro, vacas e então o que - } \\
\text { pessoas geneticamente } \\
\text { modificadas? Quem iria policiar o } \\
\text { seu uso para que as pessoas não } \\
\text { utilizassem essa tecnologia para } \\
\text { coisas más? }\end{array}$ & $\begin{array}{l}\text { Se eles permitirem a } \\
\text { clonagem, o que iria parar } \\
\text { alguns homens maus de } \\
\text { clonarem um exército dos } \\
\text { seus melhores soldados e } \\
\text { dominar o mundo? É certo } \\
\text { dar a pessoa o poder de } \\
\text { brincar de Deus como esse? }\end{array}$ \\
\hline
\end{tabular}

Fonte - Fowler, Zeidler e Sadler (2009, p. 288, tradução nossa)

Os autores observaram que embora os grupos experimentais e de comparação tenham apresentado um aumento/desenvolvimento da sensibilidade moral, em cenários específicos, como aquele envolvendo modificações genéticas de animais, o grupo de tratamento apresentou um aumento significativamente maior que o apresentado pelo grupo de comparação. No outro cenário, o da clonagem reprodutiva, essa diferença não foi significativa, o que levantou algumas questões e a necessidade de maiores investigações a respeito. Ademais, embora os resultados sugiram que o aumento da sensibilidade moral para ambos os grupos possa estar relacionado com o aumento do conhecimento científico adquirido ao longo do ano em que se deu o estudo, outras pesquisas (CLAKEBURN, 2002 e FOWLER e AMIRI, 2004), centradas na investigação 
dos efeitos do conhecimento científico no desenvolvimento da sensibilidade moral, indicam que este, por si só, não é capaz de aumentar a sensibilidade moral dos estudantes.

Isto exposto, em nosso estudo empregamos o Modelo dos Quatro Componentes para análise, principalmente, da sensibilidade moral. No entanto, pode surgir na discussão, uma vez que embora distintos os quatro componentes desse modelo se influenciam mutuamente, considerações a respeito do julgamento moral, comprometimento moral e caráter moral. Agora, no que diz respeito a como se procedeu a investigação dessa sensibilidade, diferente de Fowler, Zeidler e Sadler (2009) que empregaram pré e pós testes em seus estudos, nos baseamos em nossa investigação no material de Bebeau (1995), o qual está descrito no Capítulo 4.

Em termos gerais, nesse material, desenvolvido para professores de cursos universitários da área de ciências exatas, Bebeau (1995) apresenta um compilado de casos que envolvem dimensões morais e exigem o exercício do raciocínio informal para a sua resolução. Para cada caso o autor fornece também uma grelha que permite ao professor a análise das respostas dos alunos e da respectiva sensibilidade moral. Essas grelhas contêm o que para o autor seriam os aspectos morais envolvidos na situação, isto é, uma lista das partes direta ou indiretamente envolvidas, as quais podem ser afetadas pelas ações possíveis. Também são descritas as consequências de cada uma dessas ações, as obrigações daquele responsável por tomar a decisão, ou seja, do protagonista do caso e, por fim, a apresentação do(s) ponto(s) de conflito presentes na situação narrada. Assim sendo, um indivíduo com maior sensibilidade moral seria aquele que apresentasse em sua resposta um maior número de elementos sugeridos pelo autor.

De forma semelhante ao proposto por Bebeau (1995), a análise da sensibilidade moral em nosso estudo se deu por meio da elaboração de grelhas para cada caso extraído da HQ mencionada no tópico "Introdução" deste texto. Previamente à aplicação na formação inicial de professores, o pesquisador e a orientadora desenvolveram grelhas contendo os aspectos morais que consideraram relevantes para os distintos casos da HQ. Portanto, para além de subsidiar as discussões estabelecidas em sala de aula, estas grelhas se configuraram como principal instrumento de análise dos argumentos escritos no que diz respeito à sensibilidade moral dos licenciandos. Isto é, a quantidade de elementos morais presentes nas respostas dos futuros professores está diretamente relacionada com a sensibilidade moral dos mesmos. A opção pela adoção do material de Bebeau (1995) se encontra no detalhamento fornecido pelo autor em seu texto, o qual tem por objetivo exatamente fornecer subsídios metodológicos e analíticos para que educadores e pesquisadores possam desenvolver ações semelhantes, voltada para o desenvolvimento moral, na área científica. 


\section{Capítulo 3 - O caminho para a construção dos dados - A HQ "Trinity: a} história em quadrinhos da primeira bomba atômica"

Partindo para os elementos que nos conduzem à metodologia e aos aspectos metodológicos do nosso trabalho, este, de abordagem qualitativa, foi levado a cabo em duas principais etapas. A primeira, diz respeito à seleção, leitura e análise da HQ e, com caráter de estudo de caso, a segunda etapa corresponde à aplicação de oficinas de leitura no âmbito da formação inicial de professores de química, em que foram empregados três casos extraídos da HQ para a promoção da argumentação dos licenciandos. Discutiremos neste capítulo os aspectos relacionados à primeira etapa do estudo e, posteriormente, no Capítulo 4, evidenciaremos o percurso envolvendo a segunda etapa de investigação.

Para efeito de discussão e considerando o contexto de aplicação da proposta didática deste trabalho, isto é, a argumentação por meio da prática da leitura quadrinizada, apresentamos inicialmente um panorama envolvendo o uso de HQ no ensino de ciências, salientando a sua validade para inserção em ambientes de ensino. Outrossim, destacamos os aspectos considerados no momento de seleção da HQ "Trinity" e a análise empreendida nessa etapa com relação ao conteúdo e a forma do texto que, como já mencionado anteriormente, nos permitiu identificar o potencial pedagógico da referida $\mathrm{HQ}$, bem como os elementos da sua linguagem que poderiam influenciar a argumentação dos licenciandos.

\subsection{Histórias em quadrinhos e suas potencialidades didáticas}

As HQ, consideradas a Nona arte, são descritas por Eisner (1999), como uma forma de arte sequencial estruturada pela imagem e pela escrita. É essa característica de sequenciamento que as diferem de cartuns ou ilustrações que são encontradas nos livros didáticos. Em sua estrutura, textos e imagens trabalham em conjunto para a criação de um sentido, constituindo uma forma de expressão artística que visa representar um movimento por meio do registro de imagens estáticas. As HQ são definidas nas palavras de McCloud (2005, p. 9) como: "Imagens pictóricas e outras justapostas em sequência deliberada destinadas a transmitir informações e/ou a produzir uma resposta no espectador. "

Descritas por Ramos (2016) como um hipergênero que agregaria diferentes outros gêneros, como charges, tirinhas etc., os quadrinhos possuem uma linguagem autônoma. O autor afirma:

Quadrinhos são quadrinhos. E, como tais, gozam de uma linguagem autônoma, que usa mecanismos próprios para representar os elementos narrativos. Há muitos pontos 
comuns com a literatura, evidentemente. Assim, como há também com o cinema, o teatro e tantas outras linguagens (RAMOS, 2016, p. 17).

De forma geral, considerando essa linguagem dos quadrinhos, estes se apresentam como uma sequência de quadros (vinhetas) nos quais o discurso das diferentes personagens se localiza, geralmente, dentro de balões que podem assumir diferentes formatos mediante o objetivo do autor. Esses quadros são então separados por espaços em branco (sarjetas), os quais são elementos essenciais para a noção de tempo e espaço na linguagem dos quadrinhos, e é ao longo dessa sequência de quadros que se desenrola uma narrativa ou exposição.

No que diz respeito às potencialidades didáticas das HQ no espaço formal de ensino, Testoni e Abib (2003) e Testoni (2004) as classificam em quatro grupos pedagógicos principais, e apontam três características que validam o seu emprego em sala de aula. Segundo os autores, esse tipo de texto, no ensino de ciências, pode se enquadrar inicialmente em uma categoria ilustrativa, na qual sua função é apenas representar de forma gráfica um fenômeno previamente estudado, o que denota um valor significativo às imagens e ao aspecto visual dos quadrinhos. A segunda categoria seria a explicativa, cuja função primordial seria a explicação de um fenômeno por meio da linguagem dos quadrinhos, ou seja, uma espécie de simplificação do conteúdo trabalhado via recursos textuais empregados em conjunto com o caráter gráfico que permite uma "visualização" dos fenômenos.

As HQ podem também ser classificadas dentro de uma categoria motivadora, que almejando instigar os alunos para o conteúdo da disciplina, consiste em inserir no enredo da HQ, sem uma explicação prévia, o próprio fenômeno que será abordado posteriormente em sala de aula. Por fim, a última categoria em que as HQ podem ser alocadas é a categoria instigadora, a qual, diferente das categorias anteriores, consiste em apresentar de forma explícita, no enredo, uma situação/questão que faça o educando pensar a respeito do assunto.

Quanto às características que validam o emprego desse material em sala de aula, os autores indicam a ludicidade dos quadrinhos, sua linguagem e o cognitivismo inerente do processo de leitura desse tipo de texto. A ludicidade das HQ se apresenta na medida em que, em grande parte humorísticas, e com uma linguagem autônoma, como defendido por Ramos (2016), elas não se privam de jogar com seus personagens, códigos e leitores.

Citando Quella-Guyot (1994), Testoni (2004) sugere que a exploração dos ideogramas e da própria narrativa é utilizada com frequência nas HQ em busca de um equilíbrio entre arte e ludicidade. Assim, os quadrinhos possibilitam uma leitura a princípio livre que promove a catarse no leitor, no entanto, o autor ressalta a importância do docente quanto ao caráter didático 
das HQ, salientando que sua ludicidade deve sempre ser acompanhada de um desafio, um propósito pedagógico em sala de aula.

A linguagem das HQ, segunda característica apontada por Testoni (2004), se torna relevante no espaço formal de ensino na medida que os quadrinhos se configuram como um sistema narrativo formado por dois códigos gráficos distintos, a imagem e a escrita. Atuando em relação de complementaridade no enredo da HQ, o elemento textual (escrita) apresenta elevado poder de representação no campo dos conceitos universais, ao mesmo tempo que a parte icônica (imagens) busca a representação dos objetos, seus movimentos e sucessões. $\mathrm{O}$ texto indica aquilo que a imagem não mostra, acrescentando, por exemplo, elementos espaciais e temporais, e a imagem, por sua vez, permite a dinamização da narrativa. Essa particularidade das HQ, portanto, lhes confere uma maior participação/inserção dos leitores em seu enredo (TESTONI e ABIB, 2003).

Com relação ao terceiro aspecto mencionado por Testoni (2004), o cognitivismo, referente ao conjunto de processos cognitivos que a leitura de um quadrinho permite ao leitor, é de particular interesse no espaço formal de ensino. Tendo em vista as regras e convenções da linguagem própria dos quadrinhos, ao mesmo tempo que a mistura dos códigos atuando em complementaridade implica em efeitos positivos para a HQ, como a maior participação dos leitores na narrativa, ela também exige destes uma atenção mais complexa para a interpretação e compreensão do enredo. Dessa forma, no processo de decodificação o indivíduo poderá utilizar uma série de tarefas mentais como a capacidade de análise, síntese e decisão. Logo, quando se pensa nas salas de aula do ensino de ciências, os processos cognitivos envolvidos na leitura da HQ são passíveis de serem explorados de modo a obter melhores resultados quanto à aprendizagem dos alunos (TESTONI, 2004).

Nessa perspectiva, além dos grupos pedagógicos e das características dos quadrinhos elencadas por Testoni e Abib (2003) e Testoni (2004), que validam o emprego desse material em sala de aula, Leite (2017) sintetiza algumas das potencialidades das HQ no ensino de ciências:

O potencial didático-pedagógico das histórias em quadrinhos envolve diversas aplicações como: incentivo à leitura, discussão de conteúdos científicos, uso de dramatização e divulgação científica. As HQs além de promoverem a prática da leitura, por aqueles estudantes que não são motivados a ler outro gênero, elas possibilitam uma aprendizagem diferenciada e marcante para o estudante (LEITE, 2017, p. 61). 


\subsection{Um histórico recente das HQ e o espaço formal de ensino no Brasil}

No Brasil, foi a partir de 1950 que ocorreu certa identificação das HQ com a educação científica por meio do lançamento das revistas Ciência em Quadrinhos e Enciclopédia dos Quadrinhos (TAVARES, 2015). Contudo, apesar de hoje as HQ se apresentarem como um objeto de estudo de diversos pesquisadores das mais variadas áreas, e destes reconhecerem o seu potencial pedagógico, como aqueles apontados por Testoni e Abib (2003), Testoni (2004) e Leite (2017), a relação dos quadrinhos com a educação nem sempre foi muito amigável. Embora tenha se consolidado como "produção cultural da humanidade", esse gênero sofreu e de certa forma ainda sofre, um desmerecimento para a sua utilização no ambiente escolar (CARVALHO e MARTINS, 2013). Por muito tempo, seu uso em sala de aula ficou restrito a aplicações pontuais de professores ousados (SANTOS e VERGUEIRO, 2012; LEITE, 2017).

Foi a partir da década de 1960 que as HQ começaram a se propagar no âmbito do ensino formal, sendo utilizadas nas aulas de língua portuguesa e língua inglesa, para então passarem a ocupar espaço em disciplinas de outras áreas. É possível encontrar na década de 1970 narrativas gráficas sequenciais em livros didáticos, para sintetizar ou exemplificar um tópico ou capítulo (SANTOS; VERGUEIRO, 2012). Nesse período, é digno de nota a publicação do livro didático em quadrinhos "Física com Martins e Eu" (1969) de Pierre Lucie, que assumiu importante caráter didático voltado para o ensino universitário e médio. Segundo Vieira (2017), a aceitação dessa obra pelo público impulsionou a inserção de gêneros de HQ, como as tirinhas e as charges, em outras coleções didáticas.

A década de 1990 foi a que promoveu uma maior abertura para que as HQ pudessem se inserir nas escolas, o que está alinhada à promulgação em 1996 da LDB, cujo texto já apontava para a necessidade de inserção de outras linguagens e manifestações artísticas no ensino fundamental e médio (VERGUEIRO e RAMOS, 2009). A expansão das HQ no contexto de ensino também se relaciona aos Parâmetros Curriculares Nacionais (PCN) publicados no ano posterior, principalmente no que diz respeito às artes e língua portuguesa. Isso, no entanto, não impediu que outras áreas também pudessem se aproveitar desse rico material, e hoje, por exemplo, diversos gêneros de quadrinhos estão presentes nas diferentes áreas do conhecimento avaliadas pelo Exame Nacional do Ensino Médio (ENEM) (VERGUEIRO e RAMOS, 2009).

Mais recentemente, na primeira década do século XXI, o PNBE, instituído em 1997, passou a adquirir exemplares de HQ a partir do edital de 2006 voltado ainda apenas para o ensino fundamental. No edital de 2008, apesar de aberto para o ensino médio, foram adquiridos quadrinhos apenas para o ensino fundamental novamente, sendo estes 7 das 100 obras 
compradas para esse nível. Esse fato denota a visão de HQ mais indicada para um leitor mais novo, corroborada por muitos indivíduos que as avaliam como entretenimento puro, voltado para o público infantil.

Foi a partir de 2009 que o Programa passou a comprar quadrinhos também para o ensino médio, no entanto, dentre as obras selecionadas destacam-se as adaptações de clássicos literários como $O$ Alienista, O Guarani, Os Lusíadas etc., o que por sua vez reforça a visão de que as HQ seriam apenas a porta de entrada para leituras sérias. No entanto, Vergueiro e Ramos (2009) vislumbram a contribuição do PNBE, afirmando que a inclusão dos quadrinhos no Programa significa um avanço na maneira como a área de ensino os enxerga. Essa nova visão se torna fundamental para a inserção de quadrinhos no ensino de química, por exemplo, como afirma Leite (2017)

A utilização das histórias em quadrinhos de química em conjunto com as práticas pedagógicas suscita em todos os segmentos de educação brasileira (desde a direção, passando pelos funcionários e professores, até estudantes) o desafio de enxergarem as HQs com outra perspectiva (LEITE, 2017, p.63).

Nesse contexto, o uso de HQ no ambiente escolar se tornou objeto de pesquisas em diversas áreas. A título de exemplo, dado o grande interesse de pesquisadores pela temática dos quadrinhos, em 2011 foi realizado o primeiro congresso internacional com pesquisas com HQ na Universidade de São Paulo, com sede na Escola de Comunicação e Artes. Reunindo pesquisadores de diversas áreas, a $1^{\text {a }}$ Jornada Internacional das Histórias em Quadrinhos contou com trabalhos alocados em quinze eixos temáticos, e o destaque aqui vai para o eixo denominado "Quadrinhos e Educação", que representava dezenove dos 189 trabalhados apresentados no evento.

Em sua segunda edição, realizada no ano de 2013, o evento contou com 210 trabalhos divididos novamente em quinze eixos temáticos, e o eixo "Quadrinhos e Educação" abrangia 29 desses trabalhos. No ano de 2015 ocorreu a terceira edição das jornadas, e com ela houve 231 trabalhos agora divididos em seis eixos temáticos. O antigo eixo "Quadrinhos e Educação" passou a ser denominado "Quadrinhos, Educação e Letramentos”, o qual contou com cinquenta resumos dos trabalhos apresentados nessa edição. Por fim, a jornada mais recente, realizada no ano de 2017, contemplou 226 trabalhos, sendo 41 voltados para o eixo "Quadrinhos, Educação e Letramentos". Fica, portanto, evidente o interesse de pesquisadores de diferentes áreas quanto ao potencial didático das HQ. 


\subsection{HQ no ensino de ciências}

No que diz respeito à relação direta entre HQ e ensino de ciências naturais, são encontrados na literatura recente, segunda década do século XXI, trabalhos publicados sobre a temática em anais dos principais eventos da área, como do Encontro Nacional de Pesquisa em Educação em Ciências (ENPEC), e em diversos periódicos nacionais e internacionais relevantes para a área, como as revistas Alexandria, Práxis, Química Nova na Escola e o Journal of Science Communication.

Em diferentes buscas na literatura nacional (SANTOS e GARCIA, 2017; SILVA e QUEIROZ, 2017), verifica-se que ainda há um predomínio de uma visão infantilizada das HQ, que encontram maiores possibilidades de aplicação nos anos iniciais do ensino fundamental, e consequentemente com maiores números de trabalhos voltados para esse nível de ensino. Esse fato corrobora um dos principais obstáculos que as HQ enfrentaram para a sua inserção no ambiente escolar, e reitera a observação de Leite (2017) que aponta para a necessidade e o desafio de os diferentes agentes envolvidos no processo educativo enxergarem as HQ com outra perspectiva.

No que tange aos trabalhos voltados para os níveis médio e superior, verifica-se, conforme tais buscas, um domínio de pesquisas envolvendo o uso de HQ no ensino de física. Essa constatação pode ser reflexo do que Nardi (2005) apresenta em sua tese de livre docência ao traçar a evolução das pesquisas em ensino de ciências no país. Segundo o autor, a física representou o primeiro grupo a se consolidar em pesquisas nessa área, seguida pela química e biologia. No mais, destacam-se em pesquisas com quadrinhos no ensino de física os variados trabalhos de Leonardo André Testoni, sob orientação da Professora Doutora Maria Lúcia Vital dos Santos Abib e do Professor Doutor João Zanetic, ambos da Universidade de São Paulo, sendo Zanetic um dos principais nomes quando se pensa na relação entre ensino de ciências e artes, cuja tese de doutorado "Física também é Cultura" é referência de inúmeros estudos.

Quanto às características dos trabalhos envolvendo o uso de HQ no espaço formal de ensino de ciências, estes assumem diversas perspectivas. Há pesquisas que utilizam HQ comerciais em sala de aula com o intuito de promover reflexões sobre práticas pedagógicas nelas pautadas (CARVALHO e MARTINS, 2009; CARVALHO, 2009; SILVA, OLIVEIRA e CAMPOS. 2014), assim como estudos nos quais as HQ são empregadas com o objetivo primário de promover o conhecimento de conceitos e noções científicas (TATALOVIC, 2009).

São relatados também estudos em que os pesquisadores ou futuros professores são produtores das HQ empregadas em sala de aula (CAVALCANTE et. al. 2015; CORRÊA et. al., 
2016; TESTONI; ABIB, 2003), e até mesmo aqueles nos quais os alunos, de diferentes níveis de ensino, utilizando diferentes recursos, como ferramentas da Web 2.0 (Pixton e TooDoo), são incentivados a produzir novos quadrinhos que, de alguma forma, sintetizem o conteúdo de ciências abordado ou de interesse (TELLEZ, 2013; LEITE, 2017; VIEIRA e HIGA, 2013). Consta ainda na literatura estudo que associa indicadores de alfabetização científica ao uso da HQ no ensino de ciências (PIZARRO e LOPES JUNIOR, 2010), e pesquisas envolvendo a concepção de futuros professores sobre o emprego das mesmas (TAVARES, 2015; SANTOS e PEREIRA, 2013).

Em geral, nos estudos em que são empregados quadrinhos comerciais em sala de aula, prevalece o uso de histórias da Turma da Mônica, de Maurício de Souza. É o caso do trabalho de Carvalho (2009), o qual faz a opção de trabalhar com HQ dessa natureza justamente por elas já fazerem parte do repertório das crianças e serem as mais consumidas no Brasil pelo público infantil. Segundo o autor:

Consideramos necessário utilizar histórias que façam parte do repertório leitor das crianças, pois, apesar de já existirem grupos que preparam HQ para atender às demandas das aulas de $\mathrm{CN}$ [ciências naturais], elas possuem uma intencionalidade que, em nossa concepção, atenua um ponto primordial da leitura quadrinizada: a leveza (CARVALHO, 2009, p. 1).

Quanto aos quadrinhos elaborados com a finalidade de abordar o conhecimento de conceitos e noções científicas, Tatalovic (2009) faz uma revisão de estudos envolvendo o que ele denomina educational comics. Segundo o autor, quadrinhos produzidos especificamente para a comunicação científica constituem um gênero especial e por vezes ignorado por pesquisadores. Ainda de acordo com Tatalovic (2009), crianças apreciam a leitura dos quadrinhos, e dessa forma, a sua linguagem, que aqui não se restringe ao emprego de recursos textuais, como simplificações, explicações etc., os torna um veículo para transmitir conceitos científicos de maneira interessante.

Nesse sentido, os educational comics envolvem o conceito de quadrinização na perspectiva de Mendonça (2008), que por sua vez consiste na criação e/ou adaptação de qualquer gênero para a linguagem dos quadrinhos em sua forma comumente conhecida. No Brasil há alguns projetos voltados para a produção desse material, como a revista GIBIOzine produzida por alunos da Universidade Federal de São Carlos (UFScar) câmpus de Sorocaba ${ }^{8}$, e o Projeto Sigma Pi desenvolvido por Adriana Yumi que produz quadrinhos no estilo oriental mangá, com conteúdo de química ${ }^{9}$.

\footnotetext{
${ }^{8}$ Endereço eletrônico GIBIOzine: http://gibiozine.wixsite.com/gibiozine/edio-n-14

${ }^{9}$ Endereço eletrônico Projeto Sigma Pi: http://www.sigmapi-project.com/
} 
Como mencionado, em parte dos trabalhos são os pesquisadores e/ou futuros professores que elaboram as HQ empregadas em sala de aula da educação básica de modo a evidenciar a efetividade destas como recursos didáticos. Nessa perspectiva, por exemplo, Testoni e Abib (2003) aplicaram uma sequência didática que contou com a utilização de questionários pré-leitura, para então prosseguir com a leitura da HQ elaborada pelo autor, intitulada "Um corpo que cai". A HQ em questão apresentava uma situação problema envolvendo questões referentes à inércia. Ao final do processo, os aprendizes foram desafiados a criar novas tirinhas. Os resultados obtidos pelos autores, assim como os de trabalhos com objetivos semelhantes (CAVALCANTE et. al., 2015; CORREAA et. al., 2016), evidenciaram a contribuição dos quadrinhos utilizados para o aprendizado dos estudantes, além de um envolvimento e interesse significativo dos mesmos.

Outra parcela relevante dos trabalhos identificados na literatura propõe a construção de quadrinhos, seja por alunos da educação básica ou por professores em formação. Estas pesquisas têm como objetivos principais avaliar a contribuição do desenho e escrita para o processo de ensino e aprendizagem, analisar os sentidos produzidos pelas interações discursivas, e a argumentação dos educandos sobre diferentes temáticas.

A proposta de elaboração de quadrinhos pelos alunos é incentivada, conforme Cruz, Mesquita e Soares (2013), pelo fato de que esse tipo de aprendizagem promove o uso da criatividade pelos educandos como roteiristas e desenhistas, assim como a sua autonomia em uma perspectiva de aproximação do conhecimento científico escolar com uma linguagem mais familiar a eles.

Em contrapartida, em estudo voltado para a formação de professores, Vieira e Higa (2013) apontaram como dificuldade para a utilização das HQ em sala aula, o imaginário dos próprios professores de que esta linguagem não se materializa como recurso didático, mas sim como material lúdico, motivador ou complementar, dessa forma dispensável dentro de uma abordagem formal de ensino. Essa constatação se assemelha com a feita por Leite (2017) que em seu estudo incentivou a construção de tirinhas por licenciandos em química por meio de recursos digitais. Em seu trabalho foi aplicado um questionário aos futuros professores, e o que se identificou pelas respostas foi a visão ainda predominante das HQ como um recurso apenas para motivar o estudante.

Dessa forma, se torna necessário a superação dessa visão, e de acordo com Pereira e Fontoura (2016), atividades desse tipo na formação de professores se tornam relevantes para desmistificar tabus e romper pré-conceitos e preconceitos. Ademais se torna patente também, conforme Vergueiro e Ramos (2009) e Leite (2017), a inserção de práticas que permitam a 
familiarização dos futuros professores com a linguagem dos quadrinhos, de modo que estes façam uso dessa linguagem em suas ações docentes.

Quanto às principais temáticas abordadas por meio do uso de quadrinhos em sala de aula da educação básica, evidenciadas nos trabalhos da área de ensino de ciências, destacam-se os temas transversais, os quais contribuem para alcançar determinados objetivos educacionais, promovendo a interdisciplinaridade e a contextualização (BRASIL, 2006). Dentre estas temáticas se encontra a educação ambiental e saúde, com narrativas sobre poluição, alimentação e diferentes doenças.

No que diz respeito ao emprego de HQ especificamente no ensino de química, destacase o conceito de radioatividade, o qual segundo Cruz, Mesquita e Soares (2013), por envolver conhecimentos do mundo microscópico e exigir um nível de abstração maior dos estudantes, estimula a busca por parte dos pesquisadores de diferentes formas de abordagem. Além disso, este é um conceito comumente presente em HQ comerciais de ficção científica envolvendo super-heróis, o que é o caso dos diferentes quadrinhos da Marvel que, de acordo com Locke (2005), contam com protagonistas com poderes que desafiam a ciência e fazem referência a eventos que misturam ciência, magia, lenda e mitologia.

Nessa perspectiva, em trabalho envolvendo a radioatividade em que os alunos da educação básica foram instigados a elaborar pequenas tirinhas sobre o tema, Cruz, Mesquita e Soares (2013) concluem:

\footnotetext{
Além de exercerem a criatividade na criação de heróis que apresentam elementos radioativos em sua constituição, e apresentarem situações de risco envolvendo acidentes nucleares, [os alunos] trabalharam os conceitos sobre radioatividade de maneira correta e não cometeram erros conceituais (CRUZ; MESQUITA; SOARES, 2013, p. 4).
}

De forma geral, o que parece ser um interesse mais recente em âmbito nacional com uma expansão de publicações voltadas para o ensino de ciências a partir essencialmente do século XXI, corroborado por documentos curriculares nacionais como a LDB e os PCN, é algo debatido de forma mais intensa há um certo tempo em contexto internacional, com destaque para os trabalhos de Carter (1988a; 1988b e 1989). No fim da década de 1980, este autor apresenta em quatro diferentes trabalhos uma série de quadrinhos comerciais que trazem em seu bojo conceitos químicos, como também science comics ou quadrinhos científicos.

Segundo Carter (1988b), as HQ, para além de mostrarem um excelente trabalho artístico, entretenimento e valor nostálgico para colecionadores, podem também ser uma fonte de informação para vários tópicos. Ainda, de acordo com o autor, há um número considerável 
de referências a fatos químicos em HQ disponíveis comercialmente comuns aos educandos, as quais podem ser empregadas no espaço formal de ensino.

Pode-se encontrar nos quadrinhos, por exemplo, referências a reações e soluções, como ilustra a Figura 8, em que é possível identificar a combinação de ácidos que produzem a água régia e o seu grande poder oxidante, que dissolve metais preciosos como o ouro. Além disso, dado o caráter visual desse tipo de texto, é comum identificar referências a experimentos químicos, que devido às propriedades dos reagentes, resultam em uma explosão, como ilustra a Figura 9. E, em se tratando de reações que saem do controle e que podem resultar em riscos para as pessoas, Raddo (2006) apresenta algumas dicas de segurança para laboratórios em química através de tirinhas, o que evidencia o uso desse material também no ensino superior e na formação de profissionais da área.

Figura 8 - Os ingredientes da água régia apresentadas no quadrinho "Jornada ao Centro da Terra".

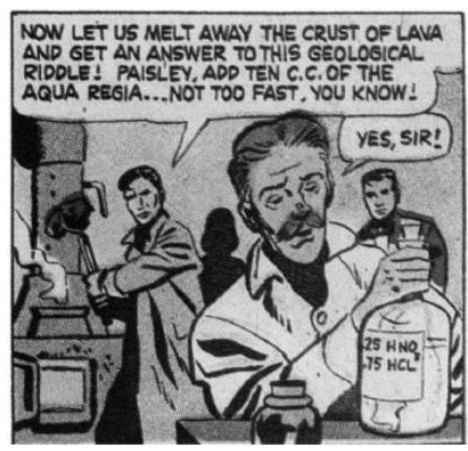

Fonte: Carter (1988b)
Figura 9 - Capa do quadrinho "Bolinha" (Tubby) $n^{0} 10$, mostrando uma reação que sai do controle.

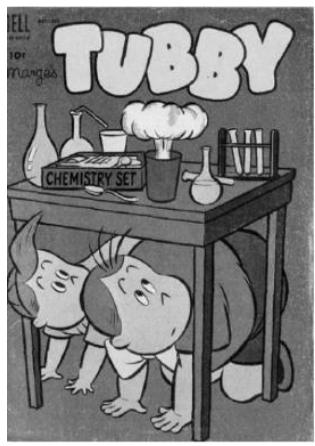

Fonte: Carter (1988b)

Isto exposto, fica claro o interesse de pesquisadores de diversas áreas pelas $\mathrm{HQ}$, como também fica evidente as potencialidades didáticas que estas assumem em sala de aula não somente para o ensino fundamental, como também para o ensino médio e até mesmo para o ensino superior. No entanto, conforme afirma Leite (2017), ainda se faz necessária a mudança da visão que pais, educadores, gestores, e todos envolvidos no processo educativo nutrem a respeito dos quadrinhos. Visão esta de leitura subversiva voltada para o público infantil e de entretenimento puro.

Contudo, essa visão se contrapõe à própria evolução e constituição da indústria produtora dos quadrinhos. A título de exemplo, após a "invasão" dos mangás orientais, no Brasil, com forte apelo ao público jovem, a própria indústria dos quadrinhos se reinventou e foi então que, voltadas para esse público, foram lançadas em agosto de 2008 e agosto de 2013, a Turma da Mônica Jovem e o Chico Bento Moço, respectivamente, ambos de Maurício de Souza. Além disso, pelo fato das HQ representarem um hipergênero textual, estas abrangem 
uma série de outros gêneros, desde as tirinhas cômicas comumente conhecidas até obras mais obscuras e dramáticas voltadas para o público adulto, como a obra Maus de Art Spiegelman, que retrata de modo peculiar a história de um judeu polonês sobrevivente ao campo de concentração de Auschwitz, Polônia.

E ainda, dadas as particularidades desse tipo de texto, a ideia de uma leitura simplista também não se sustenta, pois, a compreensão de uma narrativa em quadrinhos exige um grande nível de atenção do leitor, que coloca em prática uma série de atividades mentais. Dessa forma, se torna interessante a inserção de práticas de leitura de quadrinhos na formação inicial de professores de modo que, para a além de desmistificar a visão destes, permita a sua familiarização com a linguagem autônoma dos quadrinhos que os torna um material valioso para o ensino de ciências.

Além disso, indo ao encontro dos objetivos principais do nosso estudo, identifica-se ainda na literatura nacional um trabalho que relaciona o uso HQ para a promoção da argumentação. Testoni et. al. (2017) utilizando o mesmo quadrinho citado anteriormente "Um corpo que cai", que envolve noções de inércia no ensino de física, buscaram analisar o seu emprego como instrumento didático que contribua para o desenvolvimento das habilidades argumentativas de estudantes do ensino básico brasileiro, mais especificamente, do $9^{\circ}$ ano do ensino fundamental.

Dessa forma, para além de todos os aspectos interessantes que validam a inserção de textos mais próximos da leitura espontânea dos alunos como HQ, Testoni et. al. (2017) salientam que com a atividade realizada foi possível, por meio de proposições argumentativas no estudo dos fenômenos naturais, o desenvolvimento de diversas características científicas que contribui, segundo o autor, para o que denomina enculturação científica ${ }^{10}$.

\subsection{A seleção da HQ "Trinity: a história em quadrinhos da primeira bomba atômica"}

Considerando que estamos interessados em promover a argumentação diante de QSC a partir da leitura de uma HQ, esta deve, a princípio, sugerir esse tipo de abordagem em seu corpo. Dessa forma, ao analisarmos o título de algumas obras tomamos contato com a HQ

\footnotetext{
${ }^{10}$ Enculturação científica faz referência ao termo em inglês Scientific Literacy. Segundo Sasseron e Carvalho (2011), devido à pluralidade semântica encontrada na literatura nacional sobre o ensino de ciências, há pesquisadores que ao referenciar essa expressão fazem uso do termo "letramento científico", outros empregam "alfabetização científica" ou ainda, como no caso, "enculturação científica". O importante é ressaltar que apesar das diferenças estabelecidas pelos pesquisadores que empregam um termo ou outro, no cerne das discussões estão as mesmas preocupações, as quais estão voltadas para um ensino que forneça subsídios para os estudantes compreenderem o funcionamento da ciência e assim serem aptos a participar de discussões científicas e a tomar decisões quanto ao impacto da ciência e tecnologia na sociedade.
} 
"Trinity: a história em quadrinhos da primeira bomba atômica", de Fetter Vorm, publicada no Brasil em 2013 pela editora Três Estrelas. Como sugere o título, ao abordar questões envolvendo a bomba atômica, essa HQ não somente apresenta tópicos pertinentes ao ensino de química, física e história, bem como envolve uma temática polêmica a respeito da mobilização de conhecimentos científicos para a construção de um armamento extremamente letal que levou à destruição das cidades de Hiroshima e Nagasaki, no Japão, em meio à $2^{a}$ Guerra Mundial.

É válido ressaltar que na época da escolha da HQ estava sendo amplamente divulgado pela mídia (televisa e online) o conflito envolvendo interesses norte-coreanos e norteamericanos, o que, por sua vez, poderia promover implicações em todo o mundo globalizado. No cerne desse conflito havia a existência de uma série de ameaças envolvendo o lançamento de bombas atômicas, o que se torna ainda mais preocupante quando considerados o arsenal atômico de ambas as nações. Nessa perspectiva, diversas revistas de DC também publicaram matérias a respeito da temática, o que corroborava a sua relevância e fornecia ferramentas para a sua abordagem em sala de aula, é o caso, por exemplo, do artigo "Os donos do fim do mundo" de Pedro Henrique Tavares publicado online em julho de 2017 pela Revista Superinteressante. Isto exposto, consideramos a temática atual e relevante na formação dos futuros professores.

Mesmo com publicação em 2013, é possível identificar na literatura nacional pesquisas que utilizaram a referida HQ em seus estudos, como os trabalhos de Santos (2017) e Brugliato (2016). O primeiro, em forma de resumo apresentado nas 4as Jornadas Internacionais de Histórias em Quadrinhos ${ }^{11}$, apresentava a relação direta entre a utilização do livro quadrinizado e o ensino de história, em específico para a abordagem da $2^{\circ}$ Guerra Mundial no espaço formal de ensino. Segundo o autor, esse conflito bélico é um dos que mais chamam a atenção dos alunos nas aulas de história, no entanto, mesmo com representações de diferentes maneiras pelas mais variadas formas de mídia, predomina apenas a abordagem do holocausto e da selvageria cometida por Hitler e os nazistas contra os judeus. Assim sendo, a HQ "Trinity", ao apresentar na forma de arte sequencial, a criação, explosão e consequências do que Santos (2017) considera a maior arma de destruição em massa já criada pelo ser humano, apresenta também a selvageria norte-americana ao explodir duas bombas nucleares no Japão.

Com relação ao trabalho de Brugliato (2016), esse diz respeito a uma dissertação de mestrado do Programa de Ensino de Ciências e Matemática da Universidade Estadual de Campinas (UNICAMP). Interessado em desenvolver uma sequência didática que promovesse a aproximação dos alunos do ensino médio com diferentes tipos de discursos, o autor, com

\footnotetext{
${ }^{11}$ Os anais e cadernos de resumos de todas as edições podem ser acessadas no endereço eletrônico: http://www2.eca.usp.br/jornadas/\#
} 
formação em física, optou pela abordagem da bomba atômica e a física envolvida em sua fabricação. Conforme apresentado por Brugliato (2016), o seu interesse pela temática se consolidou com a divulgação pelo jornal Folha de São Paulo do lançamento da referida HQ.

Nessa perspectiva, o autor fez uso, em sua unidade didática aplicada a alunos do $3^{\circ}$ ano do ensino médio de uma escola pública do interior de São Paulo, de diferentes tipos de discursos sobre o desenvolvimento da bomba atômica como filme, HQ, livro paradidático e roteiro teatral. Os diferentes discursos promoveram os mais variados efeitos sobre os estudante. No que diz respeito à HQ, houve uma reação inicial positiva dos alunos, no entanto estes, depois de um tempo, dispersaram e pouco participaram das discussões estabelecidas em sala de aula. Esse fato, segundo o autor, ocorreu devido à extensão da obra e o tipo de conteúdo.

No entanto é digno de nota que Brugliato (2016) utilizou em seu estudo apenas uma aula para a abordagem de diferentes trechos da HQ dada a impossibilidade da leitura integral da mesma, uma vez que esta apresenta 159 páginas, e o estudo específico do seu funcionamento em sala de aula não era o objetivo da referida pesquisa. Dessa forma, foram selecionados trechos que englobassem principalmente o desenvolvimento da bomba atômica, apresentando uma parte histórica, porém dando abertura para alguns conceitos científicos, tais trechos estavam distribuídos em 73 páginas. Isto exposto, é interessante salientarmos que as partes da HQ escolhidas são aquelas com maior número de interferências do narrador e consequentemente maior densidade de informações. Mediante a impossibilidade de leitura integral, aspectos como a identificação do leitor com situações e personagens por meio dos recursos empregados pelo autor são minimizados.

A escolha dessa HQ para o estudo aqui proposto encontra subsídios no interesse didático que essa, mesmo recente, tem atraído de pesquisadores de diferentes áreas de ensino. A referida HQ representa uma das poucas histórias desse hipergênero que abarca conceitos químicos e temas controversos com um corpo significativo para a análise e que possibilite, a priori, a partir da sua leitura, o exercício da argumentação e do raciocínio informal em sala de aula. Assim sendo, lançamos mão em analisá-la na perspectiva do referencial teórico abordado na subseção sequente.

\subsection{Instrumento de análise da HQ}

Ao abordar a relação TDC e espaço formal de ensino, nos deparamos com múltiplas possibilidades de aplicação e consequentemente com uma grande variedade de trabalhos e focos de investigação. Nessa perspectiva, Ferreira e Queiroz (2012), ao traçarem um panorama dessas pesquisas envolvendo o uso de TDC na educação científica, constataram que o seu foco 
principal se encontra na seleção, caracterização e/ou análise dos textos que podem ser úteis em sala de aula, ou seja, estudos cujo principal objetivo é fornecer aos professores da educação básica, não somente o acesso ao referido texto, mas à sua análise. O acesso a esse tipo de análise se torna importante pois, ao mesmo tempo que aproxima universidade e educação básica, permite aos professores o contato com os pontos mais relevantes do texto, sua qualidade, isto é, com relação à informação científica e sua abordagem, e sua aplicabilidade em sala de aula.

No referido estudo, os autores analisaram trabalhos publicados em periódicos alocados na atual área de Ensino (área número 46 da Capes), até o ano de 2011. Também foram considerados trabalhos apresentados nos ENPEC, no intervalo de 1997 a 2009. Ao todo, Ferreira e Queiroz (2012) identificaram 88 trabalhos, dos quais 52 apresentados nas diferentes edições do evento, e 36 trabalhos publicados em periódicos. Por meio da Análise de Conteúdo na perspectiva de Bardin (2011), os autores, portanto, identificaram cinco focos, sendo estes: Seleção, caracterização e/ou análise de TDC para fins escolares; Formação de professores e o uso de TDC em contextos escolares; Experiências em salas de aula de ciências com TDC; Ponderações sobre divulgação científica (DC) e suas implicações no ensino de ciências; Estado da arte das pesquisas relacionadas à DC.

A distribuição dos trabalhos identificados de acordo com o seu foco temático está representada na Figura 10.

Figura 10 - Relação de trabalhos e focos temáticos identificados por Ferreira e Queiroz (2012).

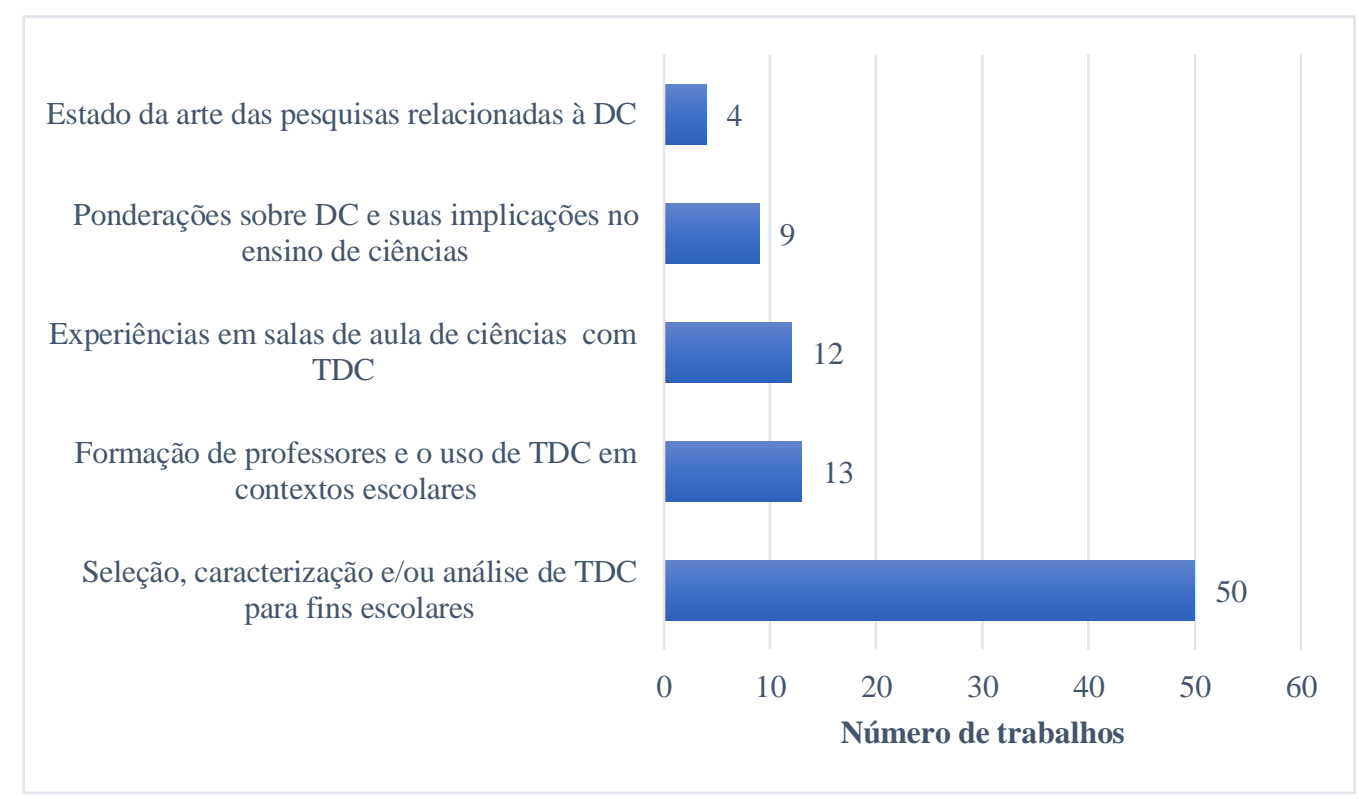

Fonte: Ferreira e Queiroz (2012)

Conforme mencionado anteriormente, fica nítido o predomínio de trabalhos que dizem respeito à seleção, caracterização e/ou análise de TDC para fins escolares, uma vez que estes 
representam aproximadamente $57 \%$ do total. Estes estudos, por sua vez, apresentam diferentes abordagens, com trabalhos centrados na busca, seleção e análise de artigos que contemplam uma área específica do conhecimento, ou um único tema, de modo que forneçam elementos capazes de orientar a seleção de TDC para o ensino dessas temáticas em questão, trabalhos que investigam as potencialidades didáticas de diferentes TDC com objetivo de verificar como notícias científicas são veiculadas pela mídia, estudos com olhar direcionado para a linguagem dos artigos de DC etc. (FERREIRA e QUEIROZ, 2012)

Segundo os autores, um dos maiores desafios da DC se apresenta na transposição do conhecimento científico. A necessária análise desse tipo de texto encontra subsídios nas ideias de Zamboni (2001), o qual apresenta uma série de considerações a respeito do discurso de DC em contraposição ao discurso veiculado no meio científico. De acordo com Zamboni (2001), a DC consiste em uma atividade de difusão dirigida para fora do contexto originário, isto é, transmitir ao público em geral, conhecimentos científicos produzidos e circulantes no interior de uma comunidade de limites restritos. Essa transposição, portanto, exige a mobilização de diferentes recursos, técnicas e processos para a veiculação das informações científicas e tecnológicas.

As ideias apresentadas por Zamboni (2001) vão ao encontro das considerações de Latour (2000), o qual reafirma a dificuldade desse processo de transposição do conhecimento científico para o público em geral. Segundo o autor, nesse processo estaríamos caminhando para o sentido oposto ao da construção de fatos na ciência, que devido às controvérsias naturais do desenvolvimento científico implica no emprego de uma série de recursos, como jargões técnicos, que garantam a credibilidade à afirmação de determinado cientista. Dessa forma, para Latour (2000):

Se quisermos aumentar de novo o número de leitores, precisaremos diminuir a
intensidade da controvérsia e reduzir os recursos [...]. É difícil divulgar a ciência
porque ela é planejada para alijar logo de cara a maioria das pessoas. Não espanta que
professores, jornalistas e divulgadores encontremos tanta dificuldade quando
tentamos trazer de volta os leitores excluídos (LATOUR, 2000, p. 88).

No entanto, em contraposição à ideia que o discurso da DC representaria uma simples reformulação do discurso veiculado na comunidade científica, Zamboni (2001) propõe que a DC implica a construção de um novo discurso, o qual pode se apresentar de diversas formas, e aqui, citamos as HQ. Dessa maneira, assim como em qualquer gênero do discurso, o da DC pode ser caracterizado com base em três elementos essenciais: o tema, o estilo e a composição.

O tema diz respeito a conteúdos próprios à temática científica, englobando, de forma mais ampla, temas sobre ciência e tecnologia. Com relação ao estilo, este envolve a seleção de 
recursos lexicais, gramaticais etc., dado que o novo discurso, direcionado a um público leigo, deve dispensar a linguagem esotérica exigida pelo discurso científico e compreensível apenas pelos cientistas. Por fim, a composição se refere, de forma geral, à estrutura do texto, responsável por colocar em funcionamento diversos procedimentos discursivos, dentre os quais, a recuperação de conhecimentos tácitos, fórmulas de envolvimento, emprego de procedimentos explicativos e busca por credibilidade (ZAMBONI, 2001).

Assim, direcionados para um diferente interlocutor, e com três objetivos principais (cívico, mobilização popular e educacional), os TDC podem apresentar diferentes graus de didaticidade, cientificidade e laicidade. Típicos do discurso científico, os traços de cientificidade revelam não apenas aspectos explícitos da práxis científica, mas também implícitos, dentre os quais características pessoais dos cientistas, motivações, implicações negativas de determinados produtos de ciência etc. Tais traços são marcados por estratégias enunciativas que permitem ao leitor compreender a temática do TDC e em especial as pesquisas científicas envolvidas, ou seja, permitem ao leitor uma maior compreensão de como a ciência é praticada, aproximando-o de sua natureza (ZAMBONI, 2001).

Os traços de laicidade, por sua vez, caracterizados por diferentes formas de contextualização, compreendem elementos próprios do discurso cotidiano e, assim, apresentam a relação existente entre este e a temática presente no TDC. Dessa forma, conta com procedimentos de aproximação, simplificação, fórmulas de envolvimento etc. Por fim, como podemos pressupor, os traços de didaticidade são aqueles que mais se aproximam do contexto do espaço formal de ensino, isto é, incluem procedimentos como explicações e recapitulações para permitir ao leitor o conhecimento de determinado conteúdo científico tratado no TDC, necessário para a compreensão da leitura.

Considerando, portanto, esses aspectos inerentes ao discurso de DC, emerge da literatura um quadro teórico elaborado por Ferreira e Queiroz (2011) com base nos estudos de Salém e Kawamura (1999) e Ribeiro e Kawamura (2005). O quadro permite a análise da potencialidade didática do TDC quanto ao seu conteúdo e a forma, o que, por sua vez, permite inferir qualitativamente sobre o grau dos traços de cientificidade, didaticidade e laicidade do referido texto. Este está esquematizado no Quadro 3. 
Quadro 3 - Esquema proposto por Ferreira e Queiroz (2011) para análise de TDC.

\begin{tabular}{|c|c|c|c|c|c|}
\hline \multicolumn{6}{|c|}{ ANÁLISE TDC } \\
\hline \multicolumn{6}{|c|}{ CONTEÚDO } \\
\hline \multicolumn{3}{|c|}{ ANÁLISE GERAL } & \multicolumn{3}{|c|}{ ANÁLISE ESPECÍFICA } \\
\hline Química & Fronteiras & $\begin{array}{c}\text { Temas } \\
\text { Transversais }\end{array}$ & Temática & $\begin{array}{l}\text { Características } \\
\text { da atividade } \\
\text { científica }\end{array}$ & $\begin{array}{l}\text { Abordagem } \\
\text { / contexto }\end{array}$ \\
\hline \multicolumn{6}{|c|}{ FORMA } \\
\hline \multicolumn{2}{|c|}{ Linguagem } & \multicolumn{2}{|c|}{ Estrutura } & $\begin{array}{r}\text { Recursos tex } \\
\text { empre }\end{array}$ & $\begin{array}{l}\text { lais e visuais } \\
\text { gados }\end{array}$ \\
\hline
\end{tabular}

Como podemos observar, a análise do TDC, na perspectiva dos autores supracitados, consiste em considerar dois principais aspectos, sendo eles o "conteúdo", ou seja, a informação científica abordada, e a "forma", isto é, como essa informação é apresentada ao leitor. Assim sendo, com relação à identificação e classificação da informação apresentada, deriva da análise do "conteúdo" do texto, uma análise geral e outra específica.

A análise geral consiste em identificar a que dimensão do conhecimento a informação ou informações científicas veiculadas no texto se relacionam. Quando a informação apresentada diz respeito a um conteúdo tipicamente abordado no ensino de química no espaço formal, podemos classificá-la na categoria "Química". No entanto, a informação pode não ser diretamente associada ao ensino de química, mas representar um conteúdo normalmente abordado em disciplinas próximas, como física ou biologia, e que se relaciona com a química. Esse tipo de informação, portanto, seria alocada na categoria "Fronteiras".

Por fim, a informação presente no texto pode representar nenhum tipo de conteúdo normalmente abordado em disciplinas específicas no espaço formal de ensino, mas consistir em temas que permeiam todas elas, nos mais variados níveis. Dessa forma, esse tipo de informação seria classificado como pertencente à terceira categoria, "Temas transversais". Dentre essas temáticas, podemos destacar a abordagem do meio ambiente, tópicos pertinentes à higiene e saúde, até mesmo à ética, e como mencionado previamente, tais temáticas são preconizadas pelos Parâmetros Curriculares Nacionais como adequadas ao desenvolvimento do educando como ser humano.

Identificados os conteúdos gerais do texto, estes são em seguida classificados segundo aspectos específicos, isto é, é feita uma análise específica, a qual consiste em considerar a temática, a sua abordagem/contexto, e as características da atividade científica presentes no 
texto. De forma geral, considerar a temática consiste em identificar a temática principal tratada no TDC e a sua relação com o conteúdo químico. Com relação às características da atividade científica, esse momento da análise, intimamente associado com identificação de traços de cientificidade, envolve a identificação de aspectos relativos à prática científica abordados no texto. Dessa forma, considera-se tais características tanto do ponto de vista dos procedimentos, como as formas pelas quais são feitas as tomadas de dados e, consequentemente como esses dados são analisados, quanto da ciência como instituição, por exemplo, a controvérsia e a diversidade de ideias no meio científico. Ademais, verificam-se aspectos implícitos da prática científica, como as características pessoais e motivações dos cientistas.

Por fim, considerar as abordagens e contextos consiste em identificar as formas de contextualização do texto, isto é, as diferentes abordagens existentes no TDC vinculadas à temática em questão tendo por base contextos sociais, políticos, econômicos, dentre outros. Das possíveis abordagens podemos destacar a polêmica, conceitual, tecnológica etc.

Agora, com relação a análise da "forma" do TDC, os autores consideram três principais elementos, a linguagem, a estrutura e os recursos textuais e visuais empregados. De acordo com as características do discurso da DC, como apresentado por Latour (2000), e reiterado por Zamboni (2001), a linguagem desempenha um papel fundamental para que os objetivos da DC sejam alcançados. Uma vez que esse novo discurso deve dispensar a linguagem esotérica própria da comunidade científica, autores interessados em apresentar a informação científica para um público em geral devem fazer uso de uma série de recursos e estratégias que facilitem a compreensão do leitor. Nessa perspectiva, considerar a linguagem do TDC envolve identificar a clareza do texto, como os termos e conceitos científicos são empregados, além de considerar a existência e a adequação dos recursos utilizados pelo autor, como analogias, metáforas, simplificações etc.

A análise da estrutura, na perspectiva de Ferreira e Queiroz (2011) diz respeito à construção do texto, isto é, como as informações científicas estão organizadas e distribuídas ao longo dele. Finalmente, ao observar os recursos textuais e visuais empregados estamos considerando a distribuição espacial das informações, e o emprego de ilustrações, quadros, esquemas, notas de rodapé etc.

Esse esquema, portanto, já foi empregado em diferentes estudos e com diferentes finalidades. A título de exemplo, Fatareli et al. (2015), interessados em utilizar TDC que subsidiasse a prática do debate em sala de aula no ensino de química, analisaram o artigo: “A 
rica polêmica do urânio empobrecido" 12 publicado na revista de DC Ciência Hoje no ano de 2007. A partir da análise, os autores identificaram que a informação abordada no texto diz respeito a conteúdos alocados na categoria "Fronteiras", uma vez que, para os autores, há um predomínio de tópicos não tradicionalmente incluídos no ensino formal da química, mas a ela relacionados, como a biologia.

Identificado o conteúdo geral, pela sua análise específica, Fatareli et al. (2015) concluíram que a temática do texto é o aproveitamento do urânio empobrecido e as consequências do seu amplo uso para a saúde humano e o meio ambiente. Além disso, como características da atividade científica, predominam aspectos relacionados à ciência enquanto instituição, com diversas menções às controvérsias científicas a respeito do assunto. De acordo com os autores, a abordagem predominante no texto é a polêmica, e por isso, como menções às características da atividade científica destacam-se as controvérsias inerentes ao seu processo de construção.

No que tange à sua forma, mais especificamente à sua estrutura, o TDC se apresenta um pouco fragmentado, o que implica na leitura progressiva do texto. Dos recursos textuais e visuais empregados, os autores observaram, dentre outros recursos, que o texto de oito páginas está dividido em 11 intertítulos, além da existência de uma figura de fundo e um box com informações ao final. Por fim, com relação à linguagem adotada pelo autor, esta foi considerada simples devido ao emprego de diversos procedimentos explicativos e ausência de termos técnico-científicos.

Assim sendo, a partir da análise realizada, foi possível concluir que o TDC "A rica polêmica do urânio empobrecido" seria adequado para a finalidade desejada, que é a promoção do debate no ensino de química, isto devido ao caráter essencialmente polêmico da questão abordada no texto.

Diversos outros TDC já foram analisados por meio do esquema proposto por Ferreira e Queiroz (2011), o que evidencia a aplicabilidade desse instrumento. Mais especificamente, professores, pesquisadores e demais interessados podem acessar a análise de diferentes TDC da Revista Ciência Hoje, na página do Grupo de Pesquisa em Ensino de Química do Instituto de Química de São Carlos (GPEQSC) ${ }^{13}$, em recursos didáticos > textos de divulgação científica > Artigos da Revista Ciência Hoje: Análise da Forma e do Conteúdo.

\footnotetext{
${ }^{12}$ OLIVEIRA. M.F. A rica polêmica sobre o urânio empobrecido. Ciência Hoje, v. 41. n. 241, p. 36-43, 2007.

${ }^{13}$ Endereço eletrônico: http://www.gpeqsc.com.br/
} 
Mediante o exposto, consideramos o esquema proposto por Ferreira e Queiroz (2011) presente no Quadro 3, pertinente para o estudo que pretendemos realizar, o qual compreende a análise do texto selecionado para a promoção da argumentação no âmbito da formação inicial de professores de química. No entanto, para esta investigação, outros aspectos se tornam relevantes e devem ser ponderados.

Partindo de um TDC apresentado na forma de uma HQ, não podemos deixar de considerar, por exemplo, a linguagem autônoma desse hipergênero textual conforme apontado por Ramos (2016). Assim sendo, de modo a tornar essa análise mais adequada para os quadrinhos, emergem outros elementos interessantes que devem ser considerados e adicionados ao esquema presente no Quadro 3.

\subsubsection{A linguagem dos quadrinhos}

A partir dessa noção de linguagem autônoma dos quadrinhos, e das ideias de quadrinistas como Scott Mcloud e Will Eisner, pioneiros em estudos com HQ, surgem ao menos cinco aspectos importantes para análise: o desenho, o letreiramento, as transições de cena, os planos de visão e os ângulos de visão.

Com relação aos desenhos e aos traços empregados pelos autores, sua importância se apresenta na medida que, de acordo com as suas características, estamos tratando de um hipergênero fundamentado em imagens. Dessa forma, os desenhos além de serem relevantes para a compreensão da informação presente na narrativa, desempenham diversas outras funções, como promover uma identificação entre o leitor e o personagem apresentado no texto.

De acordo com McCloud (2005), diretamente responsáveis pelo sucesso dos quadrinhos, e o motivo dos leitores ficarem tão envolvidos com a narrativa, os desenhos podem se encontrar em um contínuo entre realistas ou não realistas (cartunescos), complexos ou simples, objetivos ou subjetivos, específicos ou universais, a opção por um traço ou outro pode conduzir a diferentes sentidos. Segundo este autor, dada a universalidade da imagem, quanto mais cartunizado é um rosto de um personagem, por exemplo, mais pessoas ele pode descrever, e assim, torna-se possível ampliar o significado de determinada imagem. Como exemplo desse contínuo possível para os desenhos, o autor apresenta em sua obra um esquema como ilustrado na Figura 11. 
Figura 11 - A abstração de uma imagem e a ampliação do seu significado na linguagem dos quadrinhos, segundo McCloud (2005).

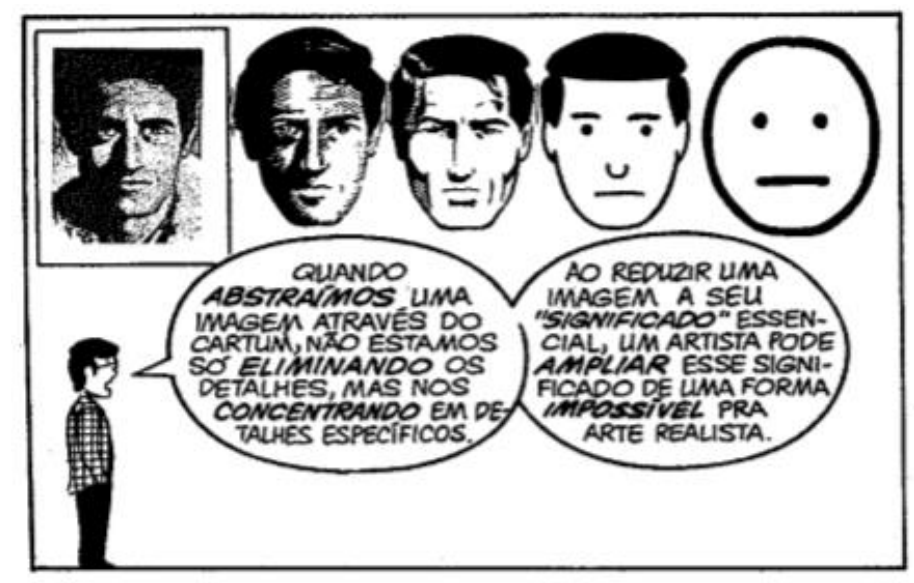

Fonte: McCloud (2005, p.30)

Nessa perspectiva, McCloud afirma que a abstração de traços promove uma maior identificação do leitor com o personagem, o que, por sua vez, é um dos objetivos principais dos autores para escolha dos traços empregados. Nas palavras do autor: "Quando você olha para uma foto ou desenho realista de um rosto ... você vê isso como o rosto de outra pessoa. Contudo, quando entra no mundo do cartum ... você vê a si mesmo.” (McCloud, 2005, p. 36).

Podemos concluir que essas características contribuem para uma maior utilização de traços cartunescos nos quadrinhos, no entanto, além disso, outro aspecto que faz com que os desenhos não realistas sejam mais empregados em HQ é o seu potencial lúdico, o qual confere um caráter humorístico à narrativa. Aqui, portanto, ressaltamos o aspecto da ludicidade inerente aos quadrinhos, que conforme Testoni e Abib (2003), validam o emprego desse tipo de texto em sala de aula.

Quando direcionamos o olhar para o ensino de ciências, e consideramos a relação existente entre TDC e traços de cientificidade abordados, podemos inferir que a caricaturização ou estilização pode fazer com que o leitor crie uma maior empatia com os personagens, o que contribui para sua aproximação com o universo do cientista, destacando que a ciência não é algo intocável e destinado somente a mentes brilhantes. Essa noção de identificação personagem-leitor é exemplificada pela obra de McCloud (2005), nos trechos apresentados na Figura 12. 
Figura 12 - Os desenhos e o envolvimento do leitor com os quadrinhos.
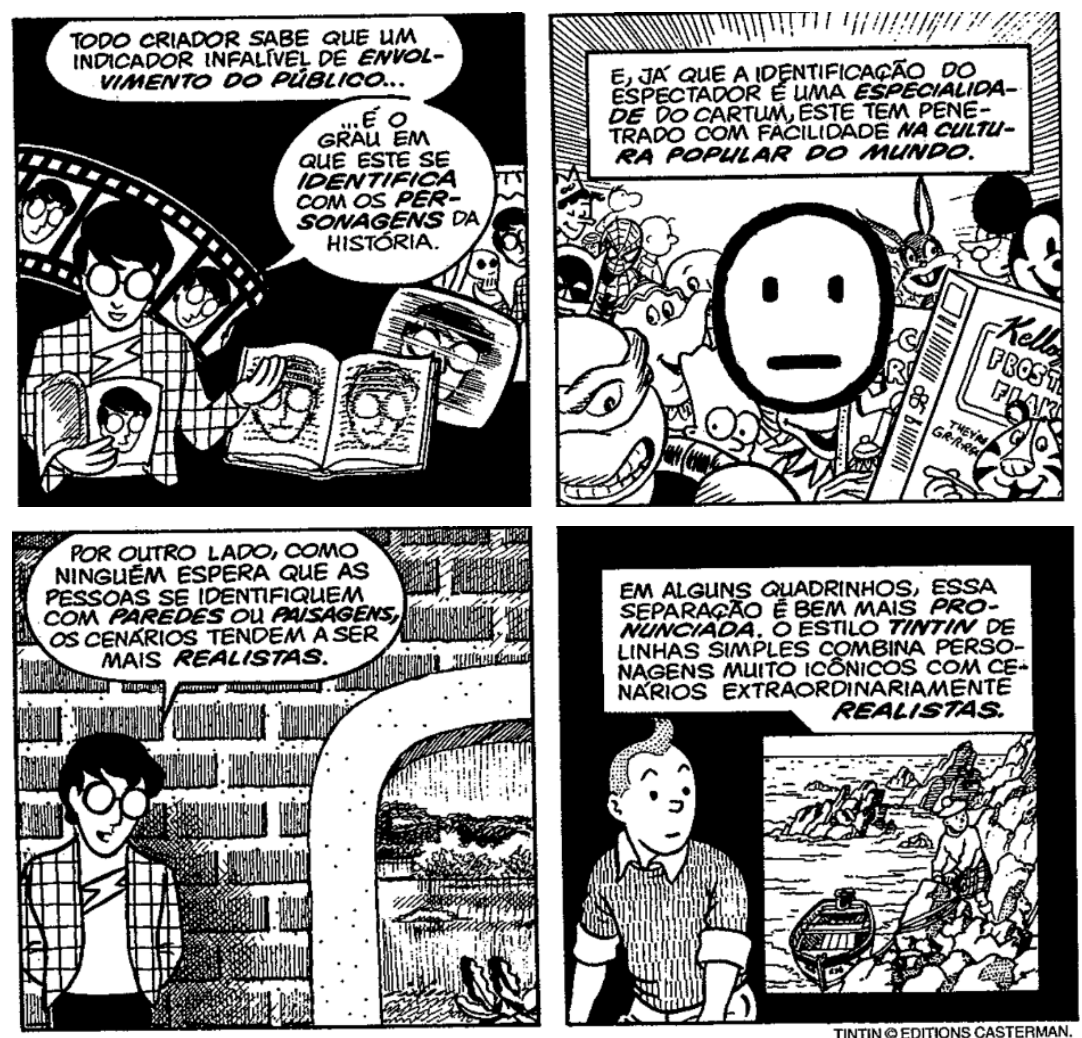

Fonte: McCloud (2005, p. 42)

No que tange à análise do letreiramento, ela nada mais é do que o olhar atento à escolha das fontes e opções de letras utilizadas na narrativa, no entanto, segundo Barbieri (2017), essa escolha, que consiste em um aspecto importante da linguagem dos quadrinhos, é pouco considerada. De acordo com Eisner (1999), o letreiramento, tratado graficamente e a serviço da história, funciona como uma extensão da imagem, e é por meio dele que é possível fornecer o clima emocional, uma ponte narrativa e até a sugestão de som. Dentre as opções de fontes e letras com objetivos específicos e comumente empregadas nos mais variados gêneros de quadrinhos, destaca-se o uso de negrito para enfatizar uma fala ou elevação do tom, o emprego de itálico para a fala do narrador, a utilização de cores fortes para ressaltar alguma informação, onomatopeias que sugerem sons às situações etc.

A partir da noção de letreiramento, é válido ressaltar a sua relação com a didaticidade do texto, uma vez que a escolha de fontes especiais em determinados momentos da narrativa pode contribuir para a compreensão de determinado conceito, consistindo, dessa forma, como um recurso explicativo interessante na linguagem dos quadrinhos.

Esses dois primeiros elementos da linguagem dos quadrinhos estão diretamente relacionados com a definição apresentada para esse hipergênero, isto é, uma vez que quadrinhos consistem no emprego de textos verbais e imagens pictóricas atuando em complementaridade 
para dar sentido à narrativa, cuidados com o desenho, e o letreiramento adotado são indispensáveis. No entanto, HQ ainda são definidas como uma arte sequencial, logo, as noções de tempo e espaço também são bastante relevantes em sua linguagem.

Nessa perspectiva, de sequenciamento e cortes, os espaços em branco (sarjetas), possuem um papel fundamental no desenvolvimento da narrativa. É nesse ponto que devem ser feitas inferências pelo leitor, o qual, segundo McCloud (2005), se torna uma espécie de cúmplice silencioso da narrativa, e é na frequência de inferências que se encontra a magia dos quadrinhos. Corroborando a ideia de Testoni e Abib (2003), que afirmam que a inserção de textos como HQ no espaço formal de ensino promove o exercício de uma série de atividades mentais, McCloud (2005) ressalta que para sobrevivermos na sociedade, observar partes e perceber o todo, isto é, chegar a uma conclusão, ou inferir algo, é fundamental, e as HQ consistem em um meio de comunicação que exercita a conclusão como nenhum outro.

Ainda de acordo com McCloud, a conclusão promove uma maior participação do leitor na narrativa, o que, conforme mencionado para a escolha do desenho empregado, consiste em um dos objetivos principais dos criadores de HQ. Além disso, a conclusão possibilita uma intimidade do leitor com os quadrinhos que só é superada pela palavra escrita. Dessa forma, as transições quadro a quadro, ou transições de cena adotadas, desempenham um papel fundamental para o desenvolvimento do texto e sua aceitação pelo leitor, pois ao mesmo tempo que o criador deve apresentar as informações ao seu público por meio da escrita, de modo a tornar o enredo compreensível, deve promover a prática da conclusão por meio do que está "escondido" nas sarjetas.

Existem para McCloud (2005) seis principais tipos de transições de cenas. A primeira, exigindo pouca conclusão, é denominada momento-para-momento (Figura 13), e apresenta as ações e reações dos personagens passo a passo, o que por sua vez, exige também um maior número de quadros. O segundo tipo de transição, apresenta uma única ação em progressão, e são assim denominadas como ação-para-ação (Figura 14), essa transição já exige um pouco mais do leitor, pois na sarjeta há escondidos alguns momentos da narrativa, é o exemplo da cobrança de um pênalti no futebol. Enquanto em um quadro vemos o jogador preparado para chutar a bola, no segundo já verificamos a bola dentro da rede do gol, ou seja, podemos concluir que a cobrança foi feita, e o jogador fez o gol. Outra possibilidade de transição é conhecida como tema-para-tema (Figura 15), como sugere o nome, esse tipo de transição conduz o leitor de tema para tema dentro de uma cena, isto é, tem como objetivo apresentar recortes de uma 
mesma cena, para que o leitor reconstrua, por meio do processo de conclusão, a imagem completa, mas esteja ciente de alguns detalhes.

Figura 13 - Transição momento-para-momento.

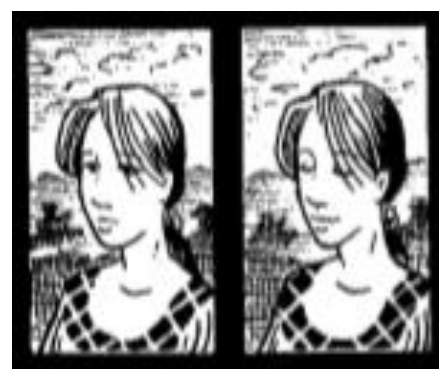

Fonte: McCloud (2005, p. 70 e 71)
Figura 14 - Transição açãopara-ação.

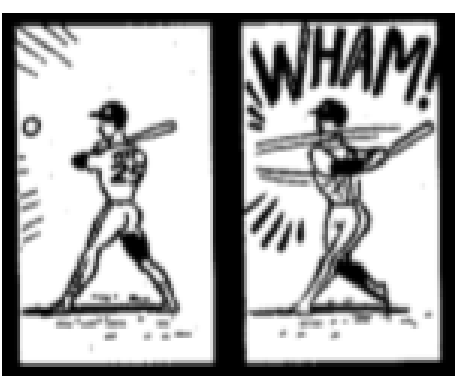

Figura 15 - Transição temapara-temas.

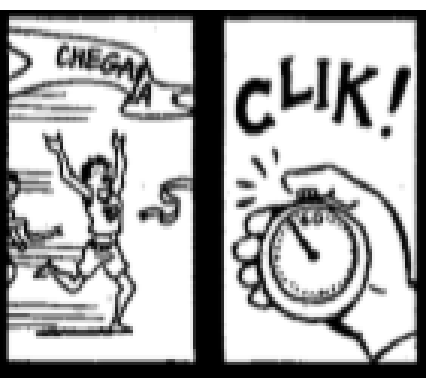

Promovendo um maior raciocínio dedutivo, o quarto tipo de transição, transição cenapara-cena (Figura 16) aborda distâncias significativas de tempo e espaço, é o caso, por exemplo, de pensamentos ou cenas paralelas. Outra transição é a aspecto-para-aspecto (Figura 17), esse tipo de transição estabelece um olhar migratório para diferentes aspectos de uma cena, muito comum em mangás, passa a noção de ver um cenário inteiro em partes, e assim, identificar onde se passa a situação. Por fim, sem uma sequência lógica entre os quadros, temos a transição non-sequitur (Figura 18).

Figura 16 - Transição cenapara-cena.

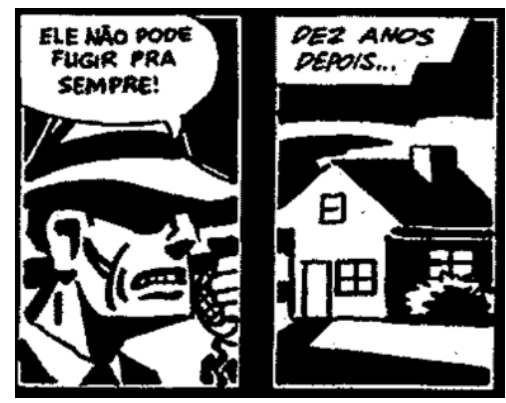

Fonte: McCloud (2005, p. 71 e 72)
Figura 17 - Transição aspectopara-aspecto.

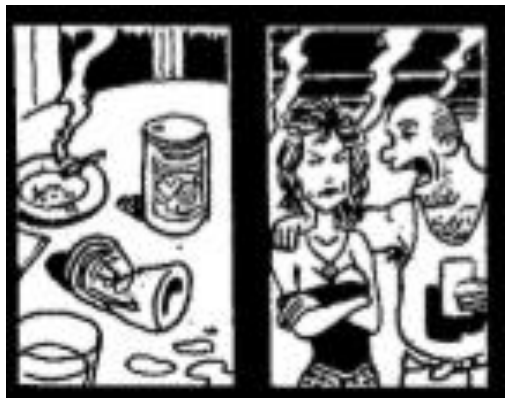

Figura 18 - Transição nonsequitur.

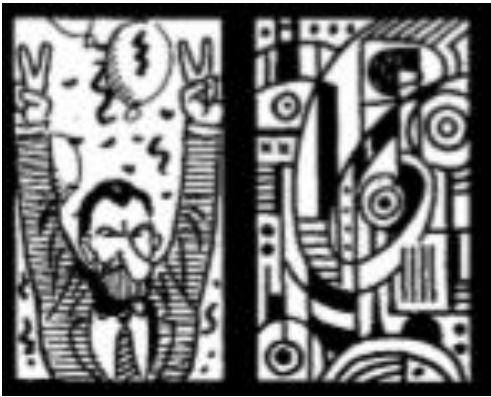

McCloud (2005) ao demonstrar esses tipos de transições, também apresenta dados obtidos a partir da análise de diversos quadrinhos norte-americanos, e o que se observou foi um padrão com predomínio de três tipos de transições. Em grande quantidade encontram-se transições ação-para-ação, seguidas pelas transições tema-para-tema e cena-para-cena, ambas quantitativamente bastante semelhantes. Dadas as características de cada transição esse predomínio é facilmente explicado por McCloud (2005), que sugere que são esses os tipos de transições que apresentam as ações acontecendo de forma mais eficiente. 
Quando consideramos as outras transições, observamos que momento-para-momento demanda um grande número de quadros para mostrar as ações acontecendo, o que impossibilita, por questões de mercado mesmo, um maior número de aparições em HQ. Em contrapartida, em aspecto-para-aspecto as ações não acontecem, e em non-sequitur não há preocupação com os eventos ou com qualquer proposta da narrativa.

Agora, ainda com relação à noção de tempo e espaço na linguagem dos quadrinhos, a percepção visual permite observar tambem que há diferentes planos e âgulos possíveis (RAMOS, 2016). Estes, por sua vez, são os dois últimos elementos da lingugem dos quadrinhos interessantes para a nossa análise. No que tange aos planos de visão ou enquadramentos, estes indicam como a imagem é apresentada ao leitor. Ramos (2016) apresenta, com exemplos dos quadrinhos do Arqueiro Verde, seis planos possíveis, sempre de acordo com a representação do corpo humano.

De acordo com Ramos (2016), há um plano geral ou panorâmico, o qual abrange tanto a figura humana como o cenário como um todo, e um plano total ou de conjunto, que reduzindo a importância do ambiente, e aumentando a atenção no personagem, representa a pessoa humana e pouco do cenário a sua volta. O terceiro enquadramento possível, consiste no plano americano, o qual retrata os personagens a partir da altura dos joelhos, de forma que começase a focar no rosto do personagem. Dessa forma, embora não ocorra necessariamente um diálogo para a existência desse enquadramento, alguns autores, como Acevedo (1990), associam esse plano, com um plano de conversação.

Há também a possibilidade de um plano médio ou aproximado, que reforçando os traços do rosto do personagem mostra os seres humanos da cintura para cima. Outro plano é o primeiro plano, cujo foco está na expressão do personagem e assim o enquadramento se limita a altura dos ombros. Por fim, existe o plano de detalhe, pormenor ou close-up, o qual realça algum elemento da figura que normalmente passaria desapercebido.

A utilização dos diferentes enquadramentos assume elevada importância para o alcance dos objetivos proposto pelo autor, uma vez que, é por meio deles que pode haver uma maior sensibilização do público, pode ocorrer momentos de interlocução direta com o leitor de forma mais eficaz, pode auxíliar na compressão da narrativa por salientar aspectos importantes que poderiam passar dasapercebidos etc.

No que tange aos ângulos de visão, isto é, como o leitor vê a imagem, estes podem assumir três formas, as quais, segundo Vergueiro (2007b), são: ângulo de visão médio, cena 
observada como se ocorresse à altura dos olhos do leitor; ângulo de visão superior, nele a ação é enfocada de cima para baixo; e ângulo de visão inferior, o leitor vê a ação de baixo para cima.

No que diz respeito ao estudo dos aspectos mencionados para análise de diferentes gêneros de quadrinhos, podemos citar a Tese de Doutorado de Mendonça (2008). O autor analisou diversas cartilhas quadrinizadas a respeito de temáticas envolvendo a saúde, em especial com relação à educação sexual, com o objetivo de investigar como a quadrinização ajuda a apresentar a informação científica em cartilhas educativas quadrinizadas integrantes de campanhas de saúde. De forma geral, a partir da análise desses aspectos inerentes à linguagem dos quadrinhos, o autor observou que as cartilhas, em sua maioria, apresentam transições do tipo cena-para-cena, usos de primeiro plano e close-ups. Tais planos assumem a função de enfatizar procedimentos, o que dada a tematica, educação sexual e DSTs, é comum. Além disso, com esses planos é possível promover um maior envolvimento do leitor por meio de interlocuções diretas e ênfases em alguns aspectos das cenas. O autor também observou nas cartilhas, um desenho caricato, como esperado, e a presença de poucos esquemas científicos à parte.

Assim, considerando esses aspectos inerentes à linguagem dos quadrinhos, o esquema proposto por Ferreira e Queiroz (2011) apresentado na Quadro 3, pode ser entendido para esse estudo como expresso na Quadro 4.

Quadro 4 - Esquema proposto para análise da HQ adaptado de Ferreira e Queiroz (2011).

ANÁLISE TDC

CONTEÚDO

\begin{tabular}{|c|c|c|c|c|c|}
\hline \multicolumn{2}{|c|}{ ANÁLISE GERAL } & \multicolumn{3}{c|}{ ANÁLISE ESPECÍFICA } \\
\hline \multirow{3}{*}{ Química } & \multirow{2}{*}{ Fronteiras } & $\begin{array}{c}\text { Temas } \\
\text { Transversais }\end{array}$ & Temática & $\begin{array}{c}\text { Características } \\
\text { da atividade } \\
\text { científica }\end{array}$ & $\begin{array}{c}\text { Abordagem } \\
\text { / contexto }\end{array}$ \\
\hline
\end{tabular}

FORMA

\begin{tabular}{|c|c|c|c|c|c|}
\hline $\begin{array}{c}\text { Linguagem } \\
\text { (texto } \\
\text { escrito) }\end{array}$ & Desenho & Letreiramento & $\begin{array}{c}\text { Transições } \\
\text { de cenas }\end{array}$ & $\begin{array}{c}\text { Planos de } \\
\text { visão }\end{array}$ & $\begin{array}{c}\text { Ângulos de } \\
\text { visão }\end{array}$ \\
\hline
\end{tabular}

Dessa forma, empregaremos para a análise da HQ selecionada, o esquema presente no Quadro 4, o qual mantém do Quadro 1 os elementos referentes à análise do "conteúdo", e amplia a análise da "forma". Assim sendo, A análise da linguagem, estrutura e recursos visuais e 
textuais empregados, passa a ser, devido à linguagem dos quadrinhos, uma análise da linguagem verbal (texto escrito), do desenho/traços, do letreiramento, das transições de cenas e dos planos e ângulos de visão.

No mais, compartilhamos das ideias de Fatareli et. al. (2015), os quais fizeram uso do Quadro 3 em suas análises, e não almejamos, com a análise a partir do esquema proposto no Quadro 4, fornecer ao professor da educação básica uma espécie de decisão tomada, mas por meio da análise do "conteúdo" e da "forma" da HQ, pretendemos apresentar suas potencialidades didáticas, principalmente no que diz respeito ao seu uso em estratégias específicas, que no caso deste estudo consiste no exercício da argumentação diante de QSC.

\subsection{Conhecendo o "conteúdo" da HQ}

Com base no Quadro 4, iniciamos a análise da HQ "Trinity" identificando a informação ou informações científicas presentes no texto, ou seja, iniciamos com a análise do “conteúdo" na perspectiva dos referenciais adotados.

Verificamos por meio de uma análise geral do texto, que embora existam tópicos que possam ser classificados como pertinentes ao ensino formal de química, principalmente no que diz respeito à linguagem simbólica da química, há um predomínio das outras duas categorias. Conteúdos classificados como fronteiras estão presentes em diversos momentos da narrativa, em especial naqueles que o autor faz menção aos conceitos científicos envolvidos na construção de uma bomba atômica. Com relação a esses conteúdos, estes são comumente abordados no ensino de física, no entanto, apresentam estreita relação com a química trabalhada em sala de aula do ensino médio.

Dentre os tópicos apresentados na HQ destaca-se a noção de radioatividade, de constituição da matéria e de processos como fissão nuclear e consequentemente energia nuclear. Tais tópicos são sugeridos, de acordo com o currículo do estado de São Paulo, para o terceiro bimestre da terceira série do ensino médio na disciplina de física sob o tema "matéria e radiação" (SÃO PAULO, 2008). Segundo essa proposta, são conceitos a serem trabalhados nessa etapa da formação do educando, propriedades e organização da matéria, com a abordagem, por exemplo, dos modelos atômicos para explicação das características macroscópicas observáveis. Também são sugeridas para essa etapa, o trato de questões envolvendo o núcleo atômico e radioatividade, ou seja, transformações nucleares que dão origem à radioatividade, a dimensão da energia envolvida nas transformações nucleares que explicam o seu uso em diversos setores industriais etc. A título de exemplo em que tais conceitos são abordados temos: 
[Narrador] Alguns elementos, como o urânio, são instáveis por princípio. Eles liberam energia e, no processo, se transformam em outros elementos. Se você deixar uma barra de urânio parada por 4,5 bilhões de anos, é possível que metade dela se transforme em chumbo. Isso é chamado de decaimento radioativo e está acontecendo ao nosso redor, na natureza (FETTER-VORM, 2013, p. 4).

[Narrador] Quanta energia exatamente é liberada numa reação nuclear? Cerca de 70 milhões de vezes mais do que numa reação química. Então, se você fissionasse, por exemplo, um quilo de urânio, isso geraria uma explosão equivalente a 20 mil toneladas de TNT. Um pedacinho de urânio tem mais energia potencial de explosão do que uma pilha de TNT de dez andares de altura. Se a fissão pudesse ser feita numa escala grande o suficiente [...], a humanidade ganharia a habilidade de produzir muito mais do que meras explosões (FETTER-VORM, 2013, p. 10)

Contudo, de particular relevância para o estudo proposto, verificamos também a presença do que pode ser classificado como temas transversais. E dentre essas temáticas, o que se observa é a existência de dilemas morais e questões éticas que permeiam a construção da primeira bomba atômica, o que se dá por meio de QSC. Essa relação entre moralidade e QSC é de se esperar, principalmente quando consideramos as características desse tipo de questão, em especial dos aspectos que as diferem de conteúdos vinculados apenas à ciência, tecnologia e sociedade, isto é, à abordagem CTS (ZEIDLER et al., 2005; RATCLIFFE e GRACE, 2003). Aqui salientamos mais uma vez a importância da inserção de temáticas dessa natureza em sala de aula, as quais não se restringem somente ao ensino de ciências, e são recomendadas pelos PCN para a promoção da educação para a cidadania preconizada pela LDB.

A principal QSC abordada na HQ, e que vem a ser alvo de maior reflexão no final do texto. diz respeito às implicações do desenvolvimento científico, o que culmina em um dilema moral, o qual empregamos posteriormente com os futuros professores. Logo no início da narrativa o autor apresenta a descoberta da fissão nuclear por Otto Hanh, Fritz Strasmann e Lise Meitner, o que levou então a criação do Projeto Manhattan e, assim, à construção das bombas atômicas. Dessa forma, ao analisar as consequências dos esforços empreendidos pelos cientistas nesse projeto, o autor apresenta o seguinte questionamento intimamente relacionado a valores éticos e morais:

[Narrador] Os cientistas voltaram do Japão com relatórios detalhados sobre as cidades destruídas e seus habitantes devastados. Pela primeira vez, Oppenheimer e todos em Los Alamos tinham uma visão completa daquilo que haviam criado. Finalmente eles tinham a resposta para a pergunta que vinham se fazendo havia anos:

[Cientista] Pode ser feito?

[Narrador] Depois do Projeto Manhattan, todavia, muitos cientistas se sentiram na obrigação de fazer uma pergunta diferente:

[Cientistas] Deveria ter sido feito? (FETTER-VORM, 2013, p. 136)

Assim sendo, identificamos de antemão, a pertinência da HQ para o prosseguimento do estudo, a qual possibilita, mediante ações na formação inicial de professores, o exercício do raciocínio informal através da argumentação diante de QSC. 
Observada a natureza das informações veiculadas na HQ por meio da análise geral, demos sequência com a análise específica do texto. Seguindo o esquema ilustrado no Quadro 2, a HQ tem como temática a descoberta do processo de fissão nuclear e suas implicações políticas e éticas em meio a $2^{\mathrm{a}}$ Guerra Mundial, o que levou à construção das bombas atômicas lançadas nas cidades japonesas de Hiroshima e Nagasaki. Sendo assim, inicialmente o leitor é apresentado a dois elementos cruciais da narrativa, o físico e também conhecido pai da bomba atômica, J. Robert Oppenheimer, e ao aparato denominado Trinity, que leva o nome da HQ. Feitas as apresentações, o leitor toma contato, por meio de um passeio dirigido pelo narrador, por diferentes anos e locais, e assim, com diversos conceitos científicos que se relacionam direta ou indiretamente com a construção das bombas atômicas. Como exemplo desses conceitos temos a radioatividade descoberta pelo casal Curie em Paris (França) em 1898, a descoberta do núcleo pelo físico britânico Ernest Rutherford em 1911, dos nêutrons em 1932 por James Chadwick até as conclusões de Hahn, Strassmann e Meitner sobre a fissão nuclear em 1939. É a partir desse momento que o texto toma um novo rumo e entra em questões políticas para a viabilidade da construção de uma arma mediante o poder recém descoberto de uma reação nuclear.

Nessa perspectiva, o autor mescla história, questões políticas e sociais e conceitos científicos, e passa por momentos como a realização do teste Trinity até o lançamento das bombas Little Boy e Fat Man, nas cidades de Hiroshima e Nagasaki, respectivamente. O desfecho do texto se dá, portanto, com a tomada de consciência dos cientistas a respeito das consequências de suas ações, o que levou ao arrependimento de uns, como do próprio Oppenheimer, e à motivação para o desenvolvimento de armas ainda mais ambiciosas, como para Edward Teller. Logo, o que fica a partir do que é colocado pelo autor, é exatamente o dilema moral citado anteriormente, envolvendo as implicações políticas, sociais e éticas do desenvolvimento científico.

Com relação às características da atividade científica, estas estão amplamente presentes no texto com menções, por exemplo: ao aspecto coletivo da ciência; às implicações do desenvolvimento científico; às motivações para a pesquisa; ao caráter histórico da ciência, isto é, a ciência não é estanque, mas sim fruto de uma série de descobertas anteriores; a metodologias e formas de interpretação de resultados; a características pessoais do pesquisador; a práxis cientifica, como a atribuição de prêmio Nobel; a financiamento de pesquisas etc. 
No que diz respeito ao aspecto coletivo da ciência, esta é uma das principais características observadas no texto, e aqui destacamos dois trechos que ressaltam a sua presença:

[Narrador] Otto Hahn e Fritz Strassmann bombardearam nitrato de urânio com neutrôns. Em lugar de rádio, eles produziram bário.

[Strassmann] Estes resultados não fazem sentido devem estar contaminados. Vamos escrever para Lise; um olhar novo pode ajudar

$[\ldots]$

[Narrador] Meitner respondeu a Hahn e Strassmann que para ela os resultados demonstravam que os neutrôns estavam destruindo os átomos de urânio. Eles chamaram esse processo de fissão nuclear. Foi uma descoberta muito empolgantes (FETTER-VORM, 2013, p. 7)

[Narrador] Mas em Los Alamos - o novo lar de algumas das mentes mais brilhantes do país - a questão do sigilo não era assim tão simples.

[Cientista] Não venham me falar de sigilo! Não há como fazer ciência sem a livre troca de ideias (FETTER-VORM, 2013, p. 35)

No primeiro exemplo, em que o autor apresenta de forma genérica como ocorreu a descoberta do processo de fissão nuclear, fica evidente a importância da contribuição de diferentes cientistas para que seja possível chegar a alguma conclusão na ciência. Assim sendo, para além de apresentar ao leitor questões referentes a tomada de dados e interpretações de resultados, o autor destaca nesse trecho a importância de diferentes olhares para que seja possível a explicação de um fenômeno observável. No segundo exemplo, em que o autor apresenta uma das dificuldades encontradas por Oppenheimer e Groves ao lidar com os cientistas em um projeto que exigia o sigilo absoluto, o autor enfatiza esse aspecto coletivo da ciência destacando a importância da livre troca de ideias e, consequentemente, a relevância do trabalho em equipe para a obtenção de sucesso na ciência.

A historicidade da ciência é outra característica marcante no texto, principalmente na parte introdutória da HQ, que como já mencionado, apresenta contribuições de diferentes cientistas que possibilitaram a construção de um armamento nuclear. Dessa forma, fica claro para o leitor que a ciência não é estanque e está em constante transformação. Como exemplo temos a evolução da noção de estrutura atômica presente no trecho a seguir extraído da parte introdutória do texto:

[Narrador] Em 1911, o físico britânico Ernest Rutherford descobriu algo muito surpreendente sobre a estrutura do átomo. Escondido no coração de cada átomo há um minúsculo e incrivelmente denso aglomerado de partículas carregadas. Rutherford chamou esse aglomerado de núcleo...

$[\ldots]$

[Narrador] Em 1932, James Chadwick - um aluno de Rutherford - observou que o núcleo em si era composto de partículas menores. Chadwick havia descoberto o nêutron, uma partícula dentro do núcleo que não possui carga elétrica (FETTERVORM, 2013, p. 5 e 6) 
Metodologias e processos científicos também são descritos na HQ, e como exemplo apresentamos o momento em que o autor, ao destacar a importância do enriquecimento do átomo de urânio para a eficiência da bomba atômica, demonstra como esse enriquecimento foi feito em Oak Ridge.

[Narrador] Em Oak Ridge, Tennessee, um conjunto de prédios enormes realizava três processos diferentes de enriquecimento, cada qual um triunfo da engenharia que havia custado centenas de milhões de dólares. O enriquecimento começava em um prédio de codinome S-50; aqui, urânio natural era transformado em uma solução líquida e aquecido em longos tubos de cobre, o que aumentava sensivelmente a concentração de U-235. Dalí, ele ia para o prédio K-25, onde a solução líquida de urânio era convertida num gás e bombeada repetidas vezes através de quilômetros de filtros, concentrando ainda mais o U-235. E, por fim, o urânio agora moderadamente enriquecido era colocado num cálutron - uma série de eletroímãs conectados - onde a maior parte do U-238 restante era eliminada (FETTER-VORM, 2013, p. 46).

Como podemos observar, nesse trecho já somos apresentados à noção de custo da atividade científica, o que fica ainda mais evidente quando o autor menciona as implicações da descoberta do processo de fissão nuclear, o qual destacamos a seguir. Dessa forma, o leitor toma contato com a importância de financiamento na pesquisa, o que muitas vezes se torna uma barreira para o desenvolvimento científico e tecnológico. Diretamente relacionado a questões políticas, é de suma importância que a sociedade tome contato com esse aspecto da ciência, uma vez que, consumidores dos seus produtores, é por meio desse desenvolvimento que os indivíduos têm acesso a novas tecnologias que propiciam, por exemplo, uma melhor qualidade de vida.

[Narrador] Assim que a descoberta da fissão nuclear foi anunciada, físicos de todo o mundo começaram a ligar os pontos [...] Leo Szilard, um físico que tinha emigrado da Hungria para os EUA nos anos de 1930, estava preocupado.

[Szilard em conjunto com outros cientistas, como Albert Einstein, redigem uma carta ao presidente Roosevelt ressaltando seus temores]

[Narrador] Szilard deu um jeito de fazer com que essa carta chegasse às mãos de Alexander Sachs, um banqueiro de Wall Street e conselheiro do presidente Roosevelt [...] O presidente se convenceu da importância da fissão nuclear, mas não necessariamente da sua urgência. Roosevelt autorizou meros 6 mil dólares para a pesquisa das propriedades físseis do urânio. $\mathrm{O}$ projeto ficou parado por meses (FETTER-VORM, 2013, p. 12, 13 e 15)

Ressaltando que a ciência não é neutra, mas praticada por indivíduos que possuem características próprias e que são movidos por anseios, estão presentes na $\mathrm{HQ}$, como destacados nos trechos a seguir, características pessoais dos cientistas e motivações para a pesquisa, em específico, para a mobilização de conhecimentos científicos em favor da construção de uma bomba atômica.

[Narrador] J. Robert Oppenheimer provou ser esse homem. Ainda que seja difícil saber bem que tipo de homem ele era ... precoce. Aluno da Ethical Culture School em Nova York; seus interesses incluíam Shakespeare e colecionar pedras. Brilhante. 
Formou-se em Harvard em três anos; estudou química, física e sânscrito. Perturbado. Doutor em física por Cambridge; colapso mental; quase foi expulso por tentar envenenar um professor. Arrogante. Pós-doutor pela Universidade de Gottingen, na Alemanha; fama de assumir o controle das aulas dos professores. Carismático. Popular entre os alunos e professores; gentil e articulado (FETTER-VORM, 2013, p. 22 e 23)

[Narrador] Oppenheimer, enquanto isso, recrutava os cientistas mais brilhantes dos país. Dado o sigilo extremo do projeto, isso era algo difícil de conseguir.

$[\ldots]$

[Cientista] Por que você está me pedindo para fazer isso?

[Oppenheimer] Porque o trabalho que você realizará possivelmente vencerá a guerra contra a Alemanha.

[Cientista] Bem, parece muito empolgante (FETTER-VORM, 2013, p. 29)

No primeiro exemplo o leitor é apresentado a diferentes características pessoais de Oppenheimer, que como destacado diversas vezes, é considerado o nome da era atômica. Com relação a esse trecho é válido destacar um aspecto negativo da forma como é apresentado, uma vez que, a menção ao brilhantismo de Oppenheimer pode reforçar a ideia de que a ciência é destinada somente a mentes excepcionais, o que, por sua vez, pode contribuir para afastar o interlocutor/educando de atividades relacionadas à ciência. Assim, ressaltamos que para fins pedagógicos e inserção desse texto em sala de aula, seja necessária a mediação do professor. No que tange ao segundo exemplo, identificamos a principal motivação que pode ter levado inúmeros cientistas a ingressarem no Projeto Manhattan. Esse trecho apresenta um forte apelo ao leitor e consiste em um recurso empregado pelo autor que será melhor abordado na sequência dessa análise, em especial, no que tange à forma como a informação é apresentada.

Por fim, mencionando ainda aspectos vinculados a práxis científica, o autor em dois momentos destaca a importância que um prêmio como o Nobel possui na comunidade científica. Em um primeiro momento essa menção surge a partir dos receios de líderes, não diretamente relacionados com a ciência, a respeito de Oppenheimer. E no segundo exemplo, a alusão ao prêmio Nobel é feita de modo a ressaltar a credibilidade de Enrico Fermi e seus estudos.

[Narrador] Groves, de sua parte, falava abertamente sobre suas preocupações com Oppenheimer.

[Groves] Olha, eu sei que ele não tem experiência administrativa. Não tem um prêmio Nobel e vai comandar pessoas que tem ... (FETTER-VORM, 2013, p. 26).

[Narrador] Muito antes de Oppenheimer ou Groves se juntarem ao Projeto Manhattan, Szilard tinha decidido demonstrar a viabilidade de uma arma atômica (e os perigos inerentes a ela). Szilard pediu ajuda a Enrico Fermi, um italiano vencedor do Nobel que havia escapado do regime fascista de seu país (FETTER-VORM, 2013, p. 32 e 33).

Ainda com relação à análise específica do texto, verificamos diferentes abordagens ao longo da narrativa. Inicialmente temos um predomínio de uma abordagem conceitual em 
conjunto com uma abordagem histórica, como resultado da opção do autor em apresentar diferentes conceitos que foram descobertos em épocas distintas, e que são pertinentes à construção de uma bomba atômica. Feito esse panorama inicial, surge um predomínio de uma abordagem polêmica a partir de questões políticas, éticas e sociais envolvendo financiamento à pesquisa, e o emprego do conhecimento científico na construção de armas tão letais como as que foram desenvolvidas. Com relação às diferentes abordagens empregadas no texto, um exemplo claro dessa mudança, de uma abordagem científica para uma polêmica, é evidenciado pelo próprio autor por meio do narrador, o qual, após a realização do teste Trinity, afirma:

...o que começou como uma experiência agora era uma bomba que funcionava. O
Projeto Manhattan saía da esfera da ciência para entrar na política, da diplomacia e da
guerra. A reação em cadeia havia começado (FETTER-VORM, 2013, p.79)

Diante da análise do "conteúdo" realizada, identifica-se incialmente a pertinência da HQ selecionada para os objetivos traçados neste estudo, uma vez que apresenta em seu bojo, por meio de uma abordagem polêmica, QSC. Por sua vez, ao envolverem aspectos éticos e morais em sua natureza, QSC permitem o exercício do raciocínio informal em sala de aula. Também podemos observar um elevado grau de cientificidade (ZAMBONI, 2001) no texto, o que permite ao leitor compreender a sua temática, bem como as pesquisas científicas envolvidas, e como a ciência é praticada, isto é, uma melhor compressão sobre a $\mathrm{NdC}$.

Com relação à $\mathrm{NdC}$, a sua abordagem no texto, e consequentemente o emprego deste no ensino de ciências, se aproxima da visão de Allchin (2012), o qual defende o trabalho em sala de aula não com uma visão consensual da mesma, mas de uma certa dependência contextual, em que a partir de diferentes situações o estudante é levado a concluir determinados aspectos da prática científica. Além disso, segundo trabalhos desse autor (ALLCHIN, 1997), episódios históricos, como o abordado na HQ, têm se mostrado fundamentais para o entendimento de questões que envolvem a $\mathrm{NdC}$.

\subsection{Conhecendo a "forma" da HQ}

Com relação a como a informação identificada pela análise do "conteúdo" é apresentada ao leitor, realizamos nesse momento uma análise da "forma" na perspectiva dos referenciais adotados, isto é, associando o esquema proposto por Ferreira e Queiroz (2011) ilustrado no Quadro 3 com noções referentes à linguagem dos quadrinhos apresentados por autores como Scott McCloud (2005), Ramos (2016) e Vergueiro (2007b). Os elementos pertinentes a essa análise estão sintetizados no Quadro 4. 
Inicialmente atentou-se para a linguagem verbal (texto escrito) apresentada pelo autor, de modo a verificar o emprego de termos técnico, de expressões do repertório comum ao leitor, de recursos metalinguísticos que aumentam a didaticidade do texto etc. Para tanto, levamos em conta algumas considerações de Zamboni (2001) a respeito do discurso da DC. Para esse autor, a DC, por si só, já representa um gênero discursivo único e, portanto, possui especificidades quanto ao conteúdo temático, o estilo verbal e a construção composicional. Como nosso interesse consiste na linguagem empregada pelo autor da HQ, nos centraremos na noção de estilo, a qual diz respeito à seleção de recursos lexicais, fraseológicos e gramaticais (ZAMBONI, 2001).

A especificidade do discurso da DC surge da ideia que, mais do que apenas uma simples reformulação de um texto previamente dirigido à comunidade científica, este consiste na elaboração de um novo voltado para um interlocutor totalmente diferente, ou seja, muda-se o polo de recepção, e nessa perspectiva, Zamboni (2001) salienta:

\begin{abstract}
Alterando-se o lugar do destinatário, o lugar do enunciador também se altera [...] alterando-se os lugares dos protagonistas da cena enunciativa, restam alteradas todas as demais configurações do cenário, inclusive o canal de comunicação [...], a modalidade da linguagem empregada, as fontes de informação, o tratamento do assunto, o formato do texto (ZAMBONI, 2001, p. 61).
\end{abstract}

Dirigido a um destinatário não científico, o discurso da DC com relação ao estilo deve dispensar a linguagem esotérica exigida pelo discurso da ciência e fazer uso de diversos recursos e/ou estratégias como analogias, aproximações, comparações e simplificações (ZAMBONI, 2001). Logo, a análise da linguagem verbal da HQ consistiu em identificar tais recursos, verificando a forma como aparecem e a função que exercem no texto, o que, por sua vez, nos permite inferir sobre os traços de cientificidade, didaticidade e laicidade presentes na HQ.

A partir dessas considerações, identificamos na narrativa que o autor, ao abordar conceitos científicos, busca um equilíbrio entre termos técnicos e expressões do repertório comum do leitor de modo a diminuir a densidade discursiva própria de um texto científico. Salientamos que, considerando o contexto de produção da HQ e os seus objetivos mercadológicos, é de se esperar que o autor busque esse equilíbrio tendo em vista alcançar um maior público leitor. Na HQ em questão, esse equilíbrio ocorre predominantemente por meio da figura do narrador, que isento da responsabilidade que os cientistas descritos no texto possuem, isto é, sem a obrigação primária de apresentar a informação da forma técnica exigida pela comunidade científica, apresenta ao leitor uma série de explicações parafrásticas como nos exemplos a seguir: 
[Narrador] A força eletrostática faz com que as partículas se repilam. A chamada força forte faz com que as partículas se atraiam. Quando essas forças poderosas se desequilibram, o átomo se quebra, ou fissiona (FETTER-VORM, 2013, p. 8, grifo nosso).

[Narrador] Dalí, ele ia para o prédio K-25, onde a solução líquida de urânio era convertida num gás e bombeada repetidas vezes através de quilômetros de filtros, concentrando ainda mais o U-235. E, por fim, o urânio agora moderadamente enriquecido era colocado num cálutron - uma série de eletroímãs conectados onde a maior parte do U-238 restante era eliminada (FETTER-VORM, 2013, p. 46, grifo nosso).

As explicações parafrásticas, portanto, consistem no emprego de um termo técnico clarificado na sequência por meio de uma linguagem próxima ao cotidiano do leitor, ou viceversa. No primeiro exemplo, o narrador apresenta inicialmente determinado processo utilizando o repertório comum do leitor, isto é, se quebrar, e em seguida fornece o termo técnico para essa ação, que no caso é fissionar. Nesse trecho, a utilização do recurso da paráfrase é feita de forma livre. Com relação ao segundo exemplo, o narrador apresenta o termo técnico para o equipamento empregado na eliminação do U-238, cálutron, e em seguida, apresenta a sua explicação. Neste caso, a paráfrase ocorreu por aposição - uso de aposto.

Tratando-se agora da constituição de frases e sentenças, para além da escolha de vocabulário, tomamos contato com o uso de recursos para a criação ou estabelecimento de um discurso científico que pretende alcançar um maior número de leitores. Dentre esses recursos, identificamos no texto simplificações, analogias e falta de rigor científico na linguagem em favor do senso comum.

Com relação às simplificações, um exemplo extraído da HQ diz respeito ao momento em que o narrador se coloca a explicar os efeitos da radiação liberada pelas bombas atômicas, e que atingiram os cidadãos japoneses:

[Narrador] Quando uma bomba atômica é detonada, ela produz uma explosão de energia, que em grande parte toma a forma de calor e luz, mas também assume uma forma que não pode ser vista ou sentida. Esses raios gama podem atravessar materiais sólidos como paredes, ou até mesmo corpos. E quando raios gama atravessam nossas células, eles podem despedaçar nosso DNA, causando mutações cancerosas (FETTER-VORM, 2013, p. 134 e 135).

Outro recurso comumente empregado no ensino de química, pois auxilia a visualizar fenômenos microscópicos ao compará-los com situações do cotidiano, são as analogias, e estas também se apresentam na HQ em alguns momentos. Uma analogia empregada pelo autor ocorre quando o narrador busca exemplificar o conceito de reação em cadeia comparando-a com o derrubamento de dominós enfileirados. Outro exemplo pode ser observado quando o narrador almeja evidenciar a dificuldade em enriquecer urânio. 
[Narrador] Nesse modelo, vamos dizer que fissão é o ato de empurrar uma peça de dominó. Se as peças estiverem muito afastadas, a 'reação' para, mas se estiverem perfeitamente alinhadas - perto o bastante umas das outras - então tudo o que você tem de fazer é derrubar o primeiro dominó da fila (FETTER-VORM, 2013, p. 40).

[Narrador] Para fazer uma bomba, você precisa enriquecer o urânio, removendo isótopos menos reativos e aumentando a concentração de U-235. Para ter uma ideia de quanto isso é difícil, imagina misturar massa de modelar de duas cores, e depois tentar separá-las novamente (FETTER-VORM, 2013, p, 45).

A falta de rigor científico na linguagem também se apresenta em alguns momentos em que há o uso de termos que se aproximem das concepções dos leitores. Um exemplo já foi demonstrado anteriormente quando apresentamos a simplificação empregada pelo autor para a abordagem da radiação e seus efeitos nos sobreviventes das cidades de Hiroshima e Nagasaki. Como podemos observar naquele trecho, ao mencionar as possíveis mutações que podem ocorrer no DNA, o leitor toma contato com o termo despedaçar, o que denota um distanciamento do rigor científico naquele momento para evidenciar o poder dos raios gama em promover alterações prejudiciais no código genético dos seres humanos. Como outro exemplo, temos o momento em que o narrador busca explicar o conceito de fissão nuclear promovido pelo bombardeamento de nêutrons, utilizando para tanto, termos mais comuns ao interlocutor, como inchado e em um piscar de olhos.

[Narrador] Esse nêutron extra é absorvido pelo núcleo de urânio já inchado, perturbando o delicado equilíbrio de forças que mantem o átomo unido. E em um piscar de olhos, o átomo se quebra por inteiro (FETTER-VORM, 2013, p. 9, grifo nosso)

Os recursos empregados pelo autor com essa finalidade de didatização, como as simplificações da linguagem, vão ao encontro da oralidade da linguagem dos quadrinhos, a qual apresenta uma maior proximidade com o discurso falado do que com o discurso escrito. Outrossim, ao nos depararmos com esses recursos, é válido salientar, assim como Ferreira (2012), que apesar deles aumentarem a didaticidade do texto, favorecendo o seu entendimento pelo leitor, também demandam alguns cuidados dos professores que optam pelo seu emprego em sala de aula. Consoante Ferreira (2012), o uso desses recursos pode implicar na distorção de algumas informações presentes no texto e, consequentemente, promover nos leitores a criação de concepções equivocadas sobre a temática abordada. Lembramos que o objetivo primário da HQ "Trinity" não consiste no seu uso para efeitos didáticos em sala de aula, contudo, quando empregado de forma coerente no espaço formal de ensino, levando-se em consideração também as suas limitações. as possibilidades pedagógicas oriundas de textos como este é ampla. 
No que diz respeito à linguagem, observa-se o emprego de vários recursos explicativos que estão colocados de diversas formas no texto, seja por aposição, inserção parentética ou forma livre. Em especial, observa-se no texto o emprego de aposto em diversas ocasiões para clarificar alguma noção ou conceito. No que tange à função de tais recursos estas são variadas, com destaque para as de nomeação e definição na perspectiva de Zamboni (2001)

O recurso de nomeação segundo o autor, é uma forma de remissão ao discurso científico e, assim, de garantia de confiabilidade do próprio dizer. Consiste em inserir fórmulas metalinguísticas do tipo: esse processo é chamado de ..., conhecido por ... etc. Alguns exemplos desse recurso empregado na HQ já foram apresentados como em: "[Narrador] Se você deixar uma barra de urânio parada por 4,5 bilhões de anos, é possível que metade dela se transforme em chumbo. Isso é chamado de decaimento radioativo..." (FETTER-VORM, 2013, p. 4, grifo nosso), “[Narrador] Escondido no coração de cada átomo há um minúsculo e incrivelmente denso aglomerado de partículas carregadas. Rutherford chamou esse aglomerado de núcleo" (FETTER-VORM, 2013, p. 5, grifo nosso). Em outro exemplo temos: "[Narrador] A cientista Marie Curie e seu marido, Pierre, descobriram os elementos polônio e rádio, que emitiam uma misteriosa energia. Eles a chamaram de radioatividade” (FETTER-VORM, 2013, p. 4, grifo nosso). Note que todos os exemplos desse recurso se encontram na parte introdutória do texto, pois esse é o momento em que o leitor é apresentado aos conceitos clássicos pertinentes a construção da bomba atômica, e que, por ventura, serão retomados mais adiante na leitura. Logo, podemos perceber por meio do emprego desse recurso, uma tentativa do autor/enunciador em aproximar o leigo do que vai ser tratado na narrativa.

O recurso de definição, por sua vez, é ainda mais comum, e com função explicitadora, pode ocorrer principalmente de três formas: por conceituação, por aproximação, ou por justaposição metalinguística. A seguir apresentamos alguns exemplos identificados: (01) "[Narrador] O conceito de reação em cadeia é relativamente simples: o produto de uma reação é suficiente para disparar outra reação” (FETTER-VORM, 2013, p. 40), (02) "[Narrador] Um isótopo é uma versão de um elemento que parece ser quase identifico ao original, mas pode se comportar de maneiras drasticamente diferentes" (FETTER-VORM, 2013, p. 43), (03) "[Narrador] Chadwick havia descoberto o nêutron, uma partícula dentro do núcleo que não possui carga elétrica” (FETTER-VORM, 2013, p. 6), (04) “[Narrador] Se você queimar um pedaço de carvão e se assegurar de que há oxigênio o bastante, o resultado será fogo (energia) e fumaça” (FETTER-VORM, 2013, p. 11), (05) “[Narrador] Esses raios gama podem atravessar materiais sólidos como paredes” (FETTER-VORM, 2013, p. 135). 
(06) [Narrador] Fissão é a reação que torna possível todas as coisas que associamos com a energia nuclear. Para explicar a fissão, vale a pena olhar mais de perto o interior de um átomo. Átomos são compostos por três tipos de partículas: nêutrons (que, como Chadwick descobriu, possuem uma carga neutra); prótons (que são positivamente carregados); e elétrons (que têm uma carga negativa) ... (FETTER-VORM, 2013, p. 8 , grifo nosso).

Diante dos trechos apresentados, identificamos em (01) e (02) a definiç̧ão por conceituação em que o termo científico "reação em cadeia" e "isótopo" é conceituado para melhor entendimento. No exemplo (03) nos deparamos com uma definição por justaposição metalinguística. Segundo Zamboni (2001), sem haver uma ruptura da ideia contida na frase, esse recurso assume uma dupla função, ao mesmo tempo em que se mostra o objeto, faz-se uso dele, ou seja, nesse exemplo o narrador apresenta o termo nêutron e o define na sequência como sendo uma partícula dentro do núcleo que não possui carga elétrica.

Com relação aos exemplos (04) e (05), esses apresentam definições por aproximação, as quais semelhantes às analogias, que como observamos estão presentes em diferentes momentos da narrativa, utilizam o recurso da comparação, isto é, buscam no cotidiano do interlocutor elementos que exibam equivalência conceitual com o objeto científico a ser explicado (ZAMBONI, 2001). Assim sendo, no trecho (04), o conceito científico de energia é relacionado ao fogo por inserção parentética, e no (05) materiais sólidos são comparados a paredes, as quais, assim como o fogo, são comuns ao leitor. Por fim, no trecho (06) diferentes recursos de definição são empregados. Inicialmente tomamos contato com uma definição de fissão por conceituação, conforme grifo inicial, e na sequência três exemplos de definição por justaposição metalinguística ao clarificar os termos nêutrons, prótons e elétrons.

Com relação à linguagem, outro aspecto digno de nota diz respeito à noção que ficou conhecida como tom do discurso introduzida por Maingueneau (1997), o qual salienta que o que é dito e a forma como é dito, isto é, o tom com que é dito, são partes integrantes da formação discursiva. Nessa perspectiva, identificamos em alguns momentos da narrativa uma atitude espontânea do autor com relação à linguagem e ao emprego de interações coloquiais típicas. Como exemplo dessa observação temos o momento em que ocorre a realização do teste Trinity pelo qual se verifica a eficácia e o poder de destruição do armamento desenvolvido: "[Groves] Robert! Funcionou! A engenhoca funcionou! Deixe-me apertar a sua mão. Agora somos todos uns filhos da puta!" (FETTER-VORM, 2013, p. 78). Com esse trecho observa-se, portanto, o número de exclamações e o emprego de coloquialismos que dão tom à fala de Groves em contentamento com a eficiência do Projeto.

Diante do exposto, as considerações levantadas com relação à linguagem empregada pelo autor/enunciador sugerem um elevado grau de didaticidade do texto, o qual está repleto de 
conceituações, simplificações e representações químicas que remetem a um texto comumente empregado em sala de aula de ciências. Ou seja, com relação à cena enunciativa (ZAMBONI, 2001), há a pressuposição de um leitor/interlocutor (polo de recepção) não especializado para o qual falta o domínio de determinados conhecimentos e conceitos pertinentes à construção de uma arma atômica (temática da HQ), assim sendo são necessários recursos metalinguísticos, como os observados para a compreensão da narrativa pelo leitor.

Prosseguindo com a análise da forma pela qual a informação é veiculada na $\mathrm{HQ}$, os traços adotados pelo autor desempenham um papel interessante no desenvolvimento na narrativa. Inicialmente, considerando as ideias de McCloud (2005), o desenho comumente empregado nos quadrinhos está diretamente relacionado com o sucesso desse hipergênero, uma vez que, é por meio dele que se torna possível uma maior identificação do leitor com os personagens, situações etc., o que contribui para um envolvimento significativo do interlocutor com o texto. Também é válido destacar que, considerando os nossos objetivos, os quais englobam o exercício da sensibilidade moral em sala de aula a partir da leitura da HQ, uma análise sistemática das imagens empregadas pelo autor se faz relevante. Isto porque, a adoção de diferentes traços podem contribuir para uma maior sensibilização do leitor e também promover uma maior empatia deste pelos diferentes personagens, e aqui relembramos a relação existente entre empatia e padrões de raciocínio informal na perspectiva de Sadler e Zeidler (2005).

Nessa perspectiva, ao considerarmos o continuo apresentado por McCloud (2005) ilustrado na Figura 11, identificamos que na HQ "Trinity" há um predomínio de traços intermediários, isto é, a caracterização dos personagens não é feita de forma puramente realista, tampouco se reduz a traços caricatos/cartunescos. Como exemplos de traços empregados na caracterização dos diferentes personagens da narrativa apresentamos as Figuras 19 e 20. Na medida que o tipo de desenho vai depender do objetivo do autor (VERGUEIRO, 2007a), e este, mediante o nível de abstração, vai permitir a ampliação ou não dos significados das imagens (McCloud, 2005), podemos atribuir a escolha por um traço entre o realista e caricato a alguns motivos, os quais abordamos na sequência. 
Figura 19 - Oppenheimer e Groves discutem a respeito do comportamento dos cientistas diante da obrigatoriedade de sigilo.

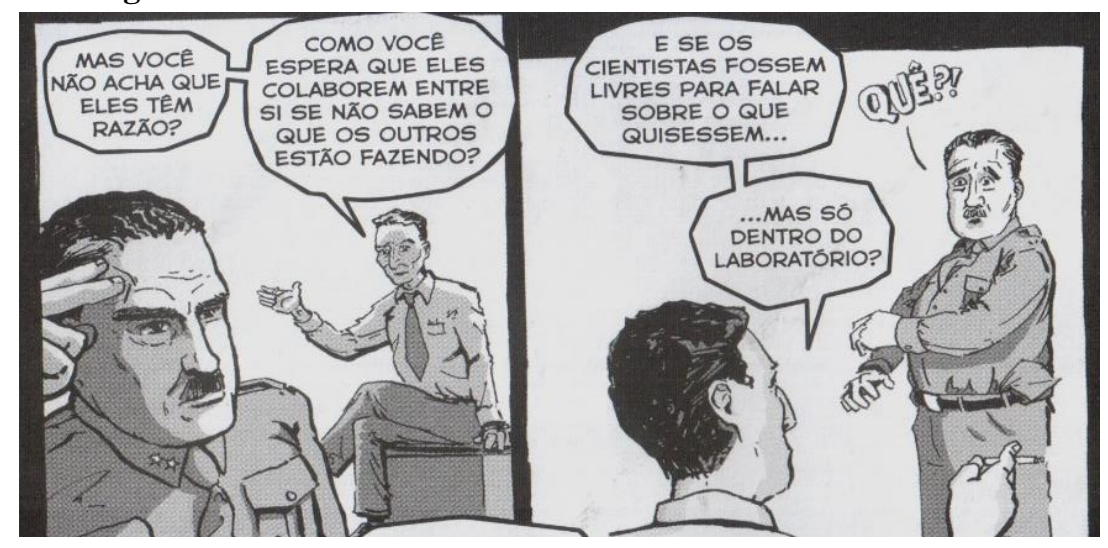

Fonte: Fetter-Vorm (2013), p. 36

Figura 20 - Diante da possibilidade de construção de armamentos nucleares, Leo Szilard busca conselhos com Albert Einstein.

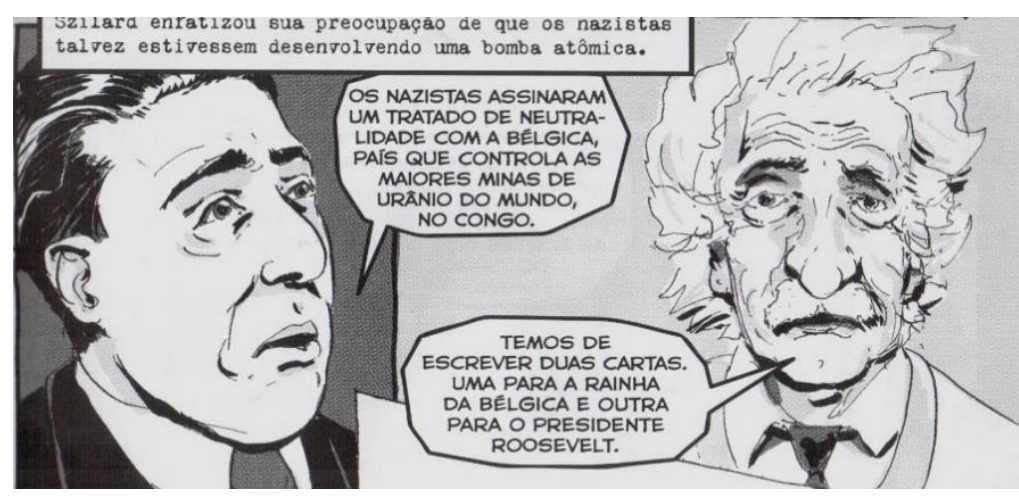

Fonte: Fetter-Vorm (2013), p. 12

Como podemos observar nas Figuras 19 e 20, há a busca por uma caracterização realista sem perder a essência dos quadrinhos, ou seja, sem deixar de empregar traços cartunescos tradicionais desse tipo de texto e que permitem uma maior identificação do leitor. O distanciamento dos traços caricatos pode ser devido a dois principais aspectos. Primeiro, por conta da própria natureza do texto que, como evidenciado pela análise do "conteúdo", não apresenta como tônica o humor, e o desenho comumente associado à comicidade (caricato) é minimizado na HQ. No mais, a narrativa, devido à sua abordagem histórica, apresenta ao leitor personagens reais conhecidos por grande parte do público, é o caso por exemplo, do físico Albert Einstein, retratado na Figura 20. Dessa forma, ao apresentar figuras conhecidas, os traços empregados pelo autor devem permitir o reconhecimento desses personagens de modo a atribuir à HQ certa credibilidade. Também é possível notar pelos exemplos apresentados que o traço empregado em conjunto com o plano de visão, que será pormenorizado adiante, permite o contato do leitor com diferentes emoções e sentimentos dos personagens, sendo esta uma forma de apelo utilizada pelo autor. 
Ainda com relação ao desenho, outra característica dos quadrinhos, principalmente de divulgação científica com amplo grau de didaticidade, que é o caso da HQ "Trinity", como evidenciado pela análise da linguagem escrita, diz respeito aos jargões visuais na perspectiva de Kress (2003). Segundo esse autor, o caráter icônico dos desenhos auxilia na criação de uma cientificidade, a qual, sendo uma construção social, emerge em signos pertencentes a determinada comunidade, assim como os jargões verbais próprios de determinadas esferas de comunicação. Nesse sentido, Kress (2003) ressalta que apesar do relevante papel das imagens na comunicação, estas em livros didáticos por muitas vezes têm sido consideradas e analisadas apenas como simples adornos ou ilustrações, o que já se contrapõe com a noção de HQ apresentada anteriormente neste capítulo. Sendo assim, esse autor sugere que em determinados gêneros textuais, que aqui abrangem os quadrinhos, o texto verbal não é meramente ilustrado por uma imagem, mas serve como um comentário a ela.

Diante dessas considerações, identificamos na HQ "Trinity" o uso, principalmente na fala do narrador, do que consideramos jargões científicos visuais. Dentre esses jargões apresentamos a estrutura atômica do átomo proposto por Rutherford (Figura 21), e a ideia de cargas e campo elétrico na Figura 22.

Figura 21 - Ilustração do modelo planetário da estrutura atômica proposto por Rutherford.

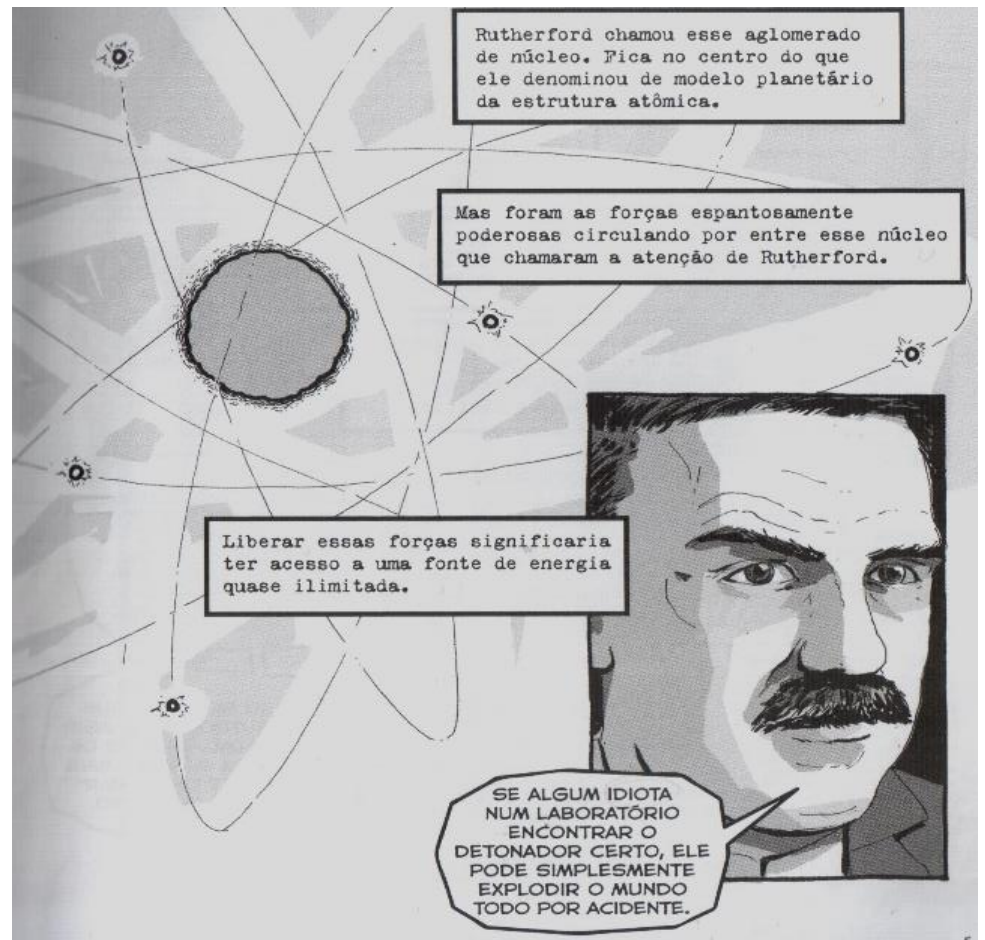

Fonte: Fetter-Vorm (2013), p.3 
Figura 22 - Ilustração das forças elétricas que constituem o átomo esquematizadas por James Chadwick.

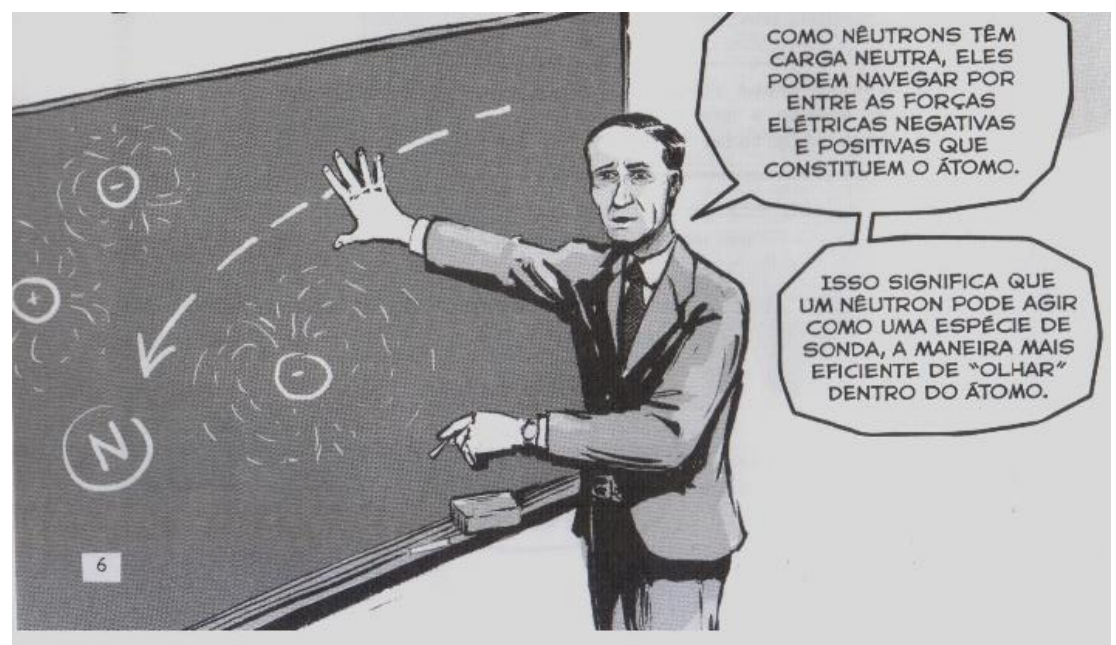

Fonte: Fetter-Vorm (2013), p. 4

Com esses exemplos (Figuras 21 e 22) reforçamos a importância que as imagens assumem para a compreensão de conceitos pertinentes ao ensino de química e física. É por meio de desenhos e esquemas que se torna possível, por exemplo, a visualização de modelos microscópicos da ciência, como a constituição da matéria. Sendo assim, o emprego de tais jargões visuais científicos, assim como a utilização de analogias no que diz respeito ao uso de recursos verbais, confere ao texto um elevado grau de didaticidade. No entanto, de maneira semelhante às analogias, o emprego de tais modelos explicativos da matéria demandam alguns cuidados dos professores com relação à sua utilização em sala de aula.de modo que estes mão venham a promover concepções alternativas equivocadas nos alunos.

Diante dessas considerações apresentadas com relação ao desenho empregado pelo autor, identificamos que a temática da narrativa e sua abordagem demandam traços mais realistas e sóbrios, no entanto, não deixam de estar presentes no texto contornos tipicamente cartunescos que são em grande parte, segundo McCloud (2005), responsáveis pelo sucesso das HQ com o público leitor. Outro aspecto relavante identificado é que, assim como a linguagem verbal, muitos dos desenhos empregados pelo autor se configuram como um recurso didático por meio principalmente do uso de jargões científicos visuais. Tais recursos responsáveis por aumentar a didaticidade do texto suscitam uma mediação adequada, de modo a evitar a construção, pelos alunos, de concepções equivocadas a respeito dos conceitos abordados. Salientamos que os obstáculos epistemológicos ao conhecimento, para além das vivências dos educandos. pode se dar via ações didáticas empregadas pelos docentes, isto é, por meio de modelos, metáforas, analogias, imagens etc.

Dando prosseguimento à análise da forma da HQ, outro recurso comumente empregado para a didatização da informação científica diz respeito ao letreiramento que, como 
mencionado previamente, consiste na escolha de fontes e seu uso pelo autor. O letreiramento pode implicar na produção de diferentes sentidos e, como afirma Eisner (1999), quando tratado graficamente e a serviço da história funciona como uma extensão da imagem. Este recurso pode fornecer o clima emocional, uma ponte narrativa e até mesmo a sugestão de som (EISNER, 1999).

Nesse sentido, na leitura da HQ “Trinity" não observamos um trabalho muito refinado quanto a esse recurso, no entanto, ele é empregado, por exemplo, na separação entre falas do narrador e dos demais personagens, o que permite ao leitor uma facilidade no reconhecimento de quem se pronuncia naquele momento (Figura 23). Assim sendo, observamos nas falas do narrador o uso de letras minúsculas convencionais, uma vez que este apenas apresenta informações que complementam a narrativa, não exigindo um clima emocional que pode se dar por meio do letreiramento. Quando da fala dos demais personagens, identificamos o emprego somente de letras maiúsculas. Essa diferenciação, portanto, possibilita uma carga emotiva nas expressões, o que vai ao encontro das ideias de McCloud (2005) quanto à identificação leitor/personagem própria desse hipergênero textual, isto é, ao apresentar as falas dos diferentes personagens impregnadas de emoções, afetividade etc., o leitor toma contato com sentimentos e anseios que o aproxima desses personagens.

Figura 23 - Exemplo de fontes tipográficas empregadas na fala do narrador e dos demais personagens.

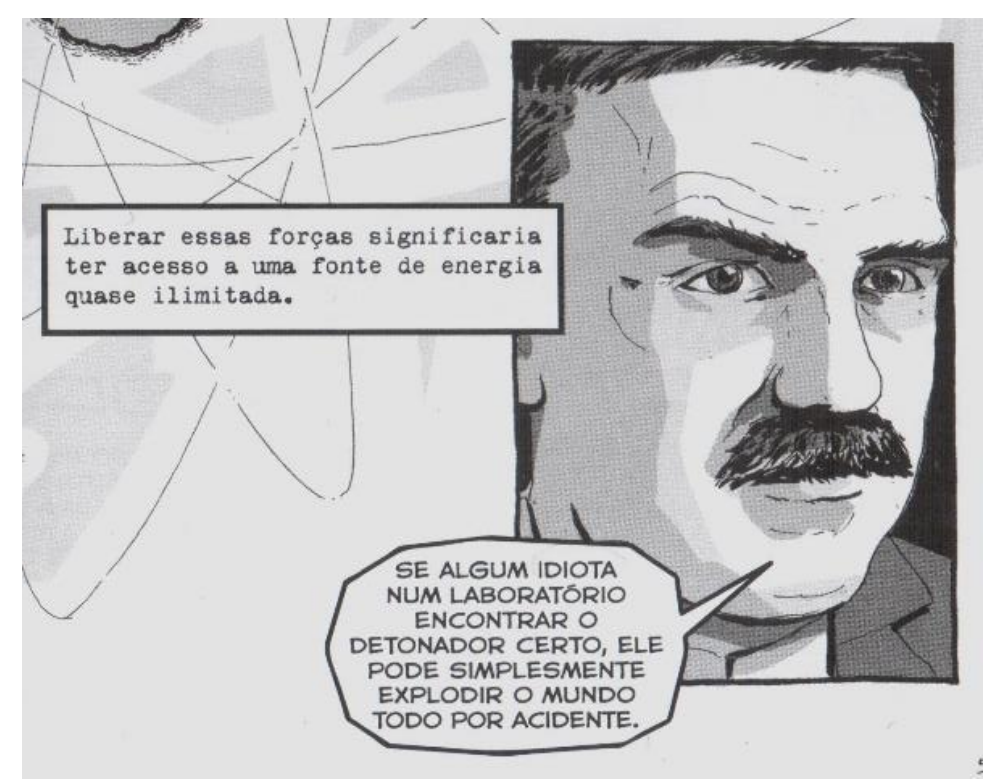

Fonte: Fetter-Vorm (2013), p. 5

Ainda consoante Eisner (1999), o letreiramento especial também funciona como recurso didático na maioria das vezes, e é o caso na HQ “Trinity”, como apresentado na Figura 
24, do momento em que o narrador apresenta ao leitor o poder de uma reação nuclear comparando-a com a energia liberada em uma reação química.

Figura 24 - Letreiramento especial que evidencia o poder de uma reação nuclear.

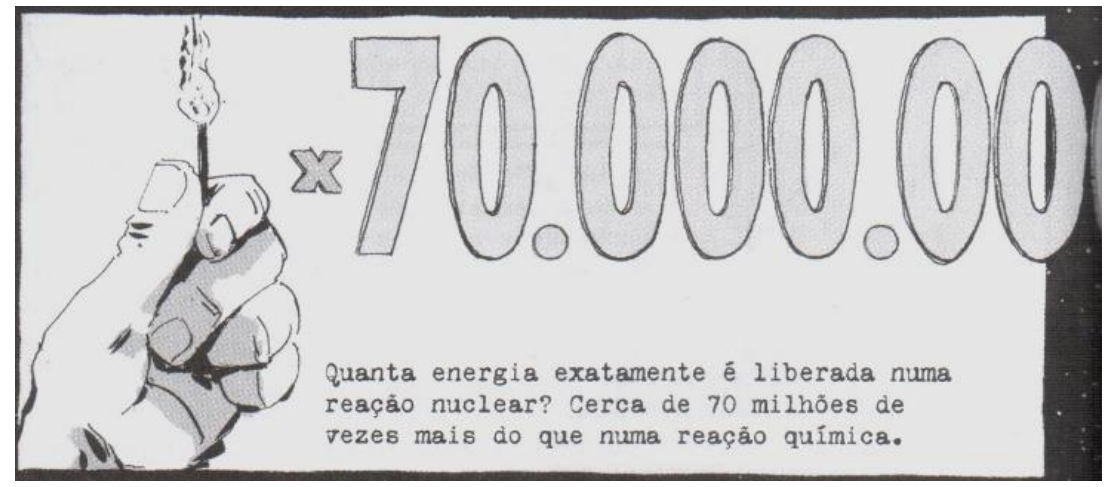

Fonte: Fetter-Vorm (2013), p. 10.

Centrando-se ainda nesse recurso, observamos a sua relevância para enfatizar algum aspecto da narrativa, como o sigilo do Projeto Manhattan. Sendo assim, o letreiramento especial, como evidenciado nas Figuras 25 e 26, é empregado na forma de grandes avisos para ressaltar o caráter secreto do projeto que envolve a construção de um armamento nuclear. $\mathrm{O}$ uso do letreiramento especial com essa finalidade reforça no leitor a ideia de conflitos políticos/sociais envolvidos no processo que se iniciou a partir do desenvolvimento científico, assim sendo torna-se ainda mais claro a presença de QSC na narrativa.

Figura 25 e 26 - Letreiramentos especiais que evidenciam uma das principais características do Projeto Manhattan: o sigilo.
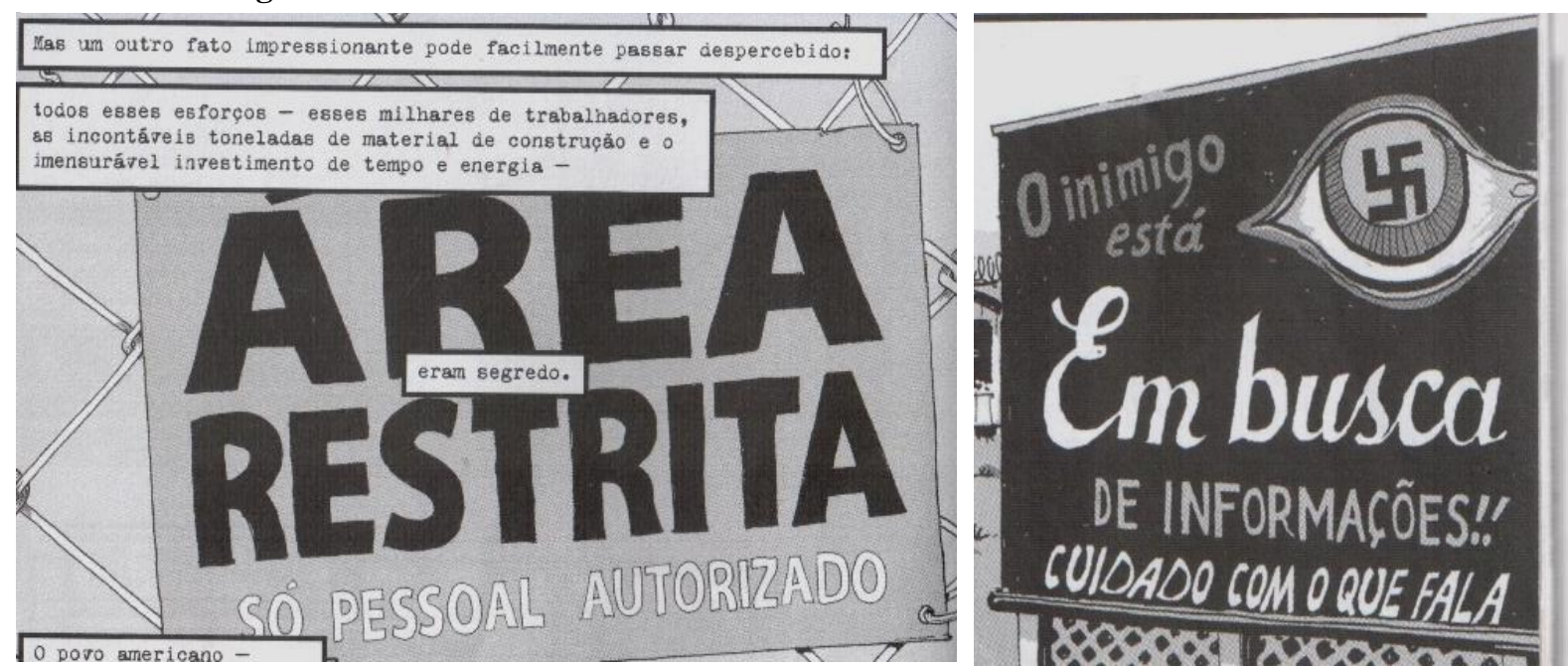

Fonte: Fetter-Vorm (2013), p. 34 e 37

Por fim, a sugestão de som por meio do emprego de letreiramento especial ocorre em diferentes momentos da HQ e também se constitui como um recurso que não somente integra o leitor na narrativa, aproximando-o ainda mais das situações narradas, como auxilia na didatização da informação científica. Como um exemplo desses momentos, apresentamos 
aquele em que, mediante anseios de Szilard, um despertador toca copiosamente (Figura 27). Esse momento, diretamente relacionado com a $\mathrm{NdC}$, reforça a ideia de trabalho árduo dos cientistas em meio a um misto de empolgação e receio como enfatizado pelo narrador.

Figura 27 - Representação de alarme tocando por meio de letreiramento especial.

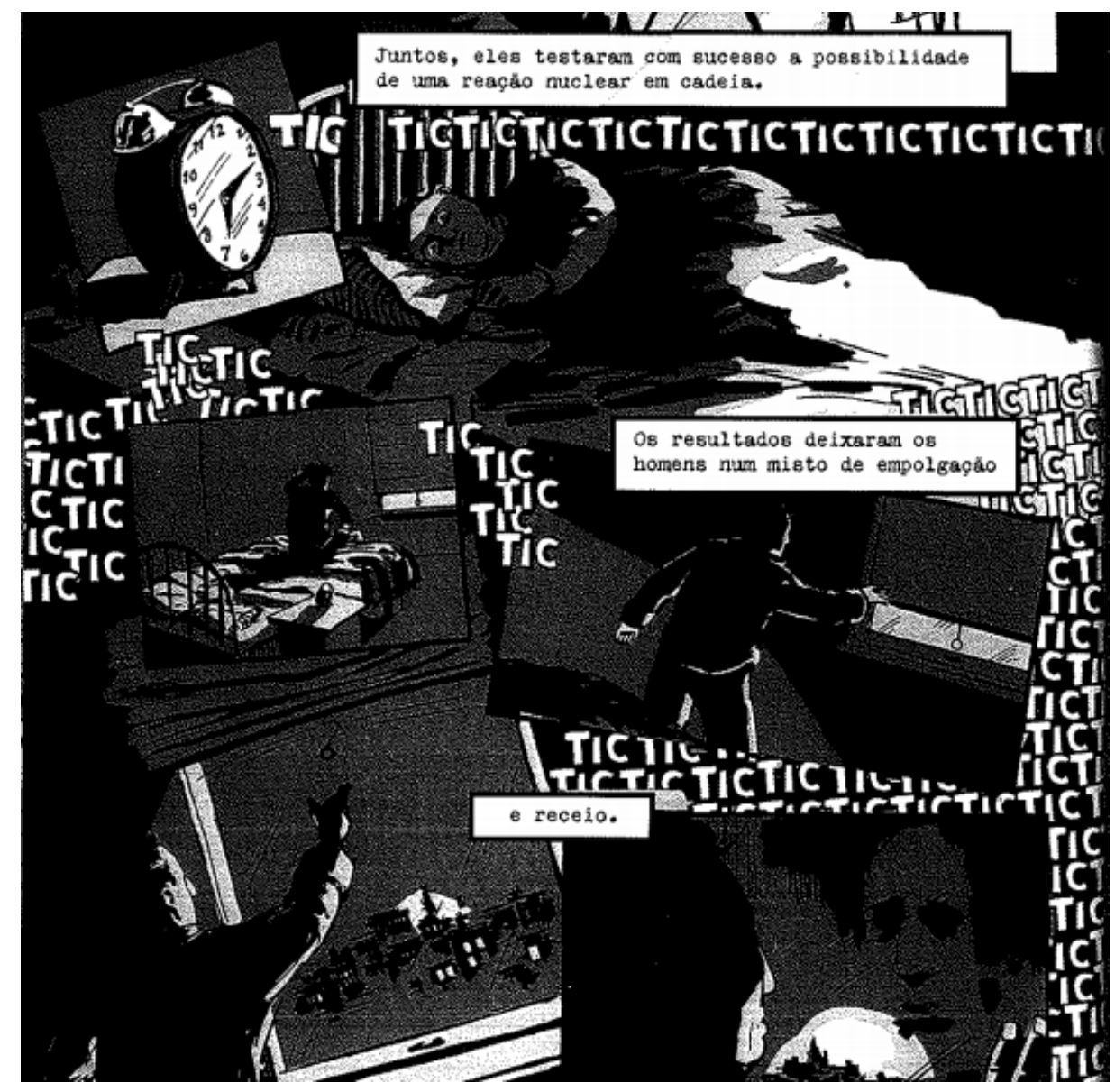

Fonte: Fetter-Vorm (2013), p. 38

Outro exemplo em que o letreiramento fornece a ideia de som é o momento em que Fermi, ao realizar seus estudos envolvendo uma reação em cadeia de fissão controlada, liga uma espécie de contador de nêutrons (Figura 28). Mais do que apenas fornecer essa ideia de som, podemos atribuir também a esse recurso um caráter didático, uma vez que, a forma como são apresentadas as onomatopeias "CLIC", em progressão e cada vez mais próximas, confirma a ideia de reação em cadeia em que poucos nêutrons iniciais vão gerando cada vez mais outros neutros que vão, por sua vez, alimentando uma arma nuclear. 
Figura 28 - Representação de som em uma reação de fissão nuclear controlada.

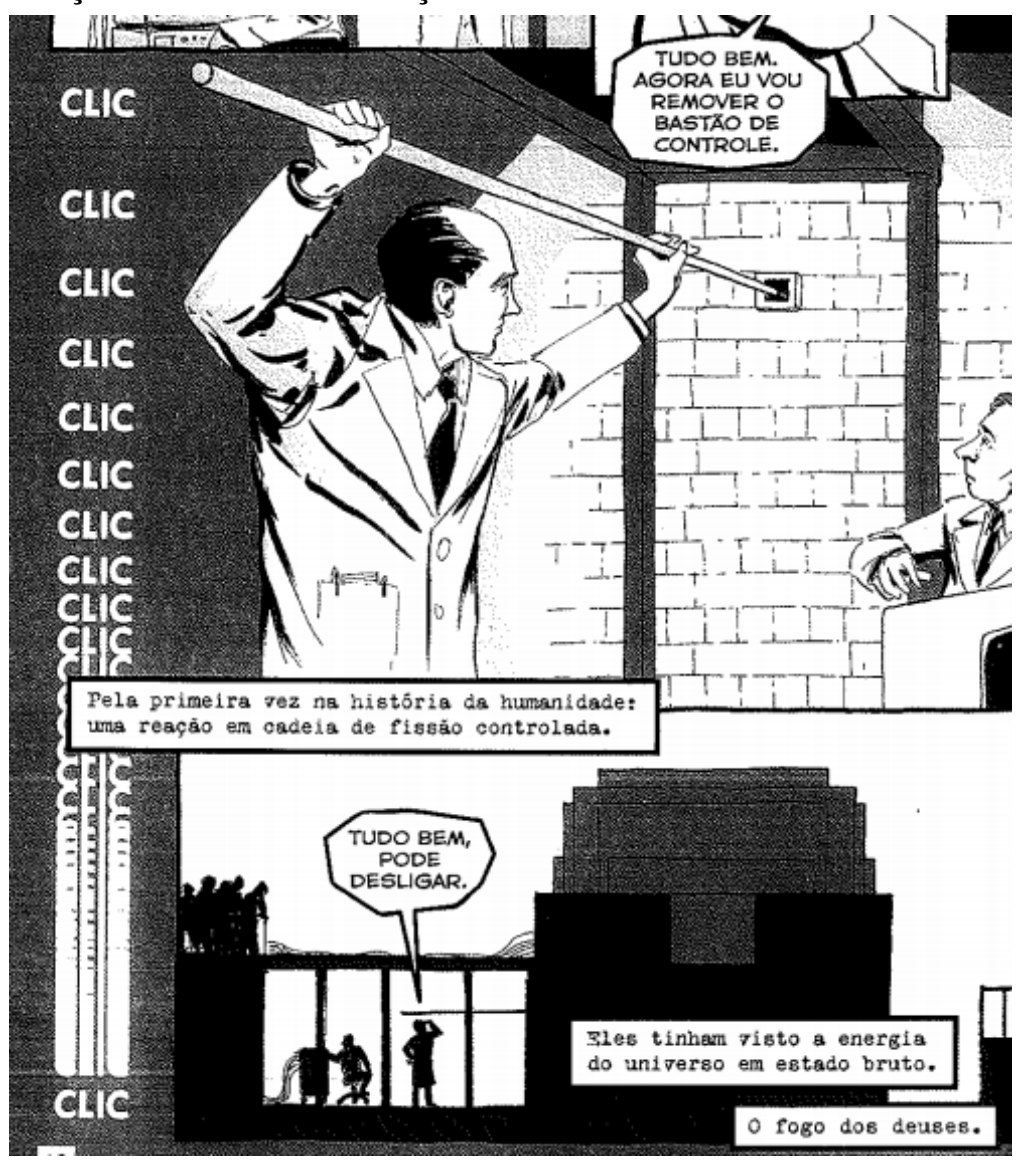

Fonte: Fetter-Vorm (2013), p. 42

Em suma, observamos por meio do letreiramento empregado uma preocupação do autor em transmitir para o leitor emoções dos diferentes personagens em suas falas, contrastando-as constantemente com as falas neutras do narrador. Esse aspecto se torna relevante para os objetivos deste estudo, uma vez que, diretamente relacionado com a afetividade, o raciocínio informal/moral dos licenciandos a serem investigados pode ser afetado pelos recursos empregados pelo autor tais como o letreiramento. Outrossim, identificamos a importância desse recurso para enfatizar diferentes aspectos da narrativa, bem como confirmamos a didaticidade proveniente de um letreiramento especial, seja de forma direta e clara como apresentado na Figura 24, ou como objetivo secundário, o que é o caso da cena ilustrada na Figura 28.

Por se tratar de uma arte sequencial as transições de cena empregadas pelo autor em uma HQ também desempenham um papel fundamental no fluxo narrativo e na compreensão do enredo pelo leitor. Nessa perspectiva, considerando os tipos de transição apresentadas por McCloud (2005) e comentadas anteriomente, a relembrar: transição momento-para-momento; transição ação-para-ação; transição cena-para-cena; transição tema-para-tema; transição aspecto-para-aspecto; transição non sequitur. Identificamos na HQ “Trinity" a presença de 
grande parte dessas transições, com exceção de aspecto-para-aspecto e non sequitur. A ausência delas é de se esperar uma vez que a primeira é mais comum em quadrinhos orientais como os mangás, e a segunda caracterizaria uma sequência não lógica, o que não tem espaço em um texto cujo objetivo é a abordagem histórica e conceitual de uma temática polêmica como a construção das armas nucleares.

Com relação às transições momento-para-momento, das quatro principais observadas essa é a que se apresenta em menor quantidade, uma vez que demanda um maior número de quadros e diminui o fluxo narrativo (McCLOUD, 2005). Como exemplo desse tipo de transição apresentamos a Figura 29, a qual ilustra, passo a passo, a ação de Oppenheimer em acender um cigarro.

Figura 29 - Exemplo de transição momento-para-momento.

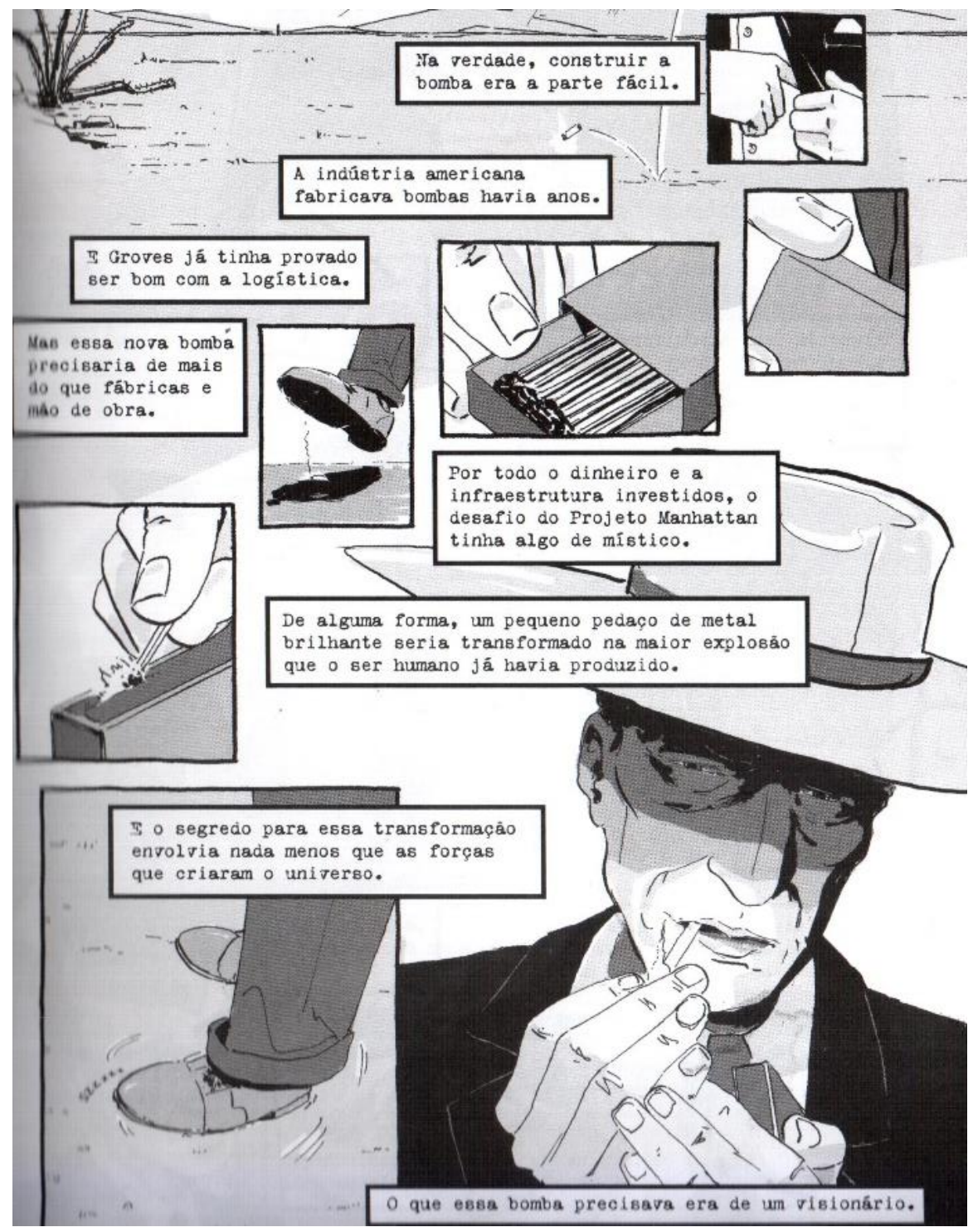

Fonte: Fetter-Vorm (2013), p. 21 
Ação-para-ação é outro tipo de transição comum em quadrinhos ocidentais como apontado por McCloud (2005) e, dessa forma, também está amplamente presente no texto. Após momento-para-momento, esse é o tipo de transição que demanda menor atenção do leitor omitindo apenas pequenos detalhes entre um quadro e outro. No exemplo apresentado (Figura 30) temos a sequência de três quadros em que Groves e Oppenheimer se conhecem, assim sendo, no primeiro quadro o cientista se apresenta à porta do escritório de Groves, em seguida ambos já estão se cumprimentando e na sequência estão conversando sobre o Projeto Manhattan, ou seja, a aproximação entre os personagens e toda a discussão anterior à conclusão da necessidade de isolamento para a execução a contento do Projeto está subentendida entre os quadros.

Figura 30 - Exemplo de transição ação-para-ação.

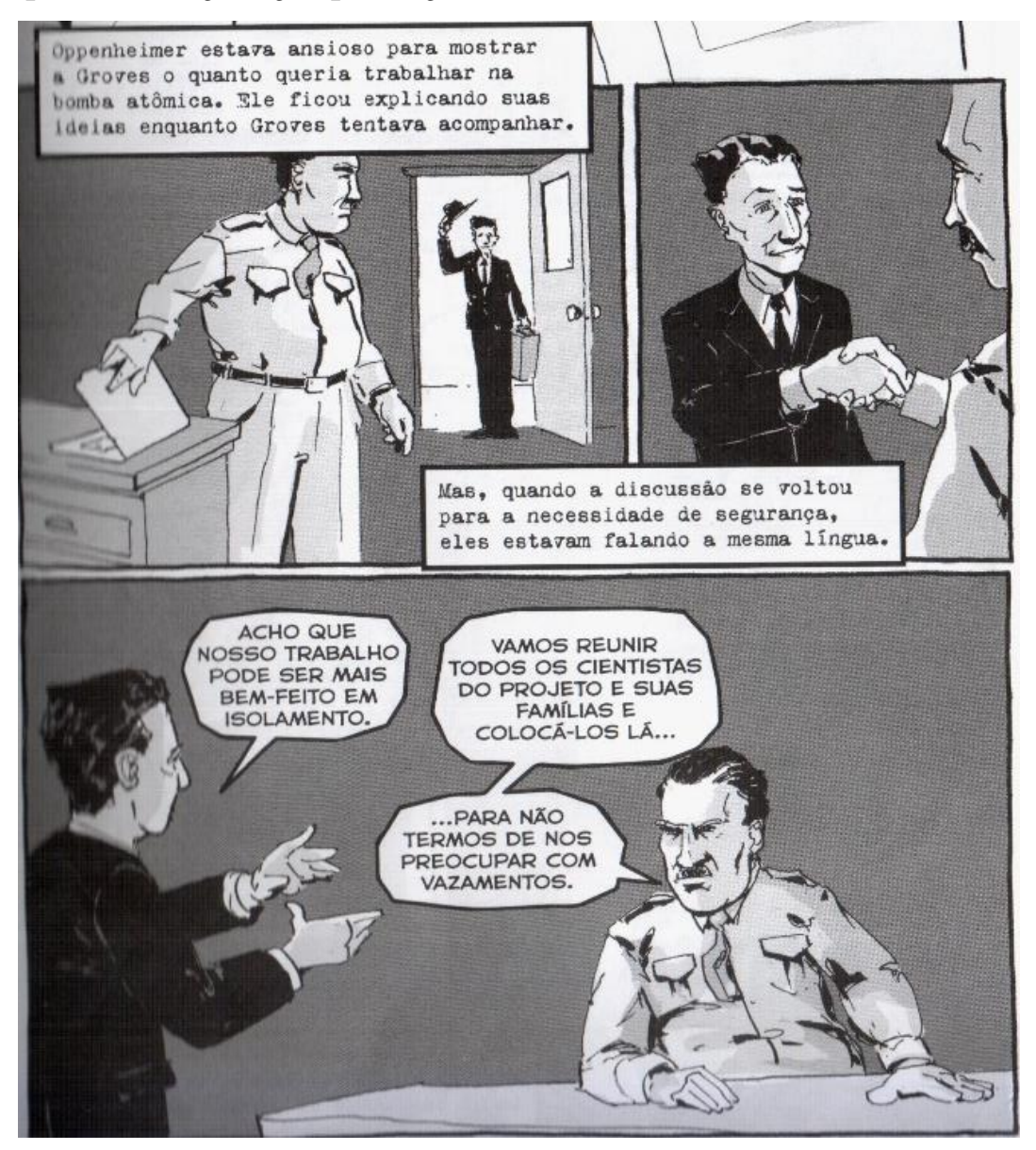

Fonte: Fetter-Vorm (2013), p. 25

Se afastando um pouco dos resultados obtidos por McCloud (2005) em sua análise de diferentes quadrinhos norte-americanos para os quais o autor identificou um predomínio de transições ação-para-ação, na HQ “Trinity” há um grande número de transições tema-paratema, nas quais há o foco em algum detalhe da cena necessário à compreensão do enredo pelo 
leitor. Em diferentes momentos, como o apresentado na Figura 31, o leitor é apresentado a algum elemento da cena que contribui para o seu melhor entendimento do texto.

Figura 31 - Exemplo de transição tema-para-tema.

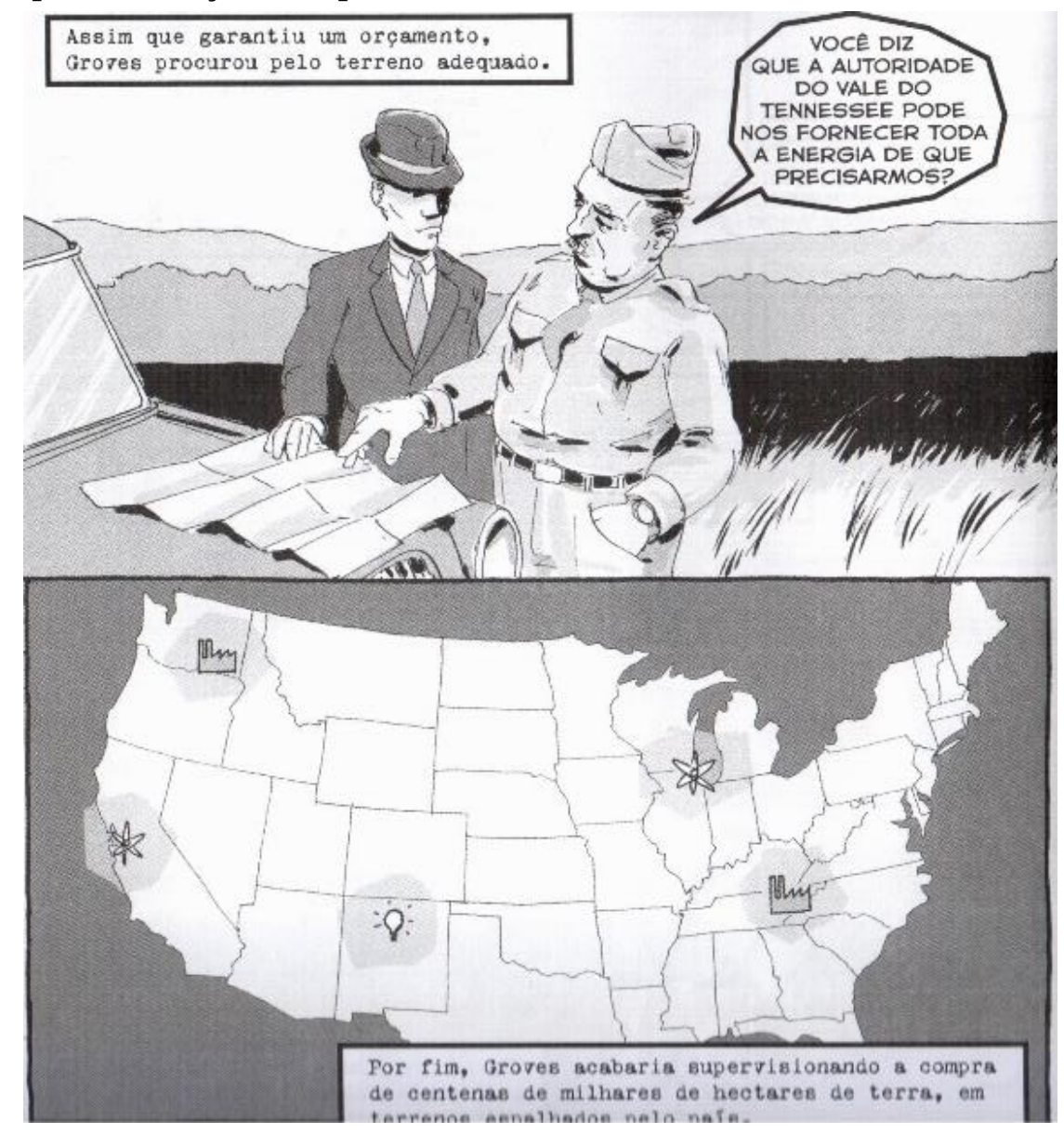

Fonte: Fetter-Vorm (2013), p. 18

Conforme podemos observar na Figura 30, a transição tema-para-tema se apresenta quando inicialmente Groves está discutindo com determinado personagem, diante de um mapa, a logística do Projeto Manhattan e a aplicação do orçamento liberado. Na sequência, o leitor é apresentado ao mapa em questão em que há pontos destacados que enfatizam a distribuição de terrenos adquiridos para a execução do Projeto, os quais estão espalhados por todo o território norte-americano. Ainda com relação a esse tipo de transição, ela é amplamente usada para ressaltar a expressão dos diferentes personagens dentro de uma cena, como naquela apresentada na Figura 32. 
Figura 32 - Exemplo de transição tema-para-tema com foco na expressão dos personagens.

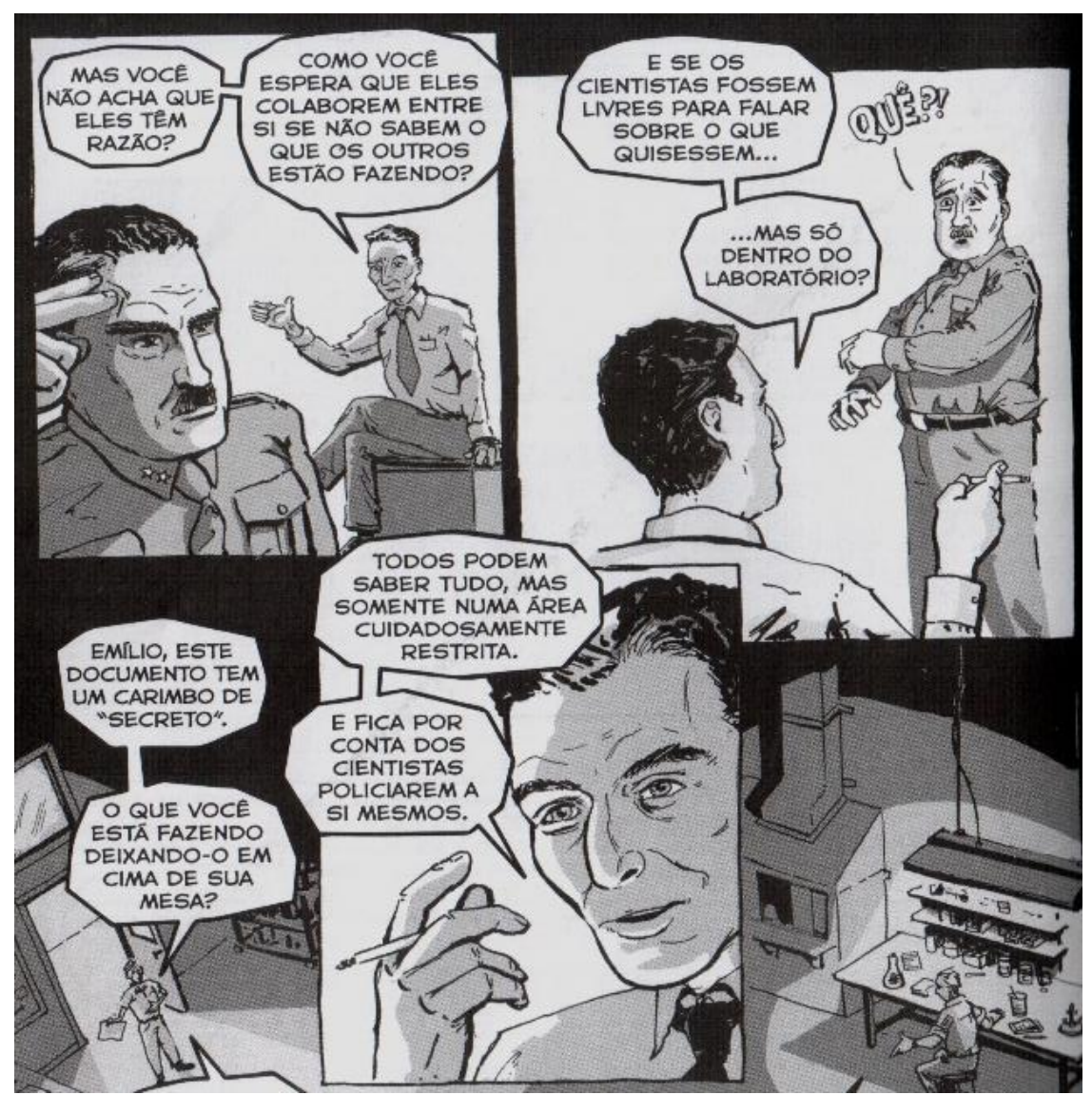

Fonte: Fetter-Vorm (2013), p. 36

No exemplo ilustrado na Figura 32 somos apresentados a um episódio no qual Groves e Oppenheimer discutem a melhor maneira de conduzir o trabalho científico, para então o autor salientar a expressão do cientista dentro da referida cena ao propor sua possível solução. Nesse sentido, como será abordado na sequência da análise da "forma", ao apresentarmos considerações sobre os planos de visão adotados pelo autor verificamos que esse tipo de transição é geralmente associado ao primeiro plano e se configura como um elemento de apelo ao leitor, principalmente quando consideramos a temática da HQ e sua abordagem polêmica. Isto exposto, identificamos nesse momento um recurso empregado pelo autor que pode influenciar posteriormente a tomada de decisão dos licenciandos diante de questões controversas que serão empregadas para o exercício do raciocínio informal/moral em sala de aula.

Por fim, o outro tipo de transição amplamente utilizado pelo autor da HQ diz respeito à transição cena-para-cena em que existem grandes saltos temporais ou espaciais entre um quadro e outro. Como exemplo apresentamos a Figura 33 que ilustra, por meio de um salto temporal e espacial, uma mudança de cena. Inicialmente o leitor está em contato com o ambiente do Projeto Manhattan em Los Alamos, e na sequência é conduzido pelo narrador a 
alguns anos atrás, para a Universidade de Columbia, onde foram realizados por Szilard e Fermi estudos envolvendo a fissão nuclear e a reação em cadeia.

Figura 33 - Exemplo de transição cena-para-cena

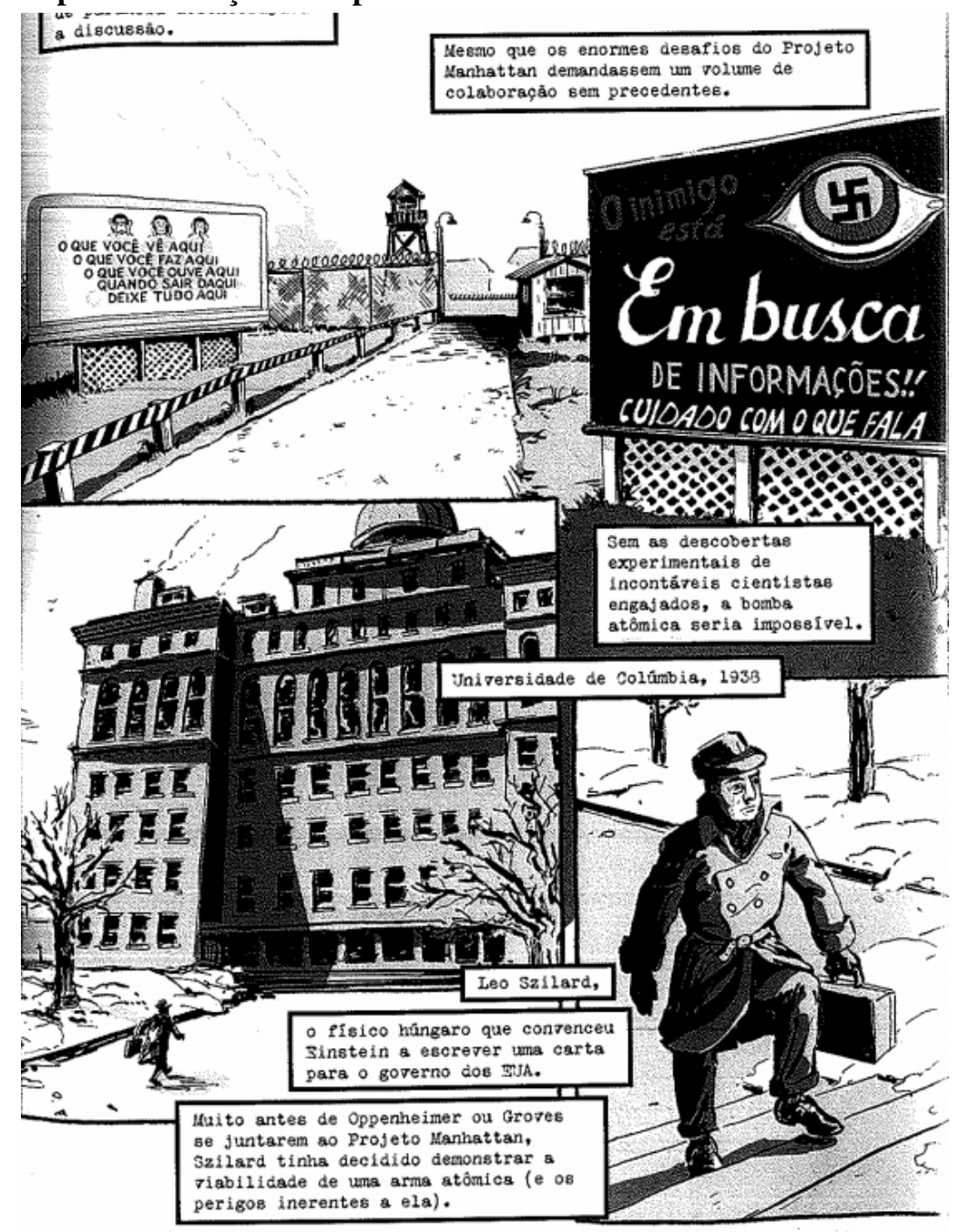

Fonte: Fetter-Vorm (2013), p. 37

Apesar da transição cena-para-cena ser o tipo mais comum conforme identificado por McCloud (2005), a sua ampla presença na HQ está diretamente relacionada com a abordagem identificada pela análise do "conteúdo", isto é, a abordagem histórica permite ao leitor o contato com diferentes momentos e situações pertinentes à construção de um armamento nuclear. Sendo assim, identificamos por diversas vezes expressões do tipo: "Local do teste Trinity: doze horas para a detonação" (FETTER-VORM, 2013, p. 16); "Ponto zero, dez horas para a detonação" (FETTER-VORM, 2013, p. 54); "Postdam, Alemanha. 16 de julho de 1945, dia do teste Trinity" (FETTER-VORM, 2013, p 80). Essas expressões são apresentadas pelo narrador como forma de auxiliar o leitor na compreensão do texto mediante esse tipo de transição que demanda uma maior atenção. Nesse sentido, a HQ também se torna interessante para fins pedagógicos na 
medida que permite ao educando o contato com diferentes acontecimentos históricos que contribuíram de certa forma para a constituição da sociedade moderna.

Diante dessas colocações observamos a presença de quantidades de transições que diferem ligeiramente daquelas identificadas pelo estudo de McCloud (2005). As transições observadas estão diretamente relacionadas com o tipo de abordagem do texto, isto é, a abordagem polêmica e o emprego de estratégias apelativas pelo autor implicam no uso de transições tema-para-tema associadas com o primeiro plano, e a abordagem histórica da HQ fundamenta o uso de transições cena-para-cena. Com relação a estas últimas, embora demandem um nível de atenção maior do interlocutor, são apresentadas normalmente pela figura do narrador e contribuem para a "formação histórica" do leitor/educando. Um exemplo que sintetiza as principais transições identificadas se encontra ilustrado na Figura 34.

Figura 34 - Exemplo dos diferentes tipos de transições de cena identificados na HQ.

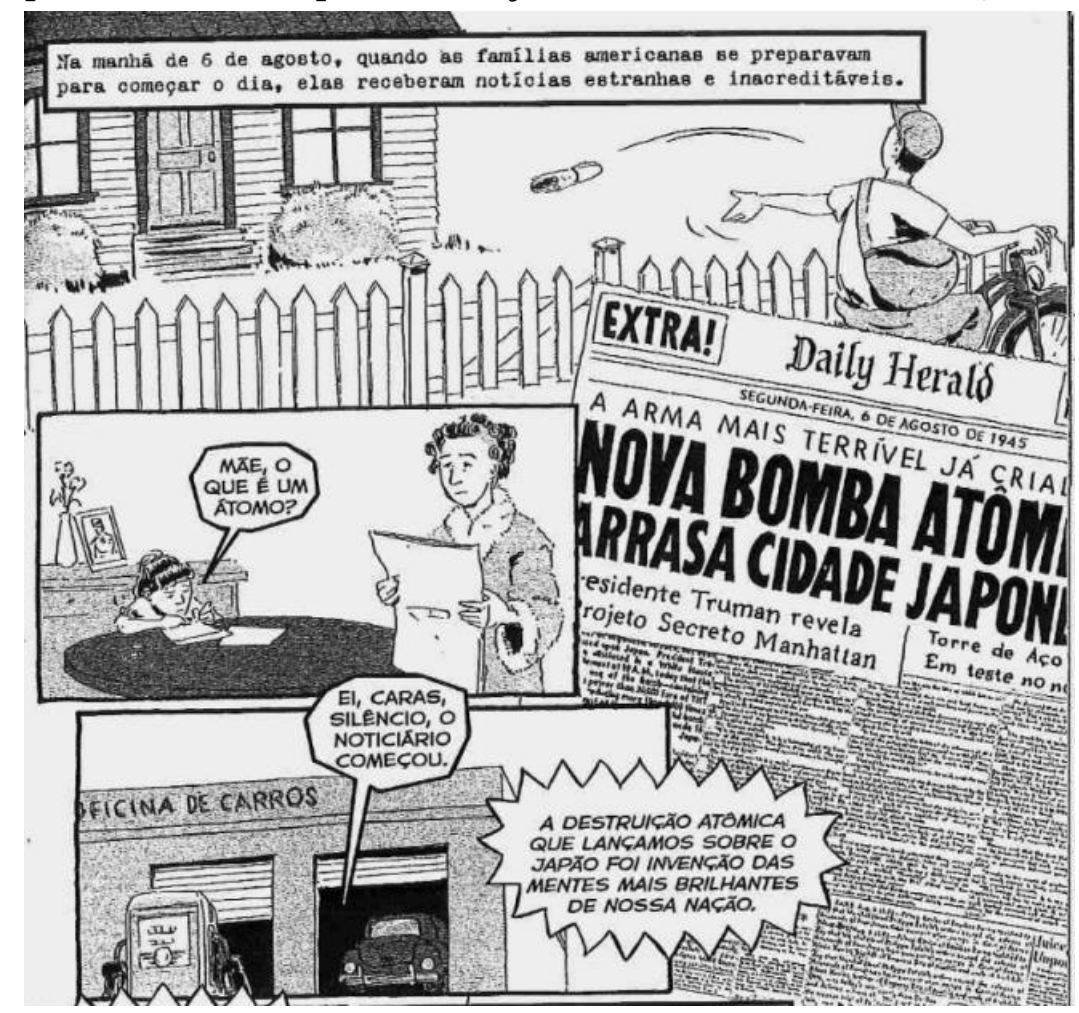

Fonte: Fetter-Vorm (2013), p. 113

Como podemos observar por essa sequência de quadros, contamos a princípio com uma transição do tipo cena-para-cena, em que o processo envolvendo a saída da senhora para pegar o jornal lançado no primeiro quadro, e iniciar a sua leitura, está subentendido na transição entre um e outro por meio de um salto temporal. Na sequência ocorre uma transição tema-paratema, cujo enfoque na manchete do jornal permite ao leitor o contato com o que estava sendo divulgado pela mídia impressa após o lançamento da primeira bomba atômica. Por fim, ocorre novamente uma transição do tipo cena-para-cena em que há um salto espacial, ou seja, muda- 
se o espaço, mas os mecânicos estão ouvindo, por meio do rádio, uma das versões da notícia envolvendo o lançamento da bomba atômica.

Como pode-se perceber pelas colocações acima, muitas vezes as transições de cena estão associadas com os planos de visão adotados pelo autor, os quais podem variar mediante os objetivos de quem os emprega. Nesse sentido, como apresentado anteriormente, os diferentes enquadramentos auxiliam na compreensão da narrativa, permitem momentos de interlocução direta, promovem um envolvimento do leitor com o enredo etc. (RAMOS, 2016).

Na HQ em questão observam-se os seis planos apresentados por Ramos (2016) os quais estão exemplificados nas Figuras 35 - 39.

Figura 35 - Exemplo de plano geral.

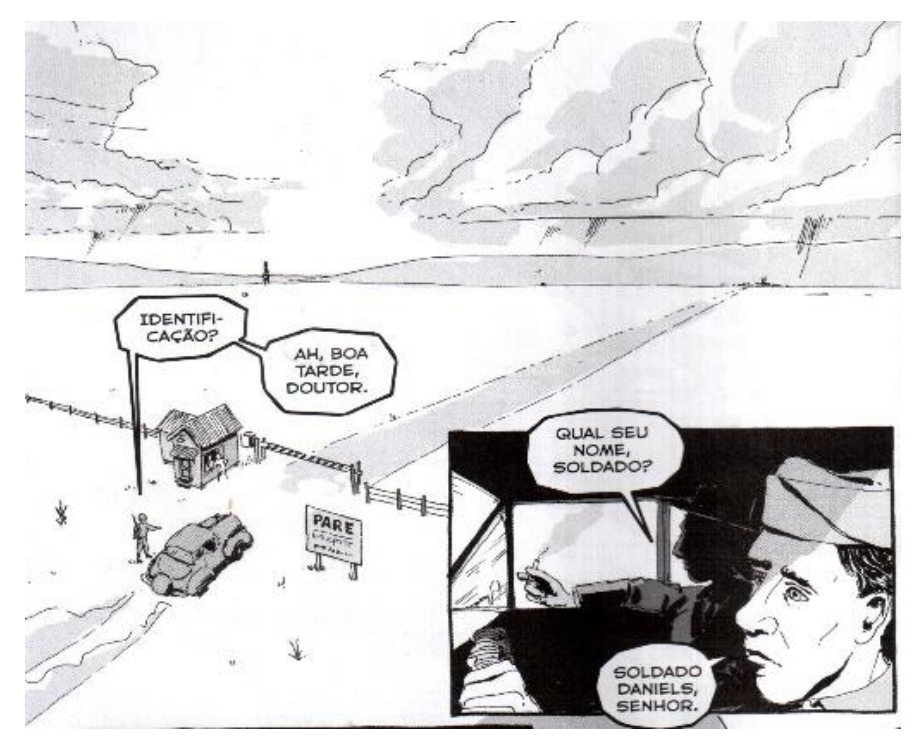

Fonte: Fetter-Vorm (2013), p. 2

Figura 36 - Exemplo de plano total.

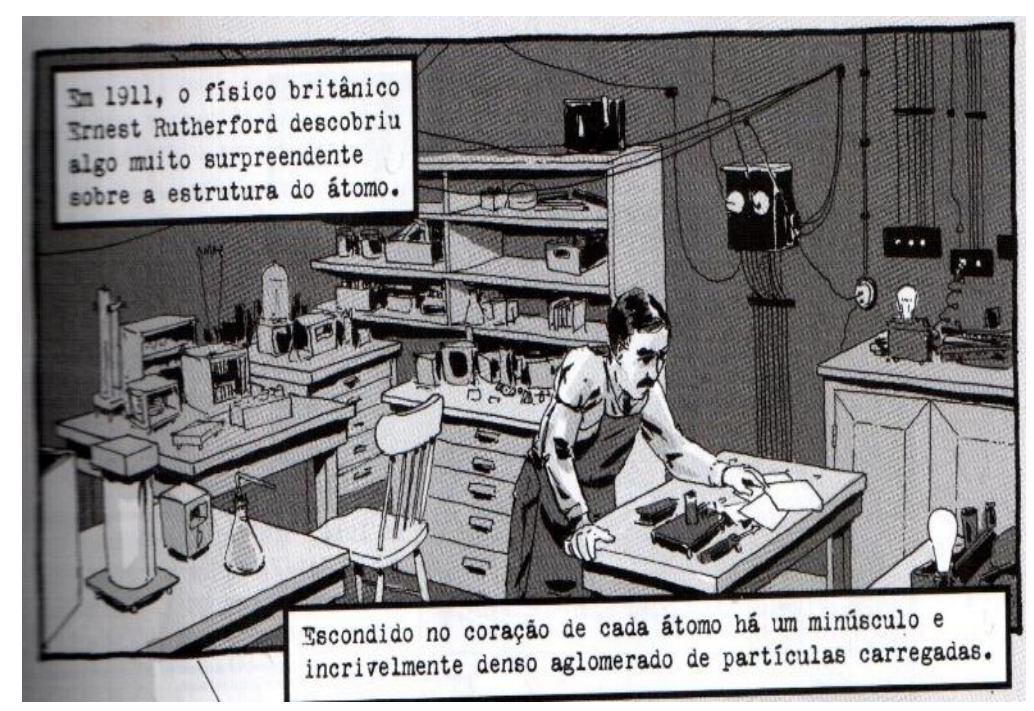

Fonte: Fetter-Vorm (2013), p. 5 
Na Figura 35 observamos um exemplo de plano geral logo no início da narrativa, o qual permite ao leitor o contato com o ambiente em que a primeira bomba atômica se encontra, isto é, o plano geral adotado nessa cena corrobora a informação fornecida pelo autor anteriormente, o qual afirma que a situação ocorre "nos desertos do Novo México num trecho de areia e arbustos" (FETTER-VORM, 2013, p.3). Na Figura 36 está ilustrado um exemplo de plano total, em que reduzindo um pouco a importância do cenário, é apresentado Rutherford realizando um experimento e parte do seu laboratório, que como podemos observar apresenta diversos elementos relacionados à eletricidade, o que confirma suas descobertas que são evidenciadas posteriormente pelo narrador consoante o trecho que é apresentado na sequência da imagem: "Mas foram as forças espantosamente poderosas circulando por entre esse núcleo que chamaram a atenção de Rutherford" (FETTER-VORM, 2013, p. 5).

O terceiro enquadramento que identificamos diz respeito ao plano americano e está ilustrado na Figura 22 presente na página 114, nela Chadwick é representado do joelho para cima e começa a se focar no rosto do personagem. Uma vez que muitos autores como Acevedo (1990) associam esse plano a um plano de conversação, já identificamos nesse exemplo indícios de interlocução direta, ou seja, podemos entender a fala de Chadwick como uma explicação direcionada ao leitor sobre a importância dos nêutrons dentro do núcleo atômico.

Reforçando ainda mais as expressões dos personagens, a Figura 37 é um exemplo de plano aproximado, nela os semblantes de dúvida de Otto Hanh e Fritz Strassmann são salientados por meio de um enfoque a partir da cintura dos mesmos.

Figura 37 - Exemplo de plano aproximado.

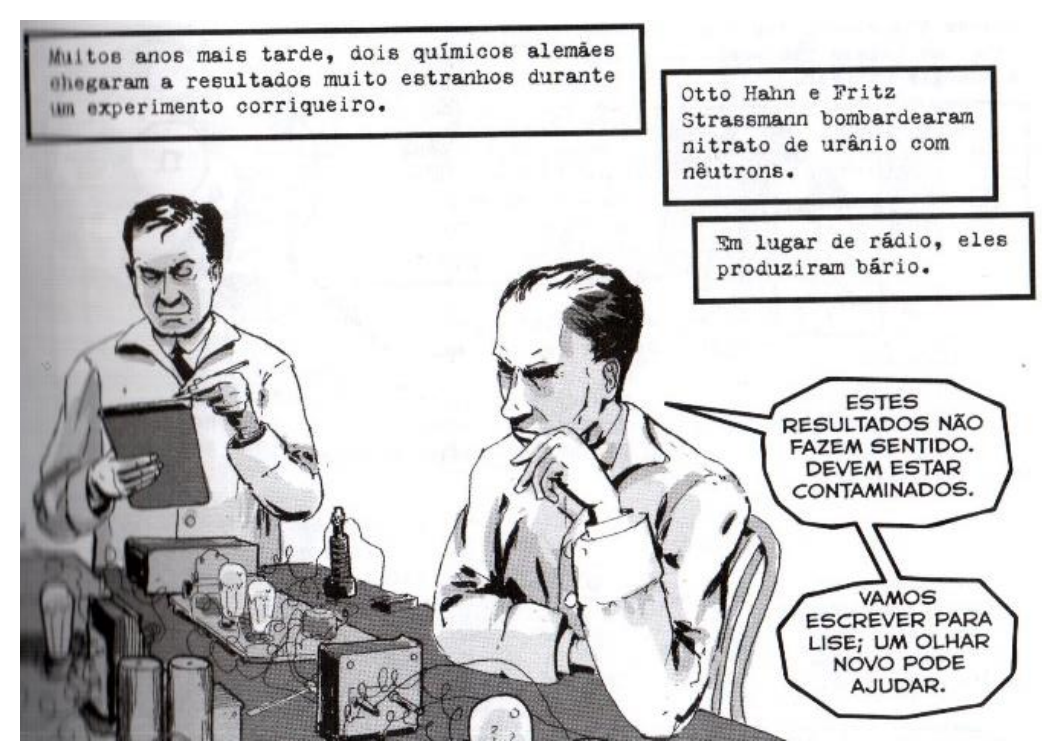

Fonte: Fetter-Vorm (2013), p. 7 
Os últimos dois planos estão diretamente relacionados com a transição tema-paratema, que como discutido, está amplamente presente na HQ. Sendo assim, identificamos como ilustrado na Figura 38, um exemplo de plano de detalhe em que o uso de óculos protetores do brilho proveniente da explosão de um armamento nuclear passaria desapercebido pelo leitor. Esse tipo de plano aumenta a didaticidade do texto ao salientar elementos que devem ser considerados na leitura. Por fim, o primeiro plano é um dos principais adotados pelo autor da HQ, nele, como exemplificado na Figura 39, ocorre um foco na expressão do personagem limitando o enquadramento à altura dos ombros. O emprego desse plano de visão consiste em um recurso que promove uma maior participação do leitor com o enredo por meio da interlocução direta, isto é, há impressão de fala direta do personagem para aquele que lê a história naquele momento. Como já enfatizado anteriormente, este plano se relaciona com a abordagem polêmica e é um elemento de apelo empregado pelo autor. No exemplo em questão, a fala de Oppenheimer ao tentar convencer outro cientista a ingressar no Projeto Manhattan pode ser entendida também como uma forma de expor os motivos para o leitor do porquê da construção de uma bomba atômica, uma vez que somos normalmente apresentados apenas às consequências devastadoras do armamento nuclear. Nessa perspectiva, esse recurso que é amplamente empregado pelo autor se configura como um elemento importante que pode afetar a argumentação dos licenciandos nas etapas subsequentes.

Figura 38 - Exemplo de plano de detalhe.

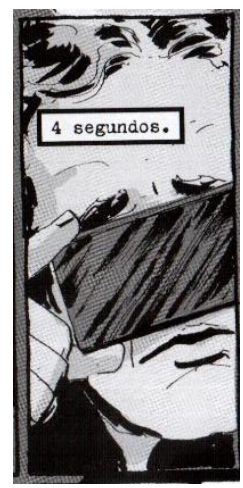

Figura 39 - Exemplo de primeiro plano.

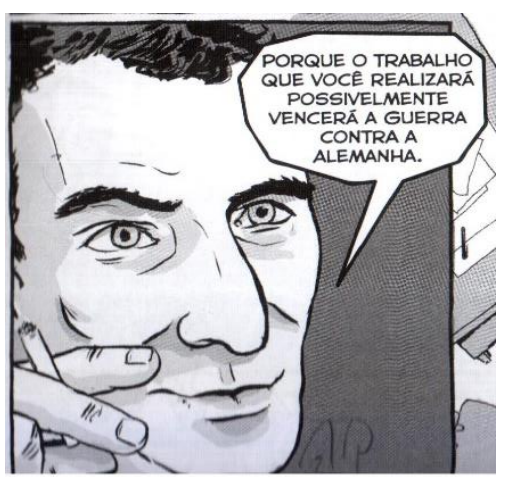

Fonte: Fetter-Vorm (2013), p. 69 e 29

Como último elemento da linguagem dos quadrinhos a ser considerado nessa análise, identificamos com relação aos ângulos de visão na perspectiva de Vergueiro (2007b), o domínio do ângulo de visão médio, isto é, a imagem é apresentada ao leitor na altura dos seus olhos. Essa constatação é de se esperar, conforme resultado de Mendonça (2008). No mais observamos, como ilustrado na Figura 40, alguns momentos em que ocorre o emprego do ângulo de visão superior, isto é, a imagem é apresentada de cima para baixo. 
Figura 40 - Exemplo de ângulo de visão superior.

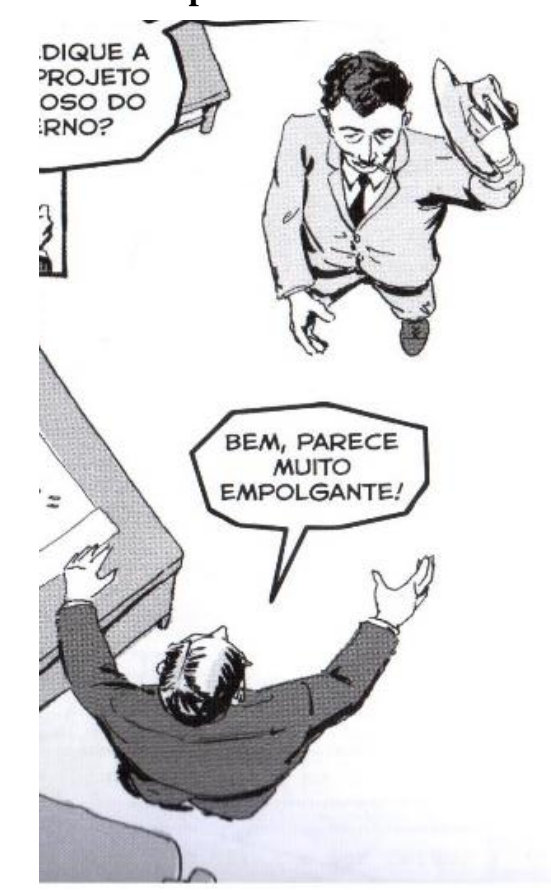

Fonte: Fetter-Vorm (2013), p. 29

Segundo Mendonça (2008), esse ângulo tem como objetivo apresentar momentos de alta tensão e a busca pelo suspense. No exemplo em questão ele aparece quando o autor apresenta a resposta do cientista mediante a proposta de Oppenheimer para a participação no Projeto Manhattan, ilustrada na Figura 39, isto é, a tensão é estabelecida no quadro anterior por meio do primeiro plano e ângulo de visão médio, e o desfecho se dá por meio de um ângulo de visão superior.

Diante do que foi apresentado quanto ao conteúdo e a forma das informações veiculadas na HQ selecionada para estudo e promoção da argumentação de licenciandos em química diante de QSC, verificamos, portanto, a adequação da mesma para o atendimento dos objetivos propostos. Em termos gerais, apresentando como temática a construção das armas atômicas que culminaram na destruição de duas cidades japonesas em meio a $2^{\text {a }}$ Guerra Mundial, é abordado na HQ, de forma histórica, conceitual e polêmica, tópicos localizados na fronteira com a química e tópicos classificados como temáticas transversais interessantes para a promoção da argumentação. Essas temáticas transversais permeiam todo o currículo de formação do educando e no caso específico diz respeito a ética. Também é válido salientar o elevado grau de cientificidade observado no texto que permite uma maior aproximação do leitor/educando com a prática científica, bem como promove uma compreensão a respeito do desenvolvimento científico e como este afeta/afetou a constituição da sociedade moderna. 
As potencialidades pedagógicas da HQ são enfatizadas pelo seu caráter didático, principalmente no que tange à linguagem verbal e aos recursos visuais adotados pelo autor, como o desenho, o letreiramento etc. Outrossim identificamos um elevado grau de didaticidade por meio de recursos empregados pelo autor, como uma linguagem mais acessível ao público leitor. Essa constatação, por sua vez, vai ao encontro dos objetivos mercadológicos da HQ, dado o seu contexto de produção. Salientamos que embora identificada essa "pseudodidaticidade", o professor não está isento de intermediar a leitura em contexto de ensino, o qual deve ter em mente os seus objetivos pedagógicos bem claros.

Ainda com relação a estes recursos utilizados pelo autor, os elementos próprios da linguagem dos quadrinhos como os traços, a transição entre os quadros em uma arte sequencial, os planos de visão etc, podem influenciar na argumentação do indivíduo, principalmente quando essa envolve valores éticos e morais. Sendo assim, ressaltamos a importância da análise empreendida para o prosseguimento do estudo, tendo em mente que tais elementos podem afetar/contribuir para o raciocínio informal daqueles que argumentam diante das questões colocadas, uma vez que, esse tipo de raciocínio envolve aspectos relacionados à emoção, afetividade etc.

Destacamos novamente que não pretendemos com essa análise fornecer ao professor, seja da educação básica ou até mesmo do ensino superior, uma espécie de decisão já tomada indicando a melhor maneira de fazer uso da referida HQ. Almejamos com esse estudo inicial estabelecer, por meio do conteúdo identificado e da forma como este é veiculado no texto, potencialidades didáticas da HQ em questão mediante os objetivos dos docentes que a empregam. Também temos como interesse, com base em pressupostos teóricos, apresentar a professores e pesquisadores uma forma de análise de textos de divulgação científica quadrinizados que permita a identificação dos diferentes graus de didaticidade, cientificidade e laicidade na perspectiva de Zamboni (2001) que, por sua vez, irão permitir distintas abordagens em sala de aula do ensino de ciências. 


\section{Capítulo 4 - O caminho para a construção dos dados - ações na formação inicial de professores de química}

Como salientado, a segunda etapa da pesquisa compreendeu a realização de oficinas de leitura da HQ discutida no Capítulo 3, na formação inicial de professores de química de modo a investigarmos a argumentação e a sensibilidade moral evidenciada pelos mesmos. Dessa forma, considerando os objetivos por nós elencados, para o desenvolvimento da proposta e a elaboração dos casos que subsidiassem a argumentação tomamos como base o material intitulado Moral Reasoning in Scientific Research de Muriel J. Bebeau (1995). Este consiste em um material desenvolvido para o projeto denominado Teaching Research Ethics: A Workshop at Indiana University, e fornece subsídios para o exercício, em sala de aula de ciências, do raciocínio informal dos educandos por meio de casos que envolvem dimensões éticas e morais.

Segundo Bebeau (1995), casos que promovam o exercício do raciocínio moral de profissionais em formação são amplamente empregados em cursos de medicina e direito, até porque os profissionais dessas áreas estão envolvidos frequentemente com questões éticas, como o caso envolvendo um paciente que inconsciente necessita de uma transfusão de sangue, mas a sua religião não permite esse tipo de procedimento. No entanto, esquece-se que na prática científica dilemas morais também estão presentes, e é nessa perspectiva que esse material foi desenvolvido e conta com seis casos para o exercício do raciocínio moral dos educandos.

Todos os casos seguem um mesmo formato, isto é, narram uma situação na qual são apresentadas diversas informações ao leitor e que culmina em um dilema para o protagonista do caso. Assim, diante do conflito, o personagem narrado toma uma decisão. Então, é perguntado ao leitor se este deve prosseguir com o seu plano/sua decisão ou não, em ambos os casos deve ser evidenciado o porquê. O interessante desse formato é que a decisão já está tomada, e cabe ao educando concordar ou não, forçando-o a argumentar e exercitar o raciocínio moral e não simplesmente apresentar uma solução, que desconsiderando os aspectos éticos seria considerada melhor na visão dos educandos.

Além de apresentar os seis casos, Bebeau (1995) sugere os passos a serem adotados pelo professor em sala de aula para a sua abordagem, bem como fornece uma grelha com os aspectos éticos de cada caso, o que auxilia no estabelecimento das discussões em sala de aula, e indica os elementos que, quando consideramos, conduzem a uma resposta bem fundamentada moralmente. Assim sendo, a sequência a ser adotada pelo professor em sala de aula a partir desses casos está esquematizada na Figura 41. 
Figura 41 - Sequência de passos para aplicação dos casos proposta por Bebeau (1995).

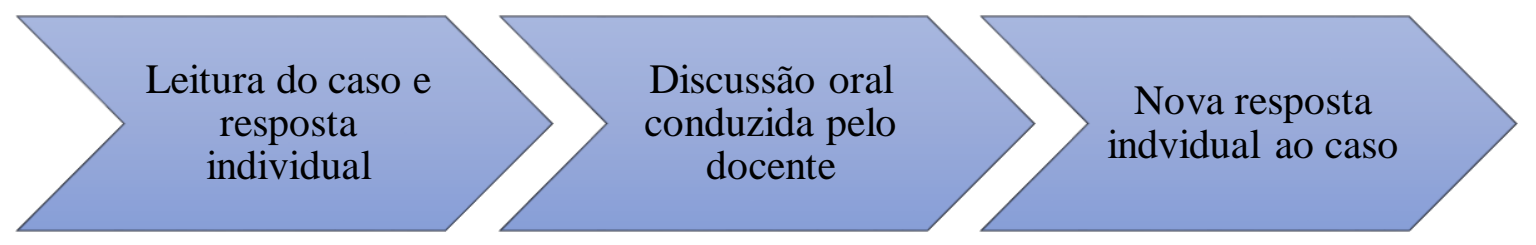

$\mathrm{Na}$ primeira etapa, que consiste na leitura e resposta individual ao caso, o educando apresentaria as suas ideias e os aspectos éticos identificados inicialmente, isto é, no que diz respeito às partes interessadas/envolvidas na situação, às possíveis consequências de cada ação, as obrigações do(s) protagonista(s) e o(s) ponto(s) de conflito. O segundo momento seria dedicado à discussão oral das respostas em que cada aluno exporia suas opiniões salientando cada um dos elementos identificados individualmente. Dessa forma, essa discussão permitiria o contato dos estudantes com aspectos que possam ter sido negligenciados inicialmente, o que nos leva ao terceiro passo, a nova resposta ao caso. Nessa etapa final, considerando o que foi exposto por todos, o indivíduo pode manter sua posição inicial acrescentado elementos que melhorariam sua resposta, ou mudar de decisão evidenciado o porquê de tal mudança. Segundo Bebeau (1995), esse último momento é fundamental para o exercício e acesso ao quarto componente do Modelo dos Quatro Componentes de Rest, Bebeau e Volker (1986), isto é, o caráter moral.

Portanto, a partir desse material e da estrutura dos casos apresentados por Bebeau, cujo um exemplo se encontra no ANEXO A, desenvolvemos a partir da leitura da HQ, três casos que promovessem a argumentação diante de QSC que consequentemente implicasse no emprego do raciocínio informal dos licenciandos. Dessa forma, durante a etapa de análise do da obra quadrinizada selecionamos diferentes trechos que envolvessem dilemas éticos na narrativa. Desses, três foram escolhidos considerando a sua posição no texto, isto é, um próximo ao começo da leitura, outro no meio e o terceiro no final da HQ, de modo que também fosse possível identificar a evolução da argumentação ao longo das discussões sobre os casos, o desenvolvimento da sensibilidade moral dos educandos, e os efeitos de uma maior quantidade de informação nos argumentos elaborados e consequentemente nos padrões de raciocínio informal. Além disso, essa configuração dos casos nos permite analisar a relação entre o contato com a linguagem dos quadrinhos e, especialmente, a sensibilidade moral evidenciada nas respostas dos alunos.

Determinados os três casos, seguimos o procedimento adotado por Bebeau (1995) e elaboramos as grelhas que representariam os aspectos éticos de uma situação, conforme discutido no Capítulo 2, na seção sobre o Modelo dos Quatro Componentes de Rest, Bebeau e 
Volker (1986). Considerando os quatro componentes de uma resposta bem fundamentada moralmente apresentamos nessas grelhas as partes interessadas em cada conflito, as quais seriam direta ou indiretamente afetadas pela decisão do(s) protagonista(s), as consequências de cada uma das ações, as obrigações daquele(s) responsável(is) pela tomada de decisão. Aqui ressaltamos que nos dois primeiros casos o protagonista é Oppenheimer, físico responsável por encabeçar cientificamente o Projeto Manhattan e no terceiro caso os protagonistas são os próprios cientistas como um todo. Também apresentamos nas grelhas, o ponto ou pontos de conflito presentes em cada caso. As grelhas, além de permitirem a análise da sensibilidade moral dos futuros professores, foram fundamentais para a condução das discussões em sala de aula.

Levando-se ainda em conta os aspectos mencionados por Brugliato (2016), o qual ressaltou as dificuldades do emprego da HQ "Trinity" com alunos do ensino médio dada a sua extensão, e considerando a importância da leitura integral da mesma, na etapa de análise da obra, dividimos o texto em fragmentos menores a serem lidos ao longo do período de aplicação da proposta. Para além dos momentos em que ocorreria a argumentação, desenvolvemos para os outros trechos da leitura, atividades que consideramos ser relevantes para o aprendizado e formação dos licenciados, as quais detalharemos mais adiante neste capítulo.

\subsection{O contexto de aplicação da proposta}

A aplicação da proposta ocorreu no segundo semestre de 2017 junto a alunos matriculados na disciplina SLC0675 - Química, Sociedade e Cotidiano, do Curso de Licenciatura em Ciências Exatas/Habilitação em Química, da Universidade de São Paulo (USP). A conveniência da aplicação da proposta na referida disciplina se deve ao fato do seu principal objetivo consistir no desenvolvimento da capacidade de investigação e análise crítica dos alunos, através do conhecimento, discussão e posicionamento diante de problemas relacionados ao impacto da química na sociedade. Nessa perspectiva, a questão tratada na HQ em foco, a criação da bomba atômica, vai ao encontro dos propósitos da disciplina.

O referido curso tem sede no Instituto de Física de São Carlos da USP (IFSC), e permite a habilitação em química, física ou matemática, todas no período noturno. Com relação à disciplina, esta é obrigatória para os alunos que fizeram a opção pela habilitação em química sendo sugerida para o oitavo semestre, o qual também pode ser o último, uma vez que o curso tem duração prevista para quatro anos. Ademais, a disciplina tem carga horária total de 90 horas e equivale a quatro créditos, sendo dois considerados de atividades teóricas e dois de atividades práticas. A disciplina apresenta outras três como pré-requisitos (Didática, Química Geral II e 
Laboratório de Química Geral para Licenciatura) e no segundo semestre de 2017 foi ministrada às segundas-feiras das $19 \mathrm{~h}$ às $21 \mathrm{~h}$.

As atividades referentes a este estudo ocorreram em dois principais espaços. A maioria dos trabalhos ocorreu em uma sala de aula do IFSC, a qual estava equipada com um projetor multimídia, apresentava 40 carteiras para os alunos e dispunha de um quadro que se desdobrava em dois o qual permitia a sistematização, por parte da docente, de uma grande quantidade de informações sem a necessidade de apagá-las para a inserção de novas. É digno de nota também que o corredor das salas de aula do Instituto apresentava quadros com a finalidade de DC incluindo dois que tratavam de informações referentes ao Projeto Manhattan, projeto este em que ocorreram os estudos referentes à construção das bombas atômicas. Tais quadros apresentavam desde a descoberta de elementos radioativos pelo casal Curie, até a criação desse novo armamento e o papel fundamental desempenhado por Oppenheimer.

Alguns dos encontros também ocorreram na biblioteca do IFSC, onde foram realizadas atividades individuais por parte dos futuros professores. A biblioteca apresenta salas para estudos em grupos e mesas de estudo individual e, em geral, quando desses encontros, os licenciandos realizaram as atividades solicitadas nessas mesas, o que não impedia, no entanto, a troca de ideias. Os encontros realizados na biblioteca foram os únicos que não foram gravados em áudio. Os procedimentos de coleta dos dados estão também melhor detalhados mais adiante neste capítulo.

Estavam matriculados na disciplina sete alunos e, pelo caráter noturno do curso é interessante salientar que este possibilita ao estudante a realização de outras atividades no período diurno, dessa forma, o curso, bem como a disciplina, conta com alunos de diversas idades e formações nos mais variados níveis (primeira graduação, graduados em outras modalidades ou até mesmo com diferentes pós-graduações). Assim, mesmo com um número reduzido de alunos, nos deparamos com um grupo bastante heterogêneo e apresentamos a seguir uma caracterização dos sete sujeitos envolvidos na pesquisa. Outrossim, durante as interações estabelecidas em sala de aula, principalmente no primeiro encontro referente à aplicação da proposta, foi possível traçar um pequeno panorama a respeito da relação entre os licenciandos e a leitura de textos em forma de quadrinhos. Ressaltamos a relevância de conhecermos esse perfil leitor dos alunos, pois nos permite uma análise dos dados mais consistente visto que todas as atividades foram realizadas a partir da leitura desse hipergênero textual. De modo a preservar a identidade dos licenciados utilizamos nomes fictícios os quais serão tomados doravante.

Assim sendo, dos sete alunos matriculados, três possuem pós-graduação em suas áreas, seja em nível de mestrado ou doutorado, é o caso dos licenciandos Alice, Débora e Francisco. 
Bacharéis de formação, vislumbram no Curso de Licenciatura em Ciências Exatas uma maior possibilidade de inserção no mercado de trabalho. Dentre os três, Francisco já atua na rede privada de ensino do estado de São Paulo.

A respeito da relação desses alunos com a leitura quadrinizada, Alice e Francisco relataram o seu amplo consumo na infância, e atualmente, com exceção de tiras cômicas em jornais, o contato com esse tipo de leitura é praticamente nulo. Nessa perspectiva, não possuem no momento uma familiaridade muito grande com a linguagem dos quadrinhos e com grande parte dos seus elementos já discutidos no Capítulo 3 deste texto. Outrossim, ambos se mostram abertos as possibilidades oriundas da inserção de HQ no contexto de ensino, as quais seriam, em suas concepções, ótimos instrumentos motivacionais face o seu aspecto gráfico (uso de imagens) e a sua linguagem facilitada. No que tange à licencianda Débora, esta não possui nenhuma proximidade com a leitura quadrinizada.

No outro grupo de alunos, contamos com os licenciandos Bianca, Caroline, Érica e Gabriel, os quais embora possuam percursos educacionais distintos encontra-se em sua primeira graduação. Com exceção de Érica que já havia ingressado anteriormente em outro curso de bacharelado oferecido pelo IFSC, mas não concluído, o Curso de Licenciatura em Ciências Exatas representa a primeira experiência em nível superior para os demais alunos.

Além dessa ser a primeira graduação para Bianca, Caroline e Gabriel, outro fator em comum desses licenciandos diz respeito a sua participação como bolsista do Programa Institucional de Bolsa de Iniciação à Docência (PIBID) em diferentes áreas, devido também à amplitude do curso que oferece possibilidades tanto para Química, Física quanto para Matemática. Nesse contexto a atuação nesse programa reforçou nos educandos o desejo pela licenciatura e o interesse em ministrar aulas na educação básica futuramente.

No que tange ao contato desses futuros professores com a linguagem dos quadrinhos, apesar de limitada, é maior do que para o primeiro grupo (Alice, Débora e Francisco), em especial em contexto de ensino. Isto é, durante a sua formação esses licenciandos relataram ter tido um número maior de experiências com esse hipergênero textual, com destaque para as tiras cômicas presentes nos livros de língua Portuguesa, e até mesmo em exames como ENEM. Esse fato vai ao encontro do que foi discutido no Capítulo 3, quando abordamos o maior espaço ganho pela leitura quadrinizada em contextos de ensino a partir da década de 1990, aliado aos documentos oficiais que regem a educação brasileira como a LDB e os então PCN.

Ainda, dentre todos os licenciandos, Caroline é a que apresenta maior contato com quadrinhos. Atualmente realizando a leitura esporádica de Mangás cuja forma e conteúdos são 
voltados para um público mais velho quando comparados com os tradicionais quadrinhos da Turma da Mônica, a relação quadrinhos e sala de aula não lhe é muito estranha. Egressa de uma escola privada, a futura professora teve ao longo de sua educação básica o contato com volumes de HQ mensais disponibilizados pela instituição, que abordavam assuntos relacionados com o cotidiano do aluno no espaço escolar. É conhecedora de diversos elementos próprios da linguagem dos quadrinhos, que pressupomos, possam auxiliá-la no desenvolvimento das atividades.

Previamente à aplicação da proposta pertinente à pesquisa, a docente da disciplina já havia apresentado o curso, e discutido com os licenciandos aspectos vinculados às abordagens CTS e QSC, diferentes modelos de tomada de decisão, como o Modelo de Kortland (1996), bem como modelos de argumentação como o TAP (TOULMIN, 2001), e o Modelo de Análise de Argumentação Aplicável a Processos de Resolução de Questões Sociocientíficas (SÁ, 2010)

\subsection{Atividades realizadas na formação inicial de professores}

As atividades propostas relacionadas a este trabalho foram conduzidas pela professora responsável da disciplina e ocorreram em nove encontros de aproximadamente 1 hora e 30 minutos cada. Uma síntese das atividades realizadas em cada encontro se encontra presente no Quadro 5. 
Quadro 5 - Atividades realizadas na disciplina Química, Sociedade e Cotidiano.

\begin{tabular}{|c|c|c|c|}
\hline Encontro & Local & Presentes & Atividades realizadas \\
\hline $1^{\mathrm{o}}$ & $\begin{array}{l}\text { Sala de aula } \\
\text { IFSC }\end{array}$ & $\begin{array}{l}\text { Alice, Bianca, } \\
\text { Caroline, Érica, } \\
\text { Francisco e Gabriel }\end{array}$ & $\begin{array}{c}\checkmark \quad \text { Apresentação da proposta } \\
\checkmark \quad \text { Discussão sobre as relações dos licenciandos com HQ, } \\
\text { e suas percepções quanto ao seu uso em sala de aula } \\
\checkmark \quad \text { Levantamento de hipóteses com relação ao título do } \\
\text { texto } \\
\checkmark \quad \text { Levantamento de conhecimentos prévios } \\
\checkmark \quad \text { Leitura p. } 1-15 \\
\checkmark \quad \text { Discussão a respeito do trecho lido }\end{array}$ \\
\hline $2^{\circ}$ & $\begin{array}{l}\text { Biblioteca } \\
\text { IFSC }\end{array}$ & Todos & $\begin{array}{c}\checkmark \quad \text { Leitura p. } 16-29 \\
\checkmark \quad \text { Atividade escrita a respeito dos aspectos científicos } \\
\text { presentes no texto até então } \\
\checkmark \quad \text { Solicitação de atividade extraclasse } \\
\end{array}$ \\
\hline $3^{\circ}$ & $\begin{array}{l}\text { Sala de aula } \\
\text { IFSC }\end{array}$ & $\begin{array}{l}\text { Alice, Caroline, } \\
\text { Érica, Francisco e } \\
\text { Gabriel }\end{array}$ & $\begin{array}{l}\checkmark \quad \text { Aplicação de "caso teste" para argumentação diante } \\
\text { de situações que envolvem dimensões éticas e morais }\end{array}$ \\
\hline $4^{\circ}$ & $\begin{array}{l}\text { Sala de aula } \\
\text { IFSC }\end{array}$ & Todos & $\begin{array}{cc} & \checkmark \quad \text { Leitura p. } 30-37 \\
\checkmark \quad \text { Aplicação do caso argumentativo I extraído da HQ }\end{array}$ \\
\hline $5^{\circ}$ & $\begin{array}{l}\text { Biblioteca } \\
\text { IFSC }\end{array}$ & $\begin{array}{l}\text { Alice, Bianca, } \\
\text { Caroline, Débora, } \\
\text { Francisco e Gabriel }\end{array}$ & $\begin{array}{ccc} & \checkmark & \text { Leitura p. } 37-57 \\
\checkmark & \text { Atividade escrita a respeito do texto } \\
\checkmark & \text { Solicitação de atividade extraclasse }\end{array}$ \\
\hline $6^{\circ}$ & $\begin{array}{l}\text { Sala de aula } \\
\text { IFSC }\end{array}$ & $\begin{array}{l}\text { Alice, Caroline, } \\
\text { Érica, Francisco e } \\
\text { Gabriel }\end{array}$ & $\begin{array}{c}\checkmark \quad \text { Feedback da docente a respeito dos argumentos } \\
\text { construídos pelos licenciandos para o caso I } \\
\checkmark \quad \text { Leitura p. } 58 \text { - } 93\end{array}$ \\
\hline $7^{\circ}$ & $\begin{array}{l}\text { Sala de aula } \\
\text { IFSC }\end{array}$ & Todos & $\begin{array}{cc}\checkmark & \text { Aplicação do caso argumentativo II extraído da HQ } \\
\checkmark & \text { Solicitação de leitura extraclasse (p. } 94-129 \text { ) }\end{array}$ \\
\hline $8^{\circ}$ & $\begin{array}{l}\text { Sala de aula } \\
\text { IFSC }\end{array}$ & $\begin{array}{l}\text { Alice, Bianca, } \\
\text { Caroline, Débora, } \\
\text { Gabriel }\end{array}$ & $\begin{array}{c}\checkmark \quad \text { Leitura p. } 130-151 \\
\checkmark \quad \text { Aplicação do caso argumentativo III extraído da HQ }\end{array}$ \\
\hline $9^{\circ}$ & $\begin{array}{l}\text { Sala de aula } \\
\text { IFSC }\end{array}$ & Todos & $\begin{array}{c}\checkmark \quad \text { Processo de Peer Review (PPR) e consequente } \\
\text { feedback dos demais casos }\end{array}$ \\
\hline
\end{tabular}

\section{Primeiro encontro}

Como apresentado no Quadro 5, em um primeiro momento, com a presença de seis dos sete alunos matriculados, a docente da disciplina os informou a respeito da proposta a ser empregada nas próximas aulas, e foi feita pelo pesquisador uma apresentação, utilizando do projetor, do trabalho a ser realizado em sala de aula. Cientes da proposta, solicitamos que os futuros professores, caso aceitassem, assinassem o Termo de Consentimento Livre e Esclarecido (APÊNDICE A) para a participação na pesquisa.

Em seguida, em forma de discussão oral, a docente levantou algumas questões, as quais estão indicadas no APÊNDICE B, para que fosse possível um acesso preliminar à relação dos licenciandos com textos como HQ, além das suas percepções no que diz respeito à inserção desse tipo de material no espaço formal de ensino. Também foi questionado aos licenciandos o que estes esperariam que um texto, o qual já sabia tratar de uma HQ, iria abordar. Para tanto, a docente escreveu o título da HQ no quadro e solicitou aos futuros professores um levantamento de hipóteses sobre a temática que seria abordada. Essa discussão foi dividida em duas partes, 
em um primeiro momento a docente apresentou para discussão apenas o título parcial do quadrinho, isto é, "Trinity". Posteriormente uma nova discussão foi estabelecida, agora com relação ao título integral do texto: "Trinity: a história em quadrinhos da primeira bomba atômica". A atividade em questão permitiu identificar o conhecimento dos alunos quanto ao teste Trinity realizado no Projeto Manhattan, e consequentemente o processo de construção da primeira bomba atômica, bem como as suas expectativas iniciais quanto ao texto.

Também foi feito, na ocasião, um levantamento de concepções prévias dos estudantes, por meio de um questionário escrito que também se encontra no APÊNDICE B. Este questionário diz respeito a conteúdos químicos que estariam presentes na HQ "Trinity”, como estrutura atômica e o processo de fissão nuclear.

Por fim, para um primeiro contato com o texto a ser trabalhado, fez-se a leitura em voz alta das páginas 1 a 15 da HQ, em que cada licenciando representava determinados personagens da narrativa, isto é, um aluno interpretava o narrador, e outro Lise Meitner, por exemplo. Ao final de leitura foi feita uma breve discussão a respeito das impressões iniciais dos futuros professores sobre o texto e uma comparação com as hipóteses levantadas anteriormente.

Nessa aula toda a dinâmica foi gravada em áudio para posterior transcrição das discussões estabelecidas, principalmente no que diz respeito à relação dos licenciandos com os quadrinhos e suas percepções iniciais a respeito desse material. Para tanto, foram utilizados quatro gravadores distribuídos pela sala, procuramos dispor um gravador a cada dois alunos de forma que todos os comentários apresentados por estes fossem facilmente identificados no momento da transcrição. Três gravadores ficaram posicionados próximos aos alunos e um próximo à mesa da professora. Também utilizamos como recurso para tomada de dados, fotografias, retiradas do celular do pesquisador, das informações presentes no quadro, pois na medida que as discussões iam sendo feitas, a docente sintetizava as ideias nele. Um exemplo em que empregamos esse recurso foi para registrar as hipóteses que os licenciandos levantaram quanto ao assunto que uma HQ denominada "Trinity" ou "Trinity: a história em quadrinhos da primeira bomba atômica" poderia abordar.

Como mencionado anteriormente, para atender o objetivo traçado, de investigar as características dos argumentos dos licenciandos diante de QSC, foram selecionados previamente três momentos da HQ que promovessem o exercício da argumentação. Dessa forma, nos encontros posteriores, prosseguimos com a leitura, e quando o trecho referente ao caso elaborado para argumentação fosse alcançado, a leitura era interrompida para esse fim. 


\section{Segundo encontro}

Realizado na biblioteca do IFSC, o segundo encontro contou com a leitura individual e silenciosa das páginas 16 a 29 da HQ por parte dos licenciandos, os quais foram solicitados a realizar uma atividade escrita referente ao texto (APÊNDICE C). Essa atividade consistia em dois itens, sendo o primeiro, identificar nos trechos da HQ lidos até o momento, características da atividade científica, e o segundo buscar outras fontes e materiais, e elaborar a partir desses materiais uma pequena sequência didática para a abordagem do conteúdo de fissão nuclear no ensino médio.

A identificação das características da atividade científica vai ao encontro da análise realizada no Capítulo 3 deste texto, e permite que os licenciandos tomem contato com outros aspectos para além dos conceitos próprios do ensino formal de química, relevantes não somente para a formação dos estudantes da educação básica. Esse item se torna ainda mais relevante, quando identificamos a partir da literatura, a necessidade de uma mudança de visão dos sujeitos envolvidos no processo de ensino e aprendizagem sobre HQ. Assim sendo, essa atividade contribui para a identificação, por parte dos licenciandos, da vasta gama de potencialidades desse tipo de texto para o ensino de ciências. Quanto ao segundo item, sua pertinência se encontra quando identificado pelos questionários de levantamento de conhecimentos prévios, algumas lacunas no que diz respeito à compreensão do conceito de fissão nuclear.

Buscando promover uma maior identificação entre os licenciandos e a narrativa, foi entregue aos alunos uma atividade (APÊNDICE D) a ser realizada extraclasse que também consistia em dois itens. No primeiro, aos alunos, os quais conhecendo o contexto atual envolvendo armamentos nucleares, foi solicitado que argumentassem, em uma carta ao presidente da República, sobre a importância ou não de se investir em armamentos nucleares em território nacional. No segundo item, os alunos deveriam pesquisar a respeito de alguma questão de interesse como cinema, lazer ou modos de trabalho das décadas de 1930/1940, adquirindo, dessa forma, um maior conhecimento sobre o contexto da $2^{\text {a }}$ Guerra Mundial, o que contribuiria para um melhor entendimento do texto.

Nesse encontro, considerando-se o ambiente da biblioteca, não foram realizadas gravações de áudio, apenas coletamos as atividades escritas dos licenciandos. 


\section{Terceiro encontro}

Mediante a proximidade do trecho referente ao primeiro caso argumentativo extraído da HQ, o terceiro encontro limitou-se à prática da argumentação pelos licenciandos na perspectiva dos referenciais adotados, isto é, Toulmin (2001) e Rest, Bebeau e Volker (1986). Assim sendo, como forma de promover o exercício do raciocínio informal dos licenciando diante de questões que envolvessem dimensões éticas e morais, utilizou-se o caso elaborado por Bebeau intitulado: The Diane Archer Case (Bebeau, 1995, p. 41), presente no ANEXO A o qual relata uma situação de plágio na ciência.

Neste caso é narrada a história de Diane, que membro titular do departamento de biologia em determinada universidade, orientou em seus quinze anos de serviço, vinte alunos, ensinando-os o modelo da escrita de projetos e, por vezes, convidando-os a ajudá-la na análise de propostas de financiamento. Certo dia, ao dar parecer para uma proposta de um ex-aluno, Charlie West, Diane percebe a mudança de estilos de escrita dentro do próprio texto e se lembra de uma revisão que este mesmo aluno, devido à proximidade de área de estudo, havia ajudado a realizar dois anos atrás. Perplexa, a professora acessa o antigo texto e verifica que Charlie copiou palavra por palavra a seção de introdução do projeto.

A protagonista, portanto, se vê diante de uma situação delicada, afinal se ela reportar o plágio, a carreira desse jovem cientista será destruída. No entanto, dentre outras consequências, se ela não disser nada, estará colocando em risco sua própria reputação se o plágio for descoberto mais tarde. Dessa forma, Diane decide contatar Charlie e confrontá-lo sobre a descoberta. Uma vez que ele aceite retirar a proposta de financiamento, ela não prosseguirá com a denúncia à agência de fomento. Isto posto, ao final do texto os licenciandos são solicitados a responder se Diane deve prosseguir com o plano de contatar o ex-aluno, evidenciando o porquê da decisão tomada.

Seguindo o modelo proposto por Bebeau (1995), o qual adotamos na elaboração e aplicação dos casos referentes à $\mathrm{HQ}$, inicialmente foi feita a leitura do caso, o qual estava em inglês, salientamos que apenas este caso foi empregado em inglês, os demais utilizados em sala de aula e extraídos da HQ estavam em português, assim qualquer dúvida de vocabulário e interpretação foi levantada e prontamente respondida. A partir da leitura, os licenciados, nesse dia, divididos em uma dupla e um trio, argumentaram a respeito da decisão que a protagonista optou por tomar na situação apresentada.

Dada a primeira resposta para o caso, foi aberto um momento de discussão coordenado pela docente que consistia, em grupo, determinar as partes interessadas no conflito em questão, 
as consequências de cada ação da protagonista, as obrigações da protagonista e por fim o(s) ponto(s) de conflito. Os aspectos levantados na discussão foram comparados com a grelha proposta pelo autor para avaliação dos argumentos escritos referentes a este caso, e serviu de base para que os licenciandos novamente argumentassem sobre a decisão da protagonista. Vale ressaltar que nesse momento, após a discussão, os licenciandos têm total liberdade para mudar de posição, adicionando e/ou reforçando justificativas a ela.

Toda a dinâmica estabelecida nesse encontro foi gravada em áudio e, posteriormente, transcrita. Para o registro em áudio dessa aula, fizemos uso de três gravadores os quais se encontravam um junto ao trio, outro junto à dupla e outro próximo à mesa da professora. Consideramos essa a distribuição adequada para que as falas fossem mais compreensíveis no momento da transcrição. A análise dos resultados referentes a esta etapa consta no artigo "Sensibilidade moral de licenciandos em química diante de conflito ético na prática científica" (SILVA e QUEIROZ, 2019).

\section{Quarto encontro}

Praticado o exercício da argumentação envolvendo a questão do plágio na pesquisa científica, o quarto encontro contou com a aplicação do primeiro caso referente ao texto da HQ, extraído das páginas 33 a 36. Dessa forma, prosseguimos inicialmente com a leitura da HQ páginas 30 a 37, a qual se deu em voz alta, com cada licenciando representando diferentes papéis da narrativa. Feita a leitura, foi entregue o texto com o caso para argumentação (APENNDICE E).

Seguindo o procedimento proposto por Bebeau (1995), inicialmente foi feita a leitura do caso individual pelos licenciados, os quais eram solicitados a elaborar o primeiro argumento escrito referente à situação. Posteriormente, deu-se início a discussão conduzida pela docente, a qual se fundamentou na grelha previamente construída para o caso com base no Modelo dos Quatro Componentes. Dessa forma, nesse momento foram discutidos e elencados aspectos morais da situação identificados pelos futuros professores, isto é, inicialmente a professora os estimulou a identificar quais seriam as partes interessadas na situação descrita e que poderiam, portanto, ser afetadas pelas ações. Esse aspecto nos leva ao segundo momento da discussão, se estas partes poderiam ser afetadas pelas ações, quais seriam então as consequências das possíveis ações?

O aspecto discutido nesse momento foi a identificação das obrigações do protagonista, nesse caso em específico, o protagonista era Oppenheimer, o qual deveria decidir se prosseguiria com o plano de conceder liberdade para os cientistas discutirem questões inerentes 
ao extremamente sigiloso Projeto Manhattan entre eles, dentro dos laboratórios. Dessa forma obrigações quanto ao seu papel como cientistas, por exemplo, foram consideradas. Diante dessas obrigações, o último elemento discutido, na perspectiva de Bebeau (1995), foi a identificação do(s) ponto(s) de conflito. Lembrando que é por meio da sensibilidade moral que o sujeito toma consciência que a situação envolve questões morais, a identificação do dilema é fundamental.

Assim, com acesso a novas informações e elementos inicialmente negligenciados, mas abordado por outros, foi solicitado aos alunos que elaborassem um novo argumento respondendo o caso. Nesse momento, salientamos mais uma vez, que os licenciandos possuíam inteira liberdade para manter ou mudar de opinião, uma vez que a sua posição não era relevante, mas sim as justificativas empregadas e os aspectos morais abordados em suas respostas que sustentassem a posição adotada.

Coletamos para análise todos os argumentos elaborados pelos alunos, versão inicial e final e, assim como nas aulas anteriores realizadas em sala de aula do IFSC, toda a dinâmica foi gravada em áudio. Nessa aula em questão, fizemos uso, mais uma vez, de quatro gravadores distribuídos pela sala, um mais próximo à professora, a qual tinha o papel de conduzir a discussão estabelecida durante a aplicação do caso, e os outros três distribuídos próximos aos alunos de modo que permitissem captar todas as suas colocações durante a discussão. Ademais, fizemos uso de registro por foto do quadro, onde a professora ia sistematizando os aspectos morais levantados pelos futuros professores durante a discussão.

\section{Quinto encontro}

Semelhante ao segundo, o quinto encontro ocorreu novamente na biblioteca do IFSC e contou com a leitura individual e silenciosa da HQ, das páginas 37 a 57, e posteriormente foi solicitado que realizassem uma atividade com relação ao texto, a qual se encontra no APÊNDICE F. A atividade em questão apresentava dois itens e abrangia a parte de conceitos químicos presentes na narrativa, de forma que os licenciandos fossem capazes de vislumbrar na HQ a possibilidade de abordagem, com a linguagem dos quadrinhos, de diferentes conteúdos próprios da disciplina de química para o ensino médio.

Ao final foi entregue uma nova atividade, também presente no APÊNDICE F, a ser realizada extraclasse. Ela envolvia dois pontos, inicialmente solicitava a busca de maiores informações a respeito das bombas lançadas nas cidades de Hiroshima e Nagasaki, e, posteriormente a procura e elaboração de uma ficha técnica de vídeos ou filmes que abordam a mesma temática dos quadrinhos. Essa atividade se torna relevante uma vez que incentiva os 
alunos a tomar conhecimento de determinadas informações que foram suprimidas da HQ, como o mecanismo detalhado de funcionamento das bombas lançadas nas cidades japonesas, as quais diferem entre si. No mais, a ficha catalográfica permite aos futuros professores a construção de um acervo de materiais a respeito da temática que pode promover desde a abordagem de conteúdos científicos, como os identificados na atividade anterior, até o debate em sala de aula para o exercício da argumentação no ensino de ciências.

Nesse encontro, com a ausência apenas da aluna Érica, não foram tomadas gravações de áudio devido aos mesmos motivos explicitados na descrição do segundo encontro, e os dados coletados dizem respeito as atividades escritas realizadas, tanto na biblioteca quanto extraclasse.

\section{Sexto encontro}

Com a proximidade do trecho referente ao segundo caso da HQ, o sexto encontro contou com um feedback, por parte da docente, dos argumentos escritos elaborados para o caso I. Esta fez uma apresentação, utilizando recursos audiovisuais, que inicialmente retomava conceitos de argumentação e modelos de argumentação já trabalhados anteriormente, como Toulmin (2001) e Sá (2010). Feita essa retomada, com base nos modelos apresentados, a docente comentou os argumentos empregados pelos licenciandos tanto antes, como após a discussão realizada a partir do caso I. Apesar da ausência das alunas Bianca e Débora, a professora comentou os argumentos empregados pelos sete alunos, de modo que os licenciandos presentes pudessem observar nos exemplos, as diferentes abordagens tomadas pelos colegas e os diferentes elementos empregados em seus argumentos.

Durante a apresentação, em alguns momentos a docente solicitava aos autores dos argumentos apresentados que explicassem o que buscavam com determinados trechos, almejando torná-los mais claros. Dessa forma, a discussão permitia que os alunos, em conjunto com a professora, determinassem em que consistiria o trecho, isto é, se determinada frase seria apenas uma contextualização, uma justificativa, um backing etc. Toda essa dinâmica levou aproximadamente 1 hora e 15 minutos.

Após essa apresentação, e da discussão estabelecida a partir da análise dos argumentos apresentados pelos alunos para o caso I, deu-se continuidade à leitura da HQ, das páginas 58 a 93. A leitura ocorreu mais uma vez em voz alta pelos licenciados, os quais representavam diferentes personagens na narrativa. Todo o encontro foi gravado em áudio, para isso, utilizamos nessa aula três gravadores distribuídos pela sala, sendo um mais próximo à docente, e os outros dois distribuídos entre os cinco licenciandos presentes. 


\section{Sétimo encontro}

Realizada a discussão acerca dos argumentos apresentados para o caso 1, no sétimo encontro, na presença dos sete licenciandos, ocorreu a aplicação do segundo caso referente à HQ, o qual se encontra nas páginas 60 e 61, e no APÊNDICE G. A questão abordada nesse caso diz respeito ao sigilo na prática cientifica em que Oppenheimer, aconselhado por Bohr, o qual não estava envolvido no Projeto Manhattan, deveria decidir se comunicava abertamente para a população e para os demais líderes o que estava sendo realizado no Projeto, evidenciando assim o poder de destruição da arma em desenvolvimento. Para Bohr, o objetivo de falar abertamente sobre a bomba era fazer com que, tomando consciência do poder de destruição desse armamento que poderia levar ao fim do mundo, os líderes/homens não seriam tolos em construir uma e buscariam por soluções menos drásticas.

Seguindo o modelo proposto por Bebeau (1995), inicialmente foi feita a leitura individual e silenciosa do caso, e os licenciandos então construíram seus primeiros argumentos para a questão apresentada. A partir das respostas iniciais foi realizada a discussão conduzida pela docente, a qual, de modo a exercitar a sensibilidade moral dos estudantes, os conduziu a identificar em conjunto: as partes envolvidas que poderiam ser afetadas pela escolha de Oppenheimer; as consequências para cada uma dessas partes; a obrigação de Oppenheimer (protagonista) enquanto cientista; e os pontos de conflito. Vale relembrar que, para além das respostas iniciais dos licenciandos, a grelha com aspectos morais elaborada previamente pelo pesquisador e pela docente, também serviu de base para a discussão estabelecida

Feito isso, alcançamos o terceiro momento de aplicação do caso 2, momento no qual os futuros professores são solicitados a responder novamente o caso. A partir dos novos aspectos morais que emergiram da discussão, os alunos devem argumentar novamente podendo manter a sua posição ou mudando e evidenciando o porquê. Ao final desse encontro, para que fosse possível a leitura completa do texto no período de aplicação da proposta, os futuros professores foram instruídos a realizar, extraclasse, a leitura das páginas 94 a 129, necessárias para a aplicação do terceiro caso extraído da HQ que ocorreu no encontro posterior.

Foram coletados pelo pesquisador, assim como no quarto encontro, todos os argumentos escritos elaborados pelos licenciandos durante a aplicação do caso 2, gravações de áudio das discussões estabelecidas, e registro fotográfico do quadro onde a docente sistematizou os elementos abordados na discussão. Dessa forma, fizemos uso de quatro gravadores distribuídos pela sala de aula, sendo um mais próximo à docente e os outros três entre os licenciandos. O registro fotográfico foi feito pelo celular do pesquisador. 


\section{Oitavo encontro}

Como já apontado no final da aula anterior, no oitavo encontro ocorreu a aplicação do caso 3 extraído da HQ (APÊNDICE H). O caso em questão encontra-se distribuído nas páginas 131, 132, 133 e 136 da narrativa, salientamos que para este caso alguns trechos da HQ foram omitidos de modo a não o tornar extenso. Nele é abordada uma das principais questões morais quando se pensa na construção das bombas atômicas pelos cientistas. Assim sendo, para este caso, a partir de tudo o que foi apresentado, como as descobertas envolvendo a radioatividade e fissão nuclear, a busca por apoio do governo para a instituição do Projeto Manhattan, e todo o processo envolvendo questões políticas, científicas e sociais para a elaboração de um novo armamento, os futuros professores foram solicitados a responder e argumentar se os cientistas deveriam, com base em seus conhecimentos, fazer parte da construção das bombas atômicas que posteriormente foram lançadas nas cidades japonesas.

Contudo, para que fosse possível a aplicação desse caso, inicialmente deu-se prosseguimento à leitura da HQ das páginas 130 a 151 finalizando dessa forma o texto. Mais uma vez a leitura ocorreu em voz alta em que cada licenciando presente representava diferentes personagens da narrativa.

A aplicação do caso 3 seguiu mais uma vez o esquema proposto por Bebeau (1995) e, então, tivemos inicialmente a leitura individual e silenciosa do caso e, consequentemente, as respostas dos futuros professores em um primeiro momento. Em seguida foi realizada a discussão conduzida pela docente, nos mesmos moldes das anteriores, em que foram identificadas possíveis partes interessadas nesse conflito, as consequências das decisões dos protagonistas, que dessa vez é toda a comunidade científica, as obrigações dessa comunidade científica e por fim o(s) ponto(s) de conflito. Feita essa discussão, os licenciandos mais uma vez tiveram que argumentar em favor de suas posições.

Nesse encontro, todos os argumentos escritos pelos cinco licenciandos presentes, assim como gravações em áudio realizadas a partir de três gravadores foram coletados para análise.

\section{Nono encontro}

De forma a contribuir de maneira significativa para o desenvolvimento das habilidades de argumentação, bem como de análise crítica e tomada de decisão dos licenciandos, o nono encontro contou com a realização do processo de Peer Review (Revisão por pares), o qual é comumente adotado pela comunidade científica para a avaliação de produções por 
pesquisadores de uma mesma área de conhecimento (OLIVEIRA e QUEIROZ, 2017). Esse processo em sala de aula implica na produção e avaliação de textos pelos próprios alunos, de modo que, no contexto em questão, os licenciandos avaliaram e emitiram um parecer a respeito do argumento empregado por outro colega. Assim sendo, essa dinâmica também permitiu um novo feedback dos argumentos dos licenciandos.

Para a realização desse processo, inicialmente os alunos foram divididos em duas duplas e um trio e receberam textos (referentes aos argumentos construídos para o caso II) anônimos para avaliarem na perspectiva do TAP (TOULMIN, 2001). Após uma discussão interna, cada grupo apresentou oralmente o seu parecer sobre um dos argumentos analisados, indicando as justificativas, os backings, as refutações e os qualificadores modais. Tal processo contribuiu para que os licenciandos tomassem contato, na prática, com os elementos necessários em um argumento e, assim, ficassem atentos a estes elementos na construção de argumentos próprios.

No entanto, para que esse processo fosse possível, o pesquisador transcreveu previamente as respostas dos licenciandos para o caso 2 , e os numerou de 1 a 7 , de modo que somente ele soubesse o autor de cada texto. Dessa forma, mediante os grupos formados no nono encontro, o pesquisador distribuiu um texto para cada aluno, se atentando para dois principais pontos, o futuro professor não poderia receber o próprio texto, e nenhum produzido pelos elementos do seu grupo naquele dia. Assim, cada grupo avaliou os textos recebidos e então selecionou apenas um para a apresentação oral do parecer.

Todo esse encontro contou com gravações em áudio em que foram utilizados quatro gravadores, um na mesa da docente, o qual permitiu nesse dia não somente uma melhor captura das suas falas, como também dos pareceres orais dos alunos. Os outros três gravadores ficaram dispostos um com cada grupo, o que permitiu acessar as discussões internas deles.

\section{Conjunto de dados coletados}

Diante do exposto, para além do livro em quadrinhos "Trinity" submetido à análise do “conteúdo" e da "forma", os dados obtidos a partir das atividades descritas e que constituem também o corpus de análise deste estudo, estão sumarizados no Quadro 6. 
Quadro 6 - Dados coletados a partir das atividades realizadas na disciplina Química, Sociedade e Cotidiano.

- Gravações de áudio das Como descrito para cada encontro, tais gravações de áudio, quando dinâmicas estabelecidas realizadas, se deram por meio do uso de diferentes gravadores distribuídos em sala de aula estrategicamente em sala de aula. Essas gravações permitem o contato com diferentes impressões apresentadas pelos alunos no decorrer das atividades, bem como auxiliam o acesso à sensibilidade moral dos licenciandos submetidos a um momento de discussão oral, conforme metodologia proposta por Bebeau (1995).

- $\quad$ Argumentos escritos $\quad$ Para cada caso extraído da HQ os futuros professores construíram dois argumentos de modo a sustentar a posição adotada nos diferentes momentos, referente às questões apresentadas. Dessa forma, analisaremos um total de trinta argumentos escritos na perspectiva de Toulmin (2001), assim como do Modelo dos Quatro Componentes (REST, BEBEAU e VOLKER, 1986).

$\mathrm{O}$ total de trinta argumentos diz respeito às produções de somente cinco futuros professores, uma vez que foram tomados para análise neste estudo as respostas fornecidas aos casos por Alice, Bianca, Caroline, Débora e Gabriel. A delimitação por estes cinco licenciandos se deve ao fato de que estes foram os alunos presentes quando da realização dos três casos extraídos da HQ. Contudo, considerações a respeito dos argumentos empregados por Francisco e Érica podem emergir na discussão dos resultados, uma vez que, mediante a dinâmica estabelecida, em que as respostas eram discutidas oralmente, um argumento pode afetar aqueles construídos por outros licenciandos.

- Registro fotográfico do O registro fotográfico foi outro recurso empregado para auxiliar na quadro sistematização das discussões estabelecidas em sala de aula quando da resolução de cada um dos casos extraídos da HQ. Dessa forma, tais fotografias podem contribuir para o acesso à sensibilidade moral dos licenciandos nos diferentes momentos de aplicação da proposta. 


\section{Capítulo 5 - As características estruturais dos argumentos empregados por licenciandos em química diante de questões socialmente controversas}

De acordo com o apresentado no Capítulo 4, a segunda fase deste estudo compreendeu a realização de oficinas de leitura no âmbito da formação inicial de professores de química de modo a promover a argumentação dos mesmos e nos permitir responder a nossa primeira questão de investigação, isto é: Quais são as características estruturais dos argumentos escritos que licenciandos em química produzem diante de QSC? A disciplina escolhida para estudo é intitulada Química, Sociedade e Cotidiano e contava com sete alunos regularmente matriculados. Os argumentos tomados para a análise ocorreram em três momentos da disciplina o que, por sua vez, correspondem a três diferentes momentos da leitura da HQ "Trinity". Sendo assim, apresentamos a seguir como resultados e discutimos apenas a argumentação dos licenciandos que estiveram presentes nestes três momentos, isto é, analisamos a qualidade estrutural dos argumentos empregados pelos licenciandos, aqueles fornecidos por: Alice, Bianca, Caroline, Débora e Gabriel.

O exercício da argumentação ocorreu por meio de três casos extraídos da HQ, disponíveis nos APÊNDICES E, G e H, os quais solicitavam aos futuros professores respostas a questões controversas. Dessa forma, para efeito de discussão, apresentaremos os resultados obtidos para cada caso separadamente e ao final teceremos algumas considerações a respeito do conjunto de argumentos empregados diante dos casos. Lembramos que para a análise da qualidade estrutural dos argumentos fizemos uso do TAP associado às ideias de Erduran, Simon e Osborne (2004) a respeito das combinações dos componentes dos argumentos na perspectiva de Toulmin (2001). Ademais, salientamos que o nosso interesse, a princípio, não consiste na investigação da validade dos elementos apresentados, apenas buscamos ressaltar tais elementos propostos por Toulmin (2001) presentes nos argumentos fornecidos pelos licenciandos, que lhes conferem diferentes graus de complexidade e elaboração.

Caso 1

O Caso 1, intimamente relacionado com a $\mathrm{NdC}$, apresentava aos futuros professores um conflito envolvendo Oppenheimer e sua relação com os cientistas mediante as condições de trabalho dos mesmos e a necessidade de sigilo exigida pelo Projeto Manhattan. Para este caso os alunos eram convidados a responder, se na situação narrada, deveria Oppenheimer seguir com o plano de deixar os cientistas livres para falarem o que quiserem, mas somente dentro do laboratório, ficando por conta deles policiarem a si mesmos. Diante dessa questão, e assumindo 
o caráter estruturado do caso em que o problema é fornecido diretamente ao licenciando, e considerando os elementos propostos por Toulmin (2001) como necessários em um argumento, definimos como o DADO: Durante a realização do Projeto Manhattan, o sigilo envolvendo as ações dos cientistas é alvo de discórdia entre Oppenheimer e Groves. As CONCLUSÕES, por sua vez, poderiam ser duas: Oppenheimer deve deixar os cientistas livres para falarem o que quiserem, mas só dentro do laboratório, ficando por conta dos cientistas policiarem a si mesmos, ou, Oppenheimer não deve deixar os cientistas livres para falarem o que quiserem, mesmo apenas dentro do laboratório.

Inicialmente apresentamos no Quadro 7 o argumento empregado por Alice anteriormente ao momento de discussão realizado em sala de aula, bem como a sua análise na perspectiva de Toulmin (2001). Relembramos que, seguindo a metodologia proposta por Bebeau (1995), para cada caso cada licenciando apresentou dois argumentos, sendo o primeiro individual e com acesso direto apenas ao trecho da HQ utilizado na elaboração do caso, e outro após a discussão conduzida pela docente a qual, fundamentada na busca pelos aspectos morais da situação narrada, permitia, por parte dos alunos, o contato com diferentes pontos de vista e justificativas.

Quadro 7 - Análise estrutural, na perspectiva de Toulmin (2001), do argumento inicial empregado por Alice em resposta ao Caso 1.

\begin{tabular}{|l|l|}
\hline \multicolumn{4}{|c|}{ Alice - Caso 1 - Resposta inicial } \\
\hline $\begin{array}{l}\text { Argumento: Sim, já que para colaborar uns com os outros precisam trocar ideias e, portanto, comunicarem } \\
\text { entre si. Assim, a chance do projeto ser um sucesso em um menor tempo possível aumenta. Isto porque, de } \\
\text { qualquer forma, todos estão distantes de sua terra natal e confinados em Oak Ridge. }\end{array}$ \\
\hline $\begin{array}{l}\text { (D) Durante a realização do } \\
\text { projeto Manhattan, o sigilo } \\
\text { envolvendo as ações dos cientistas } \\
\begin{array}{l}\text { é alvo de discórdia entre } \\
\text { Oppenheimer e Groves. }\end{array}\end{array} \mid \begin{array}{l}\text { (C) ... Oppenheimer deve deixar os } \\
\text { cientistas livres para falarem o que } \\
\text { quiserem, mas só dentro do laboratório, } \\
\text { ficando por conta dos cientistas } \\
\text { policiarem a si mesmos. }\end{array}$ \\
\hline \\
$\begin{array}{l}\text { (J1) ... já que para colaborarem uns } \\
\text { com os outros precisam (os cientistas) } \\
\text { trocar ideias e, portanto, comunicarem } \\
\text { entre si. Assim a chance do projeto ser } \\
\text { um sucesso em um menor tempo } \\
\text { possível aumenta. }\end{array}$ \\
\hline
\end{tabular}

O que verificamos para a licencianda Alice foi um argumento inicial pouco complexo e elaborado para o qual identificamos apenas a combinação básica de elementos na perspectiva de Toulmin (2001), isto é, CDJ. Observamos na resposta da aluna o uso de uma única justificativa para sustentar a sua posição, que no momento consistia em apoiar a decisão de 
Oppenheimer em deixar os cientistas livres para falarem o que quiserem dentro dos laboratórios de Los Alamos.

Após a discussão realizada em sala de aula conduzida pela docente em busca de uma melhor visão a respeito dos aspectos morais envolvidos no Caso 1, os futuros professores foram solicitados a responder novamente à questão narrada. Conforme esquematizado no Quadro 8, verificamos que a aluna Alice optou por mudar sua decisão, ou seja, Oppenheimer não deveria mais seguir adiante com o seu plano de deixar os cientistas livres para se comunicarem dentro do laboratório. Para isso, a futura professora faz uso de duas justificativas as quais não foram apresentadas inicialmente, uma vez que, naquele momento, Alice tinha assumido um outro posicionamento. Salientamos que tais justificativas foram apresentadas por outro licenciando no momento da discussão e dizem respeito à manutenção de acordo assumido previamente pelo cientista. O futuro professor em questão era Francisco, cujos argumentos não foram considerados para a análise mediante sua ausência quando da aplicação do Caso 3 extraído da HQ, no entanto, ressaltamos que este era o único aluno que inicialmente se mostrava contrário a decisão de Oppenheimer.

Quadro 8 - Análise estrutural, na perspectiva de Toulmin (2001), do argumento final empregado por Alice em resposta ao Caso 1.

\section{Alice - Caso 1 - Resposta final}

Argumento: Oppenheimer sabe que para a ciência se desenvolver melhor necessita de colaboração, mas quando entrou no Projeto Manhattan aceitou um acordo com Groves de manter o sigilo total sobre este projeto, de modo que ele tem a obrigação de articular as ideias dos cientistas por conhecer o projeto na totalidade, mas não permitir que os cientistas o saibam também. Por isso, apesar das grandes dificuldades que ele deverá enfrentar com os cientistas, motivando-os constantemente e evitando insubordinação, ele não deve permitir trocas de informações dentro dos laboratórios por uma questão de ética e compromisso firmado incialmente com Groves e consequentemente com o governo norte-americano.

(D) Durante a realização do projeto Manhattan, o sigilo envolvendo as ações dos cientistas é alvo de discórdia entre Oppenheimer e Groves.
(C) ... Oppenheimer não deve deixar os cientistas livres para falarem o que quiserem, mesmo apenas dentro do laboratório.
(J1) ... já que quando entrou no Projeto Manhattan aceitou um acordo com Groves de manter sigilo total sobre este projeto, de modo que ele tem a obrigação de articular as ideias dos cientistas por conhecer o projeto na totalidade, mas não permitir que os cientistas o saibam também.
(J2) ... já que por uma questão de ética e compromisso firmado incialmente com Groves e consequentemente com o governo norte americano. 
Os argumentos de Francisco se fundamentavam em duas justificativas como as que se seguem: “já que embora a livre troca de ideia seja um dos requisitos para a 'feitura' da ciência, muitas situações exigem confidencialidade, que muitas vezes deve ser garantida através da firmação de contrato..." e "já que a confidencialidade quando exigida deve ser plenamente aceita pelo colaborador...”. No mais, com base em sua experiência profissional, como destacamos na caracterização de cada licenciando, Francisco também fez uso de um backing para apoiar suas justificativas, o qual consistia em: "por conta de que uma vez concordando em participar de tal empreitada sigilosa, [o indivíduo] está ciente do ônus e do bônus sem direito de 'reclamar' depois (do popular: o combinado não é caro)".

Nesse contexto, isto é, diante de um argumento apresentado por outro licenciando fundamentado em duas justificativas e um backing, Alice que contava incialmente com apenas uma justificativa para assumir que Oppenheimer deveria deixar os cientistas livres para se comunicarem dentro do laboratório, se sentiu compelida a mudar de posicionamento. Assim sendo, reforçamos o grau de persuasão e a força que um argumento assume mediante a quantidade de elementos estruturais do TAP (TOULMIN, 2001).

Logo, a mudança de opinião identificada nas respostas de Alice é fruto de uma pobre argumentação inicial que não se sustentou mediante contra-argumentos apresentados por terceiros, o que, por sua vez, está intimamente ligado com o caráter moral do indivíduo. Questões vinculadas a este caráter moral serão aprofundadas na sequência deste estudo ao abordarmos o raciocínio informal/moral dos licenciandos e sua relação com a argumentação. Ademais, no que tange à complexidade do novo argumento elaborado por Alice, verificamos que embora quantitativamente exista um maior número de justificativas após a discussão, na perspectiva de Erduran, Simon e Osborne (2004) ela se mantém, uma vez que a combinação de elementos estruturais presentes é a mesma da resposta inicial, ou seja, CDJ. No entanto, enxergamos nesse ponto, assim como Sá, Kasseboehmer e Queiroz (2014), uma limitação do que é proposto pelos autores e, assim sendo, considerando também a frequência de justificativas apresentadas, classificamos o segundo argumento de Alice como ligeiramente mais elaborado e consequentemente de maior qualidade, uma vez que este último conta com duas justificativas.

Com relação ao trecho grifado no argumento apresentado por Alice (Quadro 8), o qual não pôde ser classificado dentre os elementos propostos por Toulmin (2001), este é resultado do modelo adotado para o exercício do raciocínio moral, isto é, o Modelo dos Quatro Componentes. De acordo com a fundamentação teórica apresentada para esse Modelo, uma resposta bem fundamentada moralmente suscita a determinação de alguns aspectos como as 
possíveis consequências das ações. Dessa forma, considerando as possíveis consequências das ações de Oppenheimer, Alice julga J2 determinante para a sua tomada de decisão.

A segunda licencianda, cujos argumentos serão analisados na sequência é Bianca. Conforme esquematizado no Quadro 9, verificamos que assim como apresentado por Alice, Bianca inicialmente faz uso de apenas uma justificativa para fundamentar a sua decisão, o que implica em um argumento de pouca complexidade, sendo a combinação de elementos somente CDJ.

Quadro 9 - Análise estrutural, na perspectiva de Toulmin (2001), do argumento inicial empregado por Bianca em resposta ao Caso 1.

\begin{tabular}{|c|c|c|}
\hline \multicolumn{3}{|c|}{$\begin{array}{l}\text { Argumento: Apesar do risco de vazar informação ser maior do que manter o sigilo, se os cientistas tivessem } \\
\text { esta liberdade talvez se sentissem mais motivados e poderiam trocar informações para que uns ajudassem os } \\
\text { outros e desenvolvessem o projeto mais rapidamente. }\end{array}$} \\
\hline $\begin{array}{l}\text { (D) Durante a realização do } \\
\text { projeto Manhattan, o sigilo } \\
\text { envolvendo as ações dos cientistas } \\
\text { é alvo de discórdia entre } \\
\text { Oppenheimer e Groves. }\end{array}$ & Assim, & $\begin{array}{l}\text { (C) ... Oppenheimer deve deixar os } \\
\text { cientistas livres para falarem o que } \\
\text { quiserem, mas só dentro do laboratório, } \\
\text { ficando por conta dos cientistas } \\
\text { policiarem a si mesmos. }\end{array}$ \\
\hline \multicolumn{3}{|c|}{$\begin{array}{l}\text { (J1) ... já que se os cientistas tivessem } \\
\text { esta liberdade talvez se sentissem } \\
\text { mais motivados e poderiam trocar } \\
\text { informações para que uns ajudassem } \\
\text { os outros e desenvolvessem o projeto } \\
\text { mais rapidamente. }\end{array}$} \\
\hline
\end{tabular}

Mantendo as semelhanças com Alice, verificamos na resposta de Bianca após a discussão realizada em sala de aula, e conforme esquematizado no Quadro 10, o emprego de duas justificativas para sustentar a conclusão, a qual não diferiu da apresentada inicialmente. Sendo assim, observamos a manutenção da justificativa apresentada anteriormente (J1), ou seja, com base na sua concepção da prática científica, Bianca considera que Oppenheimer permitir a troca de ideias pelos cientistas implica em uma maior probabilidade de sucesso do projeto, que poderá, por sua vez, ser finalizado em menor tempo. Também identificamos a inserção de uma J2 emergente da discussão conduzida pela professora, a qual consiste nas dificuldades que poderiam surgir se a forma como o trabalho dos cientistas estava sendo realizada se mantivesse. Ou seja, constatamos o surgimento de uma justificativa a partir do momento em que, conforme metodologia sugerida por Bebeau (1995), se é estabelecido oralmente as consequências das possíveis ações para cada uma das partes envolvidas. 
Logo, mesmo que a combinação de elementos básicos CDJ tenha permanecido, o emprego quantitativamente maior de justificativas confere ao segundo argumento de Bianca, tal qual de Alice, uma complexidade e, consequentemente uma qualidade, ligeiramente maior.

Quadro 10 - Análise estrutural, na perspectiva de Toulmin (2001), do argumento final empregado por Bianca em resposta ao Caso 1.

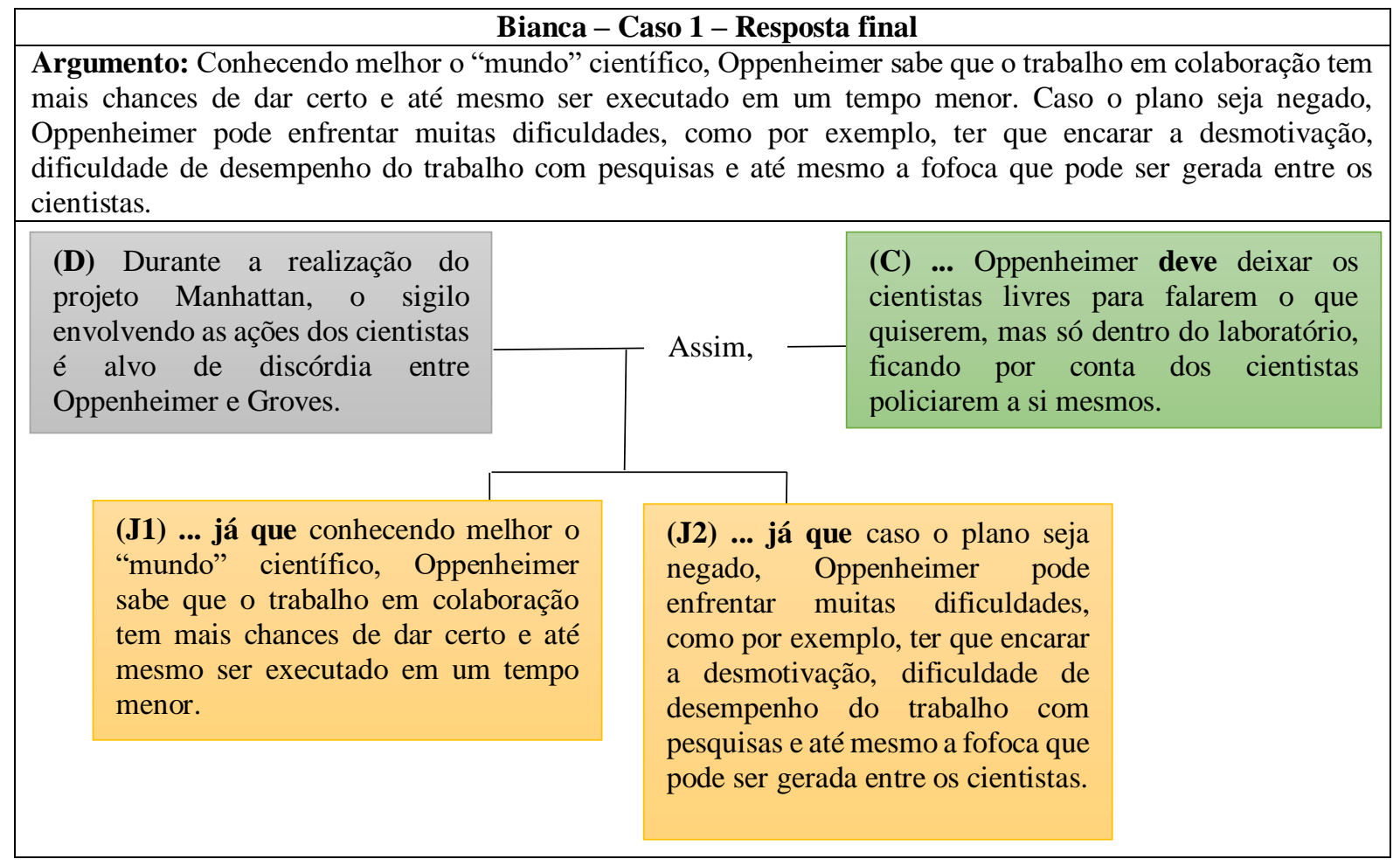

Prosseguindo com a análise da estrutura dos argumentos elaborados pelos licenciandos, apresentamos no Quadro 11 a resposta inicial fornecida pela aluna Caroline ao Caso 1. Diante do que é colocado pela futura professora tomamos contato com um elemento que não havia aparecido nas respostas das outras licenciandas, isto é, o backing, o qual atua como uma espécie de aval à justificativa. Assim sendo, ao justificar o porquê Oppenheimer deve dar a liberdade para os cientistas se comunicarem nos laboratórios, Caroline apresenta como $\mathrm{J} 1$, a necessidade de haver a troca de ideias e/ou opiniões para a prática científica, contudo ela apoia essa afirmação no fato (B1) de que muitas vezes os cientistas conseguem encontrar erros e sobrepor barreiras mediante a colaboração. Logo, caminhando um pouco mais no que diz respeito à complexidade dos argumentos, identificamos na resposta inicial de Caroline a combinação de elementos CDJB, o que lhe confere uma maior qualidade. 
Quadro 11 - Análise estrutural, na perspectiva de Toulmin (2001), do argumento inicial empregado por Caroline em resposta ao Caso 1.

\begin{tabular}{|l|l|}
\hline \multicolumn{1}{|c|}{ Caroline - Caso 1 - Resposta inicial } \\
\hline $\begin{array}{l}\text { Argumento: Acredito que na ciência deve haver uma troca de ideias e/ou opiniões, pois muitas vezes, com } \\
\text { ajuda de outros cientistas, consegue-se encontrar erros ou barreiras que estão impedindo de continuarem o seu } \\
\text { projeto. Portanto, no laboratório eles falariam entre si sobre o projeto e fora deveriam seguir com o sigilo já que } \\
\text { era o que tinha sido proposto desde o início do Projeto. }\end{array}$ \\
\hline $\begin{array}{l}\text { (D) Durante a realização do } \\
\text { projeto Manhattan, o sigilo } \\
\text { envolvendo as ações dos cientistas } \\
\text { é alvo de discórdia entre } \\
\text { Oppenheimer e Groves. }\end{array}$ & $\begin{array}{l}\text { (C) ... Oppenheimer deve deixar os } \\
\text { cientistas livres para falarem o que } \\
\text { quiserem, mas só dentro do laboratório, } \\
\text { ficando por conta dos cientistas } \\
\text { policiarem a si mesmos. }\end{array}$ \\
\hline $\begin{array}{l}\text { (J1) ... já que acredito que na ciência } \\
\text { deve haver uma troca de ideias e/ou } \\
\text { opiniões ... }\end{array}$ \\
$\begin{array}{l}\text { (B1) ... por conta de que muitas } \\
\text { vezes, com ajuda de outros cientistas, } \\
\text { consegue-se encontrar erros ou } \\
\text { barreiras que estão impedindo de } \\
\text { continuarem o seu projeto. }\end{array}$ \\
\hline
\end{tabular}

A qualidade do que é apresentado por Caroline é ainda maior quando consideramos o seu segundo argumento em resposta ao caso em questão (Quadro 12). Assim, diante do que é apresentado pela aluna, observamos que ela praticamente manteve J1 e seu backing (B1), ou seja, permanece na resposta de Caroline a ideia de que a troca de informações/opiniões é necessária para a realização da atividade científica a contento, isso com base no pressuposto de que dessa forma se torna possível identificar erros e sobrepor barreiras que se apresentem aos cientistas. No entanto, para além dessa ideia, Caroline emprega mais uma justificativa (J2) também apoiada em um backing (B2). Assim, a licenciada sugere que Oppenheimer deve deixar os cientistas livres para se comunicarem dentro do laboratório, pois acredita que estes não seriam imprudentes e não falariam fora do lugar apropriado. A sua crença, portanto, encontra subsídios no fato, que pode ter sido vivenciado por ela ou por outros colegas, de que há uma competitividade intrínseca na prática ciência e, dessa forma, os cientistas, almejando certo prestígio, evitariam expor informações que levassem outros a serem pioneiros no desenvolvimento de um artefato tecnológico.

Portanto, na perspectiva de Erduran, Simon e Osborne (2004), a complexidade do argumento apresentado por Caroline se mantém, uma vez que, a combinação de elementos próprios do TAP presente em sua resposta continua sendo CDJB. Contudo, ao analisarmos a 
frequência de justificativas e backings, inferimos que houve uma melhora na qualidade do argumento construído pela licenciada mediante o aumento da sua complexidade e elaboração.

Quadro 12 - Análise estrutural, na perspectiva de Toulmin (2001), do argumento final empregado por Caroline em resposta ao Caso 1.

\begin{tabular}{|c|c|c|}
\hline \multicolumn{3}{|c|}{ Caroline - Caso 1 - Resposta final } \\
\hline \multicolumn{3}{|c|}{$\begin{array}{l}\text { Argumento: Sabe-se que o conflito ético está no respeito ao modo de "fazer ciência" x o respeito ao sigilo que } \\
\text { Groves tinha deixado claro a todos sobre cada um fazer o seu trabalho/função. Porém, muitas vezes os cientistas } \\
\text { não conseguem prosseguir seu trabalho (costumam não perceber seus erros) e com isso, a troca de ideia e } \\
\text { discussão com outros cientistas ajudaria o trabalho a se desenvolver e até mesmo ser concluído com sucesso. } \\
\text { Portanto, acredito que para o projeto ser concluído com sucesso, Groves poderia deixar o orgulho de lado e } \\
\text { permitir a conversa APENAS no laboratório, e caso isso fosse descumprido, aí sim ele poderia impor uma } \\
\text { consequência. } \\
\text { O vazamento poderia ser uma consequência, mas acredito que bons cientistas como são, não iriam comentar } \\
\text { fora do lugar apropriado pois poderia perder o prestígio de seu projeto ser bem desenvolvido (pois sabemos que } \\
\text { há uma competitividade na ciência também). }\end{array}$} \\
\hline $\begin{array}{l}\text { (D) Durante a realização do } \\
\text { projeto Manhattan, o sigilo } \\
\text { envolvendo as ações dos cientistas } \\
\text { é alvo de discórdia entre } \\
\text { Oppenheimer e Groves. }\end{array}$ & Assim, & $\begin{array}{l}\text { (C) ... Oppenheimer deve } \\
\text { cientistas livres para falar } \\
\text { quiserem, mas só dentro do } 1 \\
\text { ficando por conta dos } \\
\text { policiarem a si mesmos. }\end{array}$ \\
\hline $\begin{array}{l}\text { (J1) ... já que a troca de ideia e discussão } \\
\text { com outros cientistas ajudaria o trabalho } \\
\text { a se desenvolver e até mesmo ser } \\
\text { concluído com sucesso. }\end{array}$ & \multicolumn{2}{|c|}{$\begin{array}{l}\text { (J2) ... já que bons cientistas como são, não } \\
\text { iriam comentar fora do lugar apropriado pois } \\
\text { poderia perder o prestígio de seu projeto ser } \\
\text { bem desenvolvido .... }\end{array}$} \\
\hline $\begin{array}{l}\text { (B1) ... por conta de que muitas vezes } \\
\text { os cientistas não conseguem prosseguir } \\
\text { seu trabalho (costumam não perceber } \\
\text { seus erros) ... }\end{array}$ & \multicolumn{2}{|c|}{$\begin{array}{l}\text { (B2) ... por conta de que sabemos que há } \\
\text { uma competitividade na ciência também. }\end{array}$} \\
\hline
\end{tabular}

Ainda com relação às respostas apresentadas por Caroline, observa-se, diferentemente das outras licenciandas, a inserção de informações presentes na HQ em seu argumento final, como a menção à ideia de: bons cientistas como são, não cometeriam erros básicos como a troca de informações em lugares inapropriados. Essa ideia faz referência ao trecho: "Mas em Los alamos - o novo lar de algumas das mentes mais brilhantes do país - a questão do sigilo não era assim tão simples" (FETTER-VORM, 2013, p. 35). Isto exposto, verificamos de antemão, com exceção de Caroline, a pouca atenção dada pelos futuros professores ao texto base no processo de argumentação, de modo que estes fizessem uso das informações ali presentes para fortalecer seus argumentos. No mais, diversas colocações expostas nessa segunda versão da resposta fornecida por Caroline estão diretamente relacionadas com as noções discutidas a respeito do raciocínio moral e ao Modelo dos Quatro Componentes (REST, BEBEAU e VOLKER, 1986), isto é, podemos observar uma fragmentação na resposta, principalmente do segundo para o terceiro parágrafo, fruto da necessidade que a licenciada considerou em 
apresentar, em sua resposta, a possibilidade do vazamento de informações como uma das possíveis consequências da ação de Oppenheimer.

No que diz respeito à licencianda Débora, verificamos, conforme Quadro 13, que também considerando o plano de Oppenheimer adequado para a situação narrada, a existência de duas justificativas para sustentar a sua decisão. Assim, Oppenheimer deve deixar os cientistas livres para se comunicarem no laboratório com base na ideia de que a argumentação é de extrema importância para o desenvolvimento científico, facilitando-o, e na hipótese de que, mesmo fornecendo essa liberdade ainda haveria algum tipo de supervisão para se certificar de que essa troca de ideias ocorrerá somente dentro dos laboratórios. Logo, considerando a combinação de elementos exibida por Débora, identificamos um argumento de baixa complexidade marcado por CDJ, em que foram empregadas duas justificativas.

Quadro 13 - Análise estrutural, na perspectiva de Toulmin (2001), do argumento inicial empregado por Débora em resposta ao Caso 1.

\begin{tabular}{|c|c|c|}
\hline \multicolumn{3}{|c|}{ Débora - Caso 1 - Resposta inicial } \\
\hline \multicolumn{3}{|c|}{$\begin{array}{l}\text { Argumento: Pois a argumentação na ciência é de extrema importância e o trabalho em equipe facilita e faz } \\
\text { com que descobertas possam ser realizadas mais facilmente. Porém, se tratando de uma operação militar } \\
\text { sigilosa, os cientistas ficariam livres para argumentar somente no laboratório, com algum controle e supervisão. }\end{array}$} \\
\hline $\begin{array}{l}\text { (D) Durante a realização do } \\
\text { projeto Manhattan, o sigilo } \\
\text { envolvendo as ações dos cientistas } \\
\text { é alvo de discórdia entre } \\
\text { Oppenheimer e Groves. }\end{array}$ & Assim, & $\begin{array}{l}\text { (C) ... Oppenheimer deve deixar os } \\
\text { cientistas livres para falarem o que } \\
\text { quiserem, mas só dentro do laboratório, } \\
\text { ficando por conta dos cientistas } \\
\text { policiarem a si mesmos. }\end{array}$ \\
\hline $\begin{array}{l}\text { (J1) ... já que a argumentação na } \\
\text { ciência é de extrema importância e o } \\
\text { trabalho em equipe facilita e faz com } \\
\text { que descobertas possam ser realizadas } \\
\text { mais facilmente. }\end{array}$ & $\begin{array}{l}(\mathbf{J} 2) \ldots \\
\text { operaçã } \\
\text { cientista } \\
\text { argumeı } \\
\text { com alg }\end{array}$ & $\begin{array}{l}\text { se tratando de uma } \\
\text { itar sigilosa, os } \\
\text { triam livres para } \\
\text { tente no laboratório, } \\
\text { trole e supervisão. }\end{array}$ \\
\hline
\end{tabular}

Analisando a resposta fornecida por Débora após a realização da discussão em sala de aula, e esquematizada no Quadro 14 na sequência, constatamos novamente a existência de duas justificativas que no caso se complementam entre si. Ou seja, Oppenheimer deve conceder a liberdade para os cientistas se comunicarem no laboratório com base nas ideias de que na ciência os cientistas devem trabalhar em equipe e de que o trabalho em equipe pode conduzir ao cumprimento dos objetivos de forma mais rápida e prática, isto é, o trabalho em equipe conduz a uma realização da atividade científica a contento. No entanto, a hipótese/ideia de que na ciência deve haver o trabalho em equipe se apoia em um backing derivado da discussão conduzida pela docente em busca dos aspectos morais da situação narrada que evidenciem um conflito ético para Oppenheimer. Sendo assim, Débora apresenta que a necessidade do trabalho 
em equipe surge do que ela denominou "moral científica", isto é, é fruto das características da atividade científica discutidas para a realização desse caso e abordadas anteriormente na disciplina conforme evidenciado no Capítulo 4.

Nesse sentido, Débora eleva a complexidade de seu argumento quando comparado com a resposta inicial, passando de uma combinação CDJ para uma combinação CDJB. No mais, ainda com relação a esse novo argumento, consideramos o trecho grifado (Quadro 14), como a condição necessária para que essa decisão pudesse ser tomada, e, portanto, não classificamos como refutação pois não diz respeito a uma condição de exceção propriamente dita, há uma menção apenas aos cuidados que devem ser tomados por Oppenheimer para ir adiante com o seu plano.

Quadro 14 - Análise estrutural, na perspectiva de Toulmin (2001), do argumento final empregado por Débora em resposta ao Caso 1.

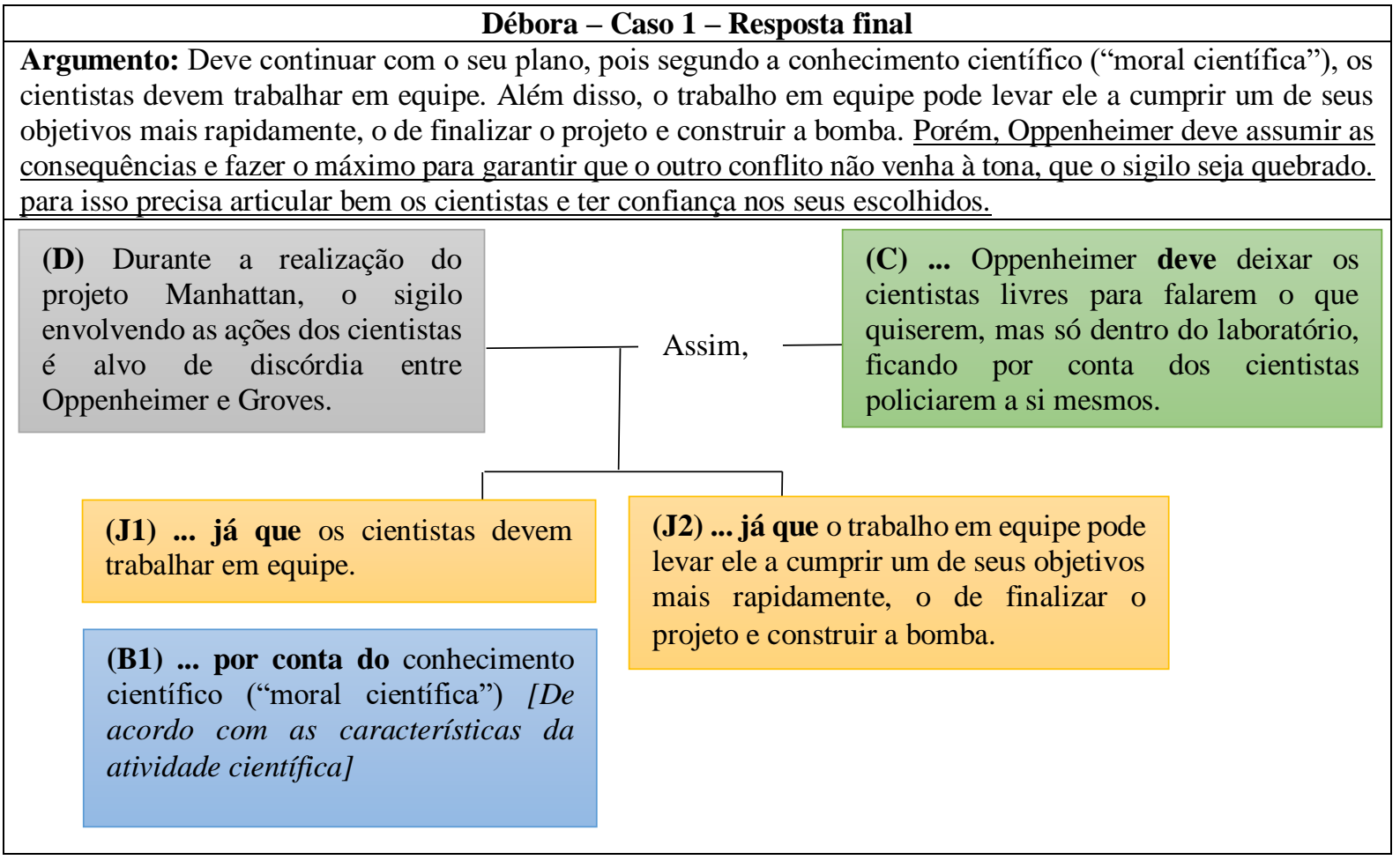

Por fim, no que diz respeito ao argumento empregado por Gabriel ao Caso 1, sua resposta e a respectiva análise na perspectiva de Toulmin (2001) estão esquematizadas no Quadro 15. Assim, o que verificamos é o emprego de duas justificativas sendo uma delas apoiada em um backing para sustentar a sua posição, que como assumida pelos outros licenciandos consiste em deixar os cientistas livres para falar o que quiserem dentro do laboratório. Nesse sentido, considerando a troca de ideias como uma característica implícita da atividade científica, Gabriel sugere que a liberdade fornecida por Oppenheimer permite essa troca de ideias, que por sua vez se dá através do diálogo. Além disso, apresentando também 
uma justificativa que não foi considerada por mais nenhum aluno, Gabriel defende a sua posição com base na ideia de que permitir a troca de informações implica em um menor policiamento e consequentemente demonstra maior confiança no trabalho dos cientistas. No que concerne à essa hipótese, ela é apoiada pelo fato de que, provavelmente por experiências vivenciadas, em especial pela mídia, o ciclo de policiamento sempre se quebra, o que faz com que alguém fique sem policiamento, dessa forma, confiando no trabalho dos cientistas, o ideal seria o encerramento desse ciclo com eles.

Quadro 15 - Análise estrutural, na perspectiva de Toulmin (2001), do argumento inicial empregado por Gabriel em resposta ao Caso 1.

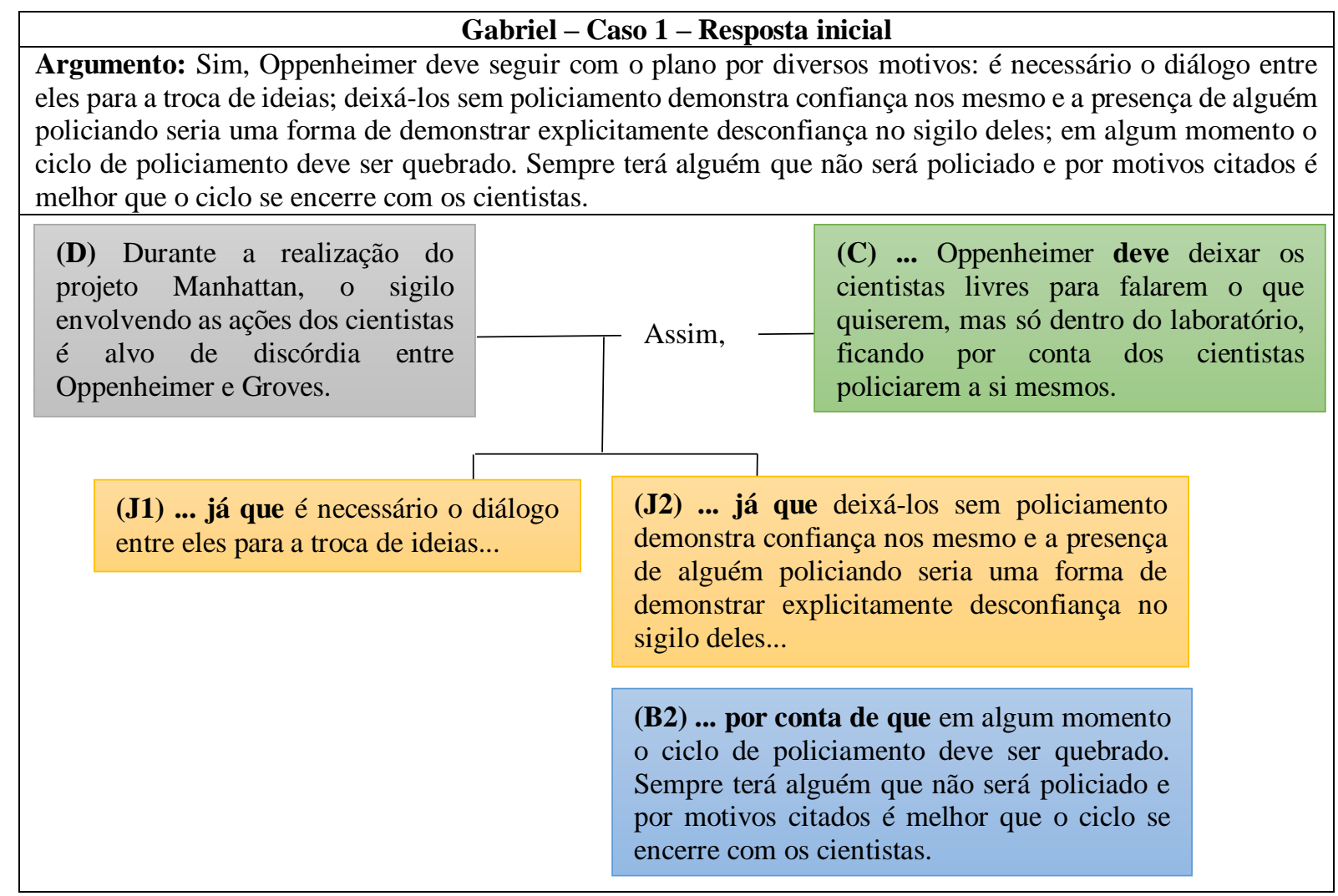

Ao analisarmos a combinação de elementos próprios do TAP presentes na resposta de Gabriel, constatamos um certo grau de complexidade do argumento mediante o emprego de CDJB, o que se torna apenas mais elaborado do que aqueles que apresentam somente os elementos básicos de um argumento propostos por Toulmin (2001), isto é, CDJ.

Considerando agora o argumento fornecido por Gabriel após a discussão referente ao Caso 1, sua análise está esquematizada no Quadro 16. O que verificamos é que, diferentemente do que ocorreu com a maioria dos futuros professores, o argumento apresentado por Gabriel após a discussão estabelecida em sala de aula teve a sua complexidade reduzida. Embora exista 
um aumento no número de justificativas empregadas, nenhuma delas é apoiada por um backing, dessa forma a combinação de elementos apresentada anteriormente CDJB passou a ser apenas CDJ.

Quadro 16 - Análise estrutural, na perspectiva de Toulmin (2001), do argumento final empregado por Gabriel em resposta ao Caso 1.

\section{Gabriel - Caso 1 - Resposta final}

Argumento: Sim, existem pontos positivos e negativos em qualquer uma das escolhas de Oppenheimer, as duas apresentam riscos, mas a escolha de prosseguir com o plano acaba sendo a mais correta pois o respeito ao modo que a ciência trabalha acarreta em um desenvolvimento muito mais rápido da mesma, além de demonstrar confiança e reconhecimento aos cientistas envolvidos. Dessa forma evita-se a desmotivação e possíveis insubordinações dos cientistas que poderia acarretar na demora ou até mesmo na não execução do projeto.

\begin{tabular}{|c|c|c|}
\hline $\begin{array}{l}\text { (D) Durante a realização do } \\
\text { projeto Manhattan, o sigilo } \\
\text { envolvendo as ações dos cientistas } \\
\text { é alvo de discórdia entre } \\
\text { Oppenheimer e Groves. }\end{array}$ & Assim, & $\begin{array}{l}\text { (C) ... Oppenheimer deve deixar os } \\
\text { cientistas livres para falarem o que } \\
\text { quiserem, mas só dentro do laboratório, } \\
\text { ficando por conta dos cientistas } \\
\text { policiarem a si mesmos. }\end{array}$ \\
\hline $\begin{array}{l}\text { (J1) ... já que o respeito } \\
\text { ao modo que a ciência } \\
\text { trabalha acarreta em um } \\
\text { desenvolvimento muito } \\
\text { mais rápido da mesma... }\end{array}$ & $\begin{array}{l}(\mathbf{J} 2) \quad \ldots \quad \text { já que } \\
\text { demonstrar confiança e } \\
\text { reconhecimento aos } \\
\text { cientistas envolvidos. }\end{array}$ & $\begin{array}{l}\text { (J3) ... já que evita a desmotivação e } \\
\text { possíveis insubordinações dos } \\
\text { cientistas que poderia acarretar na } \\
\text { demora ou até mesmo na não execução } \\
\text { do projeto. }\end{array}$ \\
\hline
\end{tabular}

Contudo, assim como para os demais alunos, como seria de se esperar, observa-se a presença de diversos aspectos levantados na discussão que contribuem para uma possível melhora do argumento, tais aspectos se converteram, em sua maioria, em justificativas, conforme podemos constatar com a argumento de Gabriel. Ou seja, ao considerar as possíveis consequências de Oppenheimer não fornecer a liberdade de troca de ideias pelos cientistas, as quais foram discutidas oralmente, emerge como justificativa o que se apresenta em J3, isto é, uma vez que seja possível o diálogo entre os cientistas, estes fariam parte de um ambiente favorável ao desenvolvimento científico e, consequentemente, evitaria desmotivações, insubordinações e atrasos na execução do projeto.

Em suma, a partir dos argumentos empregados pelos futuros professores em resposta ao Caso 1 que envolvia o sigilo no Projeto Manhattan, observamos, em sua maioria, argumentos pouco elaborados, com a ausência, por exemplo, de qualificadores modais e refutações. A respeito dessas últimas, conforme abordado previamente, consistem para Erduran, Simon e Osborne (2004) em um indicador significativo para a qualidade do argumento uma vez que a refutação e como ela se opõe ao argumento de outro indivíduo, motiva ambos a avaliar a validade e a força desse argumento. 
Esses resultados preliminares obtidos quanto à estrutura dos argumentos empregados pelos licenciandos reiteram a necessidade de práticas argumentativas em sala de aula, especificamente na formação de professores que, posteriormente, atuarão na educação básica. Essa necessidade se torna ainda maior quando consideramos o contexto da disciplina em que ocorreram as atividades, isto é, ela se encontra no último período do Curso de Licenciatura em Ciências Exatas da USP. No mais, dois dos futuros professores cujos argumentos foram analisados são formados em outros cursos voltados para a ciência da natureza. Logo, quando consideramos as ideias de Jimenez-Aleixandre (2011) a partir do que é proposto por Kelly (2008), seria esperado que tais cursos salientassem o desenvolvimento de habilidades argumentativas durante a formação, uma vez que esta é prática epistêmica central da ciência que envolve a produção, avaliação e comunicação do conhecimento.

Ao realizarmos uma análise comparativa da estrutura dos argumentos apresentados pelos licenciados nos dois diferentes momentos da dinâmica estabelecida em sala de aula, verificamos que, em sua maioria, a discussão conduzida pela docente em busca de uma ampliação da visão acerca dos aspectos morais envolvidos no caso, contribuiu para uma melhora da qualidade dos argumentos, em especial no que diz respeito à frequência de justificativas identificada. Assim, ao considerarmos a proposta de Bebeau (1995) em seu material Moral reasoning in scientific research, constatamos que o estabelecimento das consequências para cada uma das partes envolvidas mediante as possibilidades de ações, consiste em um instrumento interessante para o contato com justificativas variadas que possibilitam um aumento da complexidade do argumento diante de questões controversas que, assim como nos casos abordados neste estudo, envolvem dimensões éticas e morais.

Por fim, ainda com relação a esses argumentos, e como já foi brevemente apontado na discussão, pouca atenção foi dada às informações presentes na HQ e no próprio trecho dela extraído para a constituição do caso argumentativo. Essa observação denota a importância de práticas de leitura, não necessariamente e especificamente do hipergênero adotado (HQ), mas de textos como um todo que contribuam para a formação do sujeito leitor. Ademais, essa constatação suscita maiores investigações a respeito da relação de professores em formação com a leitura.

Caso 2

O Caso 2, como explicitado no APÊNDICE G, apresentava aos futuros professores um dilema proveniente da conversa entre Bohr e Oppenheimer a respeito do sigilo do Projeto Manhattan. Em suas colocações, Bohr, o qual não estava diretamente envolvido na construção 
da bomba atômica, sugeria que o extremo cuidado com relação ao sigilo interno do Projeto não seria necessário se fosse falado abertamente sobre o poder de destruição de um armamento como o que estava sendo desenvolvido. Sendo assim, conhecendo tal poder, ninguém seria tolo em construir uma arma que poderia facilmente acabar com todo o mundo. Mediante essas considerações do físico dinamarquês, os licenciandos eram solicitados a responder se Oppenheimer, enquanto cientista responsável pelo Projeto Manhattan, deveria ouvir Bohr e falar abertamente sobre o poder de destruição da bomba atômica em construção.

Nesse sentido, assumimos como DADO para este caso: Durante a realização do Projeto Manhattan, o sigilo envolvendo o poder de destruição da bomba é alvo de discórdia entre Bohr e Oppenheimer. E as possíveis CONCLUSÕES seriam: Oppenheimer não deve falar abertamente sobre o poder de destruição de uma bomba atômica em construção ou Oppenheimer deve falar abertamente sobre o poder de destruição da bomba atômica em construção. Nessa perspectiva, considerando o Modelo proposto por Toulmin (2001) analisamos novamente os argumentos dos cinco licenciandos que estiveram presentes na realização dos três casos extraídos da HQ.

Relembramos que previamente à aplicação do Caso 2, os licenciandos receberam um feedback fornecido pela docente a respeito dos argumentos empregados para a resolução do Caso 1. Sendo assim, apresentamos na sequência as respostas de cada licenciando a este caso, começando por Alice, cuja resposta inicial e sua respectiva análise estão esquematizadas no Quadro 17.

No que diz respeito a essa licencianda, havíamos verificado em suas respostas para a resolução do Caso 1 argumentos pouco elaborados, em especial aquele apresentado no primeiro momento da atividade realizada em sala de aula, que contribuiu para que Alice mudasse de posição quando em contato com um argumento estruturalmente mais elaborado. Ao observarmos, no entanto, o seu argumento inicial para o caso 2, verificamos que a licencianda ao afirmar que Oppenheimer não deve falar abertamente sobre o poder de destruição da bomba em construção, manteve a complexidade baixa de suas respostas no que tange à combinação de elementos pertencentes ao TAP, isto é, contamos ainda apenas com CDJ, no entanto, podemos inferir mais uma vez que Alice apresentou um argumento mais complexo que o anterior mediante a frequência de justificativas empregadas, as quais passaram de duas para três. 
Quadro 17 - Análise estrutural, na perspectiva de Toulmin (2001), do argumento inicial empregado por Alice em resposta ao Caso 2.

\begin{tabular}{|c|c|c|}
\hline \multicolumn{3}{|c|}{ Alice - Caso 2 - Resposta inicial } \\
\hline \multicolumn{3}{|c|}{$\begin{array}{l}\text { Argumento: Oppenheimer não deve falar abertamente. Ele entendeu o posicionamento de Bohr que defende } \\
\text { que o mundo deve saber do que ocorre em Los Alamos. Para Bohr, Oppenheimer deve conscientizar o mundo } \\
\text { do perigo eminente da construção de uma bomba com poder de destruição nunca visto antes. Pois se um país a } \\
\text { constrói, outro por segurança poderá também desenvolvê-la de modo que uma guerra poderia significar a } \\
\text { destruição do mundo. } \\
\text { Alertar o mundo dessa possibilidade poderia significar a tentativa de sensibilizar os governantes para tentarem } \\
\text { coexistirem sem guerra, ou seja, agirem diplomaticamente. Mas Oppenheimer possui um pacto de sigilo com } \\
\text { Groves e consequentemente com o governo dos EUA e não deve, a essa altura do campeonato, quebrar o sigilo. } \\
\text { Outro argumento pelo não é que, falar abertamente não garante que os governantes dos outros países se } \\
\text { sensibilizem e não busquem esta nova tecnologia. Ao contrário, a Alemanha poderia iniciar uma corrida pela } \\
\text { tecnologia da bomba atômica. } \\
\text { Não dá para confiar na sensatez dos homens. }\end{array}$} \\
\hline $\begin{array}{l}\text { (D) Durante a realiza } \\
\text { projeto Manhattan, o p } \\
\text { destruição da bomba é } \\
\text { discórdia entre } \mathrm{Bc} \\
\text { Oppenheimer. }\end{array}$ & 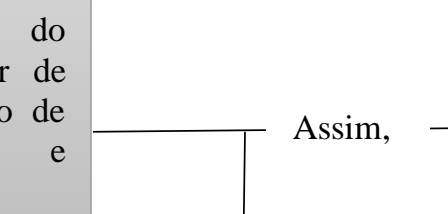 & $\begin{array}{l}\text { (C) ... Oppenheimer NÂO deve falar } \\
\text { abertamente sobre o poder de destruição } \\
\text { da bomba em construção. }\end{array}$ \\
\hline $\begin{array}{l}\text { (J1) ... já que } \\
\text { Oppenheimer possui } \\
\text { um pacto de sigilo } \\
\text { com Groves e } \\
\text { consequentemente } \\
\text { com o governo dos } \\
\text { EUA... }\end{array}$ & $\begin{array}{l}\text { (J2) ... já que falar } \\
\text { abertamente não garante que } \\
\text { os governantes dos outros } \\
\text { países se sensibilizem e não } \\
\text { busquem esta nova } \\
\text { tecnologia. Ao contrário, a } \\
\text { Alemanha poderia iniciar uma } \\
\text { corrida pela tecnologia da } \\
\text { bomba atômica. }\end{array}$ & $\begin{array}{l}\text { (J3) ... já que não dá } \\
\text { para confiar na } \\
\text { sensatez dos homens. }\end{array}$ \\
\hline
\end{tabular}

Mantendo a tendência verificada anteriormente, ao apresentar um novo argumento ao Caso 2 diante dos aspectos apresentados na discussão realizada em sala de aula, Alice exibiu novamente um argumento pouco elaborado quando consideramos simplesmente a combinação de elementos inseridos no seu texto, a qual continua sendo CDJ. Contudo, houve mais uma vez, um aumento na frequência de justificativas, isto é, passamos de três para quatro, conforme evidenciado no Quadro 18, elevando assim, ligeiramente, a qualidade do que está sendo apresentado.

Dessa forma, previamente à discussão Alice expunha a sua conclusão, a qual consiste em não falar abertamente sobre o poder da bomba atômica em construção, com base: na ideia de pacto firmado entre Oppenheimer, Groves e o governo americano; na hipótese de ocorrer o contrário do que Bohr afirmava, isto é, ao invés de selarem a paz, poderia se dar início a uma corrida armamentista; e também na hipótese/ideia de que não dá para confiar na sensatez dos 
homens, frase esta apresentada por Oppenheimer no trecho da HQ fornecido aos futuros professores.

Quadro 18 - Análise estrutural, na perspectiva de Toulmin (2001), do argumento final empregado por Alice em resposta ao Caso 2.

\begin{tabular}{|c|c|c|c|c|}
\hline \multicolumn{5}{|c|}{ Alice - Caso 2 - Resposta final } \\
\hline \multicolumn{5}{|c|}{$\begin{array}{l}\text { Argumento: Não, Oppenheimer como cientista e homem sensato deve manter sua palavra e, portanto, o acordo } \\
\text { com o governo dos EUA. Como cidadão ele não acredita na sensatez dos homens, não confia nos líderes } \\
\text { mundiais por uma saída diplomática temendo abrir um precedente do qual ao invés de selarem a paz, eles partam } \\
\text { para uma corrida armamentista aumentando os perigos de uma guerra mundial. } \\
\text { Apesar de saber o seu compromisso profissional de divulgação de dados, ele possui um acordo prévio com os } \\
\text { EUA que o impede disso. } \\
\text { Ele sabe que divulgar pode tanto levar à paz quanto à uma corrida armamentista. É um risco muito grande e ele } \\
\text { não acredita na possibilidade da paz. }\end{array}$} \\
\hline \multicolumn{2}{|c|}{$\begin{array}{l}\text { (D) Durante a realização do } \\
\text { projeto Manhattan, o poder de } \\
\text { destruição da bomba é alvo de } \\
\text { discórdia entre Bohr } \\
\text { Oppenheimer. }\end{array}$} & Assim, & \multicolumn{2}{|c|}{$\begin{array}{l}\text { (C) ... Oppenheimer NÂO deve falar } \\
\text { abertamente sobre o poder de destruição } \\
\text { da bomba em construção. }\end{array}$} \\
\hline $\begin{array}{l}\text { Op1) já que } \\
\text { Oppenheimer como } \\
\text { cientista e homem } \\
\text { sensato deve manter } \\
\text { sua palavra e, } \\
\text { portanto, o acordo } \\
\text { com o governo dos } \\
\text { EUA. }\end{array}$ & \multicolumn{2}{|c|}{$\begin{array}{l}\text { (J2) ... já que como cidadão } \\
\text { ele não acredita na sensatez } \\
\text { dos homens, não confia nos } \\
\text { líderes mundiais por uma } \\
\text { saída diplomática temendo } \\
\text { abrir um precedente do qual } \\
\text { ao invés de selarem a paz, eles } \\
\text { partam para uma corrida } \\
\text { armamentista aumentando os } \\
\text { perigos de uma guerra } \\
\text { mundial. }\end{array}$} & $\begin{array}{l}\text { (J3) ... já que } \\
\text { apesar de saber o } \\
\text { seu compromisso } \\
\text { profissional de } \\
\text { divulgação de } \\
\text { dados, ele possui } \\
\text { um acordo prévio } \\
\text { com os EUA que } \\
\text { o impede disso. }\end{array}$ & $\begin{array}{l}\text { (J4) ... já que ele sabe } \\
\text { que divulgar pode } \\
\text { tanto levar à paz } \\
\text { quanto à uma corrida } \\
\text { armamentista. É um } \\
\text { risco muito grande e } \\
\text { ele não acredita na } \\
\text { possibilidade da paz. }\end{array}$ \\
\hline
\end{tabular}

Após considerações elencadas em sala de aula, Alice mantém a ideia de acordo assumido por Groves, a de insensatez dos homens, a da possibilidade de corrida armamentista e menciona algo que não estava presente inicialmente, isto é, a contraposição entre divulgar a ciência em busca das melhores aplicações do desenvolvimento científico e a existência de um acordo firmado com os EUA. Nessa perspectiva, identificamos como elemento crucial da discussão para a elaboração do segundo argumento ao Caso 2, em especial das justificativas, as considerações abordadas a respeito das obrigações do protagonista, isto é, ao considerar as obrigações de Oppenheimer naquela situação, Alice tomou contato com mais uma justificativa que sustentasse a sua decisão.

Salientamos também que a referida aluna, na tentativa de responder os casos propostos, se detinha a uma cópia do TAP fornecida anteriormente pela professora e assim, na busca pelos elementos necessários em um bom argumento, por vezes apresentava uma resposta fragmentada 
como podemos ver no argumento presente no Quadro 18, em que as justificativas, por vezes, são apresentadas como frases soltas.

De modo a confirmar a rigidez que o TAP (TOULMIN, 2001) e a cópia fornecida anteriormente promoveram no processo de argumentação de Alice, foi possível perceber durante a realização das atividades o mecanismo adotado pela licencianda para a resolução de casos argumentativos. No terceiro encontro, por exemplo, quando da resolução em grupo do caso extraído do material de Bebeau (1995) referente a questão de plágio na prática científica e que se encontra no ANEXO A, a futura professora apresentou a seguinte afirmação para os seus colegas: "primeira coisa é se ela deve ou não deve, se ela deve, a gente monta o porquê ela deve, já que, por conta disso, provavelmente tal e tal. Se ela não deve, a mesma coisa, não deve já que ...”. Dessa forma observamos que a licenciada, ao resolver os casos, não considera a ampla gama de elementos que poderiam afetar o seu posicionamento, ela parte de uma decisão tomada para então buscar justificativas que sustentem apenas essa posição, o que, por sua vez, deixa a sua resposta facilmente suscetível a contra-argumentos, uma vez que outros elementos importantes do caso não foram ponderados inicialmente.

Contudo, diversos outros estudos têm apontado para essa limitação proveniente do uso do Modelo de Toulmin (2001) para o exercício da argumentação em sala de aula. Jorge e Puig (2000), por exemplo, salientam os cuidados que um professor ao fazer uso desse Modelo no espaço formal de ensino deve apresentar para evitar a rigidez imposta pelos elementos presentes no TAP (TOULMIN, 2001). Assim sendo, os professores, segundo os autores, devem ter cuidado para não abordar o Modelo de forma mecanicista, inibindo dessa forma a criatividade dos estudantes, tal como verificado nas respostas de Alice.

Partindo agora para os argumentos apresentados por Bianca diante da questão evidenciada no Caso 2, o Quadro 19 esquematiza a resposta inicial da licencianda e sua respectiva análise de acordo com o TAP (TOULMIN, 2001). O argumento inicial de Bianca para este caso é o primeiro que apresenta uma refutação, o que segundo Erduran, Simon e Osborne (2004) aumenta significativamente a sua qualidade, uma vez que obriga, locutor e interlocutor, a avaliar a força e validade do argumento. Ao afirmar que Oppenheimer deve falar abertamente sobre o poder de destruição da bomba em construção, a futura professora expõe como condição de exceção a essa conclusão a não existência de mecanismos que permitam o governo dos EUA, detentor dos conhecimentos que viabilizam a construção desse armamento, investigar o cumprimento de um possível acordo, como o Tratado de Não Proliferação de Armas Nucleares vigente até hoje. Nessa perspectiva, dos argumentos apresentados até então, 
este se torna o mais complexo e elaborado, o qual apesar de conter somente uma justificativa faz uso de outros elementos tais como uma refutação, o que implica em uma combinação de elementos CDJR.

Quadro 19 - Análise estrutural, na perspectiva de Toulmin (2001), do argumento inicial empregado por Bianca em resposta ao Caso 2.

Bianca - Caso 2 - Resposta inicial

Argumento: Caso a bomba já estivesse pronta, seria interessante expor o seu poder sim, desta maneira poderia haver alguma forma de acordo sem que fosse necessário utilizá-la. Mas, para que houvesse essa divulgação seria interessante ter em mente alguma forma de investigar se o acordo (caso existisse) seria de fato real e não um golpe do adversário para ganhar tempo planejando outro meio de ganhar a guerra.

(D) Durante a realização do projeto Manhattan, o poder de destruição da bomba é alvo de discórdia entre Bohr e Oppenheimer.

Assim,

(C) ... Oppenheimer deve falar abertamente sobre o poder de destruição da bomba em construção.

(R) ... a menos que não existisse uma maneira de investigar se o acordo (caso existisse) seria de fato real e não um golpe do adversário para ganhar tempo planejando outro meio de ganhar a guerra.

Contudo, prosseguindo com a análise das respostas de Bianca verificamos que seu segundo argumento, conforme ilustrado no Quadro 20, variou significativamente quanto a sua estrutura. Assim, o que observamos é a manutenção da justificativa apresentada anteriormente, a qual se encontra melhor elaborada mediante os aspectos levantados na discussão estabelecida entre uma resposta e outra, em especial das considerações a respeito das consequências de cada ação de Oppenheimer.

Verificamos ainda a inserção de mais uma justificativa acompanhada de seu backing, ou seja, ao defender que Oppenheimer deve falar abertamente sobre o poder de destruição da bomba atômica em construção, Bianca faz referência à ideia de que o governo norte-americano já se encontra em vantagem aos demais países e, dessa forma, poderiam buscar um acordo. Essa ideia, por sua vez, é apoiada no fato (conhecimento básico) de que sendo pioneiro na construção da bomba atômica, a inexistência de um acordo não seria um problema, uma vez que poderiam fazer uso desse armamento quando bem entendessem, antes que fosse possível qualquer outra nação desenvolver uma arma tão potente quanto.

Logo, ao analisarmos o que foi inserido pela licencianda, podemos constatar que a refutação apresentada inicialmente abriu espaço para esse par justificativa/backing, ou seja, ao considerar novos elementos, a condição de exceção que no caso era a criação de mecanismos para investigar o cumprimento de um possível acordo, passa a não ser mais necessária, uma vez 
que, o não cumprimento do acordo poderia ser solucionado com um ataque norte-americano mediante o seu pioneirismo na construção do novo armamento.

Nesse sentido, embora na perspectiva de Erduran, Simon e Osborne (2004) a complexidade e por consequência a qualidade do argumento de Bianca tenha reduzido ao consideramos exclusivamente a combinação de elementos presentes nas respostas, isto é, inicialmente contávamos com CDJR e passamos a ter CDJB, julgamos, mediante a frequência de justificativas e backings, em especial a natureza desses elementos que no caso específico de Bianca englobou a refutação apresentada anteriormente, que a qualidade do argumento final ao menos se manteve, podendo até mesmo ter sido ligeiramente aumentada.

Quadro 20 - Análise estrutural, na perspectiva de Toulmin (2001), do argumento final empregado por Bianca em resposta ao Caso 2.

Bianca - Caso 2 - Resposta final

Argumento: Uma vez que não falar abertamente sobre a bomba não dá a oportunidade de acordo com os rivais e traz grandes destruições sem chances de reconciliação, percebo que expor a bomba seja uma maneira de tentar um acordo, mesmo que sob pressão, sem destruir uma parte de população. Caso a exposição da bomba não intimidasse os adversários, o governo americano continuaria com vantagens já que os inimigos não tinham bomba e nem sabiam como fazer uma. Neste caso, os americanos poderiam utilizar a bomba antes dos inimigos construírem alguma arma tão potente quanto a que eles tinham.

(D) Durante a realização do projeto Manhattan, o poder de destruição da bomba é alvo de discórdia entre Bohr e Oppenheimer.

e

(J1) ... já que uma vez que não falar abertamente sobre a bomba não dá a oportunidade de acordo com os rivais e traz grandes destruições sem chances de reconciliação, percebo que expor a bomba seja uma maneira de tentar um acordo, mesmo que sob pressão, sem destruir uma parte de população.
(J2) ... já que caso a exposição da bomba não intimidasse os adversários, o governo americano continuaria com vantagens já que os inimigos não tinham bomba e nem sabiam como fazer uma.

(B2) ... por conta de que neste caso, os americanos poderiam utilizar a bomba antes dos inimigos construírem alguma arma tão potente quanto a que eles tinham.

Com relação à licencianda Caroline, analisamos no Quadro 21, a sua resposta inicial ao caso envolvendo o sigilo do Projeto Manhattan, e verificamos, assim como para o argumento inicial de Bianca, a presença de uma refutação que lhe confere um maior grau de complexidade e elaboração do que estava sendo apresentado até então. No caso, podemos assumir essa refutação como uma condição de exceção para a conclusão apresentada a partir de J2, ou seja, Oppenheimer não deve falar abertamente sobre o poder de destruição da bomba atômica em construção já que ao fazer isso poderia dividir a população e entrar em contato com mais problemas do que os já enfrentados. No entanto, essa justificativa é inválida para a conclusão 
apresentada se o governo, ao permitir a divulgação das informações pertinentes ao Projeto Manhattan, soubesse de antemão como lidar com a população do próprio país.

Quadro 21 - Análise estrutural, na perspectiva de Toulmin (2001), do argumento inicial empregado por Caroline em resposta ao Caso 2.

\section{Caroline - Caso 2 - Resposta inicial}

Argumento: Oppenheimer não deve falar abertamente, já que essa decisão não depende apenas dele, mas sim de Groves e do governo americano. Além disso, abrir o jogo para o mundo sobre o que eles estão construindo e o que ela é capaz, poderá chocar a população e dividi-la entre os que são a favor e os que são contra, e sabemos que na situação em que se passa, não seria algo que o governo queria intervir (eles têm outras preocupações). A menos que o governo aceitasse a proposta de falar abertamente, sabendo como eles iriam lidar com a população contra a construção.

A bomba está praticamente pronta, contar tudo a todos poderia atrapalhar os planos propostos a princípio.

(D) Durante a realização do projeto Manhattan, o poder de destruição da bomba é alvo de discórdia entre Bohr e Oppenheimer.

Assim,

(C) ... Oppenheimer NÃO deve falar abertamente sobre o poder de destruição da bomba em construção.
(J1) ... já que essa decisão não depende apenas dele, mas sim de Groves e do governo americano.
(J3) ... já que a bomba está praticamente pronta, contar tudo a todos poderia atrapalhar os planos propostos a princípio.

(J2) ... já que abrir o jogo para o mundo sobre o que eles estão construindo e o que ela é capaz, poderá chocar a população e dividila entre os que são a favor e os que são contra, e sabemos que na situação em que se passa, não seria algo que o governo queria intervir (eles têm outras preocupações).

Logo, verificamos para esse argumento de Caroline a combinação CDJR. Relembramos que para o caso 1 a licencianda em questão já apresentava em suas respostas a combinação CDJB, dessa forma podemos inferir que embora não tenha apresentado backings que sustentem suas justificativas para a posição tomada diante desse caso, a licencianda fez uso de outro elemento que, como mencionado em outros pontos da discussão, indica a qualidade do argumento na perspectiva de Erduran, Simon e Osborne (2004). No mais, diante da frequência de justificativas apresentadas juntamente com a refutação, consideramos o argumento inicial apresentado por Caroline em resposta ao Caso 2, o mais complexo e elaborado até então.

Continuando a análise, no segundo momento em que os futuros professores foram solicitados a responder o caso em questão, verificamos na resposta de Caroline, conforme o que se apresenta no Quadro 22, a manutenção da complexidade e da qualidade estrutural do argumento, isto é, contamos com os mesmos elementos do TAP (TOULMIN, 2001) CDJR e, nesse caso, com as mesmas frequências. No que tange à refutação podemos verificar que o que outrora era uma condição de exceção para a conclusão derivada especialmente de uma 
justificativa (J2 da resposta inicial), passa a ser uma refutação mais ampla, o que também nos leva a sugerir uma melhora da qualidade do argumento. Sendo assim, a condição de exceção apresentada, ou seja, a possibilidade de um acordo para a não construção de armamentos nucleares é capaz de invalidar as três justificativas expostas e não apenas uma como no caso anterior.

Quadro 22 - Análise estrutural, na perspectiva de Toulmin (2001), do argumento final empregado por Caroline em resposta ao Caso 2.

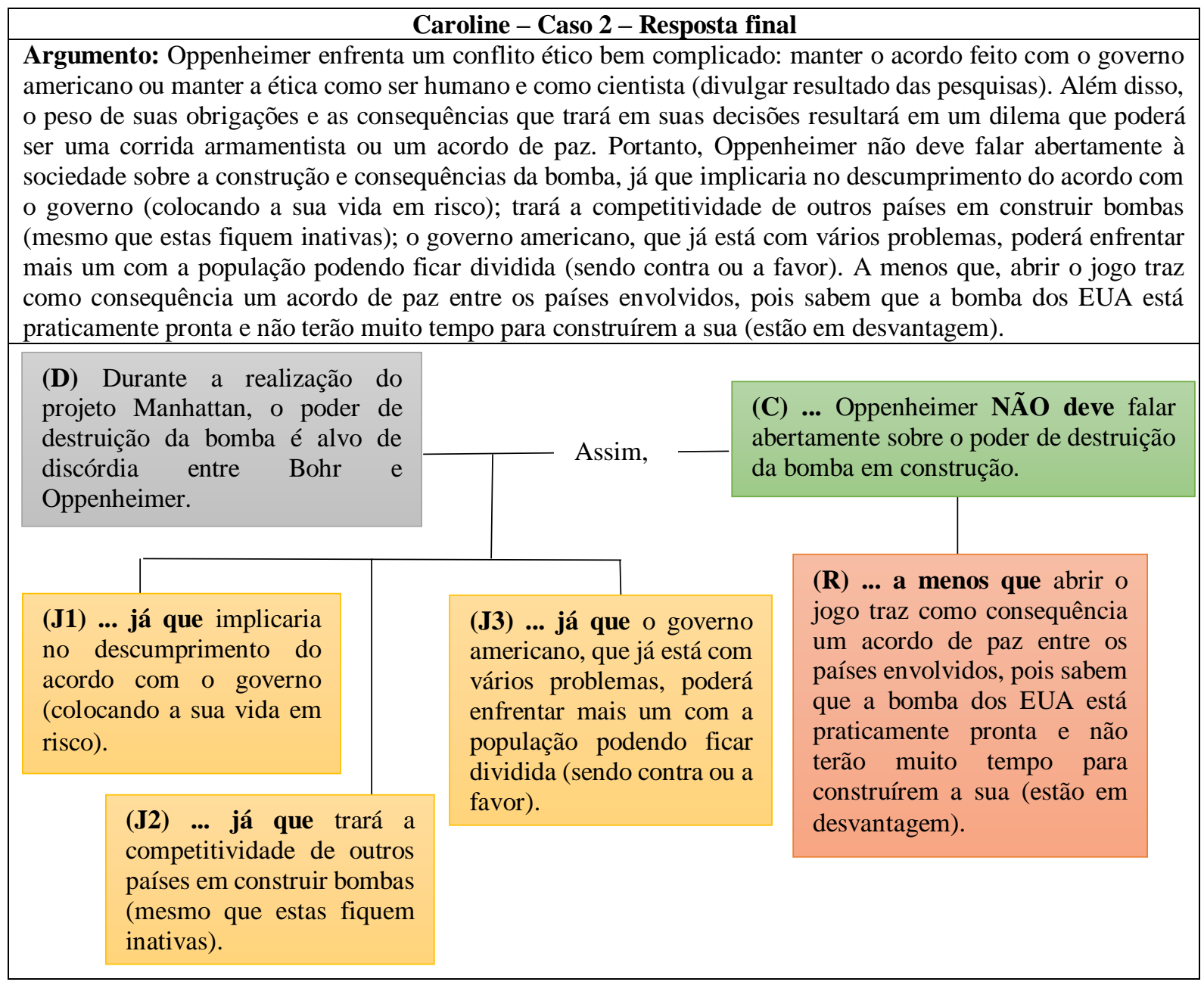

Quanto ao teor das justificativas e até mesmo da refutação apresentada no argumento final de Caroline, observamos as implicações diretas do momento de discussão, ou seja, conforme podemos constatar no Quadro 22, os elementos apresentados na resposta da licencianda surgem diante das consequências das possíveis ações de Oppenheimer para a questão, as quais foram discutidas oralmente em sala de aula. Além disso, podemos observar uma conversa direta entre os argumentos dos próprios licenciandos nas respostas fornecidas. Neste caso, por exemplo, as justificativas apresentadas por Bianca para sustentar a ideia de que Oppenheimer deve falar abertamente sobre o poder de destruição da bomba atômica em 
construção, as quais foram analisadas no Quadro 20, são, de certa forma, inseridas como refutação no argumento de Caroline, a qual é contrária à posição de Bianca.

O próximo argumento analisado diz respeito à licencianda Débora, cuja resposta inicial ao Caso 2 se encontra no Quadro 23. Verificamos na resposta dessa aluna uma combinação de elementos básicos propostos por Toulmin (2001) para sustentar a conclusão de que Oppenheimer não deve falar abertamente sobre as atividades desenvolvidas no Projeto Manhattan, ou seja, contamos inicialmente apenas com a combinação CDJ. Com relação à frequência de justificativas, Débora faz uso de duas ideias para defender o seu ponto de vista, a qual uma está relacionada ao acordo de sigilo e outro ao próprio objetivo do projeto, que é a construção da bomba atômica antes dos demais países.

Quadro 23 - Análise estrutural, na perspectiva de Toulmin (2001), do argumento inicial empregado por Débora em resposta ao Caso 2.

\section{Débora - Caso 2 - Resposta inicial}

Argumento: Pois se tratando de um projeto que foi idealizado e organizado para ser feito em sigilo, não teria sentido Oppenheimer falar abertamente sobre ele. A ideia do projeto é somente os americanos conseguirem construir a bomba e terem posse desse conhecimento. Falar abertamente dos perigos da bomba tiraria o sigilo da missão. Faz sentido o argumento de Bohr, porém seria um argumento para a não construção de bombas, não com a intenção de construí-las.

(D) Durante a realização do projeto Manhattan, o poder de destruição da bomba é alvo de discórdia entre Bohr e Oppenheimer.

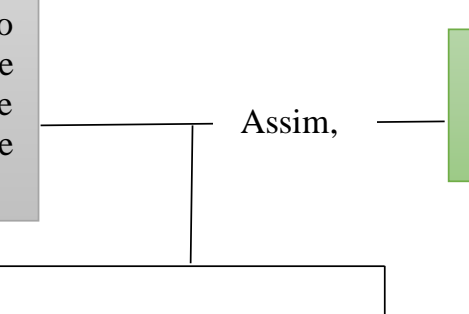

(C) ... Oppenheimer NÂO deve falar abertamente sobre o poder de destruição da bomba em construção.
(J1) ... já que se tratando de um projeto que foi idealizado e organizado para ser feito em sigilo, não teria sentido Oppenheimer falar abertamente sobre ele.
(J2) ... já que a ideia do projeto é somente os americanos conseguirem construir a bomba e terem posse desse conhecimento. Falar abertamente dos perigos da bomba tiraria o sigilo da missão. Faz sentido o argumento de Bohr, porém seria um argumento para a não construção de bombas, não com a intenção de construí-las.

Contudo, quando consideramos o argumento fornecido pela licencianda após o momento de discussão (Quadro 24), constatamos na resposta de Débora uma estrutura significativamente distinta da apresentada inicialmente. Sendo assim, ao defender novamente que Oppenheimer não deve falar abertamente sobre a bomba atômica em construção, Débora apresenta um argumento bastante semelhante estruturalmente dos apresentados pelas alunas Bianca e Caroline, ou seja, aciona mais uma justificativa, resultando em três, e emprega uma 
condição de exceção à conclusão, uma refutação. Nesse sentido, a qualidade do argumento empregado por Débora é corroborada pelas ideias de Erduran, Simon e Osborne (2004), uma vez que apresenta uma combinação de elementos CDJR, além disso a frequência de justificativas em sua resposta contribui para uma elevada complexidade do que está sendo apresentado.

Quadro 24 - Análise estrutural, na perspectiva de Toulmin (2001), do argumento final empregado por Débora em resposta ao Caso 2.

\section{Débora - Caso 2 - Resposta final}

Argumento: Segundo Bohr, e até pensando na situação atual dos governos em relação a bombas atômicas (vários governos têm bombas atômicas, porém nenhum estoura elas em cima de outra sociedade), o sim (se Oppenheimer divulgasse a bomba e os perigos dela) poderia evitar a destruição do mundo ou a destruição de alguma sociedade pois seria possível fazer acordos para que nenhum lado, nem outro, estourasse bombas. Porém, dada a época e na eminência da guerra é difícil saber se isso de fato aconteceria. O "sim", por exemplo, poderia levar os inimigos à, na verdade, construírem bombas até mais poderosas e a atacarem os americanos. Levando também em consideração que Oppenheimer tinha um acordo com o governo americano, ele estaria sendo antiético em quebrá-lo e até poderia sofrer consequências pessoais apenas em relação a isso, como até a morte ou saída de projeto.

Então, levando em consideração que não teria como se saber ao certo a consequência do "sim" e o fato do "não" trazer graves consequências a Oppenheimer, não faria sentido ele no meio do caminho quebrar o combinado. $\mathrm{O}$ que faria sentido fazer para ajudar nesse conflito dele com a sociedade (de tentar evitar a destruição dessa) é convencer o governo americano do poder e perigo da bomba e dessa forma tentar evitar que ela fosse utilizada por esse. Ou até de certa maneira tentar evitar que ela fosse de fato construída.

(D) Durante a realização do projeto Manhattan, o poder de destruição da bomba é alvo de discórdia entre Bohr e Oppenheimer.

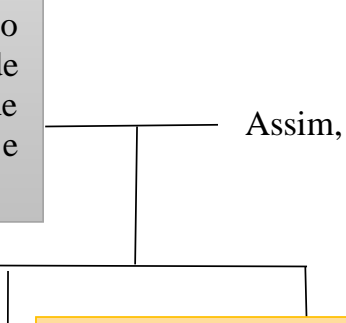

(J3) ... já que levando em

(J1) ... já que o sim (se Oppenheimer divulgasse a bomba e os perigos dela) poderia evitar a destruição do mundo ou a destruição de alguma sociedade pois seria possível fazer acordos para que nenhum lado, nem outro, estourasse bombas. Porém, dada a época e na eminência da guerra é difícil saber se isso de fato aconteceria. O "sim", por exemplo, poderia levar os inimigos à, na verdade, construírem bombas até mais poderosas e a atacarem os americanos. consideração que não teria como se saber ao certo a consequência do "sim" e o fato do "não" trazer graves consequências a Oppenheimer, não faria sentido ele no meio do caminho quebrar o combinado.

(J2) ... já que levando também em consideração que Oppenheimer tinha um acordo com o governo americano, ele estaria sendo antiético em quebrálo e até poderia sofrer consequências pessoais apenas em relação a isso, como até a morte ou saída de projeto.
(C) ... Oppenheimer NÃO deve falar abertamente sobre o poder de destruição da bomba em construção.
(R) ... a menos que para ajudar nesse conflito dele com a sociedade (de tentar evitar a destruição dessa) [Oppeheimer] convencesse o governo americano do poder e perigo da bomba e dessa forma tentasse evitar que ela fosse utilizada por esse. Ou até de certa maneira tentasse evitar que ela fosse de fato construída.

No mais, atribuímos outra vez grande parte desse aumento da complexidade do argumento à dinâmica realizada em sala de aula extraída do que é proposto por Bebeau (1995) 
para o exercício do raciocínio moral dos estudantes, isto é, à discussão realizada em busca dos aspectos morais da situação. No caso específico de Débora, observamos em seu segundo argumento, em resposta ao Caso 2, que a licencianda ao evidenciar o porquê de não atender às ideias de Bohr, apresenta uma série de considerações a respeito das consequências de cada uma das ações de Oppenheimer. Essas considerações são sintetizadas no trecho grifado presente no Quadro 24, o qual constitui a terceira justificativa empregada pela aluna.

Por fim, para as respostas do licenciando Gabriel apresentamos os Quadros 25 e 26. No que diz respeito à sua resposta inicial, esquematizada no Quadro 25, constatamos apenas uma combinação básica de elementos propostos por Toulmin (2001), isto é, CDJ. Contudo, ao observamos a frequência desses elementos, entramos em contato com três justificativas para sustentar a conclusão de que Oppenheimer não deve falar abertamente sobre o poder de destruição da bomba atômica em construção.

Quadro 25 - Análise estrutural, na perspectiva de Toulmin (2001), do argumento inicial empregado por Gabriel em resposta ao Caso 2.

\begin{tabular}{|c|c|c|}
\hline \multicolumn{3}{|c|}{ Gabriel - Caso 2 - Resposta inicial } \\
\hline \multicolumn{3}{|c|}{$\begin{array}{l}\text { Argumento: Se sim: Possibilidade de não haver guerra; possibilidade de despertar a "vontade de construir } \\
\text { bombas. Se não: possibilidade de apenas um país construir a bomba; utilização de bomba se necessário em caso } \\
\text { de ameaça. } \\
\text { Oppenheimer não deve falar abertamente sobre a bomba atômica já que: se sim, outros países que poderiam } \\
\text { nem estar envolvidos também poderiam querer construir uma bomba tendo em vista que alguém já está } \\
\text { construindo e se não, poderia se ter o caso perfeito de só um país construir e, portanto, caso uma guerra se desse } \\
\text { início possivelmente a probabilidade de menos países terem bombas seria maior e consequentemente a } \\
\text { destruição menor; se sim, países inimigos poderiam se aproveitar dessas informações para um possível contra } \\
\text { defesa ou para aprimorar os seus armamentos. }\end{array}$} \\
\hline $\begin{array}{l}\text { (D) Durante a realização do } \\
\text { projeto Manhattan, o poder de } \\
\text { destruição da bomba é alvo de } \\
\text { discórdia entre Bohr } \\
\text { Oppenheimer. }\end{array}$ & $\begin{array}{r}\mathbf{C} \\
\mathrm{ab} \\
\mathrm{da}\end{array}$ & $\begin{array}{l}\text {... Oppenheimer NÂO deve falar } \\
\text { tamente sobre o poder de destruição } \\
\text { omba em construção. }\end{array}$ \\
\hline $\begin{array}{l}\text { (J1) ... já que se sim, outros } \\
\text { países que poderiam nem } \\
\text { estar envolvidos também } \\
\text { poderiam querer construir } \\
\text { uma bomba tendo em vista } \\
\text { que alguém já está } \\
\text { construindo... }\end{array}$ & $\begin{array}{l}\text { (J2) ... já que poderia se ter o } \\
\text { caso perfeito de só um país } \\
\text { construir e, portanto, caso uma } \\
\text { guerra se desse início } \\
\text { possivelmente a probabilidade de } \\
\text { menos países terem bombas seria } \\
\text { maior e consequentemente a } \\
\text { destruição menor ... }\end{array}$ & $\begin{array}{l}\text { (J3) ... já que se sim, } \\
\text { países inimigos poderiam } \\
\text { se aproveitar dessas } \\
\text { informações para um } \\
\text { possível contra defesa ou } \\
\text { para aprimorar os seus } \\
\text { armamentos. }\end{array}$ \\
\hline
\end{tabular}

Após as considerações levantadas oralmente em sala aula, verificamos pelo que está exposto no Quadro 26, que o licenciando Gabriel manteve a combinação básica de elementos apresentados anteriormente, ou seja, continuou a apresentar somente CDJ. Contudo, assim como observado para a licencianda Alice, identificamos a inclusão de mais uma justificativa, 
aumentando a sua frequência na resposta fornecida pelo aluno à questão narrada pelo Caso 2. Nessa perspectiva, podemos atribuir um pequeno aumento da complexidade do argumento e, consequentemente, da qualidade do que é apresentado por Gabriel.

Quadro 26 - Análise estrutural, na perspectiva de Toulmin (2001), do argumento final empregado por Gabriel em resposta ao Caso 2.

\section{Gabriel - Caso 2 - Resposta final}

Argumento: O poder de destruição de uma bomba atômica é gigantesco e pensar na possibilidade de várias bombas explodindo em nosso planeta se torna algo preocupante para o destino da humanidade. Oppenheimer não deve falar abertamente sobre a construção e o poder de destruição da bomba já que evitaria que outros países, que podem ou não estar envolvidos com a guerra, se motivem a se armar sabendo que alguém está armado, além disso, países inimigos poderiam se aproveitar dessas informações para aprimorar seus equipamentos e ou para se defender. Portanto, Oppenheimer não deve falar abertamente sobre a bomba, pois a probabilidade de menos países terem bombas é maior e consequentemente menos poder de destruição cairá sobre a Terra.

(D) Durante a realização do projeto Manhattan, o poder de destruição da bomba é alvo de discórdia entre Bohr e Oppenheimer.

e

(C) ... Oppenheimer NÂO deve falar abertamente sobre o poder de destruição da bomba em construção.
(J1) ... já que $\mathrm{O}$ poder de destruição de uma bomba atômica é gigantesco e pensar na possibilidade de várias bombas explodindo em nosso planeta se torna algo preocupante para o destino da humanidade.
(J2) ... já que evitaria que outros países, que podem ou não estar envolvidos com a guerra, se motivem a se armar sabendo que alguém está armado ...
(J3) ... já que países inimigos poderiam se aproveitar dessas informações para aprimorar seus equipamentos e ou para se defender.
(J4) ... já que probabilidade de menos países terem bombas é maior e consequentemente menos poder de destruição cairá sobre a Terra.

Contudo, salientamos, principalmente no que diz respeito aos argumentos de Gabriel e Alice, o efeito da discussão realizada em sala de aula sobre os mesmos, uma vez que, parece haver, conforme constatado, uma busca exclusiva durante o processo de discussão por justificativas. Essa busca ganha espaço ao passo que quantitativamente falando, na concepção desses futuros professores, um maior número de justificativas implicaria em um melhor argumento independentemente dos demais elementos.

Dessa forma, a partir do que foi exposto neste subtópico verificamos um aumento significativo da qualidade dos argumentos apresentados pelos licenciandos diante da questão narrada pelo Caso 2 comparativamente ao Caso 1. Embora não tenhamos identificados qualificadores modais, ou o emprego em conjunto de backings e refutações, constatamos uma maior variedade dos elementos propostos por Toulmin (2001), bem como uma maior frequência 
de justificativas, as quais também contribuem para um aumento da qualidade estrutural dos argumentos.

A complexidade das respostas apresentadas até então está em consonância com o que vem sendo identificado nos diferentes trabalhos direcionados a investigar a argumentação de professores (SIMON, ERDURAN e OSBORNE, 2006), futuros professores (KAYA, 2013) e até mesmo bacharelandos em química (SÁ, KASSBOEHMER e QUEIROZ, 2014) a partir do Modelo de Toulmin (2001). Nestes diferentes estudos, os autores têm identificado que os sujeitos investigados, ao argumentarem, apresentam grandes dificuldades em empregar elementos que conferem uma maior complexidade em suas respostas, isto é, backings refutações e qualificadores modais. Em suma, tais pesquisadores têm observado um predomínio nas respostas de professores, futuros professores e bacharelandos em química, da combinação básica de elementos pertencentes ao TAP (TOULMIN, 2001), ou seja, CDJ. Ainda assim, os resultados obtidos e discutidos até então com relação à qualidade estrutural dos argumentos empregados por licenciandos em química diante de QSC, suscitam um trabalho mais significativo na formação inicial envolvendo esse processo que, assim como JímenezAleixandre (2011), consideramos ser parte epistêmica central da atividade científica.

Esse trabalho mais significativo, por sua vez, deve permitir que os futuros professores que irão atuar na educação básica compreendam e valorizem elementos para além das justificativas, que também contribuam para a qualidade de colocações apresentadas diante de questões controversas e que exigem uma tomada de decisão. Nessa perspectiva, com base na importância da argumentação e da sua relação com a prática científica, retomamos a afirmação de Archila (2012), o qual coloca: "um professor que aprende a argumentar, ensina para que se aprenda argumentando" (ARCHILA, 2012, p. 368, tradução nossa).

Outro aspecto interessante que emerge da análise empreendida, diz respeito à metodologia adotada para a abordagem dos casos argumentativos na formação inicial de professores. É possível perceber a partir dos argumentos, por exemplo, a validade de momentos como a reflexão dialogada acerca das próprias respostas para o processo de argumentação. Assim, verificamos que por vezes, aspectos morais inicialmente negligenciados pelos licenciandos, como as consequências das possíveis ações apresentadas para o caso e as obrigações dos protagonistas, se convertem principalmente em justificativas responsáveis por atribuir certa complexidade aos argumentos finais construídos pelos alunos. 
Caso 3

Prosseguindo a análise dos argumentos dos futuros professores, consideramos agora as respostas fornecidas ao Caso 3, presente no APÊNDICE H, o qual ao pensarmos em ciência e bomba atômica, parece-nos uma das principais QSC que suscitam a argumentação. Assim sendo, este caso apresentava aos licenciandos algumas das consequências dos lançamentos das bombas atômicas nas cidades japonesas de Hiroshima e Nagasaki, e solicitava-os ao final, a responder se os cientistas, de posse de conhecimentos como o da fissão nuclear, deveriam ter construído um armamento como a bomba atômica. Nesse sentido, consideramos como o DADO desse caso: Após as descobertas envolvendo a fissão nuclear e em meio a $2^{\text {a }}$ Guerra Mundial, a construção de uma bomba atômica se torna viável. Como possíveis CONCLUSÕES temos: os cientistas deveriam fazer a bomba atômica ou os cientistas não deveriam fazer a bomba atômica. Isto exposto apresentamos a seguir as análises dos argumentos empregados pelos licenciandos em resposta ao caso em questão, a começar por Alice cuja resposta inicial se encontra no Quadro 27.

Quadro 27 - Análise estrutural, na perspectiva de Toulmin (2001), do argumento inicial empregado por Alice em resposta ao Caso 3.

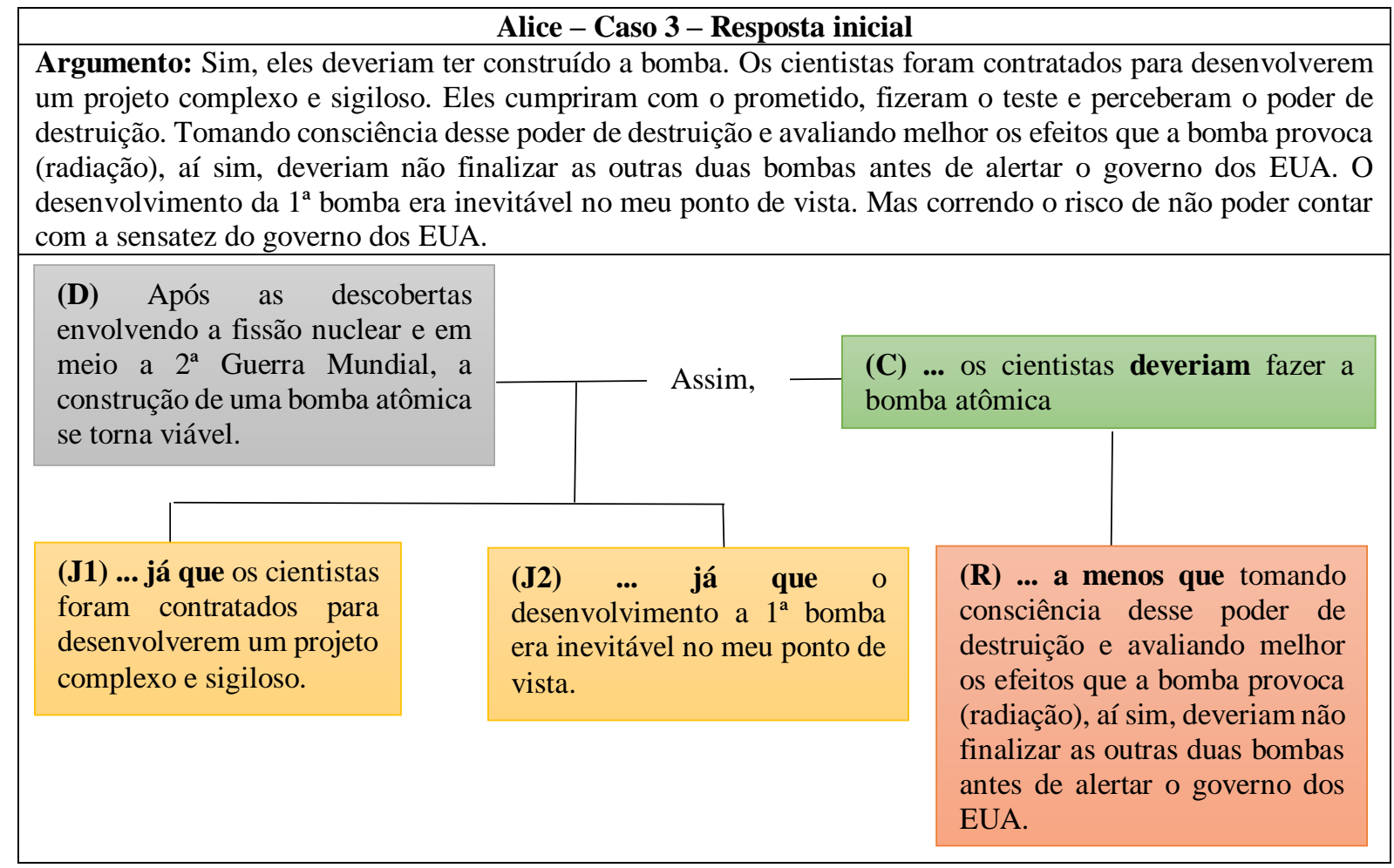

Pela primeira vez Alice faz uso em seu argumento de uma refutação, o que aumenta a complexidade da resposta em relação às anteriores. Isto é, ao afirmar que os cientistas deveriam ter construído a bomba atômica, na interpretação de Alice uma condição de exceção seria a 
tomada de consciência a partir da realização do teste Trinity. Sendo assim observamos como combinação dos elementos em sua resposta CDJR com o emprego de duas justificativas.

Contudo, a partir da refutação apresentada, observamos que a licencianda não considerou "Trinity" como já sendo a primeira bomba atômica como sugere o título da HQ e, assim, verificamos uma interpretação diferente da que prevíamos a princípio para o Caso 3. A futura professora ponderou para a resolução do dilema a construção da bomba atômica a partir da realização do teste Trinity e não como resultado da descoberta do processo de fissão nuclear. Essa constatação demonstra a multiplicidade de sentidos possíveis da leitura, a qual, por sua vez, consideramos nos momentos de discussão, como poderemos ver pelo argumento apresentado por Alice na segunda etapa da dinâmica estabelecida em sala de aula para a aplicação e resolução do Caso 3.

Quando analisamos a resposta fornecida pela licencianda após a discussão oral conduzida pela docente em busca dos aspectos morais da situação narrada (Quadro 28), verificamos que a complexidade que havia sido elevada no argumento inicial comparativamente àqueles empregados para os outros casos, foi novamente reduzida. Essa redução do grau de estruturação ocorre quando consideramos exclusivamente a combinação de elementos na perspectiva de Erduran, Simon e Osborne (2004). Nesse contexto, identificamos na resposta final de Alice o uso apenas dos elementos básicos propostos por Toulmin (2001), culminando na combinação CDJ. Contudo, ao analisarmos o argumento de acordo com as ideias apresentadas por Sá, Kasseboehmer e Queiroz (2014), isto é, consoante a frequência de justificativas e/ou backings apresentados, observamos um aumento de duas para quatro justificativas.

Assim sendo, ao afirmar agora que os cientistas não deveriam ter construído a bomba atômica, ou seja, houve uma mudança de posição, Alice conclui com base no que para ela, mediante aspectos levantados no momento de discussão, significaria participar ou não do Projeto Manhattan. Dessa forma, considerando as consequências de cada ação, a licencianda encontrou quatro justificativas que sustentassem esse novo posicionamento, ou seja, mesmo a refutação sendo um indicador da qualidade do argumento na perspectiva de autores como Erduran, Simon e Osborne (2004), o emprego quantitativamente maior de justificativas foi fundamental para a mudança de opinião. 
Quadro 28 - Análise estrutural, na perspectiva de Toulmin (2001), do argumento final empregado por Alice em resposta ao Caso 3.

\begin{tabular}{|c|c|c|c|}
\hline \multicolumn{4}{|c|}{ Alice - Caso 3 - Resposta final } \\
\hline \multicolumn{4}{|c|}{$\begin{array}{l}\text { Argumento: Conflito: Prosseguir ou Desistir. Prosseguir significa cumprir com o contrato, mas também } \\
\text { desenvolver o conhecimento científico que pode ser usado tanto par a destruição ou para o bem (como hoje em } \\
\text { dia que existem as usinas nucleares). Também significa colaborar com a morte de muitas pessoas inocentes. } \\
\text { Desistir significa arriscar que os inimigos atacassem os aliados resultando na morte de seus conterrâneos, mas } \\
\text { também não participar no desenvolvimento de uma arma tão letal. } \\
\text { Como seres humanos eles não deveriam ter participado deste projeto e como cientistas poderiam ter escolhido } \\
\text { o desenvolvimento destes conhecimentos em seus próprios laboratórios para outros fins que não fosse o da } \\
\text { destruição de vidas humanas inocentes. Pois uma vez desenvolvida a bomba, seria inevitável que o governo } \\
\text { norte-americano não a utilizasse. }\end{array}$} \\
\hline \multicolumn{2}{|c|}{$\begin{array}{l}\text { (D) Após as descobertas } \\
\text { envolvendo a fissão nuclear e em } \\
\text { meio a } 2^{\mathrm{a}} \text { Guerra Mundial, a } \\
\text { construção de uma bomba atômica } \\
\text { se torna viável. }\end{array}$} & \multicolumn{2}{|c|}{$\begin{array}{l}\text { (C) ... os cientistas NÃO deveriam fazer } \\
\text { a bomba atômica }\end{array}$} \\
\hline $\begin{array}{l}\text { (J1) ... já que significa } \\
\text { colaborar com a morte } \\
\text { de muitas pessoas } \\
\text { inocentes. }\end{array}$ & $\begin{array}{lr}\text { (J2) ... já } & \text { que } \\
\text { significa } & \text { não } \\
\text { participar } & \text { no } \\
\text { desenvolvimento } \\
\text { de uma arma tão } \\
\text { letal. }\end{array}$ & $\begin{array}{l}\text { (J3) ... já que Como seres } \\
\text { humanos eles não deveriam } \\
\text { ter participado deste projeto e } \\
\text { como cientistas poderiam ter } \\
\text { escolhido o desenvolvimento } \\
\text { destes conhecimentos em seus } \\
\text { próprios laboratórios para } \\
\text { outros fins que não fosse o da } \\
\text { destruição de vidas humanas } \\
\text { inocentes. }\end{array}$ & $\begin{array}{l}\text { (J4) ... já que } \\
\text { uma vez } \\
\text { desenvolvida a } \\
\text { bomba, seria } \\
\text { inevitável que } \\
\text { o governo norte } \\
\text { americano não } \\
\text { a utilizasse. }\end{array}$ \\
\hline
\end{tabular}

Com relação à licencianda Bianca, suas respostas estão esquematizadas nos Quadros 29 e 30. A partir do que é colocado inicialmente pela aluna, isto é, no Quadro 29, verificamos, assim como na maioria dos argumentos apresentados na resolução do Caso 1, o emprego de apenas a combinação básica de elementos propostos por Toulmin, (2001), isto é, CDJ. Dessa forma, comparativamente aos argumentos fornecidos para o Caso 2, houve uma redução da complexidade do que é apresentado pela aluna. Contudo, um aspecto relevante da resposta fornecida pela licencianda é que ela foi a única que utilizou em seu argumento questões abordadas anteriormente. Isto é, para este caso específico, ao final da sua colocação Bianca propõe como possível solução para o conflito a resposta "sim" ao Caso 2, ou seja, Oppenheimer, naquela situação, quando das considerações de Bohr, deveria ter falado abertamente sobre o poder da bomba atômica em construção. 
Quadro 29 - Análise estrutural, na perspectiva de Toulmin (2001), do argumento inicial empregado por Bianca em resposta ao Caso 3.

\section{Bianca - Caso 3 - Resposta inicial}

Argumento: Apesar da destruição e efeitos devastadores causados pela bomba atômica, ela serviu para que o governo americano ganhasse a guerra. Talvez, se a bomba não tivesse sido criada pelos americanos, mais tarde alguém de outra nação tivesse a mesma ideia e então, o poder estaria em outras mãos. O que poderia ter feito é divulgar a bomba e falado dos efeitos e assim tentar um acordo antes de utilizá-la.

(D) Após as descobertas envolvendo a fissão nuclear e em meio a $2^{\text {a }}$ Guerra Mundial, a construção de uma bomba atômica se torna viável.

Assim,

(C) ... os cientistas deveriam fazer a bomba atômica
(J1) ... já que apesar da destruição e feitos devastadores causados pela bomba atômica, ela serviu para que o governo americano ganhasse a guerra.
(J2) ... já que talvez, se a bomba não tivesse sido criada pelos americanos, mais tarde alguém de outra nação tivesse a mesma ideia e então, o poder estaria em outras mãos.

A busca por soluções alternativas para além das duas possíveis ações apresentadas no caso foi bastante comum dentre os licenciandos, e apesar de ser bem-vinda e sugerir a capacidade de propor soluções a questões controversas e de natureza sociocientífica, ressalta a dificuldade do processo de tomada de decisão e da consequente argumentação quando diante de um caso estruturado em que o aluno é apresentado há um número limitado de possibilidades.

De certa forma, essa observação se relaciona com as ideias de Osborne, Erduran e Simon (2004), os quais apresentam em seu estudo uma diferenciação da qualidade dos argumentos empregados por professores diante de um contexto sociocientífico e de um contexto científico. Os autores, ao analisar a qualidade dos argumentos empregados pelos professores por eles investigados, salientam:

Por fim, nossos dados fornecem uma indicação clara de que apoiar e desenvolver a argumentação em um contexto científico é significativamente mais difícil do que possibilitar a argumentação em um contexto sociocientífico. A nossa opinião é que a qualidade da argumentação depende de um corpo apropriado de conhecimentos que podem constituir os dados e garantias dos argumentos de um indivíduo. No contexto das questões sociocientíficas, os alunos podem recorrer a ideias e conhecimentos desenvolvidos informalmente por meio das suas próprias experiências no mundo da vida e dos seus valores éticos. Em contraste, o argumento em um contexto científico requer um conhecimento muito específico do fenómeno em questão e, pelo menos, uma noção dos critérios para avaliar as evidências científicas (OSBORNE, ERDURAN e SIMON, 2004, p. 1015, tradução nossa).

Nessa perspectiva, por exemplo, ao assumirmos que QSC são geralmente não estruturadas de modo que os alunos podem recorrer a ideias e conhecimentos desenvolvidos informalmente, em referência ao raciocínio informal, seria de se esperar a inclusão de elementos para além daqueles apresentados no caso narrado. Contudo, ao apresentarmos tais questões na 
forma como Bebeau (1995) utiliza em seu material, estamos, de certa forma, semelhantemente a problemas de natureza científica, estruturando os casos e fornecendo apenas duas possibilidades de ações a um problema dado de antemão, o que aumenta assim a dificuldade do processo de argumentação e obriga o indivíduo a considerar os mais variados aspectos éticos e morais pertinentes ao caso em estudo.

Após a discussão comumente realizada para cada caso, observamos conforme Quadro 30, que o argumento final da licencianda apresenta praticamente a mesma estrutura, salvo a inclusão de uma terceira justificativa. Sendo assim identificamos mais uma vez a combinação CDJ, no entanto agora com três justificativas. A pouca complexidade observada pode ser resultado da busca por soluções alternativas, nesse sentido, uma vez que a solução ideal para o Caso 3 já foi abordada, para Bianca, no Caso 2, não houve uma busca por mais elementos que contribuíssem para aumentar a qualidade do que estava sendo apresentado para defender sua posição.

Quadro 30 - Análise estrutural, na perspectiva de Toulmin (2001), do argumento final empregado por Bianca em resposta ao Caso 3.

Bianca - Caso 3 - Resposta final

Argumento: Fazer a bomba trouxe ao governo americano uma certa segurança e poder diante dos seus rivais. O fato dela já existir poderia pressionar os adversários a entrarem em um acordo. Apesar de todos os envolvidos no projeto já terem uma noção do poder de destruição da bomba que queriam desenvolver, o teste feito mostrou de fato o poder de destruição que esta poderia causar. A partir daí, poderiam usar a bomba como ameaça e não como um efeito surpresa. Caso a ameaça não intimidasse os líderes rivais, a bomba poderia ser usada. Até porque poderiam correr o risco da bomba ser criada pelos rivais.

(D) Após as descobertas envolvendo a fissão nuclear e em meio a $2^{a}$ Guerra Mundial, a construção de uma bomba atômica se torna viável.

Assim,

(C) ... ... os cientistas deveriam fazer a bomba atômica

(J1) ... já que fazer a bomba trouxe ao governo americano uma certa segurança e poder diante dos seus rivais. O fato dela já existir poderia pressionar os adversários a entrarem em um acordo.
(J2) ... já que apesar de todos os envolvidos no projeto já terem uma noção do poder de destruição da bomba que queriam desenvolver, o teste feito mostrou de fato o poder de destruição que esta poderia causar.
(J3) ... já que poderiam correr o risco da bomba ser criada pelos rivais.

Prosseguindo com a análise, agora dos argumentos fornecidos por Caroline, identificamos, em resposta ao Caso 3 (Quadro 31), uma colocação pouco complexa pela licencianda, cuja combinação de elementos presentes é a mais básica para um argumento válido (TOULMIN, 2001), isto é, conta apenas com CDJ e uma única justificativa. Porém, assim como já mencionado para essa licencianda, Caroline é um dos poucos alunos que fazem menções a 
informações presentes no trecho extraído da HQ, é o caso da passagem: "funcionou como seus cálculos previam", o que faz referência à:

Foi detonada quando deveria, explodiu com a força esperada ... e consumiu cidades e almas num lampejo de calor e radiação, conforme os cálculos dos cientistas que trabalharam em Los Alamos. Para ser mais exato, a bomba fez mais do que os seus criadores previram (FETTER-VORM, 2013, p. 133).

Quadro 31 - Análise estrutural, na perspectiva de Toulmin (2001), do argumento inicial empregado por Caroline em resposta ao Caso 3.

\begin{tabular}{|c|c|c|}
\hline \multicolumn{3}{|c|}{ Caroline - Caso 3- Resposta inicial } \\
\hline \multicolumn{3}{|c|}{$\begin{array}{l}\text { Argumento: Os cientistas não deveriam ter construído a bomba atômica, pois por serem pessoas estudadas } \\
\text { sabem listar os prós e contras que esse Projeto traria para o mundo, tanto é que funcionou como seus cálculos } \\
\text { previam. Cientistas costumam querer prestígio e ser reconhecido pelo seu bom trabalho, porém isso vale mais } \\
\text { do que milhares de vidas? }\end{array}$} \\
\hline \multirow{2}{*}{$\begin{array}{l}\text { (D) Após as descobertas envolvendo } \\
\text { a fissão nuclear e em meio a } 2^{a} \text { Guerra } \\
\text { Mundial, a construção de uma bomba } \\
\text { atômica se torna viável. }\end{array}$} & \multirow[b]{2}{*}{ Assim, } & \multirow[b]{2}{*}{$\begin{array}{l}\text { (C) ... os cientistas } \mathbf{N} \tilde{A} \mathbf{O} \text { deveriam fazer } \\
\text { a bomba atômica }\end{array}$} \\
\hline & & \\
\hline & \multicolumn{2}{|c|}{$\begin{array}{l}\text { (J1) ... já que [os cientistas] por serem pessoas } \\
\text { estudadas sabem listar os prós e contras que } \\
\text { esse Projeto traria para o mundo, tanto é que } \\
\text { funcionou como seus cálculos previam. }\end{array}$} \\
\hline
\end{tabular}

Essas menções ao texto extraído da HQ denota a contribuição da leitura para a construção dos argumentos dos futuros professores, o que esperávamos, a princípio, ser maior do que a observada. Essa hipótese levantada a respeito da relação entre texto e processo de argumentação emerge dos recursos adotados pelo autor da narrativa e identificados na análise especialmente da forma da HQ, os quais, podendo auxiliar na tomada de decisão, foram empregados mediante a busca de uma didatização das informações veiculadas na narrativa.

Um exemplo explícito em que tais recursos foram empregados de modo a suscitar uma conversa direta entre autor e interlocutor, que poderia se constituir em um argumento favorável a construção das bombas atômicas e que aparece timidamente nas respostas de alguns licenciandos, é o que se apresenta na Figura 39. Nesse sentido, o argumento de que os cientistas deveriam construir a bomba atômica com a finalidade primária de ganhar a guerra contra a Alemanha se dá na HQ por meio do primeiro plano, que como evidenciado pela análise da forma empreendida neste estudo sinaliza uma estratégia de apelo adotada pelo autor diante da abordagem polêmica da temática. Essa informação por exemplo, poderia ser associada a conhecimentos históricos básicos que apoiariam esse trecho enquanto justificativa, isto é, a construção de um armamento nuclear americano se torna interessante para a vitória contra a 
Alemanha, cujo regime nazista tem promovido horrores dos mais variados contra os seres humanos.

Após a discussão, e mediante o contato com novas ideias e até mesmo interpretações ao caso, como a apresentada por Alice, verificamos, conforme explícito no Quadro 32, um maior grau de estruturação no argumento final empregado por Caroline, cuja combinação de elementos é CDJR. Ou seja, para além de acrescentar duas justificativas aumentando a frequência destas, a futura professora apresenta, com base na interpretação de Alice, uma refutação à conclusão assumida, a qual consiste em afirmar que os cientistas não deveriam ter construído a bomba atômica. Assim sendo, a condição de exceção explicitada para essa conclusão na resposta de Caroline diz respeito a uma possível tomada de consciência pelos cientistas após a realização do teste Trinity. Além disso, observamos mais uma vez menções diretas e indiretas a trechos presentes na HQ, o que evidencia para essa licencianda, a contribuição da leitura no processo de argumentação. 
Quadro 32 - Análise estrutural, na perspectiva de Toulmin (2001), do argumento final empregado por Caroline em resposta ao Caso 3.

\section{Caroline - Caso 3 - Resposta final}

Argumento: Os cientistas não deveriam fazer a bomba atômica. Sabe-se que o conflito principal é em torno de empregar o conhecimento científico para a destruição de milhares de pessoas, ou não empregar e presenciar a população de seus país continuar morrendo perante a guerra. Devemos refletir que todo cientista, ao aceitar fazer parte de um projeto, analisa os prós e contras, estuda os materiais que poderão ser utilizados (no caso, nos referimos aos elementos química) e como esse projeto trará impactos positivos à sociedade. De fato, construir uma bomba resulta em muito prestígio para os envolvidos ao servir seu país, entretanto todos os cientistas que aceitaram fazer parte do Projeto Manhattan sabiam o principal objetivo que propusera o governo a financiar o Projeto (a construção da bomba). E eles não são inocentes em acreditar que o governo os chamaram para construírem uma bomba que ficaria inativa. No fundo eles sabiam que seu trabalho resultaria em uma matança (seja de civis ou militares). Portanto, o remorso que sentiriam posteriormente poderia ser evitado se eles não aceitassem fazer parte do Projeto Manhattan, a menos que eles já estivessem dentro do Projeto e visto, pelo teste, o resultado de seus conhecimentos, mas ainda sim eles poderiam optar por desistir de ser "cúmplice" da catástrofe nuclear (mesmo que isso custasse a sua vida e de suas famílias).

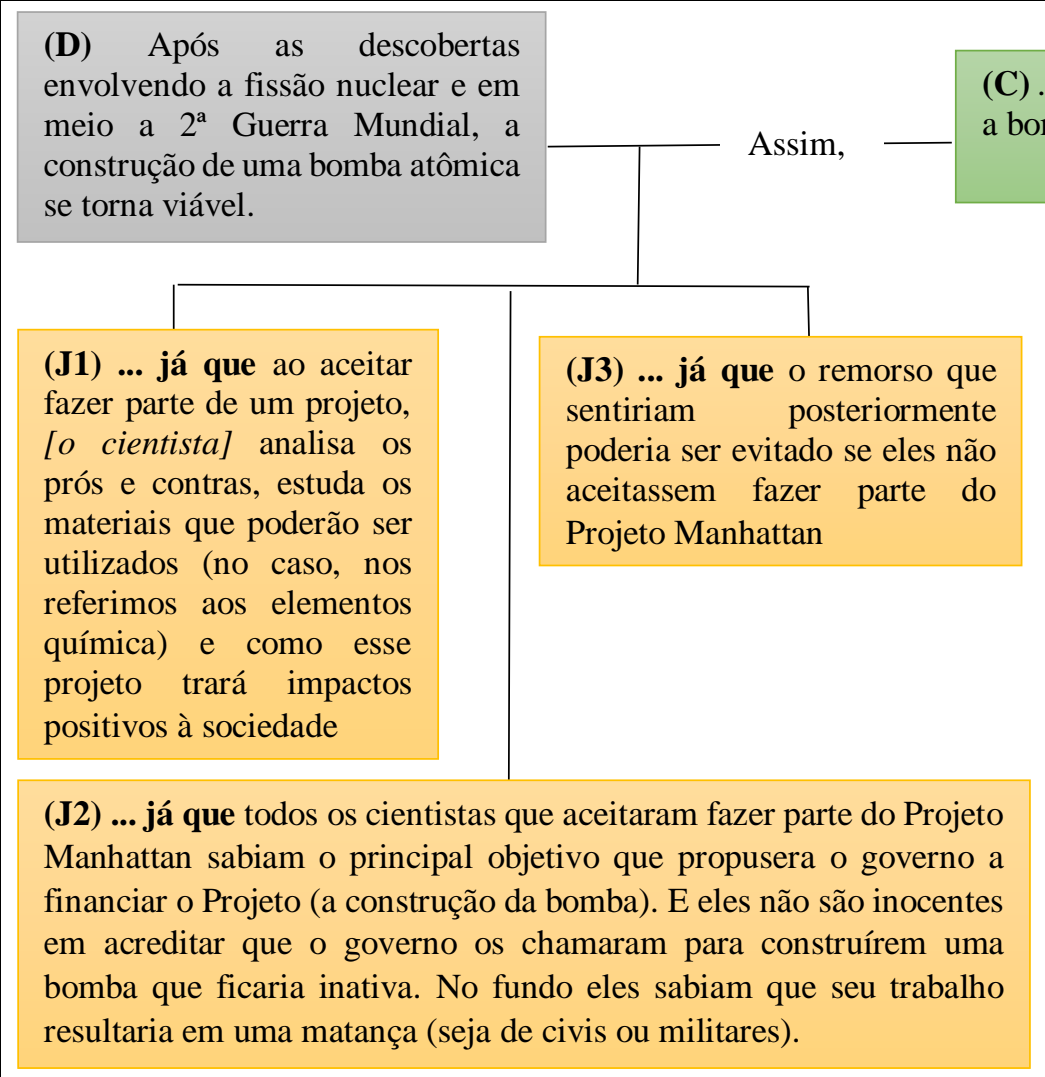

Prosseguindo a análise dos argumentos construídos pelos licenciados em resposta ao Caso 3, temos nos Quadros 33 e 34, as respostas fornecidas pela licencianda Débora. Ao analisarmos o que é apresentado inicialmente pela aluna em questão referente ao Caso 3, identificamos mais uma vez em argumento pouco elaborado na perspectiva de Erduran, Simon e Osborne (2004), dado que a futura professora faz uso apenas dos elementos básicos de um argumento propostos por Toulmin (2001) culminando na combinação simples CDJ. No entanto, salientamos mais uma vez, que em nossa concepção, assim como na de autores como Sá, 
Kasseboehmer e Queiroz (2014), a frequência de justificativas e/ou backings pode atribuir diferentes graus de complexidade aos argumentos. Nessa perspectiva, embora tenhamos observado a combinação simples CDJ, ao fazer uso de três justificativas para sustentar a ideia de que os cientistas não deveriam ter construído a bomba atômica, Débora confere ao seu texto certa complexidade.

Quadro 33 - Análise estrutural, na perspectiva de Toulmin (2001), do argumento inicial empregado por Débora em resposta ao Caso 3.

\section{Débora - Caso 3 - Resposta inicial}

Argumento: Tendo-se conhecimento dos estragos que uma bomba atômica pode causar, os cientistas não deveriam ter seguido em frente no seu projeto. Sem a ação dos cientistas uma bomba atômica nunca poderia ter sido criada, por mais que os militares quisessem e almejassem sua construção. É verdade que os cientistas não tinham pleno conhecimento da ação tão destruidora da bomba (o fato de gerar além de grande quantidade de calor também radiação) porém, tal fato é mais um motivo para se ter mais estudos sobre a bomba e seus efeitos antes de sua construção.

(D) Após as descobertas envolvendo a fissão nuclear e em meio a $2^{a}$ Guerra Mundial, a construção de uma bomba atômica se torna viável. Assim, (C) ... os cientistas NÃO deveriam fazer a bomba atômica

(J1) ... já que se tendo conhecimento dos estragos que uma bomba atômica pode causar ...
(J2) ... já que sem a ação dos cientistas uma bomba atômica nunca poderia ter sido criada, por mais que os militares quisessem e almejassem sua construção.
(J3) ... já que os cientistas não tinham pleno conhecimento da ação tão destruidora da bomba (o fato de gerar além de grande quantidade de calor também radiação) ...

Com relação à resposta fornecida por Débora em uma segunda solicitação (Quadro 34), verificamos que a discussão realizada surtiu pouco efeito no que tange à estrutura do argumento, sendo assim, mantendo três justificativas, mesmo que mais desenvolvidas, estruturalmente ainda tomamos contato com uma combinação básica de elementos (CDJ). Apesar de inferirmos nesse momento que a discussão não afetou a qualidade estrutural do argumento fornecido pela licencianda, ressaltamos que a resposta apresentada por Débora, assim como da maioria dos futuros professores nos diferentes momentos ao longo dos três casos, está mais elaborada no que tange aos aspectos morais próprios de cada situação narrada, uma vez que estes foram amplamente discutidos durante as atividades. 
Quadro 34 - Análise estrutural, na perspectiva de Toulmin (2001), do argumento final empregado por Débora em resposta ao Caso 3.

\section{Débora - Caso 3 - Resposta final}

Argumento: Na época do início do Projeto Manhattan, os cientistas já tinham certo conhecimento que estariam entrando em um grande projeto para a construção de uma das bombas mais destruidoras do mundo. Talvez tenham aceitado participar do projeto pelo grande desafio, pela busca do conhecimento ou por realmente querer ajudar seu país a acabar com a guerra. Porém, ao que parece, eles não tinham um conhecimento tão profundo de outras consequências que a bomba atômica pudesse causar, que é a alta radiação emitida, consequência até mais grave que a já alta destruição da bomba. Talvez, com a posse de tal conhecimento alguns cientistas até desistissem da construção da bomba. Porém, a falta de tal conhecimento não deixou de ser uma falha dentro da própria pesquisa realizada, visto que elementos radioativos já eram conhecidos. Outro fato que pode ter atrapalhado a obtenção desse conhecimento pelos cientistas é a pressão para que a bomba ficasse pronta. Pensando pela ética pessoal, um cientista nunca deveria usar seu conhecimento para construção de um artefato que certamente mataria milhões de pessoas, mas daí entraríamos em uma questão ética mais complicada, do por que humanos se matam a vista de poder, ao invés de se ajudarem. No mundo ideal, que eu penso, a bomba nunca deveria ser construída e guerras seriam desnecessárias.

\begin{tabular}{|c|c|c|c|}
\hline \multicolumn{2}{|c|}{$\begin{array}{l}\text { (D) Após as descobertas envolvendo } \\
\text { a fissão nuclear e em meio a } 2^{\mathrm{a}} \\
\text { Guerra Mundial, a construção de uma } \\
\text { bomba atômica se torna viável. }\end{array}$} & Assim, & $\begin{array}{l}\text { (C) ... ... os cientistas NÃO deveriam } \\
\text { fazer a bomba atômica }\end{array}$ \\
\hline $\begin{array}{l}\text { (J1) ... já que na época do } \\
\text { início do Projeto } \\
\text { Manhattan, os cientistas já } \\
\text { tinham certo conhecimento } \\
\text { que estariam entrando em } \\
\text { um grande projeto para a } \\
\text { construção de uma das } \\
\text { bombas mais destruidoras } \\
\text { do mundo. }\end{array}$ & $\begin{array}{l}(\mathbf{J} 2) \text {. } \\
\text { não ti } \\
\text { profu } \\
\text { conse } \\
\text { atômi } \\
\text { alta } \\
\text { conse } \\
\text { a já a }\end{array}$ & $\begin{array}{l}\text { to que parece, eles } \\
\text { conhecimento tão } \\
\text { de outras } \\
\text { que a bomba } \\
\text { se causar, que é a } \\
\text { ção emitida, } \\
\text { té mais grave que } \\
\text { ição da bomba. }\end{array}$ & $\begin{array}{l}\text { (J3) ... já que pensando pela ética } \\
\text { pessoal, um cientista nunca } \\
\text { deveria usar seu conhecimento } \\
\text { para construção de um artefato } \\
\text { que certamente mataria milhões } \\
\text { de pessoas. }\end{array}$ \\
\hline
\end{tabular}

No que diz respeito à resolução do Caso 3 pelo licenciando Gabriel, a estrutura de suas respostas, as quais estão esquematizadas nos Quadros 35 e 36, apresentam um nível de complexidade interessante. Em um momento inicial (Quadro 35), ao defender a ideia de que os cientistas deveriam ter construído um armamento nuclear naquela época, Gabriel faz uso de duas justificativas, das quais uma ainda é apoiada em um backing. Dessa forma, identificamos no argumento inicial do aluno a combinação de elementos CDJB cuja frequência de justificativas/backings é dois e um respectivamente. 
Quadro 35 - Análise estrutural, na perspectiva de Toulmin (2001), do argumento inicial empregado por Gabriel em resposta ao Caso 3.

\section{Gabriel - Caso 3 - Resposta inicial}

Argumento: Sim, os cientistas deveriam fazer a bomba atômica já que na construção e no desenvolvimento dessa arma, muito conhecimento foi produzido graça a grande quantidade de cientistas envolvidos que dificilmente teriam motivação para tal reunião. Além disso, a decisão de lançar uma bomba não é decidida por eles, e sim ao governo, ou seja, a culpa das consequências de um ataque com essas armas não deve cair sobre eles.

(D) Após as descobertas envolvendo a fissão nuclear e em meio a $2^{\mathrm{a}}$ Guerra Mundial, a construção de uma bomba atômica se torna viável.

Assim, (C) ... os cientistas deveriam fazer a bomba atômica

(J1) ... já que na construção e no desenvolvimento dessa arma, muito conhecimento foi produzido ...

(B1) ... por conta da grande quantidade de cientistas envolvidos que dificilmente teriam motivação para tal reunião.

Com relação ao backing empregado, este é derivado da própria leitura da HQ que menciona, por exemplo, conforme evidenciado no trecho que constitui o Caso 1, que Los Alamos foi o lar das mentes mais brilhantes da época o que, por sua vez, inviabilizava a questão do sigilo tratada naquele momento. Nesse contexto, ressaltamos as possibilidades que a leitura da HQ fornecia para o emprego de backings em diferentes momentos, no entanto, isso foi pouco explorado pelos licenciandos, os quais no momento da argumentação centravam-se apenas na questão apresentada ao final, como que, se tratando de um texto quadrinizado, poucas informações de valor poderiam ser extraídas. Essa constatação denota mais uma vez a necessidade de investigações pautadas na relação entre os futuros professores e a leitura, bem como um trabalho mais amplo no que tange ao emprego, seja na formação inicial de professores, ou até mesmo diretamente na educação básica, de textos quadrinizados os quais, mediante questões pertinentes à linguagem, ludicidade e cognicidade (TESTONI, 2004), têm sido considerados pela literatura como um instrumento valioso para a fomentação do hábito de leitura, para o exercício da criatividade e o desenvolvimento de habilidades argumentativas

Por fim, no último argumento analisado (Quadro 36), empregado após a discussão, verificamos que Gabriel manteve a estrutura geral da sua resposta fornecida inicialmente, isto é, ao defender que os cientistas deveriam ter construído a bomba atômica, o futuro professor faz uso da combinação de elementos CDJB. Dessa forma, nos deparamos de antemão com uma 
complexidade semelhante à apresentada no argumento inicial, contudo, mediante a frequência de justificativas/backings, consideramos a nova resposta como mais elaborada que a anterior, uma vez que, mantendo o conhecimento básico (backing), Gabriel insere, emergente da discussão, duas novas justificativas.

Quadro 36 - Análise estrutural, na perspectiva de Toulmin (2001), do argumento final empregado por Gabriel em resposta ao Caso 3.

\section{Gabriel - Caso 3 - Resposta final}

Argumento: Os cientistas deveriam fazer uma bomba atômica, pois no processo de construção e desenvolvimento desta arma, muito conhecimento é produzido. Haveria dessa forma uma oportunidade única de uma grande quantidade de cientistas se reunirem. Além disso, seria com base nesse estudo e pesquisa que seria possível conhecer de fato a magnitude e o poder de destruição dessa arma. Outro ponto importante é que por mais que eles tenham construído a bomba, a decisão de lançá-la foi do Governo Americano. Deve-se considerar que a não colaboração/aceitação do projeto poderia resultar em mortes de seus aliados.

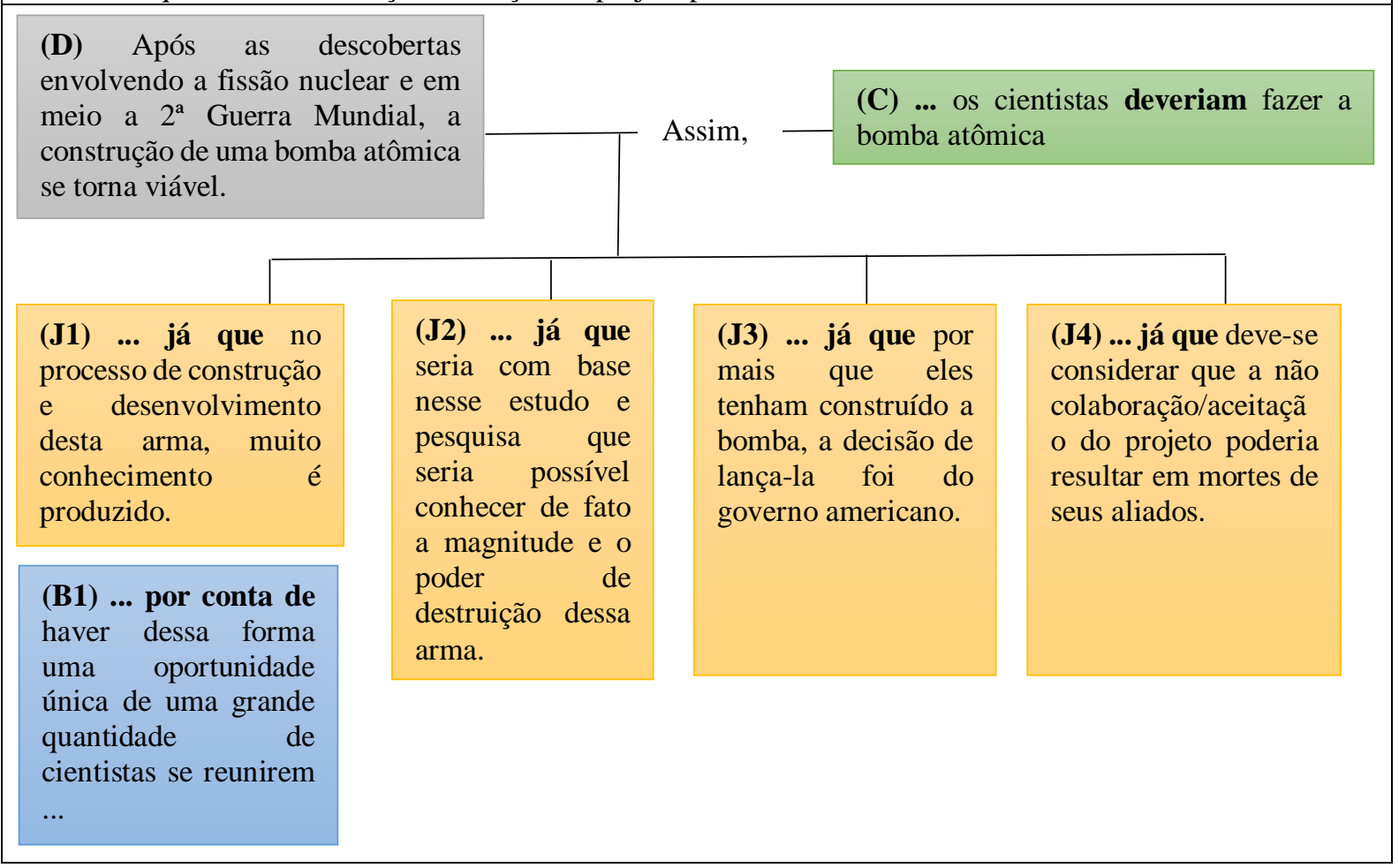

\subsection{Análise global dos argumentos empregados pelos licenciandos em respostas aos casos extraídos da HQ}

Diante dos resultados obtidos e analisados no tópico anterior, apresentamos algumas considerações globais envolvendo os argumentos produzidos pelos licenciandos ao longo da aplicação do que foi proposto neste estudo. Sendo assim, inicialmente abordaremos a melhora ou não da qualidade estrutural dos argumentos fornecidos pelos futuros professores face à metodologia adotada neste estudo, a qual, para além de inserir um texto quadrinizado de abordagem polêmica, encontrou subsídios no material elaborado por Bebeau (1995) para exercício do raciocínio moral em sala de aula. 
Nessa perspectiva, considerando os argumentos empregados por cada aluno nos dois diferentes momentos de aplicação dos três casos extraídos da HQ, construímos conforme ilustram as Figuras 42 - 46 gráficos que sumarizam a combinação de elementos propostos por Toulmin (2001) bem como a frequência de justificativas e/ou backings, em alusão às ideias de Sá, Kasseboehmer e Queiroz (2014). Lembramos que tais combinações de elementos associadas à frequência em que aparecem são indicadores de qualidade estrutural dos argumentos mediante o grau de complexidade e elaboração que promovem.

Assim sendo, nos gráficos ilustrados na sequência diferenciamos as mesmas combinações de elementos face a frequência de justificativas e backings, dessa forma, no eixo y contamos com a soma desses elementos em cada resposta. Não consideramos a frequência de refutações uma vez que, quando da sua aparição, estas são empregadas de forma única. Nesse sentido, em uma coluna em que contamos com a combinação de elementos CDJ cuja a frequência de justificativas e/ou backings seja 3, podemos dizer que nesse argumento há a existência de três justificativas. Para outro caso, por exemplo, que tenhamos a combinação CDJB, e a frequência de justificativas e/ou backings seja 4 , isto quer dizer que pode haver no referido argumento duas justificativas e dois backings, três justificativas e um backing, ou até mesmo uma justificativa e três backings que a sustente.

Figura 42 - Distribuição gráfica da combinação de elementos do TAP apresentados por Alice em seus argumentos.

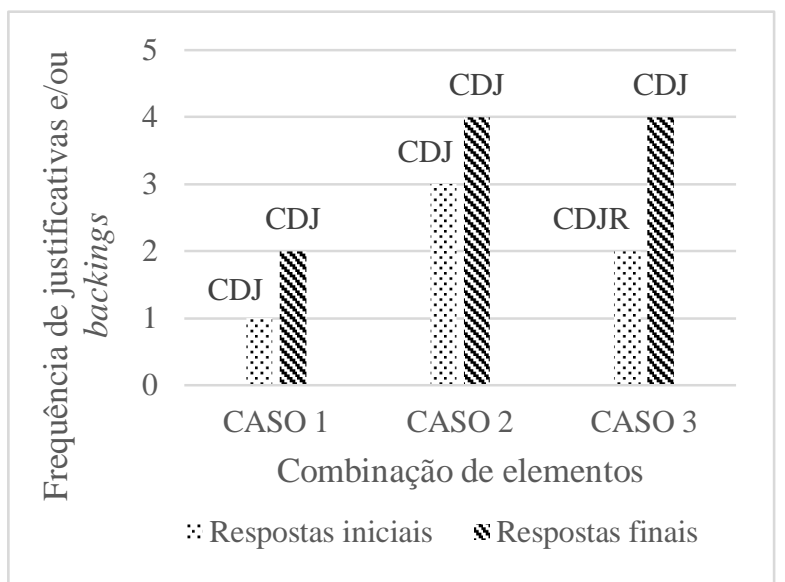

Figura 43 - Distribuição gráfica da combinação de elementos do TAP apresentados por Bianca em seus argumentos.

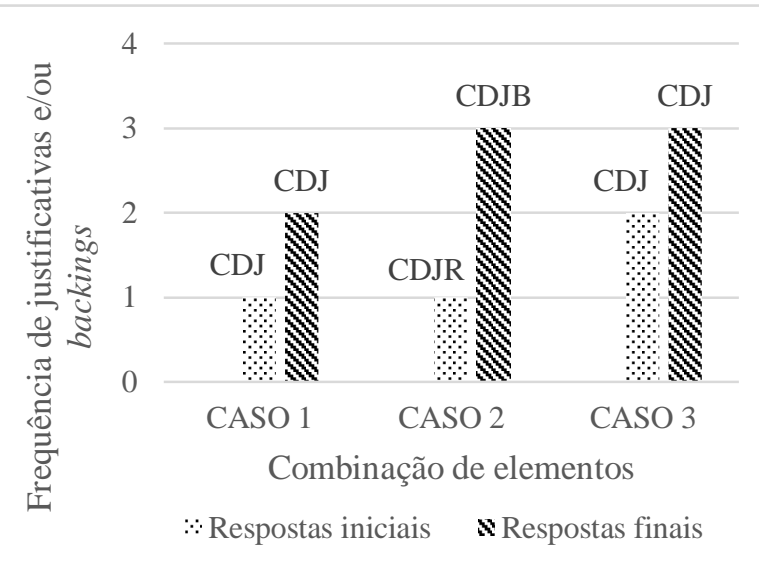


Figura 44 - Distribuição gráfica da combinação de Figura 45 - Distribuição gráfica da combinação de elementos do TAP apresentados por Caroline em elementos do TAP apresentados por Débora em seus argumentos.

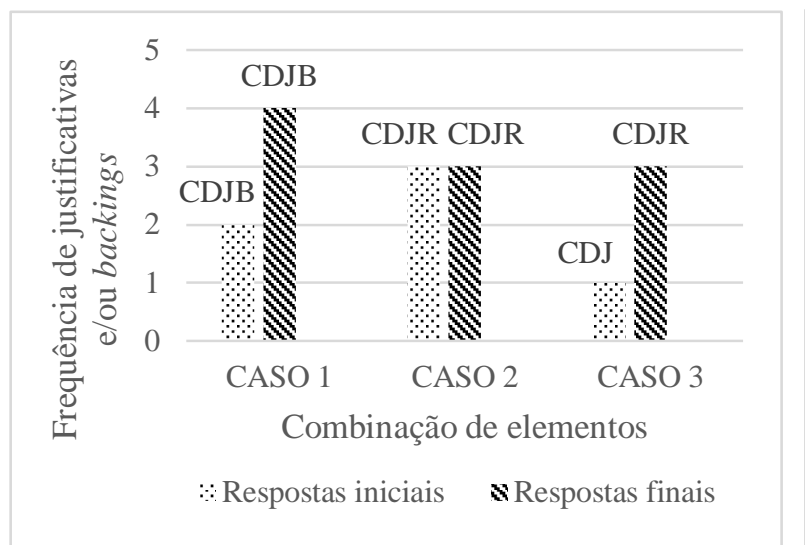
seus argumentos.

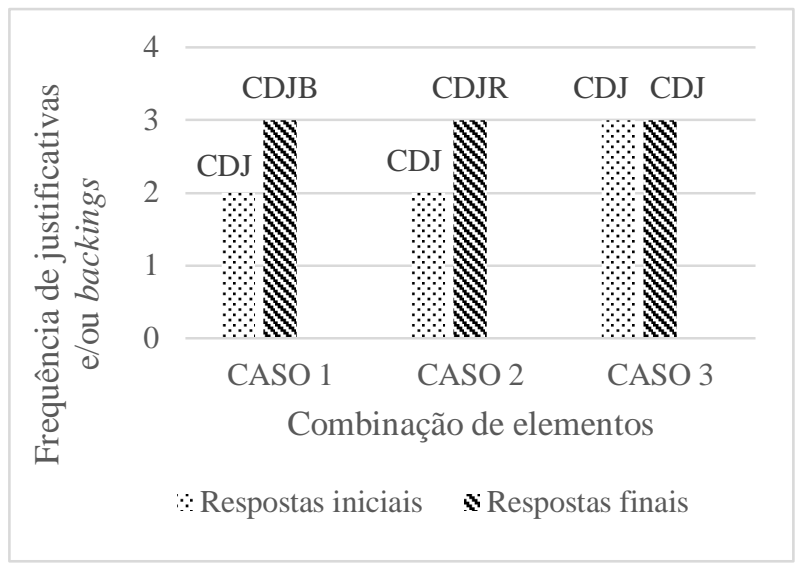

Figura 46 - Distribuição gráfica da combinação de elementos do TAP apresentados por Gabriel em seus argumentos.

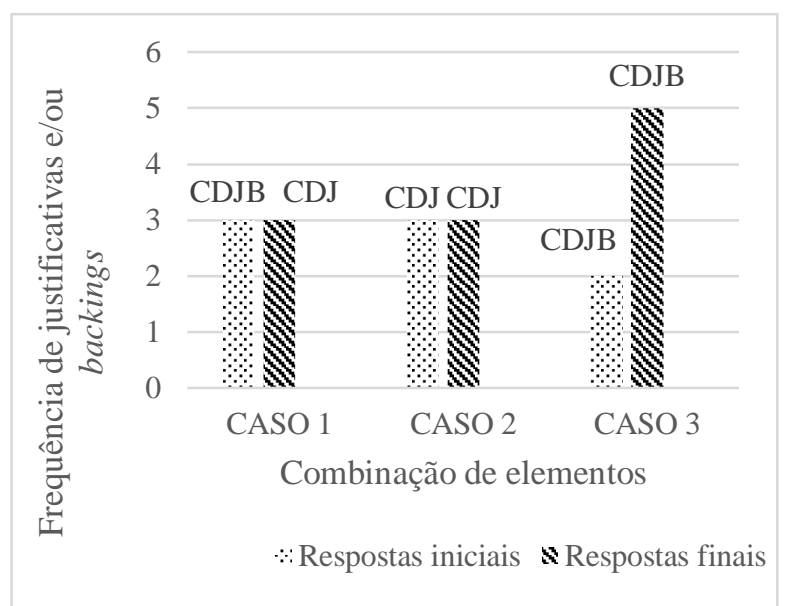

De início, identificamos nos argumentos empregados pelos licenciandos um predomínio da combinação de elementos CDJ, combinação esta indicativa de um argumento pouco complexo e elaborado na perspectiva de Erduran, Simon e Osborne (2004). No entanto, ao recorrermos à literatura, verificamos que diferentes autores têm encontrado resultados semelhantes em seus estudos, uma vez que a inserção de elementos que confiram uma maior complexidade às respostas, isto é, backings, refutadores e qualificadores modais, demandam um maior esforço por parte dos indivíduos. Ainda assim, verificamos que ao longo das atividades, com exceção de qualificadores modais, tais elementos foram sendo integrados às respostas dos alunos.

A título de exemplo em que se identifica o predomínio da combinação de elementos CDJ no processo de argumentação, Simon, Erduran e Osborne (2006) investigaram os 
argumentos orais de doze professores de ciências ao longo de um ano de intervenção, de modo que fosse possível aos autores o acesso à evolução da qualidade estrutural dos argumentos empregados por estes. Sendo assim, Simon, Erduran e Osborne (2006) apresentam os resultados obtidos da análise dos discursos pedagógicos de dois destes professores, como do docente denominado Matthew. Esse professor, excluindo as combinações que configuram um argumento não válido na perspectiva de Toulmin (2001), isto é, que não conta com aos menos a presença dos três elementos básicos (conclusão, dado e justificativa), exibiu em um dos seus discursos gravados no início do período de intervenção, segundo resultados obtidos pelos autores, aproximadamente dezessete combinações CDJ, e quatro CDJB. Ao final do ano, contudo, o padrão parece ter se mantido, com o surgimento apenas de alguns argumentos cuja combinação de elementos consistia em CDJR, sendo assim, os autores observaram no novo discurso de Matthew aproximadamente dezenove combinações CDJ, duas CDJB e três CDJR.

Resultados semelhantes foram obtidos por Sá, Kasseboehmer e Queiroz (2014) em seu estudo realizado com alunos do Curso de Bacharelado em Química do Instituto de Química de São Carlos (IQSC), da Universidade de São Paulo. Nessa investigação os autores empregaram diferentes casos, estruturados ou mal estruturados, que poderiam promover a argumentação em sala de aula. Tais casos forma aplicados em duas turmas de estudantes, uma submetida a um processo de instrução explícita a respeito de argumentação e do Modelo de Toulmin (2001), e outra que não foi submetida a esse tipo de instrução. De forma geral, os autores identificaram as dificuldades inerentes do processo de argumentação e obtiveram diferentes combinações de elementos nos argumentos orais apresentados pelos grupos em estudo. Dessa forma, nas respostas dos grupos que responderam a casos mal estruturados, por exemplo, os autores identificaram seis combinações CDJ, duas CDJB, uma CDJQ e uma CDJBR.

Retornando à análise individual de cada licenciando, verificamos nas resposta de Alice (Figura 42), que embora a combinação de elementos do Modelo de Toulmin (2001) tenha se mantido praticamente a mesma durante todo o processo, sendo essa a mais básica, isto é, CDJ, houve uma constante evolução da qualidade estrutural do que é apresentado pela futura professora, uma vez que a frequência de justificativas, elemento que também consideramos indicativo da complexidade dos argumentos, foi sendo aumentada durante o processo. Esse aumento identificado no emprego de justificativas, assim como já mencionado anteriormente, pode ser atribuído aos momentos de discussão, os quais forneciam considerações a respeito dos diferentes aspectos morais envolvidas em cada caso, que na maioria das vezes se converteram em justificativas nas respostas dos licenciandos. 
Contudo, como sinalizado na discussão individual para cada caso, Alice foi um dos futuros professores que consideramos ter sido limitada pelo Modelo de Toulmin (2001), o TAP. Se restringido todas as vezes à cópia desse Modelo fornecido pela docente previamente, Alice apresentou nas diferentes ocasiões um pensamento bastante fragmentado, o que por sua vez se tornou perceptível nos textos elaborados por ela. Essa limitação promovida pelo TAP já foi identificada por outros autores, como no já mencionado no trabalho de Sá, Kasseboehmer e Queiroz (2004). Tais autores ao analisarem as percepções dos estudantes sobre a adequação do Modelo de Toulmin (2001) para o ensino de argumentação, obtiveram respostas do tipo:

Apesar de eu acreditar que esse modelo prende a nossa argumentação impondo um formato obrigatório, acho que ele ajudou os alunos que têm dificuldade de argumentação (SÁ, KASSEBOEHMER e QUEIROZ, 2014, p. 167).

É inadequado porque o ato de argumentar é muito mais dinâmico que o colocado em aula. Esse modelo pode ser comparado a uma receita de bolo, onde se padroniza os textos e barra a capacidade de "criar", ou melhor, impede que a argumentação tenha o dinamismo e a qualidade que se deve ter (SÁ, KASSEBOEHMER e QUEIROZ, 2014, p. 167).

Essas repostas, bem como as limitações observadas nos argumentos de Alice, reforçam as ideias de Jorge e Puig (2000) no que tange ao caráter mecanicista promovido pela abordagem da argumentação em sala de aula com base no Modelo de Toulmin (2001), o que demanda, portanto, alguns cuidados a serem adotados nos espaços formais de ensino. No entanto, embora tenhamos enfatizados essa limitação, por outro lado o TAP (TOULMIN, 2001) também auxiliou a aluna na evolução da qualidade detectada em suas respostas, uma vez que este a orientou na busca por justificativas, por exemplo.

Com relação à licencianda Bianca (Figura 43), consideramos que também houve uma melhora na qualidade estrutural do que é apresentado nas respostas fornecidas aos casos, principalmente no que diz respeito do primeiro para o segundo. Nesse sentido, apresentando para o Caso 1 argumentos marcados pela combinação CDJ, cujas frequências de justificativas antes e após a discussão foram uma e duas, respectivamente, Bianca exibia respostas iniciais pouco complexas. Porém, essa complexidade observada incialmente foi amplamente elevada quando da resolução do segunda caso, mediante o emprego de elementos como refutação e backing. Associado a isso, em sua resposta final ao dilema se Oppenheimer deveria ouvir Bohr e falar abertamente sobre o poder de destruição de uma bomba atômica, a licencianda também aumenta a frequência de justificativas. No entanto, apesar de elevar a frequência de justificativas nas respostas fornecidas ao Caso 3, comparativamente às fornecidas para o Caso 1, houve do segundo para o terceiro caso uma nova redução da complexidade do que é 
apresentado pela licencianda, dado que a combinação de elementos empregados passou de CDJR/CDJB para CDJ.

Essa redução da complexidade entre os casos finais (2 e 3) também se apresentam, embora em graus diferentes, nas respostas de Caroline (Figura 44) e Débora (Figura 45). Atribuímos essa diminuição da qualidade dos argumentos apresentados pelas alunas, dentre outros motivos, à natureza do caso, o que discutiremos adiante. No mais, com exceção do Caso 3, também se verifica para essas licenciandas uma evolução da complexidade do que apresentam em suas respostas do Caso 1 para o Caso 2, nas quais podemos observar, para além de um aumento na frequência de justificativas, o emprego de refutações para responder ao Caso 2. Lembramos que, com base nas ideias de Erduran, Simon e Osborne (2004), consideramos a inserção de refutações um elemento que confere maior complexidade aos argumentos do que os backings.

Por fim, no que diz respeito ao licenciando Gabriel, constatamos que embora tenha ocorrido uma ligeira redução da qualidade estrutural entre dois primeiros casos, houve de forma geral, um aumento da complexidade do que é apresentado pelo aluno, que nos diferentes momentos fazia uso de uma elevada frequência de justificativas.

Em suma, ao analisarmos os argumentos individuais para cada licenciando, podemos constatar que a discussão realizada entre os diferentes momentos dos casos, ocorrida com base no material proposto por Bebeau (1995), se configurou como um elemento interessante para o aumento da complexidade/qualidade estrutural dos argumentos, mesmo que auxiliando alguns apenas na inserção de novas justificativas. Ainda que ao analisarmos os argumentos na perspectiva de Erduran, Simon e Osborne (2004), possamos observar respostas pouco elaboradas, estas estão condizentes com as encontradas na literatura. Dessa forma, os resultados obtidos nos diferentes estudos, bem como neste, suscitam maiores investigações e a elaboração de instrumentos/metodologias que permitam uma melhor abordagem e exercício da argumentação em sala de aula, no caso específico na formação inicial de professores, os quais serão os responsáveis por promoverem práticas desse tipo na educação básica. Assim, reiteramos a importância de trabalhos semelhantes a este no âmbito da formação de professores, dado que as práticas empregadas em sala de aula da educação básica estão diretamente relacionadas com os conhecimentos e habilidades pertinentes às diferentes atividades, bem como aos valores que os docentes atribuem a elas.

Prosseguindo com as considerações a respeito do conjunto de argumentos apresentados pelos alunos em resposta aos três casos extraídos da HQ, ilustramos graficamente 
na Figura 47, a frequência de cada combinação de elementos empregados nas respostas dos licenciandos para cada caso estudado, o que nos permite traçar um panorama sobre a estrutura geral dos argumentos bem como a sua relação com cada caso, os quais narravam situações distintas e foram aplicados em diferentes momentos da disciplina Química, Sociedade e Cotidiano. Ressaltamos que os valores em parênteses dizem respeito à frequência do elemento imediatamente anterior, a ausência de qualquer número indica que aquele elemento se apresenta uma única vez naquela combinação. Por exemplo, na combinação $\operatorname{CDJ}(2)$ observamos a presença de conclusão, dado e duas justificativas Para um outro caso em que contamos com uma combinação CDJ(2)B, essa é indicativa da presença de conclusão, dado, duas justificativas e um backing.

Figura 47 - Distribuição gráfica da frequência de cada combinação de elementos propostos por Toulmin (2001) nas respostas dos licenciandos nos diferentes casos estudados.

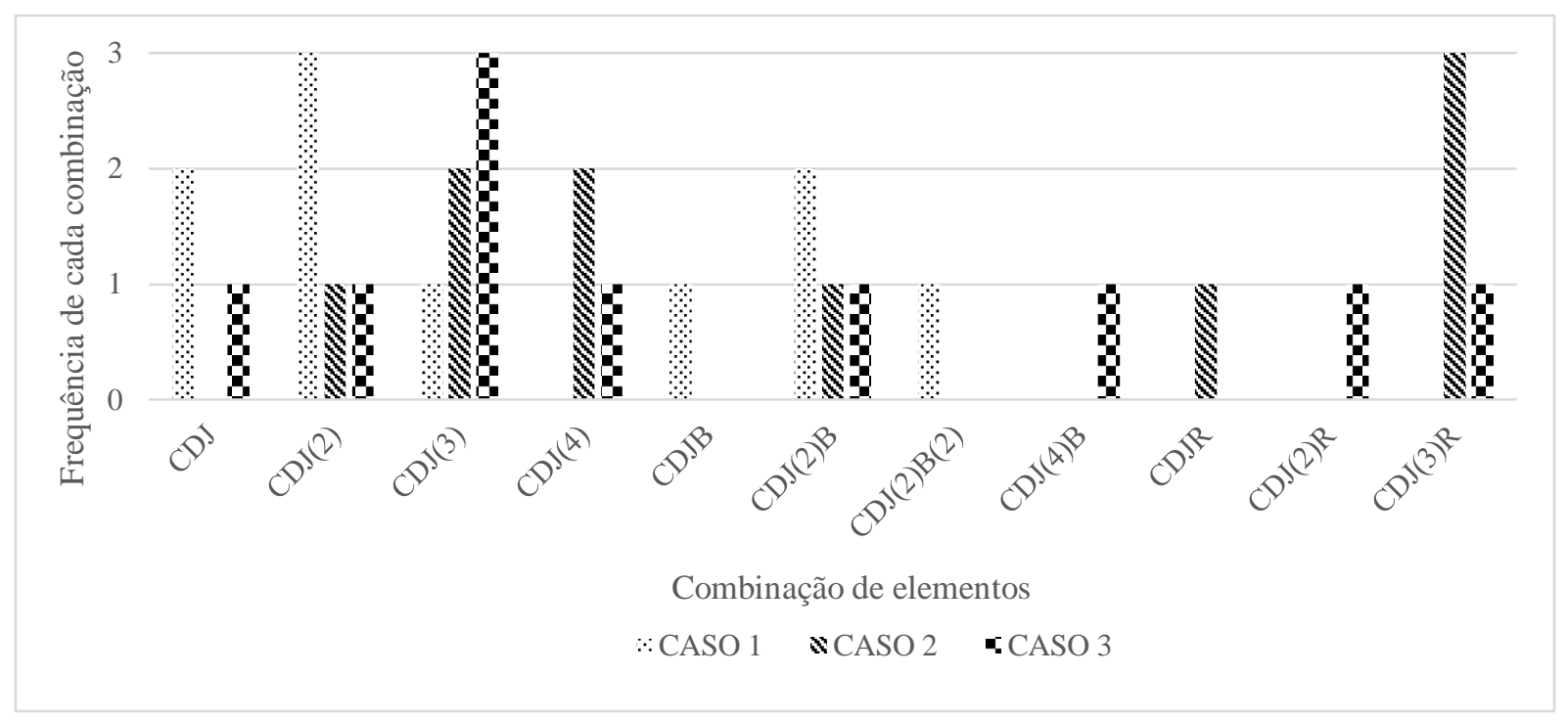

Diante do que é exposto graficamente, observamos que, de fato, as combinações apresentadas nos argumentos em resposta ao Caso 1 são aquelas que conferem menor complexidade às afirmações, e consequentemente uma menor qualidade estrutural. Essa constatação era esperada, conforme resultados obtidos por outros autores (SIMON, ERDURAN e OSBORNE, 2006; SÁ, KASSEBOEHMER e QUEIROZ, 2014), e por consistir no primeiro caso argumentativo fornecido aos futuros professores. Dessa forma, identificamos nas respostas dos licenciandos a este caso seis aparições de combinações CDJ, predominando aquela com frequência de duas justificativas.

Posteriormente, com relação ao segundo e terceiro caso, observamos um aumento significativo da complexidade dos argumentos apresentados em resposta ao Caso 2, para qual obtemos, por exemplo, três respostas que apresentavam a combinação de elementos CDJR, cuja 
frequência de justificativas também são três. Contudo, ao analisarmos os argumentos construídos quando da aplicação do Caso 3, verificamos que essa complexidade não se manteve, embora tenha sido elevada quando comparada com o Caso 1.

Assim sendo, inferimos que, em geral, as atividades realizadas no âmbito da formação inicial de professores contribuíram para uma melhora perceptível da qualidade estrutural dos argumentos dos licenciandos e, consequentemente, para o desenvolvimento da habilidade de argumentação dos mesmos. No que diz respeito à elevada complexidade observada para o Caso 2 atribuímos esta a alguns fatores, como a natureza da questão abordada naquele momento.

Na realização desse caso (Caso 2), observamos no instante da discussão, que esse, na percepção dos alunos, foi o mais complicado para resolução. Dessa forma, sem muitas ideias pré-concebidas sobre o assunto, os futuros professores se viram na necessidade de buscar um maior número possível de elementos que os permitissem responder ao caso e, nesse contexto, inserir também em suas respostas um maior número de elementos levantados oralmente. Em contrapartida, como já sinalizamos previamente, o Caso 3 parece-nos o principal quando consideramos desenvolvimento científico e bombas nucleares. Dessa forma, quando em contato com o trecho pertinente a este caso, os futuros professores já possuíam, em grande parte, ideias pré-estabelecidas a respeito da questão narrada, ou seja, ao apresentar os diferentes argumentos os licenciandos se demonstravam mais confiantes sobre suas colocações, não precisando recorrer a tantos artifícios estruturais para fortalecer o argumento.

Com relação ao efeito da leitura no processo de argumentação, verificamos que os futuros professores recorreram a poucas afirmações presentes nos trechos fornecidos em cada caso, ou até mesmo em passagens previamente lidas da HQ. Essa constatação permite-nos inferir sobre a importância que os alunos deram ao texto, e essa pode ter sido baixa mediante o hipergênero adotado nas atividades, isto é, devido ao emprego de quadrinhos. Nessa perspectiva, o instrumento que poderia auxiliar os licenciandos na apresentação de conhecimentos básicos para apoiar as mais variadas justificativas foi pouco explorado. Além disso, os diferentes recursos empregados pelo autor da HQ, os quais foram evidenciados na análise da "forma" do texto surtiram pouco ou nenhum efeito na argumentação dos licenciandos, o que também vai ao encontro da importância que os futuros professores deram à HQ no momento de argumentação.

Outrossim, um fator que pode ter dificultado uma maior frequência de combinações típicas de argumentos de alta complexidade diz respeito à ideia de estruturação dos casos. Geralmente mal estruturados, QSC possibilitam o aluno a recorrer a ideias, conhecimento 
adquiridos e desenvolvidos informalmente, valores e emoções (OSBORNE, ERDURAN e SIMON, 2004). Contudo, quando utilizamos a metodologia proposta por Bebeau (1995), apresentamos casos também de natureza sociocientífca, porém de forma mais estruturada, em que era fornecido ao licenciando uma delimitação clara do problema e duas possíveis soluções. Dessa forma, aumentávamos consideravelmente a dificuldade do processo de modo a instigálos na busca pelos aspectos morais que permitissem responder à questão apresentada.

Assim sendo, constatamos a validade das atividades empreendidas em sala de aula tanto para fins pedagógicos, dado que as práticas ali realizadas promoveram o exercício e desenvolvimento das habilidades argumentativas dos futuros professores, bem como para pesquisa, uma vez que, apesar das limitações inerentes ao nosso estudo, o qual de caráter exploratório, dado que associamos diferentes metodologias e ideias e consequentemente não existem muitos estudos realizados nessa perspectiva, contou com um número reduzido de sujeitos, os dados obtidos nos permitiram responder a nossa segunda questão de investigação. Dessa forma, verificamos que embora possa ser considerada de baixa complexidade, a qualidade estrutural das respostas empregadas pelos licenciandos diante de QSC extraídas de um texto quadrinizado está em consonância com aquela identificada para professores de ciências em atividade e para bacharelandos em química. Ademais, uma complexidade maior pode não ter sido atingida mediante a estruturação das questões apresentadas aos alunos. 


\section{Capítulo 6 - A sensibilidade moral evidenciada por licenciandos em química diante de questões socialmente controversas}

De forma a respondermos em que extensão as atividades didáticas realizadas a partir da leitura da HQ contribuíram para o desenvolvimento da sensibilidade moral dos futuros professores, empregamos, conforme exposto no referencial teórico deste trabalho, o Modelo dos Quatro Componentes proposto por Rest et. al. (1986). Com base nesse Modelo, e nos estudos de diferentes autores interessados na investigação do desenvolvimento moral dos educandos (FOWLER, ZEIDLER e SADLER, 2009), o nosso olhar está direcionado para o primeiro componente, isso é, para a sensibilidade moral, o qual permite ao indivíduo o reconhecimento da situação e dos aspectos morais e éticos nela envolvidos.

Dentre os diferentes instrumentos encontrados na literatura que nos permitem investigar a sensibilidade moral dos educandos, nos fundamentamos no material elaborado por Bebeau (1995), o qual apresenta uma coletânea de casos que permitem a argumentação dos educandos diante de conflitos éticos na prática científica e sua respetiva forma de análise. Segundo o autor, diante de um conflito ético um indivíduo que apresenta uma sensibilidade moral acurada deve apresentar para a sua tomada de decisão: uma indicação das partes direta ou indiretamente envolvidas na situação; uma análise das possíveis consequências das ações do protagonista, ou seja, daquele que na situação específica é o responsável pela tomada de decisão; as obrigações deste protagonista; os ponto(s) de conflito.

Nessa perspectiva, elaboramos para cada caso empregado em sala de aula extraído da $\mathrm{HQ}$, grelhas contendo os referidos itens. Com base nas grelhas elaboradas apresentamos, na sequência, a análise dos argumentos fornecidos pelos futuros professores diante dos três casos extraídos da HQ que nos permitirá inferir sobre a sensibilidade moral dos mesmos.

Para efeito de discussão, assim como abordado no Capítulo 5 , referente às análises da qualidade estrutural dos argumentos empregados pelos futuros professores, dividiremos este tópico de acordo com o caso em estudo. Ou seja, apresentaremos análises individuais para cada um dos três casos e teceremos, ao final, comentários globais acerca da sensibilidade moral dos licenciandos. Relembramos que os casos extraídos da HQ "Trinity" se encontram disponíveis nos APÊNDICES E, G e H, e foram selecionados tendo em vista a existência de uma questão controversa e de um conflito ético que suscitasse o exercício do raciocínio moral dos estudantes. 


\section{Caso 1}

Com relação ao Caso 1, o qual se encontra no APÊNDICE E, relembramos que este apresentava aos futuros professores um conflito envolvendo Oppenheimer e sua relação com os cientistas mediante as condições de trabalho dos mesmos e a necessidade de sigilo exigida pelo Projeto Manhattan. Essa situação implicava em um conflito para Oppenheimer que deveria decidir entre deixar os cientistas livres para falar o que quisessem, mas somente dentro do laboratório, ficando por conta deles policiarem a si mesmos, ou manter a obrigatoriedade do sigilo mesmo que isso custasse a insatisfação dos pesquisadores e, consequentemente, um possível insucesso do projeto.

Logo, de acordo com o que é narrado neste primeiro caso apresentamos no Quadro 37 a grelha de aspectos morais envolvidos nessa tomada de decisão de Oppenheimer. Conforme podemos observar, destacamos como partes interessadas pela situação narrada, o protagonista do caso, isto é, Oppenheimer, e os indivíduos cujo trabalho seria diretamente afetado pela decisão, os cientistas. Além disso, mediante acordo firmado inicialmente entre Oppenheimer, Groves e o governo norte-americano, são também estes dois últimos, partes envolvidas na tomada de decisão. Ademais, os governos rivais interessados na construção de um artefato nuclear e toda a população norte-americana se configuram como entidades que podem ser afetadas pelas consequências da ação tomada por Oppenheimer.

Com relação às consequências, destacamos algumas como: a maior possibilidade de vazamento de informações a respeito do Projeto Manhattan caso seja concedida determinada liberdade para os cientistas se comunicarem dentro dos laboratórios de Los Alamos; e a execução do projeto de forma mais rápida e a contento face à condição de trabalho ideal para os cientistas, em equipe.

Contudo são também possíveis implicações inerentes à situação narrada: um ambiente de pressão que dificulta a prática científica e um mal comportamento dos cientistas, caso sua demanda não fosse atendida, o que por sua vez conduzem a um maior tempo necessário para a finalização do projeto e um prolongamento da guerra. Ainda, ao considerarmos Oppenheimer como o protagonista da situação salientamos algumas de suas obrigações que influenciam a sua tomada de decisão, isto é, o seu dever de, enquanto cientista, respeitar a natureza da ciência; conhecedor dos diversos aspectos envolvendo o projeto, de assegurar um bom trabalho para os cientistas. Em contrapartida, deve Oppenheimer manter o acordo de sigilo assumido previamente, evitando o vazamento de informações e respondendo a Groves e ao governo norteamericano. 
Quadro 37 - Grelha de aspectos morais referente ao Caso 1.

\begin{tabular}{|c|c|}
\hline \multicolumn{2}{|l|}{ PONTOS DE CONFLITO } \\
\hline \multicolumn{2}{|l|}{ Respeitar a natureza da ciência Vs. Respeitar o sigilo acordado } \\
\hline \multicolumn{2}{|l|}{ PARTES INTERESSADAS } \\
\hline \multicolumn{2}{|l|}{ Oppenheimer } \\
\hline \multicolumn{2}{|l|}{ Cientistas } \\
\hline \multicolumn{2}{|l|}{ Groves } \\
\hline \multicolumn{2}{|l|}{ Governo norte-americano } \\
\hline \multicolumn{2}{|l|}{ Governos rivais } \\
\hline \multicolumn{2}{|l|}{ População norte-americana } \\
\hline \multicolumn{2}{|l|}{ CONSEQUENCIAS } \\
\hline Maior possibilidade de vazamento de informações & \multirow{6}{*}{ SIM } \\
\hline Condição de trabalho ideal para os cientistas & \\
\hline Execução do Projeto mais rápida e a contento & \\
\hline Prestígio devido a boa execução do Projeto & \\
\hline Manutenção de boa relação entre os cientistas e Oppenheimer & \\
\hline Confronto direto entre Oppenheimer e os demais líderes da cúpula do Projeto como Groves & \\
\hline Maior garantia de manutenção do sigilo envolvendo o Projeto Manhattan & \multirow{5}{*}{ NÃO } \\
\hline Ambiente de pressão que dificulta a prática da ciência & \\
\hline Mal comportamento dos cientistas (desmotivação, frustração, insubordinação) & \\
\hline Maior tempo necessário para a finalização do Projeto & \\
\hline Prolongamento da guerra & \\
\hline \multicolumn{2}{|l|}{ OBRIGAÇÕES DE OPPENHEIMER } \\
\hline \multicolumn{2}{|l|}{ Respeitar a natureza da ciência } \\
\hline \multicolumn{2}{|l|}{ Assegurar um bom trabalho para os cientistas } \\
\hline \multicolumn{2}{|l|}{ Evitar o vazamento de informações } \\
\hline \multicolumn{2}{|l|}{ Responder a Groves e ao governo norte-americano } \\
\hline Manter o acordo de sigilo assumido previamente & \\
\hline
\end{tabular}

Com base no Quadro 37, apresentamos inicialmente, no Quadro 38, o argumento empregado por Alice em resposta ao Caso 1 anteriormente ao momento de discussão realizado em sala de aula, e sua respectiva análise no que diz respeito à sensibilidade moral da licencianda. Relembramos que, conforme metodologia apresentada por Bebeau (1995), a argumentação envolvendo os três casos compreendeu três momentos, um argumento inicial a partir da leitura da situação que apresenta um conflito ético ao futuro professor, um momento de reflexão por meio de uma discussão conduzida pela docente e, por fim, um novo argumento a partir dos aspectos levantados oralmente e em conjunto com a turma. 
Quadro 38 - Análise da sensibilidade moral de Alice, de acordo com a resposta inicial fornecida ao Caso 1.

\begin{tabular}{|c|c|c|}
\hline \multicolumn{3}{|c|}{ Alice - Caso 1 - Resposta inicial - SIM } \\
\hline \multicolumn{3}{|c|}{$\begin{array}{l}\text { Argumento: Sim, já que para colaborem uns com os outros precisam trocar ideias e, portanto, comunicarem } \\
\text { entre si. Assim, a chance do projeto ser um sucesso em um menor tempo possível aumenta. Isto porque, de } \\
\text { qualquer forma, todos estão distantes de sua terra natal e confinados em Oak Ridge. }\end{array}$} \\
\hline & & 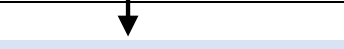 \\
\hline $\begin{array}{l}\text { Consequência (SIM): } \\
\text { Condição de trabalho } \\
\text { ideal para os cientistas }\end{array}$ & $\begin{array}{l}\text { Parte interessada: } \\
\text { Cientistas }\end{array}$ & $\begin{array}{ll}\text { Consequência } & \text { (SIM): } \\
\text { Execução do } & \text { Projeto } \\
\text { mais rápida e a } \\
\text { contento }\end{array}$ \\
\hline
\end{tabular}

Diante do que é apresentado no Quadro 38, podemos constatar, assim como a já identificada baixa complexidade estrutural do argumento de Alice, uma sensibilidade moral bastante limitada da licencianda. Apresentando apenas uma única justificativa para sustentar seu posicionamento inicial, o qual é favorável à decisão de Oppenheimer, Alice omite o protagonista em seu argumento, e considera apenas duas consequências do posicionamento assumido, isto é, uma vez que sua resposta é positiva, nos deparamos com duas consequências para esse posicionamento que reforçam a decisão tomada. Além disso, dado que a decisão envolve o trabalho dos cientistas, estes são para Alice, conforme observado em sua resposta, a única parte interessada nesse conflito.

Outrossim, constatamos a ausência de qualquer obrigação de Oppenheimer, uma vez que, na resposta da licencianda identificamos apenas os cientistas como parte interessada na situação. Dessa forma, ausentes as obrigações do protagonista, tais quais respeitar a natureza da ciência e manter o sigilo acordado inicialmente, o ponto de conflito que elencamos para o caso narrado não foi abordado pela aluna.

Ao considerarmos, contudo, os Padrões de Raciocínio Informal proposto por Sadler e Zeidler (2005), relembramos que o raciocínio moral consiste em uma vertente deste raciocínio informal que envolve o estudo de causas e consequências, vantagens e desvantagens de proposições particulares ou decisões alternativas (ZOHAR e NEMET, 2002), observamos na resposta de Alice o emprego de um raciocínio informal racionalista. De acordo com Sadler e Zeidler (2005) este padrão de raciocínio informal pode ser descrito como considerações baseadas nas razões, e dessa forma podemos atribuir o emprego desse padrão por Alice, dentre outros motivos, ao uso do TAP (TOULMIN, 2001) em sala de aula. Almenjando construir um argumento estruturalmente válido na perspectiva de Toulmin (2001), a futura professora buscou o emprego de termos racionalistas que lhe permitissem ao menos um dado, uma justificativa e uma conclusão. 
Nesse sentido, e ressaltando uma das limitações do Modelo de Toulmin (2001) em nosso estudo, a aluna em questão se restringiu em sua resposta ao esqueleto proposto por Toulmin acerca de um argumento considerado válido, e isso podemos identificar em sua resposta por meio do uso de termos como "já que”. Logo, em busca de justificativas que atendam ao Modelo proposto por Toulmin (2001), a licencianda mesmo em uma resposta classificada como estruturalmente simples, em que se identifica apenas a combinação básica de elementos CDJ, faz uso de um raciocínio informal racionalista para defender seu posicionamento. Essa constatação feita a partir do argumento de Alice corrobora os resultados obtidos por Sadler e Zeidler (2005), os quais evidenciam que embora existam três caminhos possíveis que os educandos podem adotar para a resolução de uma QSC (racionalista, intuitivo e emotivo), o padrão de raciocínio informal racionalista é aquele geralmente esperado em salas de aula de ciências. Além disso, esse raciocínio é aquele que educadores frequentemente se esforçam para desenvolver no espaço formal de ensino de ciências.

Por fim, a respeito da sensibilidade moral, considerando valores absolutos, dos 23 aspectos que destacamos como relevantes para a situação narrada e que constam na grelha presente no Quadro 37, apenas três são mencionados pela licencianda, o que representa aproximadamente $13 \%$. Destes, há o predomínio de consequências exclusivas para a posição tomada. Assim sendo, para a licencianda em questão verificamos uma limitada sensibilidade moral a qual afeta diretamente a estrutura do argumento na perspectiva de Toulmin (2001), conforme verificamos no capítulo anterior. Esta limitada sensibilidade moral é corroborada pela literatura, Bebeau (1995) por exemplo, salienta que muitos estudantes têm dificuldades em vislumbrar todos os pontos de disputa e discussão em conflito ético. Contudo, a baixa sensibilidade moral identificada na resposta de Alice não inibiu o emprego de um raciocínio informal baseado em razões.

A partir do primeiro argumento, portanto, uma discussão oral foi conduzida pela docente de modo que os licenciandos fossem capazes de vislumbrar com maior amplitude os aspectos morais pertinentes ao caso. Apresentamos no Quadro 39 uma análise da sensibilidade moral da licencianda Alice com base em sua segunda resposta ao caso. 
Quadro 39 - Análise da sensibilidade moral de Alice, de acordo com a resposta final fornecida ao Caso 1.

\begin{tabular}{|c|c|c|c|c|}
\hline \multicolumn{5}{|c|}{ Alice - Caso 1 - Resposta final - NÃO } \\
\hline \multicolumn{5}{|c|}{$\begin{array}{l}\text { Argumento: Oppenheimer sabe que para a ciência se desenvolver melhor necessita de colaboração, mas } \\
\text { quando entrou no Projeto Manhattan aceitou um acordo com Groves de manter o sigilo total sobre este projeto, } \\
\text { de modo que ele tem a obrigação de articular as ideias dos cientistas por conhecer o projeto na totalidade, mas } \\
\text { não permitir que os cientistas o saibam também. Por isso, apesar das grandes dificuldades que ele deverá } \\
\text { enfrentar com os cientistas, motivando-os constantemente e evitando insubordinação, ele não deve permitir } \\
\text { trocas de informações dentro dos laboratórios por uma questão de ética e compromisso firmado incialmente } \\
\text { com Groves e consequentemente com o governo norte-americano. }\end{array}$} \\
\hline \begin{tabular}{|l|l|} 
Consequência (NÃO): \\
Mal comportamento dos \\
$\rightarrow$ cientistas (desmotivação, \\
frustração, insubordinação)
\end{tabular} & \multicolumn{3}{|c|}{$\begin{array}{l}\text { Ponto de conflito: Respeitar a natureza da ciência Vs. } \\
\text { Respeitar o sigilo acordado }\end{array}$} & \\
\hline $\begin{array}{l}\text { Obrigação de Oppenheimer: } \\
\text { Assegurar um bom trabalho } \\
\text { para os cientistas }\end{array}$ & $\begin{array}{l}\text { Obriga } \\
\text { Evitar } \\
\text { informa }\end{array}$ & $\begin{array}{l}\text { Oppenheimer: } \\
\text { vazamento de }\end{array}$ & \multicolumn{2}{|c|}{$\begin{array}{l}\text { Obrigação de Oppenheimer: } \\
\text { Manter o acordo de sigilo } \\
\text { assumido previamente }\end{array}$} \\
\hline $\begin{array}{l}\text { Parte interessada: } \\
\text { Governo norte- } \\
\text { americano }\end{array}$ & $\begin{array}{l}\text { Parte interessada: } \\
\text { Cientistas }\end{array}$ & $\begin{array}{l}\text { Parte interessada } \\
\text { Groves }\end{array}$ & \multicolumn{2}{|c|}{$\begin{array}{l}\text { Parte interessada: } \\
\text { Oppenheimer }\end{array}$} \\
\hline
\end{tabular}

Conforme verificado anteriormente para o Caso 1, envolvendo o sigilo interno do Projeto Manhattan, a licencianda Alice optou por alterar seu posicionamento inicial, ou seja, a futura professora passou a defender em seu argumento que Oppenheimer não deveria seguir adiante com o seu plano de conceder liberdade para os cientistas falarem o que quiserem, mesmo que somente dentro dos laboratórios. Para tanto, a licencianda faz uso em sua resposta de apenas uma única consequência, a qual diz respeito exclusivamente ao seu posicionamento tomado naquele momento. Uma vez que Alice se mostra contrária à decisão de Oppenheimer, a consequência exposta no argumento se refere a um produto deste posicionamento, o qual é um possível mal comportamento dos cientistas durante o desenvolvimento do Projeto Manhattan. Contudo, apesar dessa consequência, a licencianda ao considerar dessa vez o ponto de conflito presente no caso narrado, acredita não ser suficiente para que Oppenheimer conceda a referida liberdade aos cientistas.

Prosseguindo em nossa análise, identificamos na resposta de Alice uma ampliação de sua sensibilidade moral comparativamente ao argumento fornecido inicialmente, ou seja, identificamos na resposta da futura professora um maior número de aspectos morais pertinentes ao caso e que subsidiaram a sua resposta. Podemos assumir que essa ampliação está diretamente relacionada com a discussão estabelecida em sala de aula, a qual foi conduzida pela docente conforme trecho a seguir. 
[P]: Então a gente viu na aula passada, que para conseguirmos julgar uma questão ética ou moral, como a gente queira falar, a gente tem que ter alguns parâmetros que vão auxiliar a nossa discussão. O primeiro parâmetro que a gente olha na verdade, é quem são as partes interessadas nessa situação. Então, quem são as partes interessadas nessa questão? De permitir ou não que o sigilo seja quebrado pelo menos dentro do laboratório? Porque a questão toda é o sigilo, vocês identificam isso, certo? Então quem são as partes interessadas nessa questão?

A partir da discussão que se iniciou com a fala acima citada da professora formadora, identificamos na resposta final da licencianda quatro partes interessadas, isto é, aproximadamente $67 \%$ daquelas presentes na grelha esquematizada no Quadro 37. Dentre as partes interessadas abordadas por Alice destacamos a presença de Oppenheimer, o protagonista, o que conduziu a aluna a ponderar a respeito de suas obrigações. Dessa forma se faz também presente no argumento da futura professora três obrigações do protagonista que foram negligenciadas inicialmente, ou seja, a obrigação de Oppenheimer, enquanto cientista, assegurar um bom ambiente de trabalho para os demais colegas, evitar o vazamento de informações e manter o acordo de sigilo assumido previamente.

Nessa perspectiva, com base nas obrigações do protagonista, Alice inicia sua resposta com uma sistematização do conflito existente na decisão de Oppenheimer, o qual contrapõe duas de suas obrigações (assegurar um bom trabalho para os cientistas vs. manter o acordo assumido previamente com superiores). Portanto, o que se identifica no segundo argumento da licencianda, elaborado após a discussão que permitiu os futuros professores contemplarem diferentes aspectos do caso narrado, é a indicação de alguns desses elementos em sua resposta, elementos estes que fortalecem, até certo ponto, o posicionamento de Alice, que nesse segundo momento também foi tomado de forma racionalista.

Analisando valores absolutos, nesse segundo momento Alice considera em sua resposta para o seu posicionamento nove dos 23 elementos expostos na grelha presente no Quadro 37, o que representa cerca de $39 \%$ dos aspectos julgados relevantes pelos pesquisadores, o que denota um aumento da sensibilidade moral após a discussão estabelecida em sala de aula. Dentre os elementos abordados pela licencianda, o destaque se encontra nas menções das partes interessadas, as quais envolvem o protagonista, e consequentemente nas obrigações deste. Porém, nas duas respostas de Alice, pouca atenção foi despendida para a análise das consequências das possíveis ações, principalmente daquelas contrárias ao posicionamento assumido, o que é reflexo do próprio enfoque dado pela futura professora em sua resposta.

Embora tenha apresentado posições contrárias, em ambos os argumentos de Alice identificamos o emprego de um enfoque que a literatura denomina deontológico (COSTA, 2002), em contraponto a um enfoque consequencialista. Segundo Costa (2002), neste enfoque, 
se configurando em uma moral demasiadamente simples e rígida, o centro do valor moral está nas regras morais, isto é, em preceitos universais da moralidade. Nessa perspectiva, centrandose apenas na ideia de que na ciência os pesquisadores precisam colaborar entre si (preceito que diz respeito à natureza da ciência), Alice apresenta seu posicionamento inicial. No segundo momento, mantendo um enfoque mais deontológico em sua resposta, a futura professora se restringe à ideia/moral de que ao assumir um acordo, no caso um acordo de sigilo, o indivíduo deve ir adiante com sua palavra.

Ao considerarmos a relação desses enfoques com os processos envolvidos na tomada de decisão diante de conflitos éticos, principalmente a sensibilidade moral, o enfoque deontológico assumido nas respostas vai ao encontro da moral heterônoma de Kant (2005), a qual permite a resolução de conflitos sem a necessidade de uma sensibilidade moral mais acurada. Contudo, a partir do que é apresentado por Guimarães (2011), relembramos um dos principais problemas que podem surgir a partir dessa abordagem e dessa moral heterônoma, isto é, o relativismo moral. Segundo o autor, a partir do momento que a moral é de cada sociedade e o indivíduo age de acordo com ela, este pode observar barbáries sendo cometidas em algumas sociedade e culturas, sem emitir qualquer condenação de juízo moral. Ainda segundo Guimarães $(2011$, p. 8): “ser tolerante em relação às diferentes culturas não significa endossar atos reprováveis do ponto de vista moral".

No que diz respeito à licencianda Bianca, sua resposta fornecida incialmente ao Caso 1 bem como uma análise no que tange à sensibilidade moral evidenciada em seu argumento encontram-se expostos no Quadro 40.

Quadro 40 - Análise da sensibilidade moral de Bianca, de acordo com a resposta inicial fornecida ao Caso 1.

\begin{tabular}{|c|c|c|c|}
\hline \multicolumn{4}{|c|}{ Bianca - Caso 1 - Resposta inicial - SIM } \\
\hline \multirow{2}{*}{\multicolumn{4}{|c|}{$\begin{array}{l}\text { Argumento: Apesar do risco de vazar informação ser maior do que manter o sigilo, se os cientistas tivessem } \\
\text { esta liberdade talvez se sentissem mais motivados e poderiam trocar informações para que uns ajudassem os } \\
\text { outros e desenvolvessem o projeto mais rapidamente }\end{array}$}} \\
\hline & & & \\
\hline \multirow{2}{*}{$\begin{array}{l}\text { Consequência (SIM): } \\
\text { Maior possibilidade de } \\
\text { vazamento de informações }\end{array}$} & \pm & $\downarrow$ & \\
\hline & $\begin{array}{l}\text { Consequência (SIM): } \\
\text { Execução do Projeto } \\
\text { mais rápida e a contento }\end{array}$ & $\begin{array}{l}\text { Consequência (SIM): } \\
\text { Condição de trabalho } \\
\text { ideal para os cientistas }\end{array}$ & $\begin{array}{l}\text { Parte } \\
\text { interessada: } \\
\text { Cientistas }\end{array}$ \\
\hline
\end{tabular}

Assim como discutido a partir do argumento inicial fornecido por Alice, a licencianda Bianca apresenta, antes de qualquer discussão estabelecida em sala de aula, uma limitada sensibilidade moral, a qual é esperada conforme a literatura que sugere que o indivíduo ao se deparar com situações que não possuem regras pré-estabelecidas encontra dificuldades na tomada de decisão (BEBEAU, 1995). Dessa forma, ao considerarmos valores absolutos, dos 23 
aspectos que expomos na grelha presente no Quadro 37, apenas quatro são abordados pela licencianda, isto é, apenas cerca de $17 \%$ de elementos morais estão presentes na resposta inicial de Bianca.

Dentre os elementos evidenciados na resposta da futura professora em análise, o destaque se encontra na abordagem de possíveis consequências da ação tomada, as quais assim como para Alice, são exclusivas para o posicionamento assumido. Ou seja, uma vez que a licencianda se mostra favorável à decisão de Oppenheimer de conceder liberdade para os cientistas falarem o que quiserem somente dentro dos laboratórios, as consequências que Bianca evidencia em seu argumento são exclusivas desse posicionamento. Dessa forma, tal liberdade, segundo a aluna, embora possa aumentar o risco de vazamento de informação (consequência 1), fornece uma condição de trabalho científico ideal (consequência 2) e assim, promove uma execução mais rápida do projeto (consequência 3). Nesse contexto, as ausências observadas no que diz respeito às consequências das ações são referentes àquelas fruto de um posicionamento contrário ao assumido pela licencianda, ou seja, assim como Alice, não há ainda um contraponto entre consequências de cada uma das ações do protagonista nas respostas fornecidas pelas futuras professoras.

Ainda no que diz respeito à abordagem de consequências em sua resposta, embora Bianca não tenha feito esse contraponto entre posicionamentos distintos, observamos, diferentemente de Alice, um enfoque mais consequencialista (COSTA, 2002). Nesse sentido, considerando a cadeia de eventos (consequências resultado de uma das ações), Bianca assume um posicionamento.

A partir da análise do argumento inicial fornecido pela licencianda em questão, também identificamos a menção a uma única parte interessada, os cientistas, o que mais uma vez reforça semelhanças com a resposta empregada inicialmente por Alice. Uma vez que é o trabalho dos cientistas que será afetado pela decisão de Oppenheimer, estes sem dúvida alguma, são partes interessadas, contudo, o protagonista na tomada de decisão no caso narrado é mais uma vez ignorado e, consequentemente, qualquer obrigação deste é desconsiderada na formulação da resposta em favor do posicionamento assumido. Assim sendo, desconhecendo as obrigações de Oppenheimer, uma vez que este, de acordo com o que é exposto na resposta de Bianca não é parte diretamente interessada, o ponto de conflito resultado da contraposição de obrigações do protagonista do caso não é atingido pela futura professora, ressaltando a limitada sensibilidade moral da mesma. 
Por fim, considerando ainda a resposta fornecida inicialmente por Bianca ao caso 1, identificamos, assim como para a Alice, a relação existente entre a baixa sensibilidade moral com argumentos estruturalmente pouco complexos, uma vez que, conforme constatado anteriormente, o argumento de Bianca consiste na combinação básica de elementos propostos por Toulmin (2001) para um argumento válido, CDJ (Quadro 9). No entanto, ainda assim, na busca por argumentos estruturalmente válidos observa-se para as diferentes licenciandas o emprego de um raciocínio informal racionalista na perspectiva de Sadler e Zeidler (2005).

Prosseguindo com a análise, apresentamos no Quadro 41, a segunda resposta empregada por Bianca para o Caso 1. Conforme podemos observar, a discussão estabelecida em sala de aula contribuiu para uma ligeira ampliação da sensibilidade moral da licencianda que passou a evidenciar seis dos 23 aspectos morais presentes na grelha esquematizada no Quadro 37. Ou seja, a aluna, em termos de valores absolutos apresentou um salto de $17 \%$ para $26 \%$ de aspectos morais mencionados em sua resposta que subsidiaram o seu posicionamento. Ainda assim, observa-se uma limitada sensibilidade moral no que diz respeito à tomada de decisão em conflitos que não apresentam regras estabelecidas a priori.

Quadro 41 - Análise da sensibilidade moral de Bianca, de acordo com a resposta final fornecida ao Caso 1.

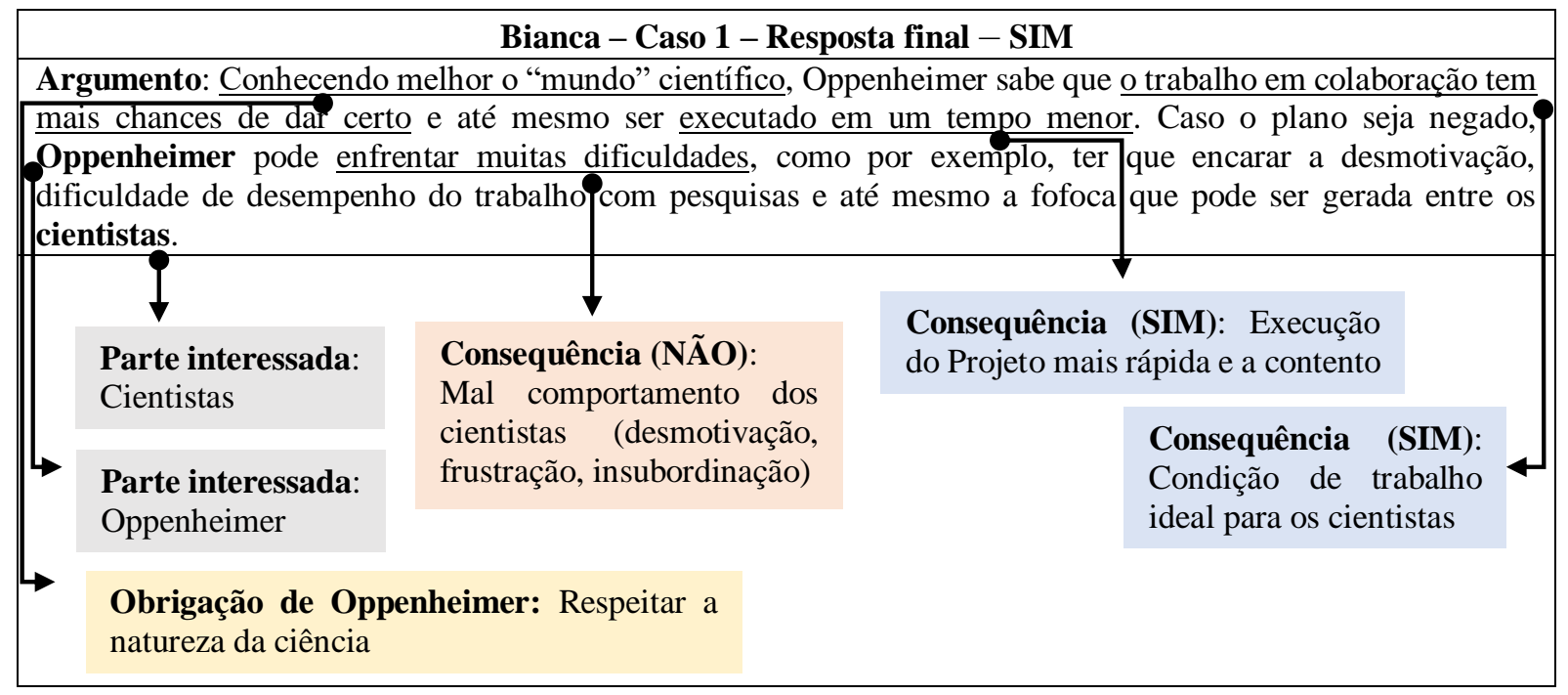

Com uma tendência a um enfoque essencialmente deontológico (COSTA, 2002), isto é, centrando na ideia de que existe uma moral a ser seguida na prática científica, nesse segundo momento a licencianda mantém o seu posicionamento fazendo uso, novamente, de três consequências. Contudo, pela primeira vez se observa um pequeno contraponto entre consequências de ações opostas, assim sendo Bianca exibe em seu argumento duas que corroboram o seu posicionamento (condição de trabalho ideal para os cientistas e execução mais rápida e a contento do projeto), ao mesmo tempo que emprega uma que assume a função 
de refutação da ação contrária (mal comportamento dos cientistas), algo que consideramos válido e confere certo grau de força ao argumento empregado. Nessa perspectiva, uma consequência utilizada inicialmente que poderia se configurar como um obstáculo à ação tomada e assumida por Bianca (maior possibilidade de vazamento de informação) foi excluída do argumento final, para a inclusão de uma que seria obstáculo à implementação da ação contrária.

Esse jogo envolvendo a análise de consequências ou prós e contras, apesar de ainda discreta nos argumentos dos futuros professores é própria do emprego do raciocínio informal, conforme definição de Zohar e Nemet (2002), e deve ser incentivada em sala de aula, de modo que os indivíduos ao se depararem com situações que exijam esse tipo de raciocínio o façam de maneira satisfatória.

Os outros dois elementos adicionados à resposta de Bianca dizem respeito ao protagonista do caso. Uma vez que ficou evidente na discussão conduzida pela docente, conforme trecho exposto na sequência, o protagonismo de Oppenheimer no caso narrado, Bianca passou a mencionar este como parte interessada e consequentemente uma de suas obrigações que deve ser considerada para a sua ação.

[P]: [...] Ok, aí qual era o outro aspecto que a gente tinha olhado na aula passada? Para a gente poder chegar num ponto de conflito? Era quais são as obrigações das pessoas, dos personagens, dos protagonistas. Então quais são as obrigações, quem são os protagonistas?

$[\ldots]$

[P]: Oppenheimer. Então, quais são as obrigações dele? Que aí a gente começa talvez a pensar que a pessoa não seja tão má quanto a gente imagina nem tão bonzinho quanto a gente pensa, e que cada um tem as suas obrigações [...]. Então quais são as obrigações do Oppenhimer?

Contudo, diferente de Alice, Bianca não apresenta ainda de forma sistematizada o ponto de conflito presente no caso em estudo, e isto porque, ao abordar as obrigações de Oppenheimer a licencianda se restringe ao seu papel como cientista e, consequentemente, ao seu conhecimento da natureza da ciência que o impõe uma moral a ser seguida. Nessa perspectiva, o enfoque principalmente deontológico (COSTA, 2002) limita a aluna nesse ponto, e como já mencionado anteriormente, não exige uma sensibilidade moral acurada para a tomada de decisão. Dessa forma, é o respeito à natureza da ciência suficiente para que Bianca se posicione, não existindo a partir de então um conflito ético a ser solucionado. Nesse contexto, salientamos novamente a barreira do relativismo moral mencionada por Guimarães (2011), a qual deve ser sobreposta com maiores ações envolvendo a abordagem da ética em sala de aula, em especial 
no ensino de ciências, a qual é preconizada pelos Parâmetros Curriculares Nacionais, enquanto tema transversal

Dando prosseguimento em nossa discussão, a terceira licencianda cuja sensibilidade moral analisamos foi Caroline, cujo argumento encontra-se esquematizado no Quadro 42.

Quadro 42 - Análise da sensibilidade moral de Caroline, de acordo com a resposta inicial fornecida ao Caso 1.

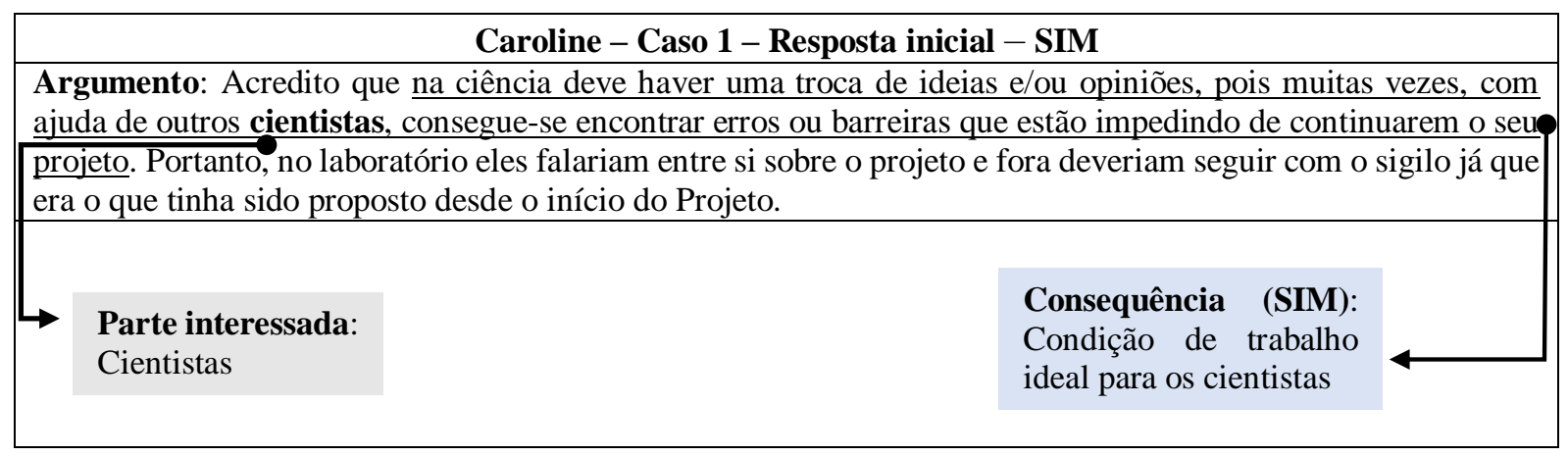

Dentre os argumentos apresentados e discutidos até o momento, este é o que indica menor sensibilidade moral do educando. Conforme podemos observar, a licencianda faz menção apenas a dois dos 23 elementos propostos na grelha presente no Quadro 37, o que representa aproximadamente $9 \%$ dos aspectos morais que consideramos pertinentes ao caso narrado envolvendo o sigilo interno do Projeto Manhattan.

Apresentando um posicionamento favorável ao de Oppenheimer, Caroline destaca uma única consequência exclusiva dessa decisão, ou seja, a ação de conceder uma maior liberdade para os cientistas se comunicarem dentro dos laboratórios implicaria em uma condição de trabalho ideal para o desenvolvimento da ciência. Outrossim, seguindo a tendência identificada nas respostas iniciais de Alice e Bianca, Caroline desconsidera o protagonismo de Oppenheimer em seu argumento, consequentemente qualquer obrigação deste se encontra ausente. Logo, ausentes as obrigações de Oppenheimer, nesse primeiro momento constatamos que a futura professora não vislumbra o ponto de conflito presente na situação narrada.

Assim sendo, considerando unicamente as partes diretamente afetadas pelas possíveis ações narradas no caso, os cientistas, Caroline também emprega um raciocínio informal racionalista (SADLER e ZEIDLER, 2005). Além disso, partindo de um dos preceitos da natureza da ciência, isto é, de que nesta deve haver a troca de ideias e opiniões para o seu desenvolvimento, identificamos novamente uma tendência a um enfoque deontológico (COSTA, 2002), o qual corrobora a tomada de decisão sem uma sensibilidade moral acurada.

É válido ainda salientar que apesar da resposta inicial de Caroline evidenciar uma menor sensibilidade moral dentre as três licenciandas analisadas até então, o argumento fornecido 
neste momento pela futura professora, é aquele que na perspectiva de Toulmin (2001) se configura como mais complexo estruturalmente (Quadro 11). Essa complexidade observada ocorre uma vez que, consoante o que foi discutido anteriormente, há pela primeira vez o emprego de um elemento que extrapola a combinação básica do TAP (TOULMIN, 2001), o backing (por conta de que muitas vezes, com ajuda de outros cientistas, consegue-se encontrar erros ou barreiras que estão impedindo de continuarem o seu projeto). Dessa forma podemos reiterar que o enfoque deontológico assumido na resposta permite ao indivíduo uma tomada de decisão, e consequentemente um maior grau de estruturação do argumento sem a necessidade de uma sensibilidade moral acurada. Contudo, almejando um distanciamento da moral heterônoma de Kant (2005), por motivos já abordados, este enfoque deve ser evitado, e a sensibilidade moral do educando deve ser exercitada e desenvolvida.

Em um segundo momento, posterior a discussão estabelecida em sala de aula, observamos, assim como para as demais licenciandas, uma ampliação de sensibilidade moral de Caroline, cujo argumento e sua respectiva análise se encontram no Quadro 43. Conforme podemos observar com o exposto neste quadro, Caroline em seu argumento final passou a mencionar sete dos 23 aspectos presentes na grelha exposta no Quadro 37, o que representa cerca de $30 \%$ dos aspectos morais que consideramos relevantes para o caso narrado.

Com um enfoque mais consequencialista (COSTA, 2002), constatamos no segundo argumento de Caroline a presença de quatro consequências, contudo todas elas são exclusivas para a mesma ação, ou seja, mantendo o seu posicionamento favorável à decisão de Oppenheimer, a futura professora emprega novamente a ideia de que dessa forma se teria uma condição de trabalho ideal para o desenvolvimento da ciência, e acrescenta que assim seria possível a execução do projeto de forma mais rápida, o que culminaria na obtenção de prestígio, embora a liberdade cedida aos cientistas pudesse promover uma maior possibilidade de vazamento de informações. Assim sendo, não se verifica mais uma vez a contraposição de consequências para cada uma das ações, algo que é típico do exercício do raciocínio informal (ZOHAR e NEMET, 2002). 
Quadro 43 - Análise da sensibilidade moral de Caroline, de acordo com a resposta final fornecida ao Caso 1.

\section{Caroline - Caso 1 - Resposta final - SIM}

\begin{tabular}{|c|c|c|}
\hline $\begin{array}{l}\text { Argumento: Sabe-se que o conflito ético est } \\
\text { Groves tinha deixado claro a todos sobre } \\
\text { cientistas não conseguem prosseguir seu tra } \\
\text { ideia e discussão com outros cientistas ajud }\end{array}$ & $\begin{array}{l}\text { o respeito ao modo de "fo } \\
\text { ada um fazer o seu trab } \\
\text { lho (costumam não perce } \\
\text { a o trabalho a se desenv }\end{array}$ & $\begin{array}{l}\text { a" x o respeito ao sig } \\
\text { lo. Porém, muitas ve } \\
\text { rros) e com isso, a tr } \\
\text { mesmo ser concluíd }\end{array}$ \\
\hline $\begin{array}{l}\text { sucesso. } \\
\text { Portanto, acredito que para o projeto ser con } \\
\begin{array}{l}\text { permitir a conversa APENAS no laboratório } \\
\text { consequência. } \\
\text { O vazamento poderia ser uma consequência, } \\
\text { fora do lugar apropriado pois poderia perder o } \\
\text { há uma competitividade na ciência também). }\end{array}\end{array}$ & $\begin{array}{l}\text { cluído com sucesso, Grove } \\
\text { e caso isso fosse descum } \\
\text { mas acredito que bons cien } \\
\text { prestígio de seu projeto ser } \\
P\end{array}$ & $\begin{array}{l}\text { ia deixar o orgulho de } 1 \\
\text { í sim ele poderia impor } \\
\text { omo são, não iriam com } \\
\text { senvolvido (pois sabemo }\end{array}$ \\
\hline $\begin{array}{l}\text { Consequência (SIM): } \\
\rightarrow \begin{array}{l}\text { Condição de trabalho } \\
\text { ideal para os cientistas }\end{array}\end{array}$ & $\begin{array}{l}\text { Ponto de } \\
\text { da ciência }\end{array}$ & $\begin{array}{l}\text { Despeitar a natureza } \\
\text { peitar o sigilo acordado }\end{array}$ \\
\hline $\begin{array}{l}\text { Consequência (SIM): Execução } \\
\text { do Projeto mais rápida e a contento }\end{array}$ & $\begin{array}{l}\text { Consequêt } \\
\text { Prestígio } \\
\text { execução d }\end{array}$ & $\begin{array}{l}\text { (SIM): } \\
\text { a boa } \\
\text { to }\end{array}$ \\
\hline $\begin{array}{l}\text { Consequência (SIM): } \\
\text { Maior possibilidade de } \\
\text { vazamento de informações }\end{array}$ & $\begin{array}{l}\text { Parte interessada: } \\
\text { Cientistas }\end{array}$ & $\begin{array}{l}\text { Parte interessada: } \\
\text { Groves }\end{array}$ \\
\hline
\end{tabular}

Outrossim, diferente do que ocorreu com as demais licenciandas cujos argumentos já foram discutidos, ao considerar as partes interessadas, Caroline continua negligenciando o papel de Oppenheimer na situação. Dessa forma, o que observamos é um certo protagonismo do militar Groves, o qual, segundo a aluna, poderia deixar o orgulho de lado e conceder tal liberdade para os cientistas, como se o general fosse o responsável pela tomada de decisão. Esse protagonismo atribuído a Groves pode ser observado na discussão conforme trecho exposto na sequência em que a professora formadora discutia os possíveis pontos de conflito existentes no caso. No enxerto a seguir a fala de cada educando é indicada pela letra inicial de cada nome, portanto $\mathrm{P}=$ professora $\mathrm{A}=$ Alice $; \mathrm{Bi}=$ Bianca $; \mathrm{Ca}=$ Caroline $; \mathrm{De}=$ Débora $; \mathrm{E}=$ Érica $; \mathrm{F}=$ Francisco; $\mathrm{G}=$ Gabriel. Doravante adotaremos essa notação.

[P]: Bom depois que a gente faz tudo isso, a gente chega no fim do que a gente queria, que é ... que era aquela coisa mais difícil que a gente sabia que tinha que encontrar, que era o que? Qual que era aquela coisa mais difícil de achar? [...] O conflito que está de fato valendo, o conflito ético né? Então, qual que é o conflito ético aqui? Conflito ético dos protagonistas? Ou é de um protagonista só que tem conflito ético?

[De]: Sigilo versus execução

[P]: Sigilo versus execução? É só isso ou vamos expandir um pouco mais? O que cada uma das coisas... ela fala que é sigilo versus execução, isso é um conflito ético? De alguém? Seria dos dois que você está pensando? Seria um conflito ético? 
[De]: Do contexto inteiro, dos dois.

[P]: Então, mas aí a gente quer o conflito ético dos protagonistas, então vou tirar aqui. Podemos até deixar sigilo versus execução, é o conflito, mas o contexto inteiro não tem ética né. Então vamos colocar aqui, o conflito do Oppie né? E é só dele ou o Groves também tem conflito ético? Vamos pensar, primeiro vamos pensar no conflito ético ...

[E]: É porque talvez ele desconhece o processo que é fazer ciência.

[P]: Você fala, o Groves.

[E]: É, ele chama os cientistas de crianças que não têm disciplina, e talvez seja pelo fato dele ser ignorante com relação ao que é produzir ciência.

[P]: Então isso aí é o que vocês enxergam do Groves, que ele não entende? Mas ele vai estar em conflito ético ou não? Sim ou não? [...] Vocês concordam com esse pensamento aqui de que pra ele não tem conflito, para ele tem umas crianças teimosas. É isso a ideia de vocês?

[F]: Não, acho que o conflito do Groves é sonegar informação, é não seguir o sigilo.

[P]: É, mas isso aí é um conflito ético?

[F]: Não, na verdade é um conflito ... operacional

Sendo assim, qualquer obrigação atribuída a Oppenheimer continua ausente da resposta de Caroline, no entanto, ainda se observa no início do argumento da futura professora o ponto de conflito vislumbrado pela mesma, o qual pode ser atribuído ao resíduo de enfoque deontológico ainda presente nas colocações de Caroline, e a um certo protagonismo que a licencianda também atribui aos cientistas. Dessa forma, o ponto de conflito evidenciado por Caroline surge face à obrigatoriedade dos cientistas como um todo para com a natureza da ciência (resíduo do enfoque deontológico inicial), e a obrigatoriedade também dos cientistas em respeitar o sigilo do projeto (ampliação do protagonismo de Oppenheimer para os cientistas como um todo).

Dando continuidade à análise dos argumentos empregados pelos licenciandos prosseguimos com um estudo da sensibilidade moral de Débora com base nas respostas fornecidas pela aluna ao Caso 1. Nessa perspectiva apresentamos no Quadro 44 o argumento empregado pela futura professora, bem como sua respectiva análise.

Quadro 44 - Análise da sensibilidade moral de Débora, de acordo com a resposta inicial fornecida ao Caso 1.

Débora - Caso 1 - Resposta inicial - SIM

Argumento: Pois a argumentação na ciência é de extrema importância e o trabalho em equipe facilita e faz com que descobertas possam ser realizadas mais facilmente. Porém, se tratando de uma operação militar sigilosa, os cientistas ficariam livres para argumentar somente no laboratório, com algum controle e supervisão.

Parte interessada:

Consequência (SIM):

Condição de trabalho

Cientistas ideal para os cientistas 
Semelhante ao argumento inicial empregado por Caroline, observamos uma sensibilidade moral bastante limitada para Débora, a qual menciona em sua resposta apenas dois dos 23 elementos que consideramos relevantes na tomada de decisão de Oppenheimer, ou seja, apenas aproximadamente 9\% dos aspectos morais indicados no Quadro 37.

Com um enfoque maioritariamente deontológico (COSTA, 2002) (a argumentação é essencial na ciência), e um padrão de raciocínio informal racionalista (SADLER e ZEIDLER, 2005), a licencianda menciona apenas os cientistas enquanto partes interessadas na situação, negligenciando o papel de Oppenheimer. Dessa forma, de modo semelhante à maioria dos futuros professores, qualquer obrigação do físico diante do dilema narrado se encontra ausente, o que inviabiliza a determinação do ponto de conflito, uma vez que este é o protagonista do caso. Outrossim, considerando exclusivamente os cientistas como partes afetadas, se encontra presente na resposta inicial de Débora uma única consequência, a qual é referente ao trabalho dos mesmos.

Contudo, seguindo a tendência observada para os demais licenciandos, a discussão conduzida pela docente foi essencial para que a aluna pudesse vislumbrar outros aspectos inerentes ao caso narrado, os quais permitem uma tomada de decisão mais consciente. Assim sendo, apresentamos na sequência, no Quadro 45, uma análise do segundo argumento apresentado por Débora em resposta ao dilema presente no Caso 1.

Quadro 45 - Análise da sensibilidade moral de Débora, de acordo com a resposta final fornecida ao Caso 1.

\begin{tabular}{|c|c|c|c|c|}
\hline \multicolumn{5}{|c|}{ Débora - Caso 1 - Resposta final - SIM } \\
\hline \multicolumn{5}{|c|}{$\begin{array}{l}\text { Argumento: Deve continuar com o seu plano, pois segundo a conhecimento científico ("moral científica"), os } \\
\text { cientistas devem trabalhar em equipe. Além disso, o trabalho em equipe pode levar ele a cumprir um de seus } \\
\text { objetivos mais rapidamente, o de finalizar o projeto e construir a bomba. Porém, Oppenheimer deve assumir } \\
\text { as consequências e fazer o máximo para garantir que o outro conflito não venha à tona, que o sigilo seja } \\
\text { quebrado. para isso precisa articular bem os cientistas e ter confiança nos seus escolhidos. }\end{array}$} \\
\hline \multirow{3}{*}{$\begin{array}{l}\text { Obrigação de Oppenheimer: } \\
\text { Evitar o vazamento de } \\
\text { informações }\end{array}$} & \multirow{2}{*}{\multicolumn{3}{|c|}{$\begin{array}{l}\text { Obrigação de Oppenheimer: Respeitar a } \\
\text { natureza da ciência }\end{array}$}} & \\
\hline & & & & \\
\hline & \multicolumn{2}{|c|}{$\begin{array}{l}\text { Obrigação de Oppenheimer: } \\
\text { Assegurar um bom trabalho } \\
\text { para os cientistas }\end{array}$} & $\begin{array}{l}\text { Consequência (SIM): } \\
\text { Condição de trabalho } \\
\text { ideal para os cientistas }\end{array}$ & \\
\hline $\begin{array}{l}\text { Parte interessada: } \\
\text { Cientistas }\end{array}$ & $\begin{array}{l}\text { nteressada: } \\
\text { heimer }\end{array}$ & $\begin{array}{l}\text { Consec } \\
\text { do Proj }\end{array}$ & $\begin{array}{l}\text { cia (SIM): Execução } \\
\text { mais rápida e a contento }\end{array}$ & \\
\hline
\end{tabular}

O que podemos observar a partir do que é apresentado no Quadro 45 é que a licencianda Débora faz menção em seu segundo argumento a sete dos 23 elementos presentes no Quadro 37, ou seja, aproximadamente $30 \%$ dos aspectos que consideramos relevantes para o Caso 1 . Dessa forma podemos concluir que, assim como esperado de acordo com Bebeau (1995), e 
como verificado para os demais futuros professores, houve um aumento da sensibilidade moral da aluna, o que ressalta mais uma vez a validade de um momento de reflexão conjunto para a construção de um argumento final.

Considerando a resposta da licencianda, identificamos o papel fundamental que ela atribui a Oppenheimer nesse momento, personagem que inicialmente havia sido negligenciado. Nessa perspectiva, assumindo que o físico deve continuar com o seu plano, isto é, de fornecer liberdade para os cientistas falarem o que quiserem dentro do laboratório ficando por conta deles policiarem a si mesmos, são mencionadas algumas de suas obrigações. Dentre as obrigações abordadas pela futura professora está a do físico de respeitar a natureza da ciência, uma vez que esta, segunda a aluna, conta com uma moral que deve ser seguida; evitar o vazamento de informações, isto é, assegurar que mesmo com a decisão tomada o sigilo não seja quebrado; e fornecer um ambiente propício para a realização do trabalho dos cientistas, mantendo a confiança dos mesmos e articulando todas as informações.

Ademais, estão presentes na resposta final de Débora duas consequências da decisão tomada, isto é, duas consequências do "sim", além dos cientistas e Oppenheimer enquanto partes interessadas, os primeiros por serem os principais afetados pela decisão que deve ser tomada pelo segundo (Oppenheimer). Mais uma vez, portanto, verificamos que talvez almejando uma resposta mais clara e objetiva não há uma contraposição de ideias, ou seja, considerações de cada um dos posicionamentos que o protagonista poderia tomar. Essa constatação, por sua vez, se opõe à própria natureza do raciocínio informal que pretendíamos exercitar e investigar com este estudo. Nesse sentido, identificamos mais uma vez um distanciamento a esse tipo de raciocínio que embora, como defendido aqui seja fundamental na tomada de decisão envolvendo aspectos éticos e morais, e até mesmo na própria construção da ciência, é pouco trabalhado em sala de aula, tanto da educação básica como no ensino superior (SADLER, 2005).

Nesse contexto, podemos concluir que no seu segundo argumento, com uma sensibilidade moral ampliada, a aluna, apesar de mencionar um número maior de consequências como resultado direto da discussão realizada em sala de aula, ainda apresenta uma tendência a um enfoque deontológico (COSTA, 2002). Esse enfoque é evidente uma vez que observamos na primeira parte da resposta da aluna, em suas duas primeiras sentenças, a manutenção do que havia sido exposto inicialmente quando enfatiza o que ela denomina de moral científica, em que os cientistas devem trabalhar em equipe e a argumentação se torna dessa forma essencial. 
A parte final da resposta apresentada pela aluna, portanto, se trata de uma retextualização do que foi abordado oralmente, conforme destacamos no trecho da discussão exposto na sequência.

[P]: Então, quais são as obrigações dele? Que dessa forma a gente começa a pensar que a pessoa talvez não seja tão má quanto a gente imagina, nem tão boa quanto a gente pensa que é, que cada um tem as suas obrigações [...]. Então quais são as obrigações?

[De]: Garantir o sigilo.

[P]: Garantir o sigilo, é isso? Qual era outra obrigação dele? Ou a única obrigação dele era essa?

[De]: Garantir que o projeto saia.

$[\ldots]$

[P]: Do ponto de vista científico, o que a gente pode colocar? Ele não tem outras obrigações também, pessoal? Além da execução do projeto? Imagina vocês cientistas, que mais obrigações que ele tem?

[F]: Ele tem que pensar.

[P]: Pensar?

[F]: É, ele é o cientista responsável pelo projeto.

[P]: Ok, ele tem obrigação de articular as ideias, sim.

Na sequência, apresentamos uma análise da sensibilidade moral exposta por Gabriel de acordo com suas repostas ao Caso 1. Assim sendo, encontra-se no Quadro 46, o argumento inicial fornecido pelo aluno antes de qualquer tipo de discussão conjunta sobre a situação narrada.

Quadro 46 - Análise da sensibilidade moral de Gabriel, de acordo com a resposta inicial fornecida ao Caso 1.

Gabriel - Caso 1 - Resposta inicial - SIM

Argumento: Sim, Oppenheimer deve seguir com o plano por diversos motivos: é necessário o diálogo entre eles para a troca de ideias; deixá-los sem policiamento demonstra confiança nos mesmo e a presença de alguém policiando seria uma forma de demonstrar explicitamente desconfiança no sigilo deles; em algum momento o ciclo de policiamento deve ser quebrado. Sempre terá alguém que não será policiado e por motivos citados é melhor que o ciclo se encerre com os cientistas.

Parte interessada: Oppenheimer

\section{Parte interessada:}

Cientistas
Consequência (SIM):

Condição de trabalho ideal para os cientistas

Iniciando sua resposta com a indicação do protagonista do caso, diferentemente da maioria dos futuros professores, Gabriel já faz menção nesse primeiro momento à Oppenheimer enquanto parte interessada no caso, uma vez que este deve tomar a decisão de seguir ou não com o plano. Na sequência são apresentados mais dois elementos comuns em outros 
argumentos, os quais são os cientistas enquanto partes diretamente interessadas, e uma consequência ao trabalho dos mesmos. Dessa forma, também exibindo uma sensibilidade moral bastante limitada o futuro professor faz menção apenas a três dos 23 elementos considerados por nós relevantes ao caso e presentes no Quadro 37, ou seja, apenas $13 \%$.

Contudo, partindo inicialmente de um enfoque que consideramos maioritariamente consequencialista (COSTA, 2002), o qual é corroborado pela estrutura adotada na resposta, isto é, por meio do emprego gráfico dos dois pontos (:), que tem como função a enumeração de motivos para a adoção de um posicionamento de Oppenheimer, observamos a presença de uma consequência que representa uma extrapolação à grelha que havíamos elaborado de aspectos pertinentes ao caso. Nessa perspectiva, identificamos com o trecho destacado em fonte itálica (deixá-los sem policiamento demonstra confiança nos mesmo e a presença de alguém policiando seria uma forma de demonstrar explicitamente desconfiança no sigilo deles), uma consequência que é melhor explicada pelo aluno no momento de discussão conforme transcrevemos na sequência.

[P]: É insubordinação, é isso mesmo.

[G]: Eu coloquei aqui também professora, mais ou menos em minhas coisas que eles vão ... uma consequência seria a desconfiança, por estar trabalhando para uma coisa que eles nem sabem muito bem o motivo.

[P]: É, desconfiança. Mas desconfiança a gente tem que entender que é desconfiança com relação ao que está sendo feito, certo? Alguém lembra de mais alguma coisa?

[A]: E eles podem começar a fofocar entre eles.

[P]: Fofocar? [...]. É mas acho que aí, a fofoca vai gerar talvez a insubordinação, e as coisas começam a...

[A]: É trocar ideias mesmo escondidos.

$[\mathrm{P}]:$ Ah, isso. Então agora tem que esclarecer a insubordinação. Insubordinação que eu estava pensando é no sentido de ...

[E]: De desobedecer.

[P]: De desobedecer e começar a trocar ideias ... agora que eu entendi, a fofoca é insubordinação. Não insubordinação do tipo: vou brigar com o Oppenheimer porque eu não estou gostando disso. É insubordinação no sentido deles começarem a ir contra a norma vigente. Então vou colocar o fofocar aqui para gente saber o que a insubordinação significa.

$[\mathrm{G}]$ : Isso.

Nesse sentido, conforme conclusão que foi tomada no momento da discussão, consideramos o trecho em destaque, como algo referente à consequência que no Quadro 37 encontra-se como (Mal comportamento dos cientistas - desmotivação, frustração, insubordinação). No entanto, não consideramos nesse momento esse elemento para a análise da sensibilidade moral de Gabriel, uma vez que essa consequência não havia ficado claro na 
resposta do aluno. Logo, o que podemos salientar com o ocorrido é a possibilidade constante de melhoria e ampliação do instrumento de análise a qual é susceptível a alterações, além disso enfatizamos mais uma vez a validade do momento de discussão e a importância do docente em propiciar a participação de todos os alunos. Essa última observação vai ao encontro do terceiro princípio que Sadler e Zeidler (2009) elencam quanto à importância da integração de QSC na educação científica para formação de cidadãos alfabetizados cientificamente. Princípio este que representa, de acordo com Bossér e Lindahl (2017), uma das principais dificuldades encontradas pelos professores ao lidarem com QSC. Segundo Sadler e Zeidler (2009):

\begin{abstract}
Quando educadores querem usar problemas reais relacionados à ciência como veículo para engajar estudantes em experiências de aprendizagem significativas eles não devem tentar destilar a ciência de forma a descartar outros elementos dos problemas que podem ser vistos como além dos limites da ciência tradicional [...] essa abordagem "segura" vai contra o propósito de usar QSC como contextos para a aprendizagem (SADLER e ZEIDLER, 2009, p. 912, tradução nossa).
\end{abstract}

Contudo, Bossér e Lindhal (2017) salientam que práticas dialógicas estabelecidas a partir de questões socialmente controversas exigem novas demandas para os professores, dentre as quais propiciar um ambiente que encoraja os educandos a expressarem suas opiniões durante as discussões.

Nessa perspectiva, após a discussão, a qual permitiu a participação dos diferentes licenciandos, como no momento no qual Gabriel apresenta a consequência que foi considerada apenas por ele inicialmente, houve, assim como para os demais futuros professores, uma ampliação da sensibilidade moral. Esse aumento da sensibilidade pode ser identificado com a análise apresentada no Quadro 47.

Quadro 47 - Análise da sensibilidade moral de Gabriel, de acordo com a resposta final fornecida ao Caso 1.

Gabriel - Caso 1 - Resposta final - SIM

Argumento: Sim, existem pontos positivos e negativos em qualquer uma das escolhas de Oppenheimer, as duas apresentam riscos, mas a escolha de prosseguir com o plano acaba sendo a mais correta pois o respeito ao modo que a ciência trabalha acarreta em um desenvolvimento muito mais rápido da mesma, além de demonstrar confiança e reconhecimento aos cientistas envolvidos. Dessa forma evita-se a desmotivação e possíveis insubordinações dos cientistas que poderia acarretar na demora ou até mesmo na não execução do projeto.

\begin{tabular}{|l|l|l|}
\hline $\begin{array}{l}\text { Consequência (NÃO): } \\
\begin{array}{l}\text { Mal comportamento dos } \\
\text { cientistas (desmotivação, } \\
\text { frustração, insubordinação) }\end{array}\end{array}$ & $\begin{array}{l}\text { Obrigação de Oppenheimer: Respeitar a } \\
\text { natureza da ciência }\end{array}$ \\
\hline $\begin{array}{l}\text { Maior tempo necessário para } \\
\text { a finalização do Projeto }\end{array}$ & $\begin{array}{l}\text { Consequência } \\
\text { Condição de trabalho } \\
\text { ideal para os cientistas }\end{array}$ \\
\hline $\begin{array}{l}\text { Parte interessada: } \\
\text { Cientistas }\end{array}$ & $\begin{array}{l}\text { Parte interessada: } \\
\text { Oppenheimer }\end{array}$ & $\begin{array}{l}\text { Consequência (SIM): Execução } \\
\text { do Projeto mais rápida e a contento }\end{array}$ \\
\hline
\end{tabular}


A princípio, com o que é exposto no Quadro 47, constatamos a presença de sete dos 23 elementos indicados no Quadro 37 considerados por nós relevantes ao caso, o que representa mais uma vez $30 \%$ dos aspectos morais. Dessa forma, observamos a manutenção dos três elementos expostos na resposta anterior de Gabriel, isto é, Oppenheimer e os cientistas enquanto partes interessadas, além da consequência referente à condição de trabalho para os cientistas.

Outrossim, identificamos mais duas consequências ausentes inicialmente, as quais representam posições opostas que poderiam ser adotadas por Oppenheimer. Nesse sentido, observamos para este aluno um movimento típico do emprego do raciocínio informal de acordo com a definição que relembramos de Zohar e Nemet (2002, p. 38, tradução nossa) “[Raciocínio informal é o] raciocínio sobre causas e consequências e sobre vantagens e desvantagens, ou prós e contras, de proposições particulares ou decisões alternativas". Dessa forma, considerando decisões alternativas possíveis para Oppenheimer, o licenciando Gabriel faz uso de quatro consequências, sendo duas resultantes da ação do físico seguir com o plano de conceder certa liberdade aos cientistas, isto é, se Oppenheimer fornecesse essa liberdade nos depararíamos com uma condição de trabalho ideal para os cientistas e consequentemente contaríamos com a execução de um projeto mais rápido e a contento. Em contrapartida, o licenciando salienta outras duas consequências para o caso do físico optar por não seguir adiante com o plano, ou seja, de acordo com as colocações de Gabriel, este se confrontaria com um mal comportamento dos cientistas e, portanto, com a necessidade de mais tempo para a conclusão do projeto.

Ademais, há também na resposta do futuro professor a menção a uma obrigação de Oppenheimer, ausente inicialmente (obrigação de respeitar a natureza da ciência), a qual, é resultado do momento de reflexão, principalmente quando da determinação do ponto de conflito presente no caso narrado, dado que nesse momento houve uma ampla participação do licenciando, conforme podemos verificar no trecho exposto na sequência.

[G]: Acho que para a gente falar de conflito ético, é bom a gente lembrar moral e ética. $\mathrm{O}$ que seria moral para a gente falar da ética. Porque a moral é aquilo que a gente deve, e ética é aquilo que a gente escolhe.

[P]: Então o que seria moral nesse caso aqui? Nessa situação o que que é a moral? A moral de quem? Porque a gente viu também que a moral depende de um lugar para outro, então de que moral estamos falando? Moral da ciência entre aspas?

[F]: Não, a moral da confidencialidade.

[De]: E tem a moral da ciência que é trabalhar em grupo. 
[P]: Moral da confidencialidade e moral da ciência, tem duas morais em disputa. Então a moral da ciência que a Débora está querendo dizer é o princípio dos cientistas trabalhem em grupo. É isso? Cientistas trabalham em grupo, em colaboração.

[G]: É, então já temos um conflito [...] para essa moral a gente já tem um conflito, os cientistas trabalham em colaboração, e o conflito é se eles vão trabalhar ou não, certo? Então, pela moral, os cientistas deveriam trabalhar em colaboração.

[F]: É só que antes de aparecerem lá, foi tudo bem explicadinho para eles. Então, combinado não é caro meus queridos. Combinou que ia ficar quieto, combinou, agora não adianta chegar lá e falar: agora não quero fazer.

[P]: Ok, o conflito ele lembrou bem, se a moral entre aspas, o que é aceito na ciência, é que a ciência é feita de forma colaborativa, quem estava com o conflito ético? Qual era o protagonista que estava no ....

[G]: Oppenheimer.

[P]: É o Oppenheimer porque ele conhece essa moral. Ele sabe que a moral é essa, então o conflito ético dele seria afinal qual? O conflito dele seria como ela falou ali no começo, a Débora, deixar fazer as coisas certas ou forçar para que eles não trabalhassem em grupo em virtude de manter o sigilo. É esse o conflito?

[G]: O conflito ético seria então ... respeitar a moral da ciência ou ...

[E]: Versus disciplina militar.

[De]: Ou respeitar o tratado, o acordo.

[P]: Respeitar o sigilo, certo? Aqui como a gente não sabe se a ciência tem moral, o que a gente poderia colocar nessa moral?

[E]: O fazer científico.

[G]: A metodologia científica, natureza da ciência.

Assim sendo, diante do que foi apresentado até o momento, constatamos uma limitada sensibilidade moral para todos os licenciandos analisados. Em sua maioria, essa baixa sensibilidade é resultado de enfoques maioritariamente deontológicos na perspectiva de Costa (2002), a qual está intimamente relacionada a moral heterônoma de Kant (2005). Além disso, observamos, a partir dos resultados obtidos, uma ampla necessidade de mais práticas voltadas para o exercício do raciocínio informal em sala de aula, no caso específico no ensino superior, o que por sua vez não deixa de sinalizar lacunas no percurso formativo dos sujeitos em estudo com destaque para a educação básica. Essa observação é tomada principalmente a partir da análise das diferentes respostas nas quais verificamos a ausência de contrapontos, e considerações como aquelas feitas por Gabriel em sua segunda resposta ao caso 1, as quais representam movimentos típicos desse tipo de raciocínio, de acordo com as definições de Zohar e Nemet (2002).

Contudo, é válido salientar que certas colocações foram feitas por parte dos futuros professores a respeito do tempo insuficiente para realizar atividade, principalmente aquele disponível para o segundo momento de argumentação. Dessa forma, podemos atribuir a ausência de respostas mais elaborados, no que tange ao exercício do raciocínio informal, ao 
tempo limitado de atividade, o qual poderia impor aos alunos a busca por respostas mais objetivas e claras. Assim sendo, destacamos um elemento da atividade empreendida que poderia representar uma limitação de nosso estudo. No entanto, diante dos dados obtidos e da discussão sistematizada para o Caso 1, podemos identificar a pertinência da metodologia empreendida para os objetivos de investigação, uma vez que, se tratando de um estudo de caso exploratório, nos permite inferir sobre a sensibilidade moral dos alunos nos diferentes momentos. E de valor análogo aos argumentos escritos empregados pelos futuros professores, destacamos, conforme análise realizada até o momento, a importância da discussão desenvolvida em sala de aula, e de sua transcrição.

Caso 2

Relembramos que o Caso 2, presente no APÊNDICE G, narrava outro dilema de Oppenheimer proveniente de uma conversa com o físico dinamarquês Niels Bohr. Como resultado da discussão entre os cientistas, os licenciandos se deparavam novamente com um conflito envolvendo o sigilo do Projeto Manhattan. Diante da ideia de Bohr que sugeria que ao falar abertamente sobre o poder de destruição do armamento em construção, ninguém ou nenhuma outra nação seria tola o suficiente para elaborar uma arma que poderia facilmente destruir o mundo, os futuros professores deveriam argumentar se Oppenheimer deveria considerar o conselho do físico dinamarquês e falar abertamente sobre o que estava sendo desenvolvido no Projeto Manhattan.

Nesse contexto, para acesso e análise da sensibilidade moral dos licenciandos, elaboramos para o Caso 2, semelhantemente ao instrumento empregado na discussão referente ao Caso 1, uma grelha presente no Quadro 48 de aspectos morais que consideramos pertinentes para a nova situação narrada. Dentre os elementos que julgamos inerentes ao caso nos deparamos com dois pontos de conflito oriundos das obrigações de Oppenheimer enquanto cientista responsável pelo projeto, tais como o seu dever de divulgar a ciência e contribuir para o seu desenvolvimento, obrigação esta que vai ao encontro do que já foi discutido para o Caso 1, dado que, de acordo com o que assumimos como $\mathrm{NdC}$, o trabalho em equipe e a contribuição de diferentes cientistas é crucial para o desenvolvimento a contento da ciência. Contudo outra obrigação de Oppenheimer presente e que se opõe à citada anteriormente diz respeito ao seu dever de manter o acordo de sigilo assumido previamente, não somente com Groves, como também com o governo norte-americano. No mais, consideramos como partes direta ou indiretamente envolvidas no Caso 2, o próprio cientista (Oppenheimer), a comunidade científica como um todo, os personagens e instituições interessadas no desenvolvimento da 
bomba atômica, as quais exigem sigilo de Oppenheimer (Groves e o governo norte-americano), além da população que se encontra diante de uma destruição eminente e os países considerados como inimigos norte-americanos, países do Eixo, em especial a Alemanha nazista e o Japão.

Conforme evidenciado no Quadro 48, elencamos 13 consequências para as possíveis ações de Oppenheimer. Caso o cientista optasse por falar abertamente sobre o poder de destruição da bomba atômica em construção, estaria colocando em dúvida sua fidelidade ao governo, o que poderia implicar em consequências para a sua própria vida e carreira. Contudo, como mencionado, o trabalho em conjunto é essencial na ciência e, dessa forma, contaríamos com as mais variadas contribuições que resultariam em um amplo desenvolvimento da ciência. Também é válido considerar que o cenário previsto por Bohr pudesse ser cumprido e um acordo de não proliferação de armas nucleares entre as diferentes nações poderia de fato ocorrer. No entanto, observaríamos a continuidade da guerra, por tempo indeterminada, com armas convencionais que, por si só, já faziam inúmeras vítimas. Considerando, por sua vez, o cenário proposto por Oppenheimer, o qual não confia na sensatez dos homens, falar abertamente sobre o poder de destruição de uma arma química em fase de construção em Los Alamos poderia instigar outras nações a desenvolverem tal, armamento de forma até mais rápida, impedindo o pioneirismo norte-americano na obtenção do artefato nuclear.

Por fim, no que tange às consequências advindas da ação de Oppenheimer em não acatar os conselhos de Bohr e não falar abertamente sobre o poder de destruição do armamento em construção, podemos destacar como consequência, a manutenção das relações internas do Projeto Manhattan tais quais existiam. Dessa forma, o sigilo interno deveria ser mantido e consequentemente uma maior pressão sobre o trabalho dos cientistas, conforme evidenciada no caso 1, seria indispensável. Mesmo assim, poderíamos nos deparar com a possibilidade de vazamento de informações e a construção de mais armamentos nucleares espalhados pelo globo terrestre. Contudo, na situação norte-americana ideal, estes seriam os pioneiros no desenvolvimento de uma bomba nuclear e poderiam colocar um ponto final no conflito que vinha assolando toda a população a certo tempo. 
Quadro 48 - Grelha de aspectos morais referente ao Caso 2.

\section{PONTOS DE CONFLITO}

Falar abertamente sobre o poder de destruição da bomba (divulgação da ciência) vs. Manter o sigilo dado o contexto de guerra

Comunicar o poder de destruição de uma arma nuclear e a guerra continuar da forma como se encontrava $v s$. manter o sigilo na certeza que assim a guerra acabaria

\begin{tabular}{ll}
\hline Oppenheimer & PARTES INTERE \\
\hline Cientistas \\
\hline Groves \\
\hline Governo norte-americano \\
\hline População mundial \\
\hline Líderes das principais potências envolvidas na guerra
\end{tabular}

\section{CONSEQUÊNCIAS}

Dúvidas quanto ao patriotismo e fidelidade de Oppenheimer (descumprimento de acordo inicial)

Desenvolvimento da ciência

Continuidade da guerra com armas convencionais

Receio que outra nação construísse uma bomba atômica

Possibilidade de acordo

Pressão popular

Não pioneirismo norte-americano na construção da bomba atômica

Manutenção das relações internas no projeto

Obrigatoriedade de manutenção do sigilo

Controle do trabalho desenvolvido pelos cientistas (situação narrada no caso 1)

Vazamento de informações e construção de mais armas nucleares

Exclusividade norte-americana

Fim da guerra

OBRIGAÇÕES DE OPPENHEIMER

Divulgar a ciência e contribuir para o seu desenvolvimento

Utilizar a ciência em favor da sociedade

Manutenção do acordo inicial

Feita essas considerações, analisamos inicialmente os argumentos de Alice em resposta ao caso em questão. Dessa forma, sistematizamos no Quadro 49 o posicionamento inicial da licencianda indicando os mais variados aspectos morais mencionados em sua resposta. Conforme podemos observar, houve uma evolução notável da sensibilidade moral da aluna comparativamente à resposta inicial fornecida ao Caso 1 . Verificamos que para o Caso 2, dos 24 elementos presentes no Quadro 48, sete já são mencionados pela licencianda nesse momento, o que representa aproximadamente $29 \%$ dos aspectos morais considerados pelos pesquisadores. Ao compararmos com o caso anterior, verificamos que houve um salto percentual de 16 pontos. Ressaltamos que para efeito de discussão confrontamos nessa etapa apenas as respostas iniciais 
da futura professora, uma vez que, como já indicado na discussão referente ao Caso 1, o momento de reflexão conduzido pela professora formadora exerce significativa influência na sensibilidade moral dos educandos, que é exibida no segundo argumento dos mesmos.

Quadro 49 - Análise da sensibilidade moral de Alice, de acordo com a resposta inicial fornecida ao Caso 2

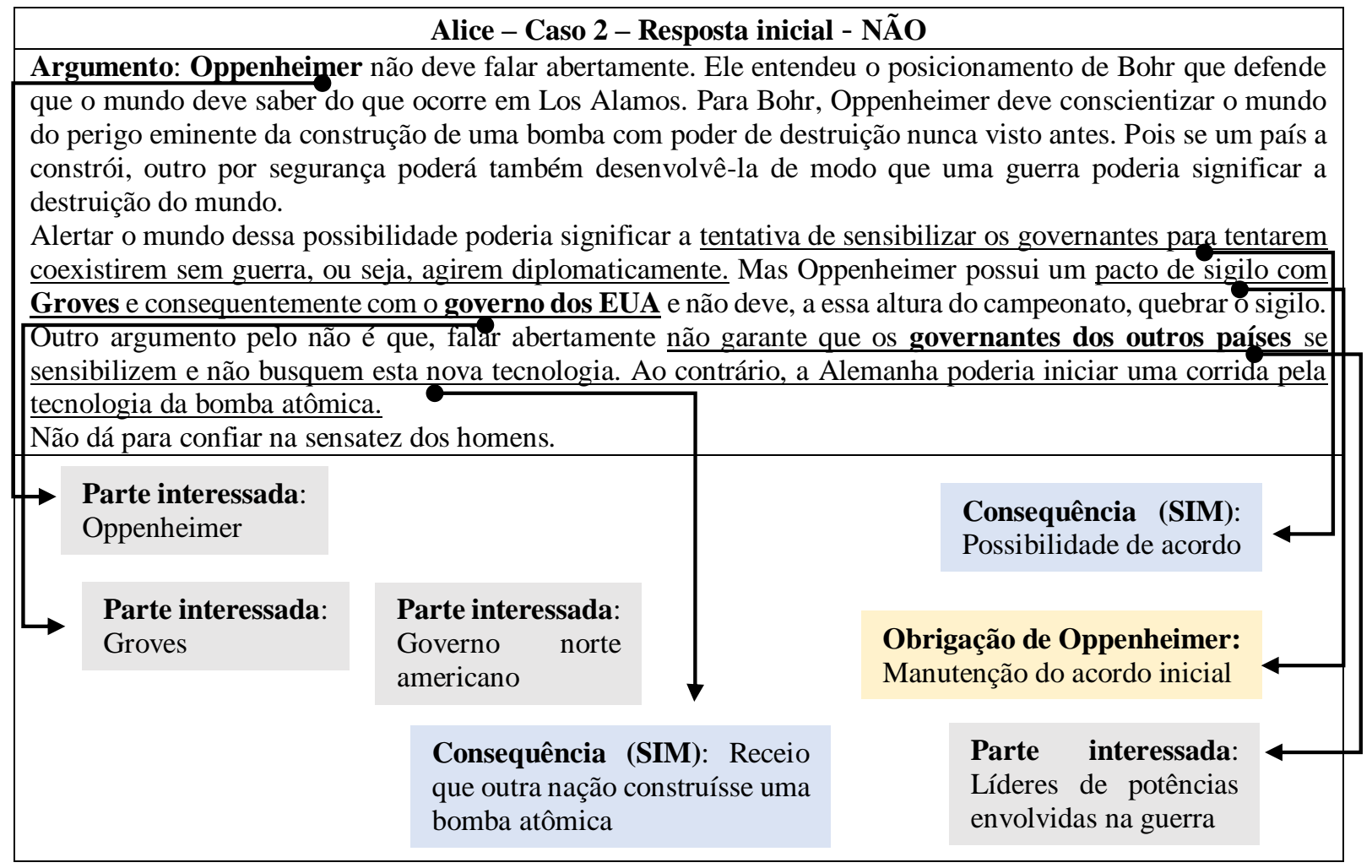

Ao analisarmos a resposta de Alice esquematizada no Quadro 49, mantendo um padrão de raciocínio informal racionalista, o qual já evidenciamos anteriormente, está diretamente relacionado com a busca de um argumento que atenda as considerações de Toulmin (2001), isto é, que apresenta ao menos a combinação básica de elementos que o torne estruturalmente válido (dado, conclusão e justificativa), a licencianda ainda tendendo a um enfoque deontológico (COSTA, 2002) faz menção a duas consequências derivadas do posicionamento contrário ao adotado na resposta. Assim sendo, verificamos um movimento pouco comum no Caso 1, em que a tomada de decisão é feita com base na contraposição de aspectos próprios da decisão alternativa, ou seja, nas palavras da licencianda, falar abertamente poderia sim conduzir a um acordo entre os diferentes países, contudo, partindo da ideia, e nesse ponto que encontramos o enfoque deontológico da resposta, de que não se pode confiar na sensatez da espécie humana, certamente a opção pelo sim implicaria em uma corrida armamentista que aumentaria o já elevado poder destrutivo da $2^{\mathrm{a}}$ Guerra Mundial. 
Constatamos também, de acordo com os aspectos mencionados pela futura professora, um destaque a considerações a respeito das partes interessadas, o que vem sendo comum na maioria das respostas dos licenciandos. Assim sendo, podemos concluir que dentre os elementos propostos por Bebeau (1995) necessários em uma resposta que sinalizaria satisfatória sensibilidade moral do indivíduo, uma facilidade na determinação das partes interessadas. Podemos atribuir essa facilidade ao tipo de texto adotado em sala de aula para realização das atividades, isto é, uma vez que contamos com o emprego de uma HQ, o educando se depara com retrato ou ilustração dos diferentes personagens representativos deles mesmos ou de instituições como, por exemplo, o governo norte-americano retratado pela figura de Roosevelt. Nesse contexto, atendendo às definições de quadrinista como McCloud (2005), tais personagens nesse hipergênero textual acabam na maioria das vezes ganhando voz e se comunicando com o interlocutor, permitindo uma melhor visualização das partes interessadas.

Com relação ainda às partes interessadas, verificamos que para o segundo caso a licencianda começou a sua resposta inicial com uma menção ao protagonista, o cientista Oppenheimer. Essa constatação, por sua vez, não foi comum no caso anterior e sinaliza uma ligeira evolução no que diz respeito à sensibilidade moral da futura professora. Além disso, a menção a Oppenheimer também pode ser atribuída à narrativa do próprio caso, o qual conta quase que exclusivamente com o diálogo entre Bohr e Oppenheimer. Dessa forma, a menção ao protagonista do caso corrobora a colocação feita no parágrafo anterior em que, ao falar diretamente com o interlocutor, facilita a sua visualização com parte diretamente interessada. Outrossim, a relevância que o diálogo presente no quadrinho assume na elaboração da resposta da licencianda é evidente conforme podemos observar pela paráfrase do trecho "Não dá para confiar na sensatez dos homens" presente no caso e na resposta da licencianda. Trecho este que contribuiu para o enfoque deontológico da resposta e que fundamentou a decisão de Alice.

Diante da menção a Oppenheimer enquanto protagonista, também observamos na resposta da licencianda uma obrigação atribuída ao cientista, o que eleva a sensibilidade moral evidenciada pela futura professora.

Contudo, ao verificarmos a segunda resposta de Alice ao Caso 2, a qual encontra-se esquematizada no Quadro 50, constatamos uma inalteração da sensibilidade moral exibida no seu argumento escrito. Assim sendo, dos 24 elementos presentes no Quadro 48, Alice faz menção novamente a sete deles, o que representa cerca de $29 \%$ dos aspectos morais. Nessa perspectiva, apesar de ter sido verificado que a sensibilidade moral exibida inicialmente foi preservada houve uma redução quando comparamos os argumentos fornecidos pela licencianda 
[P]: Então, o conflito dele [Oppenheimer] resumindo é ...

[De]: Ele ter a obrigação de cientista e falar para a sociedade ou seguir o acordo com o governo americano.

[P]: Então fala de novo, isso que a Débora falou está ok? Fala mais uma vez.

[De]: É, manter o acordo com o governo americano ou a ética do cientista de divulgar para a sociedade.

[P]: O acordo com o governo americano, ou manter a ética ...

[De]: De cientista e divulgar para a sociedade

[P]: De cientista e divulgar. Divulgar os conhecimentos, mas o que seria divulgar?

[A]: Divulgar os resultados das pesquisas.

$[\mathrm{P}]$ : os resultados das pesquisas, isso!

No que diz respeito à licencianda Bianca observamos que comparativamente aos argumentos escritos apresentados para o Caso 1, houve uma redução da sensibilidade moral exibida. Assim sendo, sistematizamos para discussão no Quadro 51 a resposta inicial da futura professora ao Caso 2 extraído da HQ.

Quadro 51 - Análise da sensibilidade moral de Bianca, de acordo com a resposta inicial fornecida ao Caso 2.

\section{Bianca - Caso 2 - Resposta inicial - SIM}

Argumento: Caso a bomba já estivesse pronta, seria interessante expor o seu poder sim, desta maneira poderia haver alguma forma de acordo sem que fosse necessário utilizá-la. Mas, para que houvesse essa divulgação seria interessante ter em mente alguma forma de investigar se o acordo (caso existisse) seria de fato real e não um golpe do adversário para ganhar tempo planejando outro meio de ganhar a guerra.

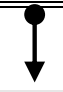

Parte interessada:

Líderes de potências envolvidas na guerra
Consequência (SIM): Receio que outra nação construísse uma bomba atômica
Consequência (SIM):

Possibilidade de acordo

Com um enfoque consequencialista (COSTA, 2002), isto é, considerando como consequência da ação a possibilidade de um acordo entre os líderes das diferentes nações envolvidas diretamente na $2^{\mathrm{a}}$ Guerra Mundial, e de suas implicações/demandas, Bianca emprega três dos 24 elementos presentes no Quadro 48 referentes àqueles que julgamos inerentes ao caso em questão. Dessa forma, há a menção a apenas aproximadamente $13 \%$ dos aspectos morais. Comparativamente ao mesmo momento quando da aplicação do Caso 1, houve uma redução percentual de 4 pontos. Contudo, observamos, de acordo, com as respostas da licencianda a retenção de uma mesma estrutura, ou seja, há nos diferentes argumentos de Bianca um predomínio da abordagem de consequências. Embora não haja ainda um contraponto entre implicações de decisões alternativas, a licencianda ainda se restringe a apresentação de consequências exclusivas de seu posicionamento. A estrutura dos seus argumentos, no que tange ao raciocínio informal, se torna interessante, ainda mais quando consideramos a 
necessária transposição de uma moral heterônoma para uma moral autônoma de Kant (2005), objetivo que vislumbramos para a educação moral em sala de aula desde a educação básica.

Analisando os elementos apresentados por Bianca, seguindo com a tendência verificada no Caso 1, há nesse momento a omissão do protagonista em sua resposta o que implica na ausência de quaisquer obrigações do mesmo e, consequentemente, inviabiliza a determinação do ponto de conflito. Ponderando apenas a respeito dos maiores interessados em informações sobre a construção de um armamento nuclear, identificamos no argumento da futura professora somente os líderes de potências envolvidas na guerra como partes interessadas no caso narrado.

Quanto ao argumento fornecido pela licencianda Bianca após o momento de reflexão realizado em conjunto em sala de aula, esquematizamos no Quadro 52 a resposta da futura professora nesse momento.

Quadro 52 - Análise da sensibilidade moral de Bianca, de acordo com a resposta final fornecida ao Caso 2.

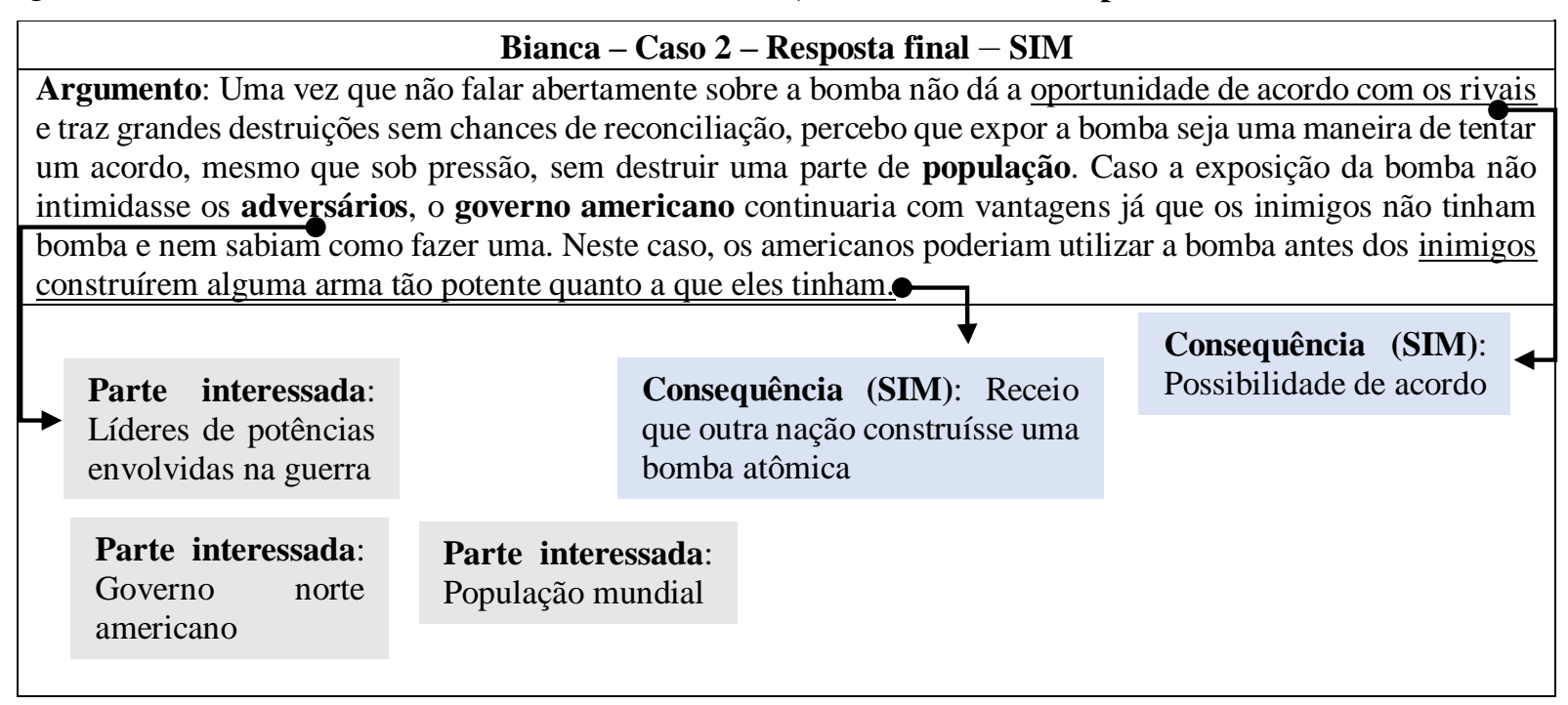

De posse da resposta que observamos no Quadro 52, constatamos mais uma vez a influência da discussão na elaboração dos argumentos dos licenciandos. Dessa forma, verificamos uma ampliação, mesmo que pequena, da sensibilidade moral de Bianca, a qual passou a mencionar cinco dos 24 elementos propostos no Quadro 48. Ou seja, houve entre os diferentes momentos de aplicação do Caso 2 um salto percentual de sete pontos, a licencianda abordou na segunda etapa 20\%. Este salto ocorreu devido à inclusão de outras duas partes interessadas omitidas inicialmente, o governo norte-americano e a população mundial.

A inclusão de novas partes interessadas é facilmente explicada pelas possibilidades advindas da leitura do hipergênero textual HQ. Como abordamos anteriormente, verificamos que o tipo de texto em questão permite um contato maior com os diferentes personagens e instituições e promove, dessa forma, uma facilidade na determinação das partes interessadas. 
No entanto, mantendo praticamente a mesma ideia apresentada inicialmente, de que falar abertamente possibilitaria a construção de um acordo entre os países, e de forma a permanecer com uma resposta objetiva, Bianca mais uma vez omite o protagonista do caso. Sendo assim, novamente qualquer obrigação atribuída a Oppenheimer é ignorada e, consequentemente o ponto de conflito não é vislumbrado pela futura professora.

Logo, diante do que foi apresentado pelas duas licenciandas cujos argumentos fornecidos ao caso 2 foram analisados e discutidos até o momento, observamos que a atividade realizada nas aulas anteriores a partir da leitura na HQ não contribuiu significativamente para a evolução do raciocínio moral, em especial da sensibilidade moral das futuras professoras. Contudo, é válido destacar novamente a dificuldade que foi atribuída pelos licenciandos ao caso 2 e às limitações provenientes do emprego do TAP (TOULMIN, 2001) em sala de aula. Nesse sentido, apesar de termos verificado que estruturalmente, na perspectiva de Toulmin (2001), a dificuldade do caso contribuiu para uma evolução da complexidade dos argumentos uma vez que os educandos foram impelidos a buscar por elementos que validassem as colocações apresentadas, essa dificuldade não conduziu, até o momento, a uma sensibilidade moral mais satisfatória. Isto pode ser devido à importância que essas alunas atribuem à formalidade comumente associada ao ensino de ciências, ou seja, almejando repostas objetivas e concretas e se atentando principalmente ao esqueleto proposto por Toulmin (2001), aspectos relacionados ao raciocínio informal são pouco evidentes nas respostas, principalmente nas de Bianca.

Prosseguindo com nosso estudo, analisamos na sequência as respostas da licencianda Caroline ao caso 2. Diferente do que foi observado para as licenciandas cujos argumentos fornecidos ao caso em questão já foram discutidos, constatamos uma ampliação significativa da sensibilidade moral exibida por Caroline comparativamente àquela observada quando em resposta ao caso anterior. Apresentamos no Quadro 53 o argumento inicial fornecido pela futura professora, bem como a indicação dos aspectos morais que identificamos no texto escrito por ela. 
Quadro 53 - Análise da sensibilidade moral de Caroline, de acordo com a resposta inicial fornecida ao Caso 2.

\begin{tabular}{|c|c|c|c|c|}
\hline \multicolumn{5}{|c|}{ Caroline - Caso 2 - Resposta inicial - NÃO } \\
\hline \multicolumn{5}{|c|}{$\begin{array}{l}\text { Argumento: Oppenheimer não deve falar abertamente, já que essa decisão não depende apenas dele, mas sim } \\
\text { de Groves e do governo americano. Além disso, abrir o jogo para o mundo sobre o que eles estão construindo } \\
\text { e o que ela é capaz, poderá chocar a população e dividi-la entre os que são a favor e os que são contra, e } \\
\text { sabemos que na situação em que se passa, não seria algo que o governo queria intervir (eles têm outras } \\
\text { preocupações). A menos que o governo aceitasse a proposta de falar abertamente, sabendo como eles iriam lidar } \\
\text { com a população contra a construção. } \\
\text { A bomba está praticamente pronta, contar tudo a todos poderia atrapalhar os planos propostos a princípio. }\end{array}$} \\
\hline$\longrightarrow$ Parte interessada: & & & $\begin{array}{l}\text { yência (SIM): Não } \\
\text { ismo norte americano na } \\
\text { ção da bomba atômica }\end{array}$ & \\
\hline$\longrightarrow \begin{array}{l}\text { Parte interessada: } \\
\text { Governo norte } \\
\text { americano }\end{array}$ & $\begin{array}{l}\text { Parte interessada: } \\
\text { Groves }\end{array}$ & $\begin{array}{l}\text { Parte interessada } \\
\text { População mundial }\end{array}$ & $\begin{array}{l}\text { Consequência (SIM): } \\
\text { Pressão popular }\end{array}$ & \\
\hline
\end{tabular}

A partir do que se encontra presente no Quadro 53, verificamos na resposta inicial de Caroline a menção a seis dos 24 elementos presentes na grelha esquematizada no Quadro 48. Sendo assim, os 9\% de aspectos morais vislumbrados no mesmo momento de aplicação do Caso 1 passou a representar $25 \%$ quando da resolução do Caso 2, o que sinaliza uma evolução significativa da sensibilidade moral da futura professora.

Com relação aos elementos apresentados por Caroline, destacamos novamente a notoriedade de menções a partes interessadas no caso narrado, a qual, como mencionamos, pode ser devido ao tipo de texto empregado em sala de aula. Outrossim, apesar de tomarmos contato com Oppenheimer enquanto parte interessada, podemos observar que a futura professora atribui certo protagonismo ao governo norte-americano, que, na sua perspectiva, é o responsável pela tomada de decisão de fato. Nesse sentido, nos deparamos com duas consequências direcionadas exclusivamente ao governo, o qual, diante da divulgação das pesquisas realizadas em Los Alamos poderia enfrentar uma pressão popular além de ter seus planos “atrapalhados”.

Logo, negligenciado o protagonismo de Oppenheimer, não observamos também para essa licencianda nesse momento, qualquer menção às obrigações do cientista, bem como a pontos de conflito presentes na situação narrada. Contudo, esta constatação não foi identificada no argumento escrito fornecido pela futura professora após o momento de discussão oral 
conduzida pela professora formadora. Para efeito de discussão esquematizamos no Quadro 54 a segunda resposta de Caroline.

Quadro 54 - Análise da sensibilidade moral de Caroline, de acordo com a resposta final fornecida ao Caso 2.

\section{Caroline - Caso 2 - Resposta final - NÃO}

Argumento: Oppenheimer enfrenta um conflito ético bem complicado: manter o acordo feito com o governo americano ou manter a ética como ser humano e como cientista (divulgar resultado das pesquisas). Além disso, o peso de suas obrigações e as consequências que trará em suas decisões resultará em um dilema que poderá ser uma corrida armamentista ou um acordo de paz. Portanto, Oppenheimer não deve falar abertamente à sociedade sobre a construção e consequências da bomba, já que implicaria no descumprimento do acordo com o governo (colocando a sua vida em risco); trará a competitividade de outros países em construir bombas (mesmo que estas fiquem inativas); o governo americano, que já está com vários problemas, poderá enfrêntar mais um com a população podendo ficar dividida (sendo contra ou a favor). A menos que, abrir o jogo traz como consequência um acordo de paz entre os países envolvidos, pois sabem que a bomba dos EUA está praticamente pronta e não terão muito tempo para construírem a sua (estão em desvantagem).

Parte interessada: Oppenheimer
Consequência (SIM): Pressão popular
Obrigação de Oppenheimer:

Divulgar a ciência e contribuir para o seu desenvolvimento

Consequência (SIM):

Possibilidade de acordo

Parte interessada: Governo norte americano
Parte interessada: População mundial

Parte interessada: Líderes de potências envolvidas na guerra
Ponto de conflito: Falar abertamente sobre o poder de destruição da bomba (divulgação da ciência) vs. Manter o sigilo dado o contexto de guerra

Obrigação de Oppenheimer: Manutenção do acordo inicial

Consequência (SIM): Dúvidas quanto ao patriotismo e fidelidade de Oppenheimer (descumprimento de acordo inicial)

Consequência (SIM): Receio que outra nação construísse uma bomba atômica

De antemão observamos, mais uma vez, uma significativa ampliação da sensibilidade moral da licencianda, tanto com relação ao argumento apresentado para o mesmo caso inicialmente quanto comparativamente à resposta fornecida no mesmo momento de aplicação do Caso 1. Nesse contexto, identificamos no texto escrito pela aluna a presença de onze dos 24 elementos existentes na grelha sistematizada no Quadro 48, o que representa aproximadamente $46 \%$ de aspectos morais mencionados. $\mathrm{O}$ valor obtido indica um salto percentual de 21 pontos quando comparado com a resposta inicial da aluna ao caso em questão, e de 16 pontos quando confrontamos os argumentos fornecidos após o momento de reflexão nos dois diferentes casos. Dessa forma, podemos atribuir certa contribuição das atividades empreendidas até o momento para a ampliação da sensibilidade moral da aluna.

No que diz respeito aos elementos mencionados por Caroline, para além do destaque das partes interessadas em sua resposta, evidenciamos a presença de quatro consequências, as 
quais são oriundas do enfoque maioritário assumido na resposta, o enfoque consequencialista (COSTA, 2002). De particular interesse observamos, assim como nos argumentos de Alice, implicações todas relativas à decisão alternativa daquela assumida na resposta. Assim sendo, face à dificuldade inerente ao Caso 2, o que se verifica é uma tendência a contrapor consequências da posição contrária à tomada, de modo a conferir segurança às colocações feitas. Essa constatação é interessante e sinaliza o exercício do raciocínio informal para resolução de questões socialmente controversas, o que representa um de nossos objetivos com a atividade proposta.

Outro elemento importante que verificamos no segundo argumento de Caroline é o retorno do protagonismo a Oppenheimer, o que ocorre devido à discussão realizada em sala de aula e que podemos observar no trecho a seguir.

[P]: [...] o dilema é do Oppenheimer, se ele falasse não, não vou contar para todo mundo, não vou divulgar, então a consequência seria a exclusividade que eles já tinham. Alguma outra consequência do não para o governo americano? Acho que eles simplesmente ficam com a bomba, eles têm e é deles. Agora o Groves nós o colocamos aqui por quê?

[A]: É junto com o Oppenheimer

[P]: Junto, como se fosse a cúpula?

[A]: Isso!

[P]: Embora quem tivesse que decidir aqui tinha seria o Oppenheimer, certo?

[G]: Não, acho que está tudo junto com governo americano, não está?

[De]: Eu acho que não, aí não.

[G]: Não?

[A]: Não

[Ca]: Mas professora, o Oppenheimer pode falar sozinho? Ele pode decidir falar para todo mundo sobre a bomba?

[P]: No nosso caso ele pode, porque a pergunta é essa.

[Ca]: Fica estranho, porque no outro [se referindo ao caso 1] o Groves tinha que aceitar

$[\mathrm{P}]$ : É, mas do jeito que acaba o caso é se ele deveria contar ou não. Acho que é por isso que vocês falaram que entrava junto com o Groves como se fosse todo mundo decidir por aquilo, não só o Oppenheimer. Mas como temos o problema então seria dele. Mas, e então, a gente junta o Oppenheimer e o Groves para poder decidir pelo sim ou pelo não?

[De]: Sim

[P]: Junta? Para eles é diferente ou a mesma coisa? Eles têm o mesmo tipo de consequência ou não?

[E]: Eu acho que é totalmente diferente

[Ca]: Eu também, eu separaria porque para mim a situação do Groves é totalmente diferente do Oppnheimer.

[A]: Deixa o Groves de fora! 
Diante do trecho transcrito, salientamos mais uma vez a importância do papel do professor no momento de condução da discussão. Essa importância entra, conforme já mencionado, em consonância com as ideias de Bossér e Lindahl (2017) a respeito das demandas que a abordagem de questões socialmente controversas em sala de aula exigem dos docentes. Nessa perspectiva, deve o professor propiciar um ambiente que encoraja a participação dos alunos e a expressão de suas opiniões durante as discussões. Logo, podemos observar que as atividades adotadas oriundas da metodologia proposta por Bebeau (1995) vão ao encontro de tais colocações, e permitiram, neste caso específico, que Caroline expusesse seu posicionamento, bem como pudesse vislumbrar outros aspectos morais ignorados inicialmente.

Continuando a análise, ao fazer essa transposição, portanto, do protagonismo do caso, Caroline passou a contemplar algumas das obrigações de Oppenheimer, como a do cientista em manter o acordo assumido inicialmente com Groves e o governo norte-americano, e o seu dever de divulgar a ciência e contribuir para o seu desenvolvimento. Contrapondo tais obrigações, Caroline foi a única licencianda até o momento que conseguiu, em ambos os casos, visualizar o ponto de conflito, o qual só se tornou apreciável a partir da discussão e o esclarecimento das mais variadas dúvidas que emergiram no momento de reflexão.

A respeito de Débora, nossa quarta licencianda, discutimos os seus argumentos ao Caso 2 e analisamos a sua sensibilidade moral na sequência. Para tanto, esquematizamos no Quadro 55 a resposta inicial da futura professora, bem como destacamos os aspectos morais evidenciados no texto.

Quadro 55 - Análise da sensibilidade moral de Débora, de acordo com a resposta inicial fornecida ao Caso 2.

\begin{tabular}{|c|c|c|}
\hline \multicolumn{3}{|c|}{ Débora - Caso 2 - Resposta inicial - NÃO } \\
\hline \multirow{2}{*}{\multicolumn{3}{|c|}{$\begin{array}{l}\text { Argumento: Pois se tratando de um projeto que foi idealizado e organizado para ser feito em sigilo, não teria } \\
\text { sentido Oppenheimer falar abertamente sobre ele. A ideia do projeto é somente os âmericanos conseguirem } \\
\text { construir a bomba e terem posse desse conhecimento. Falar abertamente dos perigos da bomba tiraria o sigilo } \\
\text { da missão. Faz sentido o argumento de Bohr, porém seria um argumento para a não construção de bombas, não } \\
\text { com a intenção de construí-las. }\end{array}$}} \\
\hline & & \\
\hline \multirow{2}{*}{$\begin{array}{l}\text { Parte interessada: } \\
\text { Oppenheimer }\end{array}$} & Obrigação de Oppenheimer: & \\
\hline & & \\
\hline $\begin{array}{l}\text { Parte interessada: } \\
\text { Governo norte } \\
\text { americano }\end{array}$ & $\begin{array}{l}\text { Consequência (SIM): Não } \\
\text { pioneirismo norte americano na } \\
\text { construção da bomba atômica }\end{array}$ & \\
\hline
\end{tabular}

Por meio da observação do Quadro 55, identificamos uma pequena ampliação da sensibilidade moral da aluna comparativamente ao mesmo momento quando da aplicação do Caso 1. Assim sendo, dado que a licenciada em sua resposta inicial ao Caso 2 faz menção à 
quatro dos 24 elementos presentes no Quadro 48, Débora aborda em seu texto aproximadamente $16 \%$ dos aspectos morais inerentes ao caso. Relembramos que no argumento inicial da licencianda ao Caso 1, esta havia mencionada apenas cerca de $9 \%$ dos aspectos morais.

Dentre os elementos evidenciados na resposta de Débora, destacamos mais uma vez a abordagem das partes interessadas, com menção, logo no início, ao protagonista do caso, Oppenheimer. Dessa forma, a futura professora também apresenta em sua resposta uma das obrigações do cientista, que seria a de manter o acordo de sigilo assumido inicialmente com o governo norte-americano. E é a partir da ideia de sigilo que a licencianda constrói todo o seu argumento, o que limita a resposta, não possibilitando ponderações de outros elementos inerentes ao caso que contribuiriam para uma ampliação ainda mais significativa da sua sensibilidade moral.

A respeito do argumento fornecido após a realização da discussão oral conduzida pela docente, expomos no Quadro 56 a resposta final da aluna e discutimos na sequência aspectos relacionados à sensibilidade moral da futura professora.

Quadro 56 - Análise da sensibilidade moral de Débora, de acordo com a resposta final fornecida ao Caso 2.

\section{Débora - Caso 2 - Resposta final - NÃO}

Argumento: Segundo Bohr, e até pensando na situação atual dos governos em relação a bombas atômicas (vários governos têm bombas atômicas, porém nenhum estoura elas em cima de outra sociedade), o sim (se Oppenheimer divulgasse a bomba e os perigos dela) poderia evitar a destruição do mundo ou a destruição de alguma sociedade pois seria possível fazer acordos para que nenhum lado, nem outro, estourasse bombas. Porém, dada a época e na eminência da guerra é difícil saber se isso de fato aconteceria. O “sim”, por exemplo, poderia levar os inimigos à, na verdade, construírem bombas até mais poderosas e a atacarem os americanos. Levando também em consideração que Oppenheimer tinha um acordo com o governo americano, ele estaria sendo antiético em quebrá-lo e até poderia sofrer consequências pessoais apenas em relação a morte ou saída de projeto.

Então, levando em consideração que não teria como se saber ao certo a consequência do "sim" e o fato do "não" trazer graves consequências a Oppenheimer, não faria sentido ele no meio do caminho quebrar o combinado. O que faria sentido fazer para ajudar nesse conflito dele com a sociedade (de tentar evitar a destruição dessa) é convencer o governo americano do poder e perigo da bomba e dessa forma tentar evitar que ela fosse utilizada por esse. Ou até de certa maneira tentar evitar que ela fosse de fato construída.

Consequência (SIM): Receio que outra nação construísse uma bomba atômica

Consequência (SIM): Dúvidas quanto ao patriotismo e fidelidade de Oppenheimer (descumprimento de acordo inicial)

Parte interessada: Oppenheimer

Parte interessada:
Governo norte
americano

Parte interessada: americano
Parte interessada: Líderes de potências envolvidas na guerra
Parte interessada

População mundial

Com destaque mais uma vez às partes interessadas, devido aos motivos já mencionados, como o tipo de texto empregado em sala de aula, verificamos mais uma vez certa ampliação da sensibilidade moral da futura professora, tanto com relação ao argumento inicial quanto à 
resposta fornecida após a discussão realizada durante a aplicação do Caso 1. Assim sendo, verificamos no texto escrito fornecido pela licencianda a abordagem de oito dos 24 elementos presentes no Quadro 48, ou seja, aproximadamente 33\% dos aspectos morais mencionados. O valor obtido indica um salto percentual de 17 pontos comparativamente à resposta inicial, e um salto de 3 pontos quando contrastados os argumentos fornecidos após as discussões conduzidas pela professora formadora.

Seguindo a tendência observada para este caso, ao se posicionar contrária à ideia de Oppenheimer falar abertamente sobre o poder de destruição de uma bomba atômica em construção nas instalações de Los Alamos, a futura professora emprega três consequências, sendo todas referentes à decisão alternativa. Ou seja, para sustentar o seu posicionamento, assim como as licenciandas Alice e Caroline, Débora busca contrapor três consequências que resultariam da tomada de decisão favorável à narrada no Caso 2. Essa constatação reforça a dificuldade do caso, bem como evidencia o exercício do raciocínio informal.

Dentre as novas consequências mencionadas por Débora nesse momento, duas se apresentam pela primeira vez, uma diz respeito à possibilidade de acordo e outra versa sobre dúvidas que poderiam surgir quanto à fidelidade de Oppenheimer ao governo norte-americano. A inserção de tais consequências ocorre devido às colocações expostas no momento de discussão, conforme trecho transcrito que apresentamos na sequência.

[G]: Uma das consequências do sim seria selar a paz

[P]: É, uma consequência do sim seria selar paz? Além da corrida, selar ....

[De]: Segundo a ideia de Bohr, seria.

[G]: Uma das possibilidades é a corrida e a outra possibilidade deles contarem seria, não vamos chegar num acordo aqui sem que nenhum seja ...

[De]: Que é a ideia do Bohr

[F]: Que seria muito improvável

[G]: Não, mas ...

[P]: Então seria selar a paz [...] construção de acordo

$[\ldots]$

[P]: Então qual a consequência do sim para o Oppenheimer? Do que ele representa lá.

[De]: Ele estaria não cumprindo com o acordo que ele tinha.

[P]: É quebrar o acordo.

[E]: Mas ele também leva em consideração a sociedade uma vez que ele é um cientista

[De]: Eu acho que ele pode até morrer

[P]: Que mais, a consequência para ele do sim é quebra de acordo e ele pode morrer? Podem matar o Oppenheimer? 
[F]: Quebra do acordo e suas consequências, físicas e psicológicas.

Por fim, no que diz respeito ao licenciando Gabriel, discutimos os seus argumentos na sequência. Assim sendo, expomos no Quadro 57 a resposta inicial do futuro professor ao Caso 2.

Quadro 57 - Análise da sensibilidade moral de Gabriel, de acordo com a resposta inicial fornecida ao Caso 2.

Gabriel - Caso 2 - Resposta inicial - NÃO

Argumento: Se sim: Possibilidade de não haver guerra; possibilidade de despertar a "vontade de construir bombas. Se não: possibiliđade de apenas um país construir a bomba; utilização de bomba se necessario em caso de ameaça.

Oppenheimer não deve falar abertamente sobre a bomba atômica já que: se sim, outros países que poderiam nem estar envolvidos também poderiam querer construir uma bomba tendo em vista que alguém já está construindo e se não, poderia se ter o caso perfeito de só um país construir e, portanto, caso uma guerra se desse início possivelmente a probabilidade de menos países terem bombas seria maior e consequentemente a destruição menor; se sim, países inimigos poderiam se aproveitar dessas informações para um possível contra defesa ou para aprimorar os seus armamentos.

\begin{tabular}{||l|l|l||}
\hline $\begin{array}{l}\text { Consequência (SIM): } \\
\text { Possibilidade de acordo }\end{array}$ & $\downarrow$ & $\begin{array}{l}\text { Consequência (SIM): Receio } \\
\text { que outra nação construísse uma } \\
\text { bomba atômica }\end{array}$ \\
\hline $\begin{array}{l}\text { Consequência (NÃO): } \\
\begin{array}{l}\text { Exclusividade norte- } \\
\text { americana }\end{array}\end{array}$ & $\begin{array}{l}\text { Parte interessada: } \\
\text { Líderes de potências } \\
\text { envolvidas na guerra }\end{array}$ & $\begin{array}{l}\text { Consequência (NÃO): } \\
\text { Fim da guerra }\end{array}$ \\
& $\begin{array}{l}\text { Parte interessada: } \\
\text { Oppenheimer }\end{array}$ \\
\hline
\end{tabular}

Com relação à quantidade de elementos mencionados na resposta de Gabriel, identificamos consoante o que é apresentado no Quadro 57, seis dos 24 presentes na grelha esquematizada no Quadro 48, ou seja, constatamos $25 \%$ de aspectos morais. O valor obtido sinaliza um aumento da sensibilidade moral comparativamente ao mesmo momento da atividade aplicada no Caso 1, em que o licenciando exibia em sua resposta apenas $13 \%$ de aspectos morais.

Com uma estrutura semelhante à da resposta fornecida após a discussão realizada para o caso anterior, Gabriel exibe um enfoque maioritariamente consequencialista (COSTA, 2002), e a partir deste enfoque nos deparamos com uma contraposição de prós e contras típicas do exercício do raciocínio informal, de acordo com Zohar e Nemet (2002). Ou seja, para além de identificarmos em seu argumento o emprego de quatro consequências somos apresentados a duas próprias de cada uma das decisões possíveis. E feita a contraposição de ideias, Gabriel opta por ser contrário à decisão de Oppenheimer falar abertamente sobre o poder de destruição da bomba atômica em construção.

Outrossim, como era de se esperar pela tendência observada nos argumentos analisados anteriormente, não deixam de estar presentes na resposta de Gabriel algumas das partes 
interessadas, e são elas, na perspectiva do licenciando, Oppenheimer, o protagonista do caso, e os lideres dos países envolvidos na $2^{\mathrm{a}}$ Guerra Mundial. Embora esteja evidente o protagonismo de Oppenheimer no argumento de Gabriel, não identificamos nenhuma obrigação atribuída ao cientista, que poderia conduzir o futuro professor na visualização de algum ponto de conflito. Esse fato pode ser resultado da abordagem adotada pelo aluno em desconsiderar qualquer obrigação moral do protagonista (enfoque deontológico), em detrimento às consequências que poderiam emergir das decisões tomadas.

No entanto, ao entrarmos em contato com o argumento escrito fornecido pelo licenciando após a discussão realizada em sala de aula, observamos que houve uma diminuição da sensibilidade moral exibida por ele. Podemos constatar essa diminuição ao analisarmos a sua resposta sistematizada no Quadro 58.

Quadro 58 - Análise da sensibilidade moral de Gabriel, de acordo com a resposta final fornecida ao Caso 2.

\section{Gabriel - Caso 2 - Resposta final - NÃO}

Argumento: $\mathrm{O}$ poder de destruição de uma bomba atômica é gigantesco e pensar na possibilidade de várias bombas explodindo em nosso planeta se torna algo preocupante para o destino da humanidade. Oppenheimer não deve falar abertamente sobre a construção e o poder de destruição da bomba já que evitaria que outros países, que podem ou não estar envolvidos com a guerra, se motivem a se armar sabendo que alguém estā armado, além disso, países inimigos poderiam se aproveitar dessas informações para aprimorar seus equipamentos e ou para se defender. Portanto, Oppenheimer não deve falar abertamente sobre a bomba, pois a probabilidade de menos países terem bombas é maior e consequentemente menos poder de destruição cairá sobre a Terra.

Parte interessada: Líderes de potências envolvidas na guerra

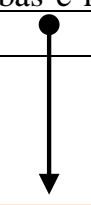

Consequência (NÃO):

Exclusividade norteamericana
Consequência (SIM): Receio que outra nação construísse uma bomba atômica

Parte interessada: Oppenheimer

Diante do que é apresentado no Quadro 58 identificamos a abordagem de apenas quatro dos 24 elementos que consideramos pertinentes ao caso, presentes no Quadro 48. Assim sendo, constatamos apenas cerca de $17 \%$ dos aspectos morais mencionados, o que representa uma redução percentual de oito pontos, quando contrastamos o argumento inicial e final fornecido pelo aluno. A respeito da ampliação ou não da sensibilidade moral entre um caso e outro, o que identificamos foi uma redução significativa de 13\%. Contudo salientamos mais uma vez a dificuldade inerente ao caso em exercício, e em especial, enfatizamos para o caso de Gabriel, a dificuldade do aluno em inserir novos elementos oriundos da discussão em seu texto. Essas constatações podem ser tomadas ao verificarmos a transcrição de um trecho referente ao final da discussão. 
[P]: Ser humano. Aí assim, teríamos que inverter, manter a ética como ser humano porque o ser humano não tem essa coisa de se comprometer com os resultados da ciência, e também como cientista. Que que foi Gabriel, por que você está inquiteto aí?

[F]: Gabriel esgotou o assunto.

[G]: Eu, na minha primeira parte achei que ficou legal, não tem muita coisa mais para acrescentar.

[D]: Eu também.

[P]: Pode acrescentar, discutimos, ninguém vai mudar de ideia? Achei que todo mundo ia mudar de ideia, não?

No mais, apesar de identificada essa redução da sensibilidade moral do aluno, observamos mais uma vez um movimento típico do exercício do raciocínio informal, comum a este licenciando, o qual diz respeito à contraposição de consequências de decisões alternativas. Nessa perspectiva observamos a manutenção das duas partes interessadas evidenciadas inicialmente e de duas consequências uma de cada posicionamento possível que Oppenheimer poderia adotar. Apesar do protagonismo atribuído ao cientista, ainda não verificamos obrigações do mesmo mencionadas no texto, tampouco a existência de um ponto de conflito para Oppenheimer.

Isto exposto, observamos a partir da análise dos argumentos fornecidos pelos licenciandos ao caso 2 que embora algumas respostas tenham evidenciado uma redução da sensibilidade moral, comparativamente ao caso anterior, em geral verificamos a sua ampliação. $\mathrm{O}$ aumento dessa sensibilidade pode não ter sido mais significativo devido à dificuldade inerente à situação narrada, que foi salientada pelos licenciandos, associada à limitação proveniente do uso do TAP (TOULMIN, 2001) e ao tempo limitado para a elaboração, principalmente da resposta final. Destacamos ainda que diante dos diversos aspectos abordados no momento de discussão oral conduzida pela docente, os futuros professores, buscando uma objetividade em seus textos, acabavam não contemplando os diferentes aspectos morais que eles próprios expunham ao longo da reflexão. Assim sendo, é válido ressaltar que a sensibilidade moral que analisamos diz respeito ao texto escrito fornecido pelo aluno. Logo, embora tenham sido vislumbrados diferentes aspectos morais, como podemos identificar nos momentos de discussão, consideramos apenas o que foi inserido pelo educando em seu argumento final.

Em geral foi possível observar ainda mais movimentos típicos do exercício do raciocínio informal, o qual almejamos com a atividade proposta, como a contraposição de consequências alternativas para a decisão e não apenas uma listagem de implicações exclusivas do posicionamento adotado. Também evidenciamos, a partir das respostas construídas pelos futuros professores, que no que tange aos elementos essenciais em uma resposta que apresenta 
satisfatória sensibilidade moral na perspectiva de Bebeau (1995), há uma facilidade na determinação, com mais menções, das partes interessadas, o que atribuímos ao tipo de leitura realizada em sala de aula, a qual permite um contato mais direto com cada personagem e instituição da narrativa.

Caso 3

Prosseguindo com o estudo da sensibilidade moral dos futuros professores investigados, damos sequência com a análise dos argumentos empregados pelos licenciandos em resposta ao Caso 3. Relembramos que o caso em questão apresentava aos alunos algumas das consequências diretas do lançamento das bombas atômicas nas cidades japonesas de Hiroshima e Nagasaki conduzindo a seguinte indagação: “ [Narrador] Finalmente eles tinham a resposta para a pergunta que vinham se fazendo havia anos: [Cientista] 'Pode ser feito' [Narrador] Depois do Projeto Manhattan, todavia, muitos cientistas se sentiram na obrigação de fazer uma pergunta diferente: [Cientista] 'Deveria ter sido feito? ". Sendo assim, ao final do texto os alunos eram solicitados a responder se os cientistas, de posse de conhecimentos como da fissão nuclear, deveriam ter construído um armamento tão letal como uma bomba atômica.

Para efeito de discussão também empregamos como instrumento de análise para o caso 3, uma grelha com aspectos morais que consideramos pertinentes à situação narrada. A grelha em questão está esquematizada no Quadro 59 e diz respeito aos elementos que Bebeau (1995) considera relevantes em uma resposta envolvendo um dilema ético/moral. Nessa perspectiva, julgamos, por exemplo, como partes interessadas no caso, os cientistas, que nesse momento se apresentam como os protagonistas, uma vez que são os responsáveis pela tomada de decisão que consiste em, com base em seus conhecimentos, construir ou não um armamento nuclear. São também partes interessadas em nossa perspectiva, o governo norte-americano em que incluímos também a cúpula do Projeto Manhattan que envolve, dentre outros, o personagem de Groves, a população não somente norte-americano como dos países aliados ${ }^{14}$, os quais sairiam também vitoriosos com o sucesso da bomba atômica e do governo norte-americano. Em contrapartida, consideramos ainda os países do Eixo, o que envolve tanto os líderes como a população de cada uma dessas nações.

\footnotetext{
${ }^{14}$ Durante a $2^{\mathrm{a}}$ Guerra Mundial, os diferentes países envolvidos formaram duas principais alianças, a dos Aliados e do Eixo. Compreendia a aliança dos Aliados a Grã-Bretanha, os Estados Unidos e a União Soviética. Com relação aos países do Eixo estes dizem respeito, principalmente, a Alemanha, Itália e Japão.
} 
Quadro 59 - Grelha de aspectos morais referente ao Caso 3.

\begin{tabular}{|c|c|}
\hline \multicolumn{2}{|l|}{ PONTOS DE CONFLITO } \\
\hline \multicolumn{2}{|c|}{$\begin{array}{l}\text { Contribuir para a morte de milhares de inocentes } v s \text {. Ver aliados morrerem e não contribuir com o } \\
\text { conhecimento científico }\end{array}$} \\
\hline \multicolumn{2}{|c|}{ PARTES INTERESSADAS } \\
\hline \multicolumn{2}{|l|}{ Cientistas } \\
\hline \multicolumn{2}{|l|}{ Governo norte-americano } \\
\hline \multicolumn{2}{|l|}{ População norte-americana e de países aliados } \\
\hline \multicolumn{2}{|l|}{ Países do Eixo (líderes e/ou civis) } \\
\hline \multicolumn{2}{|l|}{ CONSEQUENCIAS } \\
\hline \multicolumn{2}{|l|}{ Vitória norte-americana (prestígio) } \\
\hline \multicolumn{2}{|l|}{ Vitória dos aliados } \\
\hline \multicolumn{2}{|l|}{ Fim da guerra } \\
\hline \multicolumn{2}{|l|}{ Reestabelecimento da segurança para a população } \\
\hline \multicolumn{2}{|l|}{ Derrota e rendição dos países do Eixo, em especial do Japão } \\
\hline \multicolumn{2}{|l|}{ Destruição de cidades japonesas } \\
\hline \multicolumn{2}{|l|}{ Morte de milhares de pessoas, incluindo inocentes } \\
\hline \multicolumn{2}{|l|}{ Grande produção de conhecimento/desenvolvimento da ciência } \\
\hline \multicolumn{2}{|l|}{ Remorso dos cientistas } \\
\hline \multicolumn{2}{|l|}{ Possibilidade de acordos sem o lançamento efetivo da bomba } \\
\hline \multicolumn{2}{|l|}{ Prolongamento da guerra } \\
\hline \multicolumn{2}{|l|}{ Aumento do número de mortes } \\
\hline \multicolumn{2}{|l|}{ Mortes de aliados } \\
\hline \multicolumn{2}{|l|}{ Insegurança da população por tempo indeterminado } \\
\hline \multicolumn{2}{|l|}{ Possibilidade de pioneirismo dos países do Eixo quanto à construção desse tipo de arma } \\
\hline \multicolumn{2}{|l|}{ Possibilidade de derrota norte-americana } \\
\hline \multicolumn{2}{|l|}{ Consciência dos cientistas } \\
\hline \multicolumn{2}{|l|}{ OBRIGAÇÕES DOS CIENTISTAS } \\
\hline \multicolumn{2}{|l|}{ Mobilizar os conhecimentos científicos em favor da sociedade } \\
\hline \multicolumn{2}{|l|}{ Servir ao país } \\
\hline Desenvolver a ciência & \\
\hline
\end{tabular}

Com relação às consequências, elencamos, dentre outras, a possibilidade de vitória norte-americana com o lançamento efetivo de uma bomba atômica, o que resultaria no fim da guerra e no reestabelecimento da segurança para a população aliada. No entanto, dentre as implicações negativas nos depararíamos com a destruição de duas cidades japonesas, o que levaria à morte de milhares de pessoas, incluindo civis inocentes, e que poderia acarretar em certo remorso dos cientistas envolvidos. Também deveríamos considerar que o desenvolvimento de tal arma pelas mentes mais brilhantes da época resultaria em uma grande produção de conhecimento que poderia não ser tão significativa caso o conhecimento ficasse compartimentalizado em diferentes laboratórios espalhados pelo mundo. 
naquele momento abordava $29 \%$ de aspectos morais pertinentes ao caso. Contudo é válido ressaltar, conforme já mencionado previamente quando da análise estrutural do argumento da licencianda, a multiplicidade de sentidos possíveis da leitura. Nesse sentido observamos a partir do trecho em destaque (Eles cumpriram com o prometido, fizeram o teste e perceberam o

poder de destruição.), uma interpretação diferente da que consideramos inicialmente. Assim sendo, atribuindo outro sentido ao caso narrado, a futura professora o analisou sob outra perspectiva e deixando de contemplar diferentes aspectos morais que consideramos inerentes ao caso, reduzindo assim a sua sensibilidade moral.

Dentre estes elementos mencionados na resposta da licencianda verificamos novamente um predomínio de menções a diferentes partes interessadas, no caso, os cientistas, protagonistas da situação narrada e o governo norte-americano, que na concepção da futura professora, são os principais responsáveis pela elaboração da bomba ao financiar o Projeto Manhattan. Constatamos também a presença de uma única consequência, a qual semelhante às empregadas no caso 2 , diz respeito à tomada de decisão contrária à assumida na resposta, a qual, nesse momento, é favorável à construção do artefato nuclear pelos cientistas.

No entanto, ao levar a cabo a discussão verificamos que no segundo argumento escrito Alice tomou um posicionamento diferente e se mostrou contrária à decisão dos cientistas em participarem do Projeto Manhattan e contribuírem para a construção de uma bomba nuclear. Consoante o que poderemos observar por meio do trecho destacado em vermelho, logo no início do texto da aluna, em nenhum momento da discussão a docente considerou inválida a interpretação realizada por Alice anteriormente à reflexão. Com relação a este fato concordamos com as ideias de Flôr (2009) que salienta a importância de uma visão mais crítica de leitura, almejando a leitura fruição em contraposição à leitura busca de informações comumente valorizada em sala de aula do ensino de ciências ${ }^{15}$. Segundo o autor, devemos promover e buscar a produção de sentidos e não a resposta certa proveniente de um discurso pedagógico autoritário, é dessa forma que, de fato, estamos, enquanto professores formadores, incentivando a leitura e a formação de sujeitos leitores.

\footnotetext{
${ }^{15}$ Segundo definição de Geraldi (2010), na leitura-busca-de-informações o leitor vai ao texto em busca de respostas a preguntas prévias que faz a si mesmo ou que recebe de terceiros. Além disso, são para o autor outros tipos de leitura: a leitura-estudo-de-texto, na qual o leitor em contato com o texto busca extrair dele o máximo que ele possa oferecer; a leitura-pretexto, por meio da qual o leitor extrai informações necessárias para a produção de uma nova obra ou texto; leitura-fruição, tipo de leitura em que há somente o prazer pela gratuidade da presença do texto.
} 
Quadro 61 - Análise da sensibilidade moral de Alice, de acordo com a resposta final fornecida ao Caso 3.

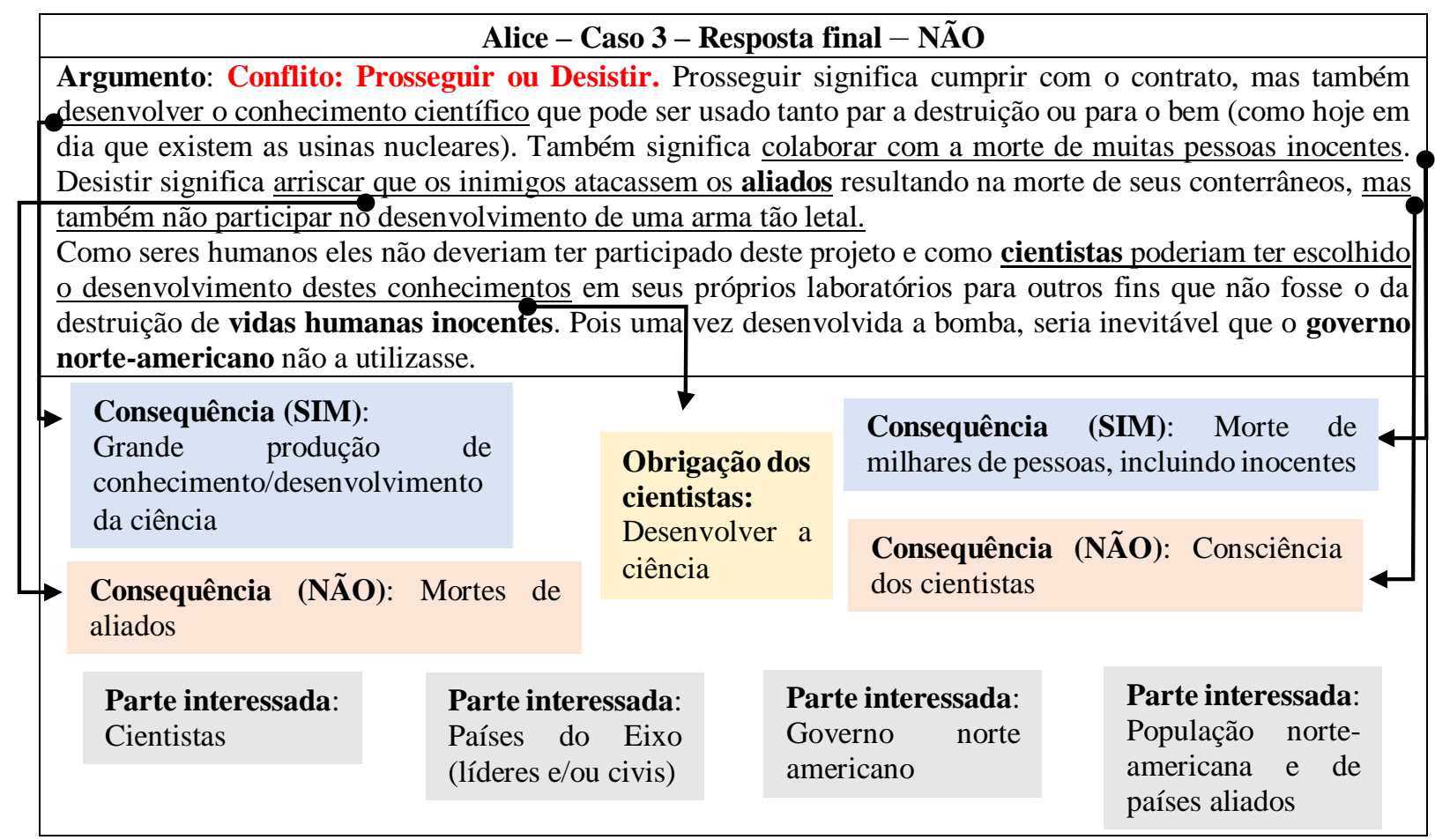

De antemão, o que verificamos é uma ampliação significativa da sensibilidade moral exibida anteriormente. Nesse sentido observamos a presença de nove dos 25 elementos presentes no Quadro 59, o que representa 36\% de aspectos morais mencionados na resposta da aluna. Assim sendo, dentre os argumentos escritos fornecidos por Alice nos deparamos nesse momento com um daqueles que sinalizam razoável sensibilidade moral da licencianda.

Para além do aumento da sensibilidade moral, identificamos por meio do enfoque consequencialista (COSTA, 2002) empregado pela futura professora, a presença de quatro consequências que sustentam a decisão tomada. Dentre as implicações das ações possíveis adotadas pelos cientistas nos deparamos com duas provenientes de um posicionamento favorável à construção do artefato nuclear (grande produção de conhecimento em contraposição à morte de milhares de pessoas, incluindo inocentes), e duas oriundas de um posicionamento contrário à construção (a morte de aliados e a consciência dos cientistas). Dessa forma, com um movimento típico do exercício do raciocínio informal e apresentando uma contraposição de ideias oriundas de decisões alternativas, verificamos uma mudança no posicionamento da licencianda.

Embora a mudança de decisão constatada possa implicar em talvez uma perseverança moral limitada, quarto componente do Modelo dos Quatro Componentes proposto por Rest, 
Bebeau e Volker (1986) que diz respeito à força das convicções e a persistência em superar distrações e obstáculos, a ampliação da sensibilidade moral e a presença de uma resposta fundamentada na contraposição de diferentes ideias corrobora a mudança de posicionamento. Nesse sentido, com base na resposta escrita da licencianda após a discussão, podemos dizer que essa mudança não ocorreu devido a uma perseverança moral debilitada, mas a uma pequena sensibilidade moral evidenciada inicialmente.

Considerando ainda os aspectos morais mencionados pela futura professora, para além do predomínio do emprego de consequências advindas do enfoque adotado em sua resposta, observamos novamente um predomínio de menções a diferentes partes interessadas, as quais são: os cientistas e o governo norte-americano, ambos já mencionados inicialmente, e os países do Eixo e a população norte-americana e aliada. Tais grupos envolvidos e inseridos na resposta estão diretamente relacionados com as consequências destacadas pela licencianda. Outrossim, apesar da limitada sensibilidade moral exibida inicialmente, salientamos mais uma vez que a dificuldade que os alunos apresentam diante de uma produção textual acaba influenciando na sensibilidade exibida. Por exemplo, no primeiro texto escrito, Alice menciona como partes interessadas apenas os cientistas e o governo norte-americano, no entanto, é a própria licencianda que menciona ao longo da discussão oral, conforme podemos observar no trecho transcrito, o Japão ou os países do Eixo como partes interessadas.

[P]: Pronto pessoal? Vamos lá, então? A gente sempre começa pelas partes interessadas, né? Quais são as partes interessadas aí nessa questão que vocês enxergam?

[A]: Cientistas.

[P]: Cientistas, quem mais?

[De]: Estados Unidos

\section{[A]: O Japão}

[P]: O governo norte-americano. E a Alice falou o Japão, é o Japão sozinho ou todo mundo que podia ser alvo da bomba? Assim, não sei como vocês chamam, porque tinham as alianças, ou era só o Japão mesmo?

[De]: Eu colocaria a população como um todo.

[P]: A população como um todo, como a população do mundo todo? A população mundial seria uma, é isso? Mas aí coloca o Japão dentro da população mundial, ou o Japão é outra fatia da população?

[A]: Eu acho que a pergunta é: deveria ter feito a bomba ou não? E no caso o que a gente viu é que os EUA soltaram a bomba no Japão, então os primeiros a sofrer, envolvidos foram os japoneses

Assim sendo, ressaltamos mais uma vez que a sensibilidade moral em análise é aquela exibida textualmente, contudo conforme podemos observar por esse trecho da discussão, muitas vezes os próprios licenciandos vislumbram alguns aspectos morais mas só os externalizam 
oralmente, evidenciando assim que a dificuldade na produção textual associado ao tempo limitado, influenciam na determinação da sensibilidade moral dos mesmos.

Por fim, observamos ainda no argumento final de Alice uma menção indireta a uma obrigação dos cientistas, a qual é contribuir para o desenvolvimento da ciência. De particular interesse, essa obrigação dos protagonistas emerge de uma passagem no texto em que observamos pela primeira vez o uso de um padrão de raciocínio informal emotivo (SADLER e ZEIDLER, 2005). Segundo Sadler e Zeidler (2005), com o emprego normalmente da primeira pessoa, ao empregar esse tipo de padrão o indivíduo adota uma perspectiva de "cuidado" em que a empatia e a preocupação pelo bem-estar dos outros guiam as suas decisões. Nesse sentido, partindo do pressuposto que os cientistas devem realmente contribuir para o desenvolvimento da ciência, conforme concluído na discussão, cujo trecho transcrevemos na sequência, Alice acredita que os cientistas poderiam ter atingido o mesmo objetivo, de desenvolvimento da ciência, em seus próprios laboratórios, sem que houvesse a destruição de vidas humanas inocentes. E é nesse trecho final que fica ainda mais evidente a perspectiva de "cuidado" ressaltada por Sadler e Zeidler, (2005).

[A]: Mas eles não tinham noção do poder de destruição. Eles deveriam primeiro fazer o teste.

[De]: Não, eles tinham uma noção.

[A]: Depois do teste eles deveriam ter essa noção.

$[\mathrm{P}]:$ Eu acho que o conhecimento científico produzido é fato. Foi muito conhecimento. [A]: Sim.

Prosseguindo com nosso estudo da sensibilidade moral de professores de química em formação inicial, apresentamos no Quadro 62, a resposta inicial fornecida pela licencianda Bianca ao Caso 3. Diante do que nos é apresentado neste quadro, já observamos a princípio uma sensibilidade moral bastante acentuada da licencianda Bianca, a qual em seu argumento inicial aborda seis dos 25 elementos que propomos no Quadro 56. Verificamos que a futura professora mencionou $24 \%$ dos aspectos morais que consideramos relevantes ao caso, ou seja, dentre os argumentos iniciais de Bianca este é o que sinaliza maior sensibilidade moral da aluna. 
Quadro 62 - Análise da sensibilidade moral de Bianca, de acordo com a resposta inicial fornecida ao Caso 3.

Bianca - Caso 3 - Resposta inicial - SIM

Argumento: Apesar da destruição e efeitos devastadores causados pela bomba atômica, ela serviu para que o governo americano ganhasse a guerra. Talvez, se a bomba não tivesse sido criada pelos americanos, mais tarde alguém de outra naçáo tivesse a mesma ideia e então, o poder estaria em outras mãos. O que poderia ter feito é divulgar a bomba e falado dos efeitos e assim tentar um acordo antes de utilizá-láa

Consequência (SIM):

Destruição de cidades japonesas

Consequência (SIM):

Vitória norte-americana

Parte interessada:

Governo norte americano
Parte interessada:

Países do Eixo (líderes e/ou civis)
Consequência (NÃO): Possibilidade de pioneirismo dos países do Eixo quanto à construção desse tipo de arma

\section{Consequência (SIM):}

Possibilidade de acordos sem o lançamento efetivo da bomba

Com um enfoque também consequencialista, observamos um destaque para o emprego de consequências em seu texto escrito. Nesse sentido somos apresentados a quatro possíveis implicações da decisão dos cientistas, dentre elas, três são favoráveis à construção do artefato nuclear, o qual também é o posicionamento da aluna, e uma referente à ação oposta, isto é, a de não participação na construção da bomba nuclear. Isto exposto, nos deparamos mais uma vez como um movimento típico do exercício do raciocínio informal que almejamos e observamos na elaboração da resposta da aluna: uma contraposição de ideias que sustenta a sua decisão.

Outrossim, identificamos duas partes interessadas, o governo norte-americano e os países do Eixo, contudo não verificamos uma menção direta aos cientistas, os protagonistas do caso. O que podemos notar é um foco em consequências da elaboração ou não de um artefato nuclear pelo governo norte-americano, o que isenta de certa forma os cientistas. Essa isenção dos cientistas das implicações oriundas da construção e lançamento das bombas atômicas é evidente em um dos poucos momentos que contamos com a participação da licencianda Bianca nas discussões, conforme trecho que transcrevemos na sequência.

[De]: Eu acho que soltaram a bomba para mostrar o poder americano ali, o poder que eles criaram como grande nação que estava emergindo. Eles basicamente falaram: agora a gente que manda aqui. Mais do que só acabar com a guerra.

[G]: Não vejo isso como iniciativa dos cientistas.

$[P]:$ Não, mas sem eles não teria acontecido nada, certo? Eles foram os agentes que levaram à produção da bomba. Então assim, é confuso mesmo.

[Bi]: Mas e se mais tarde alguém fizesse essa bomba primeiro que eles?

[P]: Tem isso também. 
[A]: Outra coisa, quando eles fizeram o teste eles não precisariam ter construido outra bomba. As duas que foram lançadas não estavam prontas.

[P]: É, eles fizeram o teste só para ver se estava tudo se encaminhando bem.

[A]: Exato.

[P]: Eles viram o que iria acontecer.

[A]: Exatamente.

[Ca]: Mas eu acho que como eles estavam seguindo ordens, como eles aceitaram participar do projeto, eles estavam dispostos a seguir aquelas ordens.

[A]: Eu não vejo remorso. Não teve. Inclusive, eles soltaram a bomba, fizeram o teste, viram o poder de destruição, deveriam ter parado ali.

[Bi]: Exatamente.

Assim sendo, isentando os cientistas das inúmeras implicações que resultaram da construção das bombas nucleares, não identificamos nenhum tipo de obrigação dos mesmos, tampouco constatamos o ponto de conflito do caso na resposta de Bianca. Essa constatação também foi observada após o momento de reflexão ocorrido em sala de aula a respeito dos aspectos morais inerentes ao caso narrado. Assim, esquematizamos no Quadro 63 o segundo argumento de Bianca.

Quadro 63 - Análise da sensibilidade moral de Bianca, de acordo com a resposta final fornecida ao Caso 3.

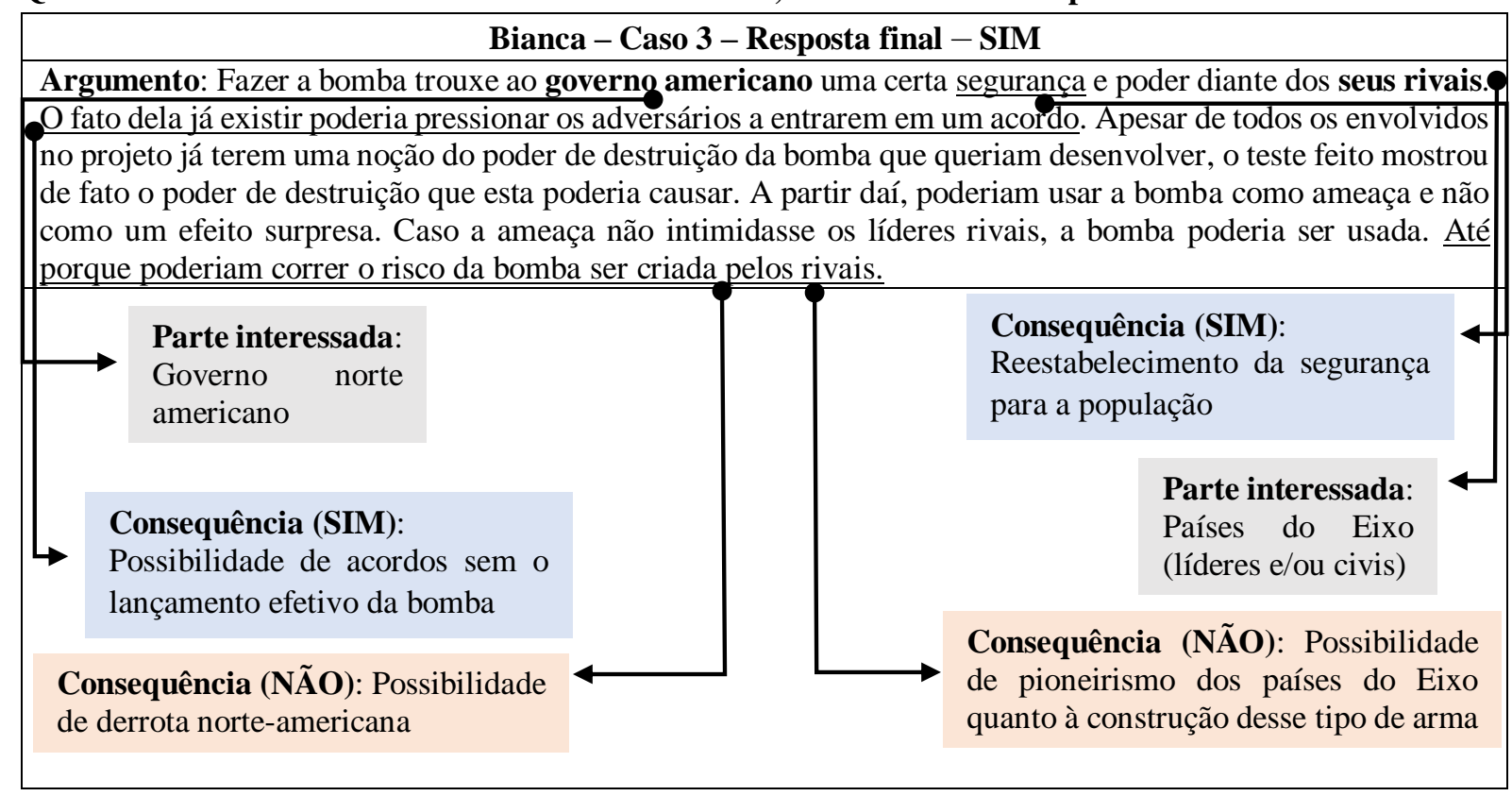

Com o mesmo padrão da resposta apresentada inicialmente, detectamos novamente no segundo texto escrito da licencianda Bianca apenas seis dos 25 aspectos morais que julgamos inerentes ao caso, ou seja, mais uma vez identificamos $24 \%$ de elementos mencionados no argumento da futura professora. Apesar da sensibilidade moral ter se mantido inalterada após a discussão, o valor de aspectos morais evidentes no texto sinaliza um dos argumentos da 
licencianda em que o primeiro componente do Modelo dos Quatro Componentes foi mais trabalhado.

Por meio de um enfoque consequencialista (COSTA, 2002) observamos na resposta final de Bianca mais uma vez quatro consequências, das quais duas são implicações de um posicionamento favorável ao da construção dos artefatos nucleares pelos cientistas e duas oriundas da decisão de não construção da bomba atômica. Nesse sentido, observamos mais uma vez elementos típicos de um raciocínio informal, cujo padrão adotado na resposta, assim como na maioria dos argumentos, é o racionalista (SADLER e ZEIDLER, 2005).

Assim como já mencionado, o papel dos cientistas está omitido no texto escrito de Bianca, a qual não os considera diretamente responsáveis pelos efeitos resultantes do lançamento das bombas atômicas nas cidades japonesas de Hiroshima e Nagasaki. Sendo assim, são partes interessadas, de acordo com a resposta da futura professora, apenas o governo norteamericano e os países componentes do Eixo. Consequentemente, não identificamos nenhuma obrigação atribuída aos cientistas e nenhum ponto de conflito.

Partindo para o estudo da sensibilidade moral exibida por Caroline nas respostas fornecidas ao Caso 3, esquematizamos no Quadro 64 o primeiro argumento da licencianda, o qual foi elaborado previamente a qualquer discussão com o anseio de vislumbrar os aspectos morais inerentes à situação narrada.

Quadro 64 - Análise da sensibilidade moral de Caroline, de acordo com a resposta inicial fornecida ao Caso 3 .

\section{Caroline - Caso 3 - Resposta inicial - NÃO}

Argumento: Os cientistas não deveriam ter construído a bomba atômica, pois por serem pessoas estudadas sabem listar os prós e contras que esse Projeto traria para o mundo, tanto é que funcionou como seus cálculos previam. Cientistas costumam querer prestígio e ser reconhecido pelo seu bom trabalho, porém isso vale mais do que milhares de vidas?

Parte interessada:

Cientistas

Obrigação dos cientistas:

Mobilizar os conhecimentos

científicos em favor da sociedade
Consequência (SIM):

Morte de milhares de pessoas, incluindo inocentes

Em uma resposta objetiva verificamos para Caroline uma sensibilidade moral limitada no que diz respeito ao primeiro momento de aplicação do Caso 3. Assim sendo, dentre os 25 aspectos morais que consideramos pertinentes à situação narrada, a licencianda faz menção a apenas três deles, ou seja, 12\% de todos os elementos listados no Quadro 59. 
Com base no que é apresentado pela futura professora verificamos que a resposta, e consequentemente o posicionamento de Caroline, se fundamentou no protagonismo dos cientistas na construção de um armamento nuclear. Considerando, portanto, esse protagonismo dos cientistas, há uma menção indireta a uma de suas obrigações, uma vez que estes devem mobilizar os conhecimentos científicos em favor da sociedade (obrigação que consideramos inerente ao caso): "os cientistas sabem listar os prós e contras que esse projeto traria para o mundo". Nesse sentido, diferente do que foi exposto por Bianca, Caroline desconsidera qualquer outra parte interessada no que diz respeito aos efeitos de uma bomba nuclear, e a percepção da licencianda fica bem evidente quando observamos novamente o trecho que transcrevemos anteriormente, o qual apresentamos novamente, complementando-o.

[De]: Eu acho que soltaram a bomba para mostrar o poder americano ali, o poder que eles criaram como grande nação que estava emergindo. Eles basicamente falaram: agora a gente que manda aqui. Mais do que só acabar com a guerra.

[G]: Não vejo isso como iniciativa dos cientistas.

$[P]$ : Não, mas sem eles não teria acontecido nada, certo? Eles foram os agentes que levaram à produção da bomba. Então assim, é confuso mesmo.

[Bi]: Mas e se mais tarde alguém fizesse essa bomba primeiro que eles?

$[\mathrm{P}]:$ Tem isso também.

[A]: Outra coisa, quando eles fizeram o teste eles não precisariam ter construido outra bomba. As duas que foram lançadas não estavam prontas.

[P]: É, eles fizeram o teste só para ver se estava tudo se encaminhando bem.

[A]: Exato.

$[\mathrm{P}]$ : Eles viram o que iria acontecer.

[A]: Exatamente.

[Ca]: Mas eu acho que como eles estavam seguindo ordens, como eles aceitaram participar do projeto, eles estavam dispostos a seguir aquelas ordens.

[A]: Eu não vejo remorso. Não teve. Inclusive, eles soltaram a bomba, fizeram o teste, viram o poder de destruição, deveriam ter parado ali.

[Bi]: Exatamente.

$[\ldots]$

[Ca] eles entraram sabendo do propósito que era fazer uma bomba,

[De]: É, sabendo que iriam fazer uma bomba superpoderosa.

[Ca]: Não iriam fazer algo simples

[P]: É, não vamos brigar. Acho que eles nem deveriam ter começado o projeto, é isso?

[Ca]: É, não participar do projeto.

[P]: Não participar

[G]: Todos os cientistas envolvidos sabiam que eram para fazer a bomba? 
[Ca]: Sim, fala aqui: que, além disso, o objetivo que levara tantos cientistas a fazer parte do projeto Manhattan foi alcançado.

A partir do trecho da discussão que mostramos, constatamos também que, assim como já destacado quando da análise estrutural dos argumentos elaborados pelos futuros professores, Caroline é a licencianda que mais emprega diferentes passagens da HQ, tanto no texto escrito quando na discussão oral. Observamos que para esta aluna o hipergênero textual adotado exerce uma maior influência. Assim sendo, é válido salientar que de acordo com o perfil de leitura que construímos a partir da discussão realizada no primeiro encontro envolvendo a aplicação do projeto, Caroline é a que apresenta maior proximidade com tipo de texto trabalhado em sala de aula. Como destacamos no percurso metodológico, a licencianda teve contato com HQ no espaço formal de ensino desde a educação básica, e a escola onde cursou o ensino fundamental fornecia folhetos em forma de quadrinhos mensais abordando temáticas relacionadas ao cotidiano dos educandos. Nessa perspectiva, são alguns exemplos de trechos da HQ "Trinity" utilizados pela licencianda ao longo da aplicação do Caso 3: "tanto é que funcionou como seus cálculos previam" - presente no argumento escrito; "tanto é que eles falam: estamos passando com os aviões e não vimos ninguém tentando atacar a gente. Eles estavam pensando que eram militares, mas não. Era para a população, mas até então os cientistas sabiam que era para fazer uma bomba" - fala da licencianda durante a discussão oral sobre o caso; "sim, fala aqui: que, além disso, o objetivo que levara tantos cientistas a fazer parte do projeto Manhattan foi alcançado - fala da licencianda também durante a discussão oral.

Identificamos também na resposta de Caroline uma menção indireta a uma das consequências do posicionamento oposto ao adotado, isto é, da decisão favorável à construção da bomba atômica pelos cientistas. Ao indagar se a busca de prestígio pelo trabalho científico vale mais do que milhares de vida, Caroline evidencia uma das implicações do armamento nuclear presente na narrativa, a morte de milhares de pessoas, incluindo inocentes.

A respeito da resposta fornecida pela licencianda após a discussão, observamos, conforme expomos no Quadro 65, uma ampliação significativa de sua sensibilidade moral, bem como a continuidade da tendência identificada nos dois argumentos da futura professora posteriormente aos momentos de reflexão realizados em sala de aula. Dessa forma verificamos no argumento da licencianda ao menos um item referente a cada tópico que Bebeau (1995) considera necessário para uma sensibilidade moral satisfatória, identificamos, portanto, no texto final escrito por Caroline: partes interessadas, consequências, obrigações e o ponto de conflito da situação narrada. 
Quadro 65 - Análise da sensibilidade moral de Caroline, de acordo com a resposta final fornecida Caso 3.

Caroline - Caso 3 - Resposta final - NÃO

Argumento: Os cientistas não deveriam fazer a bomba atômica. Sabe-se que o conflito principal é em torno de empregar o conhecimento científico para a destruição de milhares de pessoas, ou não empregar e presenciar a população de seus país continuar morrendo perante a guerra. Devemos refletir que todo cientista, ao aceitar tazer parte de um projeto, analisa os prós e contras, estuda os materiais que poderão ser utilizados (no caso, nos referimos aos elementos química) e como esse projeto trará impactos positivos à sociedade. De fato, construir uma bomba resulta em muito prestígio para os envolvidos ao servir seu país, entretanto todos os cientistas que aceitaram fazer parte do Projeto Manhattan sabiam o principal objetivo que propusera o governo a financiar o Projeto (a construção da bomba). E eles não são inocentes em acreditar que o governo os chamaram para construírem uma bomba que ficaria inativa. No fundo eles sabiam que seu trabalho resultaria em uma matança (seja de civis ou militares). Portanto, o remorso que sentiriam posteriormente poderia ser evitado se eles não aceitassem fazer parte do Projeto Manhattan, a menos que eles já estivessem dentro do Projeto e visto, pelo teste, o resultado de seus conhecimentos, mas ainda sin eles poderiam optar por desistir de ser "cúmplice" da catástrofe nuclear (mesmo que isso custasse a sua vida e de suas famílias).

\section{Parte interessada:}

Cientistas

Consequência (NÃO): Morte de aliados

\section{Consequência (NÃO):}

Prolongamento da guerra

\section{Consequência (SIM):}

Morte de milhares de pessoas, incluindo inocentes

Parte interessada: Governo norte americano
Parte interessada:

Países do Eixo (líderes ou civis)
Consequência (SIM):

Remorso dos cientistas

Ponto de conflito: Contribuir para a morte de milhares de inocentes Vs. Ver aliados morrerem e não contribuir com o conhecimento científico

Obrigação dos cientistas:

Mobilizar os conhecimentos científicos em favor da sociedade

Obrigação dos cientistas: Servir ao país

Parte interessada: População norte-americana e de países aliados

Mencionando onze dos 25 elementos presentes na grelha esquematizada no Quadro 59, Caroline aborda $44 \%$ dos aspectos morais que consideramos pertinentes ao caso trabalhado em sala de aula. Como já evidenciamos, com um enfoque maioritariamente consequencialista, a licenciada faz menção a quatro consequências. Continuando a abordar uma das implicações oriundas da construção das bombas atômicas pelos cientistas, isto é, a morte de milhares de pessoas, incluindo inocentes, Caroline insere outro resultado dessa ação, o remorso dos cientistas. A inserção dessa consequência vai ao encontro de um dos itens que já foi amplamente discutido nos argumentos anteriores, o protagonismo dos cientistas, conforme salientado nos trechos transcritos da discussão, é defendido por Caroline no momento de reflexão acerca dos aspectos morais presentes no caso narrado.

Ainda assim, a licenciando menciona outras duas consequências, ambas emergentes do posicionamento adotado em sua resposta, o de não construção do armamento nuclear pelos 
cientistas. Na perspectiva da futura professora, a não construção das bombas atômicas poderia conduzir a um prolongamento da guerra e, consequentemente, à morte de mais aliados. Dessa forma, considerando diferentes contrapontos, e exercitando o raciocínio informal cujo padrão observado diz respeito ao racionalista (SADLER e ZEIDLER, 2005), Caroline opta pela não participação dos cientistas na morte de milhares de pessoas inocentes.

Logo, diante do cenário traçado pela licencianda a partir da leitura do caso, são partes interessadas, o governo norte-americano, bem como sua população e dos países aliados, os países do Eixo e, obviamente, os cientistas. Considerando, portanto, os protagonistas, são algumas de suas obrigações, a já mencionada mobilização de conhecimentos científicos em favor da sociedade, e uma emergente da discussão, e que foi mencionada pela própria aluna segundo trecho transcrito na sequência, o dever dos cientistas em servir o seu país.

$[C]$ : É, talvez nessa parte de remorso, de destruir vidas eu acho que eles não iriam saber. Concordo com a Débora, agora no sentido de remorso pela não construção da bomba é porque nos EUA tem muito disso, de ter o patriotismo, certo? Querer servir ao seu país. Então, porque que eu não tentei fazer algo pelo meu país?

Com base então nas considerações da licencianda fica evidente, conforme trecho destacado no início de sua resposta final, a determinação do ponto de conflito presente na situação narrada. Dessa forma, Caroline após a discussão a respeito dos aspectos morais de cada caso conseguiu vislumbrar os conflitos éticos envolvidos, e que suscitam o exercício do raciocínio moral.

No que diz respeito à licencianda Débora, esquematizamos no Quadro 66 sua resposta inicial ao dilema narrado no Caso 3.

Quadro 66 - Análise da sensibilidade moral de Débora, de acordo com a resposta inicial fornecida ao Caso 3.

\section{Débora - Caso 3 - Resposta inicial - NÃO}

Argumento: Tendo-se conhecimento dos estragos que uma bomba atômica pode causar, os cientistas não deveriam ter seguido em frente no seu projeto. Sem a ação dos cientistas uma bomba atômica nunca poderia ter sido criada, por mais que os militares quisessem e almejassem sua construção. É verdade que os cientistas não tinham pleno conhecimento da ação tão destruidora da bomba (o fato de gerar além de grande quantidade de calor também radiação) porém, tal fato é mais um motivo para se ter mais estudos sobre a bomba e seus efeitos antes de sua construção.

Obrigação dos cientistas:

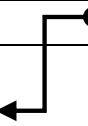

Desenvolver a ciência

Parte interessada: Cientistas

Mostrando-se contrária à participação dos cientistas na construção de uma bomba atômica e tendendo a um padrão de raciocínio informal emotivo (SADLER e ZEIDLER, 2005) o qual não está ainda explícito na resposta apresentada pela aluna nesse momento, que ao optar pela objetividade acaba deixando algumas informações subentendidas. No trecho inicial o qual 
destacamos com fonte itálica, por exemplo, Débora afirma ter conhecimento dos estragos que uma bomba atômica pode causar, contudo não os menciona. Dessa forma, estragos como a morte de milhares de pessoas, incluindo inocentes e a destruição de cidades japonesas, são consequências que, embora tenham sido consideradas pela licencianda, não são evidentes no trecho escrito. Assim sendo, analisando a sensibilidade moral a partir do que a futura professora nos fornece escrito, tal objetividade contribui para a identificação de uma sensibilidade limitada. Nessa perspectiva, dos 25 elementos presentes no Quadro 59, apenas dois são mencionados por Débora, ou seja, somente $8 \%$ de aspectos morais são evidentes na resposta da futura professora.

Dentre os elementos mencionados pela aluna destacamos os cientistas e seu protagonismo, o qual é defendido no momento de discussão pela licencianda. Logo, tendo em vista este protagonismo nos deparamos com uma das obrigações dos cientistas de forma indireta. Ao mencionar que deveriam existir mais estudos sobre a bomba e seus efeitos antes de sua construção, consideramos que a futura professora contempla o dever dos cientistas de desenvolver a ciência. No mais, prosseguimos com a análise da resposta fornecida por Débora após o momento de reflexão realizado em sala de aula. Para tanto apresentamos no Quadro 67 a resposta final da aluna.

Quadro 67 - Análise da sensibilidade moral de Débora, de acordo com a resposta final fornecida Caso 3.

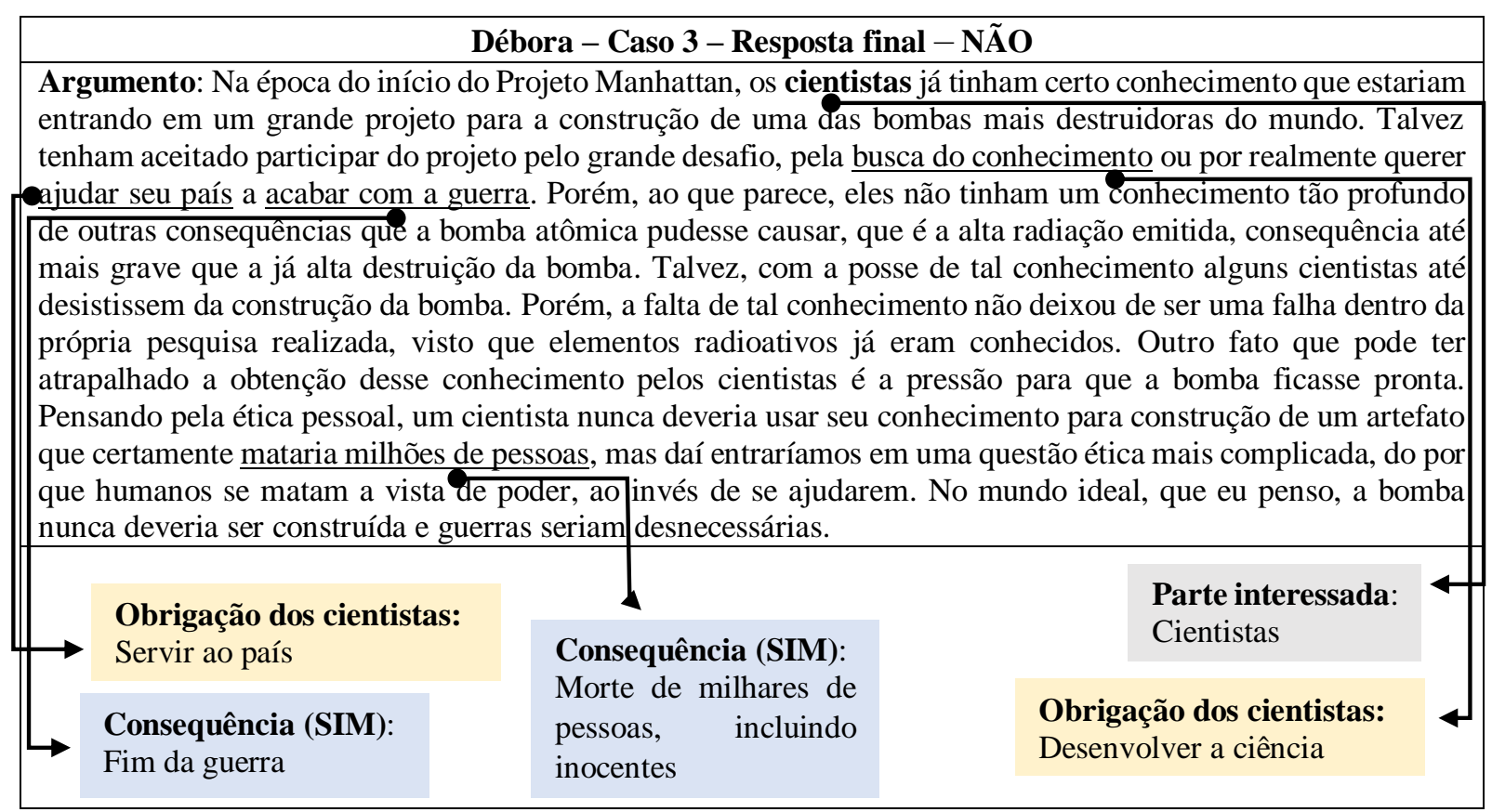

Ampliando ligeiramente sua sensibilidade moral, Débora aborda em seu segundo argumento escrito cinco dos 25 elementos que elencamos como pertinentes ao caso e presentes 
na grelha esquematizada no Quadro 59. Dessa forma são mencionados 20\% de aspectos morais na resposta da futura professora.

Dentre os elementos evidenciados na resposta identificamos duas consequências, ambas contrárias ao posicionamento adotado, isto é, implicações da decisão dos cientistas em participarem da construção do artefato nuclear. Indo ao encontro do que foi discutido durante a análise da resposta inicial da aluna, percebemos que a consequência salientada no final do segundo texto, isto é, a morte de milhares de pessoas como resultado da ação dos cientistas, foi de fato contemplada pela aluna inicialmente, contudo não esteve evidente no argumento escrito.

No mais, verificamos novamente a exclusividade dos cientistas enquanto partes interessadas, cujo protagonismo, na percepção da futura professora, é indubitável. Logo somos apresentados a duas de suas obrigações, a já mencionada anteriormente obrigação dos cientistas de desenvolver a ciência, e o seu dever de servir ao país.

De particular interesse no argumento escrito de Débora é a identificação na parte final do texto de um padrão de raciocínio informal intuitivo (SADLER e ZEIDLER, 2005). De acordo com Sadler e Zeidler (2005), esse padrão é baseado em reações imediatas ao contexto de um cenário particular. Nesse sentido partindo do pressuposto apresentado pela licencianda de que os cientistas não deveriam construir uma bomba atômica simplesmente pelo fato de no mundo ideal bombas atômicas nunca deveriam ter sido construídas e guerras seriam desnecessárias, identificamos nesse momento a existência de um padrão de raciocínio informal intuitivo.

Isto exposto, podemos atribuir a baixa sensibilidade moral observada para a aluna ao emprego desse tipo de padrão, uma vez que, baseado em reações imediatas não suscita uma sensibilidade moral para a resolução de uma questão controversa. O que observamos na resposta da licencianda é a menção de todos os aspectos morais por ela considerados, na parte inicial do texto em que predomina um padrão de raciocínio informal racionalista, e nenhum quando nos deparamos com a reação imediata da aluna ao cenário descrito (padrão de raciocínio informal intuitivo). O que podemos concluir é que para Débora a primeira parte do texto foi construída com base na necessidade da elaboração de um argumento dado que, conforme apresentado no final, ela já tinha um posicionamento intuitivo. Nesse contexto de obrigatoriedade de colocar a resposta em termos racionais, poucos aspectos morais inerentes ao caso são mencionados e, assim, a sensibilidade moral evidente não é significativa.

Ademais, conforme verificado na maioria dos argumentos analisados até o momento, há um predomínio quase que exclusivo do emprego do padrão de raciocínio informal racionalista (SADLER e ZEIDLER, 2005). Portanto, com base no que discutimos a partir do 
segundo argumento de Débora, podemos ressaltar o que já havíamos mencionado quando analisado a resposta inicial de Alice ao Caso 1, e salientar a proximidade desse padrão com o TAP (TOULMIN, 2001), também empregado em sala de aula. Dessa forma, na busca por termos racionais que permitam ao aluno a construção de argumentos estruturalmente válidos na perspectiva de Toulmin (2001), padrões intuitivos e até mesmo emotivos perdem espaço.

Por fim, apresentamos e analisamos a seguir os argumentos escritos fornecidos por Gabriel em resposta ao Caso 3. Começando com o seu texto inicial, esquematizamos no Quadro 68 a resposta elaborada pelo aluno previamente a qualquer discussão acerca de aspectos morais inerentes ao caso em questão.

Quadro 68 - Análise da sensibilidade moral de Gabriel de acordo com a resposta inicial fornecida ao Caso 3.

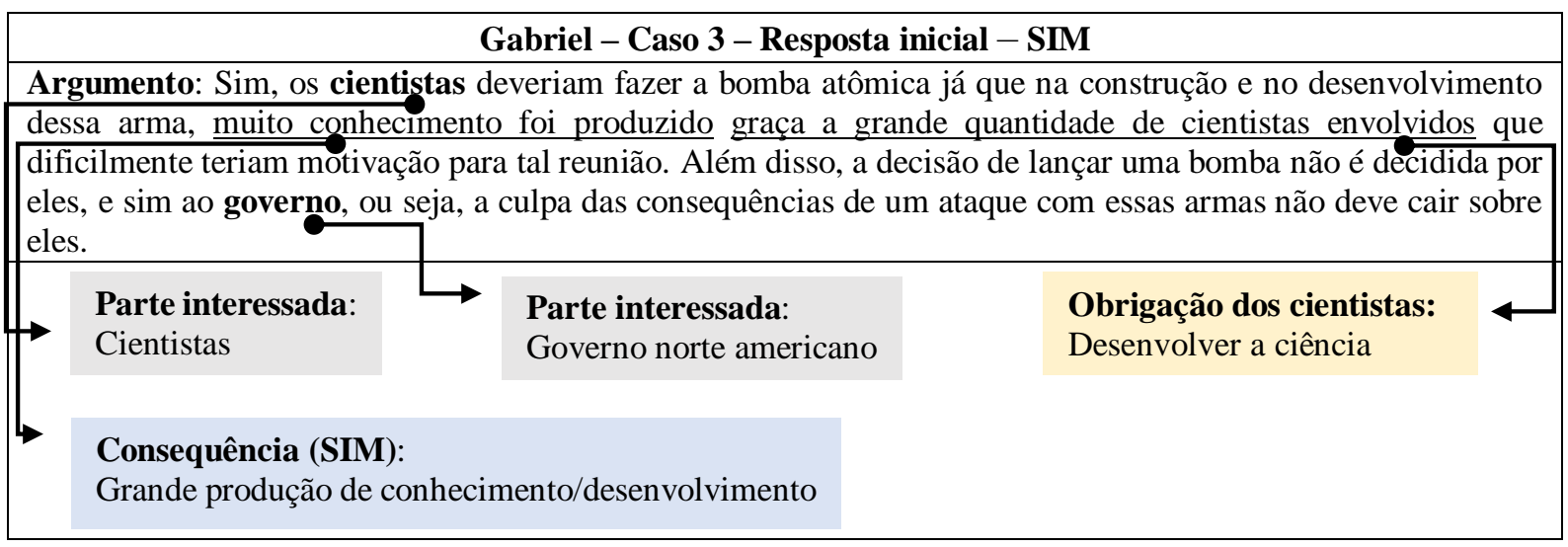

Com uma sensibilidade moral também limitada, Gabriel evidencia em sua primeira resposta ao caso 3 apenas quatro dos 25 elementos presentes no Quadro 59, isto é, há menção de apenas $16 \%$ dos aspectos morais que consideramos relevantes para a situação narrada.

De acordo com o que é fornecido pelo licenciando, identificamos um predomínio de partes interessadas, o que mais uma vez corrobora as ideias de McCloud (2005) que salienta a proximidade que o tipo de texto adotado em sala de aula promove entre personagem e leitor. Também identificamos uma única consequência presente na resposta de Gabriel, consequência esta mencionada apenas por este licenciando, isto é, seria uma implicação da construção de um artefato nuclear a grande produção de conhecimento. Essa consequência é externalizada pelo aluno no momento de discussão como podemos observar na seguinte fala de Gabriel: "Eu acho que tem um pouco disso, mas a pergunta é: deveriam os cientistas ter feito a bomba? E não: Deveria os EUA ter explodido a bomba atômica? Então, do ponto de vista de se os cientistas deveram ter feito a bomba atômica, uma consequência foi o que? Muito conhecimento produzido." 
Além disso verificamos que o governo norte-americano e os cientistas são as únicas partes interessadas consideradas por Gabriel, sendo que os últimos, segundo o licenciando, têm a obrigação de contribuir para o desenvolvimento da ciência, o que corrobora o seu posicionamento. Contudo, a baixa sensibilidade moral que observamos quando contrastamos os aspectos morais mencionados pelo futuro professor e aqueles presentes na grelha esquematizada no Quadro 59, pode ser devido à percepção do licenciando quanto ao protagonismo e envolvimento dos cientistas na história narrada. Conforme podemos observar pelo trecho final do texto escrito fornecido pelo aluno (a culpa das consequências de um ataque com essas armas não deve cair sobre eles), e pela discussão realizada posteriormente em sala de aula, cujos alguns trechos apresentamos na sequência, Gabriel discorda veementemente de alguns dos elementos que consideramos inerentes ao dilema abordado. Dessa forma, deixa-os de mencionar em sua resposta o que implica na constatação de uma sensibilidade moral limitada.

[P]: A consequência é o que? Eles alcançarem o objetivo? A consequência do sim, é alcançar o objetivo e obter sucesso na construção dela, e o que mais?

[De]: Destruir uma população.

$[\mathrm{A}]:$ Ter as mãos sujas de sangue.

[G]: Eu não acho, eu não acho, acho que isso é uma consequência do governo norte-americano, não dos cientistas.

$[\ldots]$

[G]: Vamos lembrar ali, a primeira consequência do sim para os cientistas seria o remorso? Eu coloquei aqui, que a bomba foi lançada, certo? Eles não poderiam ter sido considerados culpados pela destruição, se fosse alguém culpado, seria quem decidiu enviar, seria o governo norte-americano, sabe?

[G]: A Débora falou que a guerra estava quase acabada, não tinha necessidade da bomba, você acha que os cientistas iriam falar assim: "é, está na hora de acabar, vamos terminar de vez e jogar a bomba". Ou você acha que iria ser o governo americano? Eu não vejo os cientistas falando assim: "está tudo acabado vamos lá destruir mais."

De modo a identificarmos a sensibilidade moral exibida pelo licenciando após o momento de discussão oral conduzido pela docente em sala de aula, apresentamos no Quadro 69 o texto escrito de Gabriel em resposta ao dilema narrado no Caso 3. 
Quadro 69 - Análise da sensibilidade moral de Gabriel, de acordo com a resposta final fornecida ao Caso 3.

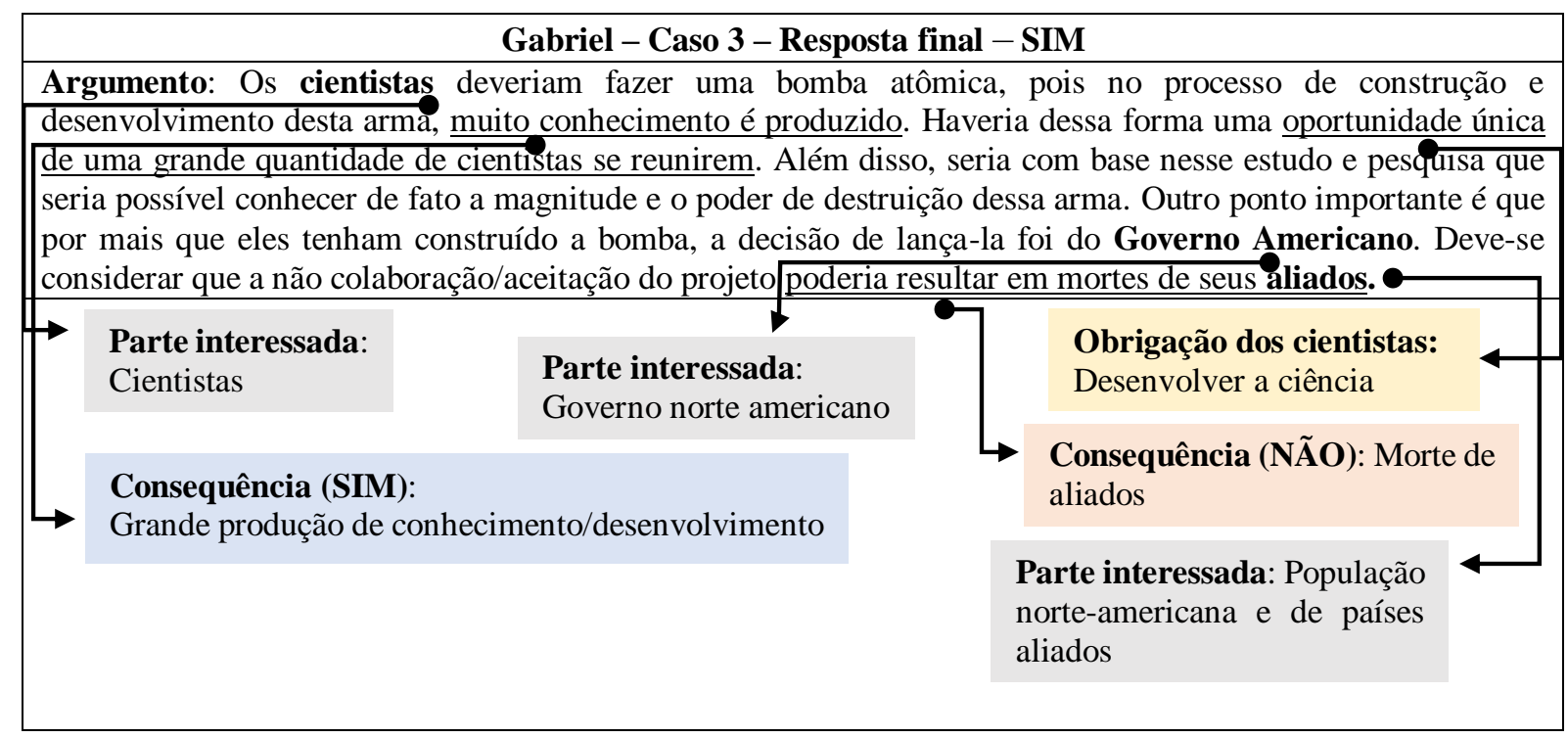

Embora identificamos, a partir do que é exposto no Quadro 69, uma ligeira ampliação da sensibilidade moral exibida por Gabriel, o aumento não foi significativo tendo em vista o que já foi discutido para o seu argumento inicial. O fato do licenciando discordar de alguns dos aspectos morais presentes na grelha esquematizada no Quadro 59, e por isso excluí-los do seu argumento escrito, o impede de atingir uma sensibilidade moral maior.

Assim sendo, o que se observa no argumento final de Gabriel é a presença de seis dos 25 aspectos morais indicados no Quadro 59, isto é, 24\% dos elementos são abordados em sua segunda resposta. Dentre os aspectos mencionados observamos que as partes interessadas contempladas inicialmente se mantêm, os cientistas e o governo norte-americano, bem como a consequência apresentada pelo licenciando (grande produção de conhecimento) e a obrigação dos cientistas de contribuir com o desenvolvimento da ciência. Nessa perspectiva são inseridas na resposta do futuro professor uma nova parte interessada, a população norte-americana e de países aliados, e uma implicação da não construção da bomba atômica pelos cientistas para essa nova parte envolvida na situação, ou seja, o aumento do número de mortes dessa parcela da população.

Portanto, a partir do que foi apresentado e discutido com relação ao Caso 3, podemos verificar que as atividades realizadas em sala de aula contribuíram para uma, ainda que pequena, ampliação da sensibilidade moral dos futuros professores quando deparados com questões socialmente controversas, a qual não foi amplamente significativa devido aos seguintes fatores, 
discutidos na sequência: a dificuldade da produção textual associada ao tempo limitado e a natureza do caso e os recursos gráficos empregados na HQ.

Com relação à dificuldade da produção textual associada ao tempo limitado, como salientado, a análise da sensibilidade moral se fundamentou nos argumentos escritos fornecidos pelos licenciandos nos dois diferentes momentos da prática realizada em sala de aula. Dessa forma, somente os aspectos evidenciados na forma escrita foram considerados para a determinação dos valores obtidos na análise de cada argumento. Nesse contexto, o que verificamos ao confrontar os dados obtidos com as respostas escritas pelos futuros professores e as transcrições das gravações das discussões realizadas em sala de aula é a ausência na produção textual de elementos que os próprios licenciandos expressam oralmente. As ausências identificadas podem ser atribuídas à dificuldade na elaboração de textos escritos, uma vez que essa prática, assim como a leitura, é pouco valorizada em sala de aula do ensino de ciências e vai ao encontro dos resultados obtidos nos trabalhos de diferentes autores como Giraldi (2010), e também ao já mencionado tempo limitado para a elaboração das respostas.

Com relação à natureza do caso e os recursos gráficos empregados na $\mathrm{HQ}$, conforme podemos observar houve pela primeira vez na aplicação do Caso 3 o emprego de padrões de raciocínio informal distintos do padrão racionalista predominante. Podemos atribuir o uso desses padrões à natureza do caso abordado, o qual narra uma situação conhecida pelos alunos que culminou na morte de milhares de inocentes. Associado a isso, verificamos, com maior extensão do que nos casos anteriores, diferentes recursos apelativos adotados pelo autor da HQ de modo a promover certa empatia no leitor e, consequentemente uma maior sensibilização dos mesmos. Dentre os recursos empregados pelo autor destacamos o emprego maioritário de transições ação-para-ação e momento-para-momento no trecho em que a bomba é lançada sobre a cidade japonesa de Nagasaki, em conjunto com o plano de visão total que permite ao autor destacar o tamanho da destruição. Assim sendo nos deparamos com páginas inteiras contendo apenas uma única cena, e personagens representados somente por uma sombra preta, os quais podem simbolizar qualquer pessoa, e esse aspecto vai ao encontro de ideia apresentada por McCloud (2005) de ampliação de significado que um autor pode promover por meio da representação do ser humano. Dessa forma apresentamos na Figura 48 uma sequência de quadros em que esses recursos estão presentes. 
Figura 48 - Trecho extraído da HQ "Trinity" com diferentes recursos gráficos adotados pelo autor no intuito de promover uma maior empatia entre leitor e personagem.

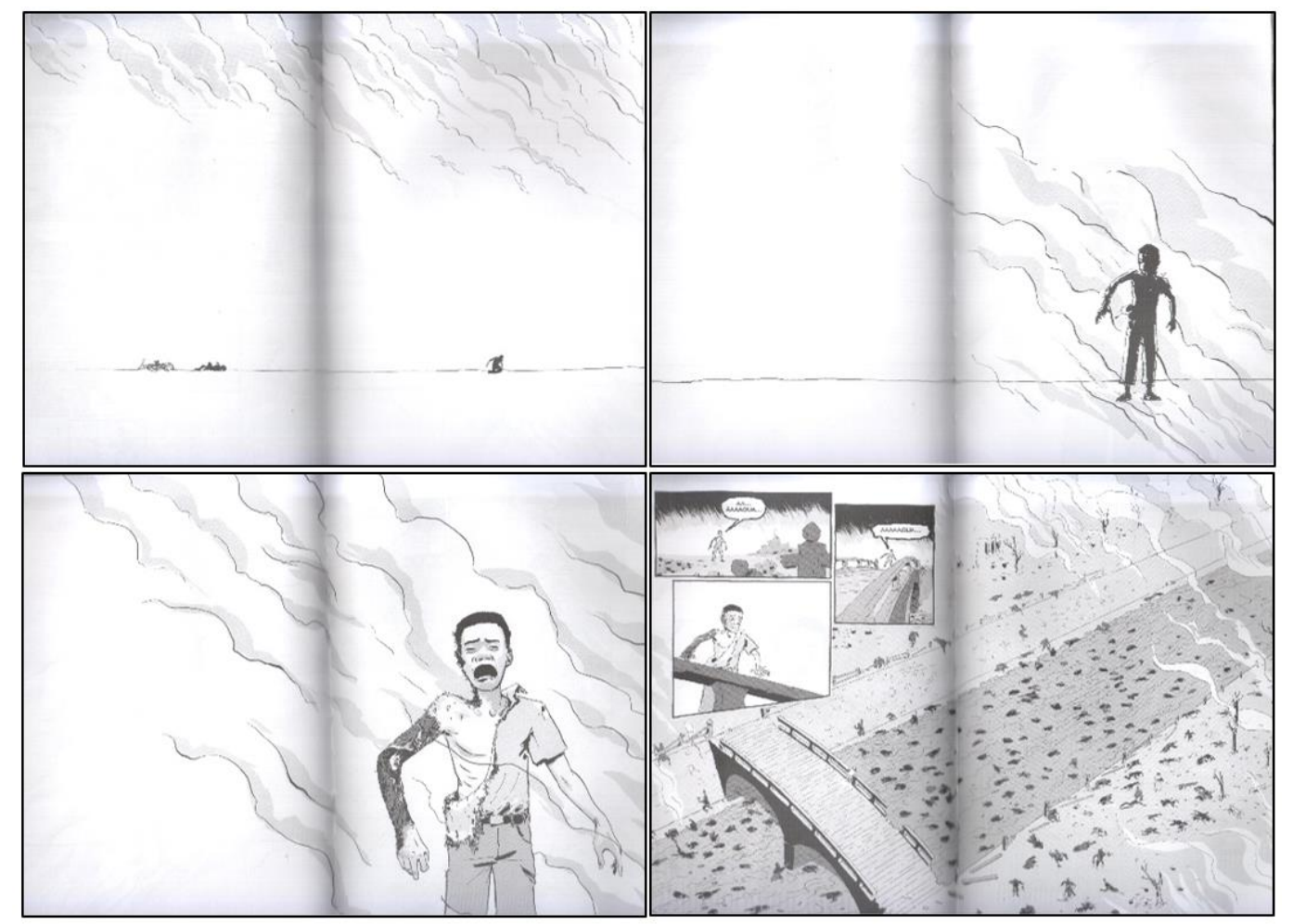

Fonte: Fetter Vorm (2013), p. 122-129

\subsection{Análise global da sensibilidade moral evidenciada nos argumentos escritos fornecidos} pelos licenciandos em resposta aos casos extraídos da HQ

Diante dos resultados obtidos e discutidos no tópico anterior, tecemos na sequência algumas considerações globais a respeito da sensibilidade moral evidenciada pelos futuros professores ao longo das atividades propostas. Nessa perspectiva, poderemos responder em que extensão a prática realizada em sala de aula contribuiu para o desenvolvimento da sensibilidade moral dos licenciandos.

Assim sendo, construímos, conforme ilustram as Figuras 49 - 53, gráficos que sumarizam os valores atribuídos à sensibilidade moral observada para os licenciandos durante os diferentes momentos de aplicação dos três casos extraídos na HQ. Lembramos que a sensibilidade moral conferida a cada aluno diz respeito aos aspectos morais evidenciados em seus textos escritos, comparativamente à grelha por nós elaborada para cada caso. 
Figura 49 - Distribuição gráfica dos valores obtidos a respeito da sensibilidade moral conferida à licencianda Alice a partir dos seus diferentes argumentos escritos.

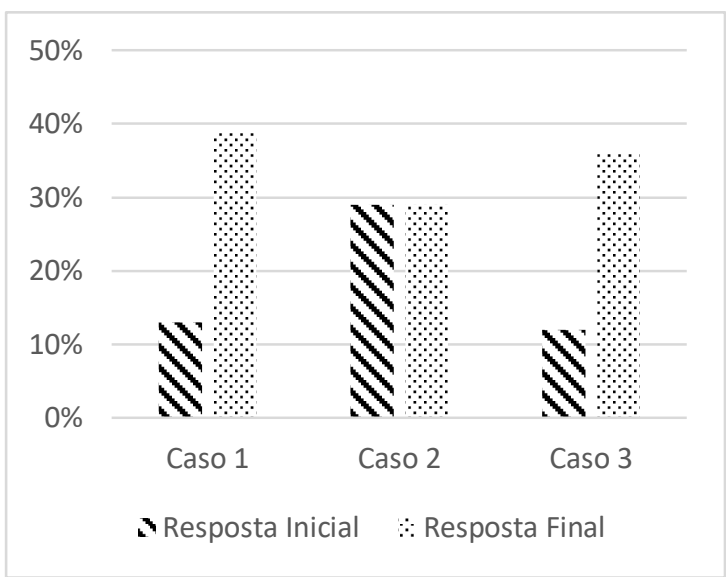

Figura 51 - Distribuição gráfica dos valores obtidos a respeito da sensibilidade moral conferida à licencianda Caroline a partir dos seus diferentes argumentos escritos.

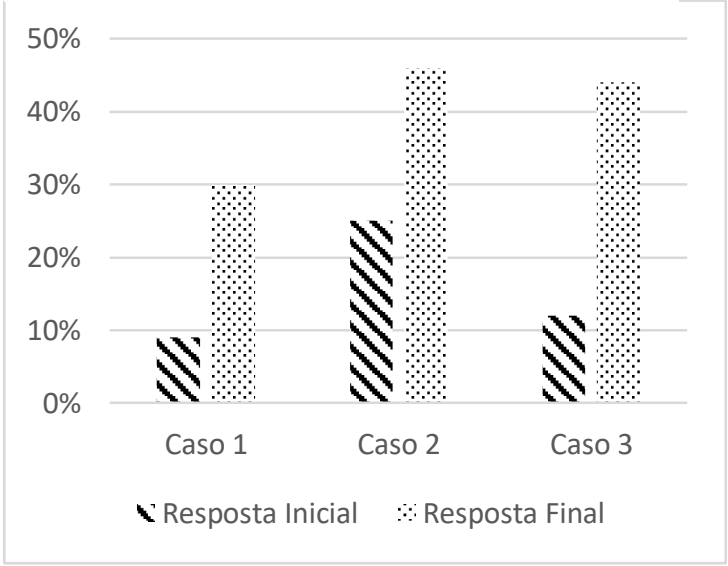

Figura 50 - Distribuição gráfica dos valores obtidos a respeito da sensibilidade moral conferida à licencianda Bianca a partir dos seus diferentes argumentos escritos.

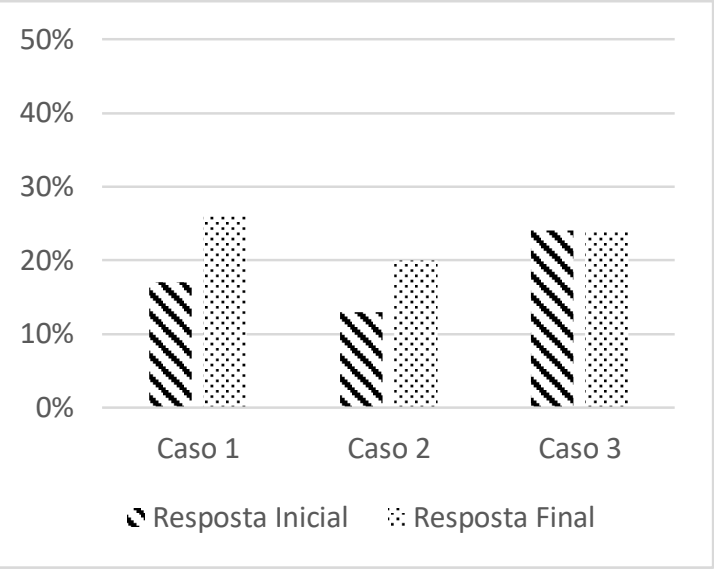

Figura 52 - Distribuição gráfica dos valores obtidos a respeito da sensibilidade moral conferida à licencianda Débora a partir dos seus diferentes argumentos escritos.

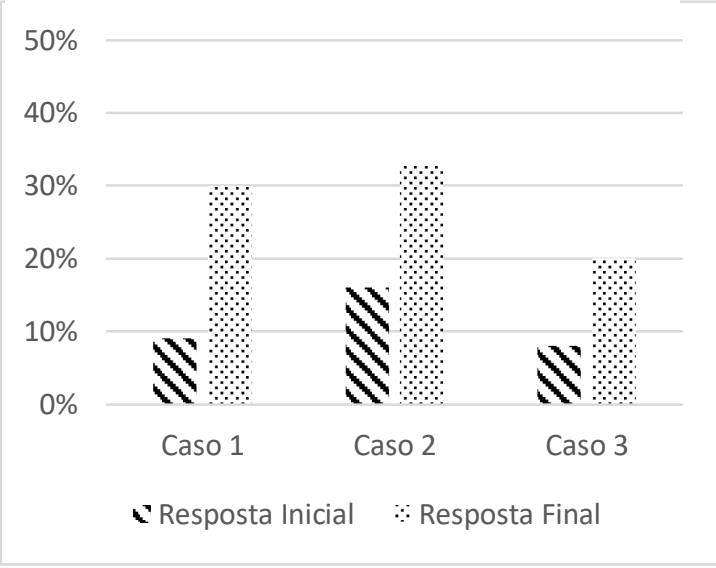

Figura 53 - Distribuição gráfica dos valores obtidos a respeito da sensibilidade moral conferida ao licenciando Gabriel a partir dos seus diferentes argumentos escritos.

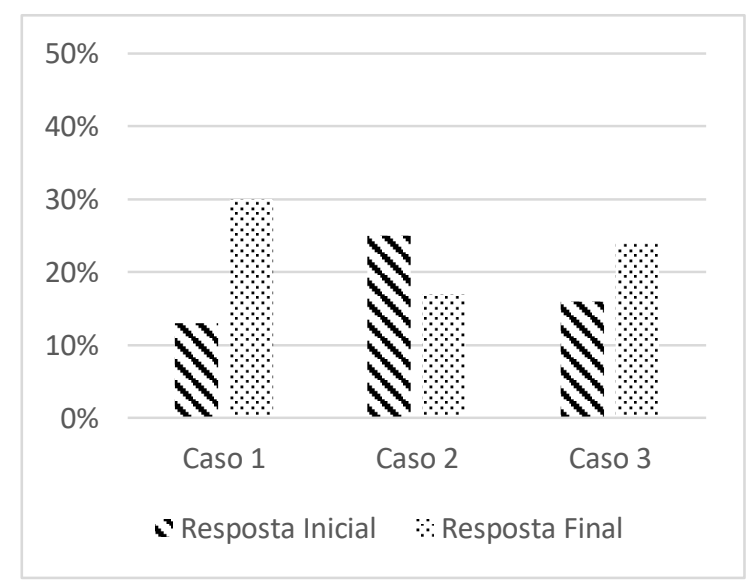


Diante dos resultados expressos graficamente podemos constatar que, assim como para a estrutura dos argumentos analisados na perspectiva de Toulmin (2001), o Caso 2, conforme podemos observar nas respostas de Alice, Figura 49, Caroline, Figura 51 e Débora, Figura 52, conferiu, em média, considerando resposta inicial e final, uma maior sensibilidade moral aos licenciandos. Essa maior sensibilidade identificada para o caso em questão pode ser atribuída aos mesmos motivos que conduziram a uma maior complexidade estrutural dos argumentos discutida anteriormente, a dificuldade inerente ao caso. Em geral, diante de uma questão socialmente controversa, o indivíduo recorre a uma série de artifícios os quais podem variar de acordo com a natureza da questão (SADLER e ZEIDLER, 2005; ACAR, TURKMEN e ROYCHOUDHURY, 2010). Por exemplo, com um teor mais emotivo, identificamos nos argumentos escritos de alguns licenciandos determinados recursos empregados exclusivamente na resolução do Caso 3, isto é, recursos oriundos de um padrão de raciocínio informal emotivo e até mesmo intuitivo, o que, como já abordado, não necessita de uma sensibilidade moral elevada para serem empregados. Nesse sentido, um dilema considerado pelos próprios licenciandos como de resolução mais complicada (Caso 2) demandou uma análise moral mais acentuada e, dessa forma, identificamos uma sensibilidade a aspectos morais pertinentes ao caso mais elevada. Analogamente, portanto, podemos verificar graficamente, em especial na Figura 52, a qual sumariza as respostas de Débora, uma redução da sensibilidade moral evidenciada pela licenciada, a qual se mostrava em evolução quando observada as respostas fornecidas pela futura professora aos Casos 1 e 2 .

Ao abordarmos os padrões de raciocínio informal na perspectiva de Sadler e Zeidler, (2005) observamos que houve um grande predomínio daquele que eles denominam racionalista. Podemos atribuir, pelo menos parcialmente, conforme discutido ao longo dos argumentos apresentados pelos alunos, a evidência desse padrão ao emprego do TAP (2001). De acordo com Toulmin (2001), um determinado argumento é válido mediante o uso de uma série de elementos em sua estrutura, como dado, conclusão e justificativa. Nesse sentido, almejando a validade de suas colocações escritas, e muitas vezes limitados pelo esqueleto de argumento proposto pelo autor, os futuros professores buscavam apresentar suas respostas em termos racionalistas. Contudo, embora tenhamos salientado em determinados momentos algumas restrições do emprego do TAP (2001) em sala de aula, podemos conferir à sua utilização, a praticamente ausência de heurísticas e vieses cognitivos (TONETTO et al., 2006) nos argumentos apresentados pelos futuros professores. Relembramos, conforme discutido no Capítulo 2 que tais recursos são comumente empregados por indivíduos quando da resolução 
de questões socialmente controversas como estratégias que ignoram parte da informação com o objetivo de tornar a escolha mais fácil e rápida.

Segundo estudos de Acar, Turkmen e Roychoudhury (2010), uma estratégia que tem afetado a argumentação dos estudantes diante de situações controversas e que envolvem o julgamento de valores é exatamente o uso de tais heurísticas e vieses cognitivos. De acordo com os autores, heurísticas são empregadas geralmente na resolução de questões com os quais o indivíduo está familiarizado, e conforme mencionado, há o negligenciamento de parte da informação com o objetivo de tornar a escolha mais fácil e rápida, e o seu uso excessivo pode ser problemático em contextos em que se é essencial a análise de uma séria de fatores como prós e contras de decisões alternativas. Nos textos analisados e discutidos, podemos constatar uma presença mínima desse recurso somente no segundo argumento de Débora ao Caso 3, quando a licencianda menciona em seu argumento para a tomada de decisão o seguinte trecho: no mundo ideal, que eu penso, a bomba nunca deveria ser construída e guerras seriam desnecessárias. Nesse sentido, ao relacionarmos raciocínio moral e TAP (TOULMIN, 2001), podemos verificar que a busca por termos racionalistas em suas respostas fez com que os futuros professores praticamente não empregassem em seus textos esse tipo de recurso identificado por Acar, Turkmen e Roychoudhury (2010) quando da argumentação sobre QSC.

Prosseguindo em nossas considerações, embora não tenhamos constatado melhores índices de sensibilidade moral na resolução do Caso 3, podemos afirmar que houve uma contribuição positiva das atividades empregadas em sala de aula para o desenvolvimento moral dos futuros professores, a qual poderia ser mais significativa com um trabalho envolvendo práticas semelhantes a deste estudo a longo prazo. Assim, uma vez que a natureza do último caso possibilitou o emprego de padrões de raciocínio moral (SADLER e ZEIDLER, 2005) que não suscitam elevada sensibilidade moral, esta não foi expressiva na resolução do dilema narrado no Caso 3. Outrossim, contamos com situações atípicas, não menos relevantes, uma vez que se trata de um estudo de caso qualitativo exploratório, em que determinados aspectos conduziram a uma redução da sensibilidade moral identificada. Como exemplo citamos o posicionamento de Gabriel durante a resolução do caso em questão, o qual discordando de forma veemente de algumas das colocações apresentadas no momento de discussão oral conduzida pela professora, não contemplou diferentes aspectos morais elencados pelos pesquisadores constantes no instrumento de análise empregado, isto é, a grelha esquematizada no Quadro 59.

No mais, é perceptível pelos gráficos ilustrados nas Figuras 49 - 53, salvo três exceções, isto é, Figura 49 - Caso 2, Figura 50 - Caso 3 e Figura 53 - Caso 2, a validade do momento de 
reflexão acerca dos aspectos morais de questões socialmente controversas conduzido oralmente pela professora em sala de aula, o qual implica em notável ampliação da sensibilidade moral exibida pelos licenciandos. Ao promover a participação dos alunos, o que é importante e necessário para alcançarmos os objetivos da alfabetização científica a partir da inserção de questões de natureza controversa (SADLER e ZEIDLER, 2009; BOSSÉR e LINDAHL, 2017), a professora permite que os diferentes educandos não só contemplem diferentes opiniões e elementos pertinentes aos conflitos negligenciados inicialmente, como também permite a externalização das próprias ideias. Nesse sentido, ao se posicionar oralmente a respeito de diferentes aspectos, o licenciando é capaz de salientar elementos contemplados inicialmente que por uma série de fatos não se apresentam em seu texto escrito.

Ao entrarmos em contato com este último fato, nos deparamos como uma desarmonia entre texto escrito e comunicação oral. Os resultados obtidos vão ao encontro das dificuldades evidenciadas por diferentes autores, como Giraldi (2010), a respeito da barreira que representa a produção textual escrita para os alunos, tanto da educação básica como da educação superior, contexto no qual levamos a cabo o nosso estudo. Essa dificuldade é resultado das poucas oportunidades vivenciadas pelos educandos em sala de aula, principalmente em disciplinas das ciências exatas e da natureza, da leitura e da escrita (QUEIROZ, 2001; FLÔR, 2009; GIRALDI, 2010; MARTINEZ et al, 2017).

A respeito dessa questão, Queiroz (2001) ao investigar os usos da linguagem escrita nos cursos de graduação em química conclui seu estudo mencionando dois aspectos preocupantes de práticas como esta em sala de aula, os quais destacamos na sequência.

Um deles é o maior tempo usualmente despendido na elaboração, execução e correção
das referidas tarefas escritas (insistindo-se no uso da linguagem escrita, não se estaria
gastando um tempo precioso que poderia ser usado para, de fato, ensinar os princípios
e conceitos da ciência? A bagagem nos alunos não seria prejudicada pela prática de
tarefas escritas?). Um outro aspecto preocupante considera a própria formação do
professor de química que foi treinado para ensinar ciências e não para discorrer com
maestria sobre gramática, retórica, estruturação de frases, etc. Assim, um fino ajuste
de vários fatores faz-se necessário quando se pretende trabalhar com linguagem
escrita em salas de aula... (QUEIROZ, 2001, p. 146).

Nesse contexto de contraste do que é observado por meio do registro das discussões orais, e verificados nos argumentos escritos fornecidos pelos licenciandos, os resultados obtidos a respeito da sensibilidade moral atribuída aos futuros professores poderiam ser significativamente melhores, uma vez que consideramos em nossas análises os aspectos morais evidenciados somente nas produções textuais dos futuros professores. Assim sendo, o estudo da sensibilidade moral de professores em formação diante de questões controversas evidenciou a necessidade patente de mais práticas envolvendo o exercício da leitura e da escrita em sala de 
aula do ensino de ciências. E, ao encontro das colocações feitas por Queiroz (2001) é evidente a importância de práticas de leitura em contexto de formação inicial e/ou continuada de professores, de modo que estes venham estar aptos a abordagem não somente dos conteúdos científicos para os quais foram treinados, como também para o trabalho com a linguagem escrita em salas de aula da educação básica.

Considerando o panorama aqui traçado, os argumentos apresentados pelos licenciandos para a resolução dos três casos extraídos da HQ "Trinity" sinalizam a dificuldade que os mesmos enfrentam na elaboração de respostas bem fundamentadas que forneçam indícios de sensibilidade moral aguçada. Contudo, de forma a entender que elementos conferem maior complexidade no que tange à determinação dos aspectos morais inerentes a um conflito ético, representamos graficamente, conforme ilustrado na Figura 54 a frequência de menções a cada um dos elementos considerados por Bebeau (1995) como indicativos de uma resposta bem fundamentada moralmente.

Nesse sentido, o gráfico exibe o percentual de elementos abordados nas respostas dos cinco licenciandos antes e após a discussão conduzida em sala de aula para os três casos, ou seja, a frequência de partes interessadas, de consequências, de obrigações do protagonista, e de pontos de conflito. Dessa forma podemos inferir também quais aspectos são mais influenciados pelo tipo de texto empregado em sala de aula, isto é, uma obra quadrinizada, e qual a extensão dos efeitos oriundos dos momentos de reflexão na construção dos argumentos finais em resposta a cada um dos casos empregados. 
Figura 54 - Representação gráfica das frequências de menções às partes interessadas, às consequências, às obrigações do protagonista e aos pontos de conflito nas respostas dos licenciados para cada um dos casos.

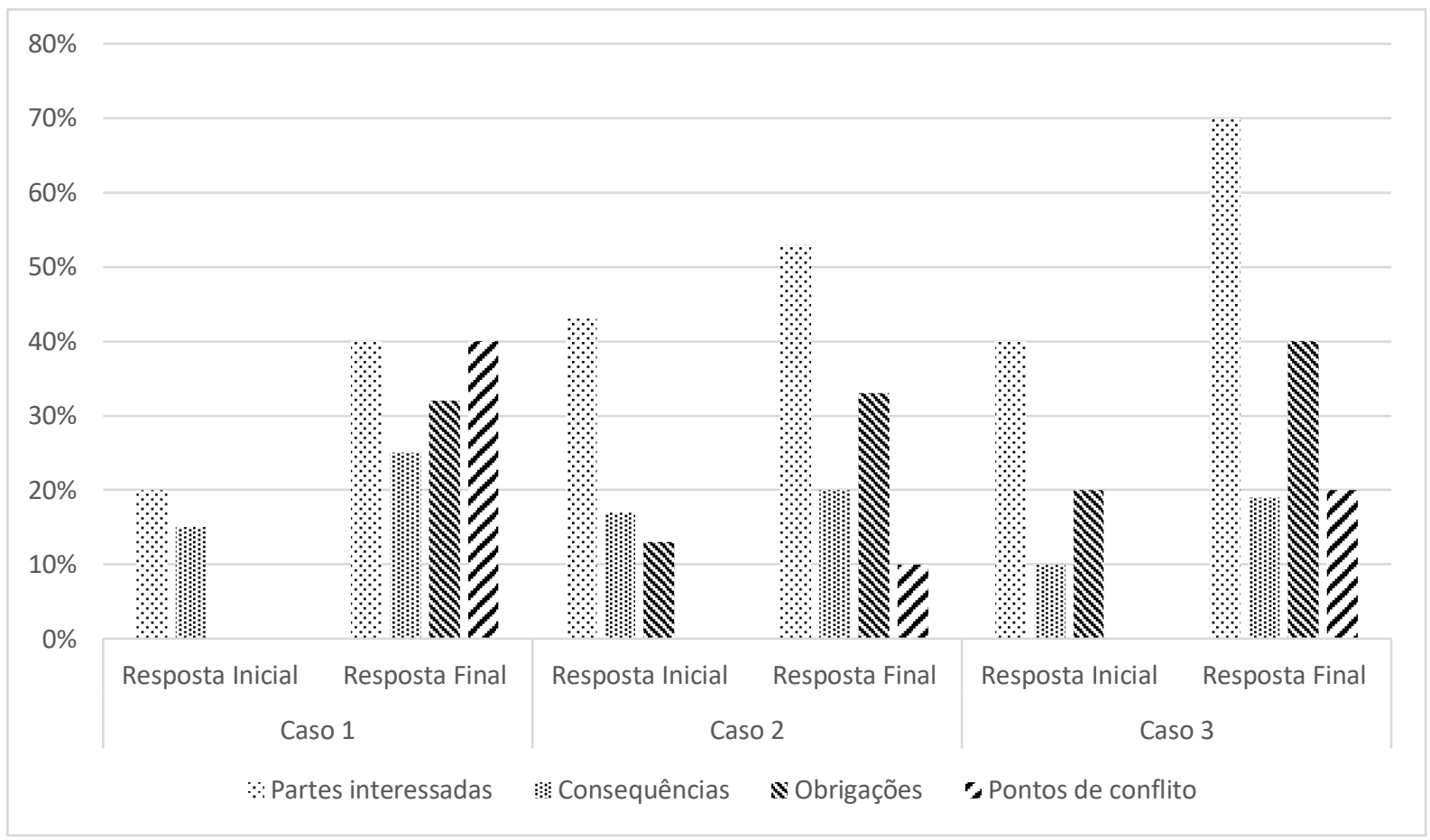

Com base no que é apresentado na Figura 54 podemos observar, assim como já sinalizado ao longo da discussão da sensibilidade moral exibida por cada licenciando, um predomínio de menções às diferentes partes interessadas envolvidas em cada caso. Essa constatação vai ao encontro das ideias de McCloud (2005) a respeito do hipergênero textual empregado em nossas atividades. Segundo o autor, grande parte do sucesso das HQ diz respeito à possibilidade de maior proximidade entre leitor e personagem, promovida pela linguagem autônoma dos quadrinhos (RAMOS, 2016), a qual emprega textos verbais e imagens em, quase sempre, perfeita harmonia. Nessa perspectiva, diante da oportunidade de visualização dos diferentes personagens, que por meio também de uma série de recursos possíveis como uso o primeiro plano, são capazes de dialogar diretamente com o interlocutor, os futuros professores exibiram maior facilidade em mencioná-los em seus textos.

Ainda com relação às partes interessadas, também é evidente o crescente percentual de menções a esse elemento. Podemos concluir que ao longo das atividades os licenciandos, que em sua maioria não tinham mais contato com obras quadrinizadas, passou a se familiarizar com o texto e sua linguagem autônoma (RAMOS, 2016). Nesse sentido, com uma proximidade cada vez maior com os personagens e entidades representados graficamente, os futuros professores passaram a inserí-los em suas respostas com mais facilidade. 
Também é digno de nota a contribuição da sequência de atividades desenvolvidas para a sensibilidade moral dos licenciandos, principalmente no que tange ao reconhecimento das obrigações dos protagonistas, o que pode futuramente levá-los a reconhecer com mais facilidade os pontos de conflito presentes em dilemas éticos e morais. Nesse contexto, o que se verifica é que, quando da aplicação do Caso 1, nenhuma resposta mencionava inicialmente qualquer tipo de obrigação de Oppenheimer, protagonista naquela situação. Com relação ao Caso 2, quando questionados inicialmente se Oppenheimer deveria falar abertamente sobre o poder de destruição de um artefato atômico em construção, observamos menções a $13 \%$ das obrigações consideradas inerentes àquela situação e que estão sinalizadas no Quadro 48. E, posteriormente, quando empregado o Caso 3, constatamos nas respostas iniciais dos alunos $20 \%$ das obrigações dos cientistas presentes no Quadro 59. Dessa forma, fica nítida a evolução do raciocínio moral dos educandos, em particular no que diz respeito à sensibilidade e identificação das obrigações morais de cada protagonista.

Com relação às consequências possíveis de cada decisão narrada nos diferentes casos empregados em sala de aula, percebemos que o número de menções a elas não foi significativamente maior devido à presença maioritária do enfoque deontológico em algumas das respostas. De acordo com Costa (2002), esse tipo de enfoque está baseado em preceitos universais da moralidade, ou seja, o centro do valor moral está nas regras morais. Logo, em contraste com um enfoque consequencialista, considerando apenas essas regras morais próprias de uma moral heterônoma de Kant (2005), a ponderação de consequências se torna irrelevante para a tomada de decisão. Portanto, o que se verifica, uma vez que entendemos como objetivo da educação moral a formação de indivíduos críticos que atendam à moral autônoma de Kant (2005), é a patente necessidade dessa temática transversal em sala de aula, nos mais variados níveis de instrução.

No mais, representando uma maior dificuldade de identificação pelos licenciandos, nenhum ponto de conflito foi mencionado nas respostas escritas iniciais dos alunos, sinalizando assim a principal lacuna no que diz respeito à sua sensibilidade moral. Porém, assim como houve um salto no que diz respeito à capacidade dos educandos em identificar, direta ou indiretamente, as obrigações dos protagonistas, os resultados obtidos fornecem indício das possibilidades oriundas da atividade empregada em sala de aula para uma ampliação de faculdade de determinação dos pontos de conflitos. Assim, somos levados a crer que práticas como esta, realizadas de forma contínua, poderiam facilitar a identificação desse elemento, uma vez que, reconhecidas as obrigações morais daquele que toma a decisão nos diferentes conflitos, sua contraposição na maioria das vezes indicaria o conflito existente. 
Por fim, mais uma vez são evidentes as contribuições e influência das discussões conduzidas em sala de aula para a ampliação da sensibilidade moral dos indivíduos. Essa influência é nítida face o aumento do número de menções de cada um dos quatro elementos presentes no gráfico ilustrado na Figura 54, após a discussão realizada em todos os casos. Salientamos ainda a importância desse momento não só para que os educandos possam vislumbrar aspectos elencados pelos colegas, mas que possam ser capazes de externalizar suas ideias e opiniões. E, nessa perspectiva, concordamos com as afirmações de Bossér e Lindahl (2017) e enfatizamos a necessidade de práticas envolvendo o uso de QSC também na formação inicial de professores, de modo que estes, em sua prática docente futura sejam capazes de lidar com aspectos relacionados a emoções oriundas da empatia com outros indivíduos, e desenvolvam estratégias que os possibilitem no trato de tais emoções. 


\section{Capítulo 7 - Considerações finais}

Considerando os objetivos propostos neste estudo, os quais compreendem a promoção, o exercício e a análise da argumentação e da sensibilidade moral exibida por licenciandos em química diante de QSC, a partir do estabelecimento de práticas de leitura em quadrinhos, iniciamos nossas conclusões tratando da HQ que subsidiou toda a investigação, "Trinity: a história em quadrinhos da primeira bomba atômica". Nessa perspectiva, com base na análise envidada a princípio almejando identificar as potencialidades não somente pedagógicos do texto, mas para os objetivos propostos com este estudo, salientamos a adequação do texto previamente selecionado.

Com relação aos conteúdos abordados na HQ, estes são de diversas naturezas, com destaque para o que Ferreira e Queiroz (2011) caracterizam como fronteiras e como temáticas transversais. Assim sendo, a partir da leitura da referida HQ identificamos conteúdos próprios do ensino formal de física que, no entanto, apresentam relações com a química, como questões envolvendo a estrutura atômica e processos nucleares. Identificamos também temáticas que permeiam todo o currículo dos diferentes níveis de formação, como a ética.

Dessa forma, diante dos conteúdos presentes na HQ verificamos que, ao tratar da construção das armas nucleares comumente conhecidas e que foram lançadas nas cidades japonesas de Hiroshima e Nagasaki, o autor o faz por meio de três abordagens principais. Inicialmente, almejando situar o leitor e apresentar informações relevantes para o entendimento da narrativa, contamos com as abordagens conceitual e histórica, as quais abrem espaço para uma abordagem polêmica, que por sua vez, suscita a argumentação. Nesse contexto, identificamos no texto questões que possibilitassem o alcance dos objetivos traçados com este estudo, o qual consiste na promoção da argumentação diante de QSC. Com relação ainda às QSC, a sua natureza permite o exercício e o acesso ao raciocínio informal dos educandos por meio do contato com aspectos éticos e morais, o que se tornou também um dos objetivos de nossa investigação.

Além disso, a análise do "conteúdo" da HQ permitiu identificar um elevado grau de cientificidade na perspectiva de Zamboni (2001), o qual permite ao leitor o contato com diferentes características da atividade científica. Abordando, portanto, aspectos vinculados à $\mathrm{NdC}$, podemos inferir que o texto, quando da sua inserção no espaço formal de ensino, permite ao educando o contato de forma contextualizada e histórica com questões relacionadas à prática científica, aproximando-os desta. Esse tipo de abordagem está em consonância com as noções de Allchin (2012), que salienta a importância de uma dependência contextual para a inserção 
desses aspectos em sala de aula, e não apenas como uma simples lista de características a serem decoradas pelos alunos.

No que tange à forma como as informações identificadas pela análise do "conteúdo" são apresentadas no texto, seu estudo é de particular interesse para verificarmos a didaticidade do mesmo e, consequentemente, o seu potencial pedagógico. Dentre os recursos empregados com essa finalidade, identificamos inicialmente a busca por um equilíbrio entre termos técnicos e aqueles comuns ao repertório do leitor, o qual lembramos, associando a ideia de cena enunciativa (discurso da DC) na perspectiva de Zamboni (2001) e as características e constituição desse hipergênero textual (VERGUEIRO, 2007a), consiste em um indivíduo não especializado no que diz respeito à ciência. Contudo, reforçarmos que muita dessa didaticidade e desse equilíbrio buscado pelo autor em suas colocações no texto, vai ao encontro do contexto de produção do mesmo, isto é, ao encontro dos seus objetivos mercadológicos.

Outras estratégias próprias da linguagem verbal responsáveis por aumentar a didaticidade do texto também foram identificadas, como o amplo uso de simplificações e analogias, além de recursos metalinguísticos, como o de nomeação e definição (ZAMBONI, 2001). Contudo, mediante o emprego desses recursos, ressaltamos a importância de uma adequada intervenção dos professores, uma vez que estes podem implicar na distorção de algumas informações presentes no texto e, consequentemente, promover nos leitores/educandos a criação de concepções equivocadas sobre a temática.

Com relação ao aspecto gráfico/visual presente na $\mathrm{HQ}$, uma série de outros recursos podem promover a didatização das informações científicas, como o letreiramento que permite ao autor, por meio da escolha de diferentes fontes, ressaltar determinadas informações, e o desenho. Nesse sentido, considerando os desenhos empregados, constatamos a presença de diversos esquemas que estão de acordo com as noções de Kress (2003), como jargões científicos visuais, os quais assim como as analogias escritas, possibilitam uma espécie de visualização dos fenômenos microscópicos. Contudo, quando recorremos aos grupos pedagógicos principais os quais as HQ podem ser inseridas em contexto de ensino na perspectiva de Testoni (2004), isto é, com as finalidades ilustrativa, explicativa, motivadora ou instigadora, a presença de tais jargões visuais pode limitar as potencialidades dos quadrinhos. Assim sendo, com base nesses jargões, a utilização desse hipergênero textual pode ficar restrita às finalidades ilustrativa e explicativa. Na ilustrativa a função das HQ é apenas representar de forma gráfica um fenômeno previamente estudado, e na explicativa há o seu emprego para que seja possível a simplificação do conteúdo trabalhado em sala de aula via recursos textuais empregados em conjunto com o caráter gráfico que permite a "visualização" dos fenômenos. 
Outrossim, identificamos que diferentemente dos quadrinhos comerciais analisados por McCloud (2005), ao despendermos esforços para o estudo das transições de cena empregadas pelo autor em uma arte denomina sequencial, verificamos o predomínio de transições que demandam, de certa forma, um maior nível de atenção do leitor. A primeira, transição cena-para-cena, está diretamente relacionada com a abordagem histórica da HQ e exige do leitor o conhecimento de determinados acontecimentos para a compreensão da narrativa, é o caso, por exemplo, da derrota de Hitler em meio a $2^{\text {a }}$ Guerra Mundial, e que está subentendida entre os grandes saltos temporais e espaciais da narrativa.

Com relação ao segundo tipo de transição (transição tema-para-tema), essa, para além de contribuir para o aumento da didaticidade do texto ao realçar determinados elementos de uma cena, se relaciona com a abordagem polêmica. E, dessa forma, ao associarmos com os planos de visão na perspectiva de Ramos (2016) podem, a princípio, afetar o processo de argumentação, por exemplo. Nesse sentido, ao identificarmos diversas vezes o uso do primeiro plano, tomamos contato com momentos de interlocução direta em que, com foco na expressão dos diferentes personagens, o autor se dirige diretamente ao leitor. A respeito das influências desses recursos, como o primeiro plano e transição tema-para-tema, no processo argumentativo destacamos o seu potencial para a empatia e sensibilização do leitor, que segundo diferentes autores, como Sadler e Zeidler (2005), estão relacionados com o raciocínio informal. Dessa forma, a sensibilidade moral investigada a partir de práticas de leitura da HQ pode, a princípio, ser ampliada quando do contato dos futuros professores com esses recursos.

Assim sendo, considerando o nosso interesse em promover a argumentação no âmbito da formação inicial de professores, extraímos da HQ "Trinity" três casos que instigassem os licenciandos à tomada de decisão. Nesse contexto, ao relacionarmos a argumentação com o exercício do raciocínio informal/moral dos estudantes, fizemos uso para aplicação desses casos da metodologia proposta por Bebeau (1995). De modo a verificarmos a qualidade estrutural dos argumentos dos licenciandos em resposta aos casos e como as atividades desenvolvidas em sala de aula contribuíram ou não para a melhora dessa qualidade, empregamos o TAP (TOULMIN, 2001).

Nesse sentido verificamos que, embora tenham apresentado argumentos de complexidade razoável, os resultados obtidos com os licenciandos estão de acordo com aqueles alcançados por outros autores como Simon, Erduran e Osborne (2006) e Sá, Kasseboehmer e Queiroz (2014). Logo, tais resultados sugerem a inserção de mais práticas que promovam o exercício da argumentação em sala de aula, ainda mais quando consideramos essa uma prática 
epistêmica central da ciência. Ainda assim, constatamos após a aplicação dos três casos uma evolução da qualidade estrutural do que é apresentado pelos licenciandos frente a questões controversas.

Com relação às atividades e seus efeitos nos argumentos produzidos pelos alunos, destacamos inicialmente que a leitura da HQ pouco influenciou na tomada de decisão e na estrutura das respostas. A título de exemplo, um elemento próprio do TAP (TOULMIN, 2001) e que poderia ser extraído dos trechos da HQ fornecidos aos alunos, aumentando assim a complexidade dos argumentos apresentados por eles, diz respeito aos backings, isto é, as justificativas elaboradas pelos licenciandos poderiam ser apoiadas em asserções presentes no texto da HQ. Essa constatação denota a baixa atenção despendida pelos licenciandos ao texto como um todo, o qual pode ser reflexo da leitura rápida realizada em sala de aula, a qual aponta para uma das limitações da dinâmica empreendida.

Um dos aspectos que parece ter contribuído significativamente para a evolução da qualidade estrutural dos argumentos empregados pelos licenciandos diz respeito às discussões com base no que é proposto por Bebeau (1995). Dessa forma, momentos de reflexão sobre os aspectos morais de cada situação apresentada aos futuros professores, permitiam o contato com elementos que fortaleciam o que estava sendo colocado. Em especial identificamos que considerações a respeito das consequências de cada uma das ações dos protagonistas dos casos, bem como suas obrigações, se convertiam em justificativas em um segundo momento de argumentação. E uma maior frequência de justificativas, por sua vez, considerando as ideias de Sá, Kasseboehmer e Queiroz (2014), implica em uma maior complexidade do argumento.

No que tange à análise do raciocínio informal dos futuros professores, em especial de sua sensibilidade moral, empregamos em nosso estudo o Modelo dos Quatro Componentes proposto por Rest, Bebeau e Volker (1986). Segundo os autores a moralidade é construída com base em quatro componentes: a sensibilidade moral; o julgamento moral; o comprometimento moral; caráter moral. O nosso interesse pela sensibilidade moral encontra subsídios nas ideias de Fowler, Sadler e Zeidler (2009), os quais afirmam que se o raciocínio moral é empregado para determinar o curso das ações diante de um problema controverso, uma das principais necessidades seria a habilidade de reconhecer os aspectos morais das situações. Nessa perspectiva, de modo a estudar efetivamente essa sensibilidade, empregamos em nosso estudo o material elaborado por Bebeau (1995), o qual de forma detalhada apresenta a comunidade científica e acadêmica possibilidades metodológicas e analíticas que permitam investigar o raciocínio moral dos licenciandos. 
Dentre as considerações de Bebeau (1995), destacamos os elementos que segundo o autor são necessários em uma resposta bem fundamentada moralmente, e que conduzam a uma sensibilidade moral mais acurada. Portanto, são na perspectiva do autor, aspectos importantes que devem ser considerados na tomada de decisão diante de questões controversas, as partes interessadas na situação, as consequências de cada uma das possíveis ações, as obrigações daquele que de fato toma a decisão, isto é, do protagonista, e os pontos de conflito que permitam dizer que há um dilema moral envolvido. Metodologicamente falando, Bebeau (1995) apresenta uma sequência de passos que o professor pode adotar em sala de aula para o exercício do raciocínio moral dos educandos. Tais passos compreendem a resolução inicial e individual de casos que apresentam ao leitor um dilema a ser resolvido, uma discussão oral conduzida pelo professor que contemple as respostas dos alunos e envolva os diferentes aspectos citados, que na perspectiva de Bebeau, confeririam uma resposta bem fundamentada moralmente e, por fim, a uma nova resolução individual do conflito pelos alunos.

Assim sendo, com a aplicação dos três casos mencionados em sala de aula e, a partir das respostas fornecidas pelos licenciandos, concluímos que as atividades didáticas realizadas no contexto de formação de professores contribuíram positivamente para o desenvolvimento da sensibilidade moral dos mesmos. E, ainda que os resultados obtidos a respeito dessa sensibilidade indicam lacunas na formação dos educandos, o que está de acordo com as considerações de Bebeau (1995), o qual salienta a dificuldade da tomada de decisão diante de situações que não possuem regras estabelecidas a princípio. Essa constatação evidencia a patente necessidade de práticas e estudos endereçados para o desenvolvimento moral dos alunos.

Considerando ainda as colocações de Bebeau (1995) a respeito das dificuldades que naturalmente encontramos frente dilemas éticos, podemos observar que ela se deve essencialmente à moral predominante na sociedade moderna, isto é, a moral heterônoma de Kant (2005). Segundo o autor, essa moral é guiada por motivos extrínsecos às pessoas, ou seja, guiados por regras que nem sempre são alvo de reflexões pelos indivíduos. Assim, podemos identificar os efeitos dessa "moral vigente" nos argumentos e consequentemente na sensibilidade moral dos licenciados, quando em diferentes ocasiões constatamos o enfoque maioritariamente deontológico em suas respostas. Segundo Costa (2002), esse enfoque envolve uma moral demasiadamente simples e rígida em que o centro de seu valor se encontra em regras morais estabelecidas previamente. Logo, fundamentados em tais regras morais, aqueles que 
apresentam em suas respostas para a tomada de decisão o predomínio desse enfoque, tendem a exibir uma sensibilidade moral limitada.

Contudo, com a realização das atividades, e até mesmo com a familiaridade que os futuros professores foram criando com a linguagem autônoma dos quadrinhos e com os personagens da narrativa, observamos que o enfoque consequencialista (COSTA, 2002) foi ganhando espaço, e embora isso não tenha refletido significativamente na sensibilidade moral exibida pelos licenciandos, sinaliza uma perspectiva de análise de problemas controversos interessante que pode conduzir a uma moral autônoma (KANT, 2005). A respeito dessa moral, Kant (2005) enfatiza que a tomada de decisão se fundamenta na razão e não na coerção social, partindo, portanto, do interior dos sujeitos. Nesse sentido, consideramos essa moral o ideal a ser alcançado em sala de aula, devendo, portanto, consistir no objetivo da educação moral, a qual reforçamos diz respeito a uma temática transversal pertinente às diferentes disciplinas nos mais variados níveis de instrução.

Prosseguindo com a ideia dos efeitos da familiaridade do leitor com a linguagem dos quadrinhos e com os personagens na argumentação dos licenciandos, em especial da sua sensibilidade moral, destacamos, conforme esperado a partir da análise da HQ "Trinity", a influência da mesma no raciocínio moral dos licenciandos. Nesse contexto, por exemplo, destacamos que dentre os aspectos morais relevantes de um caso e que devem ser considerados na perspectiva de Bebeau (1995) para que o indivíduo exiba uma resposta bem fundamentada moralmente, houve o predomínio, nos textos escritos fornecidos pelos licenciandos, de partes interessadas em cada caso. Assim sendo, atribuímos esse predomínio ao aspecto gráfico da HQ, que ao representar diferentes personagens permite a visualização destes pelos leitores, e assim promove uma maior empatia com eles. Outrossim, os efeitos da HQ para a sensibilidade moral evidenciada pelos futuros professores ainda são corroborados pela crescente frequência de menções a esses aspectos ao longo das aplicações dos três casos extraídos da HQ. Logo, podemos constatar que além da narrativa ilustrada ter permitido a visualização dos diferentes personagens, a leitura do texto ao longo dos encontros em sala de aula proporcionou uma maior familiaridade dos licenciados com a linguagem dos quadrinhos. Nesse contexto, os futuros professores passaram a despender maior atenção a outros elementos que não o texto escrito.

No que tange à metodologia proposta por Bebeau (1995), a qual envolve três diferentes etapas de aplicação, ressaltamos, com base em nossos resultados, a validade dos momentos de discussão estabelecidos em sala de aula. Estes permitiram não somente que os licenciandos pudessem contemplar aspectos negligenciados em suas respostas iniciais, como também exibissem suas ideias e opiniões. O ambiente, portanto, propiciado pelas reflexões conduzidas 
pelo professor vai ao encontro das necessidades que derivam da abordagem de QSC em sala de aula, como a de fornecer um contexto que encoraja educandos a expressarem suas concepções acerca da temática abordada. Essas discussões contribuíram significativamente para a ampliação da sensibilidade moral dos licenciados, conforme podemos constatar nas respostas finais fornecidas para cada caso.

A respeito ainda das discussões, foi possível observar os efeitos negativos da dificuldade evidenciada pelos alunos com relação à produção textual em sua sensibilidade moral. Essa dificuldade de produção escrita vai ao encontro de uma série de outros estudos, como de Flôr (2009) e Giraldi (2002), que salientam a pouca ou não existência de práticas de escrita e leitura principalmente no ensino de ciências. Embora integrantes de uma sociedade letrada, a habilidade de escrita é pouca valorizada em disciplinas popularmente conhecidas como da área das exatas. Nessa perspectiva, muitos dos elementos que os licenciandos expressavam oralmente não eram inseridos em seus textos escritos, e uma vez que nossas análises consistiram na identificação dos aspectos morais evidenciados nestes textos escritos, a não inserção desses elementos na resposta implicava no indicativo de uma reduzida sensibilidade moral. Dessa forma, os resultados obtidos com relação a esse aspecto reforçam a necessidade de realização, em ambientes de ensino, de mais práticas e propostas como a empregada neste trabalho.

Ademais, conforme esperado de acordo com a literatura, identificamos em nosso estudo um grande predomínio do padrão de raciocínio informal racionalista (SADLER e ZEIDLER, 2005) nas respostas dos licenciandos. Contudo, além deste ser o padrão comumente valorizado em sala de aula do ensino de ciências, atribuímos também sua evidência ao emprego do TAP (TOULMIN, 2001), uma vez que, almejando a validade de suas colocações escritas, e limitados pelo esqueleto de argumento proposto por Toulmin (2001), os futuros professores buscavam apresentar suas respostas em termos racionalistas. Assim sendo, embora o TAP tenha originado certas limitações ao estudo, como inibir a argumentação espontânea dos licenciandos, podemos conferir à sua utilização, a praticamente ausência de heurísticas e vieses cognitivos (TONETTO et al., 2006) nos argumentos apresentados pelos futuros professores.

Diante dos resultados obtidos em nosso estudo no que diz respeito à investigação da sensibilidade moral de licenciandos em química, também podemos salientar a validade e relevância do Modelo dos Quatro Componentes (REST, BEBEAU e VOLKER, 1985), associado ao material instrucional elaborado por Bebeau (1995), para estudos envolvendo o desenvolvimento moral dos educandos. Nessa perspectiva, com nosso trabalho evidenciamos 
as potencialidades do modelo para tratamento de um tópico que consideramos fundamental para a formação do cidadão atuante na sociedade moderna, sendo o ensino de ciências um ambiente favorável para a sua abordagem. Assim sendo, o trabalho aqui realizado a partir desse modelo permite a possibilidade de maiores reflexões a respeito de uma temática que apesar de relevante, conta com um número incipiente de estudos em âmbito nacional.

Ademais, é válido destacar como contribuições da pesquisa desenvolvida, o potencial do contexto de leitura quadrinizada associado a dinâmica empregada em sala de aula, para o exercício do raciocínio moral. Outrossim, além da validade do emprego de HQ no ensino de ciências para a abordagem dos mais variados conteúdos, espera-se que os recursos próprios de sua linguagem promovam uma maior inserção do leitor na narrativa e, consequentemente, uma maior sensibilização a diferentes temáticas. Essa maior sensibilidade frente ao texto foi identificada, por exemplo, quando da aplicação do Caso 3 extraído da HQ “Trinity", com destaque para os argumentos apresentados pela licencianda Débora. Logo, tendo em vista o desenvolvimento moral do educando, em especial de sua sensibilidade, é evidente o potencial da leitura quadrinizada.

Em suma, as ações realizadas por meio deste trabalho se mostraram viáveis para o estudo aqui proposto e possibilitam diferentes abordagens e adaptações não somente para aplicação na formação de professores de ciências como também na educação básica. E, mesmo diante das limitações próprias deste estudo, seu caráter exploratório e o número reduzido de licenciandos investigados, os dados obtidos permitem responder de forma consistente as perguntas que elencamos, no contexto dos objetivos específicos para este trabalho. 


\section{REFERÊNCIAS}

ACAR, L. T. O.; TURKMEN, L.; ROYCHOUDHURY, A. Student difficulties in socioscientific argumentation and decision-making research findings: crossing the borders of two research lines. International Journal of Science Education. v. 32(9), p. 1191 - 1206, 2010.

ACEVEDO, J. Como fazer histórias em quadrinhos. São Paulo: Global, 1990.

ALBAGLI, S. Divulgação científica: informação científica para a cidadania? Ciência da Informação, v. 25(3), p. 396 - 404, 1996.

ALLCHIN, D. Rekindling phlogiston: from classroom case study to interdisciplinar relationships. Science \& Education, v. 6(5), p. 473 - 509, 1997.

ALLCHIN, D. Teaching the nature of science through scientific errors. Science Education, v. 96(5), p. $904-926,2012$.

ALMEIDA, M. J. P. M.; PAGLIARINI, C. R. Leitura na educação em ciências. Ciência \& Educação, v.22(2), 271 - 277, 2016.

ANDRADE, I. B.; MARTINS, I. Discursos de professores de ciências sobre leitura. Investigações em Ensino de Ciências, v. 11(2), p. 121 - 151, 2006.

ARCHILA, P. A. La investigación en argumentación y sus implicaciones en la formación inicial de professores de ciências. Revista Eureka sobre Enseñanza y Divulgación de las Ciencias v. 9(3), p. $361-375,2012$.

ARROIO, A. Comics as a narrative in natural science education. Western Anatolia Journal of Educational Sciences, Número especial, p. 93 - 98, 2011.

AYDENIZ, M.; GÜRÇAY, D. Assessing quality of pre-service physics teacher's written arguments. Research in Science \& Technological Education, v. 31(3), p. 269 - 287, 2013.

BARBIERI, D. As linguagens dos quadrinhos. São Paulo: Editora Peirópolis, 2017.

BARDIN, L. Análise de conteúdo. São Paulo: Edições 70, 2011.

BEBEAU, M. J. (Org.). Moral reasoning in scientific research: cases for teaching and assessment. Indiana University, 1995.

BEBEAU, M. J.; REST, J. R.; NARVAEZ, D. Beyond the promise: a perspective on research in moral education. Education Researcher, v. 28(4), p. 18 - 26, 1999.

BIAGGIO, A. M. B. Lawrence Kohlberg: ética e educação moral. São Paulo: Editora Moderna. 2006.

BOSSÉR, U.; LINDAHL, M. Students' positioning in the classroom: a study of teacher-student interactions in a sociocientific issu context. Research in Science Education, p. 1 - 20, 2017.

BRASIL. Ciências da Natureza, Matemática e suas Tecnologias. Parâmetros Curriculares Nacionais - Ensino Médio Orientações Curriculares para o Ensino Médio. v.2. Brasília: MEC/SEB, 2006.

BRASIL. LDB: Lei de diretrizes e bases da educação nacional. - Brasília: Senado Federal, Coordenação de Edições Técnicas, 2017. 58 p 
BRICKER, L. A.; BELL, P. Conceptualizations of argumentation from science studies and the learning sciences and their implications for the practices of science education. Science Education, v. 92(3), p. 473 - 498, 2008.

BRUGLIATO, E. T. A produção de sentidos sobre a bomba atômica em diferentes tipos de discursos. Dissertação (Mestrado em Ensino de Ciências e Matemática). Instituto de Física Gleb Wataghin, Universidade Estadual de Campinas, Campinas, 2016.

CABRAL, P. F. O.; SOUZA, N. S.; QUEIROZ, S. L. Casos investigativos para a promoção da CSCL no ensino superior de química. Química Nova, v. 40(9), p. 1121-1129, 2017.

CACHAPUZ, A.; GIL-PEREZ, D.; CARVALHO, A. M. P.; PRAIA, J.; VILCHES, A. (Orgs.). A necessária renovação do ensino de ciências. São Paulo: Cortez, 2005.

CARTER, H. A. Chemistry in the comics part 1. A survey of the comics book literature. Journal of Chemical Education, v. 65(12), p. 1029 - 1035, 1988a.

CARTER, H. A. Chemistry in the comics part 2. Classic chemistry. Journal of Chemical Education, v. 66(2), p. 118 - 127, 1988 b.

CARTER, H. A. Chemistry in the comics part 3. The acidity of papel. Journal of Chemical Education, v. 66(11), p. 883 - 886, 1989.

CARVALHO, L. S. As histórias em quadrinhos como estratégia lúdica alternativa para o Ensino de Ciências: Dando Sabor ao Saber. In. Congresso Internacional da Afirse, João Pessoa, 2009.

CARVALHO, L. S.; MARTINS, A. F. P. Formação continuada com quadrinhos nas aulas de Ciências: algum problema? Linhas Críticas, v. 19(39), p. 331 - 353, 2013.

CARVALHO, L. S.; MARTINS, A. F. P.; Os quadrinhos nas aulas de Ciências Naturais: uma história que não está no gibi. Revista Educação em Questão, v. 35(21), p. 120-145, 2009.

CAVALCANTE, K. S. B.; SILVA, F. C.; MACIEL, A. P.; JÚNIOR LIMA, J. A. S.; RIBEIRO, J. S. S.; SANTOS, P. J. C.; PINHEIRO, A. E. P. Educação ambiental em histórias em quadrinho: recurso didático para o Ensino de Ciências. Química Nova na Escola, v. 37(4), p. $270-277,2015$.

CETIN, P. S. Explicit argumentation instruction to facilitate conceptual understanding and argumentation skills. Research in Science \& Technological Education, v. 32(1), p. 1-20, 2014.

CLARKEBURN, H. A test for ethical sensitivity in science. Journal of Moral Education, v. 31(4), p. $439-453,2002$.

COHEN, T. R.; MORSE, L. Moral character: what it is and what it does. In. BRIEF, A. P.; STAW, B. M. (Eds.). Research in Organizational Behavior. Elsevier, 2014.

CONRADO, D. M.; NUNES-NETO, N. Questões sociocientíficas: fundamentos, propostas de ensino e perspectivas para ações sociopolíticas. Salvador: EDUFBA, 2018.

CORRÊA, A. D.; RÔÇAS, G.; LOPES, R. M.; ALVES, L. A. A utilização de uma história em quadrinhos como estratégia de ensino sobre o uso racional de medicamentos. Alexandria. Revista de Educação em Ciência e Tecnologia, v. 9(1), p. 83 - 102, 2016.

COSTA, C. F. Razões para o utilitarismo: uma avaliação comparativa de pontos de vista éticos. ethic@ - Revista Internacional de Filosofia Moral, v. 1, n. 2, p. 155-174, 2002. 
CRUZ, T. M. G. S.; MESQUITA, N. A. S.; SOARES, M. H. F. B. H'Química - o uso dos quadrinhos para o ensino de radioatividade. In.: Encontro Nacional de Pesquisa em Educação em Ciências, 9, Águas de Lindóia, 2013. Atas... Águas de Lindóia, 2013.

CUNHA, M. B.; GIORDAN, M. A divulgação científica como um gênero de discurso: implicações na sala de aula. In: Encontro Nacional de Pesquisa em Educação em Ciências, 7., Florianópolis, 2009. Atas ... Florianópolis, 2009.

DAWSON, V. M.; VENVILLE, G. Teaching strategies for developing students' argumentation skills about socioscientific issues in high school genetics. Research in Science Education, v. 40(2), p. 133 - 148, 2010.

DRIVER, R.; NEWTON, P.; OSBORNE, J. Establishing the norms of scientific argumentation in classrooms. Science Education, v. 84(3), p. 287 - 312, 2000.

DUSCHL, R. A.; SCHWEINGRUBER, H. A.; SHOUSE, A. W. (Eds). Taking science to school: learning and teaching science in grades K-8. Washington, DC: National Academy Press, 2007.

EASTWOOD, J. L.; SADLER, T. D.; SHERWOOD, R. D.; SCHLEGEL, W. M. Students' participation in an interdisciplinary, socioscientific issues based undergraduate human biology major and their understanding of scientific inquiry. Research in Science Education, v. 43(3), p. 1051 - 1078, 2013.

EASTWOOD, J. L.; SADLER, T. D.; ZEIDLER, D. L.; LEWIS, A.; AMIRI, L.; APPLEBAUM, S. Contextualizing nature of science instruction in socioscientific issues. International Journal of Science Education, v. 34(15), p. 2289 - 2315, 2012.

EISNER, W. Quadrinhos e arte sequencial. 3ed. São Paulo: Martins Fontes, 1999. In: MENDONÇA, M.R.S. Ciência em quadrinhos: recurso didático em cartilhas educativas. 2008. Tese (Doutorado em Linguística). Universidade Federal de Pernambuco, Recife, 2008.

ERDURAN, S.; SIMON, S.; OSBORNE, J. TAPping into argumentation: Developments in the application of Toulmin's argument pattern for studying science discourse. Science Education, v. 88(6), p. 915 - 933, 2004.

FATARELI, E. F.; MASSI, L.; FERREIRA, L. N. A.; QUEIROZ, S. L. Mapeamento de textos de divulgação científica para planejamento de debates no ensino de química. Química Nova na Escola, v. 37(1), p. $11-18,2015$.

FERREIRA, A. B. H. Novo dicionário Aurélio da língua portuguesa. 4ed. Curitiba: Positivo, 2009.

FERREIRA, L. N. A. Texto de divulgação científica para o ensino de química: características e possibilidades. 2012. Tese (Doutorado em Ciências). Universidade Federal de São Carlos, São Carlos, 2012.

FERREIRA, L. N. A.; QUEIROZ, S. L. Artigos da revista ciência hoje como recurso didático no ensino de química. Química Nova, v. 34(2), p. 354 - 360, 2011.

FERREIRA, L. N. A.; QUEIROZ, S. L. Textos de divulgação científica na formação inicial de professores de química. Alexandria, Revista de Educação em Ciência e Tecnologia, v. 5(2), p. $43-63,2012$.

FETTER-VORM, J. Trinity: a história em quadrinhos da primeira bomba atômica. São Paulo: Três Estrelas, 2013. 
FLÔR, C. C. Leitura e formação de leitores em aulas de química no ensino médio. 2009. Tese (Doutorado em Educação Científica e Tecnológica). Universidade Federal de Santa Catarina, Florianópolis, 2009.

FOWLER, S. R.; AMIRI, L. The influence of content and gender on moral sensitivity about socioscientific issues. In. Meeting of the Southeasten Association for Science Teacher Education, Gainesville, 2004.

FOWLER, S. R.; ZEIDLER, D. L.; SADLER, T. D. Moral sensitivity in the context of socioscientific issues in high school science students. International Journal of Science Education, v. 31(2), p. $279-296,2009$.

FRIEDRICHSEN, P. J.; SADLER, T. D.; GRAHAM, K.; BROWN, P. Design of a socioscientific issue curriculum unit: antibiotic resistance, natural selection, and modeling. International Journal of Desings for Learning, v. 7(1), p. 1-18, 2016.

GERALDI, J. W. Portos de Passagem. 4ed. São Paulo: Martins Fontes, 2003.

GIRALDI, P. M. Leitura e escrita no ensino de ciências: espaços para a produção de autoria. Tese (Doutorado em Educação Científica e Tecnológica). Universidade Federal de Santa Catarina, Florianópolis, 2010.

GRESCH, H.; HASSELNORN, M.; BÖGEHOLZ, S. Training in decision-making strategies: an approach to enhance students' competence to deal with socio-scientific issues. International Journal of Science Education, v. 35(15), p. 2587 - 2607, 2013.

GUIMARÃES, M. A. Raciocínio informal e a discussão de questões sociocientíficas: o exemplo das células-tronco humanas. Tese (Doutorado em Educação para Ciência). Universidade Estadual Paulista, Bauru, 2011.

GUimarẽes, M. A.; CARVAlHO, W. L. P. Contribuições do ensino de ciências para o desenvolvimento moral. Educação Unisinos, v. 13(2), p. 162 - 168. 2009.

HERAWATI, D.; ARDIANTO, D. Socioscientific argumentation of pre-service teachers about genetically modified organisms. International Conference on Mathematics and Science Education (ICMScE), série 825, p. 1-7, 2017.

HEWSON, M. G.; OGUNNIYI, M. B. Argumentation-teaching as a method to introduce indigenous knowledge into science classrooms: opportunities and challenges. Cultural Studies of Science Education, v. 6; p. 679 - 692, 2011.

ISLAS. S. M.; SGRO, M. R.; PESA, M. A. La argumentación en la comunidade científica y en la formación de profesores de física. Ciência e Educação, v.15(2), p. 291-304, 2009.

JIMÉNEZ-ALEIXANDRE, M. P. 10 ideas clave - competencias en argumentación y uso de pruebas. Barcelona: Graó, 2010.

JIMÉNEZ-ALEIXANDRE, M. P. Argumentación y uso de pruebas: construcción, evaluación y comunicación de explicaciones en Biología y Geología. In: P. CAÑAL (Ed.). Didáctica de la Biología y la Geología. Barcelona: Graó, 2011.

JIMÉNEZ-ALEIXANDRE, M. P. BROCOS, P. Desafios metodológicos na pesquisa da argumentação em ensino de ciências. Revista Ensaio, v. 17, n. especial, p. 139 - 159, 2015.

JIMÉNEZ-ALEIXANDRE, M. P.; CASTRO, C. R.; PÉREZ, V. A. Argumentación en el laboratorio de física. In: Encontro de Pesquisa em Ensino de Física, Florianópolis, 1998. Resumos. Florianópolis: Sociedade Brasileira de Física, 1998. 
JIMÉNEZ-ALEIXANDRE, M. P.; ERDURAN, S. Argumentation in science education: An overview. In: ERDURAN, S. M.; JIMÉNEZ-ALEIXANDRE, M. P. (Eds.) Argumentation in science education: Perspectives from classroom-based research. Dordrecht: Springer, 2008, p. 3-27.

JORGE, A. S.; PUIG, N. S. Enseñar a argumentar científicamente: um reto de las clases de ciencias. Enseñanza de las Ciencias, v.18(3), p. 405 - 422, 2000.

KANT, I. Fundamentação da metafísica dos costumes. Lisboa: Edições 70. 2005.

KAPICI, H. O.; ILHAN, G. O. Pre-service teachers' attitudes toward socio-scientific issues and their views about nuclear power plants. Journal of Baltic Science Education, v. 15(5), p. 642 $652,2016$.

KARISAN, D.; TÜZUN, O. Y.; ZEIDLER, D. L. Quality of preservice teachers argumentation in socioscientific issues context. International Journal of Human Sciences, v. 14(4), p. 3504 3519, 2017.

KARISAN, D.; ZEIDLER, D. L. Contextualization of nature of science whitin the socioscientific issues framework: a review of research. International Journal of Education in Mathematics, Science and Technology, v. 5(2), p. 139 - 151, 2017.

KAYA, E. Argumentation practices in classroom: pre-service teachers' conceptual understanding of chemical equilibrium. International Journal of Science Education, v. 35(7), p. $1139-1158,2013$.

KELLY, G. J. Inquiry, activity and epistemic practice. In: DUSCHL, R.; GRANDY, R. (Eds.). Teaching scientific inquiry: recommendations for research and implementation. Rotterdam: Sense Publishers, 2008.

KELLY, G. J.; TAKAO, A. Epistemic levels in argument an analysis of university oceanography students' use of evidence in writing. Science Education, v. 86(3), p. 314 - 342, 2002.

KLOSTERMAN, M. L.; SADLER, T. D. Multi-level assessment of scientific content knowledge gains associated with socioscientific issues-based instruction. International Journal of Science Education. v.32(8), p. 1017 -1043, 2010.

KLOSTERMAN, M. L.; SADLER, T. D.; BROWN, J. Science teachers' use of mass media to address socio-scientific and sustainability issues. Research in Science Education, v. 42(1), p. $51-74,2012$.

KOHLBERG, L. Psicologia del desarollo moral. Bilbao: Desclée de Bouwer, 1992.

KOLAROV, T.; HADJIALI, I.; DENEV, I. High school students' reasoning in making decisions about socio-ethical issues of genetic engineering: case of gene therapy. Biotechnology \& Biotechnological Equipament, v. 27(2), p. 3737 - 3747, 2013.

KORTLAND, K. An STS case study about students' decision making on the waste issue. Science Education, v. 80, n. 6, p. 673-689, 1996.

KRESS, G. Literacy in the new media age. Londres: Routledge, 2003.

KUHN, D. The skills of argument. Cambridge: Cambridge University Press, 1991.

LA TAILlE, Y. Moral e ética: dimensões intelectuais e afetivas. Porto Alegre: Artmed. 2006. 
LATOUR, B. Ciência em ação: como seguir cientistas e engenheiros sociedade afora. São Paulo: Editora da Unesp, 2000.

LEE, H.; CHANG, H.; CHOI, K.; KIM, S. W.; ZEIDLER, D. L. Developing character and values for global citizens: analysis of pre-service science teachers' moral reasoning on socioscientific issues. International Journal of Science Education, v. 34(6), p. 925 - 953, 2012.

LEITE, B. S. História em quadrinhos e ensino de química: propostas de licenciandos para uma atividade lúdica. Revista Eletrônica Ludus Scientiae, v. 1(1), p. 58 - 74, 2017.

LOCKE, S. Fantastically reasonable: ambivalence in the representation of science and technology in super-hero comics. Public Understanding of Science, v. 14(1), p. 25 - 46, 2005.

LOURENÇO, A. B. Saberes docentes de argumentação: dinâmicas de desenvolvimento na formação inicial de professores de ciências. 2013. Tese (Doutorado em Ensino de Ciências). Universidade de São Paulo, São Paulo, 2013.

LOURENÇO, A. B.; FERREIRA, J. Q.; QUEIROZ, S. L. Licenciandos em química e argumentação científica: tendências nas ações discursivas em sala de aula. Química Nova, v. 39(4), p. $513-521,2016$.

LUCIE, P. H. Física com Martins e Eu: Dinâmica da Partícula. Rio de Janeiro: Rayal Artes Gráficas, 1969.

MCCLOUD, S. Desvendando os quadrinhos: história, criação, desenho, animação, roteiro. São Paulo: M. Books, 2005.

MAINGUENEAU, D. Novas tendências em análise do discurso. Campinas: Pontes, 1997.

MARTINEZ, G.; SILVA, G. B.; CORREA, S. M. S.; TIERA, V. A. O.; GOIS, J. Experimentação problematizadora e as concepções dos alunos sobre a utilização de textos no ensino de química. In Encontro Nacional de Pesquisa em Educação em Ciências, 11., Florianópolis, 2017. Atas ... Florianópolis, 2017.

MENDONÇA, M. R. S. Ciência em quadrinhos: recurso didático em cartilhas educativas. 2008. Tese (Doutorado em Linguística). Universidade Federal de Pernambuco, Recife, 2008.

MENDONÇA, P. C. C.; JUSTI, R. Ensino-aprendizagem de ciências e argumentação: discussões e questões atuais. Revista Brasileira de Pesquisa em Educação em Ciências, v.13(1), p. $187-216,2013$.

NARDI, R. A área de ensino de ciências no Brasil: Fatores que determinam sua constituição e suas características segundo pesquisadores brasileiros. 2005. Tese (Livre Docência). Universidade Estadual Paulista, Bauru, 2005.

NASCIMENTO, T. G. Contribuições da análise do discurso e da epistemologia de Fleck para a compreensão da divulgação científica e sua introdução em aulas de ciências. Ensaio, v. 7(2), p. $1-18,2005$.

NEWTON, P.; DRIVER, R.; OSBORNE, J. The place of argumentation in the pedagogy of school science. International Journal of Science Education, v. 21(5), p. 553-576, 1999.

OGUNNIYI, M. B. Teachers' stances and practical arguments regarding a science-indigenous knowledge curriculum: part 1. International Journal of Science Education, v. 29(8), p. 963 986, 2007. 
OLIVEIRA, J. R. S.; QUEIROZ, S. L. Comunicação e linguagem científica: guia para estudantes de química. 2 ed. Campinas: Editora Átomo, 2017.

OROFINO, R. P.; TRIVELATO, S. L. F. O uso de conceitos científicos em argumentos em aulas de biologia. Investigações em Ensino de Ciências, v. 20(3), p. 116 - 130, 2015.

OSBORNE, J.; ERDURAN, S.; SIMON, S. Enhancing the quality of argumentation in school science. Journal of Research in Science Teaching, v. 41(10), p. 994 - 1020, 2004.

OSBORNE, J.; SIMON, S.; CHRISTODOULOU, A.; HOWELL-RICHARDSON, C.; RICHARDSON, K. Learning to argue: a study of four schools and their attempt to develop the use of argumentation as a common instructional practice and its impact on students, v. 50(3), p. $315-347,2013$.

OWENS, D.; SADLER, T.; ZEIDLER, D. Controversial issues in the science classroom. Phi Delta Kappan, v. 99(4), p. 45 - 49, 2017

OZDEN, Y.; ERTEPINAR, H.; CAKIROGLU, J.; ERDURAN, S. The natures of pre-service science teacher's argumentation in inquiry-oriented laboratory context. International Journal of Science Education, v. 35(15), p. 2559 - 2586, 2013.

PEREIRA, E. G. C.; FONTOURA, H. A. Discutindo as Histórias em Quadrinhos enquanto recurso didático em Ciências. Revista Práxis, ano 8(15), p. 93 - 104, 2016.

PÉREZ, L. F. M.; CARVALHO, W. L. P. Contribuições e dificuldades da abordagem de questões sociocientíficas na prática de professores de ciências. Educação e Pesquisa, v. 38(3), p. $727-741,2012$.

PIAGET, J. O Juízo moral na criança. São Paulo: Summus Editorial. 1994.

PIZARRO, M. V.; LOPES JUNIOR, J. Os indicadores de alfabetização científica nos anos iniciais do ensino fundamental e o uso de história em quadrinhos como recurso didático em ciências. In. BASTOS, F. (Org.) Ensino de Ciências e Matemática III: Contribuições da pesquisa acadêmica a partir de múltiplas perspectivas 1ed. São Paulo: Editora Unesp, p. 109$128,2010$.

QUELLA-GUYOT, D. A história em quadrinhos. São Paulo: Unimarco Editora, 1994. In. TESTONI, L. A. Um corpo que cai: as histórias em quadrinhos no ensino de física. 2004. Dissertação (Mestrado em Educação). Universidade de São Paulo, São Paulo, 2004.

QUEIROZ, S. L. A linguagem escrita nos cursos de graduação em química. Química Nova, v.24(1), p.143 - 146, 2001.

RADDO, P. Teaching Chemistry Lab Safety through Comics. Journal of Chemical Education, v. 83(4), p. 571 - 573, 2006.

RAMOS, P. A leitura dos quadrinhos. 3.ed. São Paulo: Contexto, 2016.

RATCLIFFE, M.; GRACE, M. Science education for citizenship: teaching socio-scientific issues. Philadelphia: Open University Press. 2003.

REST, J.R.; BEBEAU, M.J.; VOLKER, J. An overview of the psychology of morality. In REST, J. R. (Ed.) Moral development: Advances in research and theory. Boston: Prager Publishers. 1986. 
REZENDE, F.; CASTELLS, M. Interanimation of voices and argumentative strategies in collaborative knowledge building of Physics teachers in an asynchronous discussion group. Revista Eletrónica de Enseñanza de las Ciencias, v. 9(2), p. 396 - 417, 2010.

RIBEIRO, R. A.; KAWAMURA, M. R. A ciência em diferentes vozes: uma análise de textos de divulgação científica". In: Encontro Nacional de Pesquisa em Educação em Ciências, 5, Bauru, 2005. Atas ... Bauru, 2005.

ROBERTSHAW, B.; CAMPBELL, T. Constructing arguments: investigating pre-service science teacher's argumentation skills in a socio-scientific context. Science Education International, v. 24(2), p. 195 - 211, 2013.

ROCHA, M. B. O potencial didático dos textos de divulgação científica segundo professores de ciências. Revista Brasileira de Ensino de Ciências e Tecnologia, v. 5(2), p. 47 - 68, 2012.

SÁ, L. P. Estudos de casos na promoção da argumentação sobre questões sócio-científicas no ensino superior de química. Tese (Doutorado em Ciências). Universidade Federal de São Carlos, São Carlos, 2010.

SÁ, L. P.; KASSEBOEHMER, A. C.; QUEIROZ, S. L. Esquema de argumento de Toulmin como instrumento de ensino: explorando possibilidades. Revista Ensaio, v. 16(3), p. 147 - 170, 2014.

SÁ, L. P.; QUEIROZ, S. L. Argumentação no ensino de ciências: contexto brasileiro. Ensaio, v. $13(2)$, p. $13-30,2011$.

SADLER, T. D. Informal reasoning regarding socioscientific issues: a critical review of research. Journal of Research in Science Teaching, v. 41(5), p. 513 - 536, 2004a.

SADLER, T. D. Moral sensitivity and its contribution to the resolution of socio-scientific issues. Journal of Moral Education, v. 33(3), 2004b.

SADLER, T. D. (Ed.). Socioscientific issues in the classroom: teaching, learning, and research. New York: Springer, 2011.

SADLER, T. D.; CHAMBERS, F. W.; ZEIDLER, D. L. Student conceptualizations of the nature of science in response to a socioscientific issue. International Journal of Science Education, v. 26(4), p. 387 - 409, 2004.

SADLER, T. D.; ROMINE, W. L.; TOPÇU, M. S. Learning science content through socioscientific issues-based instruction: a multi-level assessment study. International Journal of Science Education, v. 38(10), p. 1622 - 1635, 2016.

SADLER, T. D.; ZEIDLER, D. L. Patterns of informal reasoning in the context of socioscientific decision making. Journal of Research in Science Teaching, v. 42(1), p. 112 $138,2005$.

SADLER, T. D.; ZEIDLER, D. L. Scientific literacy, PISA, and socioscientific discourse: Assessment for progressive aims of science education. Journal of Research in Science Teaching, v. 46(8), p. $909-921,2009$.

SALÉM, S.; KAWAMURA, M. R. As perguntas dos leitores nas revistas de divulgação científica: possíveis contribuições ao ensino de física. In Encontro Nacional de Pesquisa em Educação em Ciências, 2., Valinhos, 1999. Atas ... Valinhos, 1999.

SAMPSON, V.; BLANCHARD, M. R. Science teachers and scientific argumentation: trends in views and practice. Journal of Research in Science Teaching, v. 49(9), p. 1122 - 1148, 2012. 
SANTOS, T. C.; PEREIRA, E. G. C. Histórias em quadrinhos como recurso pedagógico. Revista Práxis, ano 5(9), p. 51 - 56, 2013.

SANTOS, R. L.; VERGUEIRO, W. Histórias em quadrinhos no processo de aprendizagem: da teoria à prática. Eccos Revista Científica, n. 27, p. 81 - 95, 2012.

SANTOS, R. O. A bomba atômica e o professor: uma leitura de Trinity em sala de aula. In. $4^{a s}$ Jornadas Internacionais de Histórias em Quadrinhos, São Paulo, 2017. Caderno de Resumos ... São Paulo, 2017.

SANTOS, V. J. R. M.; GARCIA, R. N. A pesquisa sobre o uso dos quadrinhos no ensino das Ciências da Natureza apresentadas nos ENPECs de 1997 a 2015. In. Encontro Nacional de Pesquisa em Educação em Ciências, 11., Florianópolis, 2017. Atas ... Florianópolis, 2017.

SÃO PAULO, Proposta curricular do Estado de São Paulo: Física. São Paulo: SEE, 2008.

SASSERON, L. H.; CARVALHO, A. M. P. Construindo argumentação na sala de aula: a presença do ciclo argumentativo, os indicadores de alfabetização científica e o padrão de Toulmin. Ciência \& Educação, v. 17(1), p. 97-114, 2011.

SCHNETZLER, R. P. A pesquisa em ensino de química no Brasil: conquistas e perspectivas. Química Nova, v. 25(1), p. 14 - 24, 2002.

SILVA, C.R.P.; OLIVEIRA, C.D.L.; CAMPOS, R.S.P. A prática pedagógica e a história em quadrinhos no ensino de ciências, Revista da SBEnBio, n. 7, p. 1090 - 1097, 2014.

SILVA, G. B.; QUEIROZ, S. L. Histórias em quadrinhos como recurso didático para o ensino de química. In. Evento de Educação em Química, 15., Araraquara, 2017. Anais ... Araraquara, 2017.

SILVA, G. B.; QUEIROZ, S. L. Sensibilidade Moral de Licenciandos em Química diante de conflito ético na prática científca. Química Nova na Escola, 41(1), p. 69 - 81). 2019.

SIMON, S.; ERDURAN, S.; OSBORNE, J. Learnins to teach argumentation: research and development in the science classroom, International Journal of Science Education, v.28(2-3), p. $235-260,2006$.

SOUSA, P. S.; GEHLAN, S. T. Questões sociocientíficas no ensino de ciências: algumas características das pesquisas brasileiras. Revista Ensaio, v. 19(e.2569), p. 1 - 22, 2017.

STIPCICH, M.; ISLAS, M.; DOMÍNGUEZ, A. El Lugar de la argumentación en la formación de profesores de ciências. Revista Chilena de Educación Científica, v. 6(1), p. 67 - 74, 2006.

TATALOVIC, M. Science Comics as tools for science education and communication: a brief, exploratory study. Journal of Science Communication, v. 8(4), p. 1 - 17, 2009.

TAVARES Jr. M. J. As histórias em quadrinhos (HQs) na formação dos professores de Ciências e Biologia. Revista Educação, v. 40(2), p. 439 - 450, 2015.

TEIXEIRA, E. S.; SILVA NETO, C. P.; FREIRE Jr., O.; GRECA, I. A construção de uma argumentação sobre a síntese newtoniana a partir de atividades em grupos. Investigações em Ensino de Ciências, v. 15(1), p. 61 - 95, 2010.

TELLEZ, I. R. A produção de histórias em quadrinhos a partir da leitura de textos históricos por licenciandos do PIBID. In. Encontro Nacional de Pesquisa em Educação de Ciências, 9., Águas de Lindóia, 2013. Atas ... Águas de Lindóia, 2013. 
TESTONI, L. A. Um corpo que cai: as histórias em quadrinhos no ensino de física. 2004. Dissertação (Mestrado em Educação). Universidade de São Paulo, São Paulo, 2004.

TESTONI, L. A.; ABIB, M.L.V.S. A Utilização de Histórias em Quadrinhos no Ensino de Física. In. Encontro Nacional de Pesquisa em Ensino de Ciências, 4., Bauru, 2003. Atas ... Bauru, 2003.

TESTONI, L. A.; BROCKINGTON, G.; AZEVEDO, M. N.; LINARDI, P.; MARTORANO, S.; FERNANDES, R. Histórias em quadrinhos e argumentações em aulas de física. Enseñanza de las Ciencias, ${ }^{\circ}$ extraordinário, p. 1465 - 1471, 2017.

THOMA, S. J. Research using the Defining Issues Test. In Handbook of Moral Psychology, KILLEN, M.; SMETANA, J. G. (Eds.). Mahwah: Erlbaum Associates, 2006.

TONETTO, M. L.; KALIL, L. L.; VIEIRA MELO, W.; SCHNEIDER, D.; STEIN, L. M. O papel das heurísticas no julgamento e na tomada de decisão sob incerteza. Estudos de Psicologia, v. 23(2), p. 181-189. 2006.

TOULMIN, S. Os usos do argumento. São Paulo: Martins Fontes, 2001.

VAN EEMEREN, F. H.; GROOTENDORST, R. A systematic theory of argumentation: the pragmadialectical approach. New York: Cambridge University Press, 2004

VERGUEIRO, W. A atualidade das histórias em quadrinhos no Brasil: a busca de um novo público. História, Imagem e Narrativas, ano 3(5), p. 1 - 20, 2007 a.

VERGUEIRO, W. A linguagem dos quadrinhos: uma alfabetização necessária. In. RAMA, A.; VERGUEIRO, W. (Orgs.). Como usar as histórias em quadrinhos na sala de aula. 3ed. São Paulo: Contexto, 2007b.

VERGUEIRO, W.; RAMOS, P. Os quadrinhos (oficialmente) na escola: dos PCN ao PNBE. In: VERGUEIRO, W; RAMOS, P. (orgs.). Quadrinhos na educação: da rejeição à prática. São Paulo: Contexto, p.9 - 42, 2009.

VIEIRA, R, D.; NASCIMENTO, S. S. A argumentação no discurso de um professor e seus estudantes sobre um tópico de mecânica newtoniana. Caderno Brasileiro de Ensino de Física, v. 24(2), p. 174 - 193. 2007.

VIEIRA, E. F. Histórias em quadrinhos no ensino de física: de onde vem esta ideia? In. $4^{a s}$ Jornadas Internacionais de Histórias em Quadrinhos, São Paulo, 2017. Caderno de Resumos ... São Paulo, 2017.

VIEIRA, E. F.; HIGA, I. Histórias em quadrinhos: uma proposta para o ensino de física. In. Congresso Nacional de Educação, 11., Curitiba, 2013. Anais ... Curitiba, 2013.

WALKER, L. J. The model and the measure: an appraisal of the Minnesota approach to moral development. Journal of Moral Education, v. 31(3), p. 353 - 367, 2002.

WINCH, P. G.; TERRAZAN, E. A. Argumentação no ensino de ciências: resultados de pesquisas. In. Encontro Nacional de Pesquisa em Educação de Ciências, 6., Florianópolis, 2007. Atas ... Florianópolis, 2007.

WU, Y.; TSAI, C. High school students' informal reasoning on a socioscientific issue: qualitative and quantitative analyses. International Journal of Science Education, v.29(9), p. 1163 - 1187, 2007. 
ZAMBONI, L. M. S. Cientistas, jornalistas e a divulgação científica: subjetividade e heterogeneidade do discurso da divulgação científica. Campinas: Autores Associados, 2001.

ZEIDLER, D. L.; KEEFER, M. The role of moral reasoning and the status of socioscientific issues in science education: philosophical, psychological and pedagogical considerations. In. ZEIDLER, D. L. (Ed.). The role of moral reasoning on socioscientific issues and discourse in science education. Dordrecth: Kluwer Academic Press, 2003.

ZEIDLER, D. L.; SADLER, T. D. The role of moral reasoning in argumentation: Conscience, character, and care. In ERDURAN, S.; JIMÉNEZ-ALEIXANDRE, M. P. (Eds.). Argumentation in science education: Recent developments and future directions. New York: Springer, 2008.

ZEIDLER, D. L.; SADLER, T. D.; SIMMONS, M. L.; HOWES, E. V. Beyond STS: A research-based framework for socioscientific issues education. Science Education, v.89(3), p. $357-377,2005$.

ZOHAR, A. Science teacher education and professional development in argumentation. In: ERDURAN, S. M.; JIMÉNEZ-ALEIXANDRE, M. P. (Eds.) Argumentation in science education: Perspectives from classroom-based research. Dordrecht: Springer, 2008, p. 3-27.

ZOHAR, A.; NEMET, F. Fostering students' knowledge and argumentation skills through dilemmas in human genetics. Journal of Research in Science Teaching, v. 39(1), p. 35-62. 2002. 


\section{APÊNDICES \\ APÊNDICE A \\ Termo de Consentimento Livre e Esclarecido}

Nome da Pesquisa: Química em História em Quadrinhos: Leitura na Formação Inicial de Professores e Tratamento Dado à Informação Científica

Pesquisadores responsáveis: Profa. Dra. Salete Linhares Queiroz e Mestrando Guilherme Balestiero da Silva

Informações gerais sobre a pesquisa: Por meio da leitura da HQ Trinity: a história em quadrinhos da primeira bomba atômica, nas aulas da disciplina de Química Sociedade e Cotidiano, pretende-se promover nos licenciandos a argumentação e a tomada de decisão a respeito de questões sócio científicas. Com essa abordagem, busca-se investigar o potencial didático de estratégias como a argumentação no ensino de química por meio da leitura de histórias em quadrinhos, objetivando a formação para a cidadania prevista pela LDB 9394/96.

Assim, convidamos você, aluno de graduação em Licenciatura em Ciências Exatas Habilitação em Química, a participar deste estudo no segundo semestre de 2017. Assumimos o compromisso de manter sigilo quanto a sua identidade, como também garantimos que o desenvolvimento da pesquisa foi planejado de forma a não produzir riscos ou desconforto para os participantes. Pedimos também autorização para gravar (gravação em áudio e vídeo) o que for falado durante as aulas.

Profa. Dra. Salete Linhares Queiroz

Guilherme Balestiero da Silva (pesquisador) 
$\mathrm{Eu}$, RG , abaixo assinado, tendo recebido as informações referente a pesquisa “Química em Histórias em Quadrinhos: Leitura na Formação Inicial de Professores e Tratamento Dado à Informação Científica", e ciente dos meus direitos, concordo em participar da referida pesquisa, bem como ter:

1. A garantia de receber todos os esclarecimentos sobre todas as discussões antes e durante o desenvolvimento da pesquisa podendo afastar-me a qualquer momento assim que desejar.

2. A segurança plena de que não serei identificado, mantendo o caráter oficial da informação, assim como está assegurado que a pesquisa não acarretará nenhum prejuízo individual ou coletivo.

3. A segurança de que não terei nenhum tipo de despesa material ou financeira durante o desenvolvimento da pesquisa, bem como esta pesquisa não causará nenhum tipo de risco, dano físico, ou mesmo constrangimento moral e ético.

4. A garantia de que toda e qualquer responsabilidade nas diferentes fases da pesquisa é dos pesquisadores, bem como fica assegurado que haverá ampla divulgação dos resultados finais nos meios de comunicação e nos órgãos de divulgação científica em que a mesma seja aceita.

5. A garantia de que todo material resultante será usado exclusivamente para a construção da pesquisa e ficará sob guarda dos pesquisadores.

Tendo ciência do exposto acima, desejo participar da pesquisa

São Carlos, de de

Assinatura do participante 


\section{APÊNDICE B}

\section{Questões norteadoras sobre as percepções dos alunos com respeito a utilização de histórias em quadrinhos (HQ) em sala de aula de ciências}

1. Qual a sua relação particular com as HQ? Histórico de leituras?

2. Durante sua vida acadêmica - ensino fundamental, médio e até mesmo graduação - você já utilizou HQ no processo de ensino aprendizagem?

3. Como futuro professor, você enxerga possibilidades para trabalhar com HQ no ensino de química?

4. Quais características que uma $\mathrm{HQ}$ possui que poderia corroborar sua inserção no ambiente de ensino formal? (Utilização de imagens em conjunto com o texto, uma linguagem mais acessível, familiaridade com o instrumento por parte dos alunos etc.)

5. A princípio, com que objetivo você utilizaria uma HQ? (Motivação, compreensão de conceitos, compreensão sobre a atividade científica e natureza da ciência, avaliação, incentivo à leitura e o contato com termos técnicos de forma mais compreensível etc.)

\section{Questionário de conhecimentos prévios}

1. Elabore, com base em seus conhecimentos, um desenho que mostre como você imagina "ser" um átomo, indicando as partes que o constituem.

2. É possível dividir um átomo? Como esse processo ocorreria? 


\section{APÊNDICE C}

\section{ATIVIDADE EM SALA}

1. Faça a leitura silenciosa e em dupla (p. 16 - 29) do livro "Trinity: a HQ da primeira bomba atômica" e indique trechos que representam características da atividade científica conforme Queiroz e Ferreira (2013):

\section{Características da atividade científica}

- Descrição de modelos • Descrição de metodologias científicas/técnicas/equipamentos • Descrição de análise de dados • Descrição de interpretação de resultados • Apresentação de conclusões de análises/pesquisas • Características pessoais de pesquisadores • Quebra de paradigmas • Menções ao Prêmio Nobel • Obtenção de patentes • Financiamento de pesquisas • Aplicações das pesquisas científicas • Forma de tomada de dados • Presença de controvérsias científicas • Referências a publicações científicas • Caráter provisório das pesquisas científicas • Pesquisas realizadas por trabalho em equipe $\bullet$ Implicações das pesquisas científicas • Motivação para as pesquisas • Aspectos históricos da ciência • Formulação de hipóteses • Conclusões das pesquisas • Limitações/dificuldades das pesquisas científicas • Cooperação entre diferentes grupos de pesquisa $\bullet$ Necessidade de reconhecimento perante a comunidade científica

2. Conforme leitura realizada na aula anterior, as implicações da descoberta de Otto Hanh e Fritz Strassmann - fissão nuclear (p. 7 do livro "Trinity") - demonstram a importância desse fenômeno e o impacto do desenvolvimento científico na sociedade. Nessa perspectiva instruir os alunos em sala de aula sobre tal conceito é relevante. Dessa forma, busque a partir da consulta de fontes bibliográficas de acesso livre, materiais didáticos que poderiam ser úteis para a sua abordagem. Justifique a escolha e descreva possíveis etapas de aplicação desses materiais nas aulas de química do ensino médio.

Referência: Queiroz, S. L.; Ferreira, L. N. A. Traços de cientificidade, didaticidade e laicidade em artigos da revista 'Ciência Hoje' relacionados à química. Ciência \& Educação, Bauru, v. 19, n. 4, p. 947-969, 2013. 


\section{APÊNDICE D}

\section{ATIVIDADE EXTRACLASSE}

1. Leia o artigo da revista Superinteressante intitulado: "Os donos do fim do mundo" por Pedro Henrique Tavares ${ }^{1}$, envolvendo armamentos nucleares no século XXI e elabore a carta solicitada abaixo.

Tendo em vista as preocupações de Leo Szilard, principalmente no que diz respeito à construção de uma bomba atômica pelos alemães, Szilard, Eugene Wigner e Albert Einstein escreveram uma carta destinada à rainha da Bélgica, cujo país controlava as maiores minas de urânio do mundo, e ao presidente Roosevelt - ambos não cientistas - sobre o perigo e a importância de uma arma nuclear. Hoje, conforme a leitura do artigo "Os donos do fim do mundo", o contexto é bastante diferente, no entanto as preocupações são semelhantes. Dessa forma, representando um cientista preocupado com o arsenal atômico de outros países, elabore uma carta ao presidente do Brasil sobre o contexto nuclear atual, argumentando a favor ou contra a necessidade de investimentos em armamento nuclear em território nacional e a possível saída do Tratado de Não-Proliferação de Armas Nucleares. Para isso, utilize os seus conhecimentos e as informações discutidas previamente, bem como recorra a outras fontes bibliográficas, se julgar necessário.

2. Como pode-se observar pela leitura inicial do livro "Trinity: a história em quadrinhos da primeira bomba atômica", a informação apresentada se dá por meio de uma abordagem a princípio histórica. Dessa forma, para auxílio na compreensão da narrativa bem como para entender a relação existente entre ciência e sociedade durante a segunda guerra mundial, é interessante entender o contexto social da época. Nessa perspectiva, busque em diversas fontes, informações que indiquem como eram nas décadas de 1930/1940 um dos seguintes aspectos: as opções de lazer como cinema, teatro ou literatura, bem como os meios de comunicação de massa, os modos de trabalho ou até mesmo as universidades existentes. Feita a busca, indique como o aspecto escolhido para sua pesquisa foi influenciado pela guerra, ou como este influenciou de alguma forma o conflito.

\footnotetext{
${ }^{1}$ Tavares, P.H. Os donos do fim do mundo. Revista Superinteressante, publicado online em 12 julho de 2017. Acesso em https://super.abril.com.br/sociedade/os-donos-do-fim-do-mundo/
} 


\section{APÊNDICE E}

\section{CASO 1: A questão do sigilo no Projeto Manhattan}

"Trinity: a história em quadrinhos da primeira bomba atômica" (p. 33 - 36)

O Projeto Manhattan, concebido por Groves, era impressionante por muitos motivos. Sua larga escala: a unidade de difusão, em Oak Ridge, no Tennessee, era o maior prédio do mundo. O número total de pessoas envolvidas: no auge da produção, cerca de 80 mil trabalhavam em Oak Ridge. O tempo espantosamente curto entre a prancheta e a linha de montagem: equipes de operários, trabalhando contra o relógio, terminavam uma nova casa a cada 15 minutos.

Mas outro fato impressionante pode facilmente passar desapercebido - todos esses esforços esses milhares de trabalhadores, as incontáveis toneladas de material de construção e o imensurável investimento de tempo e energia - era segredo. O povo americano - incluindo o Congresso - nem sequer sabia que o Projeto Manhattan existia.

[Senador] E como essa verba solicitada será exatamente aplicada? [Membro do Projeto Manhattan]. Isso é confidencial, senador.

Groves compartimentou o Projeto Manhattan de modo que nenhuma organização ou indivíduo tivesse completa noção daquilo em que estava trabalhando.

[Operário] Cuido para que os canos não vazem.

[Operária] Faço com que as máquinas não esquentem demais.

[Militar] Lembro as pessoas de não fazerem perguntas.

O Projeto Manhattan foi tão eficiente em manter sua confidencialidade que, mais tarde, organizações secretas como a CIA o usaram como modelo. Mas em Los Alamos - o novo lar de algumas das mentes mais brilhantes do país - a questão do sigilo não era assim tão simples.

[Cientistas] Não venha me falar de sigilo! Não há como fazer ciência sem a livre troca de ideias.

Um dos primeiros desafios de Groves foi tentar separar os cientistas: muitos deles se recusaram totalmente a fazer isso.

[Militar] Eles ignoram suas ordens, senhor! O que devo fazer?

[Groves] São um bando de crianças. Eles só precisam de um pouco de disciplina.

[Oppenheimer] Você sabe que a maioria desses homens deixou a Europa para fugir do militarismo

[Groves] Mas é como se eles nem entendessem que estamos em guerra.

[Oppenheimer] Mas você não acha que eles têm razão? Como você espera que eles colaborem entre si se não sabem o que os outros estão fazendo? E se os cientistas fossem livres para falar o que quisessem ..., mas só dentro do laboratório? Todos podem saber tudo, mas somente numa área cuidadosamente restrita. E fica por conta dos cientistas policiarem a si mesmos?

Nessa situação, deveria Oppenheimer seguir com o plano de deixar os cientistas livres para falar o que quisessem, mas só dentro do laboratório, ficando por conta dos cientistas policiarem a si mesmos? Sim ou não? Por quê? 


\section{APÊNDICE F}

\section{ATIVIDADE EM CLASSE}

Faça a leitura das páginas 37 - 57 do livro "Trinity - a história em quadrinhos da primeira bomba atômica", e responda as seguintes questões:

1. No presente trecho são apresentados os últimos detalhes envolvendo aspectos científicos pertinentes à construção de uma bomba atômica. Dessa forma, indique e defina os conceitos químicos expostos desde o início da narrativa que estão envolvidos no processo, apontando a importância de cada um para o funcionamento efetivo da arma.

2. A HQ trabalhada se inicia com uma apresentação histórica do narrador sobre algumas descobertas científicas importantes afirmando que: "A bomba - o segredo do seu poder extraordinário - foi concebida muitos anos atrás, na Europa" Assim, apresenta a descoberta da radioatividade por Marie e Pierre Curie em 1898. Conhecendo os aspectos envolvidos na construção da bomba atômica na década de 1940, de que maneira, o "achado" do casal Curie se relaciona com a construção da arma?

\section{ATIVIDADE EXTRACLASSE}

1. Para a realização do Teste Trinity e o sucesso da arma desenvolvida, várias questões tiveram que ser respondidas. Contribuiu para isso o estudo de diversos cientistas envolvidos no Projeto Manhattan. No entanto, assim como indica a frase final do trecho lido para a aula do dia 30/10/2017, "até então, as respostas existiam apenas no papel".

Busque informações sobre as bombas lançadas nas cidades japonesas (Hiroshima e Nagasaki) e verifique se estas eram do mesmo tipo. Feito isso, indique os seus princípios e mecanismos de funcionamento. Caso existam diferenças entre as bombas, descreva tais diferenças no que diz respeito aos aspectos composicionais (materiais utilizados), estruturais (forma e modelo da bomba) e funcionais (mecanismos de funcionamento).

2. Localize na internet vídeos/filmes que tratam de questões abordadas no livro Trinity e construa uma ficha técnica para cada um deles. A ficha técnica deve conter os itens indicados no modelo abaixo. O número mínimo de fichas a ser construído é de 3.

\begin{tabular}{l}
\hline Título original \\
\hline Título em português \\
\hline Ano de produção \\
\hline Cor de filmagem \\
\hline Duração \\
\hline Direção \\
\hline Gênero \\
\hline País \\
\hline Sinopse \\
\hline Disponível para \\
download?
\end{tabular}




\title{
APÊNDICE G
}

\section{CASO 2 - A questão do sigilo do Projeto Manhattan}

"Trinity: a história em quadrinhos da primeira bomba atômica" (p. 60 e 61)

Em 1943, Niels Bohr, físico ganhador do Prêmio Nobel, visitou Los Alamos. Groves respeitava Bohr, mas não o incluiu no projeto, pois temia que o dinamarquês fosse um risco para a segurança. Para os cientistas, entretanto, Bohr era uma espécie de mentor.

Bohr e Oppenheimer costumavam dar longas caminhadas por Los Alamos. Deve ter sido difícil não falar sobre os assuntos em andamento...

[Bohr] "O que você está criando não é uma arma, é algo completamente novo. O que você está criando é uma ... como se diz ... uma nova situação “

[Oppenheimer] "Como assim? “

[Bohr] "Deixe-me perguntar: você tem mesmo como manter em segredo dos outros países o que você está fazendo aqui em Los Alamos?"

[Oppenheimer] "Acho que fomos bem eficazes até agora"

[Bohr] "Mas vamos imaginar que outro país, de alguma forma, construa uma bomba atômica, certamente eles construiriam mais de uma. “

[Oppenheimer] "Entendi ... e depois nós, no interesse da nossa própria segurança, produziríamos mais bombas. "

[Bohr] "E o resultado não seria a guerra; é uma coisa nova. O único resultado de uma guerra em que os dois lados usassem essas armas seria a destruição do mundo. A guerra em si se tornaria muito perigosa. E é precisamente por isso que cada país precisa entender o poder dessas armas! Só assim os líderes procurarão uma maneira de os homens coexistirem sem guerra, sem destruição ... sem bombas atômicas.

[Oppenheimer] "Então, você está dizendo que, se todo mundo soubesse que possuir uma bomba nos aproximaria cada vez mais do fim do mundo, ninguém seria idiota o suficiente para fazê-la? “

[Bohr] "O que estou dizendo é que, quando homens falam abertamente entre si, existe respeito, com segredos não pode haver respeito. “"

[Oppenheimer] "Niels, temo que você confie demais na sensatez dos homens. "

[Bohr] "Mas, Oppie, não temos escolha. A alternativa é muito angustiante. "

\author{
Enquanto cientista responsável pelo Projeto Manhattan, deveria Oppenheimer falar \\ abertamente sobre o poder de destruição da bomba atômica em construção? Sim ou não? Por \\ quê?
}




\section{APÊNDICE H}

\section{CASO 3 - As implicações do desenvolvimento científico.}

"Trinity: a história em quadrinhos da primeira bomba atômica" (p. 131, 132, 133 e 136) de seu líder.

Na manhã de 15 de agosto, o povo do Japão ouviu pela primeira vez na história a sagrada voz

[Imperador japonês] "A guerra evolui para uma situação não necessariamente vantajosa para o Japão, e todas as forças mundiais se voltaram contra os nossos interesses. Além disso, o inimigo começou a empregar uma nova e terrível bomba, cujo poder de destruição, é de fato incalculável, capaz de tirar a vida de muitos inocentes. Se continuássemos a lutar, isso não apenas resultaria no colapso final e na destruição da nação japonesa, mas também levaria à extinção total da civilização humana ... de acordo com o que ditam o tempo e o destino, resolvemos pavimentar o caminho para uma grande paz ... uma grande paz para todas as gerações futuras, suportando o insuportável, e tolerando o intolerável."

Após tirar a vida de dezenas de milhões de soldados e civis, a Segunda Guerra Mundial tinha finalmente acabado. Além disso, o objetivo que levara tantos cientistas a fazer parte do Projeto Manhattan foi alcançado: a bomba funcionou. Foi detonada quando deveria, explodiu com a força esperada ... e consumiu cidades e almas num lampejo de calor e radiação, conforme os cálculos dos cientistas que trabalharam em Los alamos. Para ser mais exato, a bomba fez mais do que seus criadores previram.

Bem depois de a fumaça sobre Hiroshima ter sido levada pela brisa suave do final do verão, um estranho castigo ainda assombrava os sobreviventes. Quando cientistas americanos chegaram ao Japão, em meados de setembro, para estudar os efeitos da bomba, eles não estavam preparados para o que viram.

\section{$[\ldots]$}

Os cientistas voltaram do Japão com relatórios detalhados sobre as cidades destruídas e seus habitantes devastados. Pela primeira vez, Oppenheimer e todos em Los Alamos tinham uma visão completa daquilo que haviam criado. Finalmente eles tinham a resposta para a pergunta que vinham se fazendo havia anos:

[Cientista] "Pode ser feito"

Depois do Projeto Manhattan, todavia, muitos cientistas se sentiram na obrigação de fazer uma pergunta diferente:

[Cientista] "Deveria ter sido feito?"

Dessa forma, enquanto cientista, você acredita que uma bomba atômica deveria ter sido feita? Sim ou não? Por quê? 
ANEXO A - The Diane Archer Case extraído do material "Moral Reasoning in Scientific Research" (BEBEAU, 1995)

\section{The Diane Archer Case}

Professor Diane Archer is a tenured member of a biology department at a major Midwestern university. She has been in the department for 15 years, and during that time she has supervised the work of $20 \mathrm{Ph}$.D. students. As part of the mentoring process, she has worked closely with her students, teaching them the ropes of writing grant proposals and on occasion inviting students to assist her in reviewing NIH grant applications.

Professor Archer is currently in her last year on an NIH study section. As she is reviewing a group of proposals, she comes upon one written by Charlie West, a former graduate student of one of her close departmental colleagues. Archer knows and remembers Charlie West because she had solicited his help two years earlier in reviewing a proposal closely related to West 's own area of research. As she now reads West 's proposal, Archer is impressed with the scientific soundness and fine writing style in the Background section. She notes, however, the extremely terse and awkward phrasing in the Research Design and Methods.

Perplexed by this shift in style, Archer retrieves from her files the grant proposal West had reviewed with her two years earlier. She is dismayed to see that West has used verbatim virtually the entire Background section of the earlier proposal for his own current proposal.

Archer is torn. If she reports her discovery of West 's plagiarism to the NIH, she knows she will have thrown this young scientist's otherwise promising scientific career into jeopardy. If, however, she says nothing, she will be shirking her responsibility to the NIH, as well as risking her own professional reputation, should the plagiarism be detected later.

She decides to contact West directly, and confront him with her finding. She plans to advise West that what he has done constitutes plagiarism and suggest to him that he withdraw the proposal. If West agrees, and withdraws the grant application, Archer feels she need take this incident no further.

Should Archer proceed with her plan to contact West? Why or why not? 


\section{The Diane Archer Case}

\section{Evaluation Checklist}

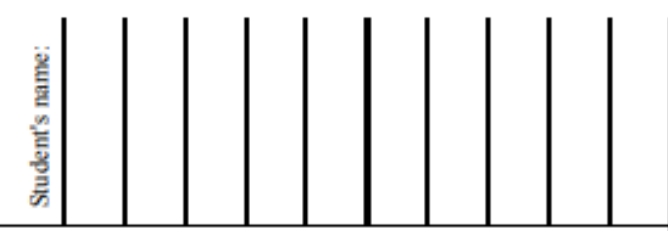

\begin{tabular}{|r|r|l|l|l|l|l|l|l|l|l|}
\hline \hline Side 1 position (yes or no) & & & & & & & & & & \\
\hline Side 2 position (yes or no) & & & & & & & & & & \\
\hline
\end{tabular}

Issues and Points of Conflict ( 5 points; $3=5 ; 2=4 ; 1=3$ )

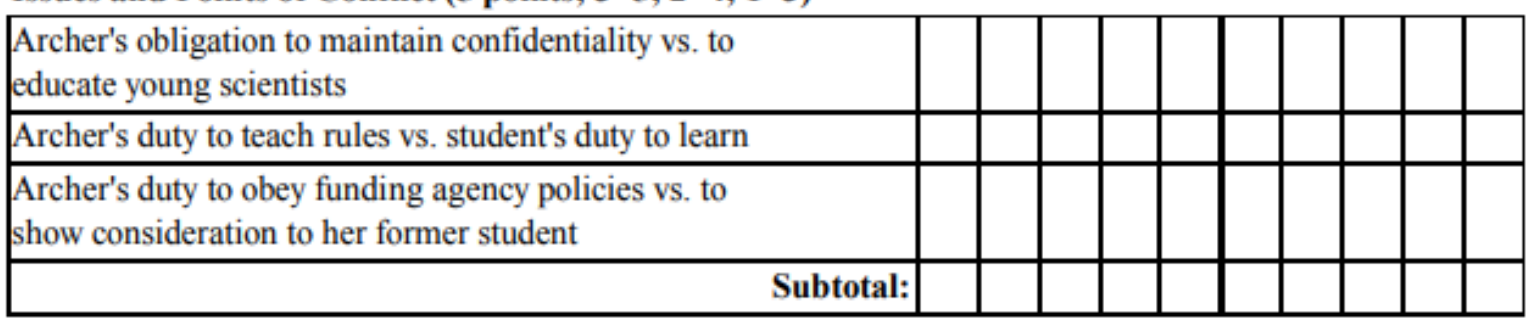

Interested Parties (3 points; 4-5=3; 2-3=2; 1=1)

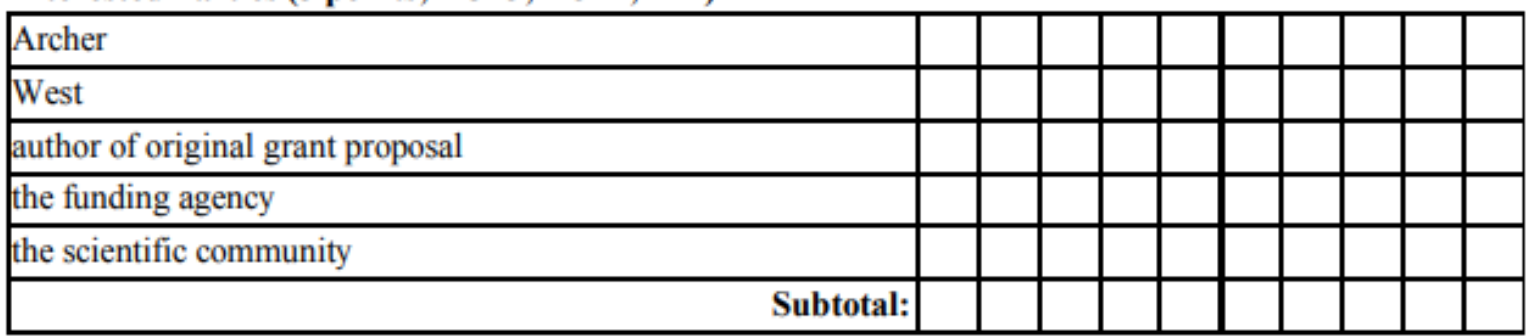

Consequences ( 4 points; $6-7=4 ; 4-5=3 ; 2-3=2 ; 1=1$ )

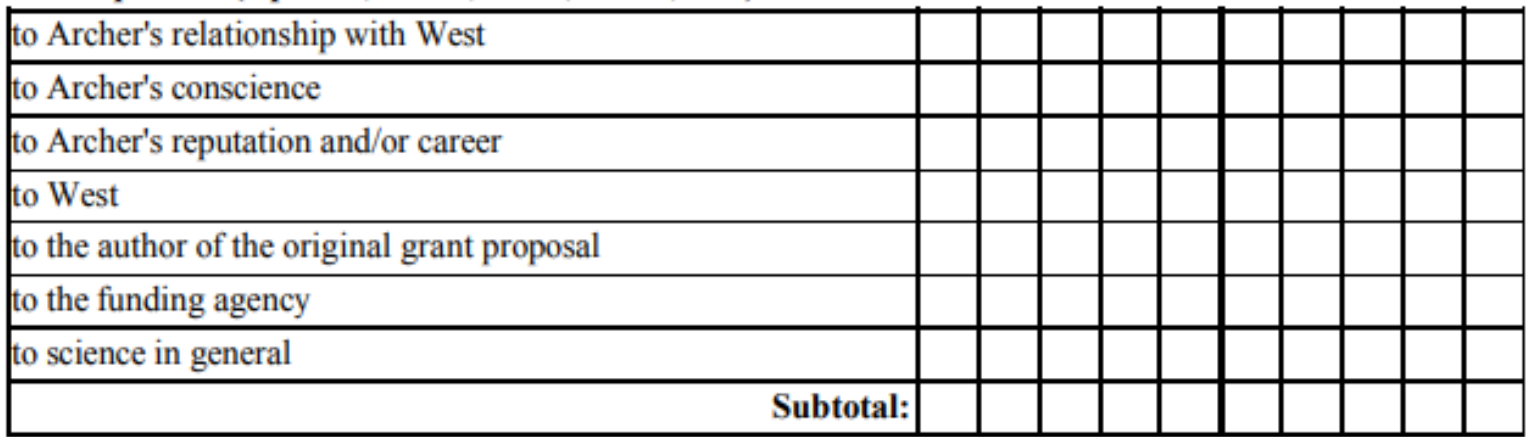

Archer's Obligations (5 points; 6-7=5; 4-5=4; 3-=3; $2=2 ; 1=1$ )

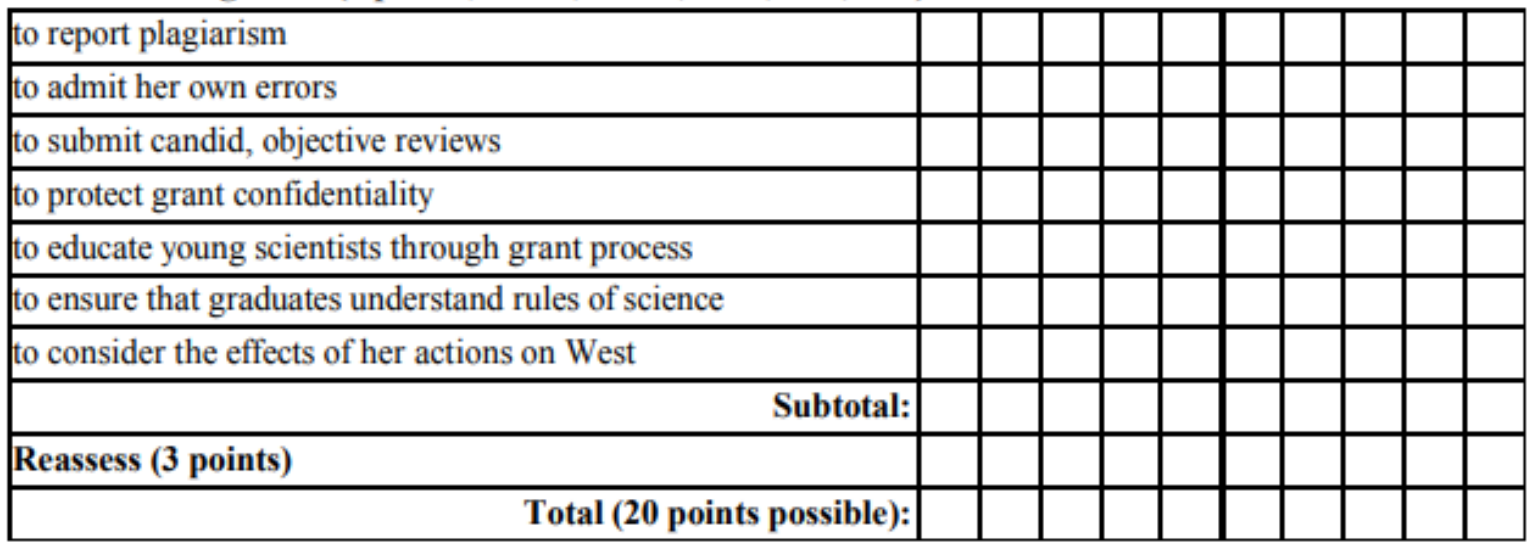

